$$
\begin{aligned}
& \text { UNIVERSIDADE DE SÃO PAULO } \\
& \text { INSTITUTO DE GEOCIÊNCIAS }
\end{aligned}
$$

\title{
EVOLUÇÃO METAMÓRFICA DOS METASSEDIMENTOS DA NAPPE LIMA DUARTE E ROCHAS ASSOCIADAS DO COMPLEXO MANTIQUEIRA, SUL DA FAIXA BRASÍLIA (MG)
}

\author{
Brenda Chung da Rocha
}

Orientador: Prof. Dr. Mario da Costa Campos Neto

\section{DISSERTAÇÃO DE MESTRADO}

Programa de Pós-Graduação em Geoquímica e Geotectônica

SÃO PAULO

2011 
Dedico este trabalho à Cauê Rodrigues Cioffi,

meu melhor companheiro 


\section{AGRADECIMENTOS}

A toda a minha família que sempre me apoiou: minha irmã (Fábia), minhas sobrinhas queridas (Bruna e Nicole), meu pai (Luciano), meus primos (Aguirre e Soraia, obrigado pelo incentivo sempre! E também Caio, Léo, Shelley, Rosângela), tios (Won, Gilberto, Micca), tias (Sun, Kátia e Mihee), meu cunhado (Adrian) e em especial para minha mãe (Mel), a quem agradeço imensamente pelo apoio, incentivo, amor e carinho constantes durante toda a minha vida, em todas as minhas escolhas. Obrigado por ser um exemplo pra mim, sempre!

Ao meu noivo Cauê Rodrigues Cioffi, um agradecimento mais do que especial, por todo amor e carinho, pela enorme paciência e compreensão, pela ajuda na confecção deste trabalho, pelas discussões geológicas, pela revisão deste manuscrito, por participar e ajudar nos trabalhos de campo, pela ajuda com o mapa geológico, enfim, por ter participado e vivido tudo isso comigo, obrigado por me aturar! Sua contribuição geológica foi imprescindível na confecção deste manuscrito, muito obrigado de coração.

À minha "segunda família”: Marisa, Paulo, Bárbara, Alice, César, Ana, Julien, João, enfim, obrigado a todos pelo carinho.

Ao meu orientador Mario da Costa Campos Neto, pelos anos de trabalho em Lima Duarte e pelo apoio dado na realização desta pesquisa.

A todos os participantes do Mapeamento Geológico de 2006 e 2007.

Aos meus amigos queridos, que sempre estiveram presentes e que colaboraram muito: Thaís Nogueira Hyppolito (Tchitcho), Jorge Emanuel dos Santos Nóbrega (Bizarro), Maurício Guerreiro dos Santos (Borboleta) e Patrícia (Pat), Roberta Pisanelli (Pisa), Ana Paula Burgoa Tanaka (Treme), Leandro Coutinho (Pulga), Dante Bianchi, Bruna Borges de Carvalho (Asnah), Renato Henrique Pinto (Lesma), Vinícius Tieppo Meira (Mikuin), Bruno Boito Turra (Melado), Simone Sonvesso (Pinguin), Ana Maciel de Carvalho (Xupeta), Fabiana dos Santos (Pará), Vivian Azor de Freitas (Cachorra), Rafael Bittencourt (Cofrinho), Bernardo Tavares Freitas (Aedes).

À amiga e quase doutora, Luana Moreira Florisbal (Lua), pela enorme disposição em ajudar, sua contribuição com a geoquímica foi fundamental, obrigado!!!

Ao Prof. Renato de Moraes, a ajuda com a geotermobarometria a longa distância e as discussões sobre o metamorfismo foram valiosíssimas, obrigado pela boa vontade.

Ao Prof. Valdecir Janasi, pela discussão sobre a geoquímica, importantíssimo! 
À Prof. Lucelene Martins, pela ajuda com os diagramas na hora do desespero.

Aos professores do IGc-USP: Johann Hans Daniel Schorscher (o campo no Quadrilátero foi inesquecível!), Romalino dos Santos Fragoso-César, Renato Paes de Almeida, Paulo Boggiani, Silvio Vlach e Osvaldo Siga Junior (aqueles cigarrinhos no jardim renderam ótimas discussões), Caetano Juliani, Gergely Szabó, Daniel Atencio, Gianna Maria Garda, Benjamin Bley de Brito Neves, obrigado pelo convívio e por contribuírem ainda mais na minha formação como geóloga.

À Prof. Maria de Fátima Bittencourt (UFRGS), pelo enorme aprendizado.

Ao Prof. Eric Essene (in memorian) (University of Michigan), pelo entusiasmo com os granulitos de Lima Duarte. Muito atencioso e gentil, contribuiu na interpretação de texturas, química mineral e geotermobarometria.

A todos os funcionários do Instituto de Geociências, em especial para: Marcos (Lab. Microssonda Eletrônica), Zé Paulo (Lab. Tratamento de Amostras), Paulinho (Laminação), Paulinho (Lab. FRX), Ricardo e Inês (Lab. Química), Sandra (Lab. Química e ICP-MS), Angélica (Lab. Óptica), Samuca (Lab. Preparação de Amostras), Zé Carlos (Audiovisual), Ana Paula e Magali (Seção de Pós-graduação), Tadeu, Brenda e Érica (Biblioteca), Thomas e Márcio (Veículos), e principalmente Claudionor, Henrique e José (Gráfica), muito obrigado pela agilidade e eficiência. Sem vocês este trabalho não existiria!

À geóloga Mariane Brumatti (LCT - Escola Politécnica), pelo excelente trabalho realizado no $\mathrm{MEV}$.

Ao pessoal da pós-graduação, pelas discussões geológicas e pelos agradáveis anos de convívio: Liza Pólo (Tops), Rafael Gonçalves Motta (Vivi), Maurício Pavan (Pavão), Gabriel Rossi (Rã), Daiane dos Santos (Popó), Alice Westin (Kenga), John Guevara Mora, Felipe Llamus, Paula Sucerquia, Alba Marina, Lucas Padoan (Rejeito), Bruno Lagler (Mininão), Gabriela (Entalada), enfim, todos vocês que participaram em sala de aula, no campo, ou mesmo no CEPEGE, obrigado!

Aos novos geólogos: Angélica Santana (Sem sal), Paula Correia (Pirua), Cinthia Nakamura (Shrek), Fabiana (Meia-boca), Ligia Garcia (Vesga), Cláudio (Kabong), Sheila Schmidt do Carmo (Sertão), Marília Aguiar (Atoladinha), e todo o pessoal que esteve em Carrancas no mapeamento de 2009.

Aos geólogos da Themag Engenharia, pelo apoio e compreensão: Marilda Tressoldi, Luiz Ferreira Vaz, Talita Muzzi, Magali Gurgueira, Rogério Araújo, Jorge Mortati, Raimundo Marcondes de Carvalho, Lucas Rangel Bittencourt, André Baradel. 
Ao Prof. Miguel Ângelo Stipp Basei, que viabilizou o desenvolvimento desta pesquisa através do projeto FAPESP (05/58688-1), meus sinceros agradecimentos.

A CAPES, pela concessão de bolsa de estudo e à FAPESP, pelo apoio financeiro. 


\section{RESUMO}

A Nappe Lima Duarte está situada no sudeste do Orógeno Brasília. É constituída por paragnaisses migmatíticos com granada, sillimanita, biotita e muscovita, e ortoquartzitos grossos, com intercalações esparsas de gnaisses calciossilicáticos e de anfibolitos. O Complexo Mantiqueira, infraestrutura alóctone da nappe, ocorre na forma de lascas tectonicamente imbricadas na mesma. É constituído por ortognaisses migmatíticos e polimetamórficos, tipo TTG, com intercalações de rochas metabásicas granulíticas, na forma de enclaves máficos alongados e boudins, geralmente concordantes com a foliação principal. Também ocorrem rochas charnockíticas aparentemente intrusivas nos ortognaisses Mantiqueira, com rochas metabásicas associadas. A associação mineral observada nos paragnaisses $(\mathrm{Grt}+\mathrm{Bt}+\mathrm{Sil}+\mathrm{Pl}+\mathrm{Rt}+$ $\mathrm{Ilm}+\mathrm{Qtz} \pm \mathrm{Ms} \pm \mathrm{Kfs} \pm \mathrm{Ky}$ ) é relacionada a um metamorfismo progressivo de fácies anfibolito superior, caracterizado por reações de quebra de muscovita e geração de feldspato potássico. As condições de pico bárico obtidas no THERMOCALC para a associação com cianita são de $10 \pm 0.6 \mathrm{kbar}$, a $807 \pm 25^{\circ} \mathrm{C}$. O pico térmico de $827 \pm$ $44^{\circ} \mathrm{C}$ a $8.2 \pm 1.8 \mathrm{kbar}$, no limite da curva de quebra da dumortierita, foi obtido no THERMOCALC com a associação mineral envolvendo sillimanita. As rochas metabásicas inseridas nos ortognaisses do Complexo Mantiqueira e rochas charnockíticas associadas apresentam a associação Grt-Cpx-Pl-Qtz $\pm O p x+H b l$, que é diagnóstica do fácies granulito de alta pressão. São caracterizadas pela presença de texturas coroníticas progressivas de Grt-Cpx-Pl-Qtz nos contatos entre Opx, Pl e/ou opacos, aparentemente de origem ígnea, que marca a passagem do campo dos granulitos de pressão intermediária para o campo dos granulitos de alta pressão. As condições de pico registradas nos veios constituídos por Grt-Cpx-Pl nos metagabronoritos é de $831.8^{\circ} \mathrm{C}$, a 10 kbar. $\mathrm{O}$ granada granulito registra o pico metamórfico a $890 \pm 41^{\circ} \mathrm{C}$, a $9.26 \pm 1.93$ kbar. Cálculos realizados no TWEEQU forneceram condições de equilíbrio de $801^{\circ} \mathrm{C}$, a $9.6 \mathrm{kbar}$ para a associação de fácies granulito. As condições de pico bárico nas rochas charnockíticas são de $14.36 \pm 1.9$ kbar, a $680^{\circ} \mathrm{C}$, enquanto que as temperaturas máximas registradas são de $885.17^{\circ} \mathrm{C}$, a $10 \mathrm{kbar}$. Cálculos realizados no THERMOCALC forneceram temperatura de $771 \pm 166^{\circ} \mathrm{C}$, a $11.8 \pm 2.4 \mathrm{kbar}$. As rochas metabásicas relacionadas ao Complexo Mantiqueira apresentam baixas concentrações de elementos LILE, possivelmente devido ao empobrecimento destes elementos durante o metamorfismo através de perdas por reações de desidratação. Os dados geoquímicos 
apontam fontes do tipo E-MORB para grande parte das rochas metabásicas, embora sempre com enriquecimento em ETR maior, o que é sugestivo de fontes enriquecidas. O Grt-cpx anfibolito simplectítico apresenta assinaturas geoquímicas distintas, com enriquecimento maior em elementos LILE e ETRL, o que sugere uma origem a partir de fontes OIB. Os padrões de ETR e diagramas de variação multi-elementares de elementos traço sugerem que as rochas charnockíticas têm fontes relacionadas à ambientes de arco vulcânico. Os paragnaisses, em fácies anfibolito superior a granulito, registram uma trajetória inicial horária, descompressiva ao campo da sillimanita. É distinta da trajetória inicial anti-horária exibida pelas rochas metabásicas e charnockíticas, que registram nas coronas de Grt-Cpx-Pl o metamorfismo progressivo de fácies granulito de alta pressão. Sugere-se que esse relativo aumento de pressão tenha sido condicionado pela colocação dos metassedimentos da Nappe Lima Duarte sobre as rochas do Complexo Mantiqueira, porém no mesmo campo de temperatura. Assim, o avanço da nappe metassedimentar pode ter sido responsável pelo soterramento das rochas metabásicas e charnockíticas relacionadas com o Complexo Mantiqueira, o que justifica a pressão mais elevada nestes litotipos. A etapa de exumação foi compartilhada por ambas, o que é evidenciado nas semelhanças de condições metamórficas durante a trajetória de resfriamento quase isobárico, porém com os litotipos do Complexo Mantiqueira em nível crustal mais profundo.

Palavras-chave: Nappe Lima Duarte; Complexo Mantiqueira; texturas coroníticas; metamorfismo; fácies granulito 


\begin{abstract}
The Lima Duarte Nappe is located in southeastern Brasília Orogen and is composed by migmatitic paragneisses presenting garnet, sillimanite, biotite and muscovite, and coarse-grained orthoquartzites, with few amphibolite and calc-silicate interlayers. The Mantiqueira Complex occurs as tectonic imbricated lenses in the Lima Duarte Nappe, resembling an allochthon structure. It comprises TTG-type migmatitic and polymetamorphic orthogneisses, presenting granulitic metabasic interlayers, as mafic bands and lenses, as well as boudins, which are often concordant with the main foliation. Charnockitic rocks are apparently intrusive in the Mantiqueira orthogneisses, with associated metabasic rocks. The mineral assemblage observed in paragneisses (Grt $+\mathrm{Bt}+\mathrm{Sil}+\mathrm{Pl}+\mathrm{Rt}+\mathrm{Ilm}+\mathrm{Qtz} \pm \mathrm{Ms} \pm \mathrm{Kfs} \pm \mathrm{Ky}$ ) is related to an upper amphibolite facies progressive metamorphism characterized by muscovite breakdown reactions producing potassic feldspar. The peak baric conditions obtained in the THERMOCALC processing software for the assemblage involving kyanite are $10 \pm 0.6 \mathrm{kbar}$ and $807 \pm$ $25^{\circ} \mathrm{C}$. The thermal peak of $827 \pm 44^{\circ} \mathrm{C}$ and $8.2 \pm 1.8 \mathrm{kbar}$ obtained in THERMOCALC for the assemblage envolving sillimanite, is placed in the boundary of breakdown curve for dumortierite. The metabasic rocks interlayered in Mantiqueira Complex orthogneisses show the Grt-Cpx-Pl-Qtz $\pm \mathrm{Opx}+\mathrm{Hbl}$ assemblage, indicating high pressure granulite facies. They are characterized by the presence of Grt-Cpx-Pl progressive coronitic textures between Opx, Pl and/or opaques boundaries, apparently with an igneous origin, which marks the transitions from intermediate pressure granulites field to high pressure granulite field. The peak conditions recorded in Grt-Cpx-Pl veins in metagabbronorites is $831.8^{\circ} \mathrm{C}$, and $10 \mathrm{kbar}$. The garnet granulite records the metamorphic peak at $890 \pm 41^{\circ} \mathrm{C}$, and $9.26 \pm 1.93 \mathrm{kbar}$. Thermobarometric calculations performed at TWEEQU revealed equilibrium conditions at $801^{\circ} \mathrm{C}$, and $9.6 \mathrm{kbar}$ based on granulite facies mineral assemblage. The peak baric conditions achieved by the charnockitic rocks are $14.36 \pm 1.9 \mathrm{kbar}$, and $680^{\circ} \mathrm{C}$, while maximum temperatures recorded are $885.17^{\circ} \mathrm{C}$, and $10 \mathrm{kbar}$. Thermobarometric calculations performed at THERMOCALC revealed temperatures of $771 \pm 166^{\circ} \mathrm{C}$, and $11.8 \pm 2.4 \mathrm{kbar}$. The metabasic rocks related to Mantiqueira Complex show low concentrations of LILE elements, possibly due to the depletion of these elements during metamorphism in dehydrating reactions. Geochemical data point out to E-MORB type sources for the great majority of metabasic rocks, even though with an REE enrichment, suggesting
\end{abstract}


more enriched sources. The symplectitic Grt-Cpx amphibolite show distinct geochemical signatures, characterized by a greater enrichment in LILE and light-REE elements, suggesting an OIB source for their origin. REE patterns and trace element spidergrams suggest that charnockitic rocks sources are related to a volcanic arc tectonic setting. Paragneisses, in upper amphibolite to granulite facies, recorded an initial clockwise path, decompressing to the sillimanite field. It differs from initial counterclockwise path exhibited by the metabasic and charnockitic rocks, which preserves the progressive high pressure granulite facies metamorphism in Grt-Cpx-Pl coronae. This pressure increase is probally related to the metassediments of the Lima Duarte Nappe, that thrusted over the Mantiqueira Complex rocks, although in the same temperature field. The buried character of metabasic and charnockitic rocks may be caused by the thrust of the metassedimentary nappe, justifying the higher pressure found in these lithotypes. The exhumation phase was shared by both of them, which is confirmed in the metamorphic similarities conditions, as they cooled out together in a near isobaric path, although the Mantiqueira Complex lithotypes were in a deeper crustal level.

Key-words: Lima Duarte Nappe; Mantiqueira Complex; coronitic textures; metamorphism; granulite facies 
1. INTRODUÇÃ

2. OBJETIVOS …….......................................................................................................... 3

3. LOCALIZAÇÃO E ACESSOS .............................................................................. 5

4. MATERIAIS E MÉTODOS.................................................................................... 5

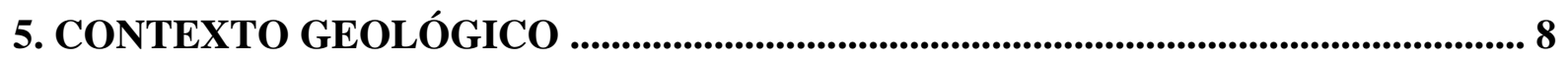

5.1 Trabalhos anteriores ............................................................................................................... 8

5.2 Orógeno Brasília Meridional .............................................................................................. 10

5.3 A Nappe Lima Duarte e o Complexo Mantiqueira ....................................................... 14

6. DESCRIÇÃO DAS UNIDADES TECTÔNICAS ............................................................ 18

6.1 NAPPE ANDRELÂNDIA .................................................................................... 18

6.1.1 Granada-biotita-plagioclásio-quartzo xisto homogêneo (Xisto Santo Antônio) ……............................................................................................................................ 18

6.1.2 Granada-sillimanita-muscovita-biotita-quartzo xisto e Muscovita-biotita gnaisse com sillimanita ............................................................................................ 18

6.2 NAPPE LIMA DUARTE ............................................................................................ 19

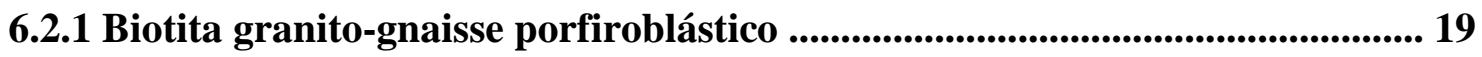

6.2.2 Granada-biotita gnaisse metatexítico ................................................................ 20

6.2.3 Sillimanita-granada-biotita gnaisse metatexítico, sillimanita-granada-biotita gnaisse porfiroblástico com cianita e biotita-sillimanita gnaisse com muscovita e dumortierita ......................................................................................................................... 21

6.2.4 Gnaisse calciossilicáticos ........................................................................................... 23

6.2.5 Rochas metabásicas .................................................................................................. 24

6.2.6 Quartzito com muscovita ...................................................................................... 25

6.2.7 Granada-sillimanita-biotita-muscovita-quartzo xisto e sillimanita-granadabiotita gnaisse quartzoso ...................................................................................................... 26

6.3 COMPLEXO MANTIQUEIRA ......................................................................... 27

6.3.1 Rochas charnockíticas ............................................................................................ 28

6.3.2 Ortognaisses ................................................................................................................ 34

6.3.3 Rochas metabásicas ............................................................................................... 36

6.3.4 Rochas metaultramáficas ................................................................................. 42 
7.1 Estruturação da área ................................................................................................. 52

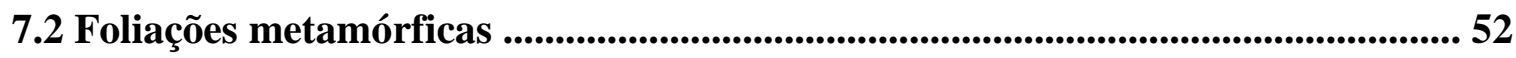

7.3 Lineações, indicadores cinemáticos e boudinagem .................................................. 55

7.4 Aspectos da microtectônica .............................................................................56

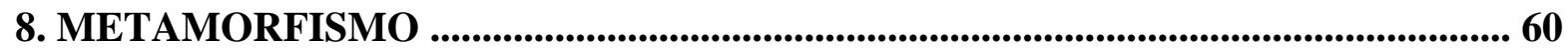

8.1 TEXTURAS E PARAGÊNESES ..........................................................................6 60

8.1.1 Considerações iniciais ........................................................................................60 60

8.1.2 Paragnaisses da Nappe Lima Duarte ..........................................................62 62

8.1.3 Rochas metabásicas inseridas nos ortognaisses do Complexo Mantiqueira 69

8.1.4 Rochas charnockíticas do Complexo Mantiqueira ........................................... 75

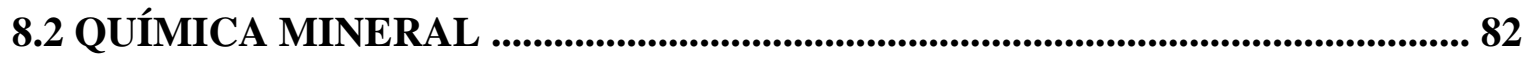

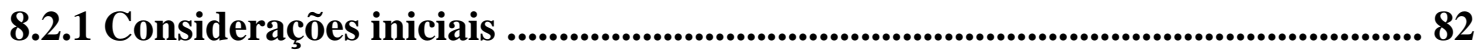

8.2.2 Paragnaisses ......................................................................................................................... 82

8.2.3 Rochas metabásicas ....................................................................................... 92

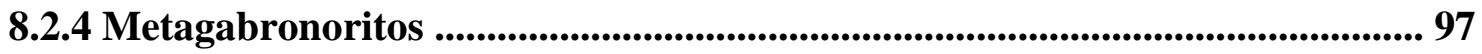

8.2.5 Rochas charnockíticas ................................................................................................... 107

8.3 GEOTERMOBAROMETRIA ....................................................................................... 120

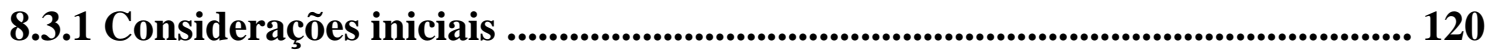

8.3.2 Diagramas de compatibilidade ..................................................................... 121

8.3.3 Geotermobarometria dos paragnaisses ................................................................... 124

8.3.4 Geotermobarometria das rochas metabásicas ................................................ 130

8.3.5 Geotermobarometria das rochas charnockíticas ............................................... 136

8.4 EVOLUÇÃO METAMÓRFICA .................................................................... 139

8.4.1 Considerações iniciais ...................................................................................... 139

8.4.2 Paragnaisses ............................................................................................................................ 140

8.4.3 Rochas metabásicas ................................................................................. 143

8.4.4 Rochas charnockíticas ........................................................................................................ 148

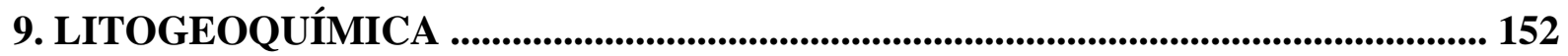

9.1 Considerações iniciais ............................................................................... 152

9.2 Grupos de rochas metabásicas e rochas charnockíticas ....................................... 153

9.3 Rochas metabásicas ............................................................................................... 156

9.3.1 Classificação das rochas metabásicas .......................................................................... 156 
9.3.2 Elementos maiores, menores e traço .............................................................. 162

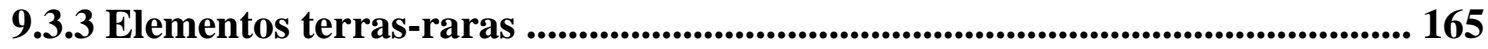

9.4 Rochas charnockíticas/enderbíticas .................................................................... 168

9.4.1 Classificação das rochas charnockíticas ...................................................... 168

9.4.2 Elementos maiores, menores e traço .......................................................................... 170

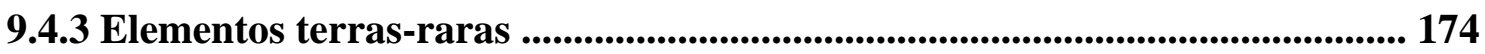

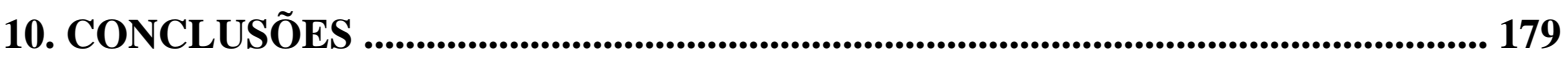

11. REFERÊNCIAS BIBLIOGRÁFICAS ......................................................................... 183

\section{ÍNDICE DE FIGURAS}

Figura 1: Localização da área da área de estudo...................................................................

Figura 2: Mapa tectônico da extensão sul do Orógeno Brasília.............................................11

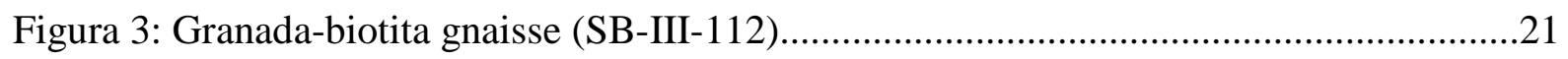

Figura 4: Sillimanita-granada-biotita gnaisse porfiroblástico (SB-IX-108)............................23

Figura 5: Topo da Serra de Lima Duarte e Topo da Serra do Pilão, sustentadas por

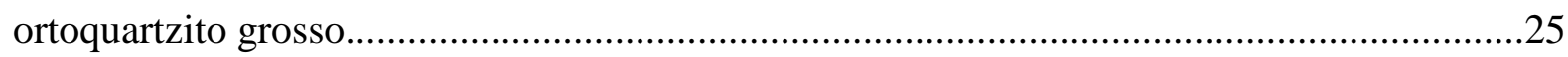

Figura 6: Depósito de talus no sopé da Serra Negra e Sil-Grt-Bt gnaisse quartzoso (SB-VII-

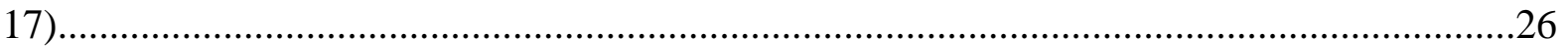

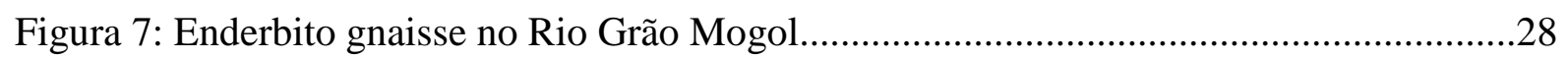

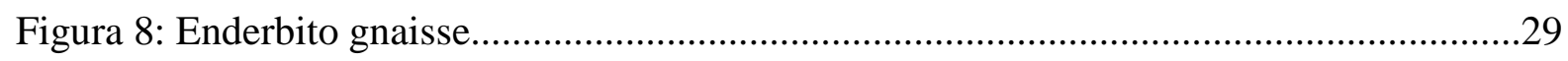

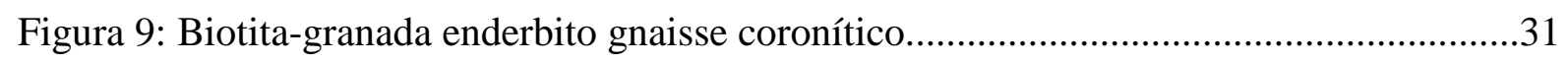

Figura 10: Estrutura bandada em meta-charnockito e dobra isoclinal em biotita gnaisse com intercalações de rochas metabásicas (SB-VII-16)................................................................

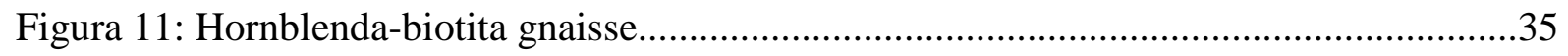

Figura 12: Boudins de rocha metabásica, com anatexia associada (NLD-40).......................36

Figura 13: Sillimanita-granada-biotita gnaisse metatexítico em contato tectônico sobre o sillimanita-granada-biotita gnaisse quartzoso, na Serra da Saudade.....................................52

Figura 14: Foliação principal paralela ao bandamento gnáissico em Hbl-Bt gnaisse..............53

Figura 15: Hornblenda-biotita gnaisse migmatítico, dobrado e dobras isoclinais em

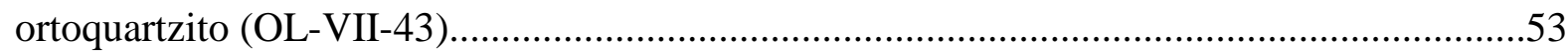

Figura 16: Megadobra recumbente na Serra Negra (quartzitos e paragnaisses)......................54 
Figura 17: Dobra isoclinal em sillimanita-granada-biotita gnaisse quartzoso (SB-VII-17), com a superfície $S_{1}$ paralela à foliação principal $S_{2}$.

Figura 18: Dobras intrafoliais em leucossoma com flanco rompido, em biotita gnaisse.........54

Figura 19: Clivagem espaçada pós-S ${ }_{2}$ em quartzito.

Figura 20: Mullion de banda félsica quartzo-feldspática e foliação milonítica principal em zona de transposição da $\mathrm{S}_{2}$ com dobras intrafoliais, em biotita gnaisse. .55

Figura 21: Boudins de rocha metabásica de dimensões variadas, com anatexia associada....56

Figura 22: Zona de cisalhamento com transporte de topo para sul, em sillimanita-granadabiotita gnaisse quartzoso (SB-VII-17).

Figura 23: Porfiroblasto de granada, com inclusões de Ky, Bt, MS, Sil, Kfs, Ilm e Zrc. Amostra OL-II-112B. .62

Figura 24: Leitos de dimensão milimétrica a subcentimétrica com concentração de Grt......70

Figura 25: Detalhe de um veio constituído por Grt intercrescida com Cpx, Qtz e opacos, com leito contínuo de quartzo no centro (NLD-42D). .71

Figura 26: Corona de Grt ao redor de Pl, no contato com o Cpx e os opacos .72

Figura 27: Corona de Grt ao redor dos opacos e do Opx, no contato com o Pl, com Kfs no contato entre a Grt e o Pl. .72

Figura 28: Corona de Grt ao redor de Pl, no contato com o Cpx e os opacos .73

Figura 29: Corona poliminerálica, com Opx manteado por Grt+Qtz, por opacos, seguida por corona de Grt no contato com o Pl. .73

Figura 30: Corona poliminerálica, com Opx manteado por Grt+Qtz, por opacos, seguida por corona de Grt no contato com o Pl. .74

Figura 31: Corona de Grt ao redor de Pl, no contato com os opacos.......................................75

Figura 32: Intercrescimento esqueletal de $\mathrm{Bt}+$ Qtz substituindo o ortopiroxênio. .76

Figura 33: Megacristais de ortopiroxênio parcialmente substituídos por Bt \pm Qtz, com coronas de Grt + Cpx \pm Qtz no contato com o plagioclásio...... .77

Figura 34: Corona de Grt $+\mathrm{Cpx} \pm \mathrm{Qtz}$ ao redor de Pll, no contato entre o ortopiroxênio e o plagioclásio (NLD-45B)..... .78

Figura 35: Mapa geológico da Nappe Lima Duarte com a localização das amostras com análises de microssonda eletrônica e microscópio eletrônico de varredura (MEV).

Figura 36: Seção química de granada, em perfil longitudinal e em perfil transversal .84

Figura 37: Fotomicrografia e mapas de concentração de elementos. .85

Figura 38: Mapas de concentração de elementos. .86

Figura 39: Imagem retroespalhada de Grt e composição falsa-cor RGB. .87 


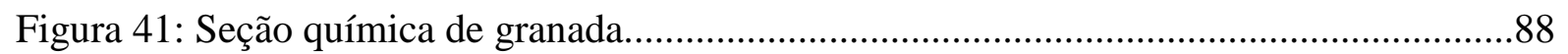

Figura 42: Diagrama para classificação de feldspatos............................................................89

Figura 43: Diagrama para classificação de biotita.................................................................90

Figura 44: Inclusões de rutilo ao longo de fraturas em porfiroblasto de granada....................92

Figura 45: Seção química de plagioclásio...........................................................................94

Figura 46: Diagrama para classificação de feldspatos........................................................95

Figura 47: Diagrama para classificação de ortopiroxênios.....................................................95

Figura 48: Diagrama para classificação de clinopiroxênios...................................................96

Figura 49: Diagrama de classificação para o grupo de anfibólios cálcicos............................97

Figura 50: Seções químicas em cristal de granada, plagioclásio e clinopiroxênio..................99

Figura 51: Seção química de granada, ao longo de em veio composto por granada + clinopiroxênio + opacos \pm quartzo \pm plagioclásio............................................................. 100

Figura 52: Diagrama para classificação de feldspatos........................................................101

Figura 53: Perfil composicional em cristal de plagioclásio e de ortopiroxênio coronítico....102

Figura 54: Perfil composicional em cristal de plagioclásio coronítico...................................103

Figura 55: Diagrama para classificação de ortopiroxênios.....................................................103

Figura 56: Seção química em cristal de ortopiroxênio coronítico..........................................104

Figura 57: Seção química em cristal de ortopiroxênio.........................................................105

Figura 58: Diagrama para classificação de clinopiroxênios ................................................ 105

Figura 59: Seção química em cristal de clinopiroxênio da matriz.........................................106

Figura 60: Diagrama de classificação para o grupo de anfibólios cálcicos.............................107

Figura 61: Perfil composicional em cristal de granada.........................................................109

Figura 62: Perfil composicional em cristal de granada........................................................110

Figura 63: Perfil composicional em cristal de granada..........................................................111

Figura 64: Diagrama para classificação de feldspatos.........................................................113

Figura 65: Perfil composicional em cristal de plagioclásio da matriz...................................113

Figura 66: Diagrama para classificação de ortopiroxênios......................................................114

Figura 67: Perfil composicional em cristal de ortopiroxênio ígneo reliquiar.........................115

Figura 68: Diagrama para classificação de clinopiroxênios....................................................116

Figura 69: Diagrama para classificação de biotita................................................................117

Figura 37: Diagrama de classificação para o grupo de anfibólios cálcicos............................118

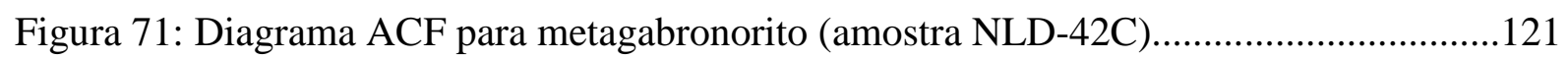

Figura 72: Diagrama ACF para metagabronorito (amostra NLD-42D)..............................122

Figura 73: Diagrama ACF para metacharnockito anidro (amostra NLD-45B).....................123 
Figura 74: Diagrama ACF para metacharnockito hidratado (amostra NLD-45D)................123

Figura 75: Diagrama ACF para metacharnockito hidratado (amostra NLD-45D).................124

Figura 76: Dados P-T dos paragnaisses obtidos no THERMOCALC ...................................125

Figura 77: Gráfico de temperatura versus ppm $\mathrm{Zr}$ com os resultados da termometria de $\mathrm{Zr}$ no

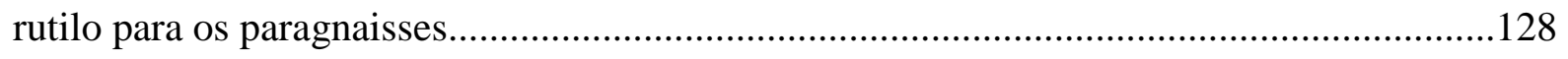

Figura 78: Dados P-T das rochas metabásicas obtidos no THERMOCALC.........................131

Figura 79: Dados P-T para granada granulito obtidos no TWEEQU (amostra NLD-7D).....132

Figura 80: Dados P-T das rochas charnockíticas obtidos no THERMOCALC......................137

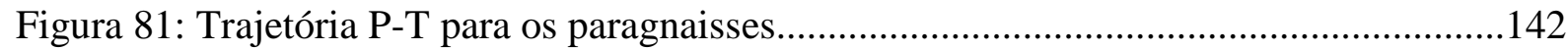

Figura 82: Grid P-T com os dados de temperatura e pressão das rochas metabásicas e rochas charnockíticas.

Figura 83: Trajetória P-T para as rochas metabásicas...................................................... 147

Figura 84: Trajetória P-T para as rochas charnockíticas....................................................149

Figura 85: Mapa geológico da Nappe Lima Duarte com a localização das amostras com análises geoquímicas

Figura 86: Diagrama de classificação de rochas gabróicas e diagrama QAP com os nomes das rochas na série charnockítica.

Figura 87: Diagrama de classificação de rochas vulcânicas e diagrama binário FeOt/Mg vs. $\mathrm{SiO}_{2}$

Figura 88: Diagrama ternário AFM, diagrama discriminatório [Ti-Zr-Sr], [Ti-Zr-Y] e diagrama de classificação de granulitos félsicos e intermediários $\left[\mathrm{CaO}-\mathrm{Na}_{2} \mathrm{O}-\mathrm{K}_{2} \mathrm{O}\right]$..... 158 Figura 89: Diagramas de Harker dos elementos maiores (expressos em \% peso) para as rochas metabásicas.

Figura 90: Diagramas de Harker dos elementos maiores (expressos em \% peso) para as rochas metabásicas. .160

Figura 91: Diagramas de Harker dos elementos menores e traço (expressos em ppm) para as rochas metabásicas. 161

Figura 92: Diagrama multi-elementar das rochas metabásicas, normalizadas pelo manto primitivo de Sun \& Mc Donough (1989), comparados com os padrões OIB, E-MORB e NMORB

Figura 93: Padrões de ETR das rochas metabásicas, normalizados ao condrito de Taylor \& Mc Lennan (1985). 166

Figura 94: Padrões de ETR das rochas metabásicas normalizados ao condrito comparados com os padrões OIB, E-MORB e N-MORB. .166 
Figura 95: Diagrama de classificação de rochas plutônicas. 170

Figura 96: Diagramas de Harker dos elementos maiores para as rochas charnockíticas.......172 Figura 97: Diagramas de Harker dos elementos menores e traço para as rochas charnockíticas. .173

Figura 98: Diagrama multi-elementar das rochas charnockíticas, normalizadas pelo manto primitivo de Sun \& Mc Donough (1989).....

Figura 99: Diagrama multi-elementar das rochas charnockíticas, normalizadas pelo manto primitivo de Taylor \& Mc Lennan (1985)...... .174

Figura 100: Padrões de ETR das rochas charnockíticas, normalizados ao condrito 176 Figura 101: Diagrama binário de ETR total vs. $\mathrm{SiO}_{2}$ para as rochas charnockíticas e diagramas de ETR normalizados ao condrito comparados com os padrões de ETR do charnockito de Louis Lake. 176

Figura 102: Diagramas de variação multi-elementar para as rochas charnockíticas, normalizados para o ORG. 177

\section{ÍNDICE DE TABELAS}

Tabela 1: Resultados dos cálculos termobarométricos obtidos no THERMOCALC para os paragnaisses. .124

Tabela 2: Resultados obtidos através do geotermômetro granada-biotita (Grt-Bt)...... 127

Tabela 3: Resultados obtidos com a termometria de zircônio no rutilo para a amostra OL-II112B. 128

Tabela 4: Resultados obtidos com a termometria de zircônio no rutilo para a amostra OL-III39A. 129

Tabela 5: Resultados obtidos através do geobarômetro granada-aluminossilicato-quartzoplagioclásio (GASP).

Tabela 6: Resultados dos cálculos termobarométricos obtidos no THERMOCALC para as rochas metabásicas..

Tabela 7: Resultados dos cálculos obtidos através do termômetro granada-clinopiroxênio e do barômetro granada-clinopiroxênio-plagioclásio para as rochas metabásicas... .134

Tabela 8: Resultados dos cálculos termobarométricos obtidos no THERMOCALC para as rochas charnockíticas. 138 
Tabela 9: Resultados dos cálculos obtidos através do termômetro granada-clinopiroxênio e do barômetro granada-clinopiroxênio-plagioclásio para as rochas

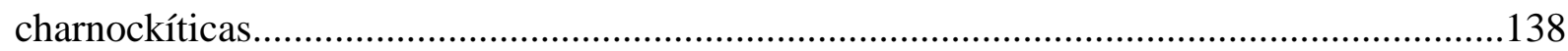

Tabela 10: Resultados analíticos de geoquímica de rocha-total por FRX e ICP-MS.............162

Tabela 11: Análises de elementos terras-raras normalizadas ao condrito...............................168

\section{ÍNDICE DE PRANCHAS DE FOTOMICROGRAFIAS}

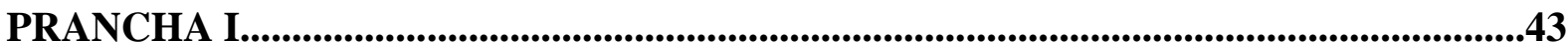

PRANCHA II.......................................................................................................................................44

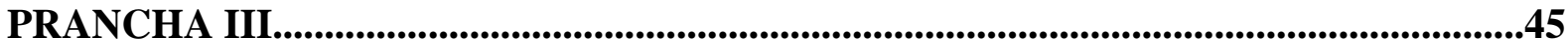

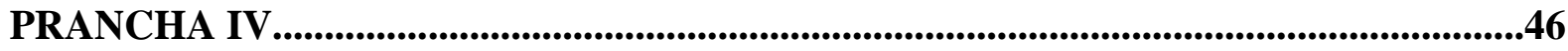

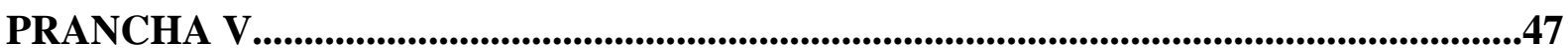

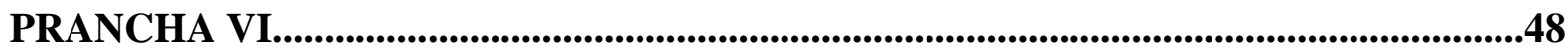

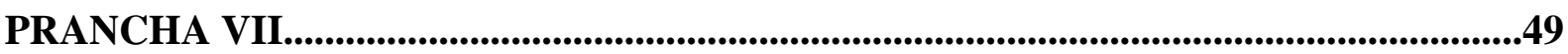

PRANCHA VIII......................................................................................................................50

PRANCHA IX.............................................................................................................................................51

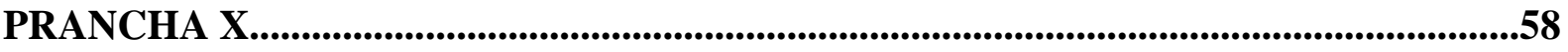

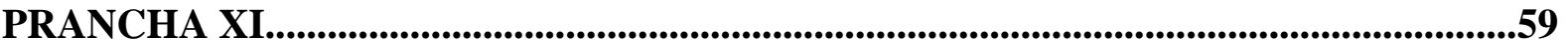

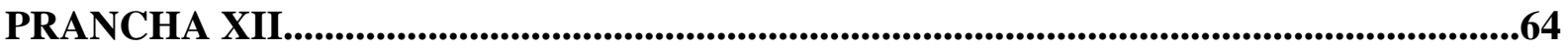

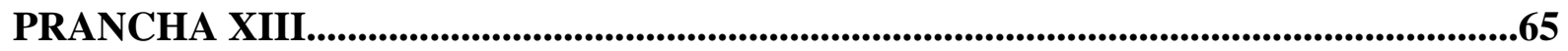

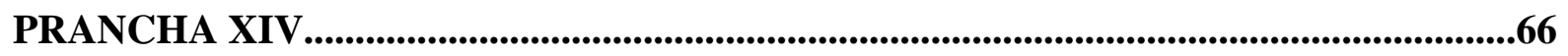

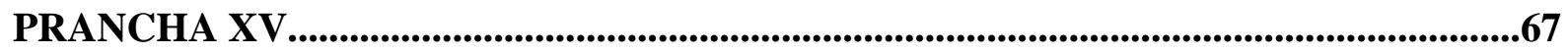

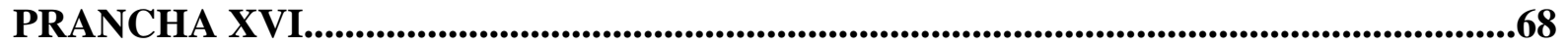

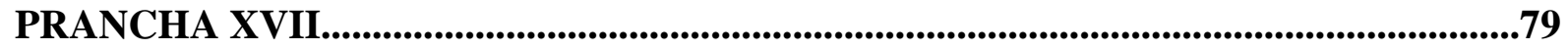

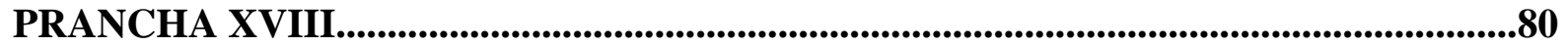

\section{ANEXOS}

ANEXO I - MAPA GEOLÓGICO

ANEXO II - TABELA DE PONTOS

ANEXO III - TABELAS DE ANÁLISES QUÍMICAS 



\section{INTRODUÇÃO}

A natureza e a composição da crosta inferior podem ser inferidas através do estudo de rochas em fácies granulito (Harley, 1989; Bohlen, 1991). Os dados geológicos e geoquímicos provenientes dos granulitos também fornecem informações relacionadas aos processos tectônicos responsáveis pela formação e evolução da crosta continental.

Os cenários tectônicos possíveis para a formação de granulitos de alta pressão são: orógenos colisionais ou granulitos de alta pressão formados na base de crosta continental com espessura "normal" e que foram exumados por um processo não-relacionado à sua formação (Baldwin et al., 2003). Os orógenos colisionais, como o Variscides (Vielzeuf \& Pin, 1989; Carswell \& O’Brien, 1993), a Província Greenville (Indares, 1995; Indares \& Dunning, 2001), os Himalaias (Liu \& Zhong, 1997) e o Complexo Hengshan na China (Zhao et al., 2001) são caracterizados por exumação relativamente rápida, posterior ao pico metamórfico (Indares \& Dunning, 1997; Kröner et al., 2000). Já os granulitos formados na base da crosta continental, registram uma perturbação termal na base da crosta seguida por resfriamento isobárico em direção à geoterma cratônica, como em Ivrea Zone (Zingg, 1991). Terrenos metamórficos formados sob condições de fácies granulito foram descritos em diversas localidades ao redor do mundo. No Brasil ocorrem extensas áreas de terrenos metamórficos de alto grau, passíveis de serem investigados e que podem potencialmente contribuir no conhecimento da evolução da crosta continental na América do Sul, conseqüentemente contribuindo para avançar no conhecimento da evolução do Gondwana.

A área de estudo está inserida na porção oriental do Sistema Orogênico Brasília Meridional (Campos Neto et al., 1999). Na Nappe Lima Duarte, no sul de Minas Gerais, ocorrem paragnaisses migmatíticos em trajetórias descompressivas ao campo da sillimanita e granulitos máficos com granada, clinopiroxênio, biotita e eventualmente ortopiroxênio, associados à ortognaisses migmatíticos tipo TTG, além de rochas charnockíticas, aparentemente com a estrutura original ígnea preservada. Esta associação pode representar o empilhamento por colisão de rochas de crosta continental subductada a níveis profundos. A Nappe Lima Duarte está relacionada ao domínio de margem passiva e registra a colisão da Placa Paranapanema com a Placa Sanfranciscana durante a Colagem Brasiliana, no Neoproterozóico (Campos Neto et al., 2004). Na região de Lima Duarte, os ortognaisses ocorrem na forma de lascas tectônicas imbricadas na Nappe Lima Duarte, configurando um embasamento alóctone (Campos Neto et al., 2004). 
A composição química responsável por assembléias minerais pouco reativas dos ortognaisses (apesar de intensamente anatéticos) dificulta o estudo das condições do auge metamórfico, além de possuir um caráter mais antigo (Arqueano-Paleoproterozóico) e polimetamórfico. Os corpos métricos de anfibolitos e de granulitos máficos, disruptos no interior destas rochas e ausentes na "cobertura" metassedimentar alóctone, oferecem paragêneses e texturas de reação passíveis de serem investigadas termodinamicamente. Os estudos da formação de metagabros coroníticos e eclogitos têm contribuído no entendimento de processos metamórficos em níveis crustais profundos durante colisão continental (Cox \& Indares, 1999). Rochas máficas anidras e pouco deformadas tendem a preservar associações de alta pressão.

Os paragnaisses da capa alóctone metassedimentar registram as condições $P-T$ do estágio de descompressão (zona da sillimanita em presença de feldspato potássico) e uma trajetória quase isobárica de resfriamento. A ausência de ortopiroxênio nos paragnaisses e a presença de dumortierita associada à sillimanita (Rocha, 2008), sugerem que essas condições obtidas encontram-se próximas ao pico térmico do metamorfismo (segundo as grades petrogenéticas de Vielzeuf \& Holloway, 1988; Le Breton \& Thompson, 1988; Vielzeuf \& Montel, 1994; Patiño Douce \& Beard, 1996; Werding \& Schreyer, 1996). No entanto a presença de inclusões de cianita em granadas e, mais na retaguarda da nappe, a presença de cianita, em diferentes estágios de crescimento, livres na matriz, indica que as condições de mais alta pressão não foram ainda obtidas.

Os mecanismos de exumação destas unidades, que apesar de registrarem distintas condições $P-T$ quando mais próximas do pico metamórfico e de compartilharem a trajetória de resfriamento em uma mesma profundidade na crosta (no domínio estudado), são temas fundamentais para o estudo da extrusão do prisma de colisão e do comportamento mecânico e térmico do limite crosta-manto durante a orogênese. As rochas metabásicas, apesar de inseridas em um contexto geológico mais antigo, possuem, em muitos afloramentos, texturas ígneas hipidiomórficas preservadas, sugerindo (juntamente com a assinatura química de toleítos intraplacas) uma colocação por intrusões profundas, sin-orogênicas (Rocha, 2007). As rochas enderbíticas com granada apresentam texturas coroníticas semelhantes àquelas que ocorrem nas rochas metabásicas, e assim, através de um estudo detalhado de petrografia, química mineral e litogeoquímica é possível comparar e estabelecer uma relação entre ambas. A capa sedimentar, submetida a altas temperaturas e pressões (estas, superiores aos resultados já obtidos), pode ter sido subductada a profundidades do manto litosférico. Como possui uma densidade relativa menor que a do manto, o maior volume da pilha sedimentar tende a ser 
expulsa, em profundidades menores, da placa em subducção; ou, em profundidades superiores a $100 \mathrm{~km}$, tendem a descolar do manto, como uma pluma, e ser injetada na base da litosfera da placa superior (Currie et al., 2007).

\section{OBJETIVOS}

O principal objetivo deste trabalho consiste na caracterização geológica e petrológica dos litotipos da Nappe Lima Duarte (com enfoque nos paragnaisses), das rochas metabásicas inseridas no Complexo Mantiqueira e das rochas charnockíticas associadas. Foi realizado um estudo detalhado de petrografia, petrologia metamórfica, química mineral quantitativa e qualitativa, cálculos termobarométricos, além de litogeoquímica, ferramentas fundamentais para estabelecer uma relação entre os litotipos, na tentativa de compreender melhor a evolução metamórfica na porção sul da Faixa Brasília, próxima ao limite com o Cráton do São Francisco.

O mapa geológico apresentado é compilado de trabalhos anteriores, sendo baseado principalmente na integração geológica na escala 1:50 000 (Bendoraitis, 2007) de uma área que abrange parte das cartas topográficas de Bom Jardim de Minas, Lima Duarte, e Santa Bárbara do Monte Verde (1:50 000, IGBE - 1975), no domínio da Nappe Lima Duarte e porção leste da Nappe Andrelândia. Esta integração foi feita a partir dos dados de mapeamento na escala 1:25 000, coletados por alunos e pelos docentes responsáveis da disciplina Mapeamento Geológico (Professores doutores Marcos Egydio da Silva, Maria da Glória Motta Garcia, Mario da Costa Campos Neto, Miguel Ângelo Stipp Basei, Oswaldo Siga Junior e Renato Moraes), ministrada no IGc-USP, em 2006 e 2007, da qual participei como aluna/bolsista de iniciação científica e monitora da graduação (Projetos Olaria e Santa Bárbara). A área que abrange parcialmente as cartas topográficas de Lima Duarte e Ewbank da Câmara (1:50 000, IBGE - 1975), no domínio das rochas do embasamento (Complexo Mantiqueira) e das rochas charnockíticas/enderbíticas associadas, foi compilada do mapa geológico 1:50 000 da região de Lima Duarte (Campos Neto et al., 1996a). O mapa é resultado da integração geológica dos mapeamentos na escala 1:25 000 realizados nas disciplinas Geologia de Campo e de Desenho e Mapeamento Geológico, ministradas no IGcUSP em 1994, que tiveram como responsáveis os seguintes docentes: Mario da Costa Campos Neto, Miguel Ângelo Stipp Basei e Oswaldo Siga Junior (Projeto Lima Duarte). Também foram utilizados mapas geológicos prévios (Duarte, 1998; Paciullo et al., 2002), bem como a 
Folha Lima Duarte (Carta Geológica SF-23-X-C-VI), escala 1:100 000, DNPM/CPRM (Pinto et al., 1991).

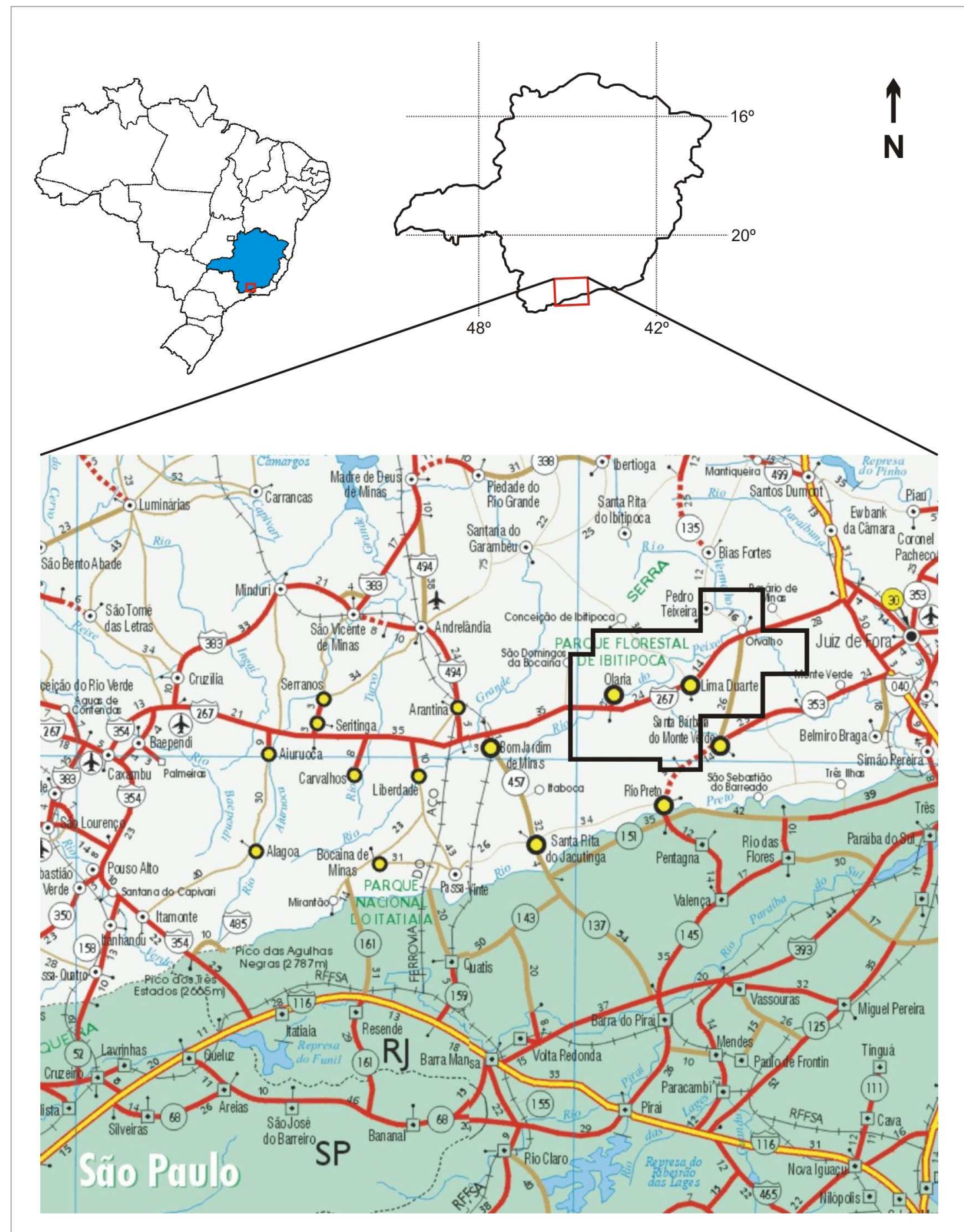

Figura 1: Localização da área de estudo (Fonte: DER, 2007). 


\section{LOCALIZAÇÃO E ACESSOS}

A área de estudo situa-se no sudeste do Estado de Minas Gerais, próximo à divisa com o Estado do Rio de Janeiro, e abrange os municípios de Lima Duarte, Olaria, Orvalho, Pedro Teixeira e São Sebastião do Monte Verde (Figura 1). É delimitada pelas coordenadas 7568000/7602000 e 606000/648000 na zona 23S (Córrego Alegre) e abrange parte das cartas topográficas de Ewbank da Câmara (SF-23-X-C-VI-2), Lima Duarte (SF-23-X-C-VI-3) e Santa Bárbara do Monte Verde (SF-23-X-C-VI-4), escala 1:50 000, do Instituto Brasileiro de Geografia e Estatística (IGBE), 1975.

O acesso a partir da cidade de São Paulo é feito através da Rodovia Presidente Dutra (BR-116) até o trevo de Cruzeiro, rodovia SP-52 até Passa Quatro, rodovia MG-158 até Pouso Alto, BR-354 até Caxambu, BR-267, sentido Juiz de Fora, até o trevo de Lima Duarte.

\section{MATERIAIS E MÉTODOS}

- Realização do levantamento bibliográfico do contexto geológico regional e da temática abordada, com a finalidade de fundamentar os principais conceitos, sendo os principais: petrologia, química mineral, geotermobarometria, evolução metamórfica e litogeoquímica;

- Realização de trabalhos de campo nas folhas Ewbank da Câmara (SF-23-X-C-VI-2), Lima Duarte (SF-23-X-C-VI-3) e Santa Bárbara do Monte Verde (SF-23-X-C-VI-4), escala 1:50 000 - IGBE (1975), para levantamento de uma seção geológica contínua e na escala 1:50 000 através de toda a nappe, com coleta de amostras e obtenção de dados estruturais;

- Petrografia macroscópica e microscópica, que incluíram a descrição de aproximadamente 65 afloramentos para identificação da mineralogia, texturas e estruturas. Foi feita a seleção de amostras de rochas e de feições litológicas e texturais para estudos de petrografia microscópica, química mineral, geotermobarometria e litogeoquímica. Foram descritas 60 seções delgadas, utilizando os microscópios ZEISS (Axioplan) e OLYMPUS (BXP-50) do Laboratório de Microscopia Petrográfica (LMP) e OLYMPUS (BXP-40) do Laboratório Didático de Microscopia Petrográfica (LDMP), Instituto de Geociências, Universidade de São Paulo;

- Realização de tingimento diferencial de minerais através da coloração de feldspatos alcalinos em 6 fatias de rocha de aproximadamente $15 \times 10 \mathrm{~cm}$, de acordo com o método descrito por Sandra Andrade, revisto por Horstpeter Ulbrich (1998), no Laboratório de Tratamento de Amostras (LTA), Instituto de Geociências, Universidade de São Paulo. Este procedimento é indicado para colorir os feldspatos potássicos em fatias de rocha, para 
distinguí-los dos feldspatos sódicos ou cálcicos. Consiste na retirada da parte alterada da fatia de rocha através da imersão em ácido fluorídrico (HF) $40 \%$ por 3 minutos, seguida de lavagem com abundância de água. Após a secagem, a fatia de rocha é imersa em uma solução de cobaltinitrito de sódio, que reage e precipita com sais de potássio, resultando em um precipitado amarelo. A solução é obtida através da mistura de $18 \mathrm{~g} \mathrm{NaNO}_{3}+50 \mathrm{~mL} \mathrm{H}_{2} \mathrm{O}$ com $5 \mathrm{~g} \mathrm{Co}\left(\mathrm{NO}_{3}\right)_{2}+5 \mathrm{~mL}$ ácido acético glacial $+45 \mathrm{~mL} \mathrm{H}_{2} \mathrm{O}$;

- Realização de química mineral qualitativa em 5 amostras, por microscópio eletrônico de varredura (MEV) - FEI Quanta 600F, com detector de EDS tipo SDD (Silicon Drift Detector), Bruker XFlash 4030 e software de microanálise Esprit Bruker, do Laboratório de Caracterização Tecnológica (LCT), Departamento de Engenharia de Minas e de Petróleo, Escola Politécnica, Universidade de São Paulo;

- Realização de química mineral quantitativa em 8 amostras para obtenção de análises químicas pontuais (WDS) além de espectros por (EDS), utilizando a microssonda eletrônica JEOL JXA 8600 SuperProbe, do Laboratório de Microssonda Eletrônica, Instituto de Geociências, Universidade de São Paulo. Para as análises de granada, biotita, muscovita, feldspato, ilmenita, piroxênios e anfibólios foi utilizada a voltagem de $15 \mathrm{kV}$ e corrente de 20 $\mathrm{nA}$, com diâmetro de feixe entre 5 e $10 \mu \mathrm{m}$. As condições de análise para o rutilo foi de $20 \mathrm{kV}$ de voltagem e corrente de $120 \mathrm{nA}$, com diâmetro de feixe em $5 \mu \mathrm{m}$;

- Determinação da distribuição catiônica dos minerais para sua classificação através do AxWin (Holland, 2008) e confecção de parte dos diagramas binários e ternários de classificação de minerais através do software MINPET 2.02 (Richard, 1995). Os valores apresentados para os elementos químicos são expressos em número de cátions por fórmula unitária;

- Realização de cálculos termobarométricos utilizando a versão 3.26 do programa THERMOCALC (Holland \& Powell, 1988), com banco de dados termodinâmicos internamente consistentes atualizado em 22/11/03, e parte dos cálculos foi realizada através da versão 1.02 do TWEEQU (Berman, 1988, 1991). Os dados obtidos através do método de banco de dados internamente consistentes foram complementados por geotermobarometria clássica. Foram utilizados os geotermômetros granada-biotita (Ferry \& Spear, 1978; Indares \& Martignole,1985) e de zircônio-em-rutilo (Watson, 2006; Tomkins et al., 2007) e o geobarômetro GASP (Newton \& Haselton, 1981; Koziol \& Newton, 1988; Koziol, 1989) para os paragnaisses. Para as rochas metabásicas e charnockíticas foi utilizado o geotermômetro granada-clinopiroxênio (Ganguly, 1979; Sengupta et al., 1989) e o geobarômetro granada- 
clinopiroxênio-plagioclásio (Eckert et al., 1991). Parte dos cálculos de temperatura e pressão foi realizada através da planilha Excel GPT (Reche \& Martinez, 1996) para os paragnaisses e do software PTMAFIC 2.0 (Soto \& Soto, 1995) para as rochas metabásicas e charnockíticas;

- Realização de análises químicas para a determinação de elementos maiores, menores e traço através de espectrometria de fluorescência de raios-X utilizando um equipamento automático Philips, modelo PW2400, de acordo com o método descrito por Mori et al. (1999), no Laboratório de Química e no Laboratório de Fluorescência de Raios-X, Instituto de Geociências, Universidade de São Paulo. Foram selecionadas 16 amostras para estudos de litogeoquímica, preparadas no Laboratório de Tratamento de Amostras (LTA), do Departamento de Mineralogia e Geotectônica (GMG) do IGc-USP, seguindo as seguintes etapas: britagem com marreta, prensagem, moagem com moinho de anéis utilizando panelas de ágata, micronização e prensagem para confecção de pastilhas prensadas;

- Realização de análises químicas em 9 amostras selecionadas para a determinação de 14 elementos terras raras, além de 11 elementos traço por espectrometria de massa com plasma induzido acoplado - ICP-MS, dotado de espectrômetro do tipo quadrupolo, modelo ELAN 6100DRC da PerkinElmer/Sciex, no Laboratório de Química e ICP-MS, Instituto de Geociências, Universidade de São Paulo;

- Confecção de parte dos diagramas binários e ternários de classificação geoquímica utilizando o software PetroGraph 1.0.5 (Petrelli, 2005). A interpretação dos dados foi feita a partir de Rollinson (1993), Sun \& Mc Donough (1989) e Pearce et al., (1984).

- Tratamento dos dados estruturais e dados químicos. 


\section{CONTEXTO GEOLÓGICO}

\subsection{Trabalhos anteriores}

Os trabalhos pioneiros com unidades pré-cambrianas na região sul do Estado de Minas Gerais foram desenvolvidos por Ebert (1954, 1955, 1956a, 1956b, 1958, 1968, 1971), quando definiu as Séries Andrelândia, Juiz de Fora e Paraíba (Ebert, 1954) e por Barbosa (1954), quando definiu a Série Mantiqueira. Ebert (1956, 1968, 1971) propôs um modelo de compartimentação tectônica que envolvia duas faixas orogenéticas nas margens de uma zona tectonicamente estável: Faixa Paraibídes, na região costeira, e a Faixa Araxaídes, que se estende do sul de Minas Gerais ao norte de Goiás. O Cinturão Paraíba foi posteriormente denominado Cinturão Ribeira por Almeida et al., (1973).

As rochas notadamente granulíticas da região foram primeiramente descritas por Ebert (1954) ao definir a Série Juiz de Fora. Posteriormente (1955, 1956a, 1956b, 1968, 1971) essa associação foi englobada no Grupo Paraíba por este autor. A unidade foi redefinida por Barbosa \& Grossi Sad (1983a, 1983b, 1983c) e Grossi Sad \& Barbosa (1985), que passaram a denominá-la Complexo Juiz de Fora, definido como a associação de duas unidades litológicas intimamente relacionadas, a Comendador Venâncio (charnockitos melhor preservados) e Raposos (migmatitos e biotita gnaisses kinzigíticos), apresentando várias faixas de granulitos variados associadas, definidas pelos autores como Unidade Itaperuna. Nos trabalhos de Almeida et al., (1980) e Hasui (1982) os termos Cinturão Granulítico Rio Grande e Cinturão Granulítico Atlântico eram utilizados para designar faixas granulíticas de idade arqueana, retrabalhadas nos eventos termo-tectônicos transamazônico e brasiliano.

Alguns autores sugeriram que o Complexo Juiz de Fora e os Gnaisses Mantiqueira fazem parte de um mesmo conjunto litoestratigráfico (porções inferiores e superiores, respectivamente) e interpretaram os granulitos ortoderivados do Complexo Juiz de Fora como os equivalentes mais metamórficos do Complexo Mantiqueira (Figueiredo et al., 1992; Heilbron, 1993; Heilbron et al.,1994b). Segundo Heilbron et al. (1994b), os granulitos ortoderivados do Complexo Juiz de Fora apresentam semelhanças mineralógicas, estruturais, texturais e composicionais com os ortognaisses do Complexo Mantiqueira. A constituição litológica resumida definida pelos autores é formada por rochas granulíticas de derivação ígnea e sedimentar, além de gnaisses e migmatitos de alto grau.

O Complexo Juiz de Fora ocorre na forma de lascas tectônicas e são constituídos predominantemente por enderbito gnaisses que compõem suítes cálcio-alcalinas de afinidade 
juvenil (Figueiredo \& Teixeira, 1996; Duarte et al., 1997). Os corpos lenticulares de rochas metabásicas intercalados nos litotipos do Complexo Juiz de Fora são caracterizados por toleiítos de baixo-K similares a IAB (basaltos de arco de ilhas) e MORB (basalto de cadeia meso oceânica) (Costa, 1998).

Trouw et al., (1983) redefiniram as unidades do Grupo Andrelândia, reconhecendo os seguintes litotipos: quartzito intercalado com xisto, com predomínio dos xistos quartzosos, compostos por quartzo e muscovita, com granada, estaurolita e cianita subordinados (eventualmente sillimanita); Xisto Santo Antônio, homogêneo, que grada para gnaisse finamente bandado, rico em quartzo, muscovita e granada e Xisto Cachoeira das Marias, semelhante ao Xisto Santo Antônio, que alterna níveis ricos em cianita com níveis mais micáceos e lentes de gnaisses calciossilicáticos e boudins de anfibolitos.

Foi realizado um mapeamento na escala 1:100 000 (Folha Lima Duarte) por Pinto et al., (1991) que determinou um embasamento constituído de ortognaisses tipo TTG e granadabiotita gnaisses migmatizados pertecentes ao Complexo Mantiqueira, como uma unidade do proterozóico inferior, em domínio de infra-estrutura de crosta intermediária, cavalgado por uma seqüência metassedimentar, com paragnaisses, xistos e quartzitos, do proterozóico médio.

O mapeamento na escala 1: 50000 realizado por Campos Neto et al., (1996a) reconheceu na região de Lima Duarte (MG) unidades pré-cambrianas do Complexo Mantiqueira, Grupo Andrelândia e Complexo Juiz de Fora organizados em zona de cisalhamento dúctil-rúptil de baixo ângulo. O Complexo Mantiqueira ocorre alóctone (Nappe Lima Duarte) na base de sistemas rúpteis de cavalgamentos, exibindo na foliação principal um metamorfismo na transição anfibolito alto-granulito. É composto por ortognaisses tonalito-trondjhemíticos bandados, com lentes tectônicas métricas de granada anfibolitos e corpos alongados de enderbitos, com cerca de $15 \mathrm{Km}^{2}$, aparentemente intrusivos. O Grupo Andrelândia ocorre alóctone sobre o Complexo Mantiqueira e estruturado em duplexes de sistemas de cavalgamentos Serra Negra (superior) e Conceição do Ibitipoca (inferior), na forma de espessos pacotes $(750 \mathrm{~m})$ de quartzitos grossos recristalizados na foliação milonítica, entre (sillimanita)-granada-biotita-plagioclásio gnaisses e gnaisses francamente peraluminosos, com mica branca, sillimanita e relíquias de rutilo (Campos Neto et al., 1996b).

A Nappe Lima Duarte foi descrita por Campos Neto \& Caby (1999) como Complexo Nappe Quartzítica, composto por rochas quartzíticas e metapelitos (com estaurolita, ilmenita, granada, muscovita, quartzo e turmalina subordinada) alóctones sobre um terreno mais antigo, composto por lascas de ortognaisses migmatíticos e metaultramáficas, já considerado por 
Trouw et al., (1983). No mapeamento da Folha Andrelândia, Paciullo et al., (2002) separaram o embasamento gnáissico das sucessões metassedimentares do Neoproterozóico, interpretadas como Megasseqüência Andrelândia. Consideraram o embasamento constituído por ortognaisses granodioríticos e tonalíticos, localmente granulíticos e em parte modificados por anatexia com ocorrência de intercalações de anfibolito e de rochas metaultramáficas, que corresponderiam ao Complexo Mantiqueira (Figueiredo \& Teixeira, 1996 e Campos Neto et al., (2004). A Megasseqüência Andrelândia foi mapeada com cinco unidades, sendo uma associação de seis litofácies sem nomenclatura formal de grupo ou formação.

\subsection{Orógeno Brasília Meridional}

A Colagem Brasiliana no sudeste brasileiro pode ser dividida em dois sistemas orogênicos maiores: Tocantins e Mantiqueira (Brito Neves et al., 1999; Campos Neto, 2000) ou Faixas Brasília e Ribeira (Trouw et al., 2000). Segundo Campos Neto \& Caby (1999), a Colagem Orogênica Brasiliana resulta de múltiplas orogêneses entre diferentes placas e terrenos, que culminaram na aglutinação do protocontinente Gondwana. O Orógeno Tocantins Meridional registra os episódios de subducção e colisão neoproterozóicos durante o fechamento do paleo-oceano Goianides, oriundo da quebra toniana de Rodínia, representando a convergência da Placa Sanfranciscana sob a Placa Paranapanema (Marangoni, 1994). O Sistema Orogênico Mantiqueira reúne diacronicamente, microplacas e terrenos, associados ao fechamento do paleo-oceano Adamastor (Campos Neto et al., 2004).

O Orógeno Tocantins Meridional representa uma pilha colisional de nappes entre três ambientes tectônicos principais (de WSW para ENE): domínio de arco magmático desenvolvido na margem continental ativa da Placa Paranapanema (Nappe Socorro-Guaxupé), domínio continental subductado (Terreno Andrelândia), e domínios com afinidades de margem passiva e/ou relacionados à Placa Sanfranciscana (Sistema de Nappes Carrancas e Nappe Lima Duarte) (Figura 2).

A Nappe Socorro-Guaxupé é uma espessa pilha alóctone $(\sim 15 \mathrm{Km})$, representada por três unidades distintas de crosta continental profunda: a Unidade Granulítica Basal, a Unidade Diatexítica Intermediária e a Unidade Migmatítica Superior (Campos Neto \& Caby, 2000). A Unidade Granulítica Basal é constituída de Grt-Bt-Opx ( \pm Cpx-Amp) granulito-gnaisses bandados, de composição enderbítica a charnockítica, intercalados por gnaisses gabro-noritos. Os granulitos possuem uma assinatura química cálcio-alcalina e composição intermediária, enquanto que os granulitos máficos exibem uma assinatura toleí́tica (Campos Neto et al.,1996; Choudhuri et al.,1998; Janasi, 1999). Também apresentam leucossomas anidros, 
hololeucocráticos, a Grt e Opx e ortognaisses migmatíticos de composições tonalitogranodioríticas (Fernandes et al.,1987) que ocorrem em faixas descontínuas no topo da unidade granulítica.

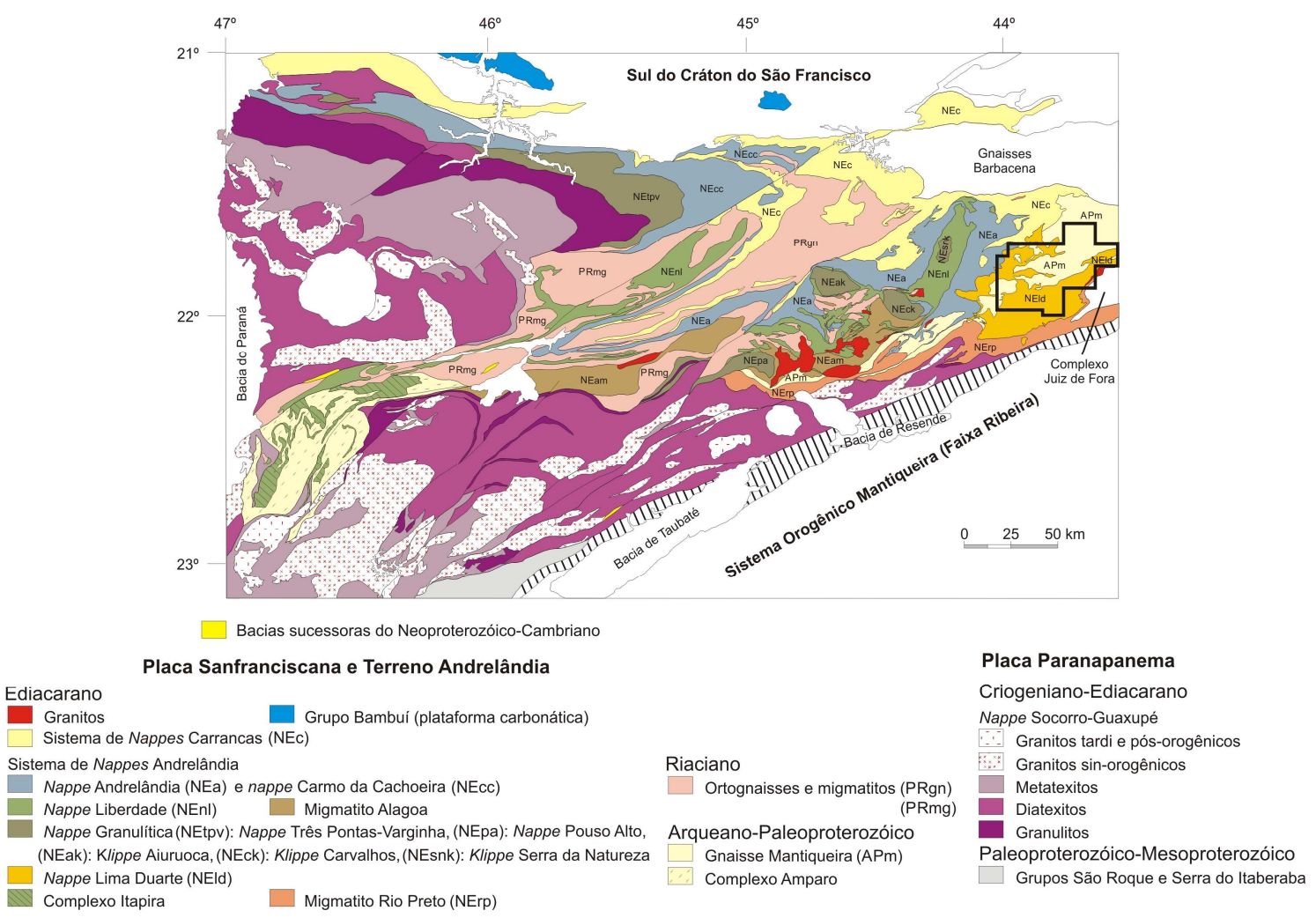

Figura 2: Mapa tectônico da extensão sul do Orógeno Brasília (Campos Neto et al., 2010), com indicação da área de estudo.

Essas unidades mostram uma foliação metamórfica de baixo ângulo, com lineação mineral desenvolvida em condições de deformação não-coaxial, com modificação do volume. Prevalecem indicadores cinemáticos de topo para ENE. Também ocorrem zonas de cisalhamento sin-metamórficas normal-oblíquas.

Dados geocronológicos sugerem que o metamorfismo de ultra-alta temperatura, que foi o principal gerador de rochas no interior da nappe, ocorreu há $625 \pm 5 \mathrm{Ma}$. As unidades superiores mostram uma trajetória de aquecimento quase isobárico e atingem condições de $900 \pm 50^{\circ} \mathrm{C}-6,5 \pm 2 \mathrm{Kbar}$. Essas temperaturas elevadas em baixa profundidade sugerem um forte gradiente termal, em um modelo geotérmico relaxado, análogo aos ambientes de margem ativa com manto astenosférico raso. A unidade basal registra condições de alta pressão $\sim 850^{\circ} \mathrm{C}-14 \mathrm{Kbar}$ (Campos Neto \& Caby, 2000), sendo este cenário metamórfico compatível com um ambiente tectônico relacionado a uma profunda raiz de arco magmático. 
O terreno Andrelândia representa um sistema de nappes de alta pressão, estiradas e transportadas para ENE e NE, que estão colocadas sob a nappe Socorro-Guaxupé. Consiste da pilha metassedimentar do Grupo Andrelândia redefinido por Trouw et al.,1983. As nappes superiores ( $\sim 5 \mathrm{Km}$ de espessura), de alta pressão e alta temperatura ocorrem a WSW (Três Pontas -Varginha, Pouso Alto e Klippe Carvalhos) e consistem de Rt-(Sil)-Ky-Grt granulitos, com bandamento composicional herdado da estratificação sedimentar e delineado por distintas proporções entre Ky e Grt e entre Pl e Kfs. Intercalações de (Ky-Grt-Bt) quartzitos, gnaisses calciossilicáticos e granulitos básicos, são frequentes. Leucossomas de Ky gnaisse granítico branco e filões de (Ky-Grt) leucogranito também estão presentes (Campos Neto et al., 2004).

As nappes inferiores de alta pressão ( 1500 metros de espessura) (Carmo da Cachoeira e Aiuruoca-Andrelândia) apresentam na base quartzitos com intercalações de micaxistos e subordinadamente gnaisses calciossilicáticos. Regionalmente Rt-Grt-Bt-Pl-Qtz xisto/gnaisse homogêneo e com espessura de até 750 metros (Xisto Santo Antônio, Trouw et al.,1983) ocorre no interior de Rt-Als-Grt-Bt-Ms xistos com espessura aparente de 2000 metros. Tanto a unidade do Xisto Santo Antônio quanto os níveis de Ky-Grt gnaisse granulíticos das nappes superiores, possuem uma assinatura química de grauvacas, com área fonte em ambiente de margem ativa (Campos Neto et al., 2004).

São reconhecidas duas trajetórias metamórficas distintas na pilha metassedimentar (Campos Neto \& Caby, 1999, 2000). O primeiro caminhamento metamórfico é de descompressão isotérmica e está registrado tanto no cianita granulitos basais da nappe superior como nas metabásicas retro-eclogíticas da nappe inferior. $\mathrm{O}$ segundo caminhamento é de aquecimento quase isobárico e ocorre no topo e na retaguarda das nappes com granulitos se reequilibrando na zona da sillimanita a $900^{\circ} \mathrm{C}$. O metamorfismo de alta pressão (Ky granulitos) da base da nappe Três Pontas-Varginha possui idade de $635 \pm 20 \mathrm{Ma}$ e o metamorfismo de ultra-alta temperatura (Sil granulitos) do topo da estrutura foi datado em $612 \mathrm{Ma}$, o que separa os dois eventos metamórficos em 16Ma, com uma velocidade de exumação estimada de $0,75 \mathrm{~mm} /$ ano. A subducção ocorreu concomitante com rápida exumação por cavalgamentos, acompanhados de erosão e denudação tectônica. $\mathrm{O}$ encurtamento colisional devido às pilhas adelgaçadas de nappes e megadobras recumbentes está registrado em níveis de crosta médio-inferior, definindo um padrão metamórfico inverso (Campos Neto et al. 2004).

A Nappe Lima Duarte está localizada na porção oriental do sistema orogênico. É cavalgada a SE pela Nappe Andrelândia e ambas cavalgam a sequência metassedimentar do 
Grupo Carrancas. É limitada pela Zona de Cisalhamento Rio Preto a sul, que representa a extensão meridional da sutura Abre Campo com o Terreno Juiz de Fora (Haraly et al., 1985; Fischel et al., 1998; Costa et al., 1998; Pedrosa-Soares \& Noce, 1998). Seu conteúdo litológico consiste de ortoquarzitos miloníticos, muito grossos, imbricados com paragnaisses e xistos pelíticos, e subordidamente gnaisses calciossilicáticos. Difere das unidades do Grupo Andrelândia na definição original de Trouw et al., (1983) no conteúdo litológico, no registro metamórfico e na infraestrutura antiga incorporada. Na região de Lima Duarte (MG), os gnaisses do Complexo Mantiqueira ocorrem como parte de um segmento alóctone, amalgamado à borda cratônica durante a colagem orogênica Neoproterozóica. Estas rochas representam lascas de uma crosta inferior imbricadas tectonicamente na Nappe Lima Duarte (Campos Neto et al. 2004).

A Nappe Lima Duarte está articulada em duplexes de um sistema de cavalgamentos. As lineações minerais sin-metamórficas indicam o transporte da nappe para ENE a sul, que inflete em direção ao norte para NNE, definindo uma trajetória curva ao longo de $60 \mathrm{Km}$ de transporte, controlado pela foliação de baixo ângulo para SE. A delgada capa metassedimentar superior reorganizou-se um duplex rúptil, thin-skinned, posterior ao dobramento da foliação com vergência para NW (Campos Neto et al., 2004).

O sistema de Nappes Carrancas compreende uma sequência metassedimentar, organizada em quatro escamas de cavalgamento com infraestrutura gnáissica engajada e sotoposta às nappes Aiuruoca-Andrelândia e Lima Duarte. É constituído pelo Grupo Carrancas (Trouw et al.,1982, 1983) com Ms quartzitos placosos sobre Mag-Ms-Bt-Qtz gnaisses (Fm. São Tomé das Letras), seguidos por (Grt)-Qtz-Ms xistos, no geral grafitosos com lâminas rítmicas de quartzito fino e níveis discretos de metacalcáreo (Fm. Campestre). A idade de deposição da pilha sedimentar pode ser admitida no Neoproterozóico. A posição paleogeográfica de margem passiva da borda sul da Placa Sanfranciscana tem sido referida por Ribeiro et al. (1995), Trouw et al. (2000), Campos Neto (2000). O enxame de rochas ultramáficas pode representar injeções do manto no estágio de adelgaçamento e rompimento da borda continental. O metamorfismo aumenta de norte para sul, da fácies xisto verde a fácies anfibolito em presença de (Sil)-St-Grt-Ky (Ribeiro \& Heilbron, 1982; Heilbron, 1985) e metapelitos do front alóctone apresentam condições metamórficas de $\sim 500^{\circ} \mathrm{C}-7,5 \pm 0,5 \mathrm{Kbar}$ (Campos Neto \& Caby, 1999).

Em processos relativamente rápidos de extrusão acompanhados de erosão e denudação tectônica contemporâneos ao cavalgamento, há o registro de padrões metamórficos invertidos (Hogdes et al, 1993; Vannay \& Hodges, 1996), semelhante ao registrado no Sistema 
Orogênico Himalaiano. Segundo Campos Neto \& Caby (1999), existiria um único evento colisional, do tipo himalaiano, na formação do complexo sistema de nappes.

Alguns autores consideram o segmento meridional da Faixa Brasília como resultante da interferência de duas faixas móveis, Brasília e Ribeira (Ebert, 1984; Trouw et al., 1994). Heilbron et al. (1995) consideram a área em questão como sendo um segmento central da Faixa Ribeira e propuseram para este setor uma compartimentação tectônica regional subdividida em quatro domínios tectônicos imbricados em direção ao cráton do São Francisco: Domínio Autóctone (mais próximo à área cratônica), Domínio Alóctone Inferior, Domínio Alóctone Médio e Domínio Alóctone Superior, sendo os domínios alóctones correspondentes aos domínios Andrelândia e correlatos, Juiz de Fora e Paraíba do Sul, respectivamente.

Ribeiro et al., (1995) acreditam que essas seqüências participaram de mais de um episódio de deformação e metamorfismo brasilianos. O episódio mais antigo teria ocorrido em torno de 600Ma produzindo transporte tectônico de topo para leste, associado ao metamorfismo de fácies granulito de alta pressão no campo de estabilidade da cianita, resultando na formação de rochas retro-eclogíticas. Corresponderia à colisão entre o Maciço Guaxupé com o proto-cráton do São Francisco, sendo correspondente ao episódio que produziu a Faixa Móvel Brasília. Um novo episódio tectônico teria ocorrido em torno de $570 \mathrm{Ma}$, resultando em encurtamento crustal com transporte para NNW, acompanhado de dobramentos em escala regional. O metamorfismo relacionado a este evento seria de pressão intermediária, no campo de estabilidade da sillimanita, e é caracterizado pela formação de numerosos corpos anatéticos. O último episódio corresponde a uma compressão E-W que gerou zonas de cisalhamento transpressionais, subverticais de orientação NE-SW e com sentido de movimentação dextral. Estes dois últimos episódios são relacionados à Faixa Móvel Ribeira, sendo assim, esta região é considerada por alguns autores como uma zona de interferência entre as faixas móveis Brasília e Ribeira.

\subsection{A Nappe Lima Duarte e o Complexo Mantiqueira}

A Nappe Lima Duarte é constituída predominantemente por paragnaisses migmatíticos com granada, biotita e sillimanita e ortoquartzitos de granulação grossa, com intercalações esparsas de gnaisses cálciossilicáticos e anfibolitos (Campos Neto et al., 2004). O Complexo Mantiqueira constitui o embasamento das rochas do Ciclo Deposicional Andrelândia no domínio tectônico homônimo (Andreis et al., 1989; Heilbron, 1993; Duarte, 1998). 
A pilha metassedimentar da Nappe Lima Duarte consiste de ortoquartzitos muito grossos, recristalizados em textura milonítica, que predominam sobre os quartzitos imaturos (com muscovita, feldspato, sillimanita e turmalina) e ocorrem em lascas alóctones, espessas de até 750m, imbricadas com sillimanita-granada-biotita gnaisses migmatíticos (superiores), com intercalações esparsas de gnaisses calciossilicáticos e rochas metabásicas. Segundo Nummer (1990, 1992), as unidades litológicas na região de Lima Duarte (MG) podem ser divididas em dois conjuntos principais. A seqüência inferior é constituída por gnaisses migmatíticos bandados, que correspondem aos ortognaisses do Complexo Mantiqueira, com intercalações de máficas e ultramáficas, além de rochas ígneas intrusivas, com textura grossa, metamorfizadas ou não, em fácies granulito superior. A seqüência superior é constituída por metassedimentos proterozóicos pertecentes ao Grupo Andrelândia.

Foram reconhecidas duas unidades tectono-estratigráficas distintas no Grupo Andrelândia, separadas por falhamento de empurrão que dividiu o Grupo Andrelândia em uma parte autóctone e outra alóctone (Nummer, 1990). O Grupo Andrelândia Autóctone possui características de deformação intensa e é constituído por biotita gnaisse finamente bandado, associado com muscovita xisto na base, e com granada-estaurolita-cianita (sillimanita) xisto no topo. O Grupo Andrelândia Aulóctone foi subdividido em três unidades por Nummer (1990), baseado em correlações com colunas estratigráficas propostas por Trouw et al., (1986), Valeriano (1985), Noce (1987), Gonçalves (1987), Ribeiro \& Heilbron (1983) e Andreis et al., (1989).

A unidade basal é composta por gnaisse finamente bandado, intercalado com quartzito micáceo, granada-estaurolita-muscovita xisto e sillimanita xistos, que constitui a transição litológica para um quartzito grosso com textura semelhante a "sal grosso", que delineia as principais serras da região. Ocorrem adelgaçamentos e espessamentos neste quartzito, que pode ainda conter intercalações com mica xisto e quartzo xisto.

A unidade intermediária é composta por biotita gnaisse bandado, granada-biotitamuscovita xisto homogêneo, tipo Santo Antônio (Trouw et al., 1983) e hornblenda gnaisse, localmente com intercalações de quartzitos micáceos, mica xistos, sillimanita xistos e gnaisses finamente bandados.

A unidade de topo engloba grande quantidade de litotipos interestratificados, com níveis basais mais quartzosos, gradando para termos mais micáceos no topo ("sequiência estratificada” de Trouw et al., 1983; Gonçalves, 1987). É constituída por quartzitos micáceos, gnaisses bandados com níveis anfibolíticos, quartzo xistos e raramente rochas calciossilicáticas. Na região de Lima Duarte também foram descritas faixas de 
metassedimentos compostas por sillimanita gnaisse bandado, sillimanita-granada-quartzobiotita xisto e granada-muscovita-sillimanita xisto, além de gabro fino, com textura granular idiomórfica e fenocristais euédricos de plagioclásio (labradorita), relacionado a um provável evento magmático tardio (Nummer, 1990).

O Complexo Mantiqueira, infraestrutura alóctone da nappe, é constituído de ortognaisses migmatíticos e polimetamórficos, de composição granodiorítica, tonalítica ou trondhjemítica, destacando-se os biotita gnaisses e hornblenda-biotita gnaisses, que correspondem ao "núcleo" Mesoarqueano (2,98 Ga, Figueiredo \& Teixeira, 1996). Os ortognaisses migmatíticos e policíclicos do Complexo Mantiqueira ocorrem associados com rochas de composição enderbítica a charnockítica que constituem suítes cálcio-alcalinas, com freqüentes intercalações de rochas metabásicas pertencentes à série toleiítica transicional (Duarte et al., 2004). As rochas metabásicas ocorrem intercaladas na forma de boudins ou enclaves métricos alongados, que acompanham a estruturação das rochas encaixantes, onde podem formar bandas pouco ou totalmente transpostas. As rochas metabásicas são anfibolitos com variadas proporções de clinopiroxênio-granada-biotita e com características texturas coroníticas mono e pluriminerálicas. Também são comuns corpos anatéticos associados, de composição granítica e em geral indeformados, além de granada-biotita gnaisse enderbítico e lascas métricas de granada-clinopiroxênio-quartzo-hornblenda granulito, ambos de 2,08Ga (Campos Neto et al., 2004).

Duarte (1998) definiu através de análises isotópicas, que o Complexo Mantiqueira tem formação em parte no Arqueano e em parte no Paleoproterozóico. Esta unidade apresentaria características geoquímicas de ambientes extensionais para algumas rochas básicas e compressivas para as intermediárias a ácidas. O ambiente tectônico de formação do Complexo Mantiqueira teria sido caracterizado por grande instabilidade e um regime rápido, onde as rochas cálcio-alcalinas intermediárias e ácidas teriam se formado em ambientes equivalentes a arcos vulcânicos/magmáticos de ambientes colisionais. A mesma autora descreve a ocorrência de dois pulsos metamórficos distintos nas unidades dos Complexos Juiz de Fora e Mantiqueira. O mais antigo é definido por uma textura granoblástica, de fácies granulito e caracterizado por temperaturas mais elevadas e pressões baixas a intermediárias, enquanto que o pulso mais novo é contemporâneo à deformação principal, com temperaturas e pressões intermediárias, responsável pelo desenvolvimento da foliação milonítica principal.

Dados de geocronologia (U-Pb SHRIMP) existentes na literatura indicam que os ortognaisses do Complexo Mantiqueira foram retrabalhados em pelo menos dois eventos metamórficos distintos: um no Transamazônico e outro no Brasiliano (Duarte, 1998; Silva et 
al., 2002; Silva et al., 2005a). Noce et al. (2007) obtiveram 2050 Ma (U-Pb ID TIMS) para os ortognaisses do Complexo Mantiqueira, que corroboram com os resultados previamente obtidos por geocronologia (U-Pb SHRIMP). Silva et al. (2002) obteve 2182-2058 Ma para a idades de cristalização dos ortognaisses Mantiqueira e 2180-2160 Ma para os núcleos de zircões herdados, que derivam da fusão parcial de granitóides relacionados a arco magmático (magmatismo sin-colisional a 2102-2058 Ma). Heilbron et al. (2001) obteve idade de cristalização a $2203 \pm 17$ Ma, com evento metamórfico a 2040 447 Ma. Os resultados obtidos por Heilbron et al. (2001) sugere uma evolução complexa, relacionada a ambiente de arco magmático para as rochas do Complexo Mantiqueira. Campos Neto et al., (2004) realizaram datações em rochas ortoderivadas intrusivas no Complexo Mantiqueira, que forneceram idades de $2080 \mathrm{Ma}$ (U-Pb SHRIMP) para o granito gnaisse e $2082 \pm 33 \mathrm{Ma}\left(\mathrm{U}_{-}-\mathrm{Pb}_{\mathrm{Zrc}}\right)$ para o enderbito gnaisse da região de Pedro Teixeira (MG), que se situam no intervalo de 2182-2058 Ma definido por Silva et al. (2002) para a cristalização dos litotipos do Complexo Mantiqueira.

Os estudos de Vilela (2000) (Opx-Sil em quartzitos) e Campos Neto et al. (2004) apontam condições metamórficas de alto grau na região de Lima Duarte. O equilíbrio da paragênese ocorre a $850^{\circ} \mathrm{C}$ a $10 \mathrm{Kbar}$ (Campos Neto et al. 2004), em contraste com os paragnaisses, que não teriam atingido temperaturas superiores a $800^{\circ} \mathrm{C}$. Vilela (2000) calculou condições P-T máximas de $750^{\circ} \mathrm{C}$ a $16 \mathrm{Kbar}$ para os granulitos máficos. O equilíbrio metamórfico definido pela migração de nappes no Sistema Orogênico Brasília Meridional

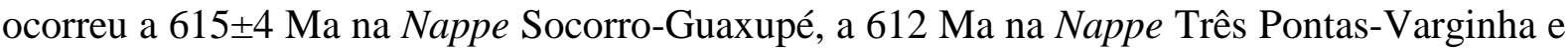
a $607 \pm 3$ Ma na Nappe Aiuruoca-Andrelândia (Campos Neto et al., 2004). Idades (U-Pb $\left.\mathrm{Zrc}_{\mathrm{Zc}}\right)$ em zircão apontam idade de 611 Ma para o sillimanita-muscovita quartzito da Nappe Lima Duarte (Machado et al., 1996). A anatexia relacionada ao relaxamento térmico colisional está registrada nos leucogranitos intrusivos na Nappe Lima Duarte, há 580-570 Ma (Campos Neto et al., 2004). Datações (U-Pb SHRIMP) em zircões forneceram idades de 620.8 $\pm 2 \mathrm{Ma}$ e 586.9 \pm 9 Ma (Trouw et al., 2008) para os litotipos da Nappe Andrelândia. O primeiro evento de 620.8 \pm 2 Ma é interpretado como metamorfismo associado à Faixa Brasília, enquanto que o evento em 586.9 \pm 9 Ma é relacionado ao metamorfismo da Faixa Ribeira (Trouw et al., 2008). 


\section{DESCRIÇÃO DAS UNIDADES TECTÔNICAS}

Observação: Mapa geológico em anexo. As abreviações de minerais adotadas neste texto são baseadas em Kretz (1983).

\subsection{NAPPE ANDRELÂNDIA}

\subsubsection{Granada-biotita-plagioclásio-quartzo xisto homogêneo (Xisto Santo Antônio)}

Esta unidade constitui uma camada intermediária na Nappe Andrelândia (Campos Neto et al., 2007). Na região de Lima Duarte (MG) esta unidade é o topo e ocorre em contato gradacional sobre o granada-sillimanita-biotita-quartzo xisto. Foi denominada de Xisto Santo Antônio por Trouw et al. (1983). Apresenta estrutura bandada, com textura porfiroblástica inequigranular média a grossa (porfiroblastos milimétricos a centimétricos de granada), em matriz inequigranular fina a média, que alterna leitos quartzo-feldspáticos granoblásticos com leitos lepidoblásticos ricos em biotita.

Ocorrem duas gerações de granada: uma pré a sin-cinemática, com muitas inclusões de biotita, quartzo, estaurolita, muscovita, apatita e opacos, freqüentemente esqueletal, com sombras de pressão de biotita e outra pós- cinemática, sub-idioblástica, com menor quantidade de inclusões. Também são observadas três gerações de biotita: pré a cedocinemática inclusa na granada; $\sin$-cinemática $\left(\sin -S_{2}\right)$ como sombras de pressão na granada e orientada segundo a foliação oblíqua $S_{3}$. A fase retrometamórfica é caracterizada pela formação de clorita e muscovita substituindo a biotita. As principais fases acessórias são: muscovita, clorita, estaurolita, zircão, apatita e opacos.

\subsubsection{Granada-sillimanita-muscovita-biotita-quartzo xisto e Muscovita-biotita gnaisse com sillimanita}

Esta unidade constitui a base da Nappe Andrelândia e ocorre predominantemente como um corpo alóctone, em contato tectônico de cavalgamento sobre gnaisses do Complexo Mantiqueira. É cavalgado pelos quartzitos da Nappe Lima Duarte. Na maior parte das exposições, a rocha encontra-se muito alterada, com coloração característica avermelhada a violeta, com bandas mais claras. Localmente apresenta intercalações métricas de biotita gnaisses. 
O granada-sillimanita-muscovita-biotita-quartzo xisto apresenta textura porfiroblástica grossa (porfiroblastos de granada de até $1,5 \mathrm{~cm}$ ), em matriz lepidoblástica (biotita e muscovita), onde localmente desenvolve aspecto nematoblástico, quando rico em sillimanita. A foliação principal $S_{2}$ é definida pelos leitos ricos em biotita e muscovita, que localmente marcam também a $S_{3}$. A foliação anterior encontra-se mimetizada na forma de arcos poligonais de micas.

O muscovita-biotita gnaisse com sillimanita apresenta textura predominantemente granoblástica, com leitos micáceos com sillimanita, apresentando textura nematolepidoblástica. A foliação principal $S_{2}$ é definida pelos leitos ricos em biotita e muscovita, que amoldam os leitos quartzo-feldspáticos bastante estirados e com forma sigmoidal. Esta foliação encontra-se dobrada, e freqüentemente com o crescimento de micas (principalmente muscovita) ao longo dos planos axiais.

Há um registro da foliação anterior $S_{1}$ na forma de arcos poligonais de sillimanita, com os flancos paralelizados a foliação principal. Também foram observados cristais idioblásticos de sillimanita, com recristalização estática na forma de pares S-C. Estes tipos de estruturas ocorrem na forma de inclusão em muscovita tardia, idioblástica, de granulação grossa e com orientação oblíqua em relação à foliação principal.

\subsection{NAPPE LIMA DUARTE}

\subsubsection{Biotita granito-gnaisse porfiroblástico}

A unidade ocorre em contato com o Gnaisse Mantiqueira e o sillimanita-granadabiotita gnaisse metatexítico. Constituem corpos intrusivos de orientação geral NE-SW, alojados junto a zonas de falha e injetados entre bandas dos gnaisses vizinhos.

São rochas de coloração cinza clara, em geral homogêneas, com biotita, foliação incipiente na matriz e megacristais idiomórficos a subidiomórficos de feldspato $(1-10 \mathrm{~cm})$. Os feldspatos chegam a ocupar aproximadamente $20 \%$ em volume da rocha. Apresenta estrutura incipientemente bandada e foliada, com textura porfiroblástica grossa em matriz inequigranular fina, composta por quartzo, feldspato e biotita (20-40\%), predominantemente granoblástica. Exibe um caráter porfiroclástico nas proximidades de zonas de cisalhamento, onde ocorre deformação dos megacristais de feldspato. As bandas félsicas quartzofeldspáticas (dimensão centimétrica) apresentam textura granoblástica grossa e se alternam com bandas lepidoblásticas finas, ricas em biotita. 
Essas rochas podem apresentar tanto o feldspato alcalino como o plagioclásio (andesina) como predominante na rocha. Os grãos de quartzo e feldspato que constituem a matriz são em geral granoblásticos, de granulação fina a média $(0,2-0,5 \mathrm{~mm})$. Os porfiroblastos/porfiroclastos de feldspato são subidioblásticos a xenoblásticos, muito fraturados e alterados para sericita. Nas bordas destes cristais e no contato com outros grãos há domínios de sub-grãos. O quartzo exibe com frequiência extinção ondulante e também ocorre intercrescido com feldspato (mirmequitas). Turmalina e muscovita ocorrem como minerais acessórios abundantes $(\sim 5 \%)$. Os minerais acessórios presentes são: alanita, zircão e opacos.

\subsubsection{Granada-biotita gnaisse metatexítico}

Esta unidade apresenta contato normal sobre os paragnaisses com sillimanita, mas também ocorre em contato tectônico com os quartzitos e com os ortognaisses do Complexo Mantiqueira. A rocha apresenta cor cinza, textura granoblástica e estrutura bandada (Figura 3). As bandas de coloração cinza clara predominantes são inequigranulares de granulação média, constituídas de quartzo, feldspato, biotita e granada. Sillimanita pode estar presente, mas nunca em grande proporção. A granada em geral não ultrapassa $1.0 \mathrm{~cm}$. As bandas félsicas apresentam contato difuso e são constituídas por quartzo e feldspato de granulação grossa a muito grossa.

As bandas félsicas são constituídas por quartzo (75\%), andesina (20\%) e biotita (5\%). A biotita e a fábrica de forma dos grãos de quartzo e feldspato definem a foliação paralela ao bandamento. Alguns agregados policristalinos de quartzo são sigmoidais, com divisão interna em sub-grãos poligonizados, evidência de deformação não-coaxial, com posterior recristalização estática dos grãos.

As bandas lepidoblásticas são constituídas de biotita (30-40\%), granada (5\%), quartzo $(30-40 \%)$, sillimanita $(<1 \%)$, muscovita $(<1 \%)$ e andesina $(20-30 \%)$. Os minerais acessórios são: zircão, apatita e opacos. Quartzo e feldspato em geral são granoblásticos, interlobados. Biotita apresenta coloração verde escura a marrom, hábito subidioblástico, alongada, definindo a foliação. A granada ocorre preferencialmente em associação com biotita, e pode estar parcialmente substituída pela biotita (Fotomicrografia 1). Possui hábito subidioblástico a xenoblástico, quase sempre com bordas corroídas e fraturadas, e contém diversas inclusões: quartzo, feldspato, biotita e opacos. O mineral quase sempre apresenta biotita na borda, e eventualmente clorita que pode aparecer na borda ou preenchendo fraturas, evidências de retro-metamorfismo. A sillimanita ocorre preferencialmente com hábito de fibrolita. 
A foliação principal da rocha $\left(S_{2}\right)$ é definida por biotita, sillimanita e muscovita. Ocorre granada com sombra de pressão, localmente com inclusões de biotita, quartzo e opacos alinhados, que marcam a foliação interna $\left(S_{\mathrm{i}}\right)$.

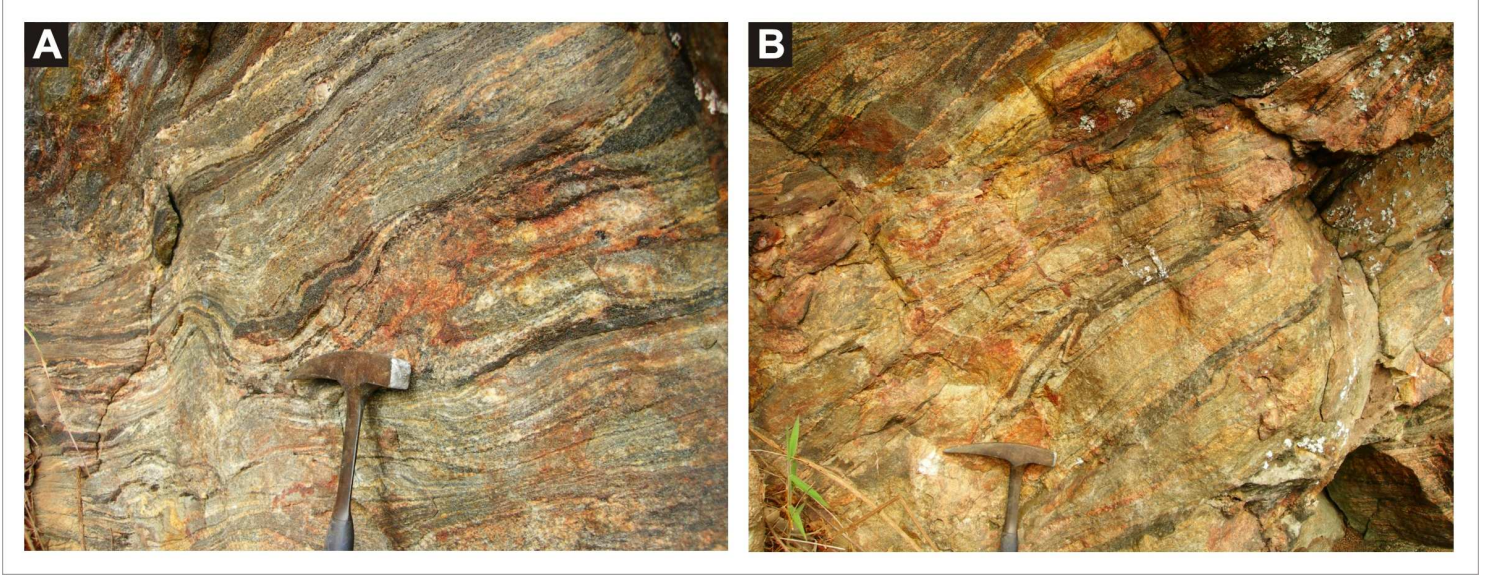

Figura 3: Granada-biotita gnaisse (SB-III-112).

\subsubsection{Sillimanita - granada - biotita gnaisse metatexítico, sillimanita-granada-biotita gnaisse porfiroblástico com cianita e biotita-sillimanita gnaisse com muscovita e dumortierita}

O litotipo predominante é o sillimanita-granada-biotita gnaisse metatexítico, com textura porfiroblástica, localmente com intercalações centimétricas a decimétricas de rochas básicas e de gnaisses calciossilicáticos, concordantes com a foliação principal. Pode ocorrer como um gnaisse homogêneo ou exibir bandamento composicional. O leucossoma estromático é inequigranular grosso, com espessura variável (dimensão centimétrica a métrica). Ocorrem bolsões quartzo-feldspáticos (leucogranito) de dimensão métrica, freqüentemente caulinizados, truncando a foliação e ocasionalmente concordando com ela. Localmente ocorrem camadas compostas exclusivamente por sillimanita, na forma de "pods" centimétricos (sillimanititos).

A foliação $S_{1}$ é admitida na charneira de dobras intrafoliais ou mimetizada como arcos poligonais de micas e/ou sillimanita na matriz (Fotomicrografia 2) ou mesmo como trilhos de opacos no interior de porfiroblastos intercinemáticos de granada. A foliação regional $\left(\mathrm{S}_{2}\right)$, localmente milonítica, está associada a um bandamento que alterna bandas granoblásticas quartzo-feldspáticas e bandas nematolepidoblásticas (sillimanita + biotita) (Fotomicrografia 3). Em algumas porções ocorrem dobras assimétricas, gerando uma foliação $S_{3}$ plano axial definida pelas micas e oblíqua em relação à foliação principal. 
Possui quantidades variadas de granada, sillimanita, biotita e muscovita. Há o predomínio de plagioclásio, porém em alguns locais ocorre somente o ortoclásio. Localmente apresenta relíquias inclusas de cianita, associadas a ortoclásio, indicando a passagem por um campo bárico de pressão alta.

O sillimanita-granada-biotita gnaisse porfiroblástico com cianita tem ocorrência restrita na parte sul da área (Figura 4). A rocha apresenta cor cinza, estrutura bandada, e textura porfiroblástica (porfiroblastos pré-cinemáticos de granada e de plagioclásio, de granulação grossa) em matriz que alterna bandas granoblásticas com quartzo sigmoidal, bandas lepidoblásticas compostas por biotita e bandas lepidonematoblásticas compostas por sillimanita, com biotita, muscovita e cianita subordinadas. Localmente a foliação principal é milonítica, com porfiroclastos de plagioclásio e granada envolvidos por fitas de quartzo e leitos nematolepidoblásticos (Fotomicrografia 4).

A granada (5-7\%) é em geral porfiroblástica e apresenta inclusões de plagioclásio, quartzo, biotita e muscovita, e possui zonas de sombra de pressão de biotita e sillimanita. Localmente ocorre xenoblástica, quando está substituída pela cianita (5\%) (Fotomicrografias 5 e 6). A associação $\mathrm{Grt}+\mathrm{Ky}+\mathrm{Sil}+\mathrm{Ms}+\mathrm{Bt}+\mathrm{Pl}$ é bastante freqüente, com a sillimanita substituindo a cianita. A sillimanita (10-15\%) ocorre com hábito prismático e fibroso, em geral intercrescida com a biotita da matriz, na foliação principal $S_{2}$.

É possível reconhecer duas fases distintas de biotita (20-25\%): uma principal, de coloração castanho-avermelhada, possivelmente de alta temperatura e uma segunda, de coloração verde-clara, de baixa temperatura, em associação com granada, cianita e sillimanita. A muscovita (5-10\%) substitui a cianita (Fotomicrografias 7 e 8), a sillimanita e a granada, e também ocorre em associação com $\mathrm{Pl}+\mathrm{Sil}+\mathrm{Bt}$. Ocorre cianita na foliação principal $\mathrm{S}_{2}$, associada com arco poligonal de biotita de coloração esverdeada.

O plagioclásio está situado no limite composicional oligoclásio/andesina $\left(\mathrm{An}_{30}\right)$. Os porfiroblastos de plagioclásio (25-30\%) encontram-se deformados, às vezes com sombra de pressão de biotita, muscovita e sillimanita ou amoldados pelas lentes granoblásticas de quartzo. O quartzo (15-20\%) é poligonizado, apresentando contatos retos e com fraca extinção ondulante, indicando uma recristalização estática. Localmente invade os porfiroblastos de plagioclásio em zonas de sombras de pressão. As principais fases acessórias são: opacos, zircão e rutilo. 

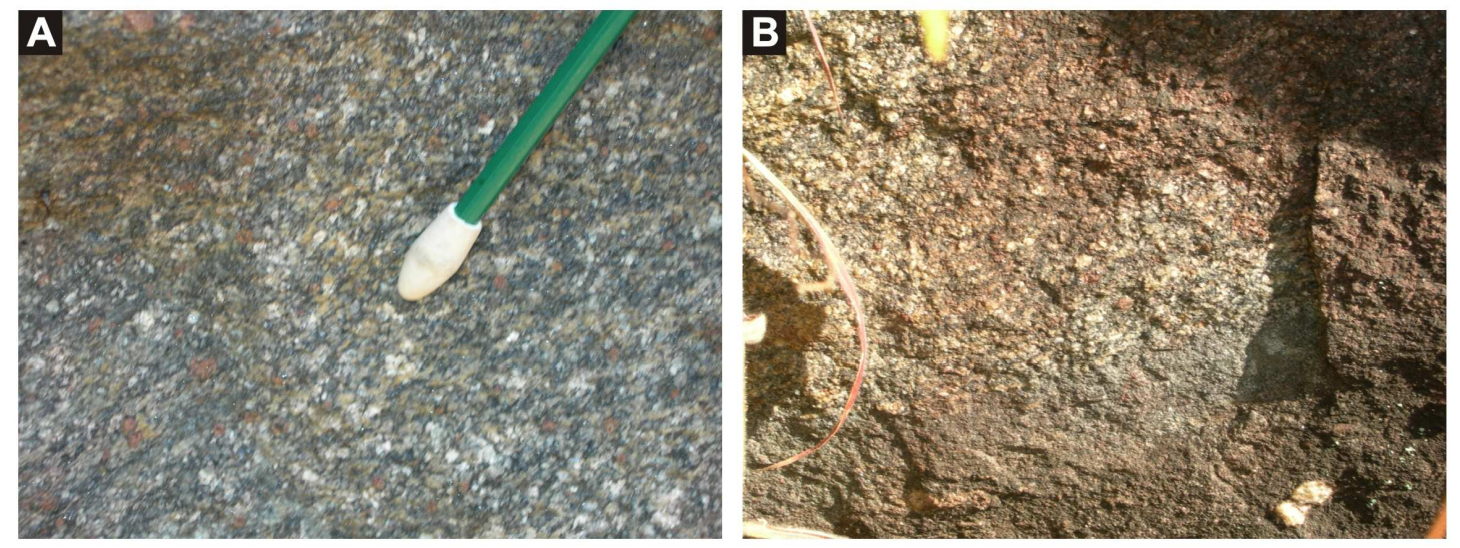

Figura 4: Sillimanita-granada-biotita gnaisse porfiroblástico (SB-IX-108).

O biotita-sillimanita gnaisse com muscovita e dumortierita foi descrito em um único afloramento (LD-III-219). A rocha possui textura nemato-granoblástica, inequigranular fina a grossa, caracterizada pela presença de concentrações localizadas de sillimanita (25-30\%) e de lentes quartzo-feldspáticas sigmoidais, com biotita (5-10\%) subidioblástica orientada na foliação principal. A sillimanita ocorre com hábito fibroso ou prismático, na forma de leitos estirados, definindo dobras intrafoliais em bainha, associadas a zonas de boudins. Em alguns locais, está intercrescida com biotita, na zona de charneira da crenulação.

O plagioclásio (20-25\%) é inequigranular médio a grosso, bastante deformado e saussuritizado. Predomina o oligoclásio $\left(\mathrm{An}_{20-30}\right)$, com quartzo equigranular poligonal fino nas bordas dos cristais maiores. O quartzo (35-40\%) também ocorre como grãos maiores, bastante recristalizados, na forma de sigmóides. A muscovita $(<2 \%)$ é geralmente simplectítica e xenoblástica, associada com biotita idioblástica, sillimanita prismática e plagioclásio.

A dumortierita $(<5 \%)$ ocorre em associação com sillimanita fibrolítica da matriz e, localmente associada com a biotita e o plagioclásio. Possui um pleocroísmo bastante intenso, variando de incolor a rosa-choque. A dumortierita é um borossilicato aluminoso, freqüente em condições de temperatura alta. Outras fases acessórias observadas são: zircão $(<1 \%)$ subarredondado gerando halos pleocróicos na biotita e monazita $(<1 \%)$ arredondada, associada com os leitos quartzo-feldspáticos.

\subsubsection{Gnaisses calciossilicáticos}

Esta unidade ocorre intercalada com os paragnaisses descritos anteriormente, ou com rochas metabásicas. Apresentam um bandamento gnáissico com alternância de bandas 
granoblásticas ricas em quartzo e plagioclásio e bandas granonematoblásticas com hornblenda, clinopiroxênio, granada, epídoto e zoisita, orientadas segundo a foliação principal $\mathrm{S}_{2}$. Também podem ocorrer bandas nematolepidoblásticas nas rochas ricas em biotita. $\mathrm{O}$ clinopiroxênio freqüentemente ocorre substituído por hornblenda nas bordas. A titanita geralmente aparece manteada por ilmenita. Localmente ocorrem coronas de epídoto no plagioclásio, quando em contato a hornblenda (Fotomicrografia 9). Também ocorrem gnaisses ricos em granada de coloração alaranjada (possivelmente rica no membro-final grossulária), formando leitos milimétricos a subcentimétricos granonematoblásticos, com hornblenda e epídoto (Fotomicrografia 10). Outros minerais acessórios observados são: clorita, muscovita, apatita, escapolita e zircão.

\subsubsection{Rochas metabásicas}

\subsubsection{Clinopiroxênio anfibolito com titanita}

Apresenta textura granonematoblástica, inequigranular fina a média (Fotomicrografias 11 e 12). A hornblenda (50-65\%) define a foliação principal $S_{2}$, que está localmente dobrada. Freqüentemente apresenta inclusões de titanita, quartzo, plagioclásio e opacos. Localmente ocorrem cristais de hornblenda sigmoidais, com grãos de quartzo e plagioclásio nas bordas (NLD-37B).

O plagioclásio (10-35\%) apresenta contatos suturados a lobados com outros grãos e está intensamente deformado na matriz. O quartzo (1-10\%) ocorre principalmente incluso na hornblenda, goticular ou amebóide, ou na forma de leitos contínuos, aparentemente sem conexão com o quartzo da matriz. Esta feição pode sugerir uma recristalização de líquido no interior da hornblenda.

Os cristais de clinopiroxênio (5-20\%) encontram-se bastante fraturados, sendo substituídos pela hornblenda nas bordas e ao longo das fraturas. Apresenta inclusões de quartzo, e localmente de plagioclásio, titanita e opacos. $\mathrm{O}$ ortopiroxênio $(<5 \%)$, quando presente, é substituído por hornblenda pelas bordas e também apresenta inclusões de opacos, titanita e apatita. A titanita (5\%) é xenoblástica ao redor de opacos e idioblástica a subidioblástica na matriz.

As principais fases acessórias são: opacos $(<5 \%)$, biotita $(<5 \%)$ apatita $(<2 \%)$, epídoto $(<1 \%)$ e zircão $(<1 \%)$. Biotita subidioblástica, tardia, ocorre substituindo a hornblenda ao longo de fraturas e em direção concordante com a foliação principal. A apatita $(<2 \%)$ ocorre na forma de cristais prismáticos subidioblásticos, dispersos na matriz, associados com 
plagioclásio ou inclusos em hornblenda. Também ocorre carbonato $(<1 \%)$ preenchendo interstícios, associado com hornblenda e quartzo.

\subsubsection{Biotita anfibolito}

Rocha foliada, com a foliação principal $\mathrm{S}_{2}$ definida por hornblenda, plagioclásio e biotita. É caracterizada por uma textura lepidogranonematoblástica, com biotita (10-15\%) idioblástica a subidioblástica, substituindo a hornblenda. O plagioclásio (35-40\%) ocorre poligonizado na matriz com o quartzo (5-10\%), sendo a andesina a fase predominante $\left(\mathrm{An}_{30}\right.$ 40). Também ocorre plagioclásio reliquiar incluso em hornblenda (55-60\%), assim como quartzo goticular. Localmente os opacos $(5 \%)$ apresentam textura poiquiloblástica, englobando grãos de hornblenda, biotita, plagioclásio e quartzo. Também ocorre apatita (< $2 \%$ ), na forma de cristais prismáticos e aciculares, geralmente associada com hornblenda, plagioclásio ou quartzo.

\subsubsection{Quartzito com muscovita}

Esta unidade se destaca geomorfologicamente, pois sustenta as serras de maior altitude na região (Figura 5). Também ocorre tectonicamente intercalado nas rochas do Complexo Mantiqueira ou em outros litotipos da Nappe Lima Duarte, associado com intensa milonitização. É constituída por ortoquartzito homogêneo, inequigranular médio a grossomuito grosso. Agregados policristalinos de quartzo apresentam contatos suturados entre os grãos, podendo adquirir formas sigmoidais e estrutura milonítica.
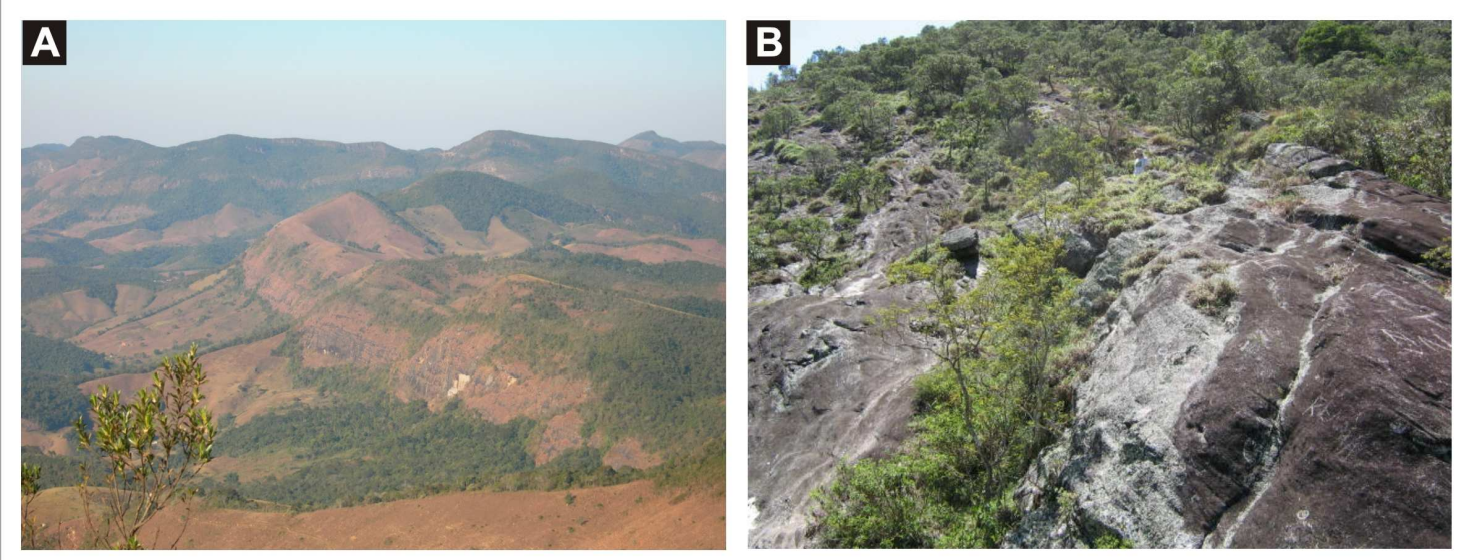

Figura 5: (A) Topo da Serra de Lima Duarte sustentada por ortoquartzito grosso, vista do Pão de Angu; (B) Topo da Serra do Pilão, sustentada por ortoquartzito grosso. 
A muscovita e a biotita ocorrem na foliação principal $S_{2}$, e definem uma lineação mineral. As micas também aparecem recristalizadas na direção da foliação oblíqua $S_{3}$. Dobras intrafoliais e mullions de intersecção também são freqüentes, às vezes formando pequenos "charutos", de dimensão centimétrica a decimétrica. Foram observadas dobras recumbentes de dimensão métrica a decamétrica, antiformais, indicando vergência para NE.

Localmente ocorrem quartzitos com sillimanita e ortoclásio, indicando um metamorfismo progressivo passando por reações de quebra de muscovita. A fase retrógrada é caracterizada pela geração de muscovita e clorita, substituindo a biotita. Outras fases acessórias observadas são: opacos e zircão.

Associado a esta unidade, são freqüentes grandes depósitos de talus no sopé das serras quartzíticas de maior altitude. São constituídos por areia quartzosa muito grossa inconsolidada, proveniente da desagregação mecânica do quartzito, e por grandes blocos e matacões angulosos de quartzito (Figura 6A).

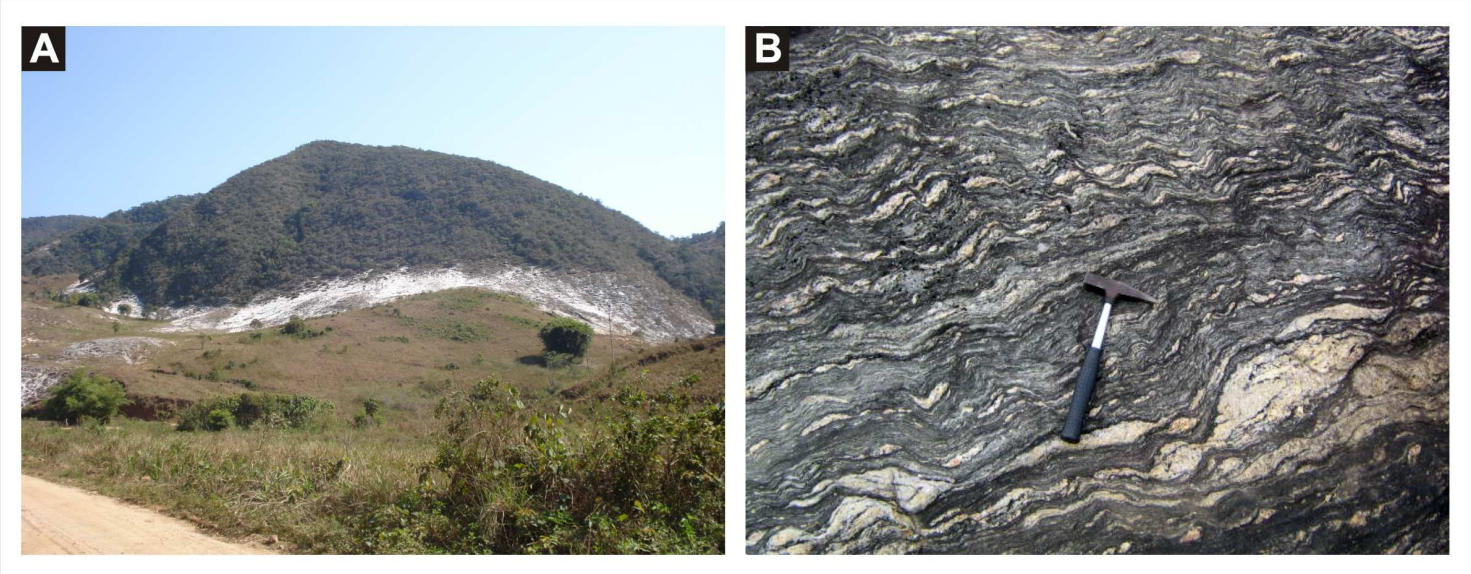

Figura 6: (A) Depósito de talus, proveniente da desagregação do quartzito, no sopé da Serra Negra; (B) Sillimanita-granada-biotita gnaisse quartzoso (SB-VII-17).

\subsubsection{Granada-sillimanita-biotita-muscovita-quartzo xisto e sillimanita-granada-biotita gnaisse quartzoso}

Esta unidade ocorre predominantemente como um corpo alóctone. O granadasillimanita-biotita-muscovita-quartzo xisto apresenta textura porfiroblástica, com porfiroblastos sub-idioblásticos de granada (até $1 \mathrm{~cm}$ ), em matriz de textura lepidonematoblástica nos leitos ricos em biotita e sillimanita e granoblástica nos leitos quartzosos. Estes leitos definem a foliação dominante $S_{2}$ localmente crenulada. Localmente o quartzo ocorre lenticularizado segundo a foliação milonítica principal $\left(\mathrm{S}_{2}\right)$, na forma de 
boudins milimétricos a centimétricos. São observados arcos poligonais de sillimanita, mimetizando a foliação anterior $S_{1}$.

A biotita ocorre freqüentemente intercrescida com a sillimanita fibrolítica ou como sombra de pressão na granada. A granada está substituída por quartzo e biotita nas bordas. É intercinemática e definida por um trilho de foliação interna (inclusões de biotita, muscovita, quartzo e sillimanita), discordante em relação à foliação externa.

O sillimanita-granada-biotita gnaisse quartzoso apresenta estrutura bandada, alternando leitos mais micáceos ricos em biotita, com estrutura xistosa e textura nematolepidoblástica, com leitos quartzo-feldspáticos granoblásticos, de dimensão milimétrica a centimétrica, granulação fina a média $(0,5-2 \mathrm{~mm})$, inequigranular (Figura 6B). Localmente ocorrem leitos nematoblásticos constituídos exclusivamente por sillimanita (Fotomicrografia 13). Os porfiroblastos de granada são de granulação média, com sombra de pressão formada por biotita e sillimanita.

O sillimanita-granada-biotita gnaisse quartzoso possui uma composição modal aproximada de plagioclásio (20\%), quartzo (40\%), biotita (20\%), opacos (5\%), sillimanita (5$10 \%)$, granada $(10-15 \%)$.

O gnaisse quartzoso encontra-se numa estrutura sinformal na Serra da Saudade (seção geológica anexo ao mapa geológico). As lentes quartzo-feldspáticas de leucossoma são concordantes com a foliação principal, e localmente apresentam dobras intrafoliais preservadas. Encontram-se estiradas e em boudins ao longo da foliação milonítica. Porções quartzosas mais espessas $(\sim 30 \mathrm{~cm})$ ocorrem como boudins estirados ao longo da foliação principal. Ocorre sillimanita na forma de arcos poligonais, indicando recristalização estática em fácies anfibolito (SB-VII-17).

\subsection{COMPLEXO MANTIQUEIRA}

Esta unidade consiste de ortognaisses migmatíticos com intercalações centimétricas a decimétricas de rochas metabásicas, na forma de boudins ou lentes concordantes com a foliação principal, além de rochas charnockíticas/enderbíticas. Os ortognaisses foram subdivididos em ortognaisses de composição granodiorítica a granítica (biotita gnaisse) e ortognaisses de composição tonalítica-trondhjemítica (hornblenda-biotita gnaisses e biotita gnaisses com granada). 


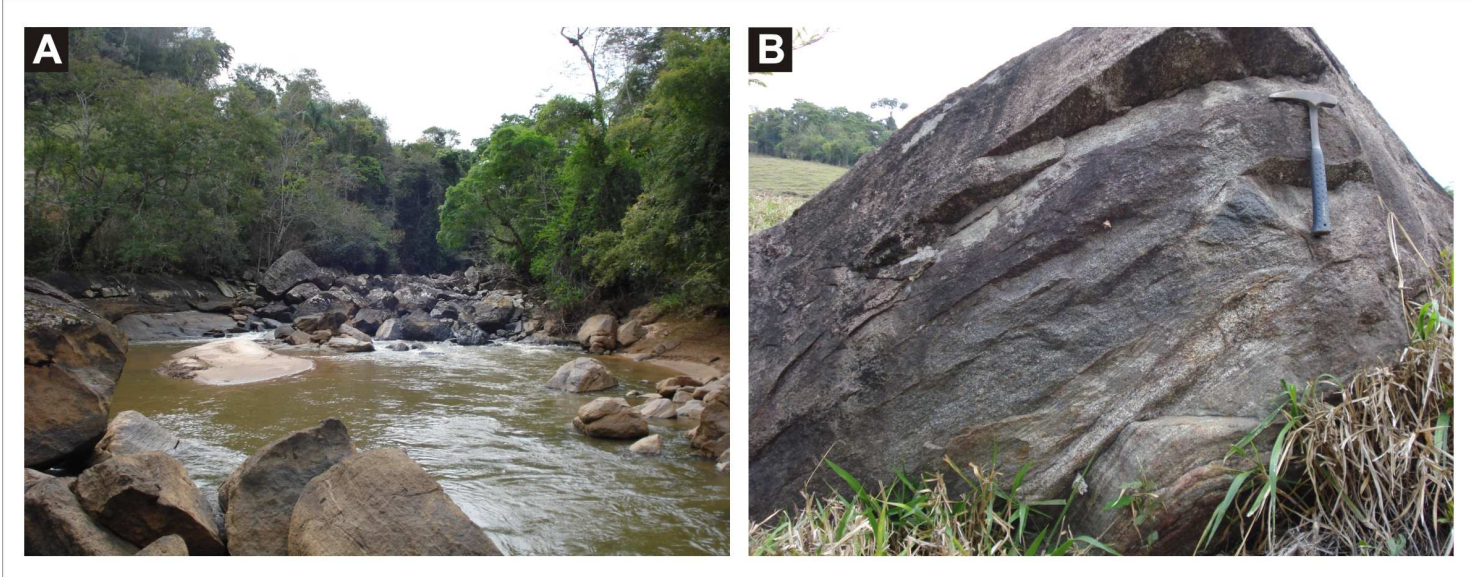

Figura 7: (A) Afloramento extenso de enderbito gnaisse no Rio Grão Mogol (município de Pedro Teixeira-MG); (B) Enderbito gnaisse, com enclave máfico de dimensão decimétrica (NLD-44).

\subsubsection{Rochas charnockíticas}

As rochas charnockíticas e granulíticas relacionadas ao Complexo Mantiqueira ocorrem no norte da área estudada (nas proximidades do município de Pedro Teixeira). Estão afetadas por zonas de cisalhamento, que localmente definem o contato com os ortognaisses do Complexo Mantiqueira e com a sequiência metassedimentar da Nappe Lima Duarte. Afloram na forma de lajes em drenagens ou na forma de grandes blocos angulosos, o que dificulta determinar a natureza dos contatos em alguns locais (Figura 7A). Comumente são cortadas por injeções tonalíticas de dimensões variadas (milimétrica a decimétrica) e possuem rochas metabásicas associadas, tanto na forma de boudins ou enclaves máficos (Figura 7B). Localmente cortam ou venulam as rochas mais máficas, de composição intermediária a básica. Os charnockitos apresentam coloração cinza-esverdeada, granulação fina a média, chegando à grossa nos tipos mais félsicos, com estrutura maciça a foliada.

\subsubsection{Enderbito gnaisse}

Aflora na forma de grandes blocos e lajedos, freqüentemente com intercalações lenticulares de rochas metabásicas de dimensão centimétrica a subdecimétrica (Figura 8A). A estrutura do enderbito gnaisse é foliada, com textura nematogranoblástica a lepidonematogranoblástica, inequigranular fina a média $(0,1-2,0 \mathrm{~mm})$, com cristais idioblásticos a subidioblásticos de hornblenda e biotita orientados na $S_{n}$ (Figuras 8B, 8C e 8D), localmente com megacristais de feldspato de até $4 \mathrm{~mm}$ (Fotomicrografia 14). 

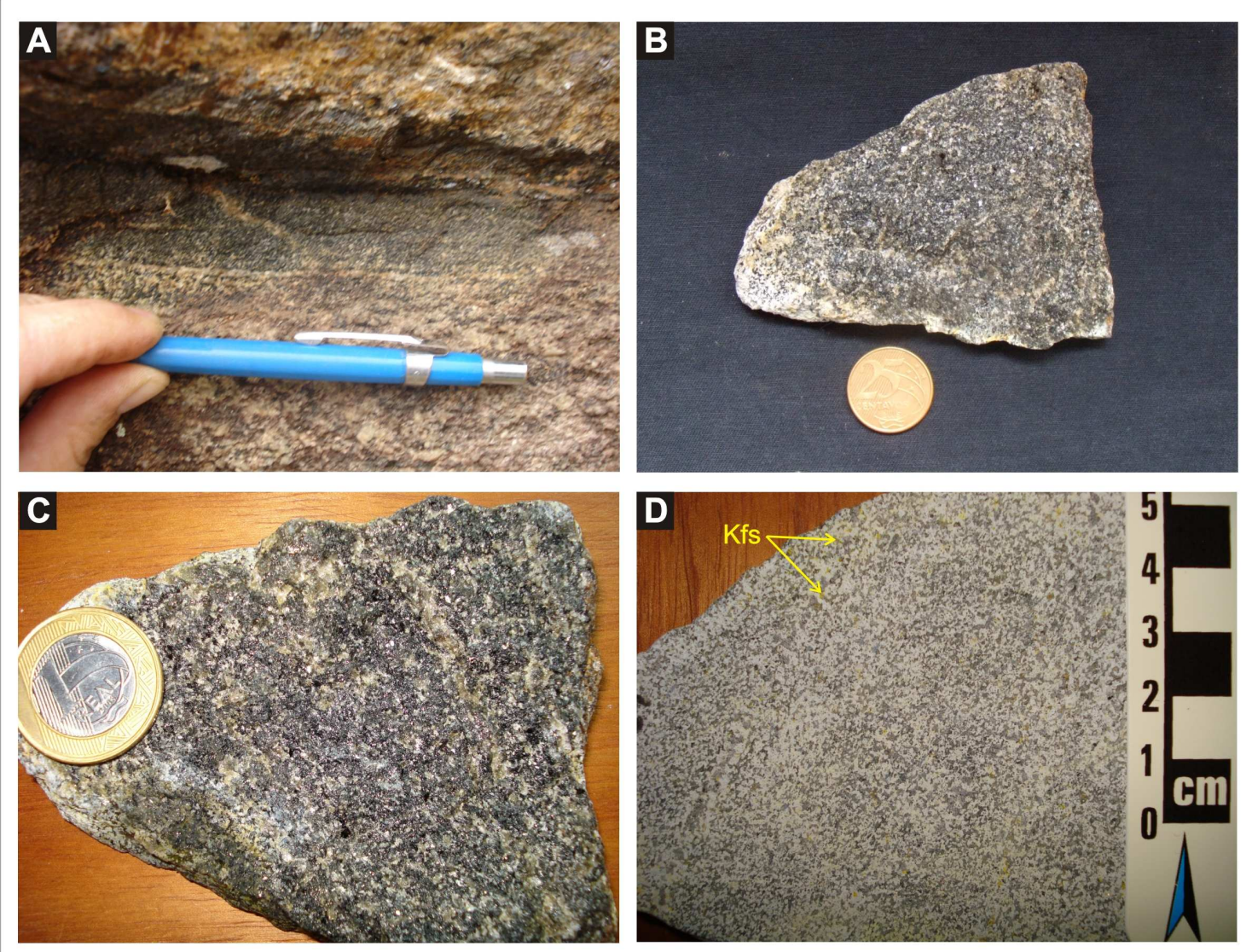

Figura 8: (A) Enderbito gnaisse, com intercalação de granada granulito (NLD-41); (B) Enderbito gnaisse (NLD41H); (C) Estrutura incipientemente foliada em enderbito gnaisse (NLD-41I); (D) Enderbito gnaisse, com pouco feldspato potássico (em amarelo, após tingimento diferencial) (NLD-41I).

O plagioclásio (40-45\%) encontra-se no limite composicional oligoclásio/andesina $\left(\mathrm{An}_{20-50}\right)$. Os contatos entre os grãos são predominantemente curvilíneos a lobados (localmente suturados). Os contatos retos são restritos aos grãos de plagioclásio poligonizados (Fotomicrografia 15). Os cristais maiores $(1-2 \mathrm{~mm})$ geralmente apresentam geminações curvadas e pontiagudas, com terminações voltadas para as bordas. Localmente ocorrem mirmequitas no contato entre os grãos de plagioclásio e feldspato potássico $(<2 \%)$.

A hornblenda (30-35\%) ocorre na forma de cristais subidioblásticos, orientados segundo a $S_{n}$, freqüentemente com microexsoluções inclusões goticulares de opacos, que tendem a se concentrar em clivagens, fraturas ou nas bordas dos grãos, com quartzo associado. Agregados de opacos de dimensão maior ocorrem associados à hornblenda e/ou biotita.

O ortopiroxênio (5-8\%) está concentrado em leitos de dimensão subcentimétrica. Geralmente encontra-se substituído por anfibólio fibroso (uralita), intercrescimentos esqueletais de $\mathrm{Bt}+\mathrm{Qtz}$, seguido por biotita de granulação grossa e por hornblenda nas bordas 
(Fotomicrografias 16, 17, 18, 19 e 20). Quando esta substituição é total, forma leitos lepidonematogranoblásticos, ricos em hornblenda, biotita e plagioclásio. O clinopiroxênio $(<5 \%)$ apresenta granulação fina $(<0,4 \mathrm{~mm})$ e é restrito aos contatos do ortopiroxênio com o plagioclásio ou ao longo de fraturas no ortopiroxênio.

\subsubsection{Biotita-granada enderbito gnaisse coronítico}

Este litotipo aflora na forma de pequenos lajedos ou blocos angulosos de rocha com estrutura maciça a incipientemente foliada (estrutura blasto-milonítica), de coloração cinza muito escura, inequigranular fina a média. É cortado por injeções de rochas tonalíticas de granulação grossa, constituída por quartzo e plagioclásio de coloração esverdeada, típica de rochas charnockíticas (Figuras 9A e 9B). O biotita-granada enderbito gnaisse é caracterizado por uma textura porfiroclástica, constituída predominantemente por cristais reliquiares ígneos de ortopiroxênio e plagioclásio de granulação grossa em matriz inequigranular fina a média, composta por grãos de plagioclásio poligonizados, quartzo, granada, clinopiroxênio e biotita (Fotomicrografias 21 e 22). Localmente ocorrem porções lepidogranoblásticas, ricas em biotita (NLD-45D).

O plagioclásio (45-60\%) ocorre na forma de porfiroclastos de até $4 \mathrm{~mm}$, com geminações curvadas e contatos irregulares, e em grãos poligonizados finos, na forma de agregados granoblásticos monominerálicos (Fotomicrografias 23 e 24). Os primeiros podem apresentar relíquias ígneas em meio a textura granoblástica metamórfica. O plagioclásio dominante é a andesina $\left(\mathrm{An}_{30-40}\right)$, com poucos grãos de oligoclásio $\left(\mathrm{An}_{20-30}\right)$ isolados. $\mathrm{O}$ feldspato potássico $(<5 \%)$ é não-geminado e alguns grãos encontram-se poligonizados. Os cristais de ortopiroxênio (10-20\%) são euédricos a subeuédricos, de granulação grossa (até $5 \mathrm{~mm}$ ), por vezes intensamente fraturados e penetrados por cristais de biotita de até $5 \mathrm{~mm}$, na forma de escamas (5-10\%) e/ou por intercrescimentos esqueletais de $\mathrm{Bt}+\mathrm{Qtz}$ (Fotomicrografias 25 a 29). Alguns grãos foram intensamente substituídos, apresentando-se na forma de relictos em meio a massas biotíticas (Fotomicrografias 30 e 31). A biotita também forma agregados divergentes e decussados de escamas delgadas, geralmente intercaladas com pequenos grãos de quartzo, e parece resultar da substituição do piroxênio (Fotomicrografia 32). O ortopiroxênio também está freqüentemente manteado por coronas pluriminerálicas constituídas por Grt $+\mathrm{Cpx} \pm \mathrm{Qtz}$ no contato com o plagioclásio (Fotomicrografia 33). 

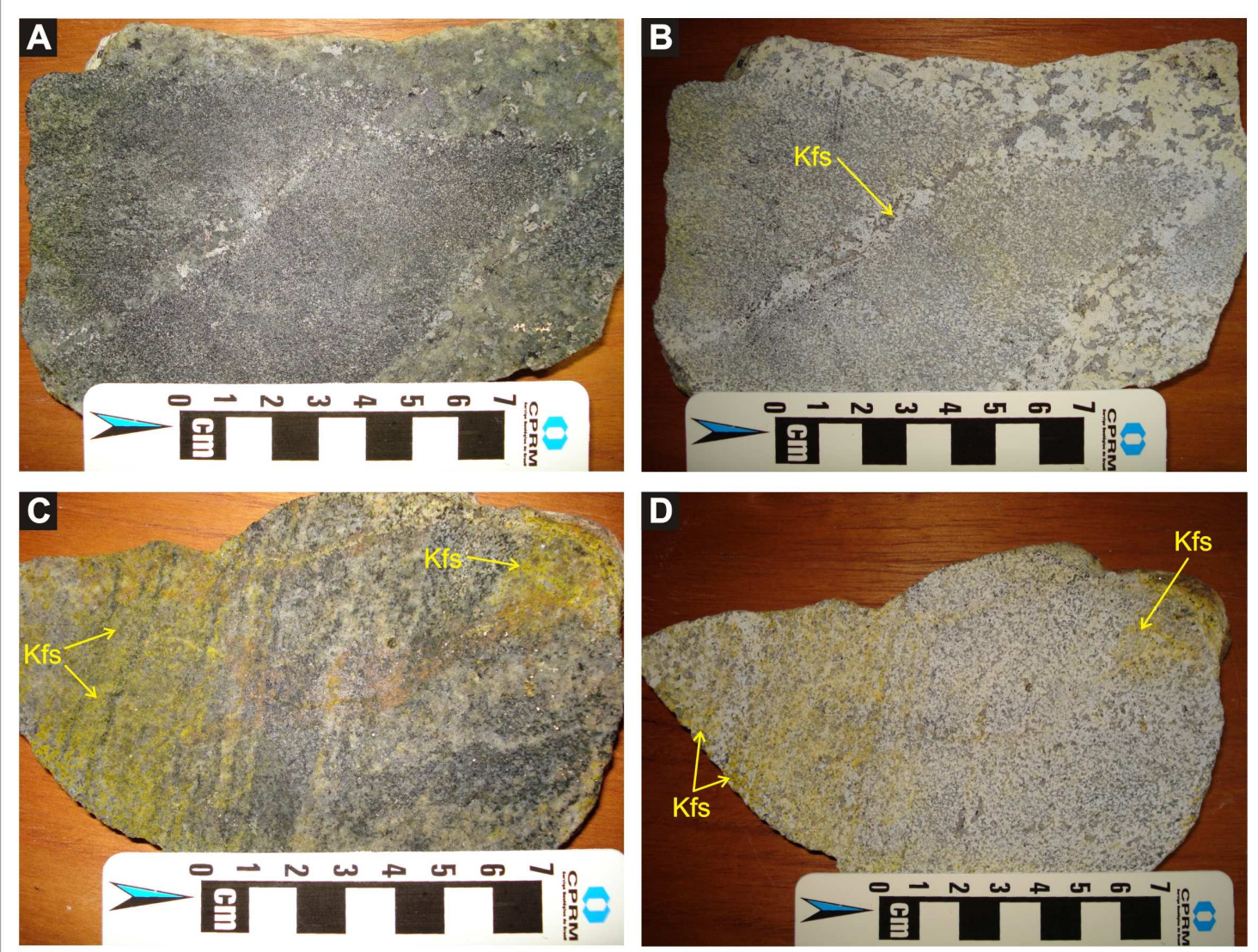

Figura 9: (A), (B) Biotita-granada enderbito gnaisse coronítico cortado por injeções tonalíticas (NLD-45C); (C), (D) Estrutura incipientemente foliada em meta-mangerito. Notar que a foliação é mais evidente nas porções ricas em feldspato potássico (NLD-41E).

Os cristais de clinopiroxênio (10-15\%) possuem granulação fina a média. Estão geralmente inclusos em ortopiroxênio ou compõem coronas com Grt e Qtz (Fotomicrografia 23). Também ocorrem alguns grãos com substituição discreta por hornblenda $(<1 \%)$ nas bordas ou ao longo de fraturas e clivagens. A granada (5-10\%) é subidioblástica a idioblástica fina, localmente com inclusões goticulares de quartzo e/ou opacos $(<2 \%)$. Outros minerais acessórios são: apatita $(<5 \%)$, zircão $(<1 \%)$, rutilo $(<1 \%)$ e calcita $(<1 \%)$.

\subsubsection{Meta-mangerito (Meta Opx-monzonito)}

A rocha apresenta estrutura dominantemente maciça, a localmente foliada, com textura granoblástica, inequigranular fina a grossa, com megacristais de feldspato de até 2,5-3,0 mm (Figuras 9C e 9D). Em escala macroscópica apresenta textura glomeroporfirítica de biotita grossa, que também ocorre na forma de bandas subcentimétricas, desenvolvendo localmente uma textura lepidogranoblástica. 
Os contatos entre os grãos de feldspato são predominantemente suturados a lobados (localmente poligonizados com contatos retos). O plagioclásio (30-35\%) dominante é o oligoclásio ( $\left.\mathrm{An}_{20-30}\right)$, exibindo evidências de deformação intracristalina, na forma de geminações curvadas e pontiagudas. Apresenta mirmequitas e inclusões vermiformes de quartzo no contato com o ortoclásio (40-45\%) (Fotomicrografias 34 e 35). O ortoclásio é não-geminado, encontra-se freqüentemente fraturado e com inclusões de clorita. Também ocorre ortoclásio pertítico, com finas lamelas de plagioclásio exsolvidas, de dimensão submilimétrica (Fotomicrografia 36). O quartzo (5-10\%) é em geral intersticial e deformado, com extinção ondulante e também ocorre associado às mirmequitas no contato entre os feldspatos.

A biotita (10-15\%) ocorre esparsa na matriz, comumente associada com a apatita. $\mathrm{O}$ ortopiroxênio (5-7\%) ocorre concentrado em leitos mais máficos, bastante corroído e fraturado, substituído por hornblenda pelas bordas e/ou por biotita pelas bordas ou ao longo de fraturas. No contato entre ortopiroxênio e biotita ocorre a substituição por intercrescimentos esqueletais de Bt + Qtz. Em uma amostra foi observado um pseudomorfo de ortopiroxênio com fraturas radiais, possivelmente causadas pela expansão por hidratação.

Os minerais acessórios mais comuns são apatita (3-5\%), na forma de cristais euédricos a subeuédricos, comumente em seção basal e hornblenda $(<5 \%)$ de coloração verde escura, substituindo o ortopiroxênio e sendo substituída por biotita. O zircão $(<3 \%)$ ocorre na forma de grãos subeuédricos alongados, bipiramidados na matriz e arredondados quando inclusos em biotita e freqüentemente dando halos pleocróicos na mesma. Também ocorrem agregados de opacos $(<2 \%)$ associados à biotita e sericita $(<1 \%)$ como produto de alteração do feldspato.

\subsubsection{Meta-charnockito (Meta Opx-granito)}

A rocha apresenta estrutura bandada, alternando leitos granoblásticos e nematogranoblásticos, de dimensão milimétrica a subcentimétrica (Figura 10A). A textura da rocha é dominantemente granoblástica, inequigranular fina a média $(0,1-2,5 \mathrm{~mm})$, com bandas nematogranoblásticas a lepidonematogranoblásticas ricas em minerais máficos, com biotita, hornblenda e alguns grãos de piroxênio definindo uma foliação principal. A maioria dos grãos de piroxênio e de feldspato apresenta uma orientação aleatória pré-foliação (estrutura ígnea reliquiar?).

O plagioclásio (25-30\%) dominante é o oligoclásio $\left(\mathrm{An}_{20-30}\right)$ e, subordinadamente, andesina $\left(\mathrm{An}_{30-40}\right)$. Alguns grãos exibem evidência de deformação intracristalina, com extinção ondulante e geminações curvas e pontiagudas, com terminações voltadas para as 
bordas dos grãos. Os contatos entre os grãos são predominantemente curvilíneos a lobados (localmente suturado). O feldspato potássico (35-40\%) é não-geminado (ortoclásio). Mirmequitas ocorrem entre esses feldspatos. Apresenta-se fraturado, com sericita ao longo das fraturas. Ocorrem pertitas com lamelas de exsolução de plagioclásio de dimensão submilimétrica $(0,01-0,05 \mathrm{~mm})$ e localmente ocorre antipertita, com lamelas de exsolução na forma de blocos de ortoclásio, de dimensão milimétrica (0,1-0,2mm) (Fotomicrografias 37 e 38). O quartzo (20-25\%) geralmente preenche interstícios entre os cristais de feldspato e biotita ou lobado associado à mirmequitas.

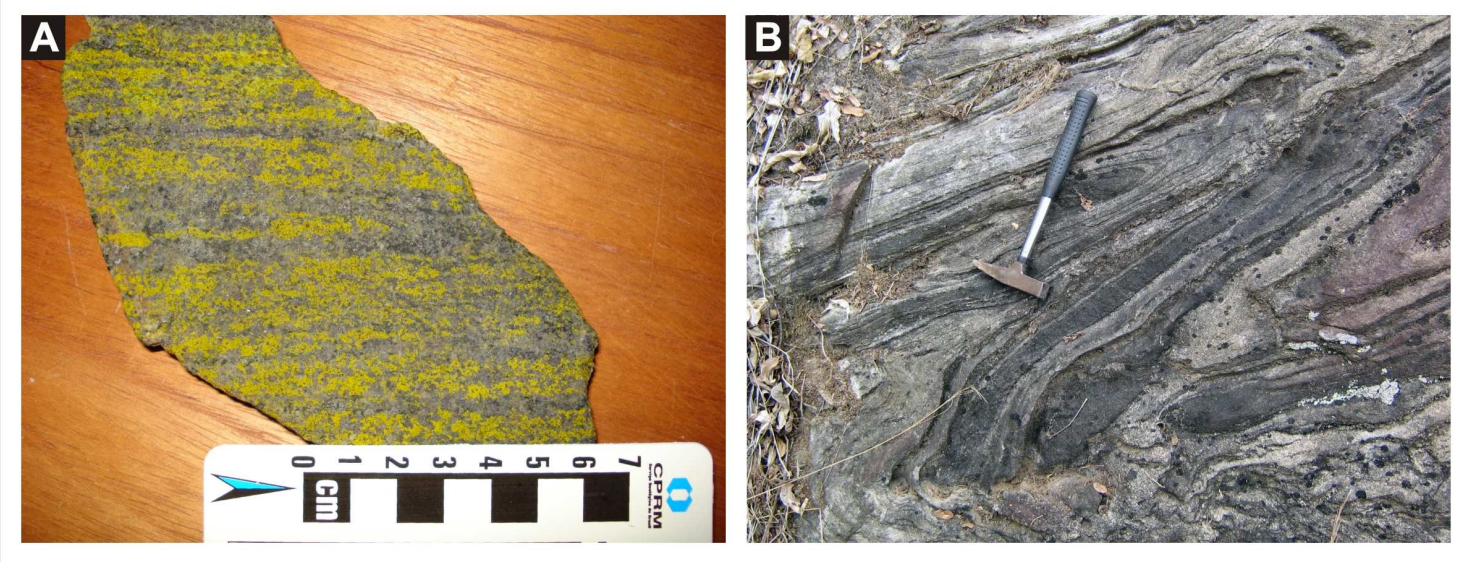

Figura 10: (A) Estrutura bandada em meta-charnockito, alternando leitos ricos em feldspato potássico (coloração amarela), com leitos ricos em plagioclásio, quartzo e minerais máficos (NLD-41F); (B) Dobra isoclinal em biotita gnaisse com intercalações de rochas metabásicas (SB-VII-16).

Ocorrem bandas ricas em minerais máficos, de dimensão milimétrica a subcentimétrica, com textura nematolepidogranoblástica, em que os grãos de ortopiroxênio (5-7\%) ocorrem muito fraturados e frequientemente substituídos por intercrescimentos esqueletais de $\mathrm{Bt}+$ Qtz e/ou por anfibólio fibroso (uralita). A biotita (7-10\%) possui granulação grossa e substitui hornblenda e/ou ortopiroxênio. Também ocorre dispersa na matriz na forma de grãos menores, associados com quartzo poligonizado.

Os minerais acessórios mais comuns são hornblenda $(<5 \%)$, apatita $(<4 \%)$, opacos $(<3 \%)$, granada $(<1 \%)$, zircão $(<1 \%)$ e clorita $(<1 \%)$. A apatita ocorre na forma de cristais euédricos a subeuédricos, comumente associada ao plagioclásio. Os minerais opacos geralmente formam agregados associados à biotita ou apatita. A granada forma coronas incompletas ao redor de opacos, nos contatos com o feldspato. Localmente apresenta microexsoluções de opacos. O zircão é em geral subeuédrico, mas também ocorrrem grãos 
ovalados e arredondados. A clorita é retrometamórfica, e ocorre substituindo a biotita ou preenchendo microfraturas em feldspatos.

\subsubsection{Ortognaisses}

\subsubsection{Biotita gnaisse}

Gnaisse metatexítico com intercalações decimétricas a métricas de diatexito com estrutura nebulítica-schilirien e boudins máficos de dimensão centimétrica a decimétrica. A rocha é caracterizada por um bandamento estromático fino a médio, com textura predominantemente granoblástica nas bandas quartzo-feldspáticas e textura lepidogranoblástica nas bandas com biotita, quartzo e feldspato.

Uma primeira fase de deformação é bem marcada nestes gnaisses por um leucossoma em dobras isoclinais sin-metamórficas $\left(\mathrm{D}_{1}\right)$ (Figura 10B), paralelas ao bandamento principal que define a $S_{2}$. Ocorrem arcos poligonais de micas mimetizando a foliação anterior $S_{1}$. Localmente a biotita e a muscovita estão recristalizadas segundo a direção da foliação $S_{3}$, oblíqua em relação à $S_{2}$. Foram observadas feições de descompressão, com injeção de veios quartzo-feldspáticos na direção do plano axial de dobras intrafoliais, assim como canais de migração de leucossoma.

O quartzo freqüentemente aparece com forma arredondada a lobada, cristalizado na forma de gotas no interior do plagioclásio. Também ocorre granoblástico e recristalizado em textura flaser. O microclínio às vezes ocorre na forma de subgrãos e localmente está substituído por muscovita. Também ocorre feldspato alcalino não-geminado (albita + ortoclásio), freqüentemente com mirmequitas nas bordas. Há texturas ígneas preservadas, evidenciadas pela presença de porfiroclastos de plagioclásio e ortoclásio pertítico com extinção ondulante (OL-VI-24). Também ocorrem porfiroclastos de feldspato em escala de afloramento, rotacionados e com cauda de pressão do tipo- $\sigma$. As principais fases acessórias são: apatita, zircão, opacos, monazita e alanita.

\subsubsection{Hornblenda-biotita gnaisse}

Metatexito estromático, caracterizado pela alternância de bandas quartzo-feldspáticas com textura granoblástica, inequigranular média a grossa e bandas ricas em biotita e hornblenda, com textura nematolepidoblástica, inequigranular fina a média (Figura 11). Ocorrem feições de fusão "in situ", com o leucossoma bem desenvolvido, e localmente com cristais subuédricos, de hornblenda de granulação grossa (até $1 \mathrm{~cm}$ ). Geralmente forma 
bolsões decimétricos a métricos de leucogranito foliado, inequigranular médio a grosso, concordante com a foliação principal. Foram descritos diversos fragmentos de paleossoma, desorientados e dispersos no neossoma, o que caracteriza uma estrutura do tipo schollen. Isto sugere que a fragmentação do paleossoma, já estruturado, se deu em um neossoma ainda em estado plástico. A foliação milonítica principal $\left(S_{2}\right)$ ocorre dobrada na forma de dobras na escala desde centimétrica a métrica, freqüentemente com injeção de leucossoma ao longo do plano axial destas dobras, ou paralelo ao bandamento principal. A foliação oblíqua $S_{3}$ é definida por cristais subidioblásticos de biotita e hornblenda.
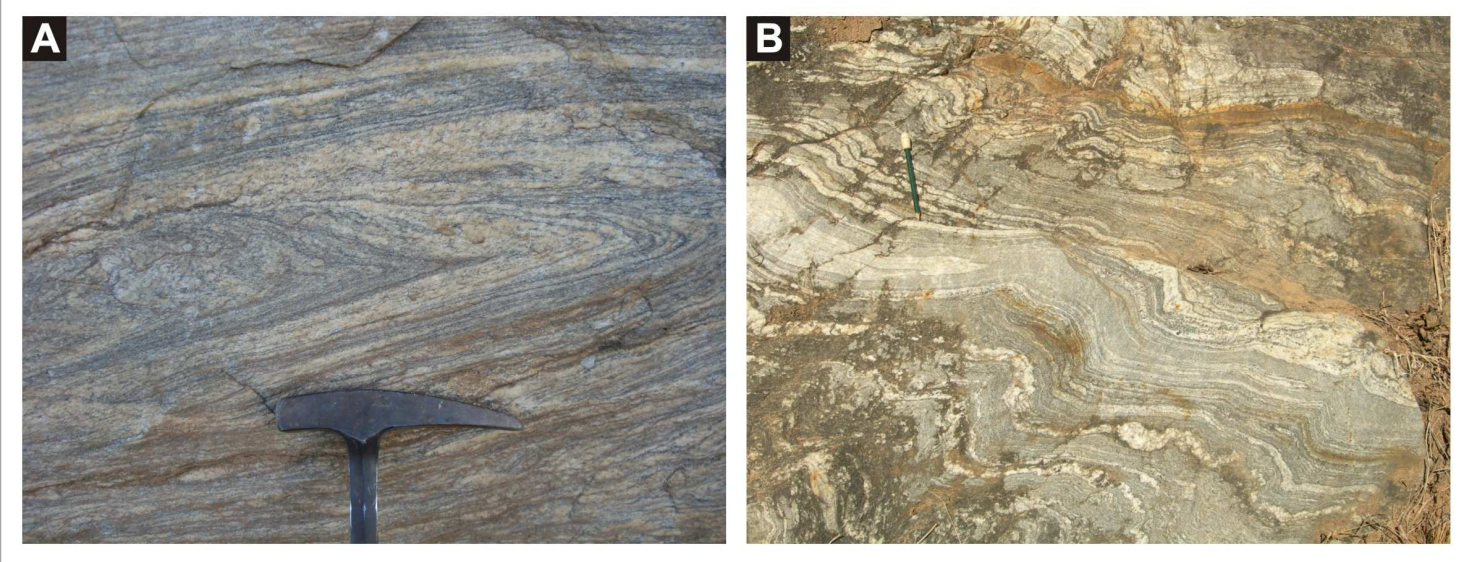

Figura 11: (A) Hornblenda-biotita gnaisse dobrado (NLD-40); (B) Hornblenda-biotita gnaisse migmatítico, com bandas extensionais de cisalhamento (LD-1).

O quartzo ocorre poligonizado na matriz, intersticial e goticular associado ao plagioclásio porfiroclástico. O microclínio freqüentemente está associado à mirmequita. Cristais esqueletais de hornblenda e zoisita apresentam inclusões de quartzo amebóide. O clinopiroxênio, de ocorrência mais restrita, às vezes apresenta inclusões de quartzo goticular no contato com a hornblenda. A titanita aparece manteada por ilmenita. Ocorrem opacos poiquiloblásticos tardios englobando cristais de zoisita, hornblenda e quartzo. A fase retrometamórfica é caracterizada pela substituição de hornblenda por biotita, de clinopiroxênio por hornblenda e de plagioclásio por epídoto.

\subsubsection{Biotita gnaisse com granada}

Diatexito estromático, caracterizado por textura granoblástica, inequigranular média a grossa e bandas ricas em biotita, com textura lepidoblástica, inequigranular fina a média. As porções mais máficas (melanossoma) são bastante ricas em biotita, pobres em quartzo e apresentam como mineral acessório a granada $(<2 \%)$, de dimensão milimétrica. Há níveis 
mais quartzosos, centimétricos, em que o quartzo ocorre fortemente estirado, definindo uma lineação de estiramento que indica transporte de topo para NW.

\subsubsection{Rochas metabásicas}

Ocorrem intercaladas nos ortognaisses do Complexo Mantiqueira em lentes métricas a decamétricas na forma de boudins, bandas pouco a totalmente transpostas ou corpos alongados, em geral concordantes com a foliação principal (Figura 12). São representadas por anfibolitos bandados e maciços, que variam de biotita anfibolitos, clinopiroxênio anfibolitos e clinopiroxênio-granada anfibolitos. Também ocorrem rochas máficas com estrutura maciça e quantidades variadas de granada, clinopiroxênio, ortopiroxênio, hornblenda e plagioclásio, com o predomínio dos piroxênios em relação ao anfibólio. Geralmente apresentam texturas coroníticas e cristais bem desenvolvidos (granada granulitos).
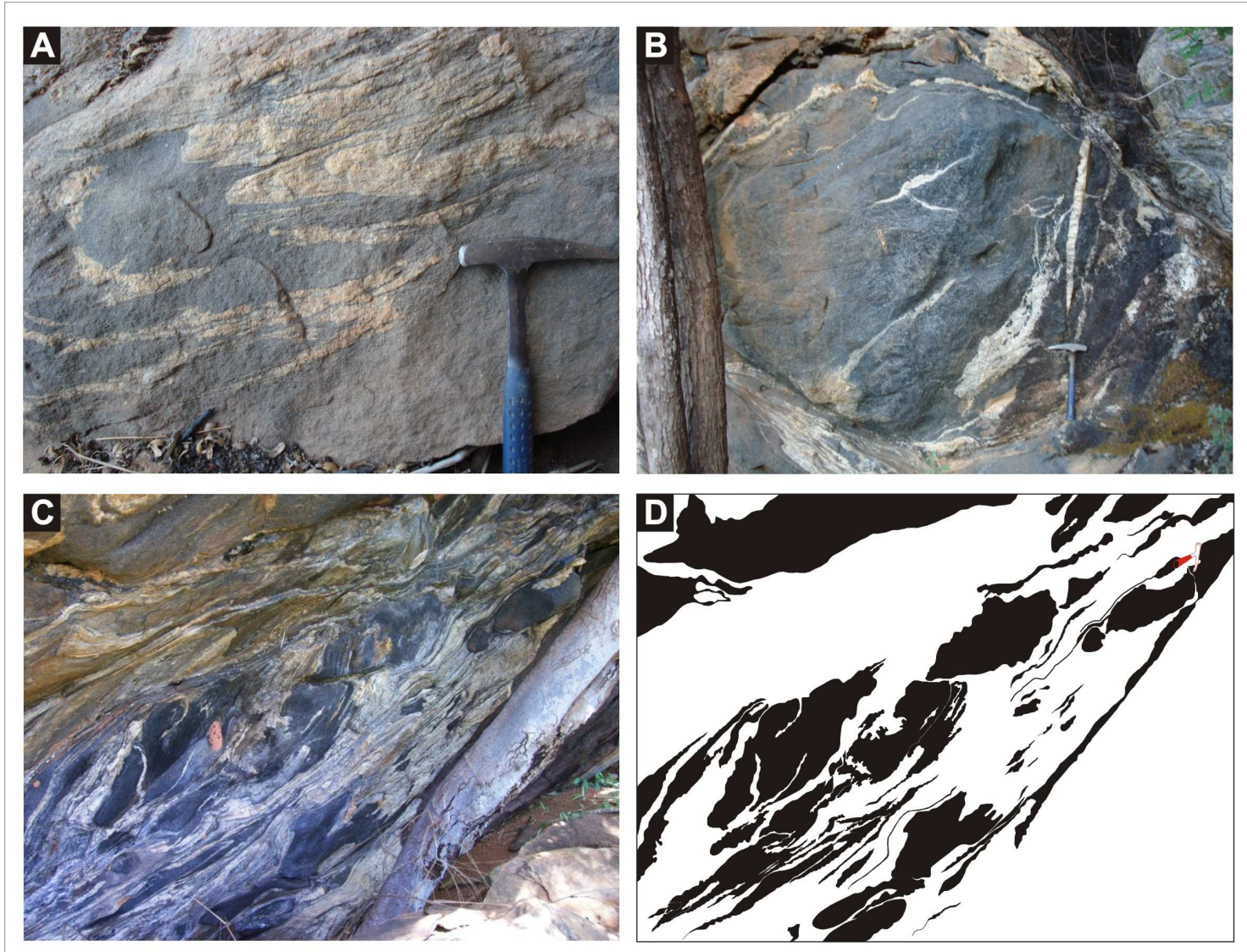

Figura 12: (A), (B), (C), (D) Boudins de rocha metabásica, com anatexia associada (NLD-40).

\subsubsection{Hornblenda metagabro simplectítico com granada}

A rocha apresenta uma estrutura predominantemente maciça, sem uma foliação bem definida, sendo caracterizada por uma textura hipidiomórfica reliquiar, inequigranular fina a 
muito fina, com cristais ripiformes de plagioclásio e textura simplectítica de $\mathrm{Hbl}+\mathrm{Pl}+\mathrm{Qtz}$ posterior, que substitui os piroxênios (Fotomicrografias 39 e 40).

A hornblenda (50-60\%) é o mineral máfico dominante e substitui o clinopiroxênio e ortopiroxênio na forma de intercrescimentos simplectíticos e freqüentemente apresenta inclusões xenomórficas de opacos e granada, além de titanita, plagioclásio e quartzo. Os cristais de $\operatorname{Cpx}(5-15 \%)$ e Opx $(<10 \%)$ são reliquiares; estão bastante fraturados e substituídos por hornblenda. Alguns cristais maiores de $\mathrm{Cpx}$ apresentam geminação preservada (Fotomicrografia 41). Em alguns locais foram observadas feições de desequilíbrio entre os piroxênios, em que o Opx aparenta estar consumindo parcialmente o Cpx (NLD-22A).

O plagioclásio (15-30\%), quando visto com os polarizadores descruzados, é ripiforme e aparenta possuir uma textura ígnea. Porém, com os polarizadores cruzados, muitos grãos estão recristalizados e poligonizados junto com o quartzo, apresentando contatos retos a suturados (Fotomicrografia 42). Grãos de plagioclásio alongados favorecem uma origem

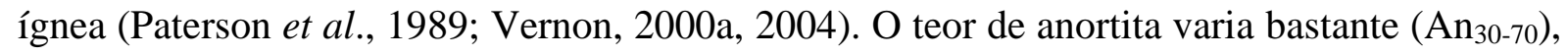
sendo que o plagioclásio predominante nestas rochas é a andesina, mas também ocorre labradorita. A granada $(<5 \%)$ ocorre na forma de cristais submilimétricos $(<0,1 \mathrm{~mm})$, subidioblásticos a xenomórficos, geralmente associada com o plagioclásio. Localmente ocorrem texturas coroníticas de granada manteando o plagioclásio ou os opacos, que por sua vez é envolvida por hornblenda (NLD-20A). O quartzo (5-10\%) ocorre principalmente intercrescido com hornblenda ou poligonizado na matriz com plagioclásio.

Aparentemente há três gerações de opacos $(<5 \%)$ : uma fase xenomórfica principal, que ocorrem inclusa em hornblenda e localmente manteada por titanita ( $<1 \%)$ (ilmenita). Ocorre uma geração de cristais bem formados na matriz, com hábito cúbico, associados ao plagioclásio e hornblenda (magnetita). Há ainda uma fase tardia, intersticial em relação aos grãos de hornblenda e quartzo (NLD-22A). A apatita (<3\%) apresenta hábito prismático bem desenvolvido, localmente com hábito acicular. Ocorrem megacristais de apatita de até 2,5mm, associados com a hornblenda e o plagioclásio da matriz.

\subsubsection{Hornblenda granulito com granada}

A rocha é inequigranular fina a média $(0,1-1,5 \mathrm{~mm})$, apresentando uma textura geral nematogranoblástica, definida pela orientação preferencial de hornblenda na foliação. Muitos 
grãos de piroxênio apresentam uma orientação preferencial oblíqua em relação à foliação. A biotita é pós-foliação.

Os grãos de ortopiroxênio são idiomórficos a subidiomórficos, pleocróicos (com pleocroísmo variando de verde-claro a bege-acastanhado), e em geral apresentam-se muito fraturados. O clinopiroxênio apresenta-se na forma de cristais idiomórficos a subidiomórficos, de coloração verde-clara, parcialmente substituídos por Hbl \pm Qtz nas bordas. Hornblenda geralmente ocorre com quartzo lobado, na forma de simplectitos substituindo os piroxênios. Localmente apresenta microexsoluções de opacos no núcleo ou nas bordas dos grãos.

É muito comum a substituição dos piroxênios por intercrescimentos simplectíticos de Hbl + Qtz. Também é observada a substituição direta dos piroxênios por Hbl. A hornblenda mimetiza o clinopiroxênio, que pode ocorrer como inclusão reliquiar.

O plagioclásio encontra-se em grande parte recristalizado, na forma de grãos poligonizados com contatos predominantemente retos. Ocorrem duas modas de plagioclásio: andesina $\left(\mathrm{An}_{30-50}\right)$ está freqüentemente em paragênese com o clinopiroxênio, enquanto que o oligoclásio $\left(\mathrm{An}_{20-30}\right)$ ocorre geralmente em paragênese com a hornblenda e a granada.

Localmente ocorre textura coronítica reliquiar de Grt $+\mathrm{Cpx}+\mathrm{Pl} \pm$ Qtz envolvendo cristais de Opx e Pl de dimensão maior (1-1,5mm), possivelmente minerais da associação magmática pretérita. Esta textura é obliterada pela substituição posterior de Hbl+Qtz. Ocorre calcita tardia, associada a zonas de maior percolação de fluidos em fraturas, possivelmente ricos em $\mathrm{CO}_{2}$.

\subsubsection{Granada granulito}

Rocha leucocrática a mesocrática, pouco foliada, com textura granoblástica inequigranular fina a média, caracterizada pela presença de cristais bem formados de clinopiroxênio e ortopiroxênio substituídos por hornblenda pelas bordas (Fotomicrografias 43 e 44). A hornblenda (15-45\%) freqüentemente apresenta inclusões de opacos e cristais reliquiares de clinopiroxênio e plagioclásio, indicando que houve um consumo parcial destes minerais. Localmente observa-se um intercrescimento simplectítico de $\mathrm{Hbl}+$ Qtz entre cristais de granada e de ortopiroxênio (Fotomicrografias 45 e 46). Ortopiroxênio (10-20\%) apresenta pleocroísmo forte, variando de verde claro a bege-rosado. Ocorre em contatos retos com o clinopiroxênio (10-30\%), que apresenta pleocroísmo variando de verde amarelado a verde-azulado claro. Freqüentemente com inclusões de quartzo e plagioclásio; localmente com inclusão de granada e plagioclásio (NLD-7A). 
A granada é poiquiloblástica a xenoblástica em alguns locais, englobando cristais de hornblenda, plagioclásio, apatita e opacos. Há um predomínio de granada tardia, idioblástica a subidioblástica (1-5\%), sendo envolvida por hornblenda e manteando parcialmente os opacos e o plagioclásio. O plagioclásio (25-45\%) encontra-se bastante fraturado e saussuritizado, com contatos retos a suturados com outros grãos. Há o predomínio de andesina $\left(\mathrm{An}_{30-50}\right)$, mas também ocorre labradorita $\left(\mathrm{An}_{50-60}\right)$. O quartzo $(<5 \%)$ ocorre intersticial na matriz ou intercrescido com hornblenda. Os opacos $(<7 \%)$ são, em geral, xenomórficos e freqüentemente ocorrem inclusos em hornblenda. Foram observados megacristais de apatita $(<3 \%)$, na forma de cristais prismáticos euédricos a subeuédricos, alongados ou na seção basal, associados com o plagioclásio da matriz. Em algumas amostras, ocorre actinolita tardia $(<1 \%)$ substituindo a hornblenda. A biotita $(<1 \%)$ está substituindo a hornblenda e a actinolita, apresentando pleocroísmo variando de marrom a pardo.

\subsubsection{Metagabronorito coronítico}

A rocha aflora na forma de blocos de dimensão decimétrica, no domínio das rochas charnockíticas. Apresenta estrutura maciça e a textura é predominantemente granoblástica, inequigranular fina a média $(0.1-2,0 \mathrm{~mm})$ caracterizada pela presença de coronas poliminerálicas compostas por Grt $\pm \mathrm{Cpx} \pm$ Qtz, ao redor de ortopiroxênio e plagioclásio (Fotomicrografias 47 e 48). Em alguns locais ocorrem leitos de dimensão milimétrica a centimétrica, com concentração de granada (NLD-42D).

Os cristais de clinopiroxênio e ortopiroxênio encontram-se bem preservados, com pouca substituição por hornblenda pargasítica (5-10\%) nas bordas. O clinopiroxênio (20$30 \%$ ) é subeuédrico a anédricos, com pleocroísmo médio variando de incolor a verde claro. Alguns grãos maiores são ricos em inclusões de plagioclásio e quartzo, enquanto que os grãos de granulação menor são isentos de inclusões e ocorrem associados com a granada. $\mathrm{O}$ ortopiroxênio (10-20\%) ocorre principalmente na forma de grãos reliquiares com as bordas corroídas, freqüentemente manteados por Grt, Qtz, Cpx ou Hbl; poucos cristais são subidiomórficos. Apresenta pleocroísmo forte, variando de verde claro a bege-rosado.

O plagioclásio (35-45\%) predominante é a andesina $\left(\mathrm{An}_{30-40}\right)$, embora haja alguns grãos de oligoclásio $\left(\mathrm{An}_{20-30}\right)$. Geralmente apresentam contatos predominantemente retos a lobados com outros grãos. A granada (10-20\%) é xenoblástica, com inclusões goticulares de quartzo e opacos, com terminações idioblásticas em direção ao contato com o plagioclásio. As 
coronas de granada se desenvolvem preferencialmente ao redor de grãos de opacos e plagioclásio e/ou ao redor de grãos de opacos e o clinopiroxênio.

Os opacos (5-10\%) são constituídos principalmente por ilmenita e hematita, com proporções menores de pirita, calcopirita e pirrotita. São muito freqüentes as texturas do tipo moat, comumente com agregados de ilmenita manteados por granada ou por uma fina corona composta por hornblenda pargasítica. Localmente desenvolvem textura poiquilítica, englobando cristais de granada, clinopiroxênio e/ou plagioclásio. A hematita $(<2 \%)$ ocorre freqüentemente associada ao ortopiroxênio, clinopiroxênio ou granada, com venulações sulfetadas tardias, constituída por pirita \pm calcopirita $(<1 \%)$ e geralmente associadas com calcita. O quartzo $(<5 \%)$ ocorre na forma de veios milimétricos associados com a granada e o clinopiroxênio ou preenchendo interstícios no contato entre a granada e o ortopiroxênio. Outros minerais acessórios são: apatita $(<3 \%)$, zircão $(<3 \%)$, calcita $(<2 \%)$, rutilo $(<1 \%)$ e epídoto $(<1 \%)$.

\subsubsection{Granada-clinopiroxênio anfibolito}

Este litotipo aflora na forma de grandes boudins intercalados nos ortognaisses, apresentando variações estruturais e texturais dependendo de sua posição (se na borda ou no núcleo do corpo anfibolítico). Quando localizado nas bordas do boudin, a rocha é caracterizada por uma estrutura protomilonítica, com textura granonematoblástica, inequigranular fina a média (Fotomicrografias 49 e 50). A hornblenda (55-65\%) define a foliação principal, localmente dobrada na forma de dobras suaves. O clinopiroxênio (5-10\%) ocorre manteado por hornblenda, em geral com intercrescimentos de $\mathrm{Hbl}+$ Qtz associados, além de opacos. Há duas gerações de granada (15-20\%): uma alongada na foliação e parcialmente substituída por hornblenda, também orientada na foliação. A outra geração é caracterizada por grãos equigranulares, subidioblásticos a idioblásticos, praticamente isento de inclusões. Constitui a fase principal, formando texturas do tipo moat, manteando o plagioclásio, eventualmente os opacos, e sendo envolvida por hornblenda. Ocorrem intercrescimentos de Qtz + Hbl na borda da granada e entre os cristais de hornblenda, estes em associação com os opacos.

Os cristais de plagioclásio (5-10\%) estão bastante estirados, alguns saussuritizados, manteados por granada e/ou hornblenda. O quartzo (5\%) ocorre predominantemente nos interstícios e também como inclusão na granada ou intercrescido com hornblenda. As principais fases acessórias são: opacos $(<5 \%)$, apatita $(<1 \%)$ e zircão $(<1 \%)$. Os opacos são 
predominantemente xenoblásticos, inclusos em hornblenda ou manteados por granada. A apatita é subidioblástica, em geral associada ao plagioclásio e o zircão ocorre na forma de cristais arredondados.

Quando representa o núcleo de um corpo anfibolítico de dimensão métrica é menos afetado pelo cisalhamento e apresenta estrutura maciça. É caracterizada pela presença de texturas do tipo moat bem desenvolvidas, com o plagioclásio sendo envolvido por granada, que por sua vez é manteada por hornblenda. Também são freqüentes os intercrescimentos de $\mathrm{Hbl}+\mathrm{Pl}+\mathrm{Qtz}$ substituindo os piroxênios, que localmente aparentam ser pseudomorfos de piroxênios totalmente substituídos (Fotomicrografias 51 a 54). Os cristais de clinopiroxênio (15-20\%) são bastante fraturados e xenomórficos, localmente na forma de megacristais ( 2mm). A hornblenda (45-50\%) é idioblástica a subidioblástica, com inclusões amebóides de opacos e quartzo.

O plagioclásio (10-15\%) é equigranular poligonizado, freqüentemente manteado por granada (15-20\%) e em alguns locais por hornblenda. Possui o teor de anortita variável, apresentando duas modas: uma de andesina $\left(\mathrm{An}_{40-50}\right)$, predominante, e outra de oligoclásio $\left(\mathrm{An}_{20-30}\right)$. A granada é tardia, idioblástica a subidioblástica, manteando o plagioclásio e localmente os opacos. Os principais acessórios são: opacos, $(<5 \%)$, apatita $(<1 \%)$, titanita $(<1 \%)$ e zoisita $(<1 \%)$.

\subsubsection{Clinopiroxênio-granada anfibolito simplectítico}

Rocha pouco foliada, inequigranular fina a muito fina, caracterizada pela presença de texturas simplectíticas de $\mathrm{Hbl}+\mathrm{Pl}+$ Qtz substituindo os piroxênios. A hornblenda (55-60\%) substitui o clinopiroxênio (5-10\%) e o ortopiroxênio $(<5 \%)$ nas bordas e ao longo de fraturas, geralmente com intercrescimentos de quartzo associados. Apresenta inclusões xenoblásticas de opacos $(<5 \%)$, que também ocorre na matriz com granada e biotita. Os piroxênios também são em geral, xenoblásticos.

A granada (5-10\%) é idioblástica a subidioblástica, freqüentemente associada ao plagioclásio e a hornblenda, porém sem formar coronas. Ocorrem alguns cristais poiquiloblásticos, englobando quartzo e hornblenda. O plagioclásio (25-30\%) predominante é andesina $\left(\mathrm{An}_{45-50}\right)$, na forma de cristais poligonizados na matriz, associados com quartzo (< $5 \%)$ e apatita $(<1 \%)$, localmente saussuritizados. A apatita apresenta hábito prismático, mas também ocorre com hábito acicular. A biotita (5-10\%) é tardia, idioblástica a subidioblástica, substituindo a hornblenda. 


\subsubsection{Rochas metaultramáficas}

Esta unidade aflora como grandes blocos angulosos. Ocorrem na forma de lentes métricas a decamétricas, inseridas nos ortognaisses do Complexo Mantiqueira. Nas zonas de contato ocorre um intenso imbricamento tectônico, em que os corpos ultramáficos estão geralmente localizados na base dos empurrões. São compostos por olivina, serpentina, Mgclorita, anfibólio magnesiano, clinopiroxênio, ortopiroxênio, espinélio, escapolita e opacos. Os principais litotipos são: metadunitos, meta-olivina-ortopiroxenito, metaharzburgito, metalherzolito e serpentinito (Mora, 2010). Apresentam estrutura predominantemente maciça (localmente foliada), granulação fina e textura nematogranoblástica a lepidogranonematoblástica. A textura mesh é a mais comumente observada, com a olivina sendo substituída por serpentina ao longo das fraturas. 


\section{PRANCHA I}
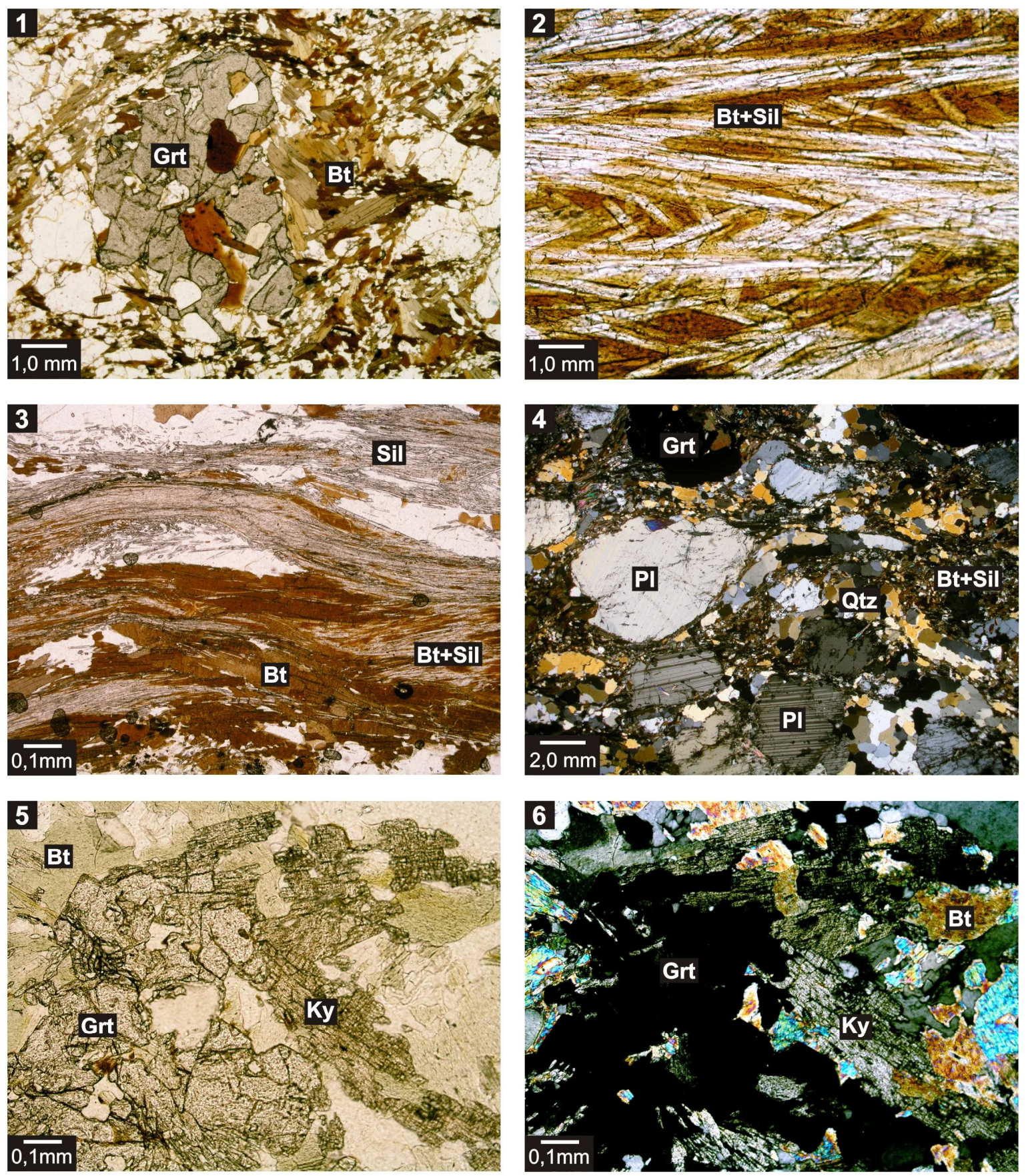

Fotomicrografia 1: Porfiroblasto de granada parcialmente substituído por biotita. Amostra SB-VII-133. Aumento de 2,5X. Polarizadores paralelos.

Fotomicrografia 2: Arcos poligonais de sillimanita e biotita. Amostra SB-IX-89. Aumento de 20X. Polarizadores paralelos. Fotomicrografia 3: Aspecto da textura nematolepidoblástica, compostos por leitos ricos em Bt+Sil definindo a foliação principal. Amostra SB-IX-89.Aumento de 10X. Polarizadores paralelos.

Fotomicrografia 4: Porfiroclastos de plagioclásio e granada, envolvidos por fitas de quartzo sigmoidal. Amostra NLD-61. Aumento de 1,25X. Polarizadores cruzados.

Fotomicrografia 5: Granada xenoblástica, parcialmente substituída por cianita. Amostra NLD-61. Aumento de10X. Polarizadores paralelos.

Fotomicrografia 6: Idem anterior. Polarizadores cruzados. 


\section{PRANCHA II}
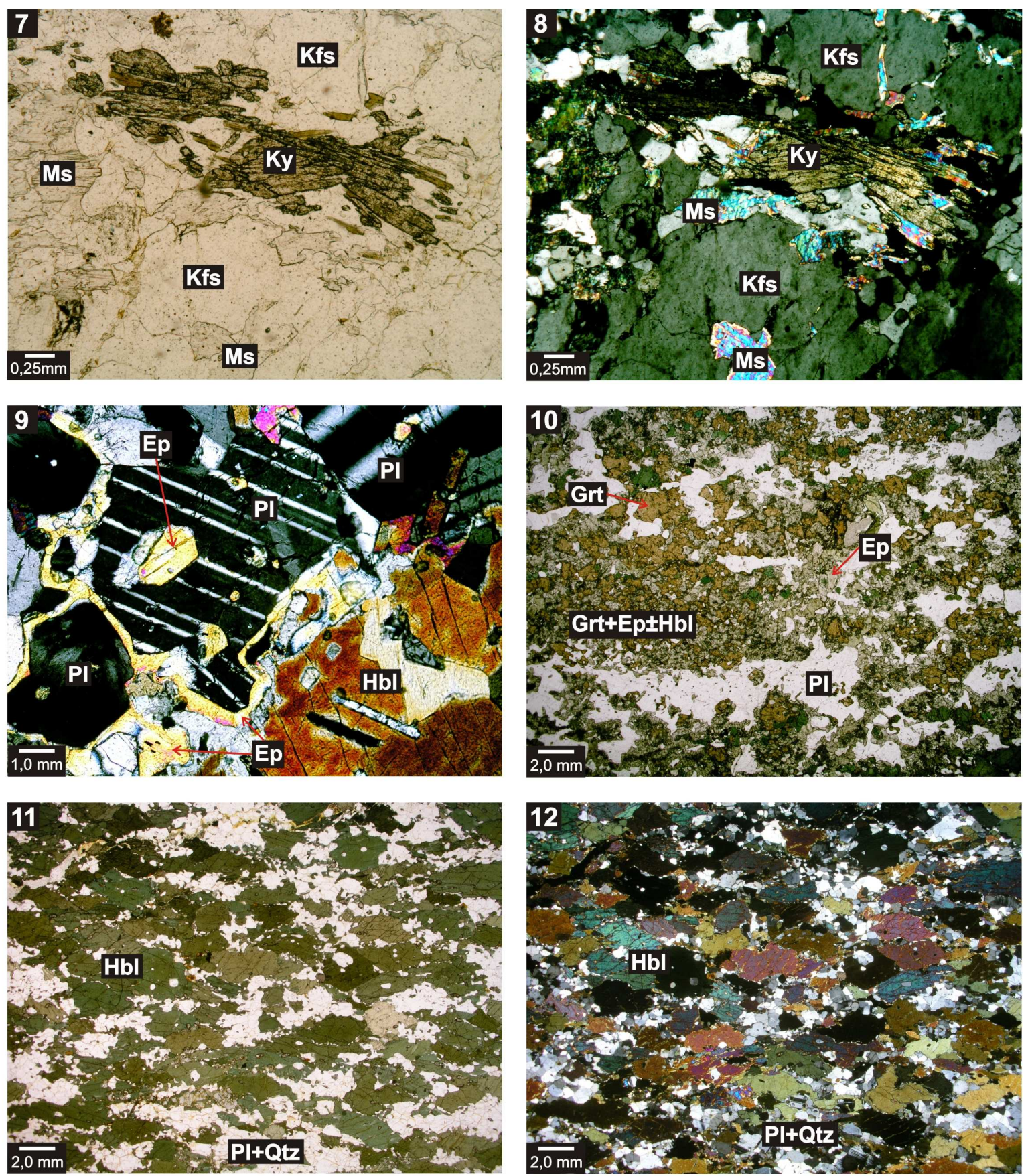

Fotomicrografia 7: Muscovita substituindo cianita, na matriz. Amostra NLD-61A. Aumento de 8X. Polarizadores paralelos. Fotomicrografia 8: Idem anterior. Polarizadores cruzados.

Fotomicrografia 9: Corona de epídoto no contato entre plagioclásio e hornblenda. Amostra SB-IV-93B. Aumento de 10X. Polarizadores cruzados.

Fotomicrografia 10: Bandas ricas em $\mathrm{Grt}+\mathrm{Ep} \pm \mathrm{Hbl}$ alternadas com bandas ricas em plagioclásio e quartzo, em gnaisse calciossilicático. Amostra SB-VII-41. Aumento de 1,25X. Polarizadores paralelos.

Fotomicrografia 11: Aspecto da textura granonematoblástica. Amostra NLD-37B. Aumento de1,25X. Polarizadores paralelos. Fotomicrografia 12: Idem anterior. Polarizadores cruzados. 


\section{PRANCHA III}
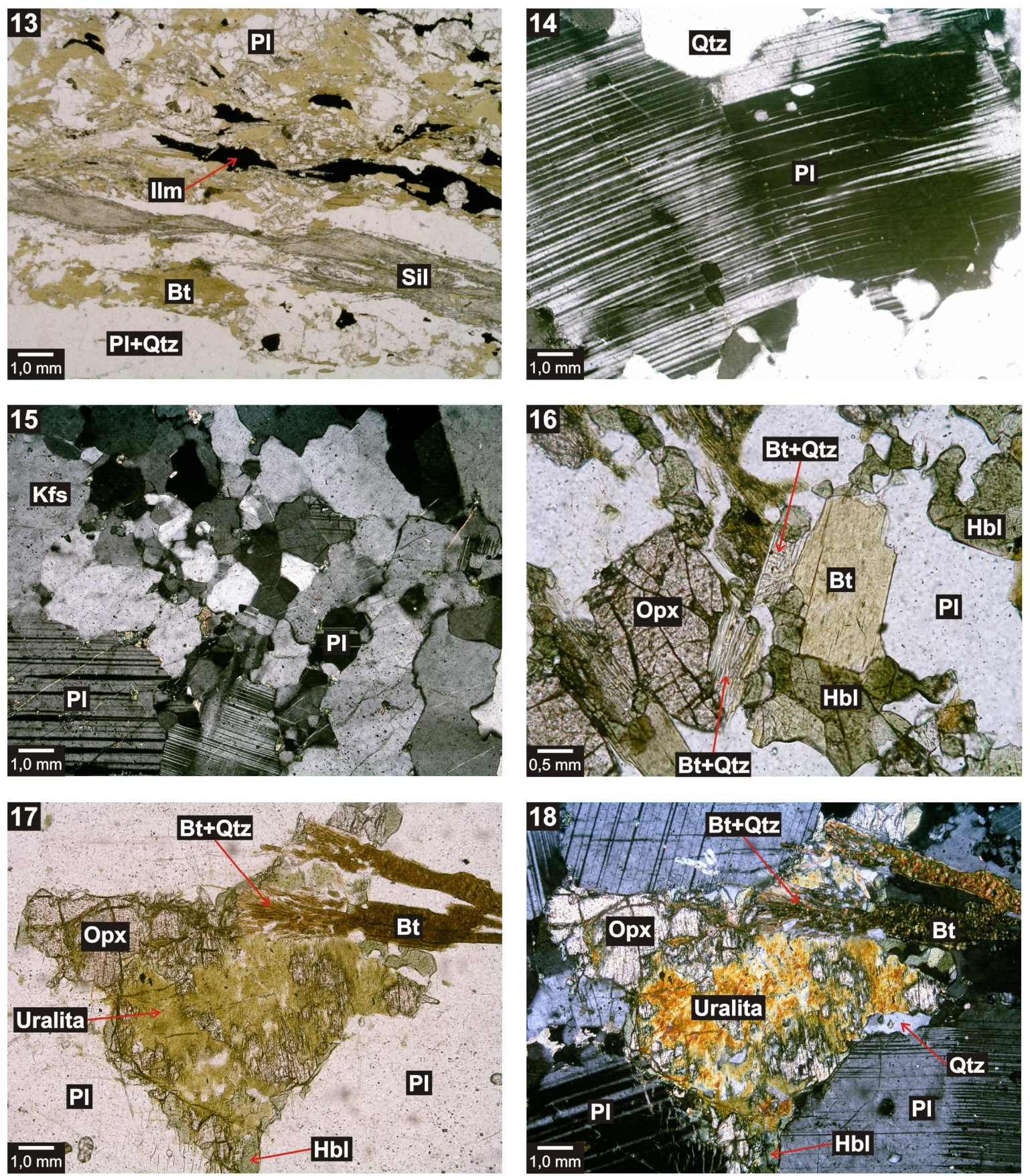

Fotomicrografia 13: Aspecto da textura nematoblástica, definida por leitos ricos em sillimanita, alternados com leitos ricos em $\mathrm{Bt}+\mathrm{Sil}$, com textura nematolepidoblástica e leitos granoblásticos ricos em quartzo e feldspato. Amostra SB-VII-17. Aumento de 2,5X. Polarizadores paralelos.

Fotomicrografia 14: Megacristal de plagioclásio, com geminações curvadas. Amostra NLD-41G. Aumento de 10X. Polarizadores cruzados.

Fotomicrografia 15: Grãos de plagioclásio recristalizados e poligonizados. Amostra NLD-41G. Aumento de 10X.

Polarizadores cruzados.

Fotomicrografia 16: Cristal de ortopiroxênio substituído por intercrescimento esqueletal de Bt+Qtz. Amostra NLD-41G. Aumento de 20X. Polarizadores paralelos.

Fotomicrografia 17: Substituição de Opx por uralita, intercrescimento esqueletal de $\mathrm{Bt}+\mathrm{Qtz}$ e por $\mathrm{Hbl}$ nas bordas. Amostra NLD-41H. Aumento de10X. Polarizadores paralelos.

Fotomicrografia 18: Idem anterior. Polarizadores cruzados. 


\section{PRANCHA IV}
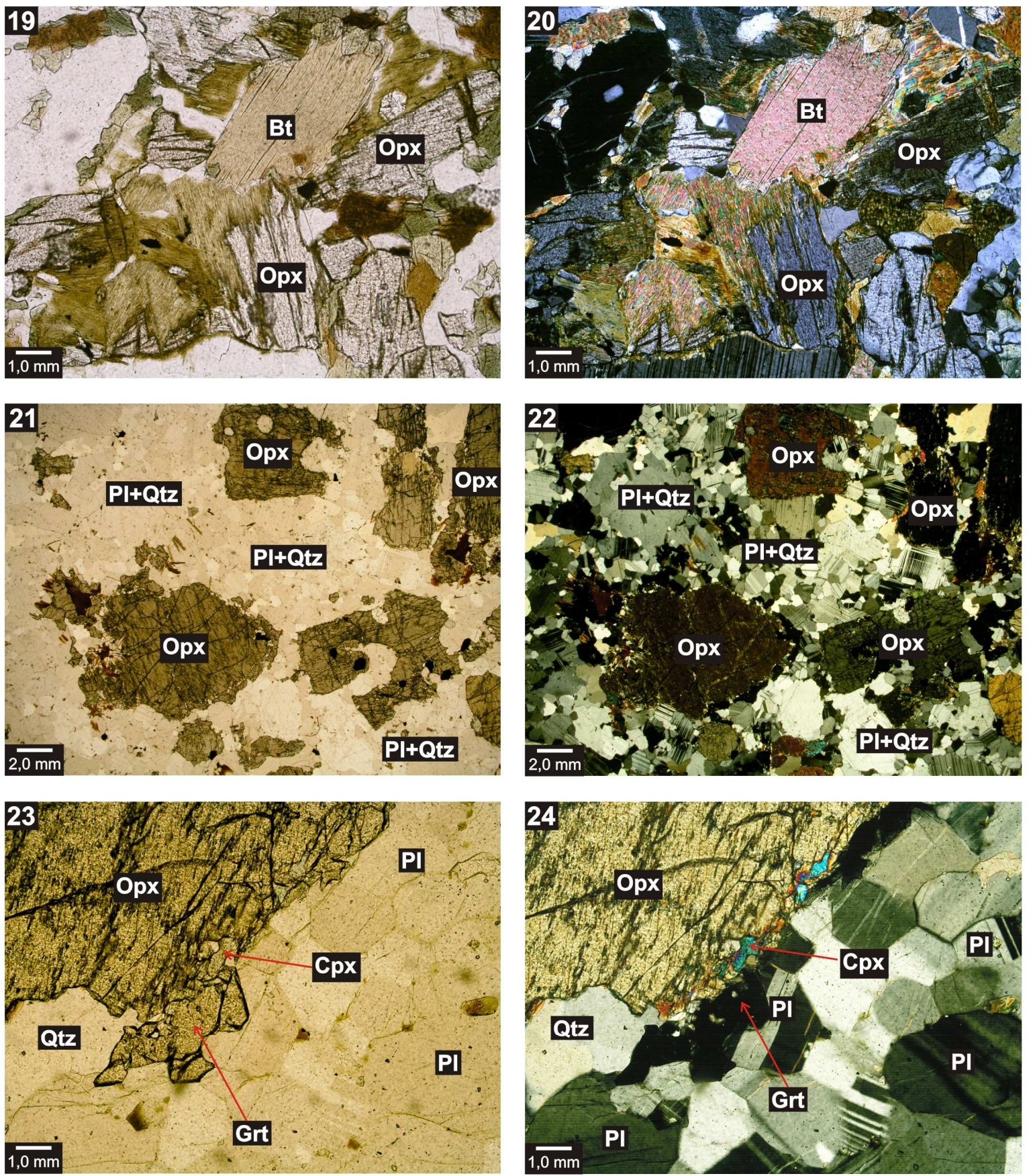

Fotomicrografia 19: Ortopiroxênio uralitizado, com substituição posterior por Bt+Qtz e por Hbl. Amostra NLD-41G. Aumento de 10X. Polarizadores paralelos.

Fotomicrografia 20: Idem anterior. Polarizadores cruzados.

Fotomicrografia 21: Aspecto da textura granoblástica, constituída por cristais grossos de Opx e PI da associação ígnea pretérita, com plagioclásio recristalizado em grãos finos. Amostra NLD-45B. Aumento de 1,25X. Polarizadores paralelos. Fotomicrografia 22: Idem anterior. Polarizadores cruzados.

Fotomicrografia 23: Plagioclásio poligonizado. Notar que no contato entre o plagioclásio e o Opx, ocorre Grt+Cpx+Qtz. Amostra NLD-45B. Aumento de10X. Polarizadores paralelos.

Fotomicrografia 24: Idem anterior. Polarizadores cruzados. 


\section{PRANCHA V}
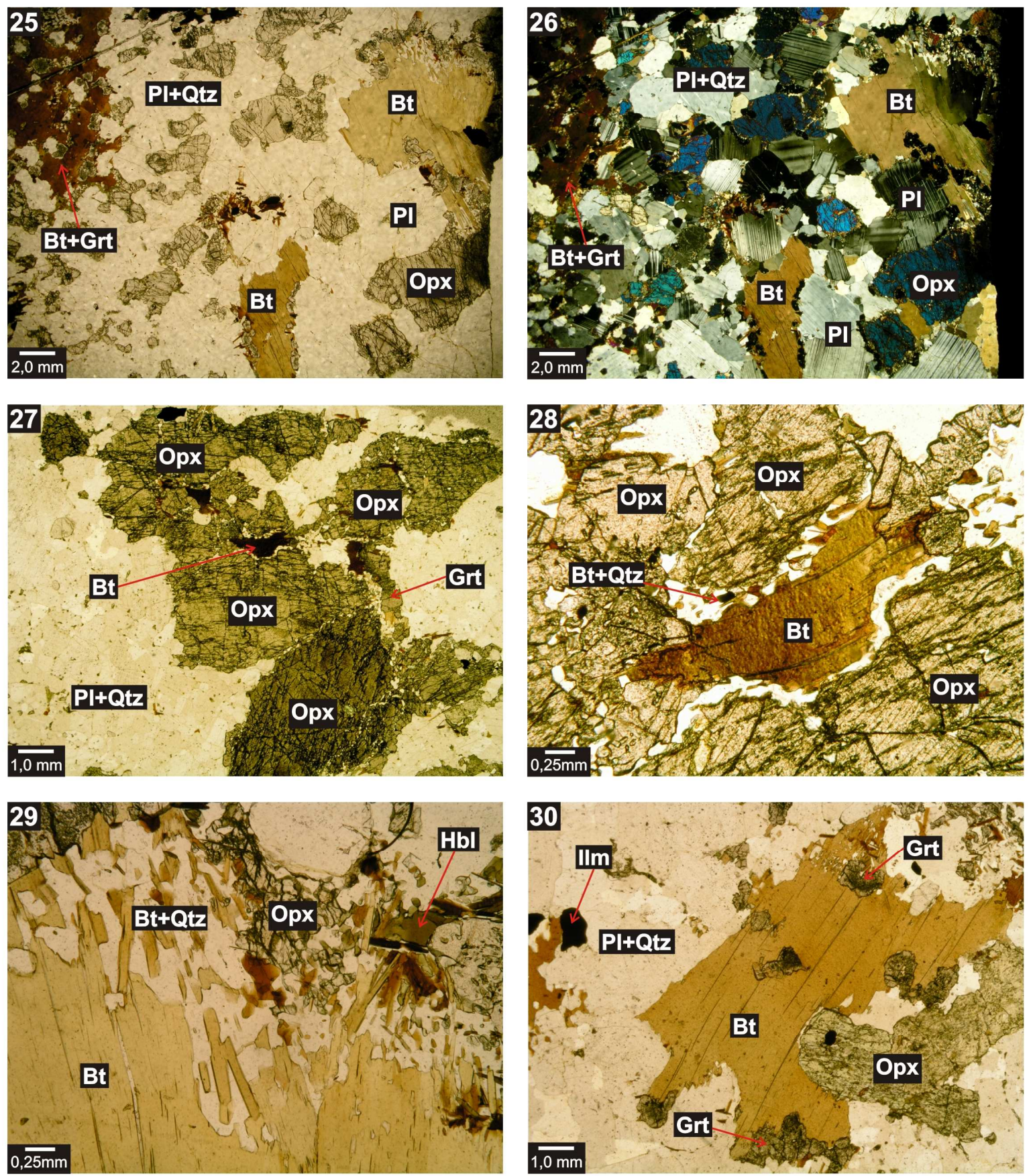

Fotomicrografia 25: Aspecto geral da textura, com porções em que predominam cristais reliquiares de ortopiroxênio preservados, e porções onde a substituição foi mais intensa e predomina biotita. Amostra NLD-45D. Aumento de 1,25X. Polarizadores paralelos.

Fotomicrografia 26: Idem anterior. Polarizadores cruzados.

Fotomicrografia 27: Megacristais de Opx com substituição por Bt+Qtz nos contatos entre os grãos. Amostra NLD-45B. Aumento de 1,25X. Polarizadores paralelos.

Fotomicrografia 28: Detalhe da foto anterior. Aumento de 8X. Polarizadores paralelos.

Fotomicrografia 29: Substituição de Opx por Bt+Qtz. Amostra NLD-45D. Aumento de 8X. Polarizadores paralelos.

Fotomicrografia 30: Megacristal de biotita, resultante da substituição de ortopiroxênio. Amostra NLD-45B. Aumento de 2,5X. Polarizadores paralelos. 


\section{PRANCHA VI}
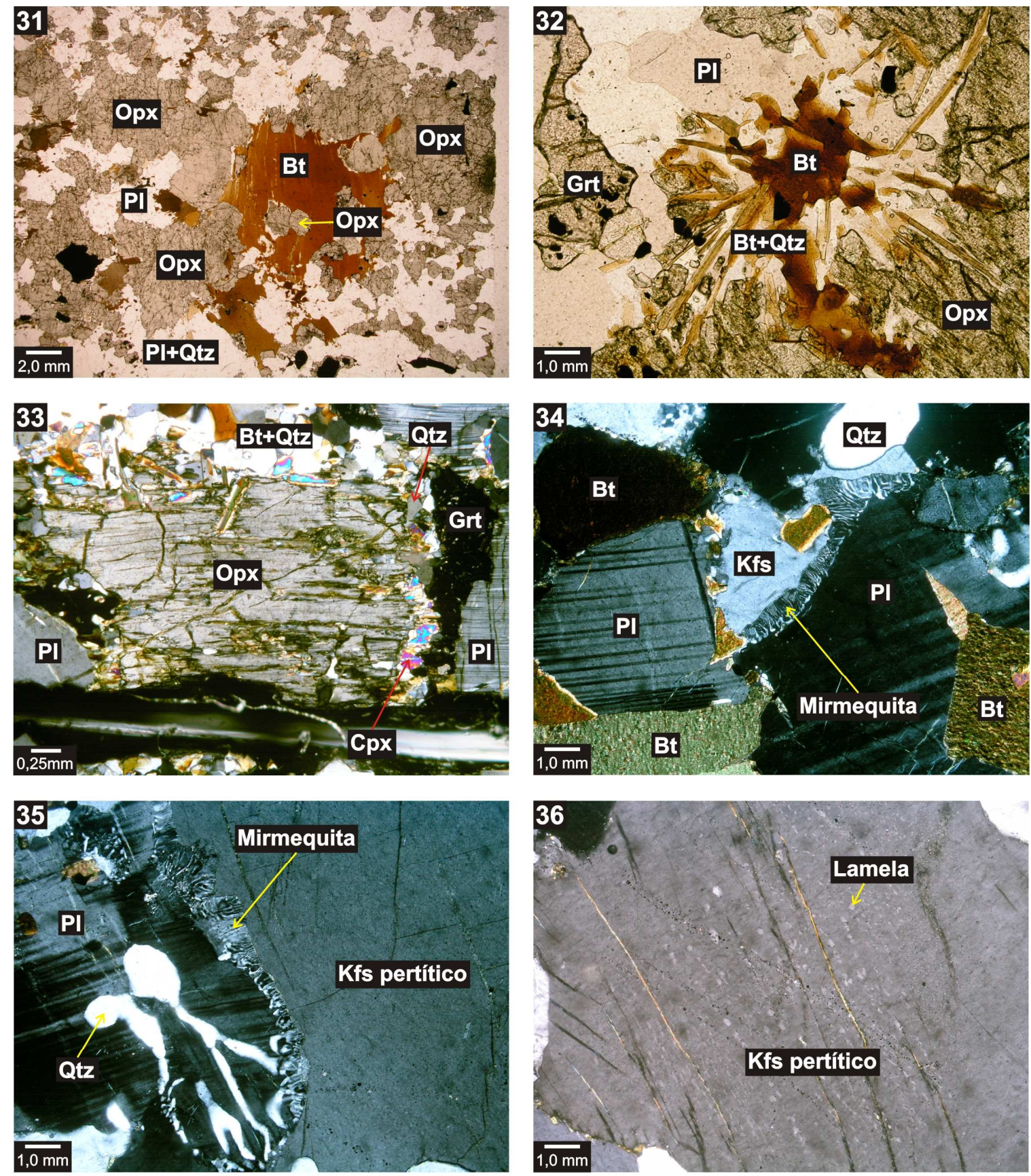

Fotomicrografia 31: Megacristais de ortopiroxênio substituídos por biotita, onde sobram relíquias de Opx em meio a massa biotítica. Amostra NLD-44A. Aumento de 1,25X. Polarizadores paralelos.

Fotomicrografia 32: Biotita formando agregados divergentes com quartzo, substituindo o Opx. Amostra NLD-45B. Aumento de 10X. Polarizadores paralelos.

Fotomicrografia 33: Opx com corona composta por Grt+Cpx+Qtz nos contatos com o plagioclásio. Nos locais onde não há formação de corona, o Opx é substituído diretamente por Bt+Qtz. Amostra NLD-45B. Aumento de 10X. Polarizadores cruzados.

Fotomicrografia 34: Mirmequita no contato entre o plagioclásio e o feldspato potássico. Amostra NLD-41E. Aumento de 10X.

Polarizadores cruzados.

Fotomicrografia 35: Mirmequita no contato entre feldspato pertítico e plagioclásio. Amostra NLD-41E. Aumento de 10X.

Polarizadores cruzados.

Fotomicrografia 36: Detalhe de um cristal de feldspato pertítico. Amostra NLD-41E. Aumento de 10X. Polarizadores cruzados. 


\section{PRANCHA VII}
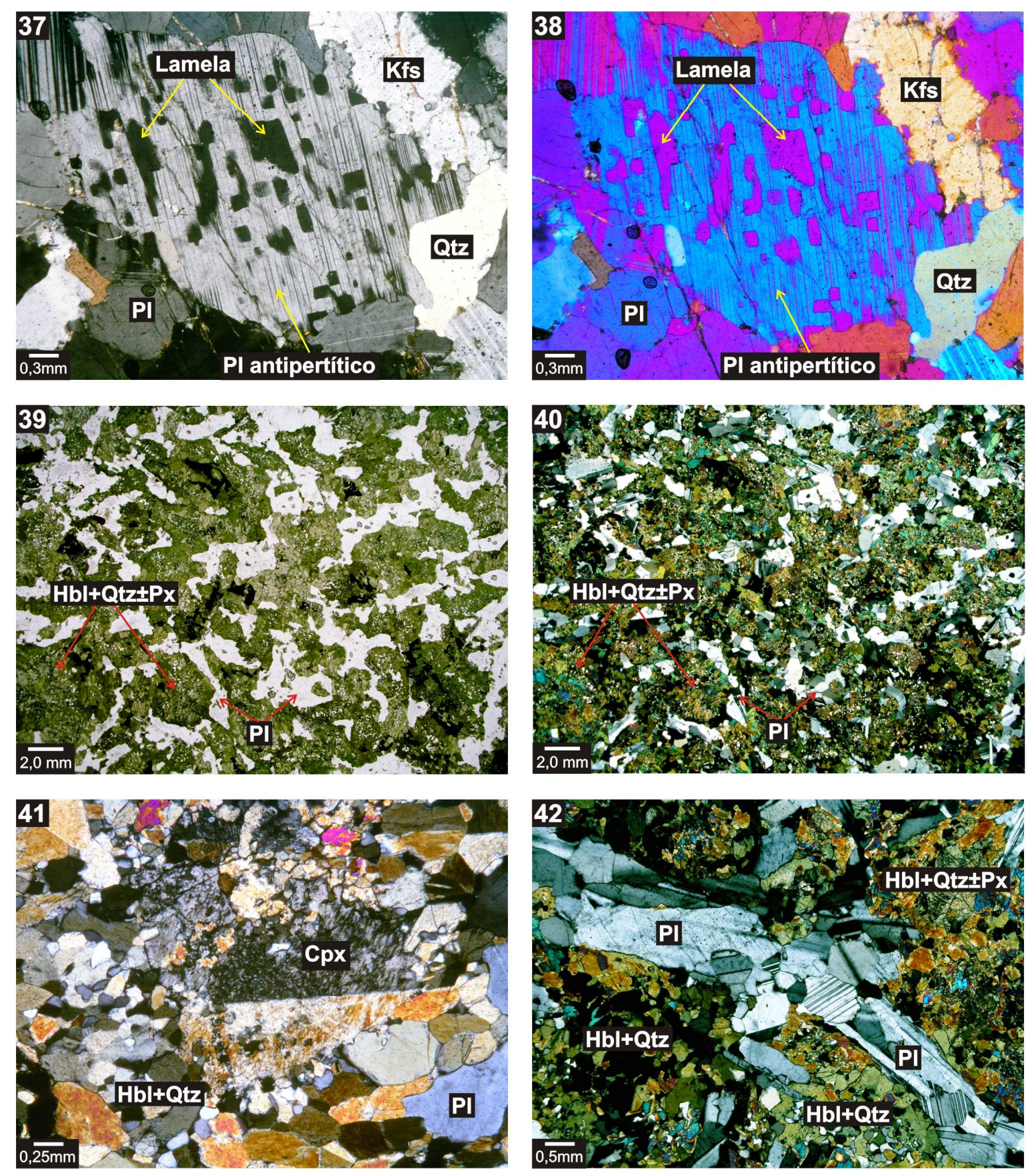

Fotomicrografia 37: Plagioclásio antipertítico. Amostra NLD-41F. Aumento de 4X+1,6. Polarizadores cruzados.

Fotomicrografia 38: Idem anterior. Polarizadores cruzados, com analisador inserido.

Fotomicrografia 39: Aspecto da textura subofítica reliquiar. Amostra NLD-20A. Aumento de 1,25X. Polarizadores paralelos. Fotomicrografia 40: Idem anterior. Polarizadores cruzados.

Fotomicrografia 41: Clinopiroxênio reliquiar, com geminaçaõ preservada. Amostra NLD-22B. Aumento de 8X. Polarizadores cruzados.

Fotomicrografia 42: Plagioclásio poligonizado. Amostra NLD-20A. Aumento de 4X. Polarizadores cruzados. 


\section{PRANCHA VIII}
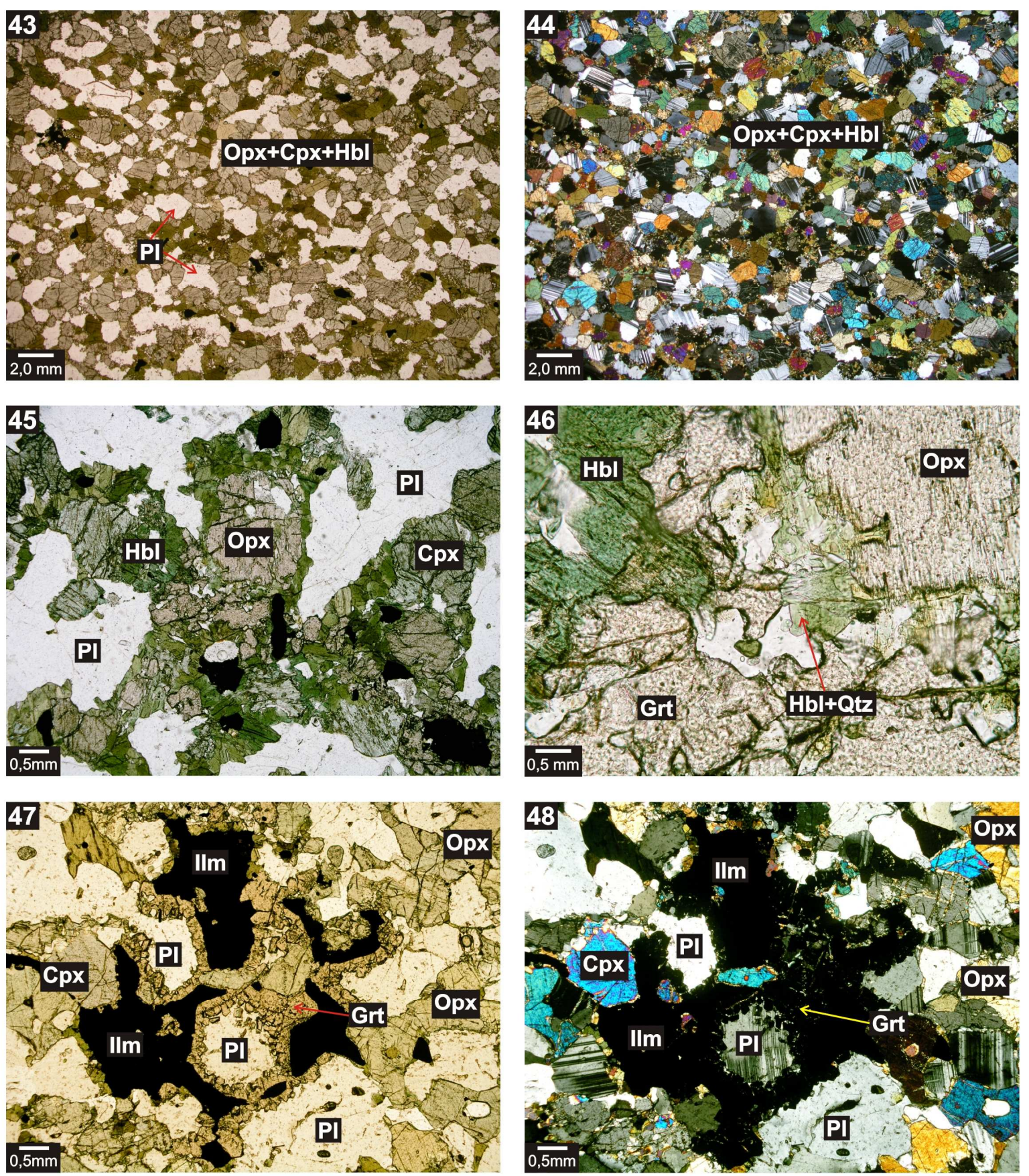

Fotomicrografia 43: Aspecto da textura granoblástica. Amostra NLD-7A. Aumento de 1,25X. Polarizadores paralelos.

Fotomicrografia 44: Idem anterior. Polarizadores cruzados.

Fotomicrografia 45: Ortopiroxênio substituído por Hbl+Qtz no contato com a granada. Amostra NLD-7D. Aumento de 4X.

Polarizadores paralelos.

Fotomicrografia 46: Detalhe da foto anterior. Aumento 20X. Polarizadores paralelos.

Fotomicrografia 47: Texturas coroníticas com Grt+Cpx \pm Qtz no contato entre plagioclásio, ilmenita e piroxênios da associação magmática pretérita. Amostra NLD-42D. Aumento de 4X. Polarizadores paralelos.

Fotomicrografia 48: Idem anterior. Polarizadores cruzados. 


\section{PRANCHA IX}
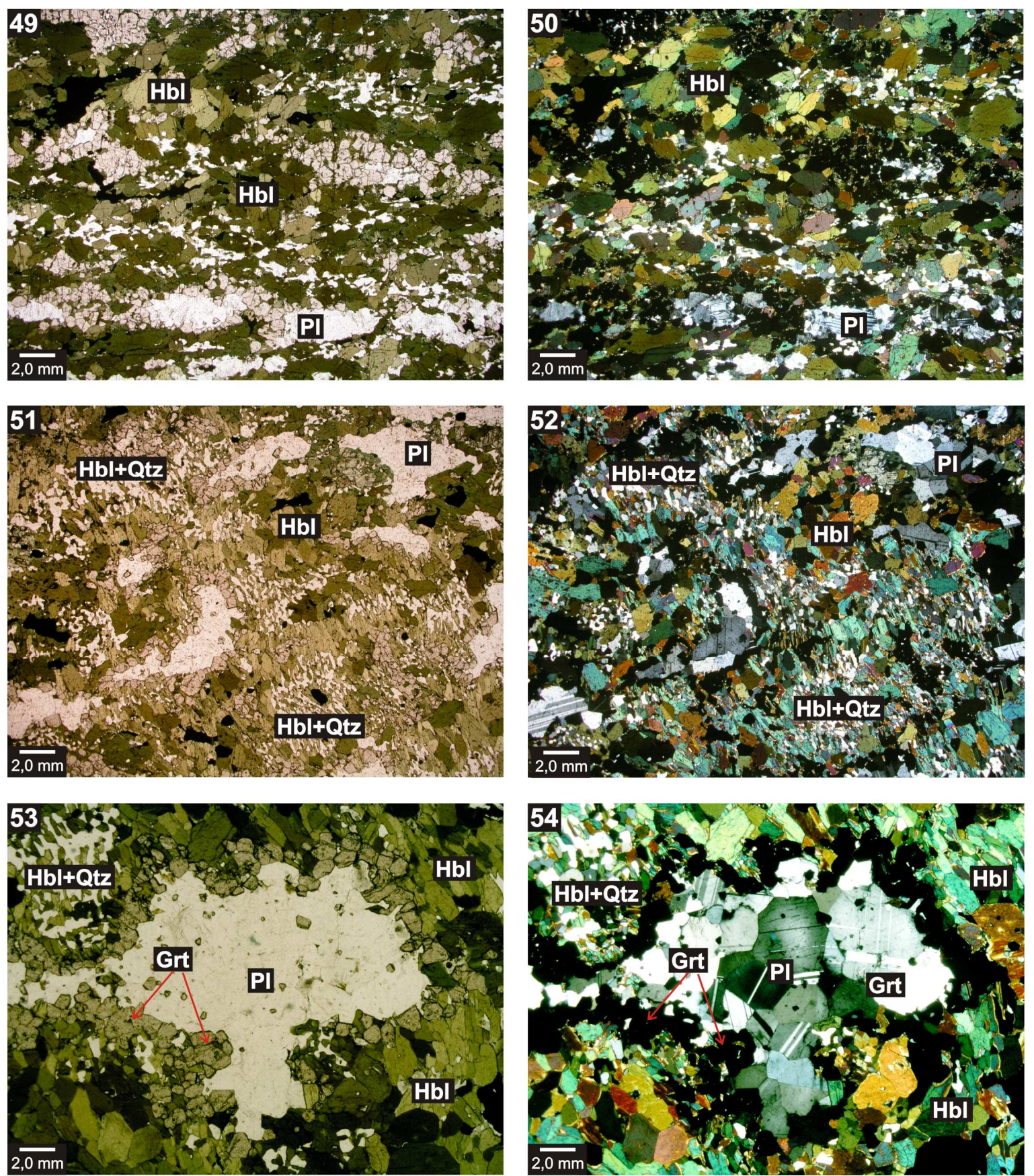

Fotomicrografia 49: Aspecto geral da textura granonematoblástica. Amostra NLD-8A. Aumento de 1,25X. Polarizadores paralelos.

Fotomicrografia 50: Idem anterior. Polarizadores cruzados.

Fotomicrografia 51: Aspecto geral da textura simplectítica, com Hbl+Qtz sibstituindo os piroxênios.. Amostra NLD-8C. Aumento de 4X. Polarizadores paralelos.

Fotomicrografia 52: Idem anterior. Polarizadores cruzados.

Fotomicrografia 53: Textura coronítica com colar de granada ao redor de plagioclásio no contato com pseudomorfo de piroxênio substituído por simplectitos de Hbl+Qtz. Amostra NLD-8C. Aumento de 1,25X. Polarizadores paralelos.

Fotomicrografia 54: Idem anterior. Polarizadores cruzados. 


\section{GEOLOGIA ESTRUTURAL}

\subsection{Estruturação da área}

A Nappe Lima Duarte está localizada na porção oriental do sistema orogênico, e é cavalgada a SE pela Nappe Andrelândia e ambas cavalgam a seqüência metassedimentar do Grupo Carrancas. A estrutura da pilha alóctone se deu sob condição de fácies anfibolito superior, com anatexia associada. A foliação principal regional $\left(S_{2}\right)$ é relacionada ao auge metamórfico e possui orientação NE-SW, com mergulhos de baixo a médio ângulo para SE. A infra-estrutura gnáissica apresenta a foliação principal $S_{3}$, correlata na orientação e metamorfismo com a foliação regional $S_{2}$ presente na pilha metassedimentar. São destacadas as superfícies de cavalgamento, que reorganizam as unidades em duplexes e imbricados (Figura 13). As escamas de cavalgamento são rompidas por imbricações da infra-estrutura gnáissica. Ocorrem dobramentos tardios que deformam localmente as superfícies de cavalgamento (mapa geológico e seção geológica em anexo).

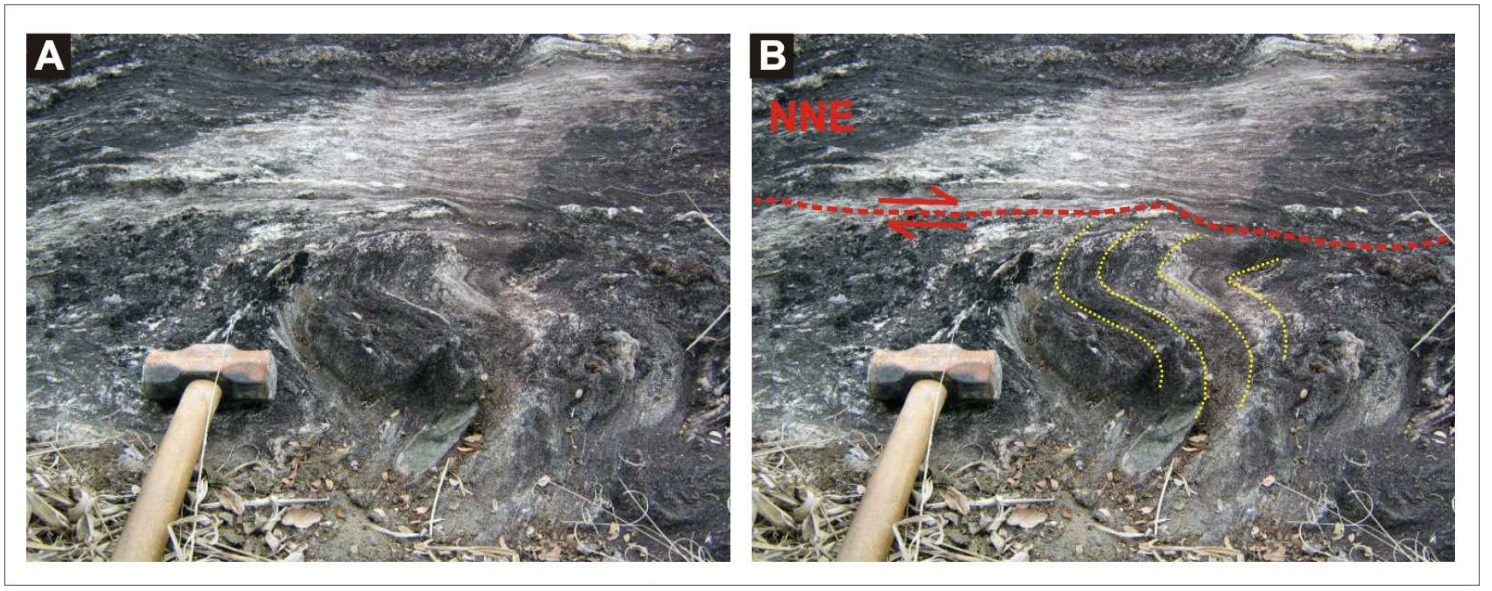

Figura 13: Sillimanita-granada-biotita gnaisse metatexítico em contato tectônico sobre o sillimanita-granadabiotita gnaisse quartzoso, na Serra da Saudade.

\subsection{Foliações metamórficas}

A foliação principal regional $\left(S_{2}\right)$ é definida por uma alternância de bandas granoblásticas (ricas em quartzo e feldspato) e bandas lepidoblásticas (ricas em biotita) a lepidonematoblásticas (biotita e sillimanita) nos paragnaisses, que é paralela a leucossomas e a um bandamento composicional nos ortognaisses (Figura 14). Pode ser caracterizada como uma foliação gerada por cisalhamento dúctil (acompanhada por recristalização dinâmica), localmente com caráter milonítico, principalmente nas unidades metassedimentares. A fase de 
deformação $\left(\mathrm{D}_{2}\right)$ é manifestada na forma de dobramentos de dimensão centimétrica a decamétrica (Figura 15). Também foi responsável pala geração de megadobras recumbentes (ex: Serra Negra), com vergência para NW (Figura 16).

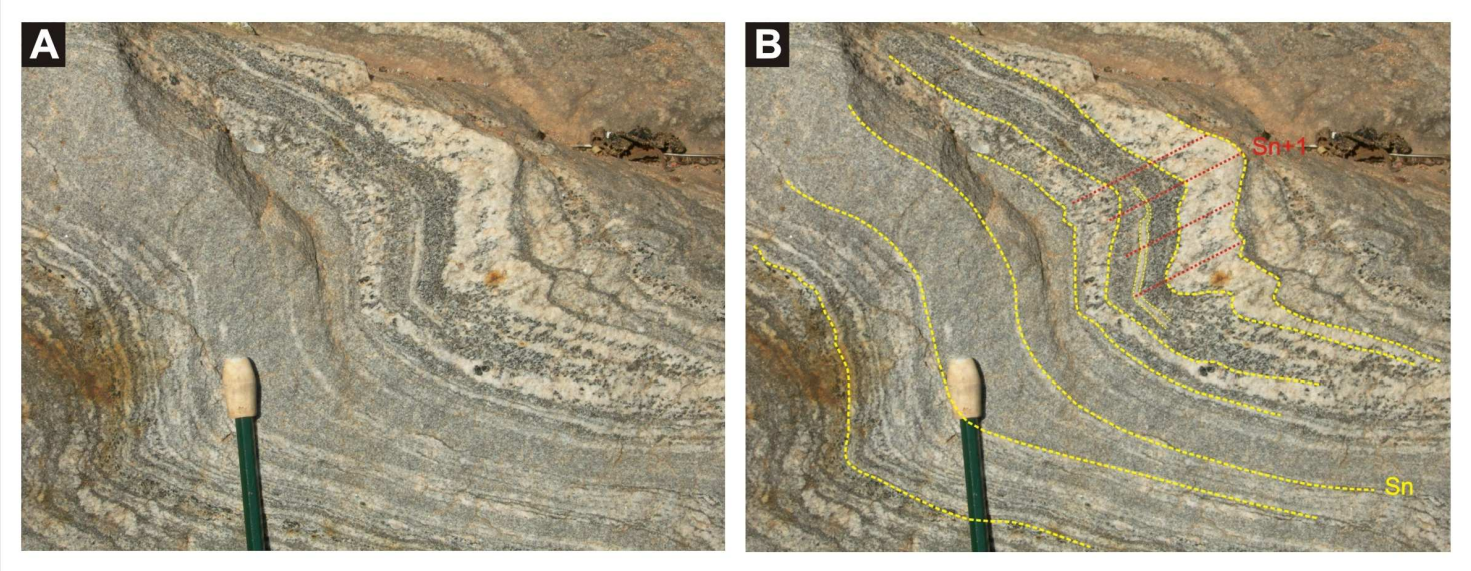

Figura 14: Foliação principal $S_{n}$ paralela ao bandamento gnáissico em Hbl-Bt gnaisse (NLD-1), com cristais de hornblenda no leucossoma orientados segundo a foliação oblíqua $S_{n+1}$.
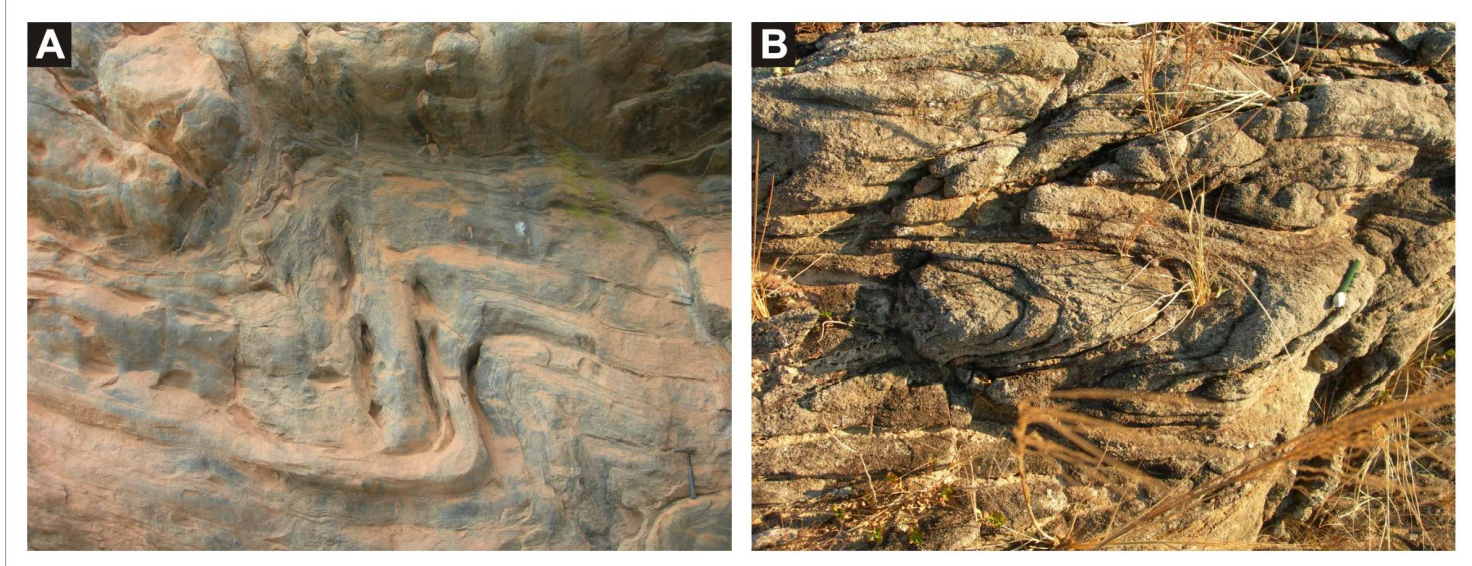

Figura 15: (A) Hornblenda-biotita gnaisse migmatítico, dobrado (NLD-23); (B) Dobras isoclinais em ortoquartzito (OL-VII-43).

A primeira fase de deformação gerou a foliação $S_{1}$, que está totalmente transposta pela foliação principal $S_{2}$. A superfície $S_{1}$ é reconhecida em dobras de dimensão milimétrica a centimétrica, apertadas a isoclinais (Figura 17), intrafoliais a $S_{2}$, geralmente com flanco rompido (Figura 18). A terceira fase de deformação $\left(D_{3}\right)$ também é reconhecida como uma xistosidade oblíqua ao bandamento gnáissico. Uma clivagem espaçada pós- $\mathrm{S}_{2}$ ocorre nos quartzitos plano axial de dobras subseqüentes (Figura 19). 

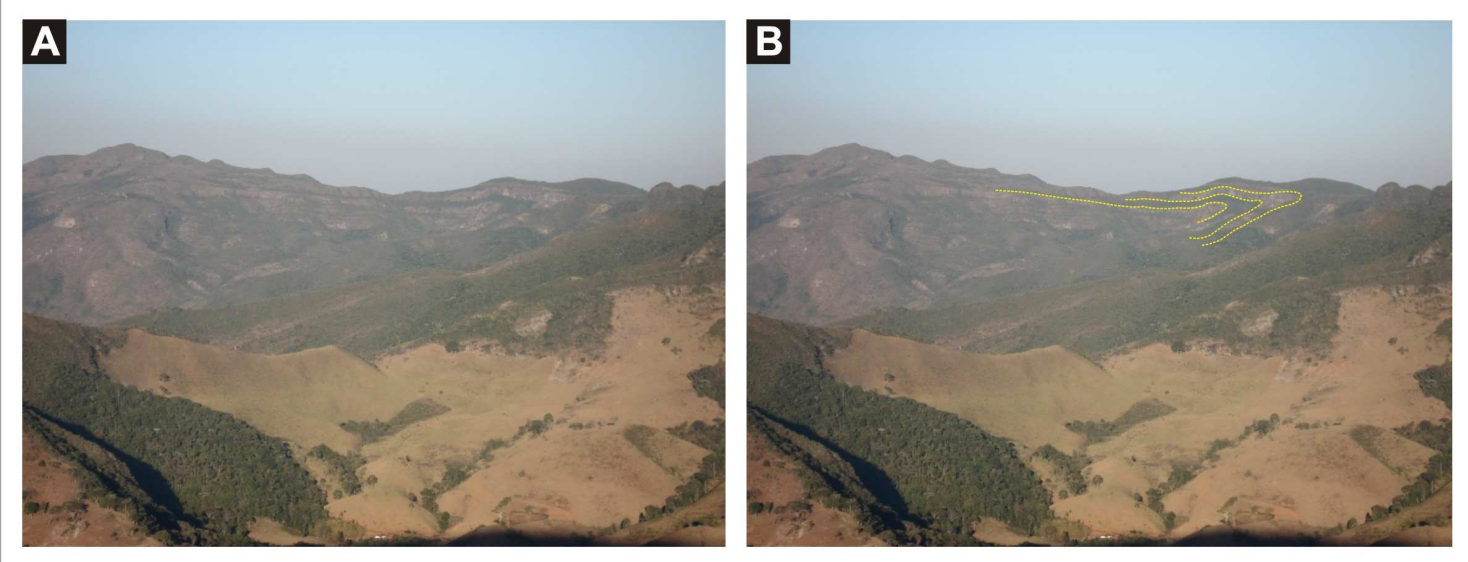

Figura 16: Megadobra recumbente na Serra Negra (quartzitos e paragnaisses).
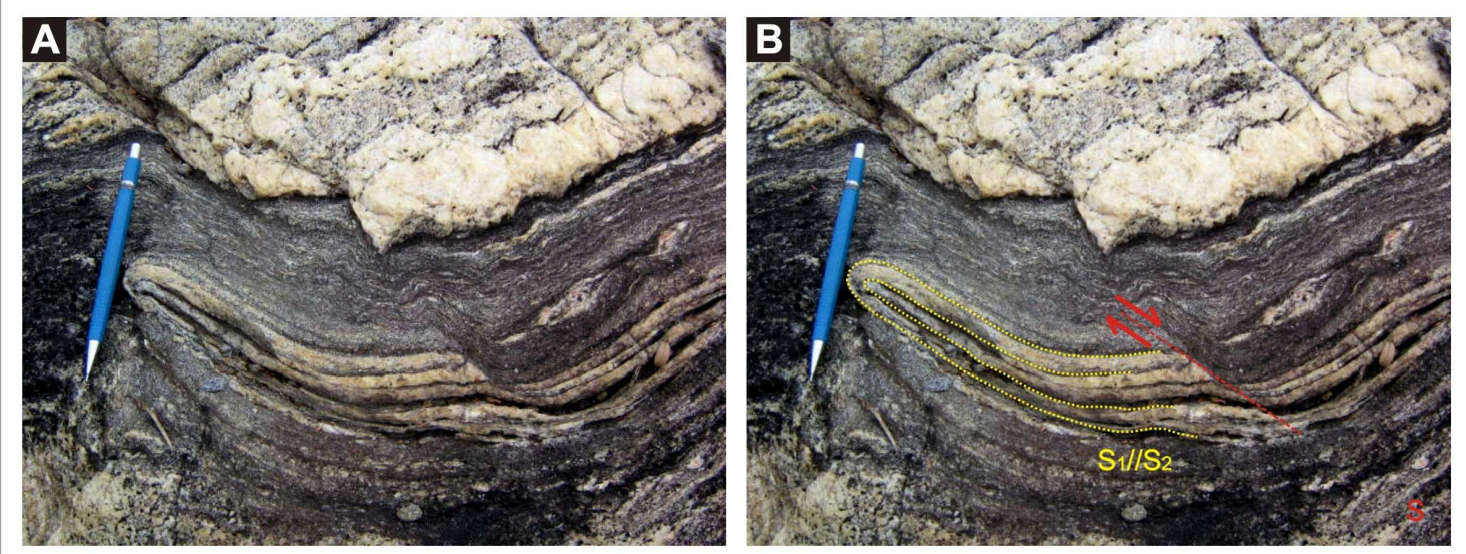

Figura 17: Dobra isoclinal em sillimanita-granada-biotita gnaisse quartzoso (SB-VII-17), com a superfície $\mathrm{S}_{1}$ paralela à foliação principal $\mathrm{S}_{2}$. Notar falha com transporte de topo para sul.

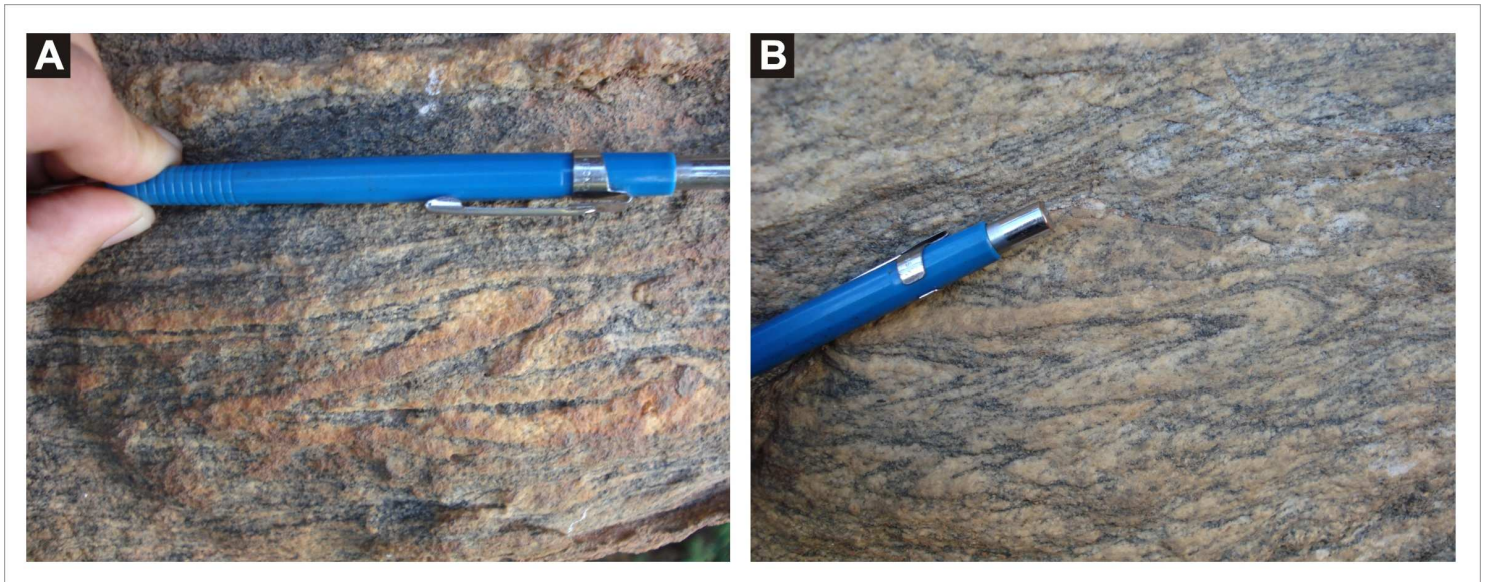

Figura 18: (A), (B) Dobras intrafoliais em leucossoma com flanco rompido, em biotita gnaisse (NLD-40). 

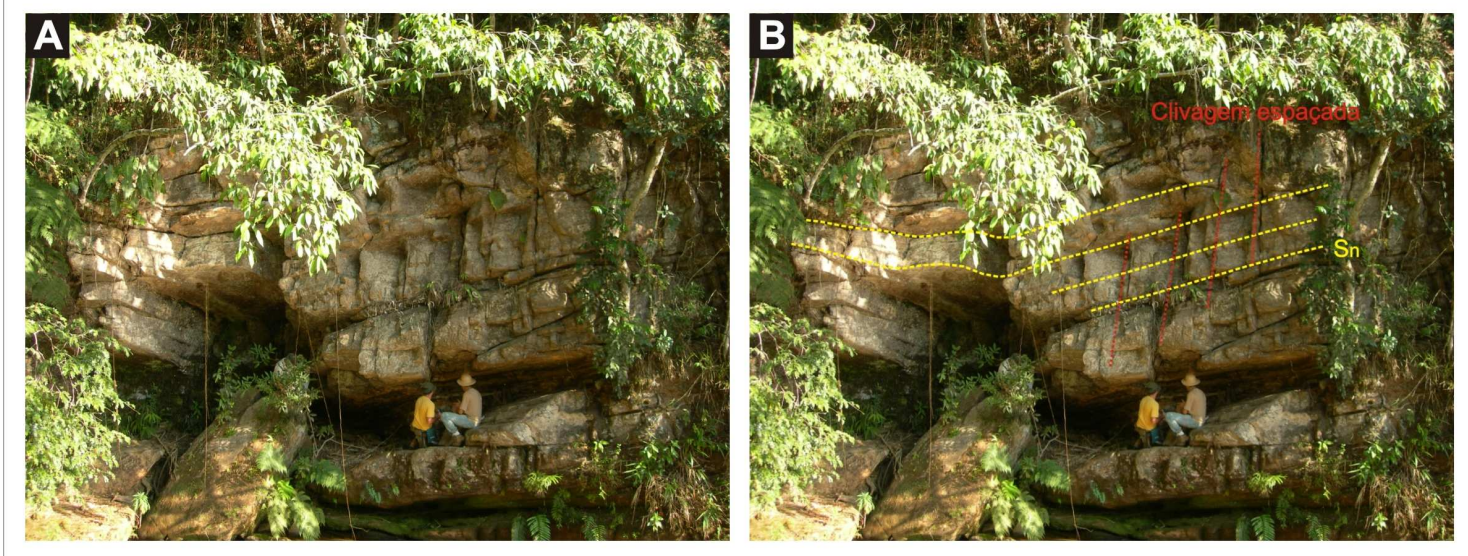

Figura 19: Clivagem espaçada pós-S $\mathrm{S}_{2}$ em quartzito.
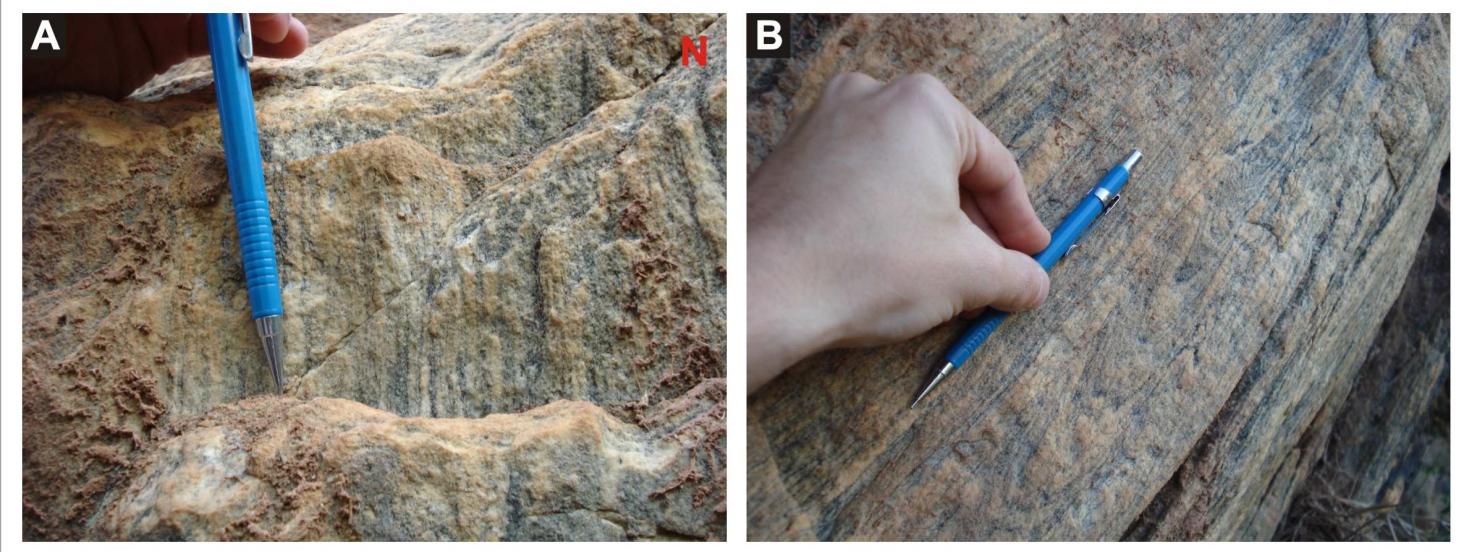

Figura 20: (A) Mullion de banda félsica quartzo-feldspática, alternada com lâminas máficas ricas em biotita e paralelas ao estiramento mineral; (B) foliação milonítica principal em zona de transposição da $S_{2}$ com dobras intrafoliais, em biotita gnaisse do Complexo Mantiqueira (NLD-40).

\subsection{Lineações, indicadores cinemáticos e boudinagem}

As lineações minerais são definidas pela orientação de biotita, muscovita, sillimanita, feldspato e quartzo nas rochas metassedimentares. Nos ortognaisses, a lineação é definida por quartzo, biotita e/ou anfibólio e nas rochas metabásicas por anfibólio, piroxênio e eventualmente, biotita. Estas estruturas indicam a direção preferencial do transporte sinmetamórfico da nappe. Quando associadas a indicadores cinemáticos indicam o transporte para N, em direção ao cráton do São Francisco (Figura 20).

O intenso estiramento ao longo da foliação, paralelo a lineação metamórfica, é evidenciado pela freqüente presença de boudins de rochas metabásicas com anatexia associada, principalmente nas unidades do Complexo Mantiqueira (Figura 21). É comum a presença de leucossoma nas zonas surreicas dos boudins. Quando associado a estruturas assimétricas tipo pares $\mathrm{S}-\mathrm{C}$, porfiroclastos manteados e com caudas ou com zonas de sombra 
de pressão assimétricas e mica-fish, indicam transporte da nappe para N. Subordinadamente indicam transporte em sentido contrário, para sul em um processo sin-metamórfico que deve estar relacionado com o adelgaçamento do alóctone (Figura 22). Essa estrutura dúctil sinmetamórfica evolui a um sistema de cavalgamento rúptil pós-metamórfico e sub-horizontal e mantendo o transporte para norte (Bendoraitis, 2007; Rocha et al., 2008).

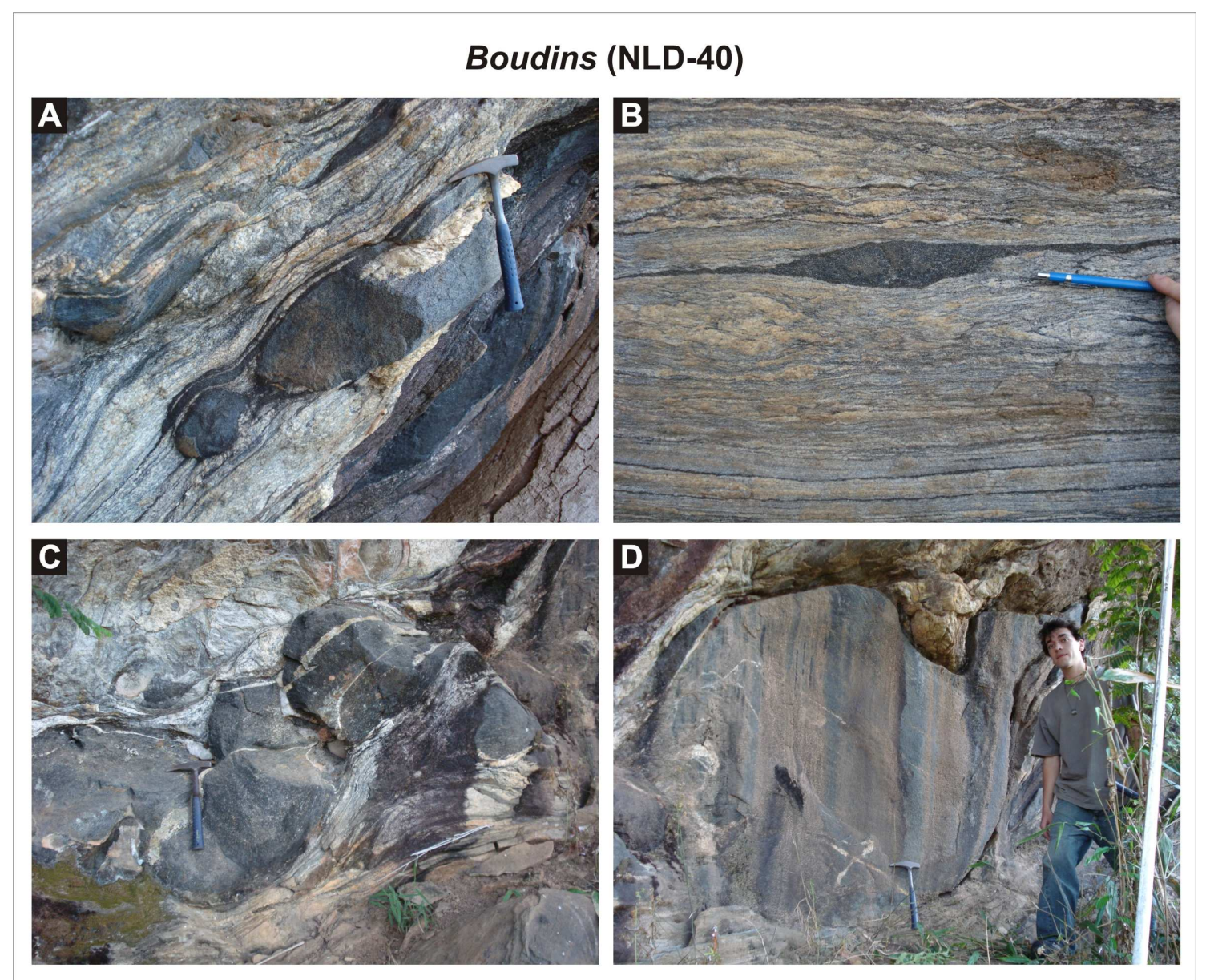

Figura 21: (A), (C), (D) Boudins de rocha metabásica de dimensões variadas, com anatexia associada, (B) Boudin de rocha metabásica com zonas estiradas assimétricas em degrau, indicando transporte para N. (NLD40).

\subsection{Aspectos da microtectônica}

Na Nappe Andrelândia as diferentes fases de deformação são bem definidas pelas micas e pela sillimanita. A sillimanita registra uma foliação anterior à $S_{2}$, quando inclusa em muscovita. Ocorre como arcos poligonais de crescimento estático, definindo uma foliação interna na forma de cristais idioblásticos com a mesma orientação da foliação principal externa (Fotomicrografia 55). A recristalização estática de sillimanita também mimetiza 
pares S-C, preservados como inclusões em muscovita pós-cinemática, idioblástica e oblíqua em relação à $S_{2}$ (Fotomicrografia 56).

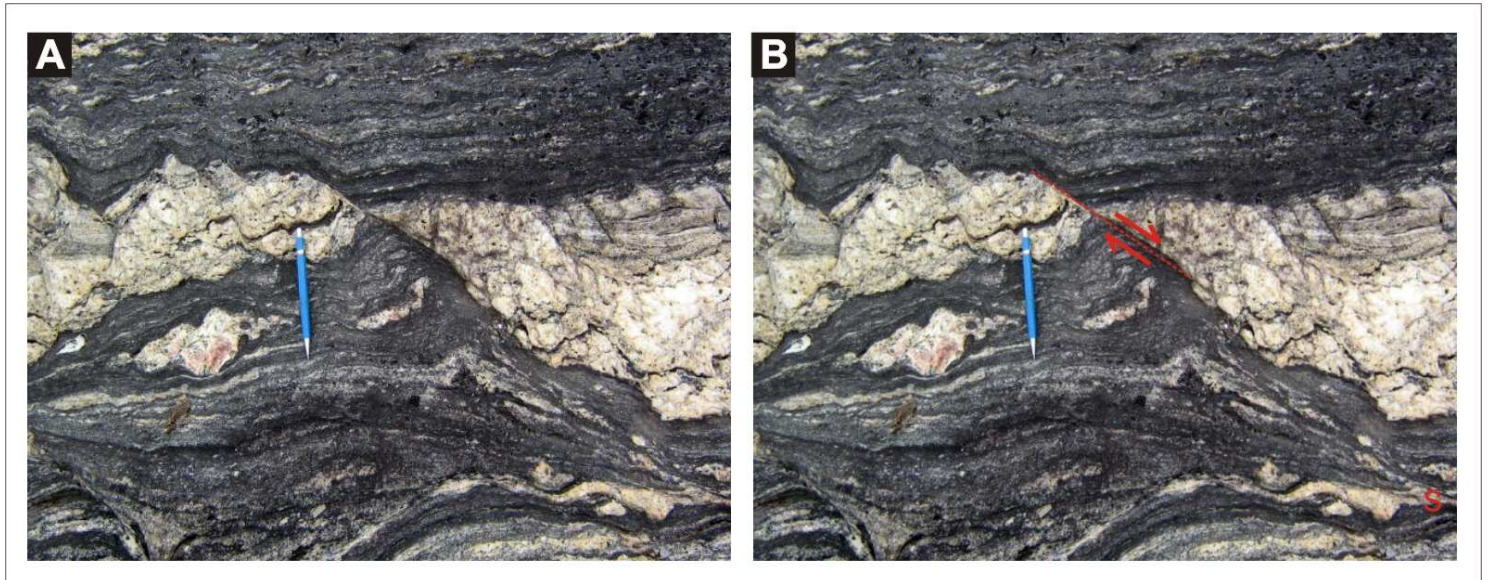

Figura 22: Zona de cisalhamento com transporte de topo para sul, em sillimanita-granada-biotita gnaisse quartzoso (SB-VII-17).

Nos paragnaisses da Nappe Lima Duarte, a foliação principal $\mathrm{S}_{2}$ freqüentemente ocorre dobrada, às vezes com o crescimento de uma nova fase mineral ao longo do plano axial (Fotomicrografia 57). Nos leitos mais micáceos as fases de dobramento são bem marcadas por biotita e muscovita no plano axial. Ocorrem leitos nematoblásticos milimétricos de sillimanita, configurando dobras intrafoliais (Fotomicrografia 58). Em rochas de composição mais aluminosa, a cianita associa-se a arcos poligonais de biotita. A fase de dobramento $\left(\mathrm{D}_{2}\right)$ está preservada na forma de arcos poligonais de muscovita, biotita ou sillimanita recristalizados estaticamente (Fotomicrografia 59).

Nas proximidades da klippe quartzítica da Serra Negra, ocorrem paragnaisses com raras inclusões de cianita + feldspato potássico (OL-II-112B) e paragnaisses com cianita + sillimanita na matriz (NLD-61). Além de granadas pré-cinemáticas, com inclusões randômicas, ocorrem granadas intercinemáticas, com foliação interna $\left(\mathrm{S}_{\mathrm{i}}\right)$, na forma de trilhos de ilmenita e rutilo, oblíquos e descontínuos em relação à foliação externa principal. $\mathrm{O}$ crescimento do porfiroblasto de granada em estágio intercinemático, se deu na transição do campo de estabilidade da cianita para o campo da sillimanita (OL-II-112B). Nas bordas do porfiroblasto, a foliação interna encontra-se paralelizada à foliação externa, sugerindo um crescimento sin-cinemático, tipo strain-cap. Localmente ocorre uma microestrutura de porfiroblasto em atol (SB-III-126B), que se desenvolveu através da substituição de granada por sillimanita fibrolítica (Fotomicrografias 61 a 63). Também ocorrem pequenos cristais de granada pós-cinemáticos, livres de inclusões, arredondados a subidioblásticos, truncando a 
foliação metamórfica. Nas proximidades dos contatos tectônicos, é freqüente a ocorrência de pares S-C (Fotomicrografias 64 a 66).

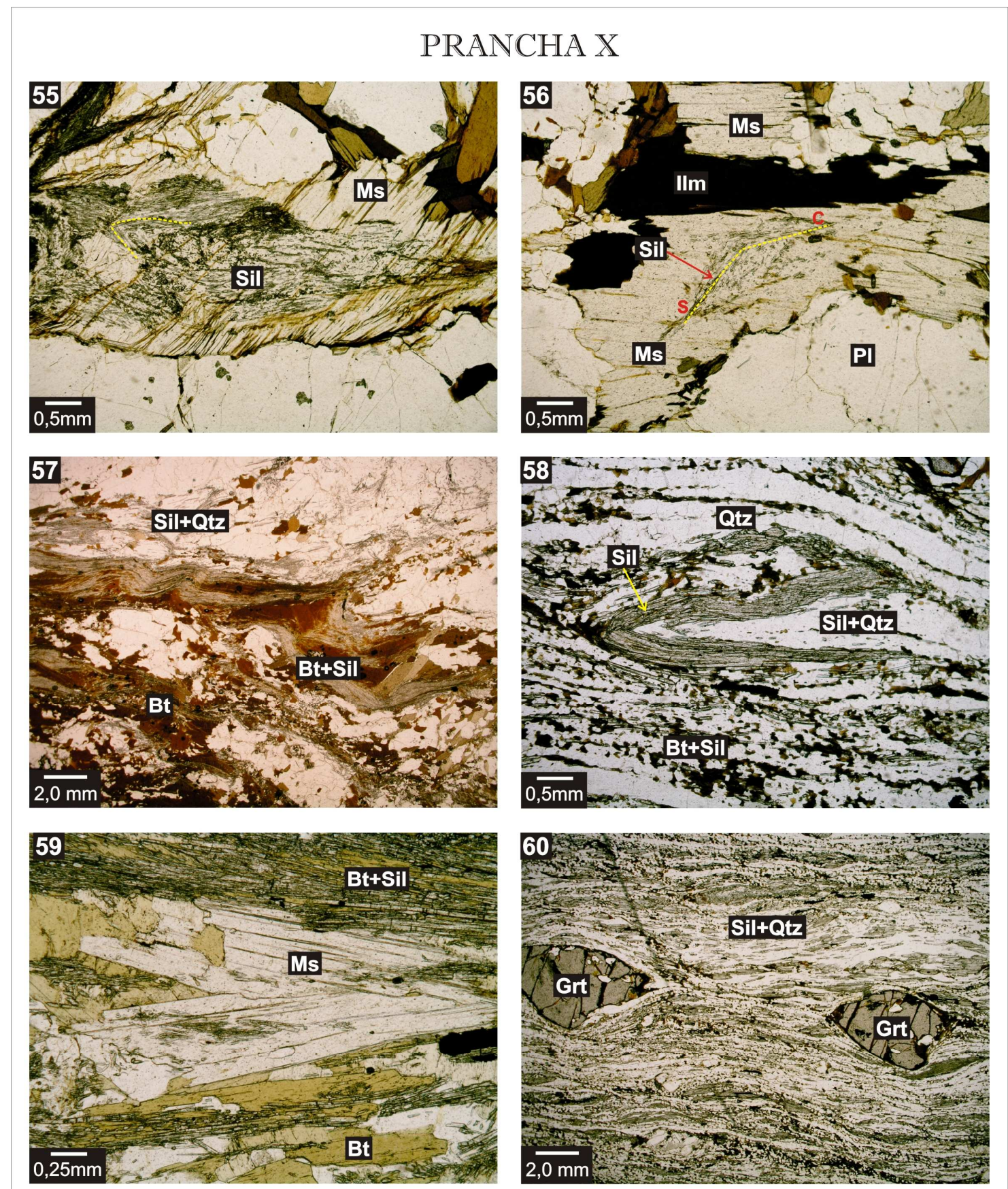

Fotomicrografia 55: Arco poligonal de sillimanita incluso em cristal de muscovita pós-cinemático. Amostra SB-I-108. Aumento de $4 X$. Polarizadores paralelos.

Fotomicrografia 56: Pares S-C de sillimanita, preservado um cristal pós-cinemático de muscovita. Amostra SB-I-108. Aumento de 4 X. Polarizadores paralelos.

Fotomicrografia 57: Leitos nematolepidoblásticos compostos por Bt+Sil definindo a foliação principal S2,que está dobrada, com crescimento de biotita idioblástica no plano axial. Amostra SB-IX-89.Aumento de 1,25X. Polarizadores paralelos. Fotomicrografia 58: Dobra intrafolial de sillimanita. Amostra SB-VII-149B. Aumento de 4X. Polarizadores paralelos. Fotomicrografia 59: Arco poligonal de muscovita.Amostra SB-VII-109. Aumento de 8X. Polarizadores paralelos.

Fotomicrografia 60: Porfiroclastos de granada em matriz nematogranoblástica rica em sillimanita, plagioclásio e quartzo, definindo a foliação milonítica principal. Amostra SB-VII-149B. Aumento de1,25X.Polarizadores paralelos. 


\section{PRANCHA XI}
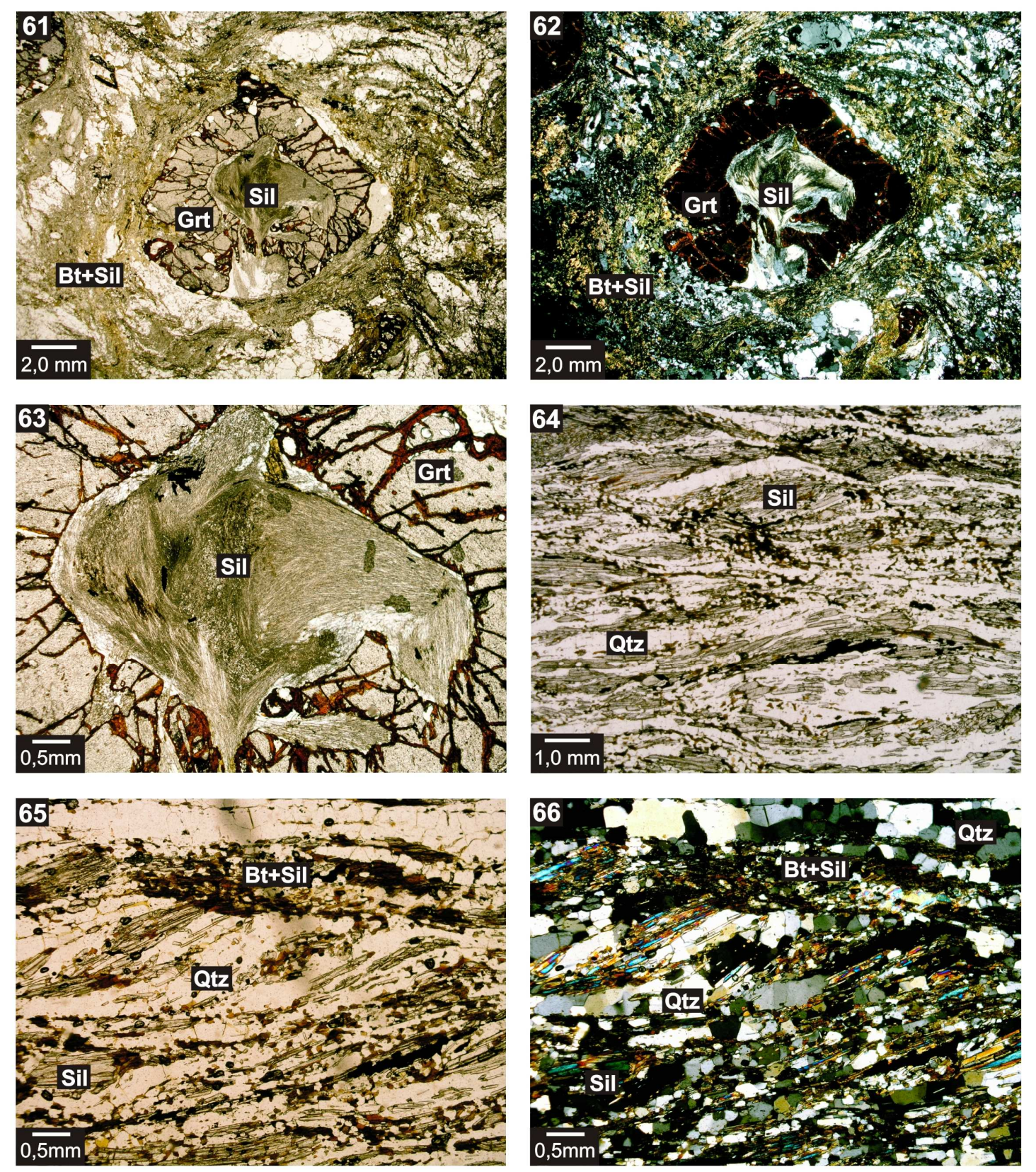

Fotomicrografia 61: Granada em atol, substituída por sillimanita fibrolítica de fora para dentro do porfiroblasto. Amostra SB-III-126B. Aumento de 1,25X. Polarizadores paralelos.

Fotomicrografia 62: Idem anterior. Polarizadores cruzados.

Fotomicrografia 63: Idem anterior. Detalhe para a substituição por sillimanita. Aumento de 4X. Polarizadores paralelos. com crescimento de biotita idioblástica no plano axial. Amostra SB-IX-89.Aumento de 1,25X. Polarizadores paralelos.

Fotomicrografia 64: Pares S-C de quartzo e Sil+Bt. Amostra SB-VII-149B. Aumento de 2,5X. Polarizadores paralelos. Fotomicrografia 65: Pares S-C de quartzo e Sil+Bt. Amostra SB-VII-149B. Aumento de 4X. Polarizadores paralelos. Fotomicrografia 66: Idem anterior. Polarizadores cruzados. 


\section{METAMORFISMO}

\subsection{TEXTURAS E PARAGÊNESES}

\subsubsection{Considerações iniciais}

As mudanças nas condições metamórficas podem estar registradas na forma de inclusões em porfiroblastos, ou na substituição parcial de uma fase mineral por outra. Geralmente estas substituições ocorrem nos limites entre os grãos dos minerais, o que pode resultar no desenvolvimento de anéis de reação (reaction rims). Estes anéis de reação podem ser monominerálicos ou poliminerálicos e são chamadas coronas se formarem um anel fechado ao redor de um grão; coronas monominerálicas também são referidas como moats (Passchier \& Trouw, 1996). O termo atol não é recomendado, pois pode causar confusão com uma microestrutura denominada "porfiroblasto em atol”, em que o núcleo de um porfiroblasto zonado reage para formar outros minerais (Barker, 1998). Coronas poliminerálicas constituídas de novas fases minerais intercrescidas, de granulação fina e forma vermicular, são conhecidas por coronas simplectíticas (symplectitic coronas) (Passchier \& Trouw, 1996). As mirmequitas constituem o produto da quebra de feldspato potássico durante $o$ retrometamorfismo, formando lamelas vermiculares de quartzo em plagioclásio (Smith, 1974; Phillips 1974, 1980; Shelley, 1993). São bastante comuns em rochas ígneas e rochas de alto grau.

As coronas são excelentes indicadores de reações metamórficas, pois fornecem evidência de mudança na paragênese mineral com a mudança das condições metamórficas através da substituição incompleta de minerais de uma associação pretérita (minerais no núcleo da corona) por uma paragênese posterior (minerais que compõem a corona), possibilitando inferir a história P-T da rocha (Droop \& Bucher-Nurminen, 1984; Clarke \& Powell, 1991; Vernon et al., 2008). As texturas coroníticas são mais bem preservadas em volumes de rocha que não sofreram deformação durante a reação. Desta forma, podem fornecer informações das reações em rochas adjacentes, em que a deformação removeu as evidências de reações incompletas (Clarke \& Powell, 1991). Esse tipo de textura é comumente encontrada em metagabros. O problema é determinar se a textura coronítica nestas rochas foi causada por uma série de recristalizações com o tempo, durante o resfriamento de um magma gabróico ou por metamorfismo sin-tectônico profundo (Bard, 1986). 
Um pseudomorfo é definido como um cristal que foi parcial a totalmente substituído por outro mineral ou por um agregado de minerais, e os novos minerais preservam o formato original do cristal substituído (Passchier \& Trouw, 1996; Barker, 1998). O pseudomorfismo parcial e as coronas são os critérios mais confiáveis para inferir uma reação (Vernon, 1996a; Vernon et al., 2008; Vernon \& Clarke, 2008), em que tanto o mineral substituído (reagente) como os produtos da reação coexistem na mesma textura (Guidotti \& Johnson, 2002).

Os porfiroblastos possuem baixas razões de taxa de nucleação por taxa de crescimento, o que resulta na incorporação de minerais de granulação mais fina da matriz pelo porfiroblasto. Algumas inclusões podem representar relíquias de uma fase pretérita do metamorfismo, mas geralmente as inclusões pertencem à mesma associação mineral que o porfiroblasto. As inclusões não reagem quimicamente com o porfiroblasto, mas tendem a adquirir formas mais suaves no sentido de minimizar a energia livre nos limites dos grãos com o porfiroblasto (Kretz, 1966a, 1994; Vernon, 1968, 1970, 1976, 2004).

Inclusões em porfiroblastos e relações porfiroblasto-matriz são indicadores indiretos de reações metamórficas, fornecendo informações relativas à ordem de crescimento dos minerais ou associações minerais (Vernon et al., 2008; Vernon \& Clarke, 2008). Desta forma, as interpretações texturais resultantes de inclusões em porfiroblastos devem ser feitas com cautela, pois é necessário definir se as inclusões são inclusões verdadeiras ou se não são produtos de exsolução ou crescimento coaxial (Vernon, 1978a). Os minerais possuem taxas de nucleação e de crescimento distintas, assim dois minerais podem nuclear ao mesmo tempo, porém se um mineral possui taxa de crescimento maior do que o outro, este irá englobar o outro mineral, resultando em uma "falsa inclusão" (Vernon, 1977; Vernon, 2004). Portanto o fato de um mineral estar incluso em outro não significa que o mineral incluso é mais antigo que o mineral hospedeiro.

Inclusões de minerais herdados de uma associação pretérita podem ser tanto relíquias estáveis ou metaestáveis, como minerais de uma associação anterior instável, isolados dos minerais da matriz através do porfiroblasto. Neste último caso, as interpretações de inclusões como sendo instáveis ou metaestáveis só são feitas com segurança se os minerais inclusos não ocorrem na matriz e são compatíveis com alguma outra evidência (Krogh, 1982; St-Onge, 1987). 


\section{Inclusões em porfiroblasto de granada - Amostra OL-II-112B}
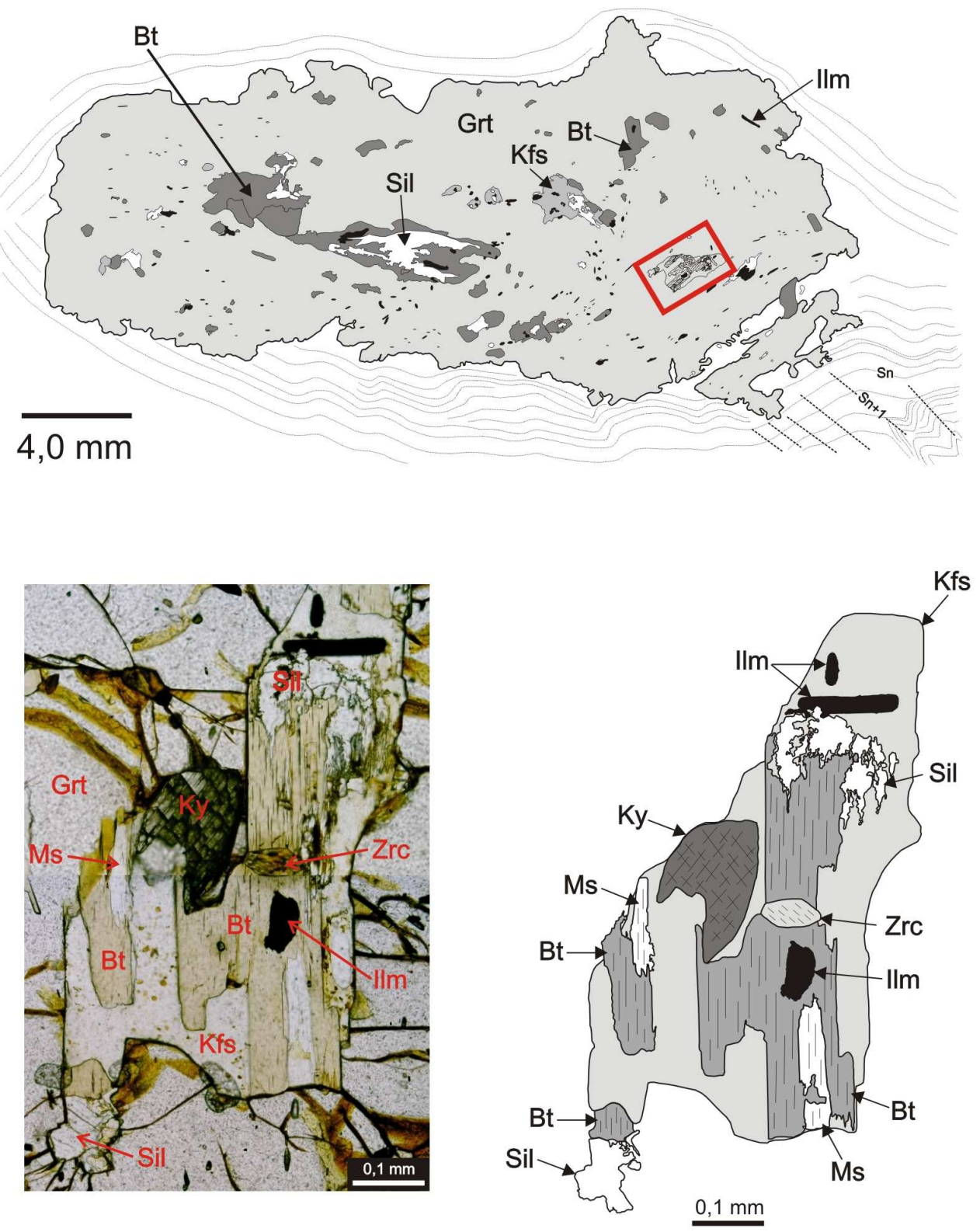

Figura 23: Porfiroblasto de granada, com inclusões de Ky, Bt, MS, Sil, Kfs, Ilm e Zrc. Amostra OL-II-112B.

A associação mineral predominante nos paragnaisses é: granada + biotita + sillimanita + muscovita + plagioclásio + quartzo. As elevadas razões de taxas de crescimento por taxa de nucleação de granada permitiu o desenvolvimento de porfiroblastos de granulação grossa, ricos em inclusões minerais, que constituem a principal fonte de informação do metamorfismo progressivo nos paragnaisses. As inclusões mais comuns nos porfiroblastos de 
granada são: biotita, sillimanita, ilmenita, rutilo e plagioclásio. A matriz alterna leitos lepidonematoblásticos ricos em sillimanita e biotita, alternados com leitos granoblásticos, ricos em feldspato e quartzo. Na amostra OL-II-112B ocorre um porfiroblasto intercinemático de granada $(\sim 2.5 \mathrm{~cm})$, com inclusão de cianita em associação com $\mathrm{Bt}+\mathrm{Ms}+\mathrm{Sil}+\mathrm{Kfs}+\mathrm{Ilm}$. Na Figura 23 estão ilustrados os minerais que ocorrem em paragênese com a cianita e a localização das inclusões no porfiroblasto de granada, indicada em vermelho.

A inclusão de cianita está localizada na porção mais rica em grossulária do porfiroblasto de granada (ver item 7 - Química Mineral). O feldspato potássico que envolve as inclusões de $\mathrm{Ky}$, Sil, Bt, Ms, Ilm e Zrc tem o aspecto de filme, sugerindo mimetizar um líquido silicático que se formou no metamorfismo progressivo, durante o desenvolvimento do porfiroblasto (Holness \& Sawyer, 2008). A cianita é rara na matriz, e associado às evidências provenientes do quimismo da granada, é possível inferir que o porfiroblasto registra um episódio de regime bárico mais elevado, associado ao campo de estabilidade da cianita.

As principais texturas presentes nos paragnaisses estão relacionadas com a retrogressão. A granada é consumida para formar biotita ou intercrescimentos de Bt+Sil, pelas bordas ou ao longo de fraturas (Fotomicrografias 67 e 68). Em algumas amostras, o retrometamorfismo foi mais intenso, o que resultou em pseudomorfos de granada totalmente substituídos por Bt+Sil (Fotomicrografias 69 e 70). Localmente, onde ocorre cianita na matriz (NLD-61A), observa-se a substituição de cianita por cristais prismáticos de sillimanita (Fotomicrografias 71 e 72).

É bastante comum a formação de sillimanita fibrolítica pseudomorfizando a sillimanita prismática. Também ocorre a geração de muscovita tardia na foliação principal, dispersa na matriz ou substituindo os aluminossilicatos e o feldspato. As reações de volta de quebra da muscovita estão registradas, tanto através da substituição parcial de sillimanita por muscovita (Fotomicrografias 73 e 74), ou de cianita por muscovita (Fotomicrografia 75). A biotita pode estar substituída por muscovita e clorita. Ocorrem cristais de plagioclásio intensamente saussuritizados, processo retrometamórfico posterior (Fotomicrografia 76). Simplectitos de plagioclásio e quartzo ocorrem localmente e são possivelmente relacionados ao resfriamento (Fotomicrografias 77 e 78). 


\section{PRANCHA XII}
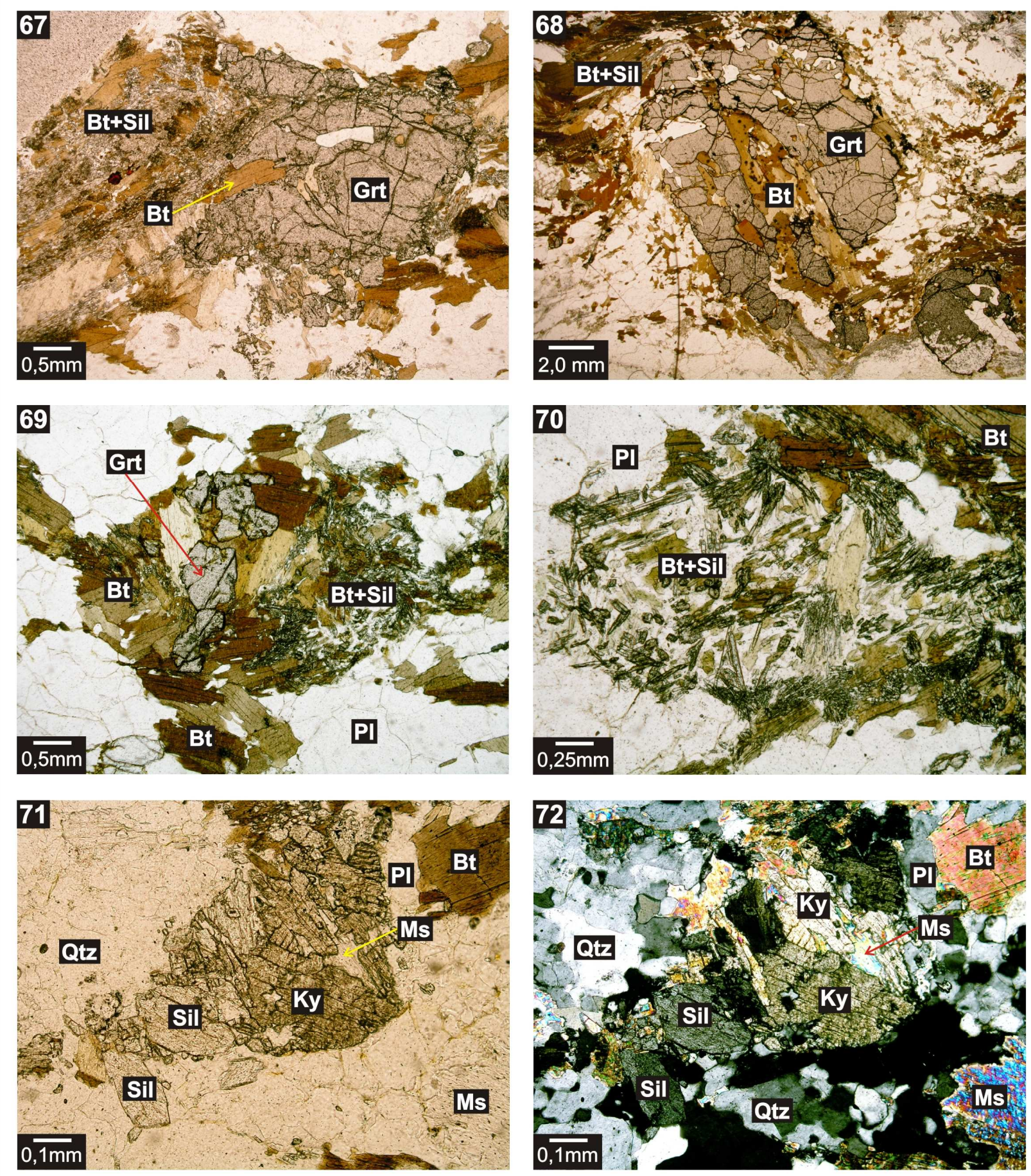

Fotomicrografia 67: Granada sendo consumida por Bt e por Bt+Sil. Amostra SB-IX-5C. Aumento de 4X. Polarizadores paralelos.

Fotomicrografia 68: Granada substituída por biotita ao longo de fratura. Amostra SB-IX-89. Aumento de 1,25X. Polarizadores paralelos.

Fotomicrografia 69: Pseudomorfo de granada, parcialmente substituído por Bt+Sil. Amostra SB-IX-5C. Aumento de 4X. Polarizadores paralelos.

Fotomicrografia 70: Pseudomorfo de granada, totalmente substituído por Bt+Sil. Amostra SB-IX-5C. Aumento de 8X. Polarizadores paralelos.

Fotomicrografia 71: Sillimanita substituindo cianita. Amostra NLD-61A. Aumento de 10X. Polarizadores paralelos.

Fotomicrografia 72: Idem anterior. Polarizadores cruzados. 


\section{PRANCHA XIII}
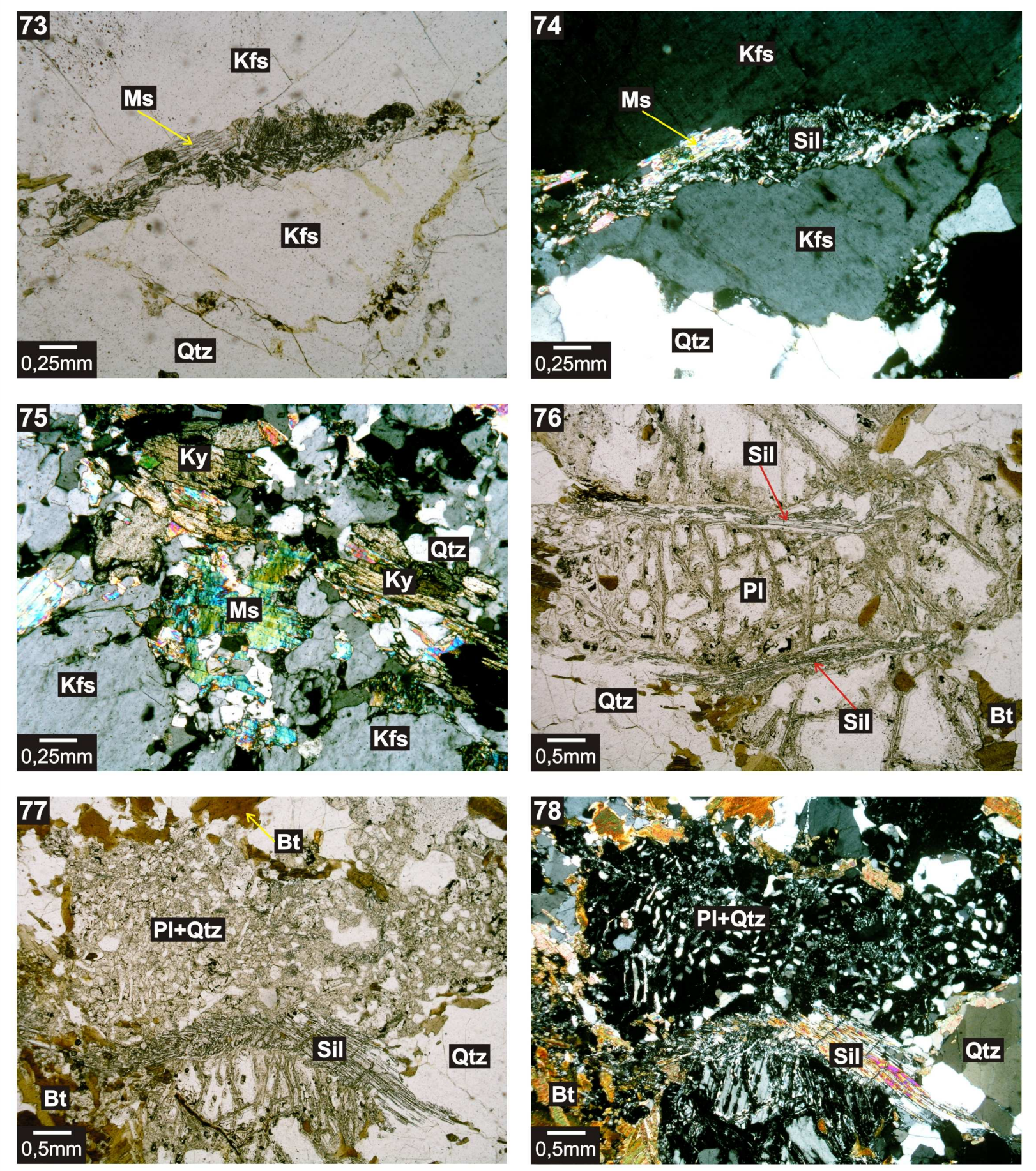

Fotomicrografia 73: Sillimanita na borda de feldspato potássico, sendo substituída por muscovita. Amostra SB-VII-17. Aumento de 8X. Polarizadores paralelos.

Fotomicrografia 74: Idem anterior. Polarizadores cruzados.

Fotomicrografia 75: Muscovita substituindo cianita. Amostra NLD-61A. Aumento de 8X. Polarizadores cruzados.

Fotomicrografia 76: Plagioclásio saussuritizado, com cristais de sillimanita nas bordas. Amostra SB-VII-84B. Aumento de 4X. Polarizadores paralelos.

Fotomicrografia 77: Textura simplectítica de PI+Qtz, com saussuritização posterior. Amostra SB-VII-84B. Aumento de 4X. Polarizadores paralelos.

Fotomicrografia 78: Idem anterior. Polarizadores cruzados. 


\section{PRANCHA XIV}
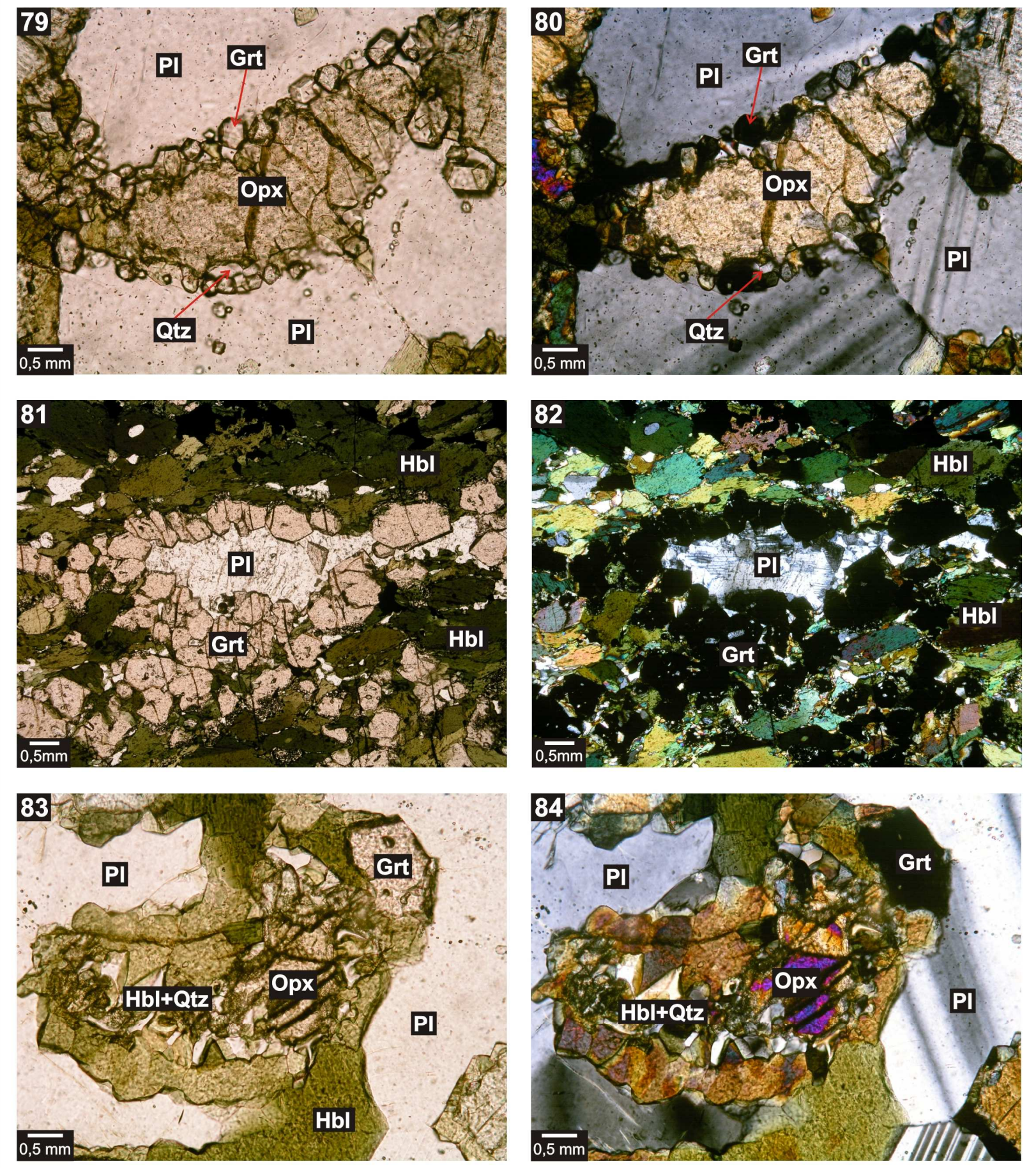

Fotomicrografia 79: Corona de Grt \pm Qtz ao redor de Opx, no contato com o plagioclásio. Amostra NLD-7A. Aumento de 20X. Polarizadores paralelos.

Fotomicrografia 80: Idem anterior. Polarizadores cruzados.

Fotomicrografia 81: Textura coronítica de Grt ao redor de plagioclásio. Todo o piroxênio foi substituído por hornblenda. Amostra NLD-8A. Aumento de 4X. Polarizadores paralelos.

Fotomicrografia 82: Idem anterior. Polarizadores cruzados.

Fotomicrografia 83: Ortopiroxênio parcialmente substituído por Hbl + Qtz. Amostra NLD-41A. Aumento de 20X.

Polarizadores paralelos.

Fotomicrografia 84: Idem anterior. Polarizadores cruzados. 


\section{PRANCHA XV}
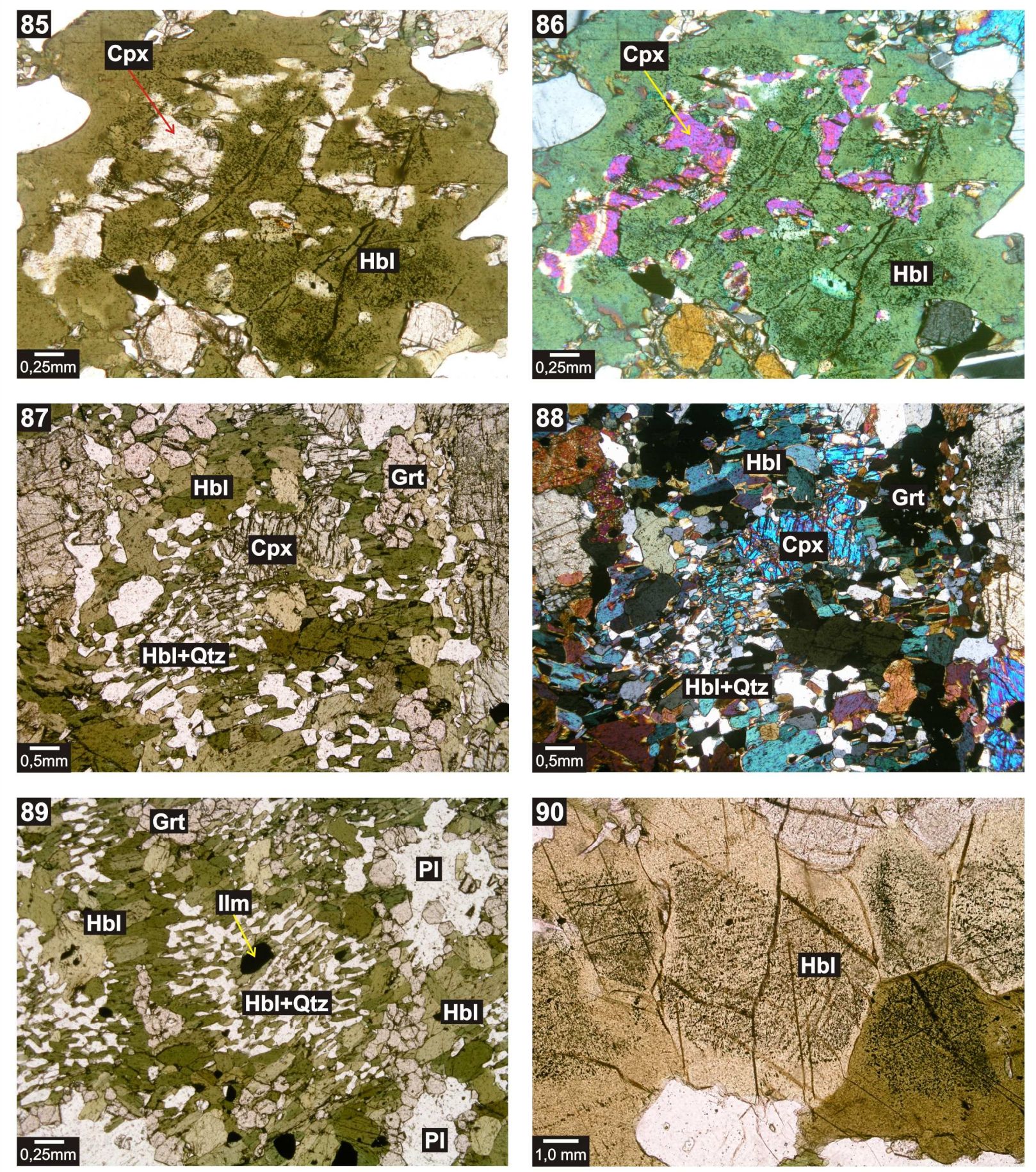

Fotomicrografia 85: Clinopiroxênio reliquiar na hornblenda, resultante da substituição retrometamórfica. Amostra NLD-41A. Aumento de 8X. Polarizadores paralelos.

Fotomicrografia 86: Idem anterior. Polarizadores cruzados.

Fotomicrografia 87: Clinopiroxênio parcialmente substituído por intercrescimentos de Hbl + Qtz. Amostra NLD-8C. Aumento de 4X. Polarizadores paralelos.

Fotomicrografia 88: Idem anterior. Polarizadores cruzados.

Fotomicrografia 89: Textura simplectítica, com pseudomorfo de piroxênio, totalmente substituído por Hbl + Qtz. Amostra NLD-8C. Aumento de 8X. Polarizadores paralelos.

Fotomicrografia 90: Hornblenda com exsoluções goticulares de opacos de núcleo do cristal Amostra NLD-7A. Aumento de 10X. Polarizadores paralelos. 


\section{PRANCHA XVI}
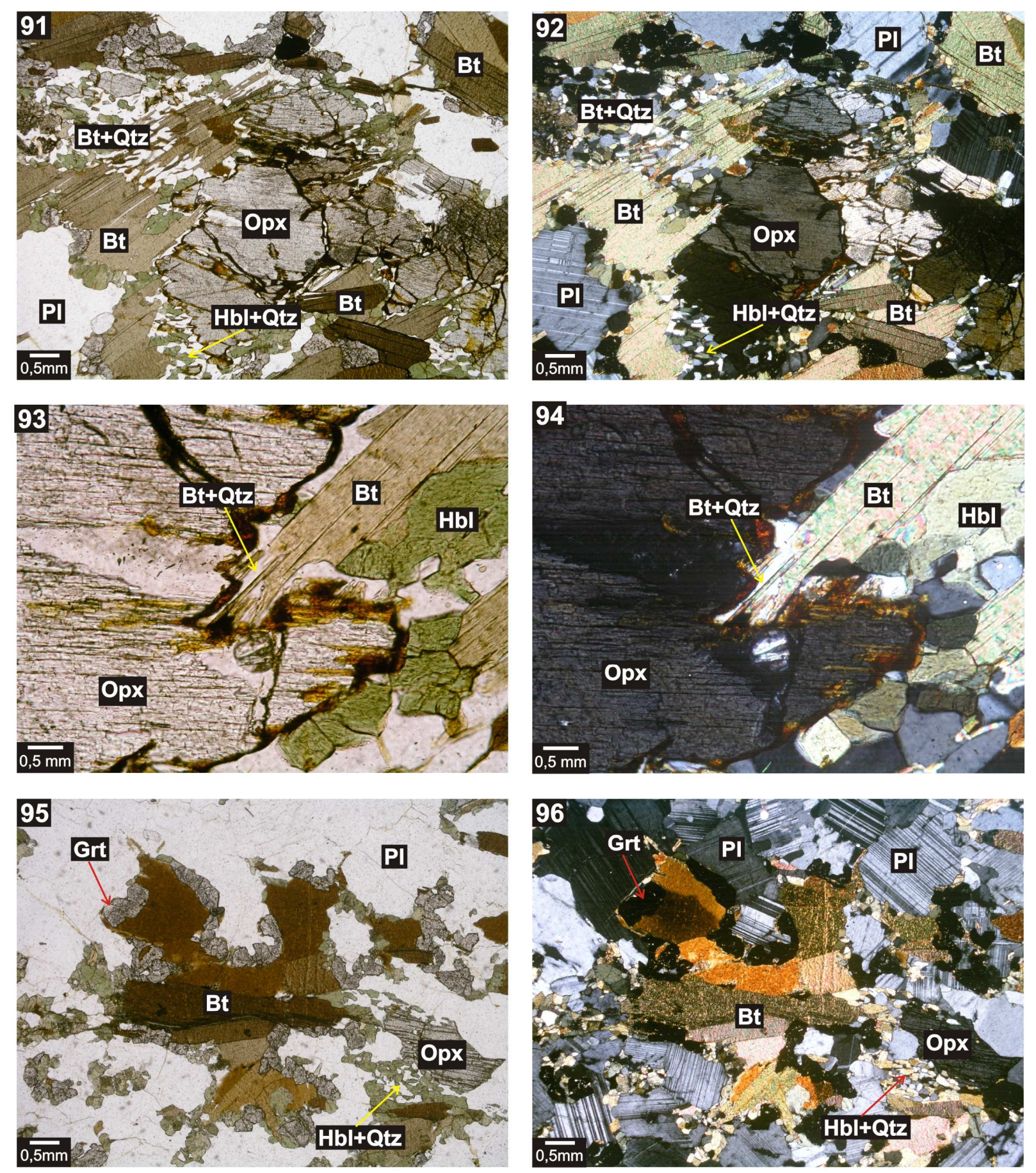

Fotomicrografia 91: Ortopiroxênio substituído por intercrescimentos de $\mathrm{Hbl}+\mathrm{Qtz}$, de Bt + Qtz e por biotita grossa. Amostra NLD-41D. Aumento de 4X. Polarizadores paralelos.

Fotomicrografia 92: Idem anterior. Polarizadores cruzados.

Fotomicrografia 93: Detalhe da foto anterior, para a substituição de Opx por intercrescimentos de Bt + Qtz. Aumento de 20X. Polarizadores paralelos.

Fotomicrografia 94: Idem anterior. Polarizadores cruzados.

Fotomicrografia 95: Opx totalmente substituído por biotita, resultando em textura com biotita manteada por granada. Amostra NLD-41D. Aumento de 4X. Polarizadores paralelos.

Fotomicrografia 96: Idem anterior. Polarizadores cruzados. 


\subsubsection{Rochas metabásicas inseridas nos ortognaisses do Complexo Mantiqueira}

As rochas metabásicas estão intercaladas nos ortognaisses do Complexo Mantiqueira e nas rochas charnockíticas associadas ao Complexo Mantiqueira, na forma de boudins de dimensão variada (centimétrica a decamétrica) ou enclaves máficos alongados ao longo da foliação principal. Os boudins de dimensão maior restringem o acesso de fluidos no núcleo, permitindo a preservação de paragêneses anidras relacionadas ao metamorfismo progressivo (NLD-42C, NLD-42D). Nas bordas cisalhadas do boudin ou em estruturas de dimensão menor, a circulação de fluidos é maior, resultando em processos retrometamórficos mais intensos, principalmente através da substituição de minerais anidros (e.g. piroxênio) por fases hidratadas (e.g. hornblenda, biotita) (NLD-8A). Desta forma, a textura varia de acordo com a localização da amostra na estrutura. A associação mais comum nas rochas metabásicas é: clinopiroxênio + granada + hornblenda + plagioclásio + quartzo \pm ortopiroxênio. São bastante comuns as texturas coroníticas de Grt + Cpx \pm Qtz ou de Grt \pm Qtz (Figuras 26 a 31) (Fotomicrografias 79 e 80) no contato entre ortopiroxênio, plagioclásio e/ou opacos. Freqüentemente os piroxênios estão substituídos por hornblenda nos tipos mais básicos (Fotomicrografias 81 e 82).

O retrometamorfismo é caracterizado principalmente pela substituição dos piroxênios por hornblenda, sendo que em alguns locais com maior percolação de fluidos, essa substituição é quase total (Fotomicrografias 83 a 86). Também é comum a substituição dos piroxênios por intercrescimentos simplectíticos de Hbl+Qtz (Fotomicrografias 87 a 89). A hornblenda pode apresentar exsoluções de opacos na forma de gotas no núcleo dos cristais (Fotomicrografia 90). Possivelmente isto está relacionado com composições mais titaníferas do anfibólio em temperaturas mais elevadas.

As coronas de Grt $+\mathrm{Cpx}+\mathrm{Qtz}$ ao redor dos piroxênios e do plagioclásio isolam o ortopiroxênio do sistema, preservando o cristal. No entanto, quando há acesso para circulação livre de fluidos ricos em $\mathrm{H}_{2} \mathrm{O}$ a hidratação é mais intensa, o que favorece a substituição direta de ortopiroxênio por biotita nos tipos de composição intermediária (Fotomicrografias 91 a 94). Esse processo posterior de hidratação resulta em uma textura caracterizada por colares de granada ao redor da biotita. A geração de granada ocorreu em reação com ortopiroxênio, que foi totalmente substituído por biotita (Fotomicrografias 95 e 96). 


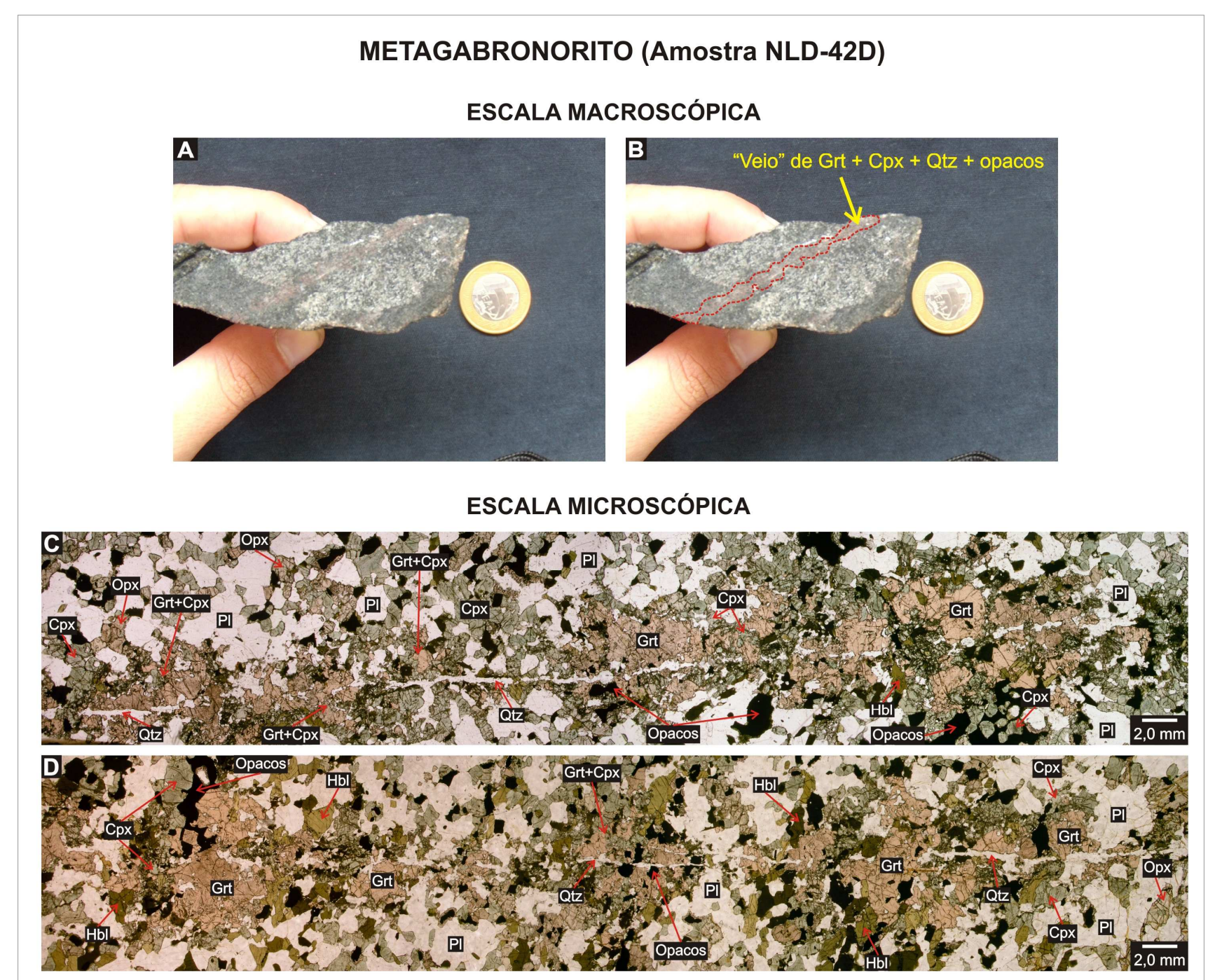

Figura 24: Leitos de dimensão milimétrica a subcentimétrica com concentração de granada. (A), (B) Escala macroscópica; (C), (D) Escala microscópica. Amostra NLD-42D. 


\section{Amostra NLD-42D}
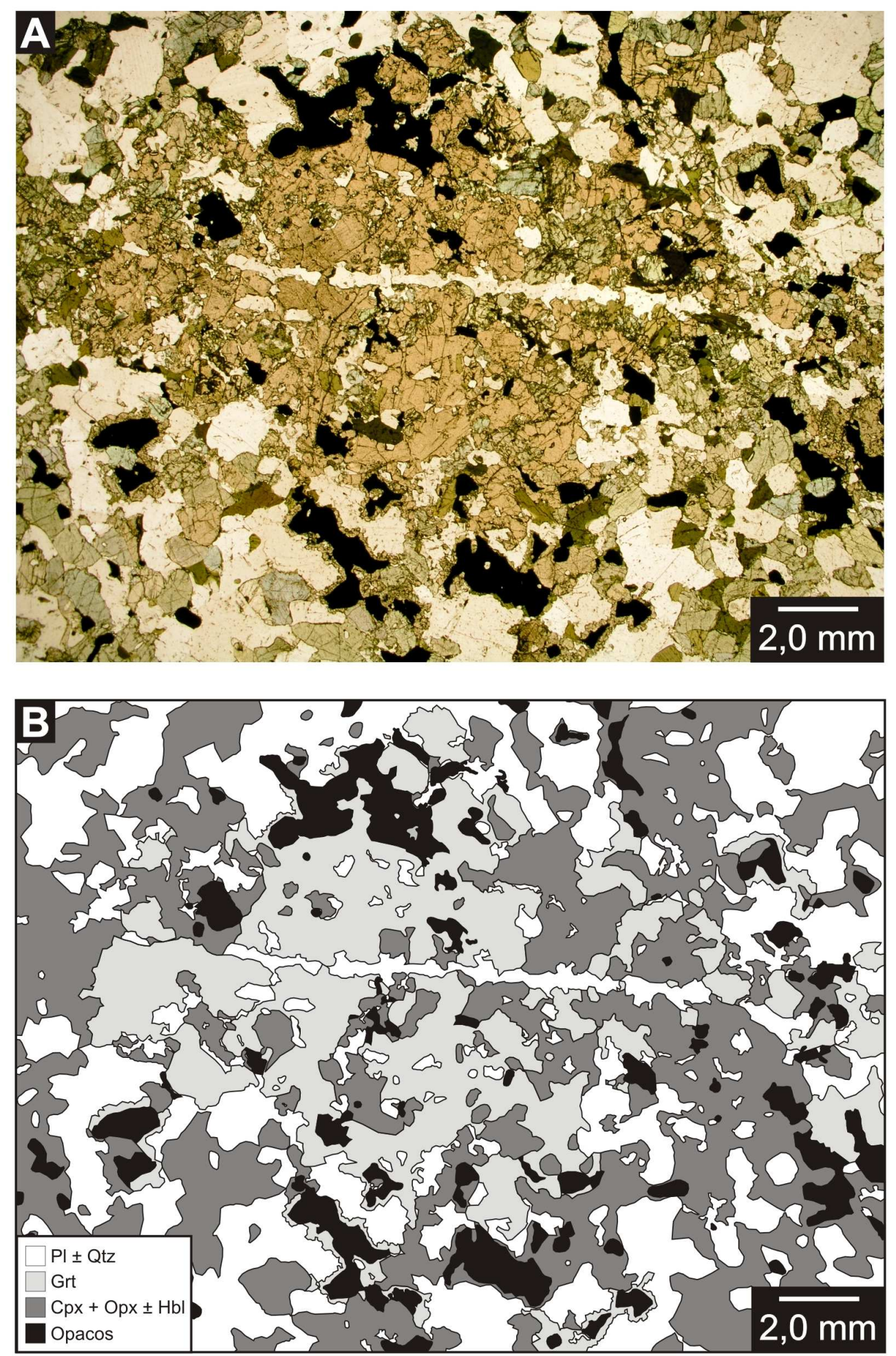

Figura 25: Detalhe de um veio constituído por granada intercrescida com clinopiroxênio, quartzo e opacos, com leito contínuo de quartzo no centro. (A) Polarizadores paralelos, (B) Esboço da textura. Amostra NLD-42D. 


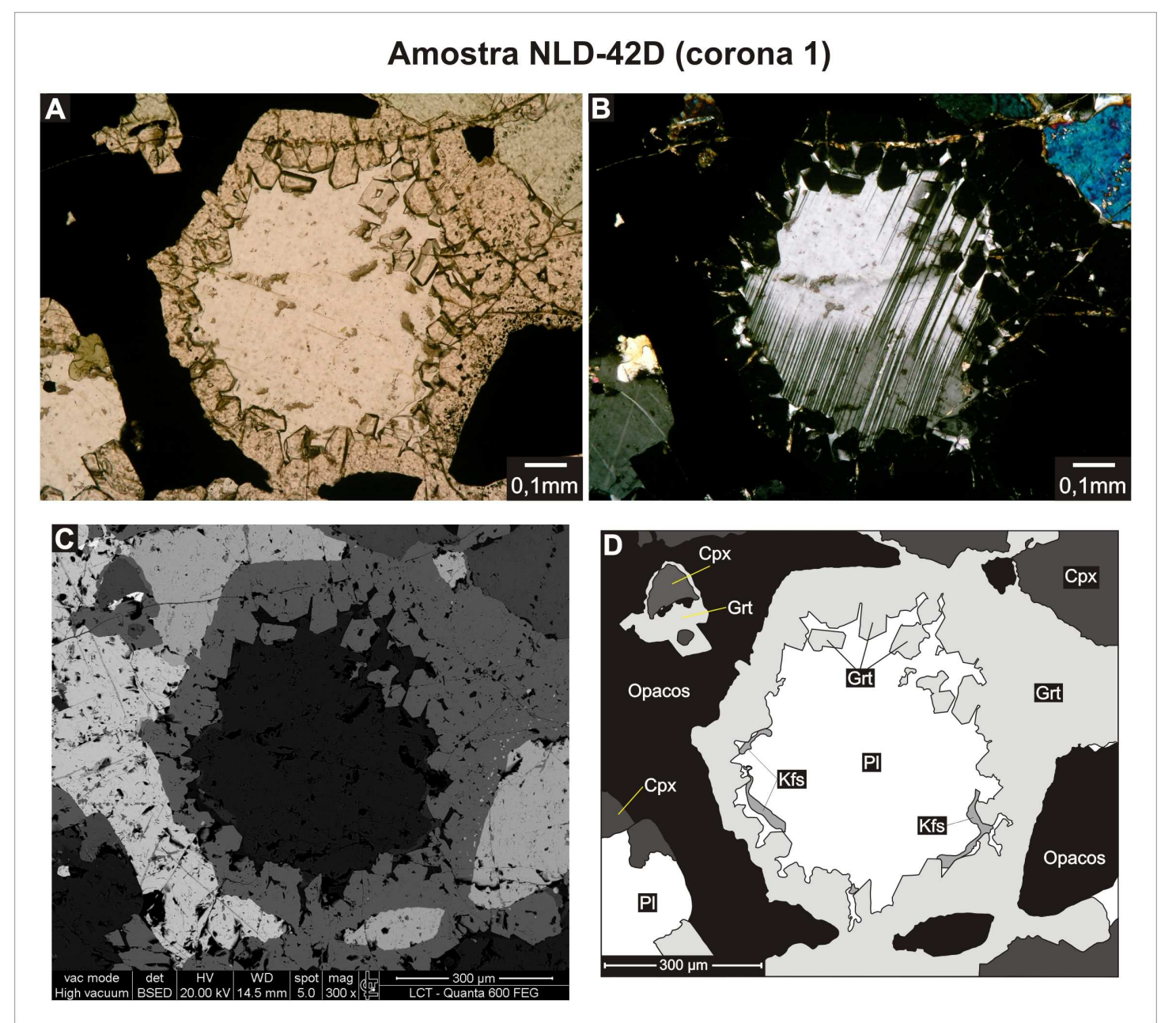

Figura 26: Corona de Grt ao redor de Pl, no contato com o Cpx e os opacos. Notar que ocorre Kfs na parte interna da corona, no contato entre a Grt e o Pl. (A) Polarizadores paralelos, (B) Polarizadores cruzados, (C) Imagem retroespalhada obtida no MEV, (D) Esboço da textura. Amostra NLD-42D.

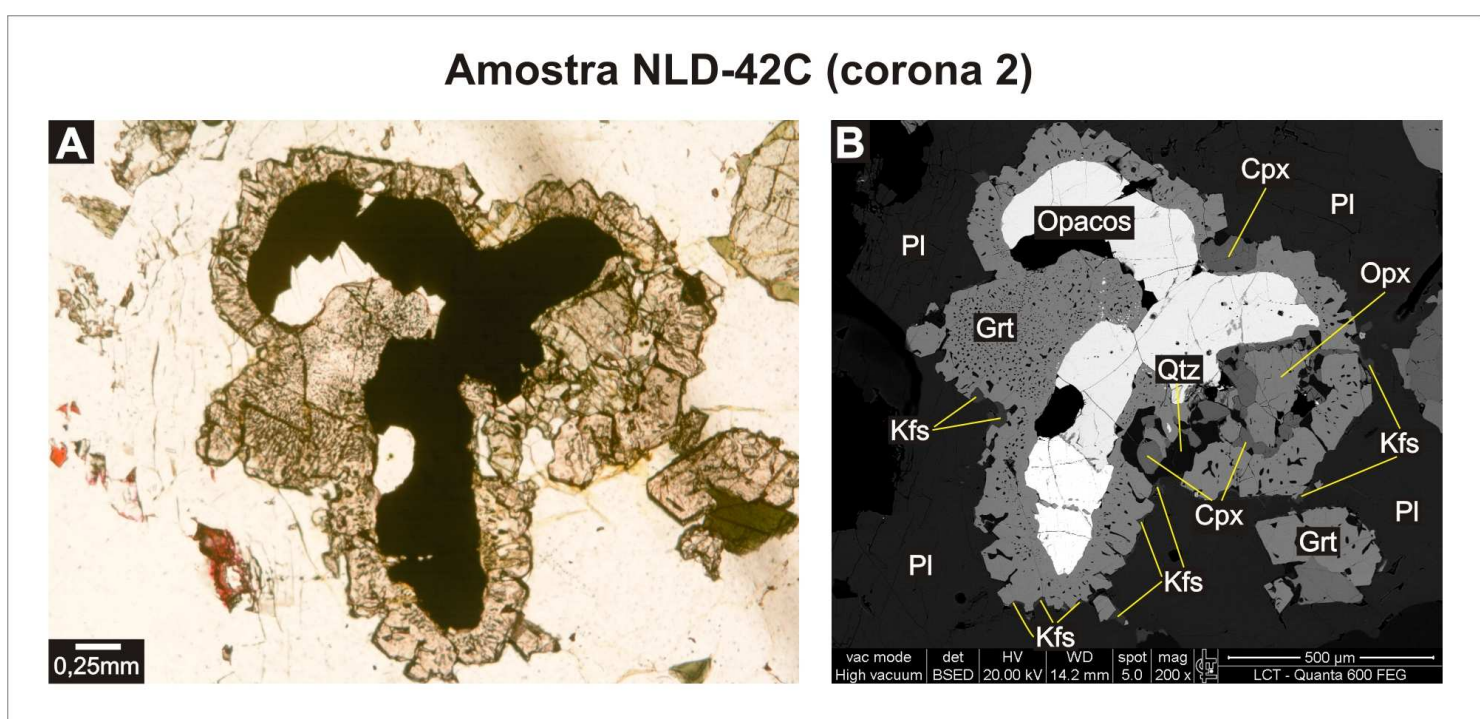

Figura 27: Corona de Grt ao redor dos opacos e do Opx, no contato com o Pl, com Kfs no contato entre a Grt e o Pl. (A) Polarizadores paralelos, (B) Imagem retroespalhada obtida no MEV. Amostra NLD-42C. 


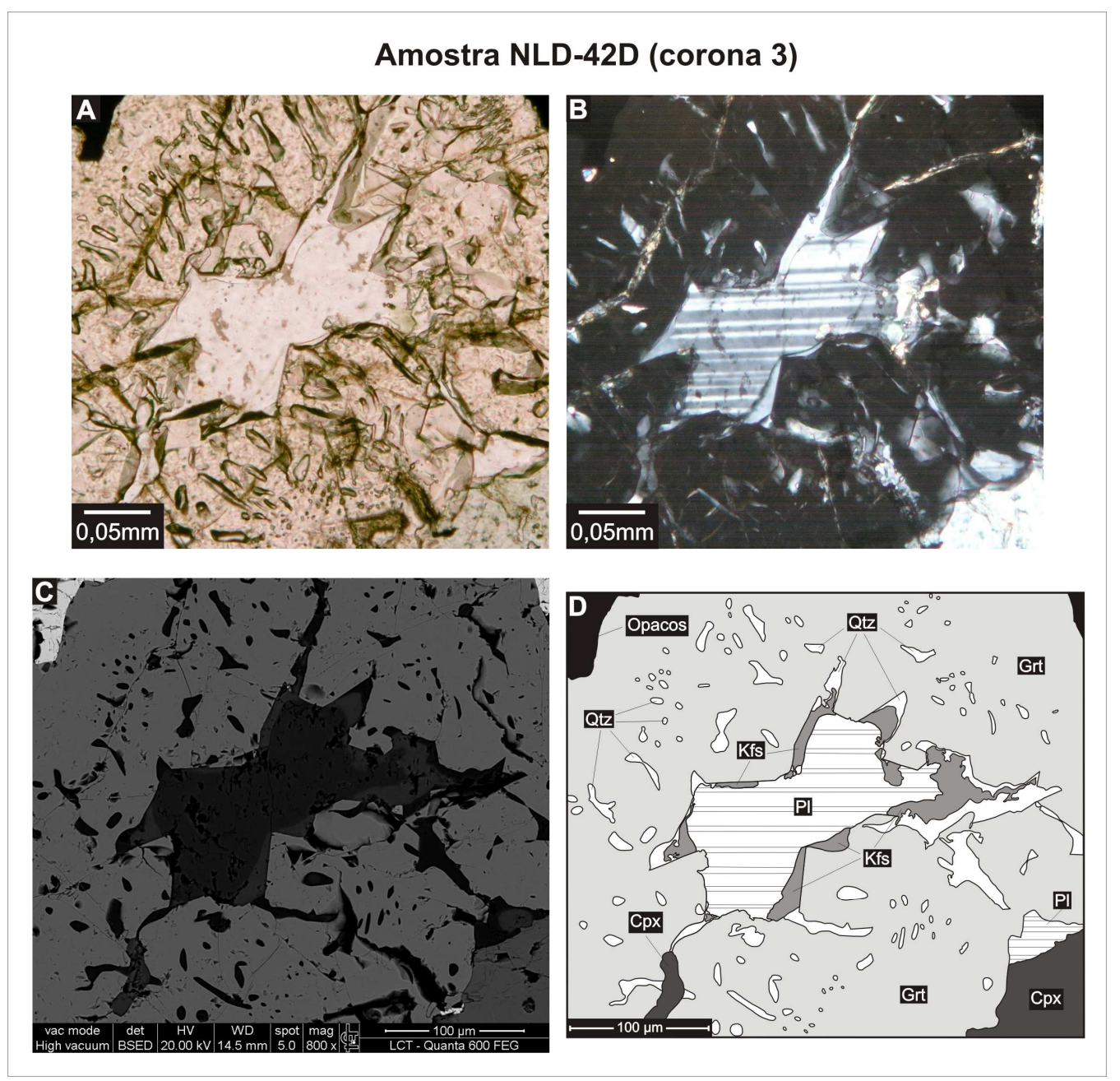

Figura 28: Corona de Grt ao redor de Pl, no contato com o Cpx e os opacos. Notar que ocorre Kfs + Qtz na parte interna da corona, no contato entre a Grt e o Pl. (A) Polarizadores paralelos, (B) Polarizadores cruzados, (C) Imagem retroespalhada obtida no MEV, (D) Esboço da textura. Amostra NLD-42D.

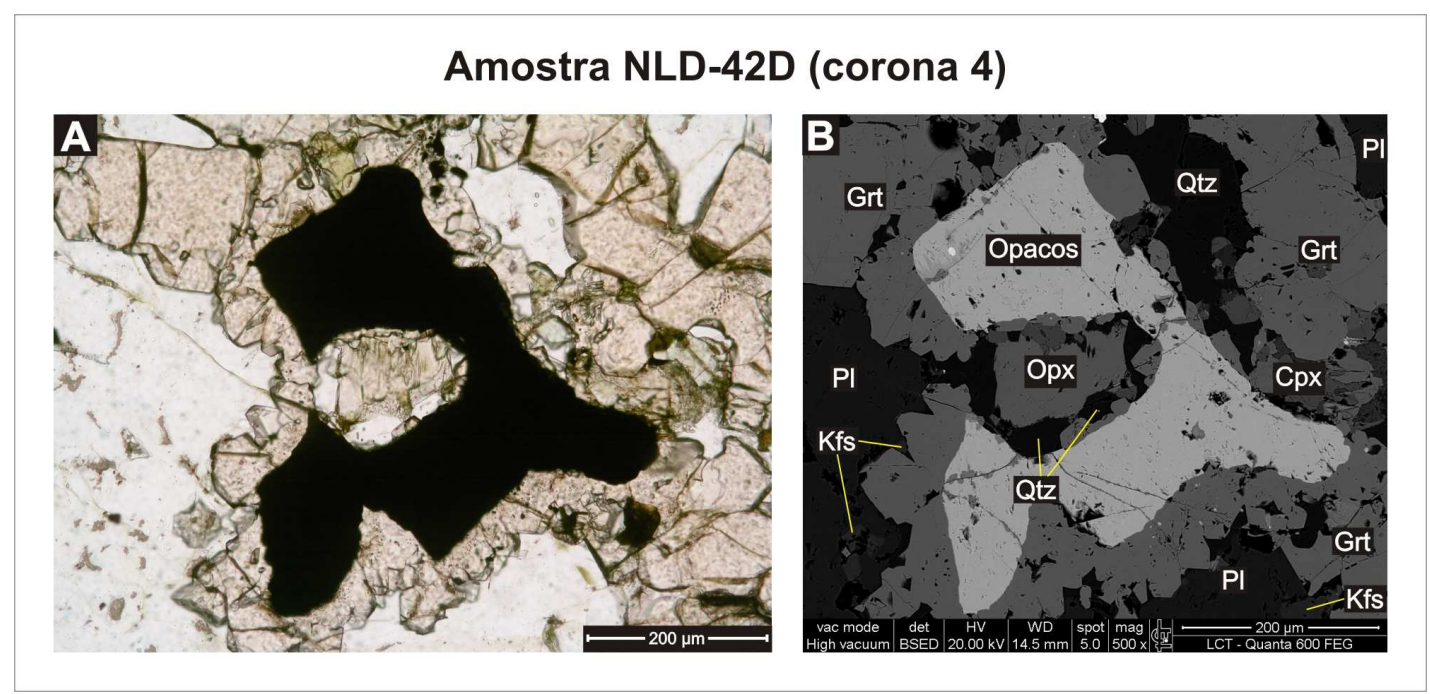

Figura 29: Corona poliminerálica, com Opx manteado por Grt+Qtz, por opacos, seguida por corona de Grt no contato com o Pl. Notar que ocorre Kfs na parte externa da corona, no contato entre a Grt e o Pl. (A) Polarizadores paralelos, (B) Imagem retroespalhada obtida no MEV. Amostra NLD-42D. 


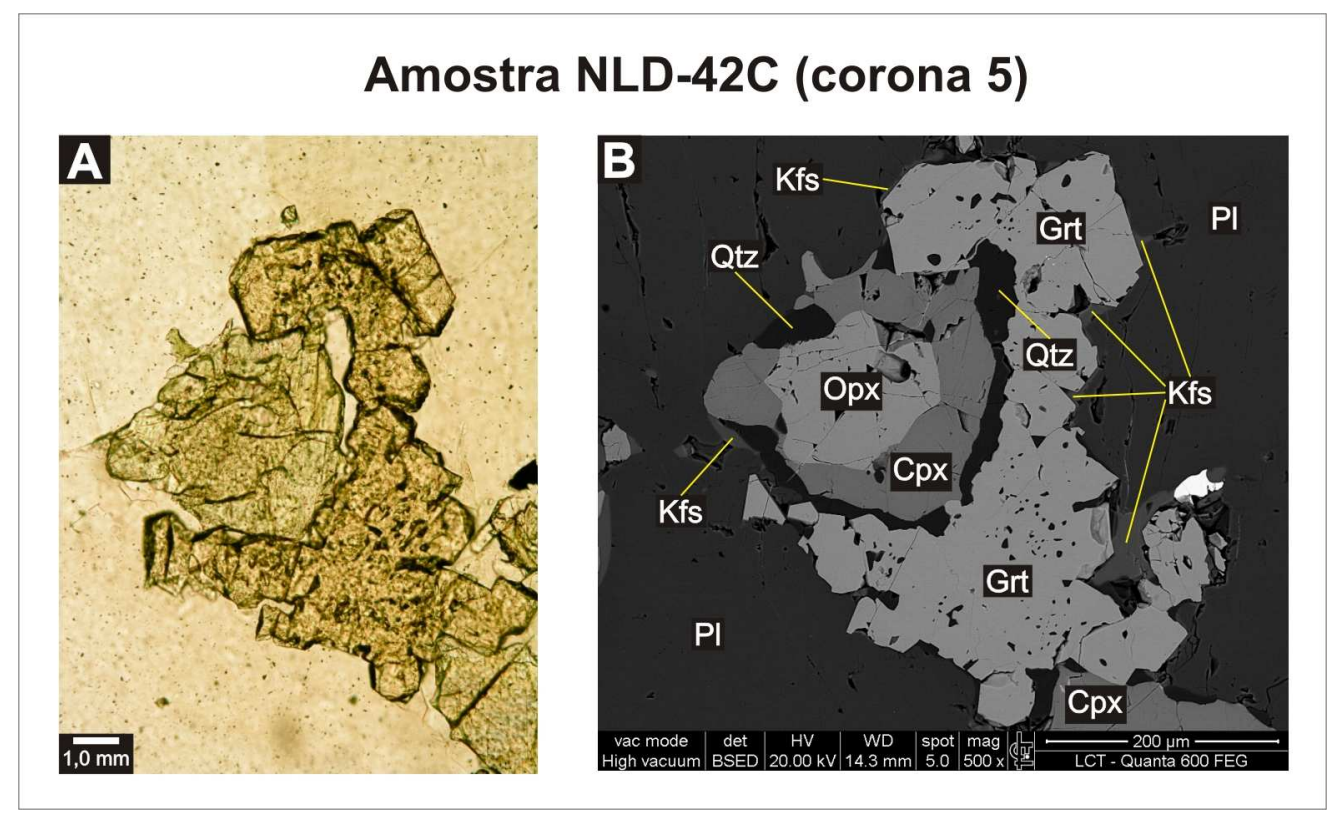

Figura 30: Corona poliminerálica, com Opx manteado por Grt+Qtz, por opacos, seguida por corona de Grt no contato com o Pl. Notar que ocorre Kfs na parte externa da corona, no contato entre a Grt e o Pl. (A) Polarizadores paralelos, (B) Imagem retroespalhada obtida no MEV. Amostra NLD-42C.

Nas amostras NLD-42A e NLD-42D ocorrem leitos milimétricos a subcentimétricos com concentração de granada (Figura 24). Visto ao microscópio petrográfico, esses leitos são constituídos predominantemente por granada xenoblástica, intercrescida com clinopiroxênio, quartzo e opacos, com calcita preenchendo os interstícios entre os grãos de granada e clinopiroxênio (Figuras 24 e 25). A granada apresenta terminações idioblásticas em direção ao plagioclásio. No centro destes leitos sempre ocorrem veios de quartzo milimétricos contínuos, o que sugere que essa textura tenha sido gerada através da percolação de fluido. Embora ocorra uma substituição posterior dos piroxênios por hornblenda, a associação mineral anidra Grt $+\mathrm{Cpx}+\mathrm{Qtz} \pm$ Pl foi bem preservada e provavelmente facilitada pela infiltração de um fluido possivelmente rico em $\mathrm{CO}_{2}$, evidenciado pela presença de calcita intersticial.

Também é bastante freqüente a ocorrência de feldspato potássico associado com as coronas, no contato entre a granada e o plagioclásio (Figuras 26 a 31), tanto nas rochas metabásicas como nas rochas charnockíticas. Nestas texturas o feldspato potássico sempre ocorre com formas lobadas, com ou sem quartzo associado, possivelmente mimetizando um líquido silicático. 


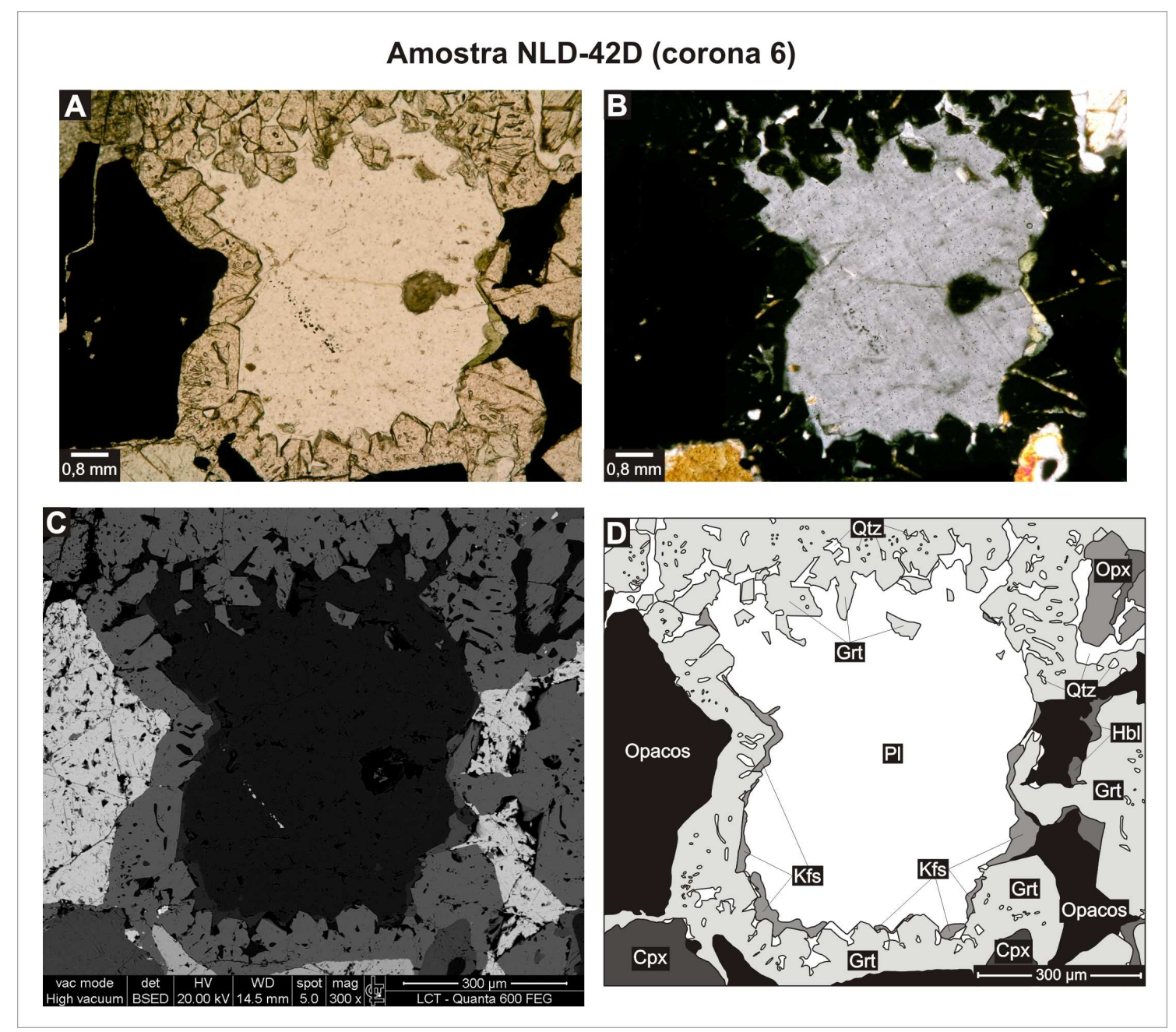

Figura 31: Corona de Grt ao redor de Pl, no contato com os opacos. Notar que ocorre Kfs na parte interna da corona, no contato entre a Grt e o Pl. (A) Polarizadores paralelos, (B) Polarizadores cruzados, (C) Imagem retroespalhada obtida no MEV, (D) Esboço da textura. Amostra NLD-42D.

\subsubsection{Rochas charnockíticas do Complexo Mantiqueira}

As rochas charnockíticas do Complexo Mantiqueira ocorrem no norte da área estudada, aparentemente sob a forma de um corpo intrusivo engajado em zona de cisalhamento. São representados por tipos intermediários a ácidos, com proporções mineralógicas variadas, com graus de deformação distintos. Predominam os enderbito gnaisses (Opx-tonalito gnaisses), com abundância menor de meta-charnockito (Opxgranito) e meta-mangerito (Opx-monzonito). A associação mineral típica é constituída por: $\mathrm{Opx}+\mathrm{Pl}+\mathrm{Grt}+\mathrm{Cpx}+\mathrm{Qtz}+\mathrm{Hbl}+\mathrm{Bt} \pm \mathrm{Kfs} \pm$ opacos. São caracterizados pela presença de texturas coroníticas de Grt $+\mathrm{Cpx} \pm \mathrm{Qtz} \pm \mathrm{Pl}$ no contato entre cristais de ortopiroxênio e plagioclásio reliquiares ígneos (Fotomicrografias 97 e 98). Esta textura sugere a passagem do campo dos granulitos de pressão intermediária (estabilidade Opx 
+ Pl) para o campo dos granulitos de alta pressão (Grt + Cpx \pm Qtz) e é interpretada como indicativa de metamorfismo progressivo.

Nas rochas charnockíticas são bastante comuns as texturas relacionadas com a retrogressão. Os cristais de ortopiroxênio encontram-se freqüentemente substituídos por uralita, um agregado de anfibólio fibroso de granulação muito fina. Às vezes essa substituição chega a ser quase total, pseudomorfizando o ortopiroxênio (Fotomicrografias 99 e 100). O processo de uralitização pode estar associado aos estágios magmáticos tardios da cristalização do charnockito, pois todas as outras substituições são posteriores à uralitização. O ortopiroxênio também está substituído por intercrescimentos esqueletais e vemiformes de $\mathrm{Bt}+\mathrm{Qtz}$ (Figura 32) (Fotomicrografias 101 a 104), por vezes o cristal está intensamente fraturado e penetrado por escamas grandes de biotita. Essa substituição pode ser total, configurando relíquias de ortopiroxênio em meio a massas biotíticas (Fotomicrografias 105 a 108). O ortopiroxênio pode ainda estar substituído por intercrescimentos de Hbl + Qtz.

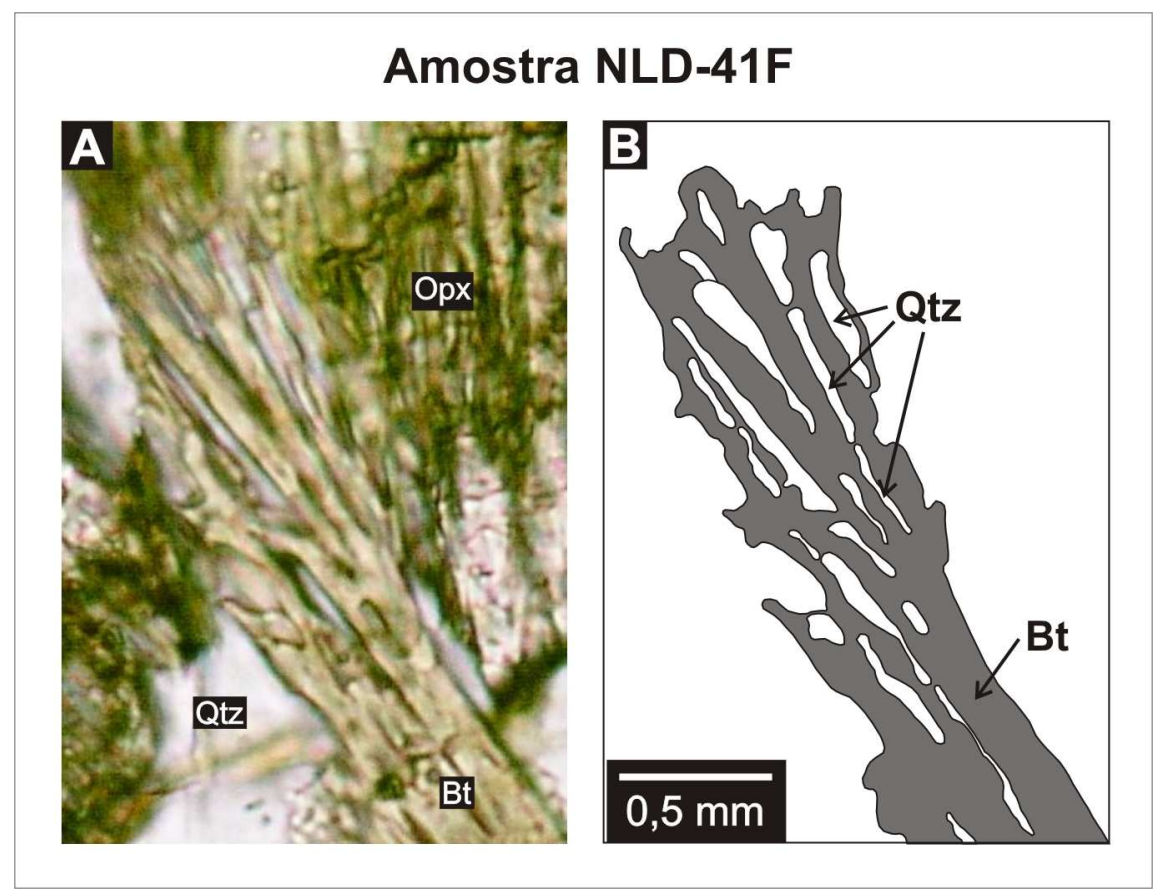

Figura 32: Intercrescimento esqueletal de Bt + Qtz substituindo o ortopiroxênio. (A) Polarizadores paralelos, (B) Esboço da textura. Amostra NLD-41F.

$\mathrm{Na}$ amostra NLD-45B ocorrem megacristais de ortopiroxênio reliquiares parcialmente substituídos por $\mathrm{Bt} \pm \mathrm{Qtz}$, com texturas coroníticas de Grt $+\mathrm{Cpx} \pm$ Qtz no contato com o plagioclásio (Figura 33). Na parte interna da corona 9, também ocorre 
feldspato potássico com formas lobadas associado com o quartzo, no contato entre a granada e o plagioclásio (Figura 34). Assim como nas rochas metabásicas, essa textura sugere a mimetização de um líquido silicático formado durante o desenvolvimento da corona (metamorfismo progressivo) ou a exsolução de feldspato potássico a partir do plagioclásio associado com a formação da corona. Nesta corona também há o surgimento de plagioclásio subeuédrico neoformado $\left(\mathrm{Pl}_{2}\right)$, na borda da corona no contato com a granada.

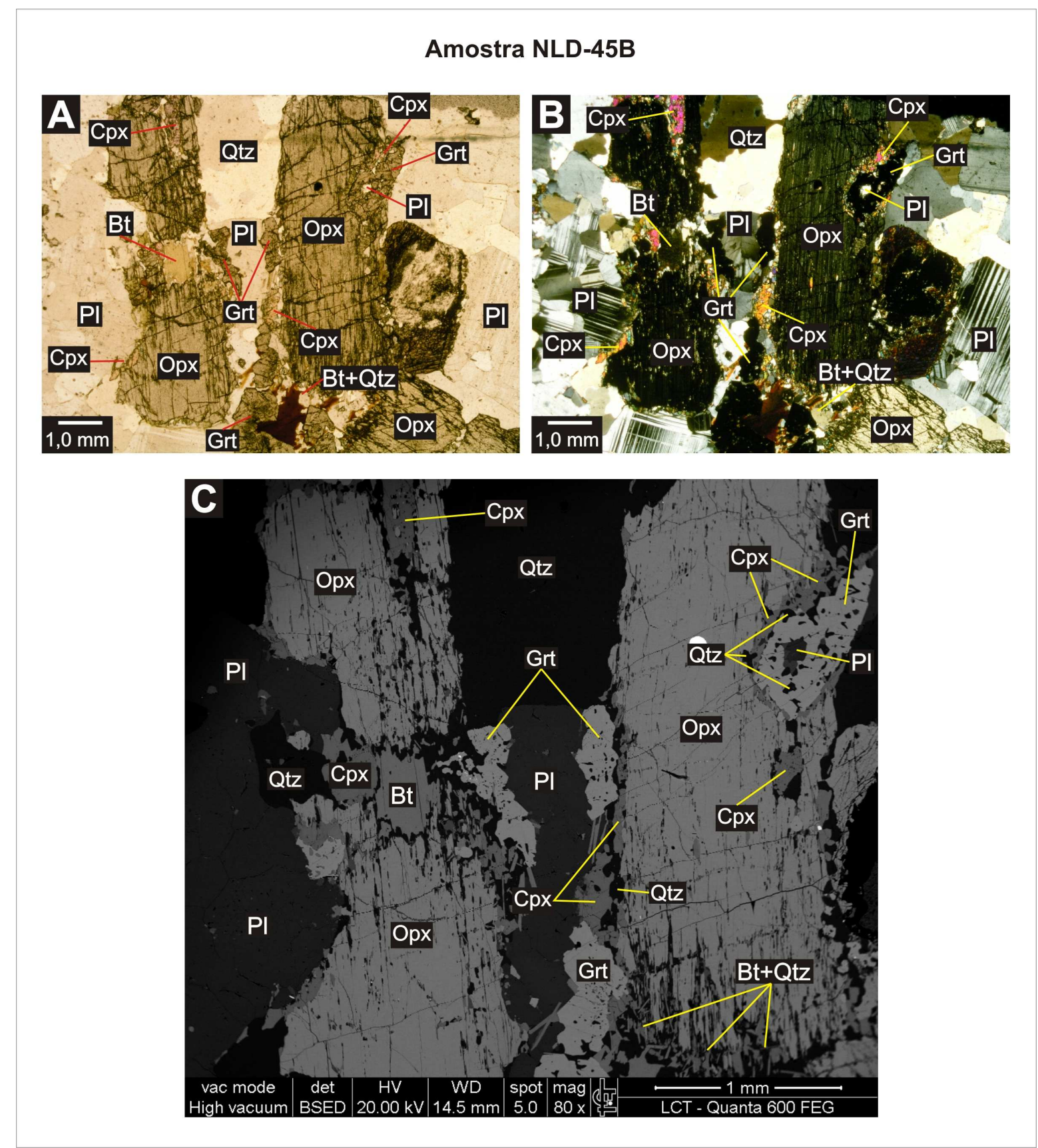

Figura 33: Megacristais de ortopiroxênio parcialmente substituídos por Bt \pm Qtz, com coronas de Grt + Cpx \pm Qtz no contato com o plagioclásio. (A) Polarizadores paralelos, (B) Polarizadores cruzados, (C) Imagem retroespalhada obtida no MEV. Amostra NLD-45B. 


\section{Amostra NLD-45B (Corona 9)}
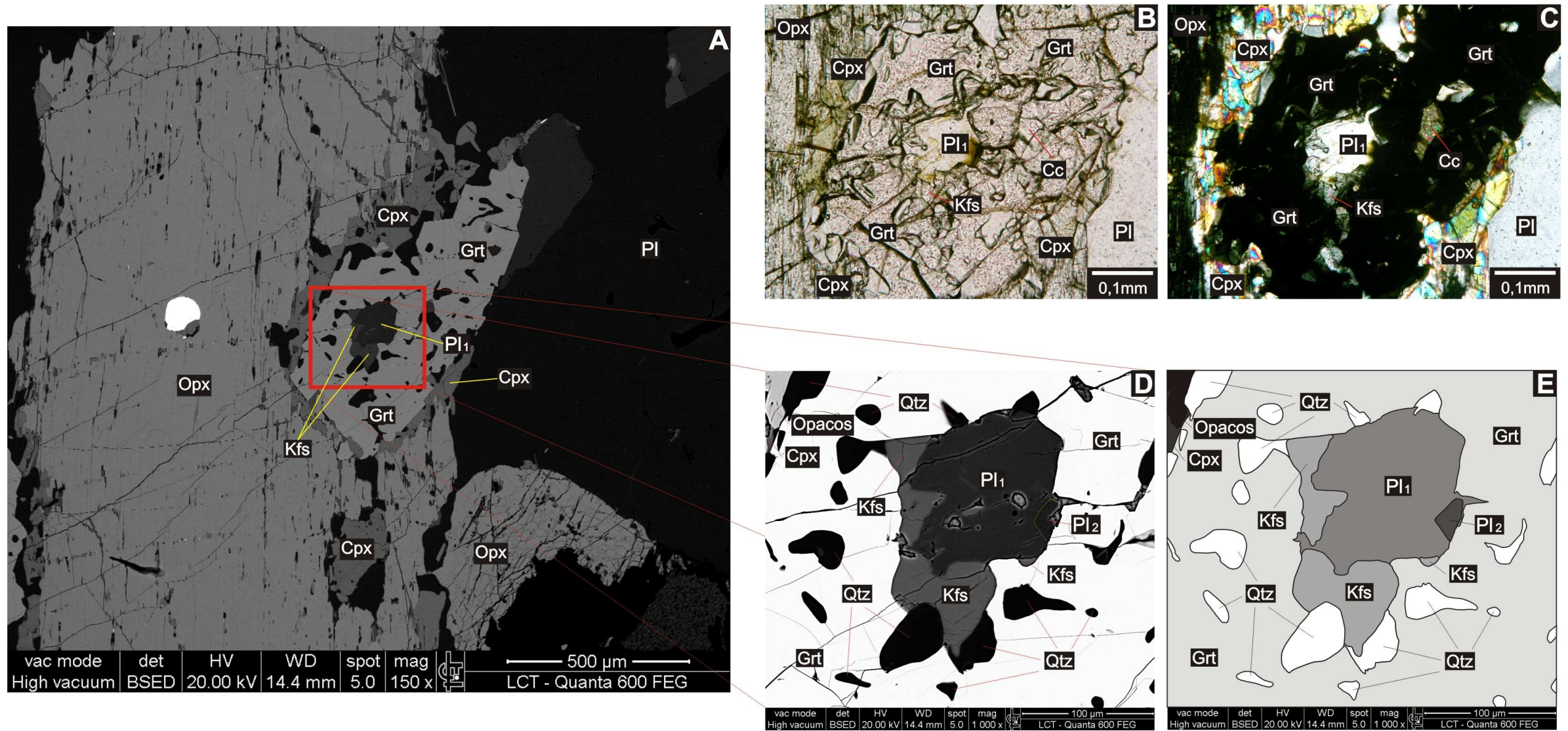

Figura34: Corona de Grt $+\mathrm{Cpx} \pm \mathrm{Qtz}$ ao redor de Pl, no contato entre o ortopiroxênio e o plagioclásio. Notar que ocorre Kfs na parte interna da corona, no contato entre a Grt e o Pl. (A) Imagem retroespalhada obtida no MEV, (B) Polarizadores paralelos, (C) Polarizadores cruzados, (D) Imagem retroespalhada obtida no MEV, com detalhe da corona, (E) Esboço da textura. Amostra NLD-45B. 


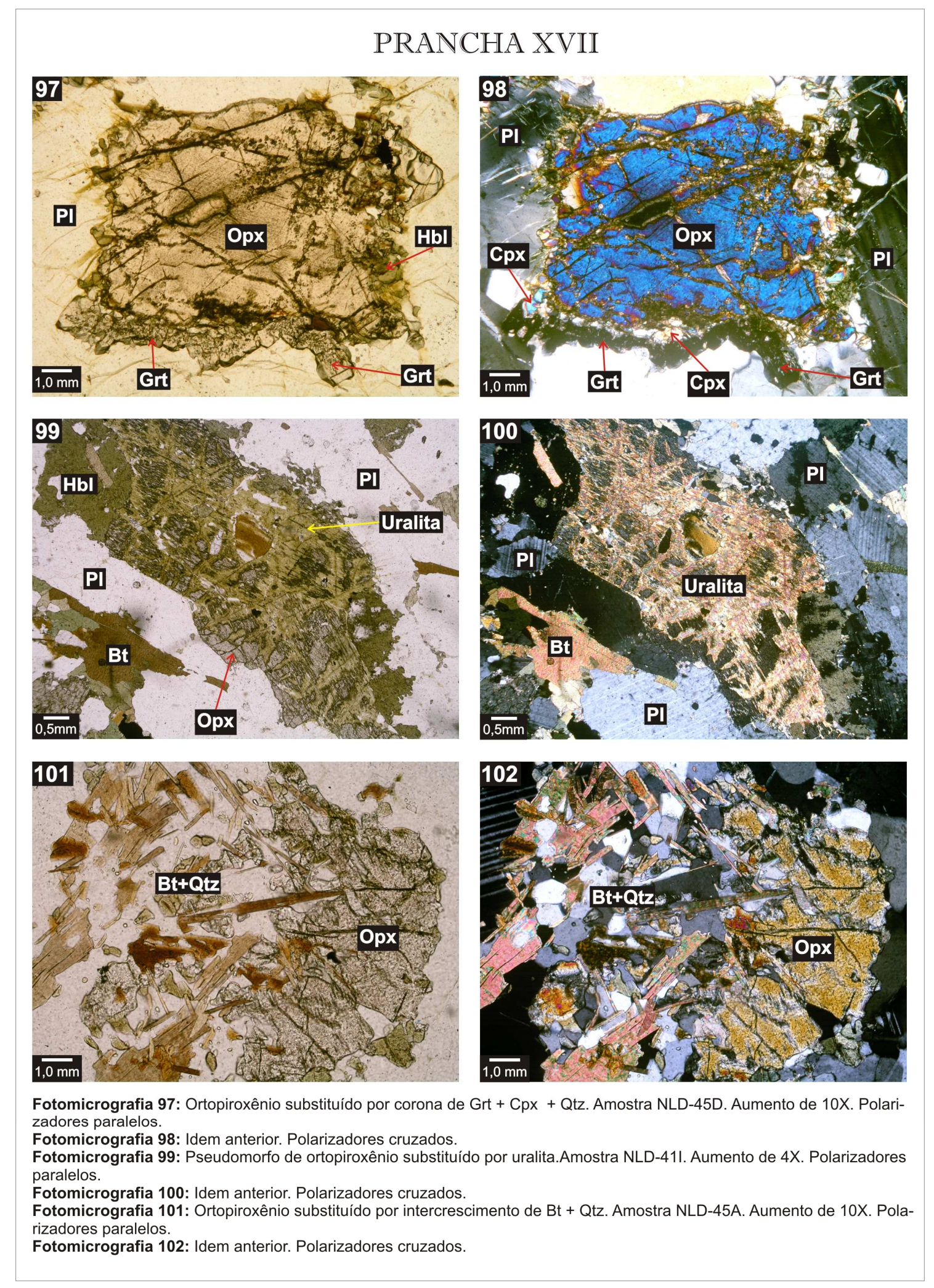




\section{PRANCHA XVIII}
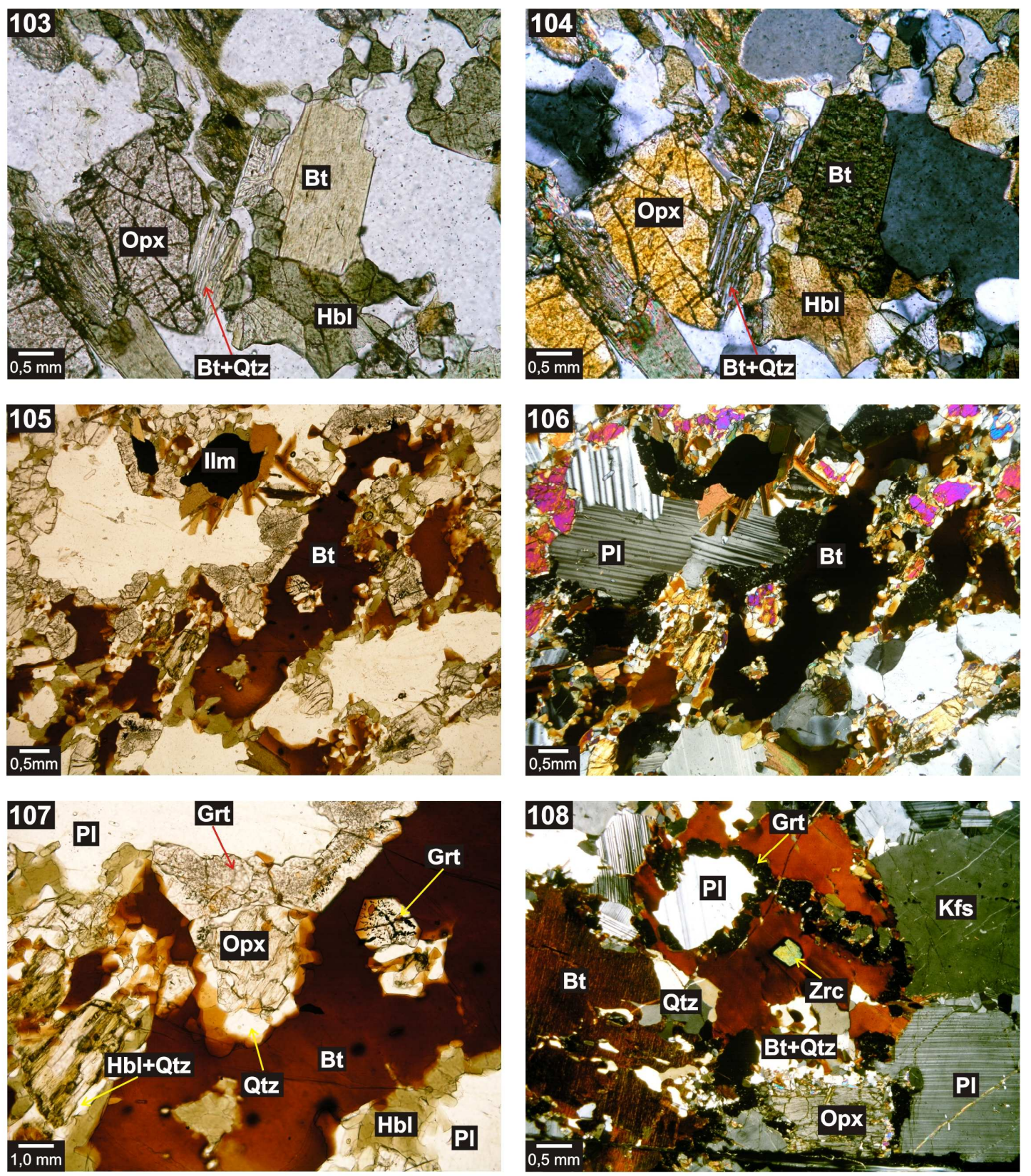

Fotomicrografia 103: Ortopiroxênio substituído por intercrescimento vermiforme de Bt + Qtz. Amostra NLD-41G. Aumento de 20X. Polarizadores paralelos.

Fotomicrografia 104: Idem anterior. Polarizadores cruzados.

Fotomicrografia 105: Pseudomorfo de ortopiroxênio substituído por uralita. Amostra NLD-45D. Aumento de 20X. Polarizadores paralelos.

Fotomicrografia 106: Idem anterior. Polarizadores cruzados.

Fotomicrografia 107: Ortopiroxênio manteado por Grt + Qtz, posteriormente substituído por biotita e por intercrescimentos de $\mathrm{Hbl}+\mathrm{Qtz}$. Amostra NLD-45D. Aumento de 10X. Polarizadores paralelos.

Fotomicrografia 108: Ortopiroxênio manteado por corona de Grt + Cpx + Qtz, com substituição posterior por intercrscimentos de $\mathrm{Bt}+\mathrm{Qtz}$. Amostra NLD-45D.Aumento 20X. Polarizadores cruzados. 


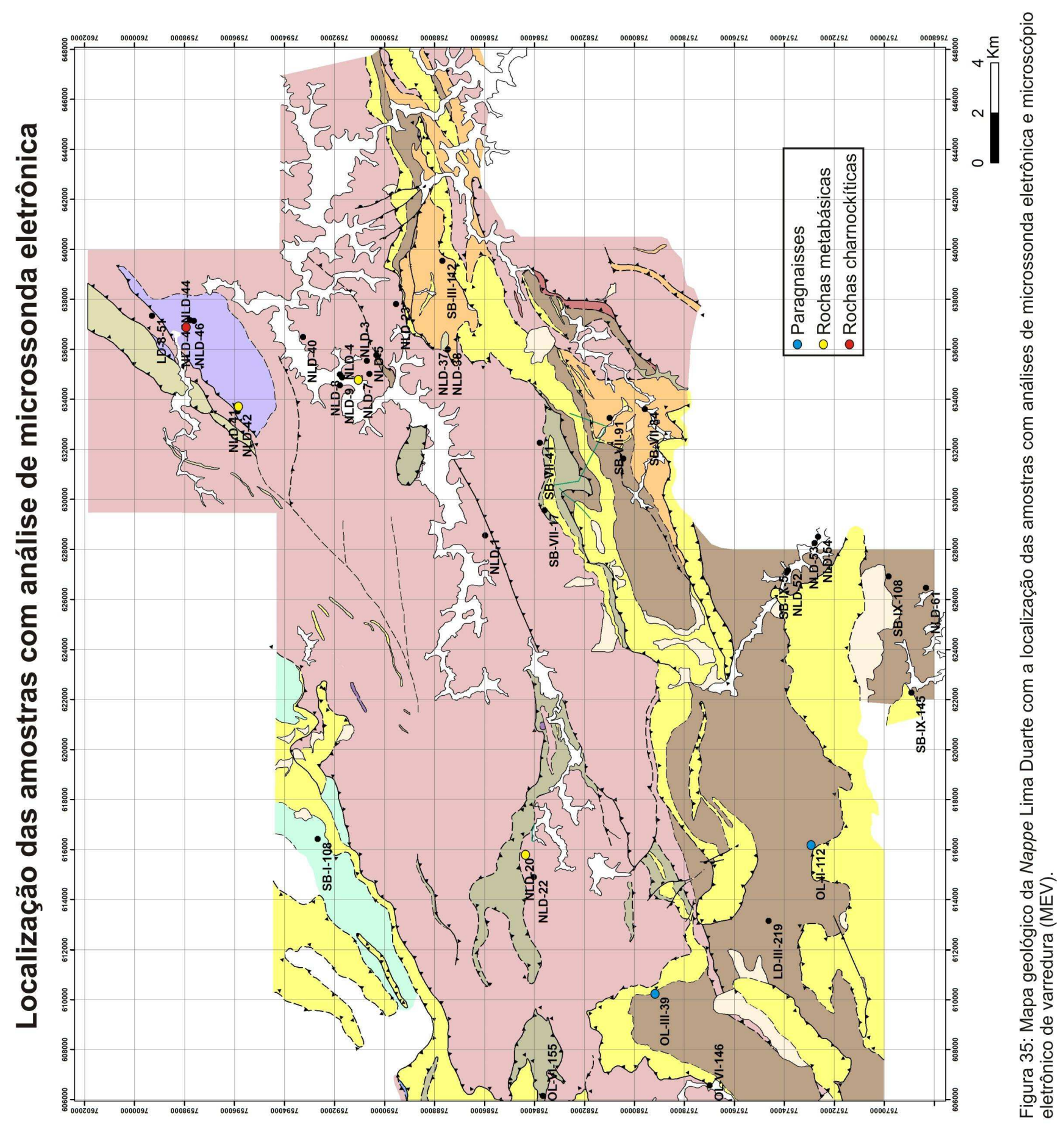




\subsection{QUÍMICA MINERAL}

\subsubsection{Considerações iniciais}

As análises químicas pontuais foram realizadas no Laboratório de Microssonda Eletrônica do Instituto de Geociências - Universidade de São Paulo, utilizando a microssonda eletrônica JEOL JXA-8600. Foram selecionadas oito amostras no total, sendo duas amostras de paragnaisses (OL-II-112B e OL-III-39A), quatro amostras de rochas metabásicas (NLD-7A, NLD-20A, NLD-42C, NLD-42D) e duas amostras de rochas charnockíticas (NLD-45B e NLD-45D) (Figura 35). As fases minerais analisadas nos paragnaisses foram: granada, biotita, muscovita, feldspato e rutilo. Nas rochas metabásicas e charnockitos foram analisados: granada, biotita, feldspato, piroxênios e anfibólios. As condições de análise para os minerais foram: voltagem de 15 $\mathrm{kV}$ e corrente de $20 \mathrm{nA}$, com diâmetro de feixe entre 5 e $10 \mu \mathrm{m}$, exceto para as análises de rutilo, em que foi utilizada voltagem de $20 \mathrm{kV}$ e corrente de $120 \mathrm{nA}$, com diâmetro de feixe em $5 \mu \mathrm{m}$. As distribuições catiônicas dos minerais foram calculadas através dos softwares MINPET 2.02 (Richard, 1995) e Ax2 (Holland, 2008), parte integrante do THERMOCALC, versão 3.26 (Powell \& Holland, 1988). As distribuições catiônicas do clinopiroxênio foram calculadas segundo o método de Appleyard et al., (2007) e Capitanio et al., (2005).

\subsubsection{Paragnaisses}

\subsubsection{Descrição sucinta das amostras}

\section{- OL-II-112B}

A rocha apresenta estrutura bandada e textura porfiroblástica, inequigranular fina a grossa, com porfiroblastos de granada de granulação grossa $(\sim 1,5 \mathrm{~cm})$. Apresenta matriz de granulação fina a média, que alterna bandas quartzo-feldspáticas granoblásticas e bandas nemato-lepidoblásticas, ricas em sillimanita e biotita intercrescidas, orientadas paralelamente à foliação principal $\mathrm{S}_{2}$. O quartzo (35-40\%) e o feldspato potássico $(<5 \%)$ ocorrem na matriz na forma de leitos bastante estirados. Os porfiroblastos de granada (10-15\%) são xenoblásticos e intercinemáticos, e registram no seu interior a foliação $\left(S_{n-1}\right)$ na forma de trilhos de ilmenita e rutilo. Ocorre um porfiroblasto intercinemático de granada com inclusão de cianita, associada à sillimanita, muscovita $(<5 \%)$, biotita, feldspato potássico e ilmenita $(<5 \%)$ que foi 
analisado nesta amostra. Os principais minerais acessórios são: rutilo $(<3 \%)$, cianita $(<1 \%)$, zircão $(<1 \%)$ e turmalina $(<1 \%)$.

\section{- OL-III-39A}

A rocha apresenta estrutura gnáissica e textura porfiroblástica inequigranular fina a média, com porfiroblastos de granada de granulação média a grossa, freqüentemente com zonas de sombra de pressão de biotita e sillimanita. Os porfiroblastos de granada (10-15\%) são elipsoidais e amalgamados, com a predominância de uma fase intercinemática, rica em inclusões de biotita, quartzo, ilmenita, rutilo, plagioclásio e zircão, com um sobrecrecimento tardi a pós-cinemático, com menor quantidade de inclusões. No interior da granada freqüentemente ocorre biotita idioblástica de granulação grossa, substituindo a granada ao longo das fraturas. Também ocorrem porfiroblastos sin-cinemáticos de granada, com a foliação interna definida por trilhos de opacos e biotita, em continuidade com a foliação externa da matriz $\left(S_{2}\right)$. A matriz apresenta lentes granoblásticas sigmoidais, ricas em quartzo (15$20 \%$ ) e plagioclásio (25-30\%), circundadas por leitos ricos em biotita (20-25\%) e sillimanita $(5-10 \%)$. O plagioclásio predominante é o oligoclásio $\left(\mathrm{An}_{10-20}\right)$. Os principais minerais acessórios são: rutilo $(<5 \%)$, ilmenita $(<5 \%)$ e zircão $(<2 \%)$.

\subsubsection{Granada}

Nos paragnaisses, todas as granadas são ricas em almandina $\left(\mathrm{Alm}_{76-84}\right)$, com conteúdos menores de piropo $\left(\operatorname{Prp}_{9-12}\right)$, grossulária $\left(\mathrm{Grs}_{2-10}\right)$ e espessartita $\left(\operatorname{Sps}_{2-4}\right)$. Foram obtidos dois perfis composicionais através de um porfiroblasto elipsoidal de granada de aproximadamente 2,5cm de diâmetro na amostra OL-II-112B (Figura 36). O perfil composicional (A-A') abrange o domínio sin-cinemático da granada (foliação interna é paralela à foliação externa principal $S_{2}$ ) e parte do domínio intercinemático (foliação interna na forma de trilhos de ilmenita e rutilo, oblíquos em relação à foliação externa principal $\mathrm{S}_{2}$ ) (Figura 36A). O perfil composicional (B-B') abrange o domínio intercinemático da granada (Figura 36B). A composição química é aproximadamente homogênea, exceto para os conteúdos de grossulária, em que o cálcio atinge valor máximo no núcleo $\left(\mathrm{Grs}_{10}\right)$, nas proximidades de uma inclusão de cianita (Figuras 36, 37 e 39). Os maiores conteúdos em grossulária estão destacados em tons de vermelho, na composição falsa-cor $\mathrm{Ca}(\mathrm{R}) \mathrm{Mg}(\mathrm{G}) \mathrm{Fe}(\mathrm{B})$ (Figura 39). Esta associação sugere que as condições de pico bárico foram atingidas, no campo de estabilidade da cianita. 
O núcleo da granada apresenta os menores conteúdos de piropo. O conteúdo de almandina é essencialmente homogêneo ao longo dos perfis analisados, com um aumento significativo nas bordas, correspondente com a diminuição em piropo. Isto pode ser correlacionado com a composição da biotita da matriz que é mais rica no membro annita, enquanto que a biotita inclusa apresenta maiores conteúdos de flogopita (Figura 39). Esta associação é resultante da troca de $\mathrm{Fe}-\mathrm{Mg}$ entre a granada e a biotita (almandina + flogopita $\leftrightarrow$ piropo + annita). As bordas da granada são ligeiramente mais ricas em Mn (membro-final espessartita).

As variações de quimismo das fases minerais apresentam uma correlação da composição com as texturas e paragêneses. Ocorrem picos de ferro associados com uma ligeira diminuição no teor de cálcio no núcleo do porfiroblasto, nas proximidades de inclusões de biotita e feldspato (Figura 39). A difusão química é facilitada pela existência de uma zona de fraturamento interna na granada.

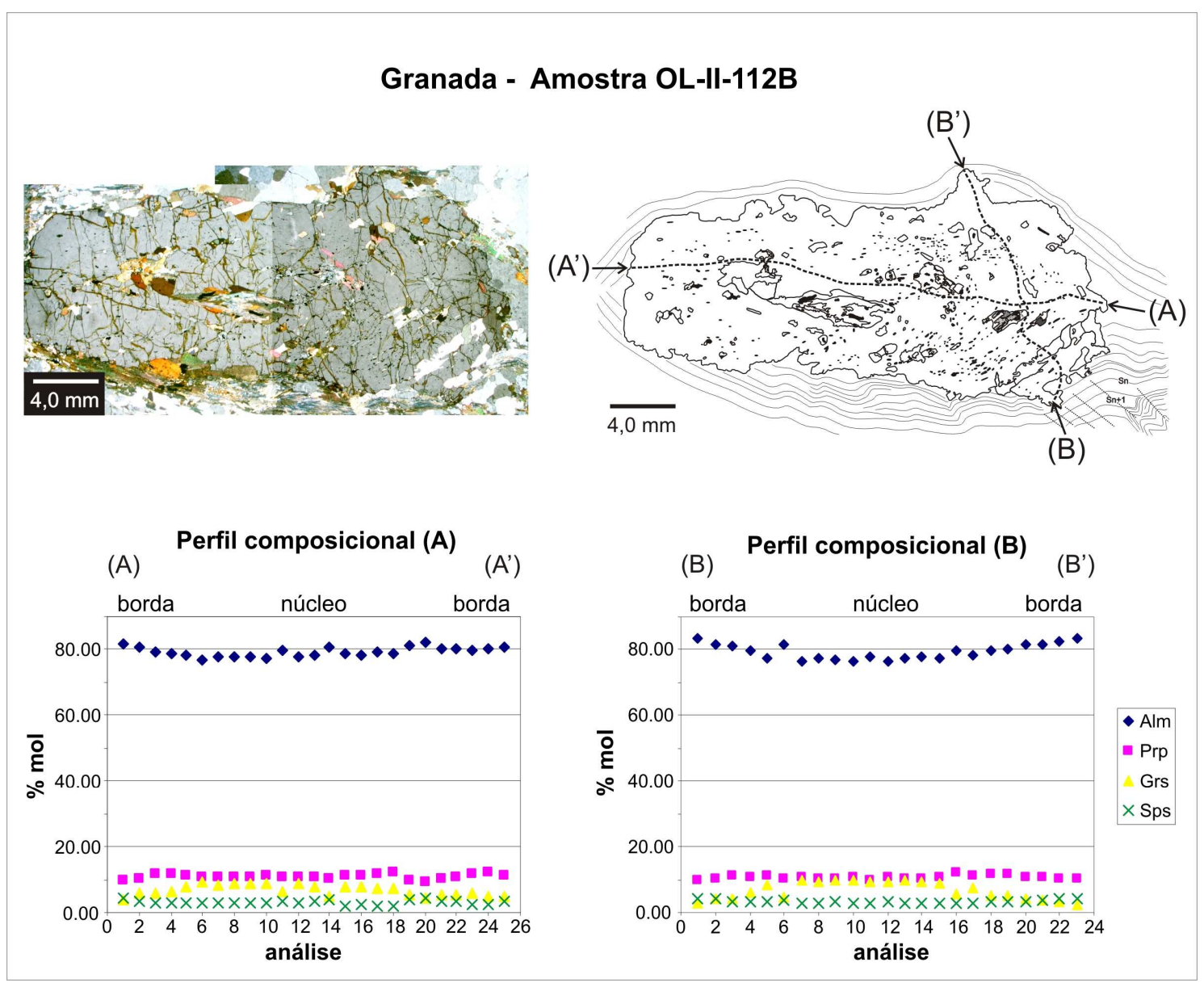

Figura 36: Seção química de granada, em perfil longitudinal (seção A-A’) e em perfil transversal (seção B-B'). Polarizadores cruzados. Amostra OL-II-112B. 
Mapas composicionais (Granada) - Amostra OL-II-112B
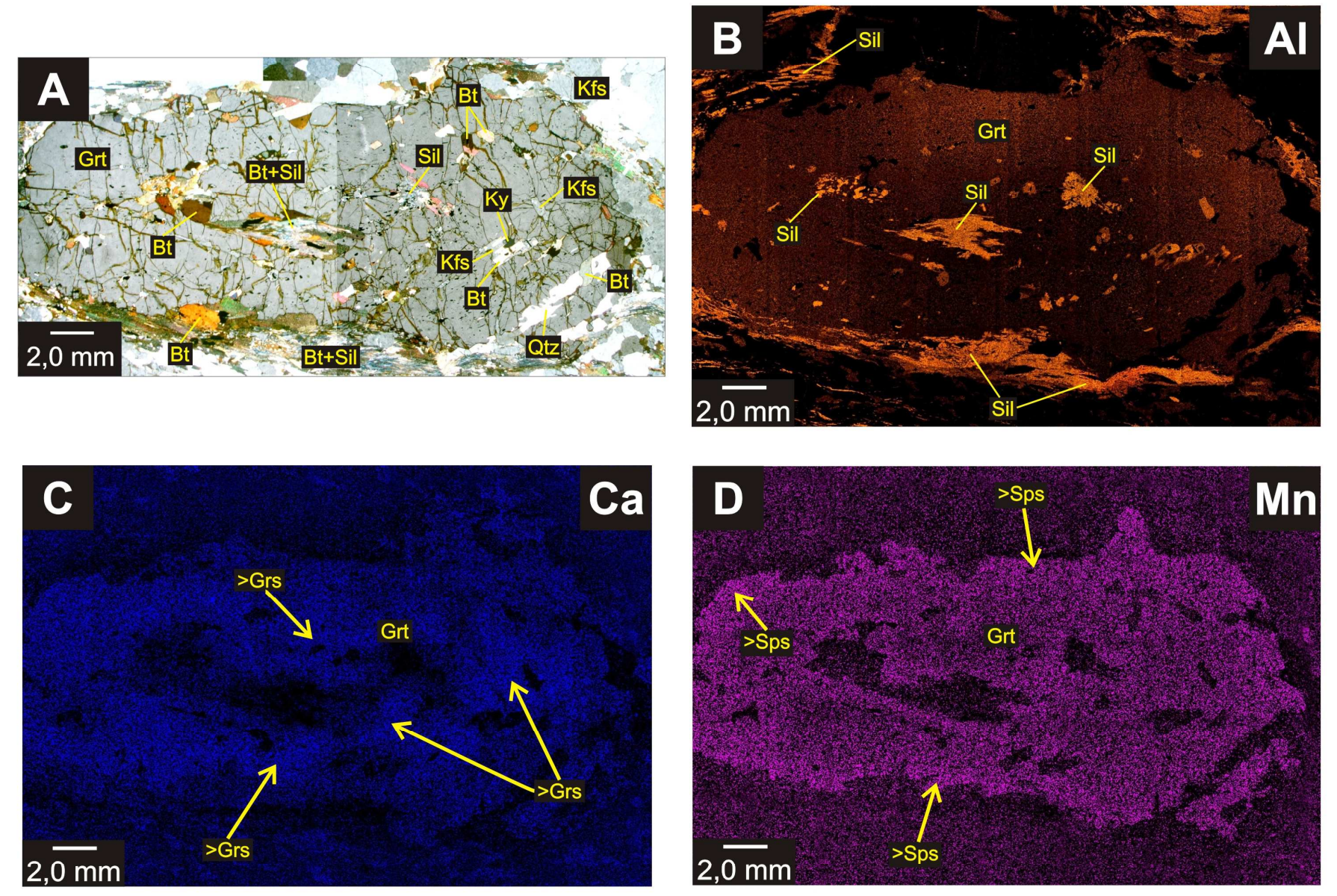

Figura 37: Fotomicrografia e mapas de concentração de elementos, ilustrando o zoneamento químico de um porfiroblasto de granada e de suas inclusões. Amostra OL-II-112B. (A) Fotomicrografia, (B) Mapa composicional de Al, (C) Ca, (D) Mn. 
Mapas composicionais (Granada) - Amostra OL-II-112B
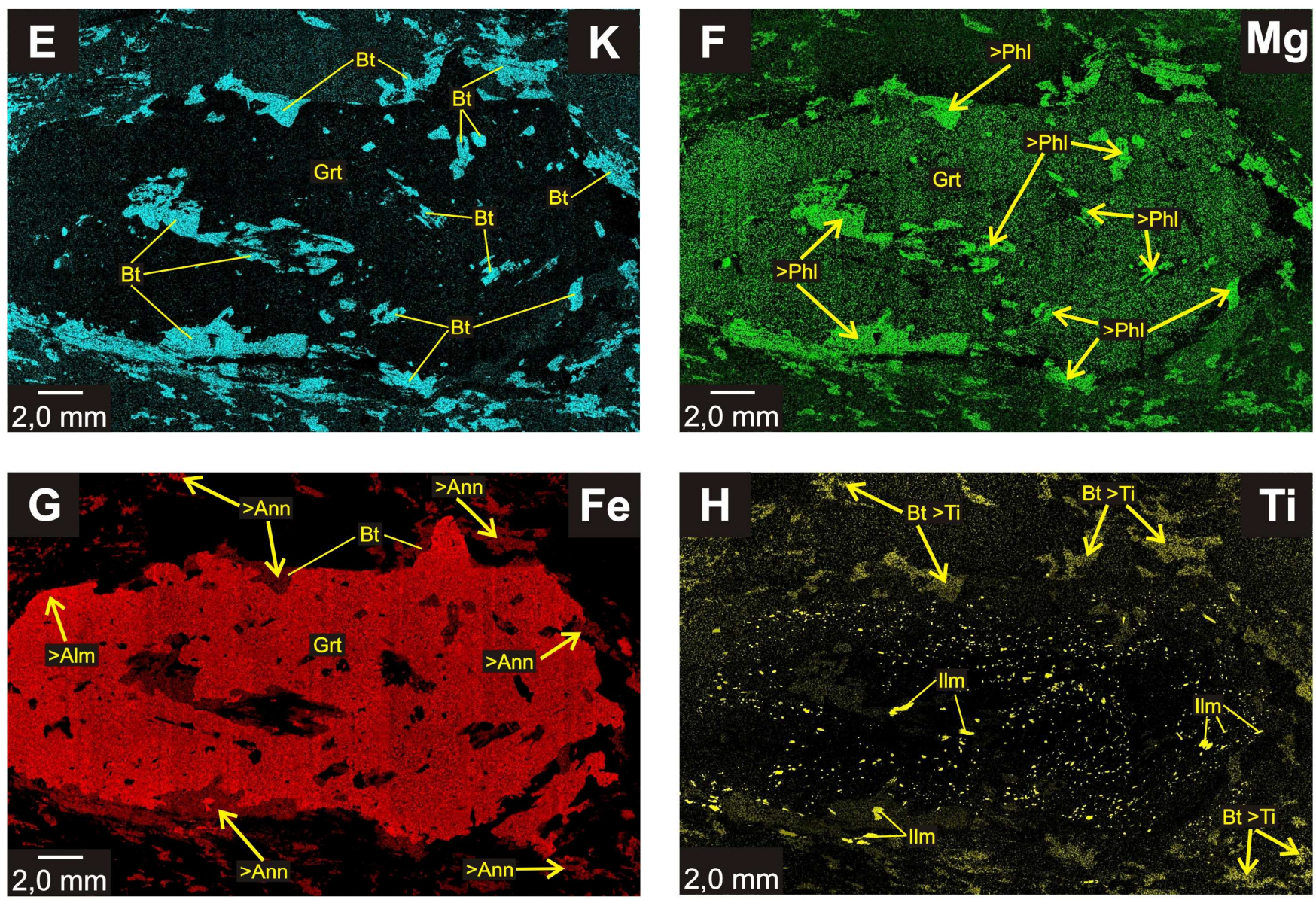

Figura 38: Mapas de concentração de elementos, ilustrando o zoneamento químico de um porfiroblasto de granada e de suas inclusões. Amostra OL-II-112B. (E) Mapa composicional de $\mathrm{K},(\mathrm{F}) \mathrm{Mg},(\mathrm{G}) \mathrm{Fe},(\mathrm{H}) \mathrm{Ti}$ 


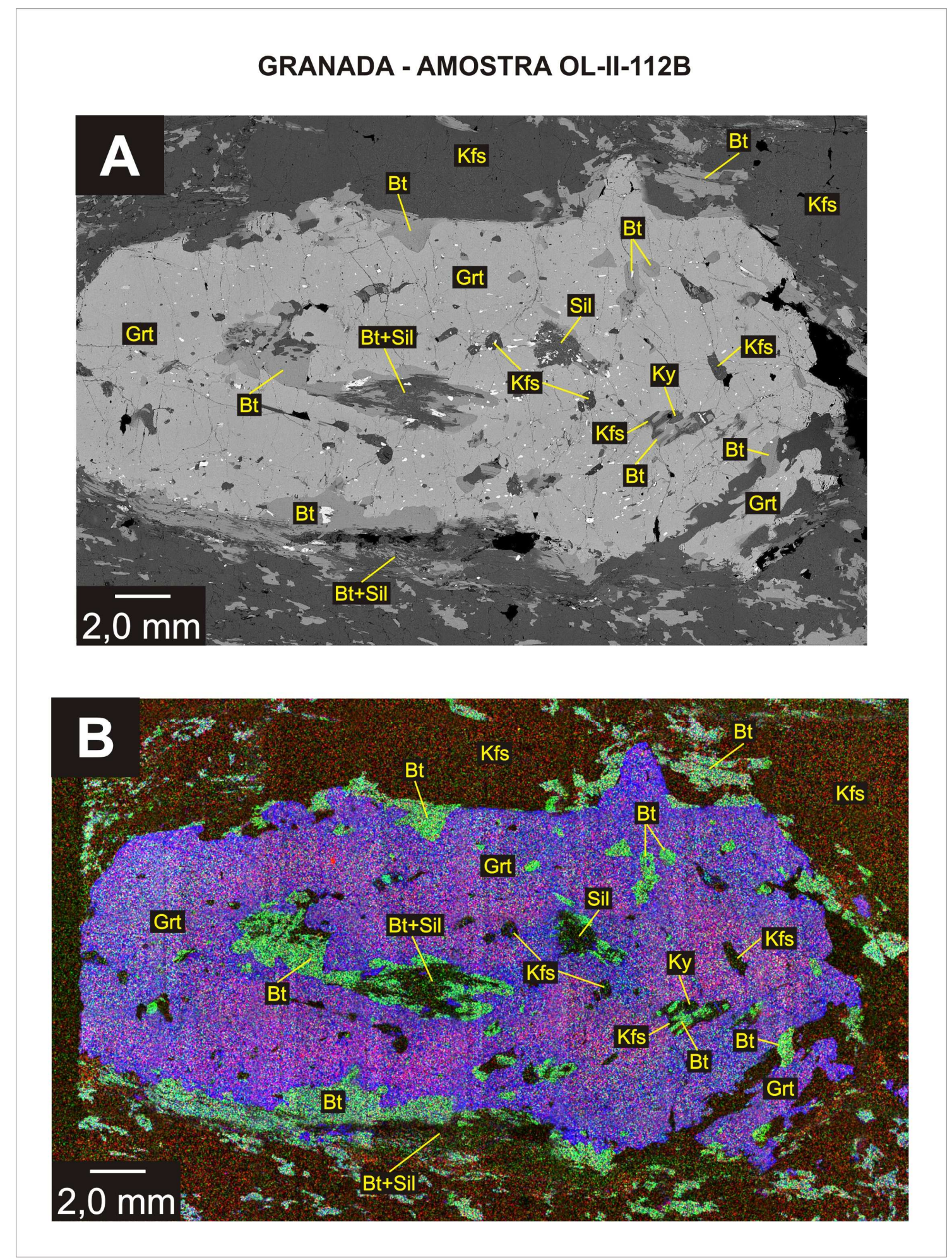

Figura 39: (A) Imagem retroespalhada de um porfiroblasto de granada, obtida através de microscópio eletrônico de varredura (MEV), (B) Composição falsa-cor Ca (R), Mg (G), Fe (B) de um porfiroblasto de granada. Amostra OL-II-112B. 


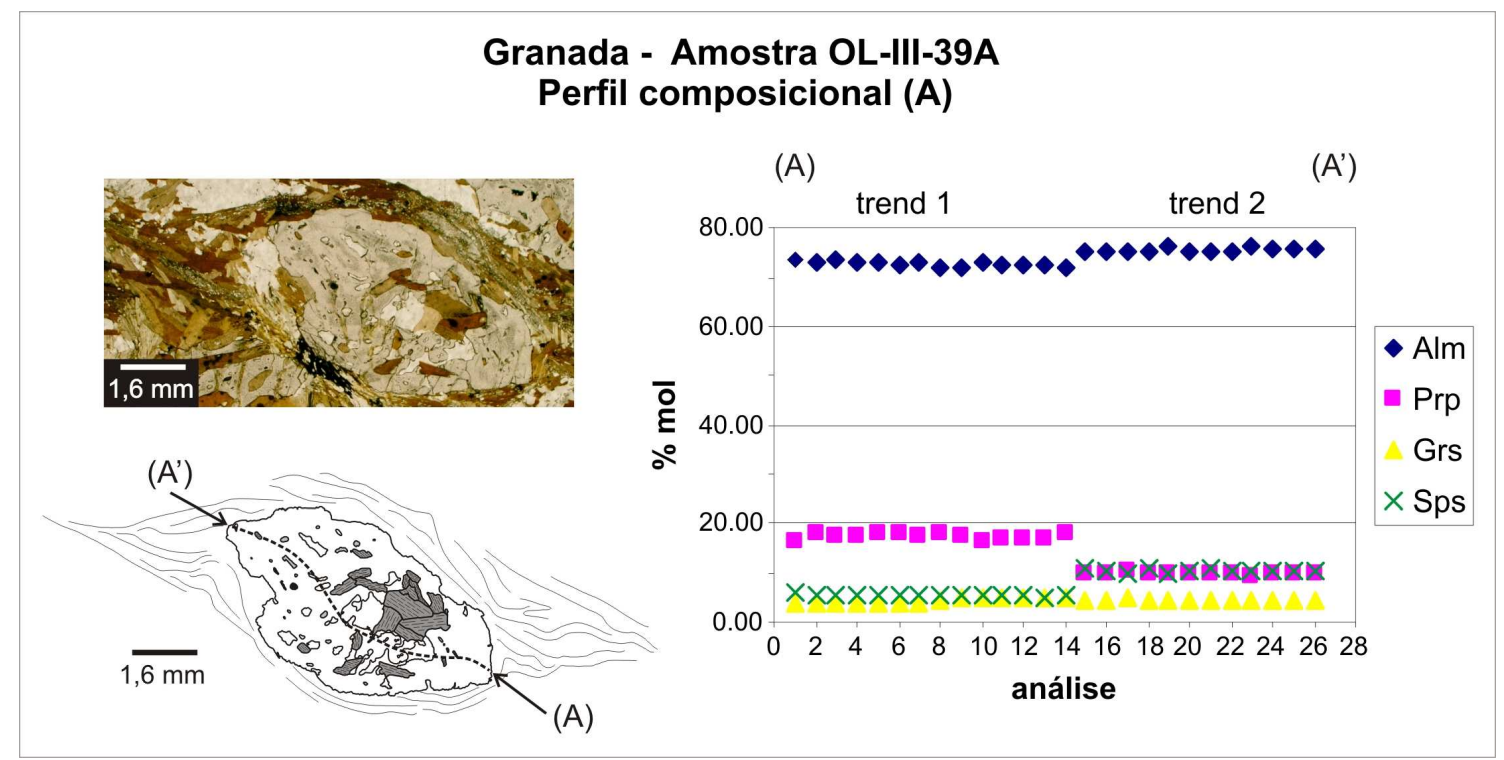

Figura 40: Seção química de granada (A-A'). Polarizadores paralelos. Amostra OL-III39A.

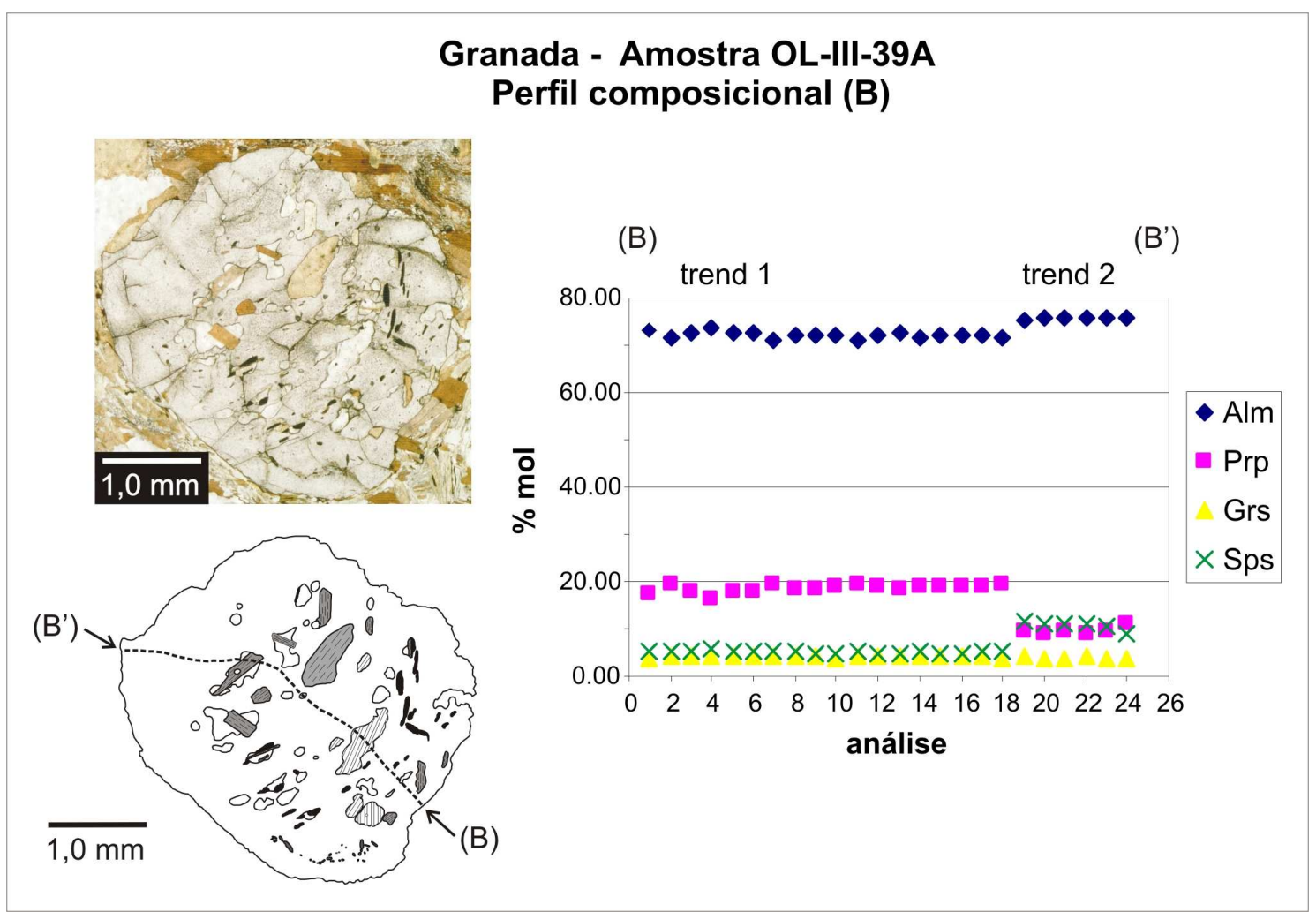

Figura 41: Seção química de granada (B-B'). Polarizadores paralelos. Amostra OL-III-39A.

$\mathrm{Na}$ amostra OL-III-39A foram analisados dois porfiroblastos de granada com uma variação composicional brusca $\left(\mathrm{Alm}_{76} \operatorname{Prp}_{9} \mathrm{Sps}_{10}\right.$ para $\left.\mathrm{Alm}_{72} \operatorname{Prp}_{18} \mathrm{Sps}_{5}\right)$ (Figuras 40 e 41). A fase intercinemática pode corresponder a uma primeira geração de granada, mais rica em piropo $\left(\operatorname{Prp}_{16,4-18}\right)$ e empobrecida em almandina $\left(\operatorname{Alm}_{72-74}\right)$ e espessartita $\left(\operatorname{Sps}_{5-6}\right)$, apresentando muitas inclusões de biotita, ilmenita, rutilo, quartzo e 
plagioclásio. A segunda geração de granada é caracterizada por um sobrecrescimento tardio, praticamente isento de inclusões. Ocorre um aumento em almandina (Alm $\left.{ }_{75-76}\right)$ e espessartita $\left(\operatorname{Sps}_{10}\right)$ acompanhado por uma diminuição em piropo (Prp9-10), nas proximidades do domínio rico em biotita de granulação grossa (troca Fe-Mg). Este hiato composicional sugere um crescimento descontínuo da granada.

\subsubsection{Feldspato}

Os feldspatos variam de oligoclásio/andesina a sanidina no diagrama An-Ab-Or (Figura 42). O feldspato da amostra OL-II-112B ocorre na forma de cristais de ortoclásio não-geminados, anédricos a subeuédricos e apresentam composição química aproximadamente homogênea $\left(\mathrm{An}_{0} \mathrm{Ab}_{14-20} \mathrm{Or}_{80-85}\right)$, exibindo concentrações mais baixas de ortoclásio nas bordas externas. Na matriz está associado com quartzo, biotita, sillimanita e granada. Em geral, o teor de ortoclásio é mais elevado nos cristais inclusos na granada em comparação com o feldspato da matriz $\left(\mathrm{An}_{0} \mathrm{Ab}_{4-12} \mathrm{Or}_{87-96}\right)$ (Figura 42). Os cristais analisados da matriz apresentam uma pequena variação no teor de ortoclásio, que diminui do núcleo em direção às bordas. $\mathrm{O}$ feldspato potássico incluso na granada ocorre em paragênese com cianita, sillimanita, biotita, muscovita e ilmenita.

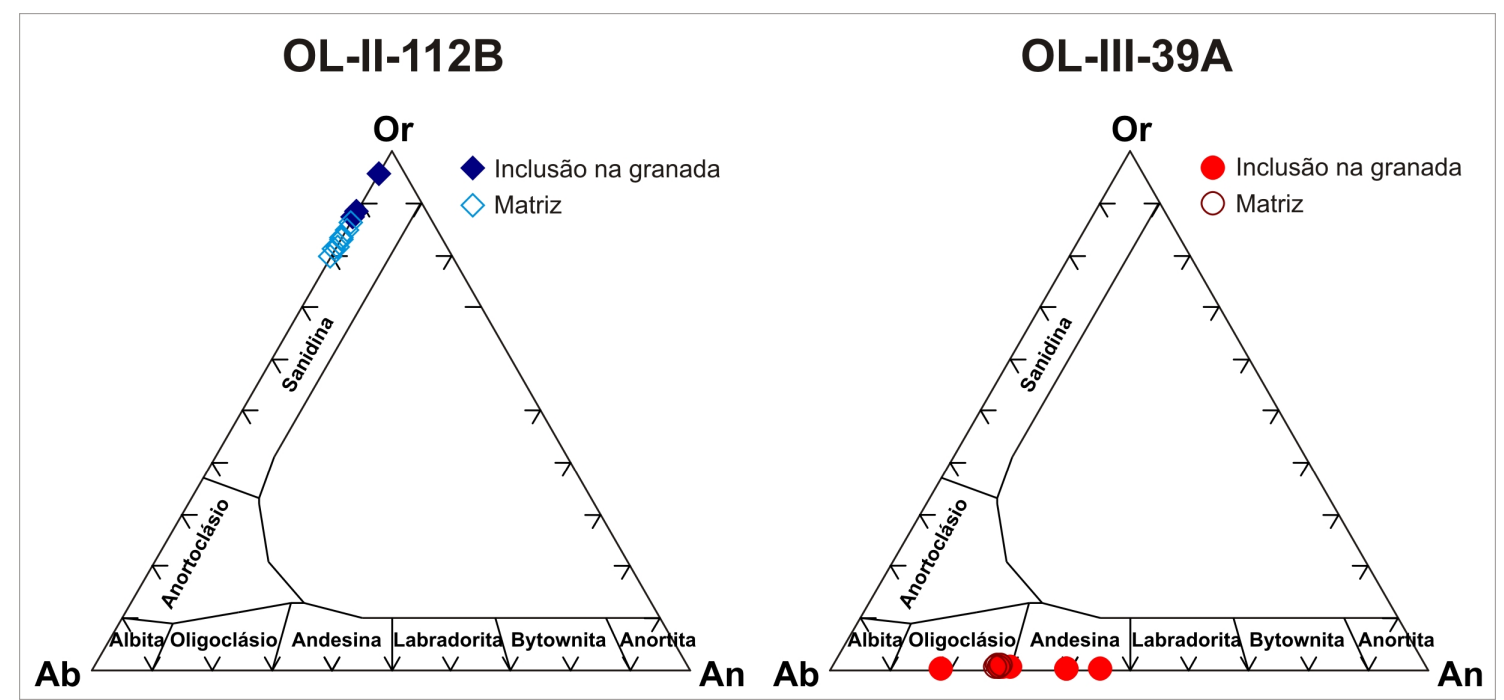

Figura 42: Diagrama para classificação de feldspatos no sistema CaO- $\mathrm{Na}_{2} \mathrm{O}-\mathrm{K}_{2} \mathrm{O}$ (An-Ab-Or) (MINPET 2.02 - Richard, 1995).

A maioria dos cristais de plagioclásio da matriz são composicionalmente homogêneos, freqüentemente representados por um oligoclásio cálcico $\left(\mathrm{An}_{27-28} \mathrm{Ab}_{71 \text { - }}\right.$ ${ }_{72} \mathrm{Or}_{0.8-1.0}$ ). Ocorrem em associação com biotita, sillimanita, quartzo e ilmenita na matriz 
e com biotita, ilmenita e quartzo no interior da granada. Os cristais inclusos na granada apresentam maior variação no teor de anortita, sendo mais cálcico nas bordas e mais sódico no núcleo $\left(\mathrm{An}_{18-45} \mathrm{Ab}_{55-81} \mathrm{Or}_{0.3-0.8}\right)$, variando de $\mathrm{An}_{26-30}$ no oligoclásio e $\mathrm{An}_{39-45}$ na andesina (ex.: OL-III-39A).

Apresentam as seguintes proporções entre os membros-finais:

- Matriz: $\mathrm{An}_{27-28} \mathrm{Ab}_{71-72} \mathrm{Or}_{0,8-1,0}$

- Inclusão: $\mathrm{An}_{18-45} \mathrm{Ab}_{54-81} \mathrm{Or}_{0,3-0,8}$

\subsubsection{Biotita}

A biotita apresenta coloração castanho-avermelhada e forte pleocroísmo. Foram analisados grãos de biotita da matriz e grãos inclusos na granada, que são em geral mais ricos no membro-final flogopita do que a biotita da matriz, apresentando razões $\left[\mathrm{Mg} * 100 /\left(\mathrm{Mg}+\mathrm{Fe}^{2+}\right)\right]$ mais elevadas $(\# \mathrm{Mg}=39-42)$ do que os grãos da matriz $(\# \mathrm{Mg}=$ 31-35) (amostra OL-II-112B).

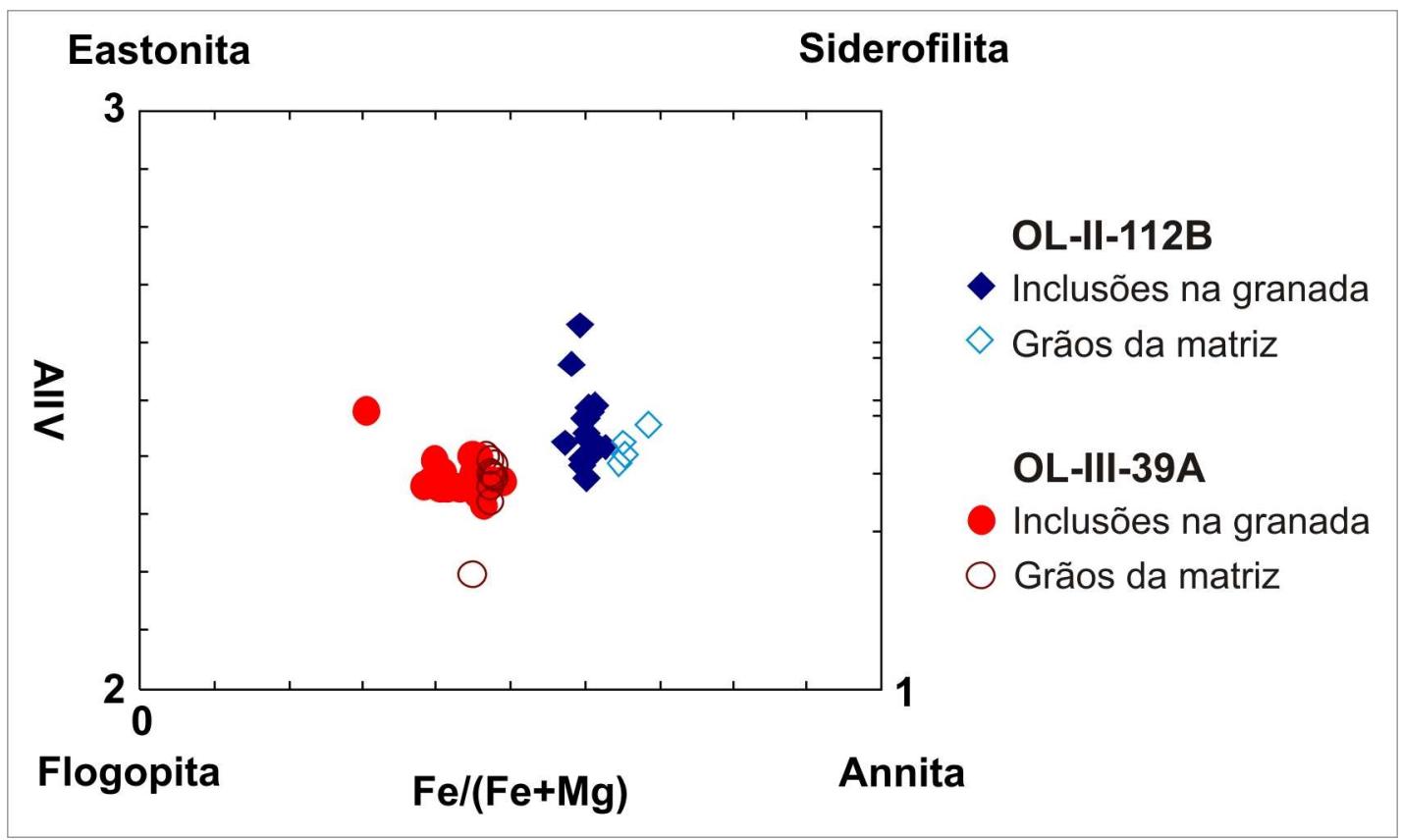

Figura 43: Diagrama para classificação de biotita (MINPET 2.02 - Richard, 1995).

A variação composicional entre os grãos da matriz e as inclusões provavelmente representa um re-equilíbrio difusional entre a granada e a biotita durante o resfriamento, onde o equilíbrio é demonstrado pelo inverso da seguinte reação de troca: Prp + Ann $\leftrightarrow$ Alm + Phl. Esta variação composicional também é evidenciada através da composição falsa-cor CaR MgG FeB (Figura 39), em que as inclusões de biotita no interior do 
porfiroblasto de granada apresentam uma coloração de verde mais intensa do que os grãos da matriz, indicando maior conteúdo de magnésio nas inclusões. Os grãos de biotita da amostra OL-II-39A apresentam teor de magnésio mais elevado e também apresentam razões $\left[\mathrm{Mg}^{*} 100 /\left(\mathrm{Mg}+\mathrm{Fe}^{2+}\right)\right]$ ligeiramente mais elevadas nos grãos inclusos em granada (\#Mg = 60-62) do que nos grãos da matriz (\#Mg = 51-59) (Figura 43).

Nas duas amostras analisadas ocorre biotita idioblástica de granulação grossa que substitui a granada ao longo de fraturas e que possui a mesma composição da biotita da matriz ou da zona de sombra de pressão na granada (rica no membro-final annita), contrastando com a composição da biotita inclusa. Inclusões de biotita de granulação fina são relativamente pobres em Ti (aproximadamente 0.118-0.152 p.f.u.), enquanto que a biotita de granulação grossa em áreas fraturadas internas dos porfiroblastos de granada possui conteúdos mais elevados de Ti (0.157-0.189 p.f.u.), semelhante ao teor de Ti nos cristais de biotita do domínio da zona de sombra de pressão (0.152-0.169 p.f.u.) (Figuras 38 e 39). O maior conteúdo em titânio possivelmente reflete composições químicas de temperaturas mais elevadas preservadas nestes grãos.

\subsubsection{Rutilo}

As análises de rutilo foram realizadas somente em grãos inclusos em granada, onde ocorre em maior abundância. O principal objetivo destas análises foi identificar os teores de $\mathrm{Zr}$, para a aplicação do geotermômetro de $\mathrm{Zr}$ em rutilo. Na amostra OL-II112B é possível identificar duas modas de teores de $\mathrm{Zr}$ nos cristais de rutilo analisados. Os cristais de rutilo com teores de $\mathrm{Zr}$ menores (230-489 ppm $\mathrm{Zr}$ ) geralmente ocorrem nas bordas do porfiroblasto ou associados à zonas de fraturamento internas da granada. Já os cristais de rutilo, cujos valores de ppm de Zr são maiores (710-910 ppm Zr), apresentam hábito acicular e ocorrem no núcleo da granada, onde a difusão química é menor.

Na amostra OL-III-39A não ocorre um contraste bem marcado no conteúdo de $\mathrm{Zr}$ entre os diferentes cristais de rutilo analisados. Os grãos de rutilo com teores menores de $\mathrm{Zr}$ (289 - 377 ppm Zr) ocorrem nas bordas da granada e associados com fraturas, o que facilita a difusão (Figura 44). O teor mais elevado (466 ppm Zr) ocorre no núcleo de um porfiroblasto de granada, isento de fraturas. 
OL-III-39A
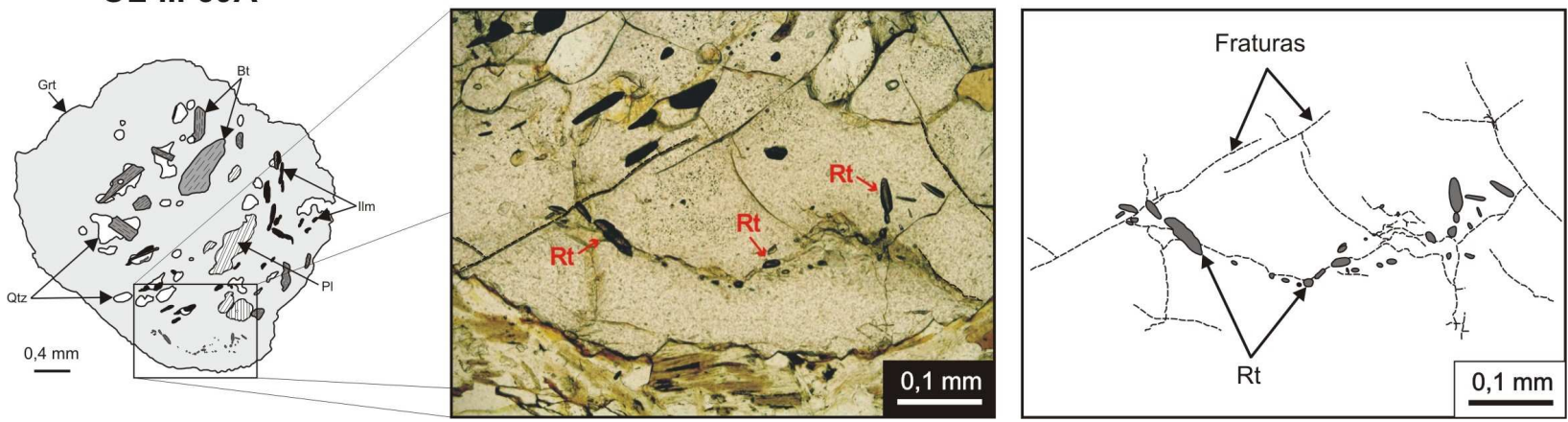

Figura 44: Inclusões de rutilo ao longo de fraturas em porfiroblasto de granada. Amostra OL-III-39A.

\subsubsection{Rochas metabásicas}

\subsubsection{Descrição sucinta das amostras}

- NLD-7D

A rocha é mesocrática e pouco foliada, com textura granoblástica inequigranular fina a média. É caracterizada pela presença de cristais bem formados de clinopiroxênio e ortopiroxênio, substituídos por hornblenda pelas bordas. A hornblenda (15-20\%) freqüentemente apresenta inclusões de opacos. O ortopiroxênio (10-20\%) ocorre em contatos retos com o clinopiroxênio (10-30\%), que freqüentemente apresenta inclusões de quartzo e plagioclásio. A granada (1-5\%) é predominantemente idioblástica e de granulação fina, freqüentemente manteando os opacos (<7\%) e o plagioclásio (25-35\%). Localmente ocorre granada poiquiloblástica englobando cristais de hornblenda, plagioclásio, apatita e opacos. O plagioclásio predominante é a andesina $\left(\mathrm{An}_{30-50}\right)$, mas também ocorre labradorita $\left(\mathrm{An}_{50-60}\right)$. O quartzo $(<5 \%)$ ocorre intersticial na matriz ou intercrescido com hornblenda. Os principais minerais acessórios são: apatita $(<3 \%)$, actinolita $(<1 \%)$ e biotita $(<1 \%)$.

\section{- NLD-20A}

Rocha mesocrática com estrutura maciça e textura granoblástica inequigranular fina a muito fina, cuja característica principal é o arranjo denso de cristais prismáticos de plagioclásio orientados em todas as direções (textura blasto-ofítica), em uma matriz constituída predominantentemente por hornblenda com textura simplectítica de $\mathrm{Hbl}+\mathrm{Pl}$ + Qtz que substitui os piroxênios. O plagioclásio (15-30\%) preserva aspecto ripiforme da cristalização ígnea, embora esteja recristalizado e poligonizado em grãos finos. $\mathrm{O}$ plagioclásio predominante é a labradorita $\left(\mathrm{An}_{60-70}\right)$. A hornblenda (50-60\%) 
freqüentemente apresenta inclusões xenomórficas de opacos e granada, além de titanita, plagioclásio e quartzo. Os cristais de clinopiroxênio (5-15\%) e ortopiroxênio $(<10 \%)$ são reliquiares e estão bastante fraturados. Alguns grãos apresentam geminação preservada. A granada $(<5 \%)$ é subidioblástica a xenoblástica, freqüentemente manteando parcialmente os opacos ou o plagioclásio. O quartzo (5-10\%) ocorre principalmente intercrescido com hornblenda ou poligonizado na matriz com plagioclásio. Os prinipais minerais acessórios são: opacos $(<5 \%)$, apatita $(<3 \%)$ e titanita $(<1 \%)$.

\subsubsection{Granada}

Os cristais de granada nos granulitos máficos são caracterizados por grãos idioblásticos, com composição aproximadamente homogênea, e perfis composicionais relativamente planos.

Apresentam as seguintes proporções entre os membros-finais:

- Amostra NLD-7D: (Alm59-62 $\left.\operatorname{Prp}_{13-15} \mathrm{Grs}_{19-20} \mathrm{Sps}_{4-6}\right)$

- Amostra NLD-20A: (Alm53-64 $\operatorname{Prp}_{8-15}$ Grs $\left._{16-30,6} \operatorname{Sps}_{4-7}\right)$

As variações composicionais estão associadas com a paragênese, pois ocorrem ligeiras variações entre cristais de granada adjacentes a plagioclásio, piroxênio ou anfibólio. Os conteúdos de almandina e espessartita são ligeiramente mais elevados nas bordas dos grãos de granada quando adjacentes a hornblenda + plagioclásio do que no contato com piroxênio + plagioclásio e/ou coronas (ex.: NLD-7D, NLD-20A). Quando a granada está em paragênese com a hornblenda, ocorre uma ligeira diminuição no conteúdo de piropo e grossulária, do núcleo em direção às bordas, acompanhado de um pequeno aumento no teor de almandina e espessartita. A maior quantidade de Fe nas bordas da granada também pode estar associada ao resfriamento. Nas texturas do tipo moat, em que a granada ocorre manteando o plagioclásio, há um ligeiro aumento no conteúdo de grossulária e diminuem os teores de almandina e piropo.

\subsubsection{Plagioclásio}

O plagioclásio da amostra NLD-7D $\left(\mathrm{An}_{42-47} \mathrm{Ab}_{52-57} \mathrm{Or}_{1-1,3}\right)$ ocorre na forma de cristais anédricos levemente deformados, com geminações curvadas. São composicionalmente homogêneos, representados por uma andesina cálcica.

$\mathrm{Na}$ amostra NLD-20A, o plagioclásio $\left(\mathrm{An}_{44-65} \mathrm{Ab}_{34-55} \mathrm{Or}_{0,2-0,1}\right)$ apresenta hábito tabular alongado, ripiforme, sugerindo fenocristais ígneos reliquiares (Figura 46). 
Foram realizadas duas seções químicas ao longo do mesmo cristal, que indicam uma variação composicional contínua do núcleo (labradorita cálcica) em direção às bordas (andesina) (Figuras 45 e 46). O plagioclásio freqüentemente está manteado por hornblenda ou granada e, nestes contatos, o teor de anortita é menos expressivo (andesina), correlacionado com um incremento em cálcio na granada e no anfibólio. $\mathrm{O}$ maior conteúdo em anortita em cristais ripiformes também poderia estar relacionado a temperaturas de cristalização mais elevadas.

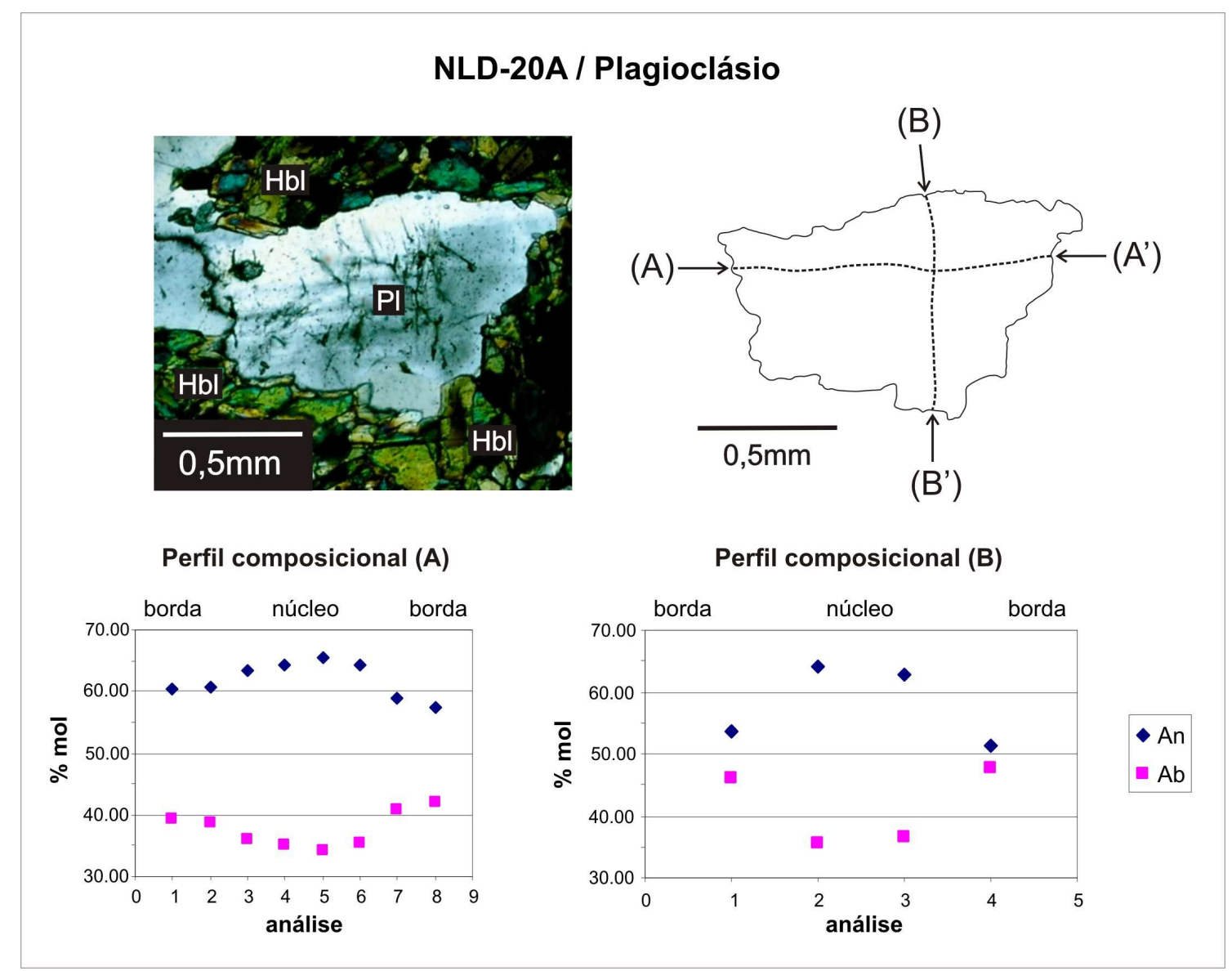

Figura 45: Seção química de plagioclásio, em perfil longitudinal (seção A-A') e transversal (seção B-B'). Polarizadores cruzados. Amostra NLD-20A.

\subsubsection{Ortopiroxênio}

O ortopiroxênio da amostra NLD-7D é subeuédrico, de granulação fina a média, com pleocroísmo forte, variando de verde claro a bege rosado. Localmente está substituído por intercrescimentos de hornblenda + quartzo no contato com a granada. Possui composição química homogênea, com um aumento pouco expressivo no conteúdo de ferrossilita no núcleo, acompanhado de uma diminuição em enstatita nas 
bordas. O teor de Al varia de 0.034 a 0.162 Al p.f.u. Está situado no limite composicional enstatita/ferrossilita, de acordo com a classificação de Morimoto (1988) (Figura 47). Apresenta as seguintes proporções entre os membros finais: $\mathrm{Wo}_{0,6-2,3}$ $\mathrm{En}_{47,1-50,1} \mathrm{Fs}_{48,9-51,5}$.

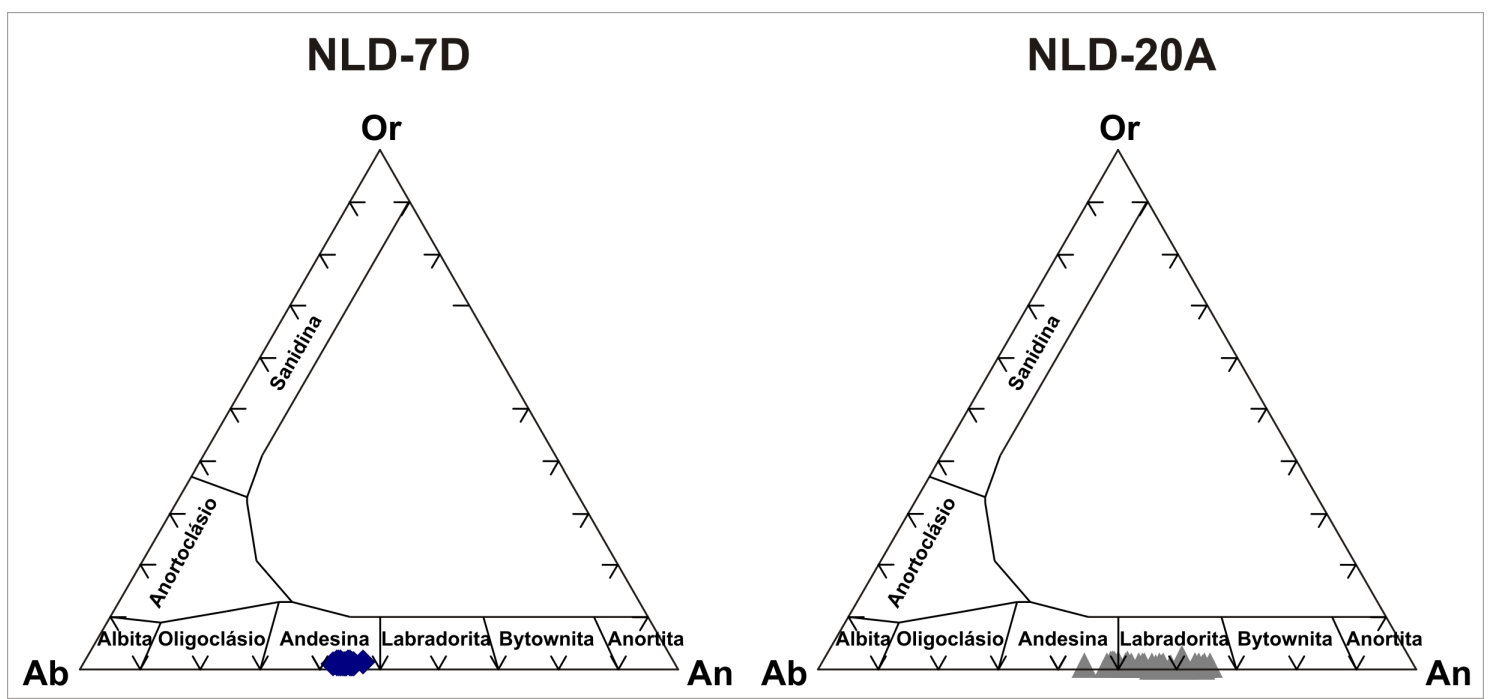

Figura 46: Diagrama para classificação de feldspatos no sistema CaO- $\mathrm{Na}_{2} \mathrm{O}-\mathrm{K}_{2} \mathrm{O}$ (An-Ab-Or) (MINPET 2.02 - Richard, 1995).

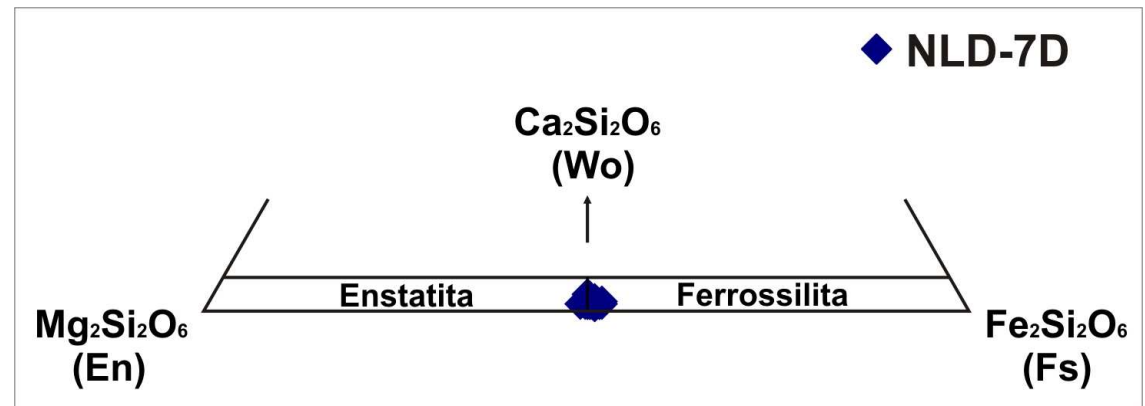

Figura 47: Diagrama para classificação de ortopiroxênios no sistema $\mathrm{Mg}_{2} \mathrm{Si}_{2} \mathrm{O} 6-\mathrm{Fe}_{2} \mathrm{Si}_{2} \mathrm{O}_{6}-\mathrm{CaFeSi}_{2} \mathrm{O}_{6}(\mathrm{En}-$ Fs-Wo).

\subsubsection{Clinopiroxênio}

Nos granulitos máficos, o clinopiroxênio é subeuédrico, com pleocroísmo médio variando de verde-amarelado a verde-azulado claro, freqüentemente com inclusões de quartzo e plagioclásio, e localmente com inclusões de granada. No metagabro simplectítico, os cristais de clinopiroxênio são anédricos, bastante fraturados e substituídos por hornblenda. O clinopiroxênio é classificado como diopsídio e augita, de acordo com a classificação proposta por Morimoto (1988) (Figura 48). 
$\mathrm{Na}$ amostra NLD-20A, os cristais de augita são mais abundantes e com composição variável $(\mathrm{Mg \#}=53-70)$. O clinopiroxênio presente na amostra NLD-7D exibe menor variação na razão $[\mathrm{Mg} * 100 /(\mathrm{Mg}+\mathrm{Fe})](\mathrm{Mg} \#=60-66)$, com valores semelhantes aos encontrados na maioria dos granulitos máficos. Os teores de Al variam de 0.04-0.108 Al p.f.u. na amostra NLD-7D, e 0.037-0.457 Al p.f.u. na amostra NLD$20 \mathrm{~A}$.

Apresentam as seguintes proporções entre os membros-finais:

- NLD-7D: $\mathrm{Wo}_{42,8-47,3} \mathrm{En}_{34,2-36,7} \mathrm{Fs}_{17,7-21,5}$

- NLD-20A: $\mathrm{Wo}_{41,1-48,6} \mathrm{En}_{35,8-38,5} \mathrm{Fs}_{15,4-21,5}$

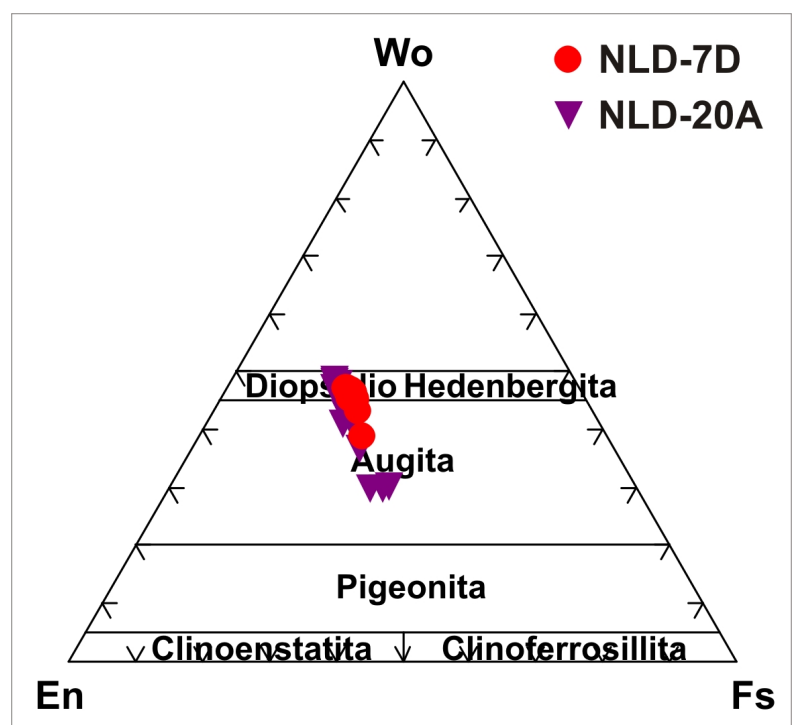

Figura 48: Diagrama para classificação de clinopiroxênios no sistema $\mathrm{Mg}_{2} \mathrm{Si}_{2} \mathrm{O} 6-\mathrm{Fe}_{2} \mathrm{Si}_{2} \mathrm{O}_{6}-\mathrm{CaFeSi}_{2} \mathrm{O}_{6}$ (En-Fs-Wo).

\subsubsection{Anfibólio}

Os anfibólios das rochas metabásicas são classificados em anfibólios cálcicos. Os cristais de hornblenda são subeuédricos a anédricos, com pleocroísmo médio variando de verde-pálido a verde escuro. Ocorre substituindo os piroxênios pelas bordas e também na forma de intercrescimentos simplectíticos com quartzo e freqüentemente apresenta inclusões xenomórficas de opacos e granada, além de plagioclásio, clinopiroxênio, titanita e quartzo.

Nos metagabros simplectíticos o anfibólio predominante é a magnésiohornblenda, enquanto que nos granulitos máficos há o predomínio de hornblendatschermakítica, com poucas ocorrências de magnésio-hornblenda (nomenclatura de Leake et al., 1997; Hawthorne \& Oberti, 2007) (Figura 49). O teor de alumínio nos 
anfibólios varia de 1.6-2.3 Al p.f.u., com um relativo aumento nos contatos com a granada. A razão [Mg*100/(Mg+Fe)] varia de 49-61 e diminui em direção ao contato com a granada, assim como o teor de $\mathrm{Ca}$. $\mathrm{O}$ teor de $\mathrm{Fe}$ e Ti é mais expressivo nas proximidades com ilmenita, enquanto que nos contatos com o clinopiroxênio ocorre um pequeno aumento nos teores de $\mathrm{Ca}, \mathrm{Mg}$ e $\mathrm{Mn}$.

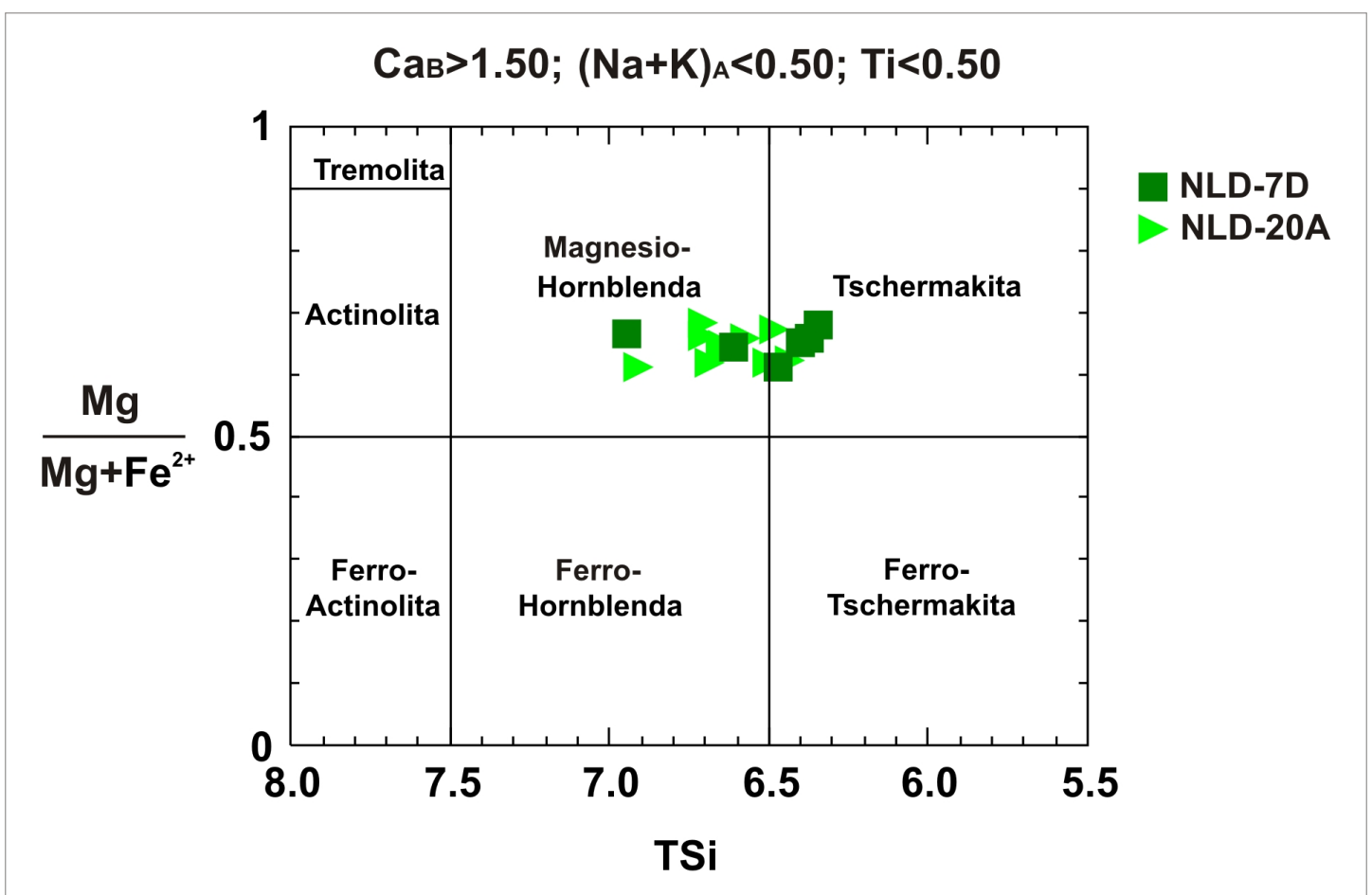

Figura 49: Diagrama de classificação para o grupo de anfibólios cálcicos com $\mathrm{Ca}_{\mathrm{B}}>=1.50 ;(\mathrm{Na}+\mathrm{K})_{\mathrm{A}}<=0.5$; Ti<0.5 (Leake et al., 1997; Hawthorne \& Oberti, 2007).

\subsubsection{Metagabronoritos}

\subsubsection{Descrição sucinta das amostras}

\section{- NLD-42C}

A rocha apresenta estrutura maciça e textura predominantemente granoblástica, inequigranular fina a média $(0.1-1.5 \mathrm{~mm})$, com desenvolvimento de texturas coroníticas, principalmente com anéis de granada no contato entre plagioclásio e opacos. $\mathrm{O}$ clinopiroxênio (25-30\%) ocorre fraturado, localmente com inclusões de quartzo ou com granulação fina, compondo coronas com a granada. O ortopiroxênio (15-20\%) está freqüentemente associado com o quartzo quando manteado por clinopiroxênio e granada. Há gerações distintas de granada (10-15\%): uma anédrica $\left(\mathrm{Grt}_{1}\right)$, na forma de finas coronas no contato entre os opacos e clinopiroxênio, ou entre opacos e $\mathrm{Grt}_{2}$; uma 
geração idioblástica a subidioblástica, rica em microexsoluções de opacos $\left(\mathrm{Grt}_{2}\right)$, no contato com opacos ou $\mathrm{Grt}_{1}$, seguida por uma geração idioblástica tardia, límpida e isenta de inclusões $\left(\mathrm{Grt}_{3}\right)$. O plagioclásio (40-45\%) dominante é a andesina $\left(\mathrm{An}_{30-45}\right)$, geralmente na forma de grãos poligonizados. A hornblenda (5-10\%) ocorre na borda de opacos ou substituindo os piroxênios. Os opacos (7-10\%) formam agregados, comumente manteados por granada idioblástica no contato com o plagioclásio. $\mathrm{O}$ quartzo $(<5 \%)$ é geralmente intersticial. Outros minerais acessórios são: apatita $(<2 \%)$ e zircão $(<2 \%)$.

\section{- NLD-42D}

A rocha apresenta estrutura maciça e textura dominantemente granoblástica, inequigranular fina a média $(0.1-2.0 \mathrm{~mm})$, caracterizada pela presença de coronas de Grt $\pm \mathrm{Cpx} \pm$ Qtz no contato entre ortopiroxênio e plagioclásio e/ou opacos. Nesta amostra ocorrem leitos de dimensão milimétrica a subcentimétrica, com concentração de granada (15-20\%) xenoblástica intercrescida com clinopiroxênio (20-25\%), e quartzo $(<5 \%)$, com terminações idioblásticas em direção ao contato com o plagioclásio (4045\%). Nestes leitos ocorrem veios de quartzo milimétricos contínuos, com calcita intersticial $(<2 \%)$ entre grãos de granada e clinopiroxênio. Esta textura sugere que a preservação da associação mineral anidra Grt $+\mathrm{Cpx}+\mathrm{Qtz} \pm \mathrm{Pl}$ foi facilitada com a infiltração de um fluido rico em $\mathrm{CO}_{2}$, evidenciado pela presença de calcita nos interstícios. O ortopiroxênio (10-15\%) ocorre na forma de grãos reliquiares corroídos, freqüentemente manteados por Grt, Qtz, Cpx e/ou Hbl. Outros minerais acessórios são: apatita $(<3 \%)$, zircão $(<1 \%)$, rutilo $(<1 \%)$ e biotita $(<1 \%)$.

\subsubsection{Granada}

Os cristais de granada são em geral idioblásticos a subidioblásticos, de granulação fina, ricos em inclusões de quartzo, comumente formando coronas ao redor de plagioclásio, clinopiroxênio no contato com opacos. Também ocorrem moats de granada com clinopiroxênio e quartzo associado, ao redor de grãos de ortopiroxênio no contato com o plagioclásio (NLD-42C).

Apresenta as seguintes proporções entre os membros-finais:

- Amostra NLD-42C: (Alm $\left.61,2-64,9 \operatorname{Prp}_{11,5-13} \operatorname{Grs}_{19,8-22} \operatorname{Sps}_{3,5-5,2}\right)$

- Amostra NLD-42D: (Alm $60,5-65,8 \operatorname{Prp}_{11,4-15,1}$ Grs $\left._{19,2-24,4} \operatorname{Sps}_{2,1-4,3}\right)$ 


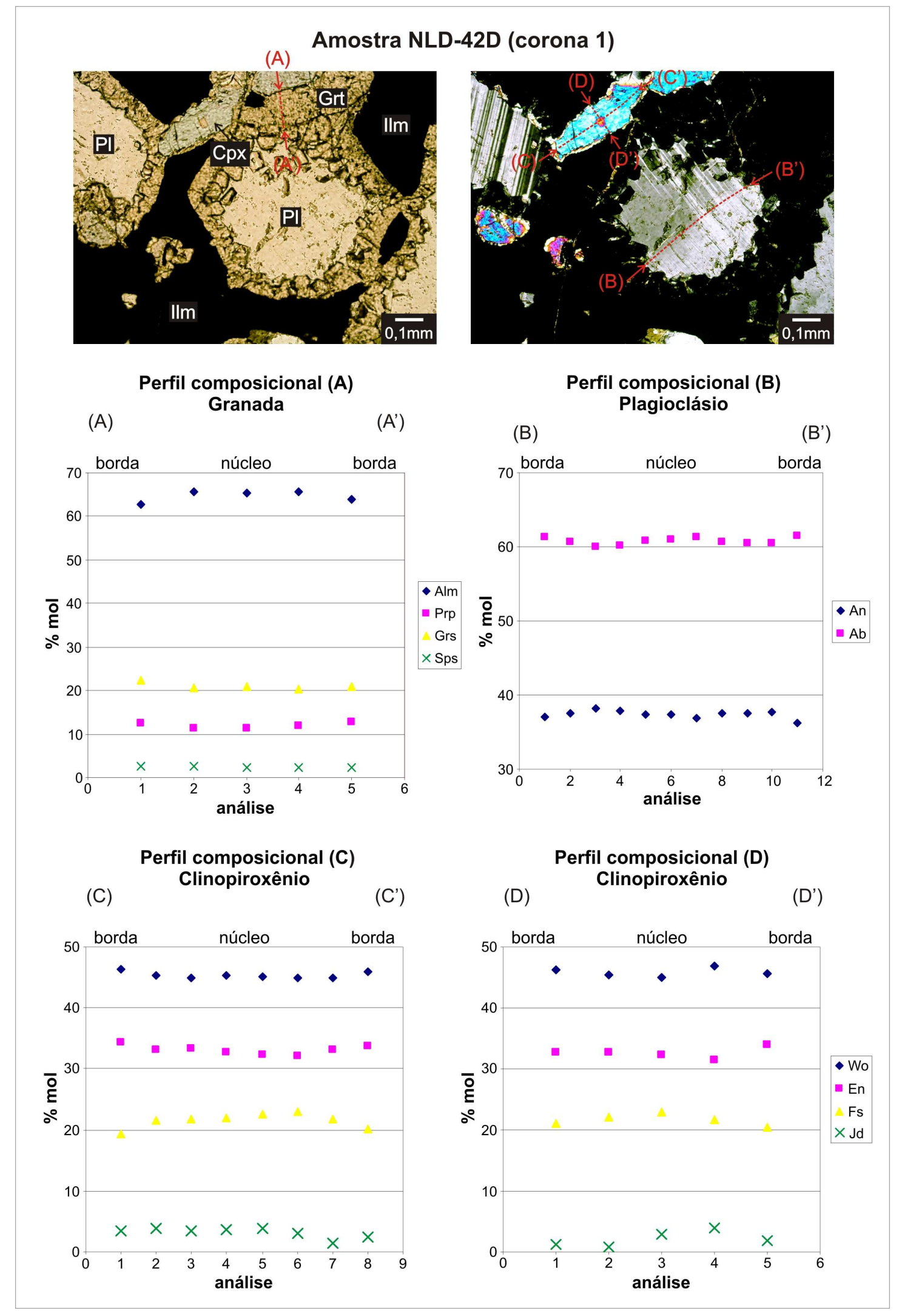

Figura 50: Seções químicas em cristal de granada (seção A-A'), plagioclásio (seção B-B') e clinopiroxênio (seção C-C'). Notar corona composta por granada + clinopiroxênio + opacos no contato com o plagioclásio. (A) Polarizadores paralelos, (B) polarizadores cruzados. Amostra NLD-42D. 
A granada também ocorre xenoblástica, com terminações idioblásticas límpidas e isentas de inclusões, em direção ao contato com o plagioclásio. A composição química é aproximadamente homogênea, exibindo perfis composicionais relativamente planos. Geralmente ocorre um ligeiro incremento nos conteúdos de grossulária e piropo, do núcleo em direção às bordas, acompanhado por uma diminuição nos conteúdos de almandina (Figura 50).

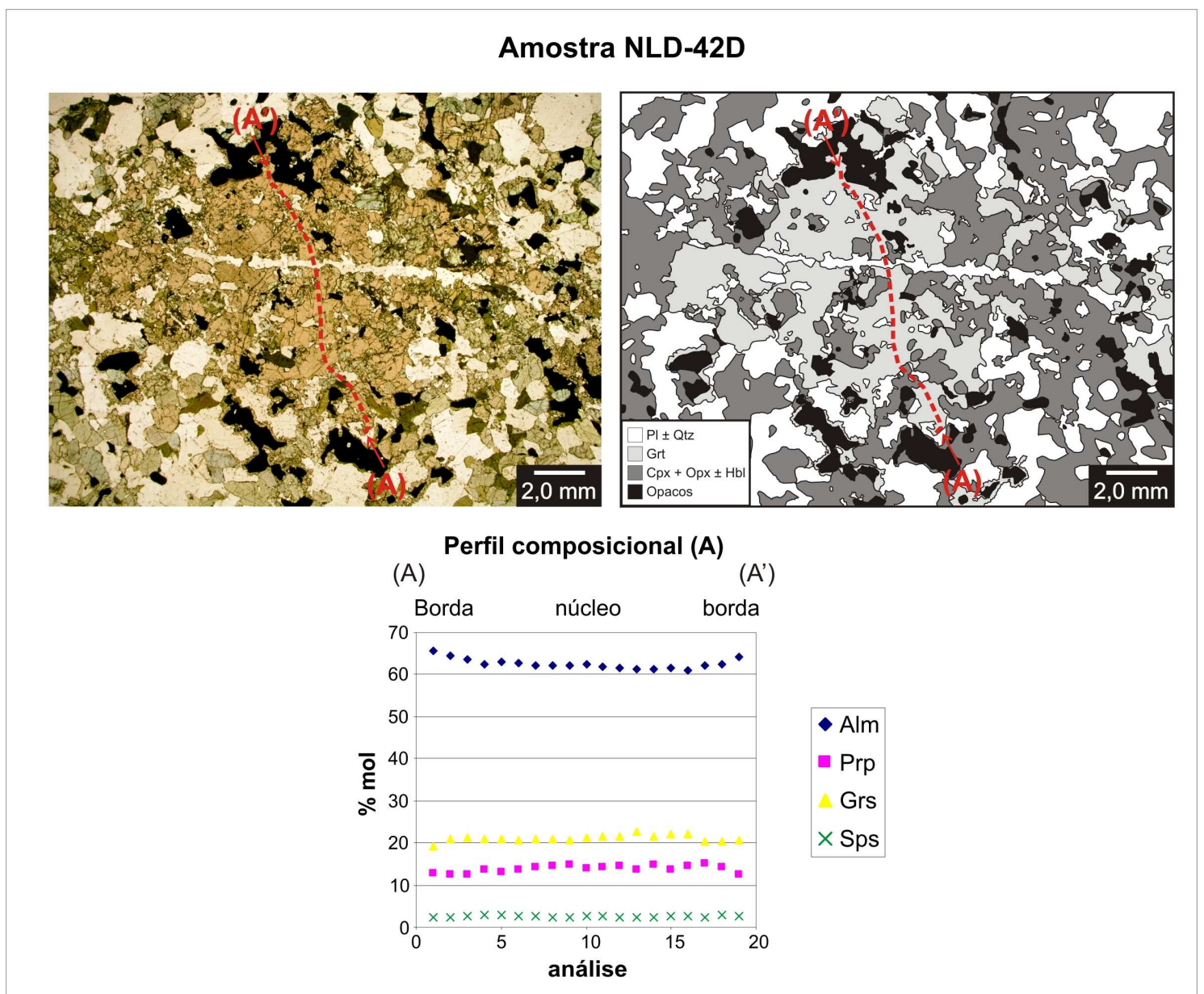

Figura 51: Seção química (A-A') de granada, ao longo de em veio composto por granada + clinopiroxênio + opacos \pm quartzo \pm plagioclásio. Amostra NLD-42D.

$\mathrm{Na}$ amostra NLD-42D, ocorre uma descontinuidade preenchida por granada + clinopiroxênio + quartzo \pm opacos \pm calcita, associada com percolação de $\mathrm{CO}_{2}$, o que possibilitou a preservação de paragêneses minerais anidras (Figura 51). Neste local, a granada apresenta um enriquecimento em Fe nas bordas, acompanhado por um ligeiro decréscimo em $\mathrm{Ca}$ e $\mathrm{Mg}$, possivelmente devido à difusão entre a granada com os opacos e clinopiroxênio (Figura 51). 


\subsubsection{Feldspato}

Os cristais de plagioclásio dos metagabronoritos são subeuédricos, de granulação fina a média. São classificados como andesina $\left(\mathrm{An}_{36-43}\right)$ (Figura 52). Estão freqüentemente manteados por moats de granada ou coronas mistas compostas por granada + clinopiroxênio + opacos \pm quartzo no contato com o ortopiroxênio. $\mathrm{O}$ plagioclásio apresenta um leve enriquecimento em albita do núcleo em direção às bordas (Figuras 52 e 53).

Apresentam as seguintes proporções entre os membros-finais:

$$
\begin{aligned}
& \text { - NLD-42C: } \mathrm{An}_{35-42,7} \mathrm{Ab}_{55,2-63,1} \mathrm{Or}_{1-2,2} \\
& \text { - NLD-42D: } \mathrm{An}_{35,9-39} \mathrm{Ab}{ }_{58,8-62,2} \mathrm{Or}_{1,4-2,3}
\end{aligned}
$$

O feldspato potássico $\left(\mathrm{An}_{0,2-0,7} \mathrm{Ab}_{3,5-3,8} \mathrm{Or}_{94,6-95,8}\right)$ ocorre com freqüência no interior das coronas, lobado a goticular associado com quartzo, no contato entre o plagioclásio coronítico e os moats de granada.

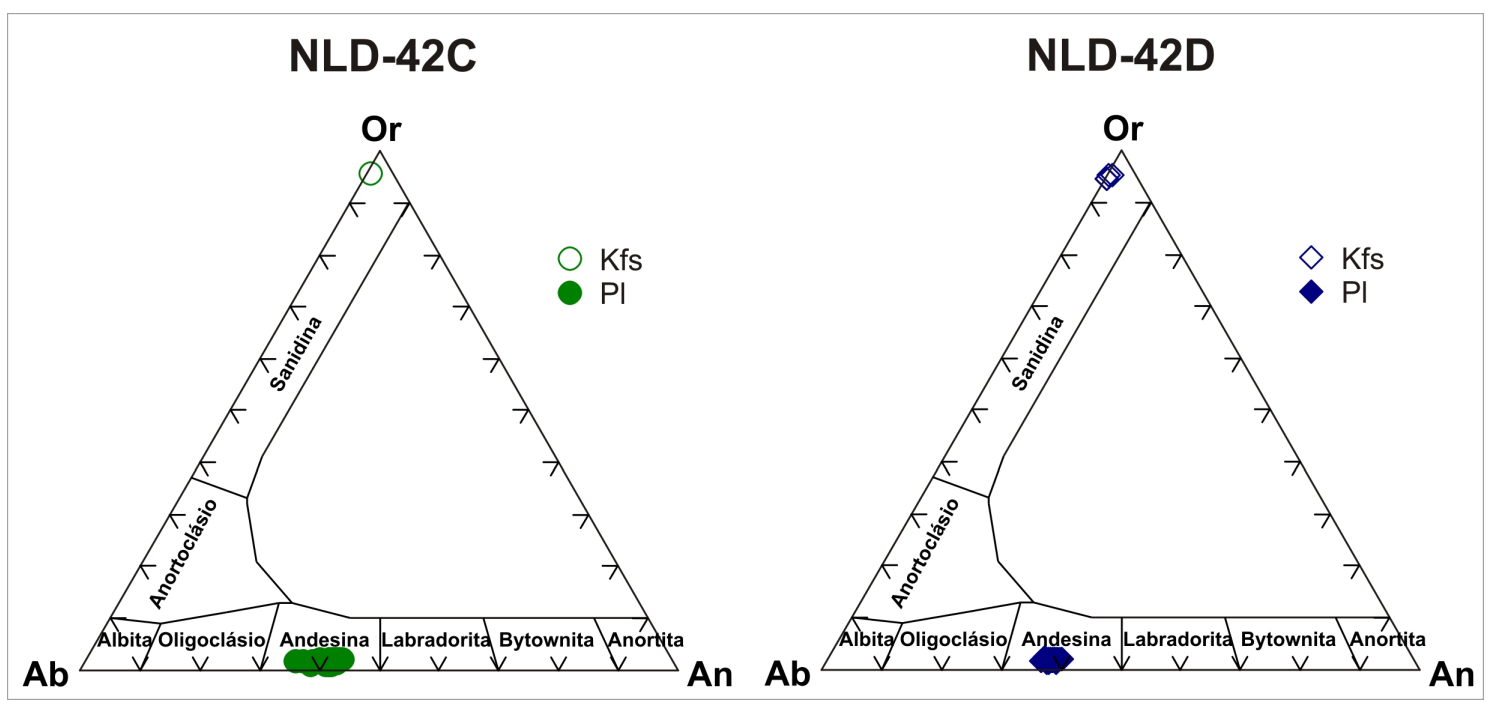

Figura 52: Diagrama para classificação de feldspatos no sistema $\mathrm{CaO}-\mathrm{Na}_{2} \mathrm{O}-\mathrm{K}_{2} \mathrm{O}$ (An-Ab-Or) (MINPET 2.02 - Richard, 1995).

\subsubsection{Ortopiroxênio}

Os cristais de ortopiroxênio das amostras NLD-42C e NLD-42D são anédricos a subeuédricos, com pleocroísmo médio variando de verde claro a bege rosado, freqüentemente manteados por clinopiroxênio, granada e quartzo no contato com o plagioclásio ou com substituição discreta por hornblenda nas bordas. Localmente ocorrem grãos de ortopiroxênio parcialmente substituídos por magnetita e quartzo. São classificados como ferrossilita, segundo a classificação de Morimoto (1988) (Figura 
55). Apresenta as seguintes proporções entre os membros finais: $\mathrm{Wo}_{0,8-1,4} \mathrm{En}_{43,8-47,4}$ $\mathrm{Fs}_{51,6-54,9 \text {. }}$

Apresentam composição química homogênea, com $\mathrm{Mg \#}=45-48$ e teor de $\mathrm{Al}$ variando de 0.027-0.048 p.f.u. Os cristais de ortopiroxênio coroníticos apresentam um ligeiro aumento nos conteúdos de enstatita nas bordas, acompanhado por uma diminuição nos teores de ferrossilita (Figuras 53, 56 e 57).

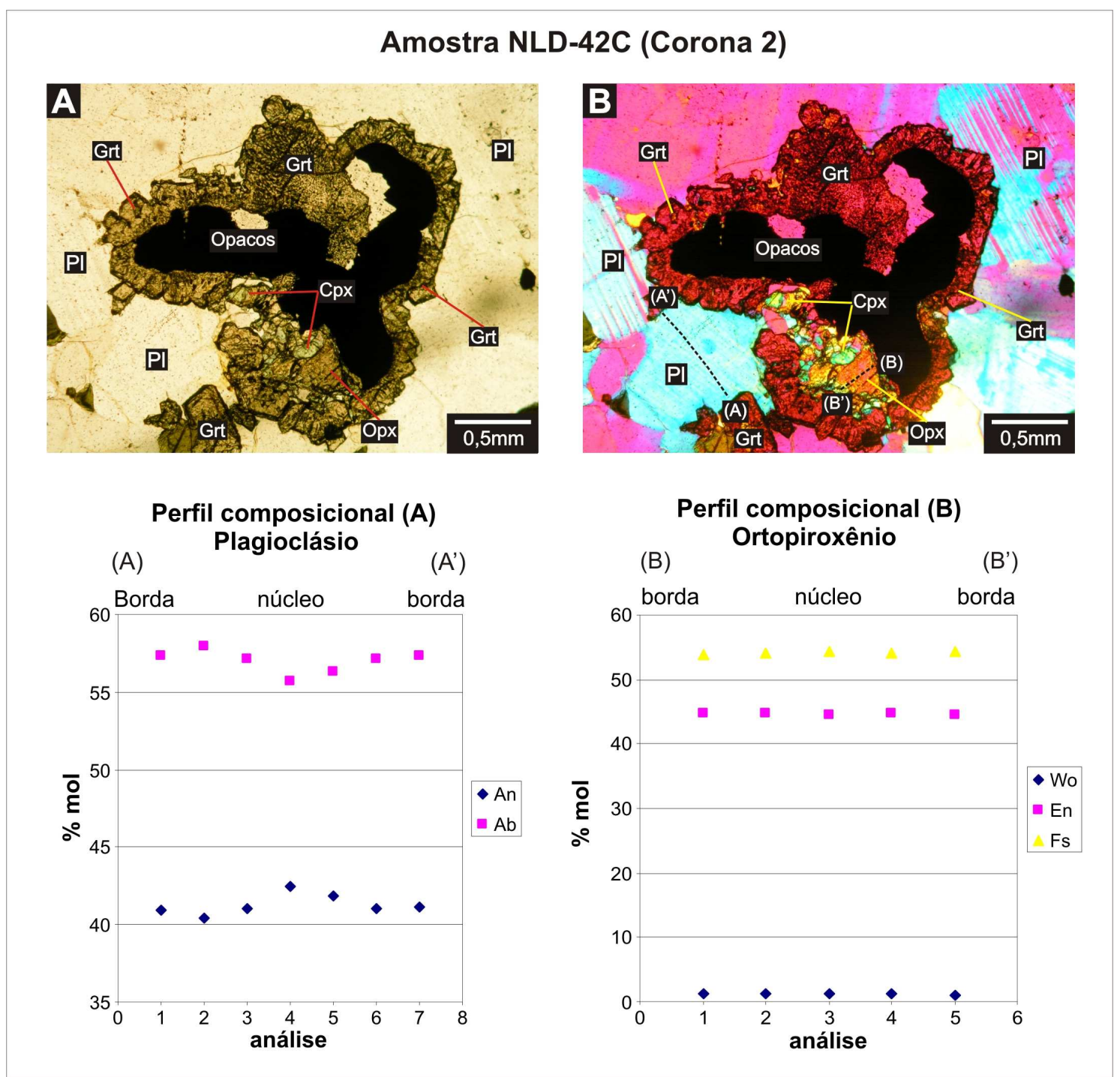

Figura 53: Perfil composicional em cristal de plagioclásio (seção A-A') e de ortopiroxênio coronítico (seção B-B'). Notar corona composta por clinopiroxênio + granada \pm quartzo no contato entre $o$ ortopiroxênio e o plagioclásio. (A) Polarizadores paralelos, (B) polarizadores cruzados, com cunha de quartzo (analisador). Amostra NLD-42C. 


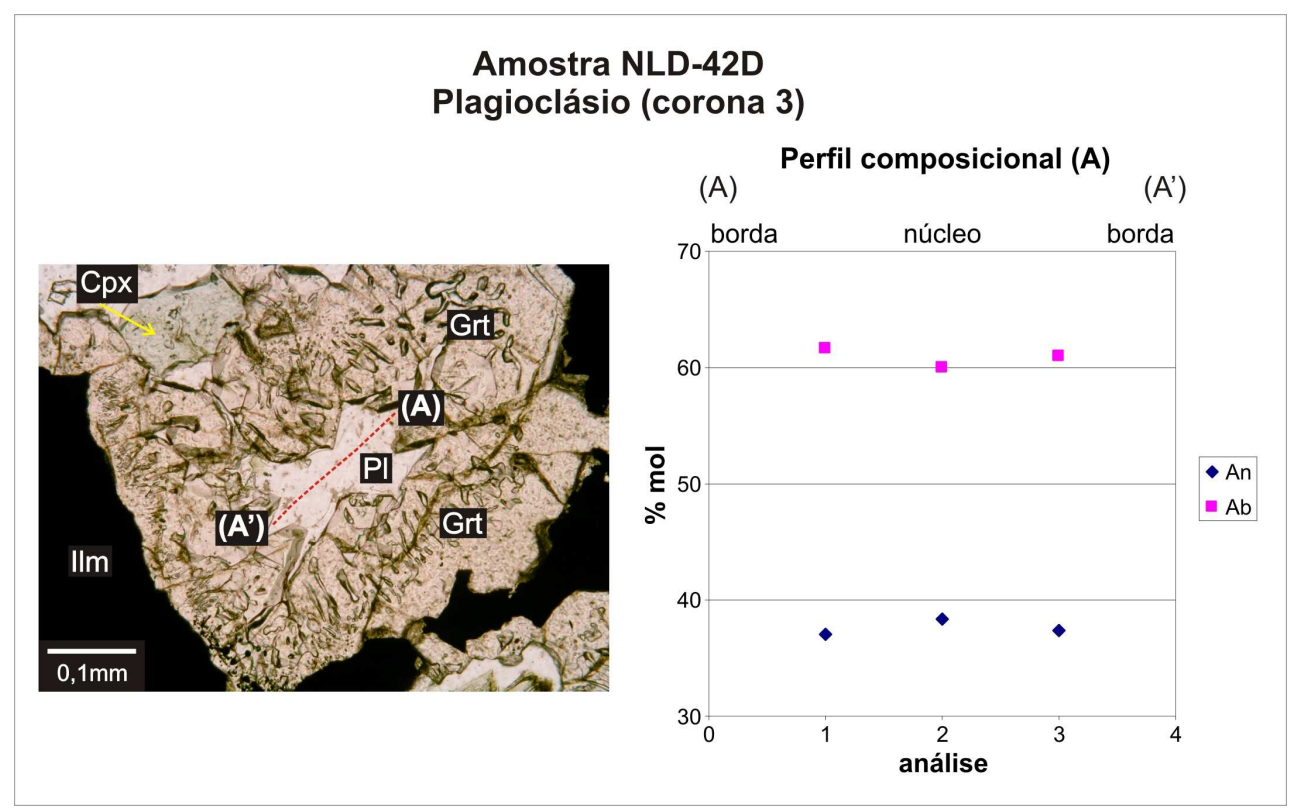

Figura 54: Perfil composicional em cristal de plagioclásio coronítico. Polarizadores paralelos. Amostra NLD-42D.

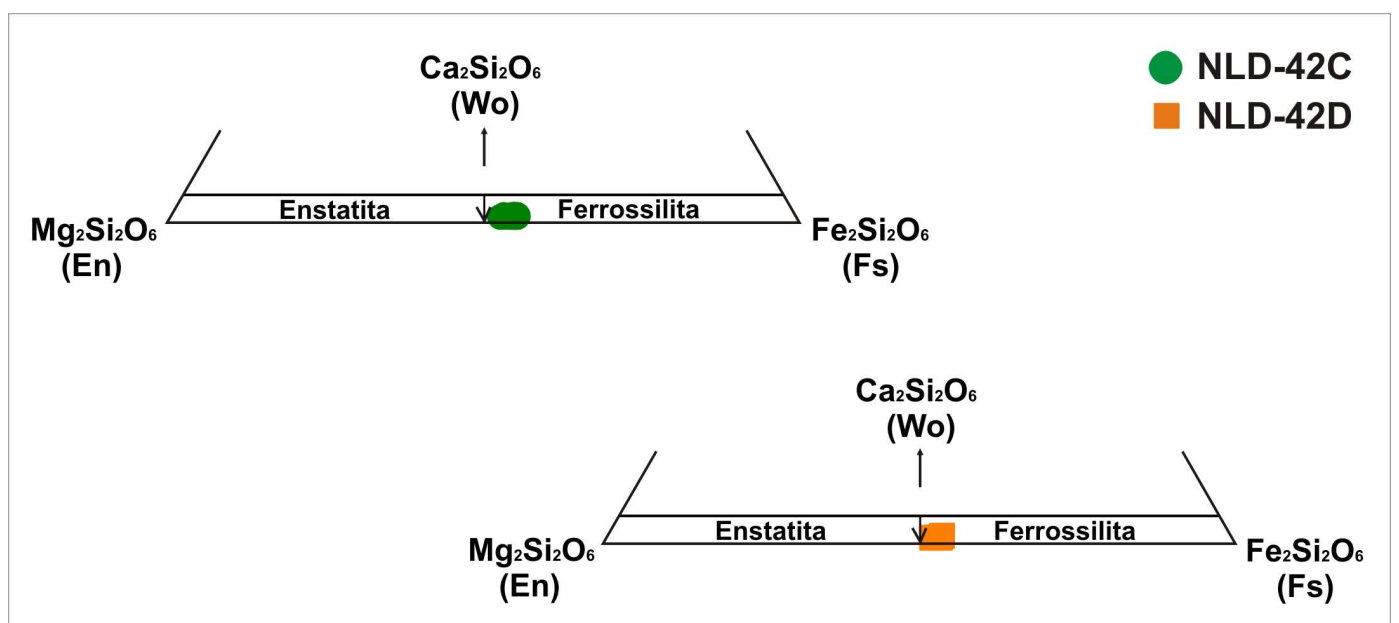

Figura 55: Diagrama para classificação de ortopiroxênios no sistema $\mathrm{Mg}_{2} \mathrm{Si}_{2} \mathrm{O} 6-\mathrm{Fe}_{2} \mathrm{Si}_{2} \mathrm{O}_{6}-\mathrm{CaFeSi}_{2} \mathrm{O}_{6}(\mathrm{En}$ Fs-Wo).

\subsubsection{Clinopiroxênio}

O clinopiroxênio é subeuédrico a anédrico, de granulação fina a média, com pleocroísmo fraco variando de incolor a verde claro. É classificado como diopsídio, segundo a classificação de Morimoto (1988) (Figura 58). Apresenta as seguintes proporções entre os membros finais: $\mathrm{Wo}_{42,5-46,8} \mathrm{En}_{31,2-34,3} \mathrm{Fs}_{19,3-25,2}$.

Os cristais de dimensão milimétrica comumente formam coronas com granada e quartzo, no contato entre ortopiroxênio e plagioclásio (Figuras 50, 53, 54, 56 e 57). 


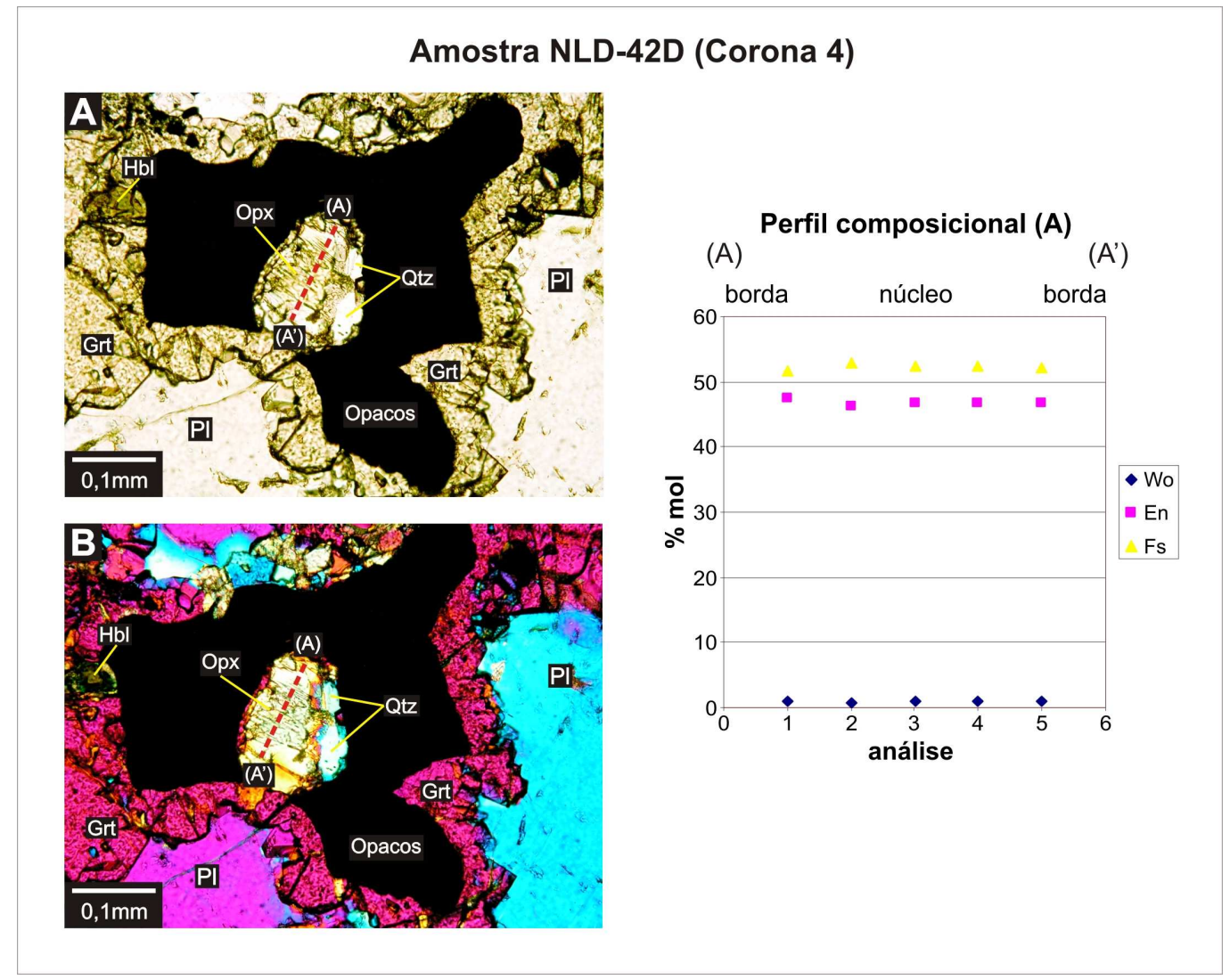

Figura 56: Seção química em cristal de ortopiroxênio coronítico. Notar corona composta por quartzo + granada ao redor do ortopiroxênio, seguido por corona de opacos e granada. (A) Polarizadores paralelos, (B) polarizadores cruzados, com cunha de quartzo (analisador). Amostra NLD-42D.

Cristais individuais de dimensão maior freqüentemente apresentam inclusões de plagioclásio, quartzo, granada e opacos e estão parcialmente substituídos por hornblenda pelas bordas. Na amostra NLD-42D os cristais são xenomórficos e estão intercrescidos com granada e em associação com plagioclásio e quartzo (Figura 51).

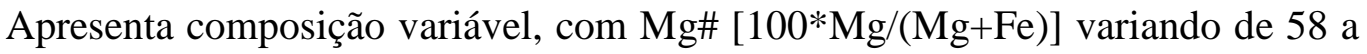
71. Os cristais de clinopiroxênio presentes na amostra NLD-42D possuem menor variação no $\mathrm{Mg \#} \mathrm{(58-65),} \mathrm{semelhante} \mathrm{à} \mathrm{maioria} \mathrm{dos} \mathrm{granulitos} \mathrm{máficos}(\mathrm{Mg \#}=60-65)$, de acordo com Baldwin et al., (2003). Os teores de Al variam de 0.059-0.081 Al p.f.u., com conteúdos ligeiramente mais elevados nos cristais coroníticos. Em geral, apresentam conteúdos maiores de ferrossilita e jadeíta no núcleo (Figuras 50 e 59). Localmente apresentam um ligeiro aumento no Mg\# nas bordas, possivelmente representando uma troca difusional com a granada durante o resfriamento. 


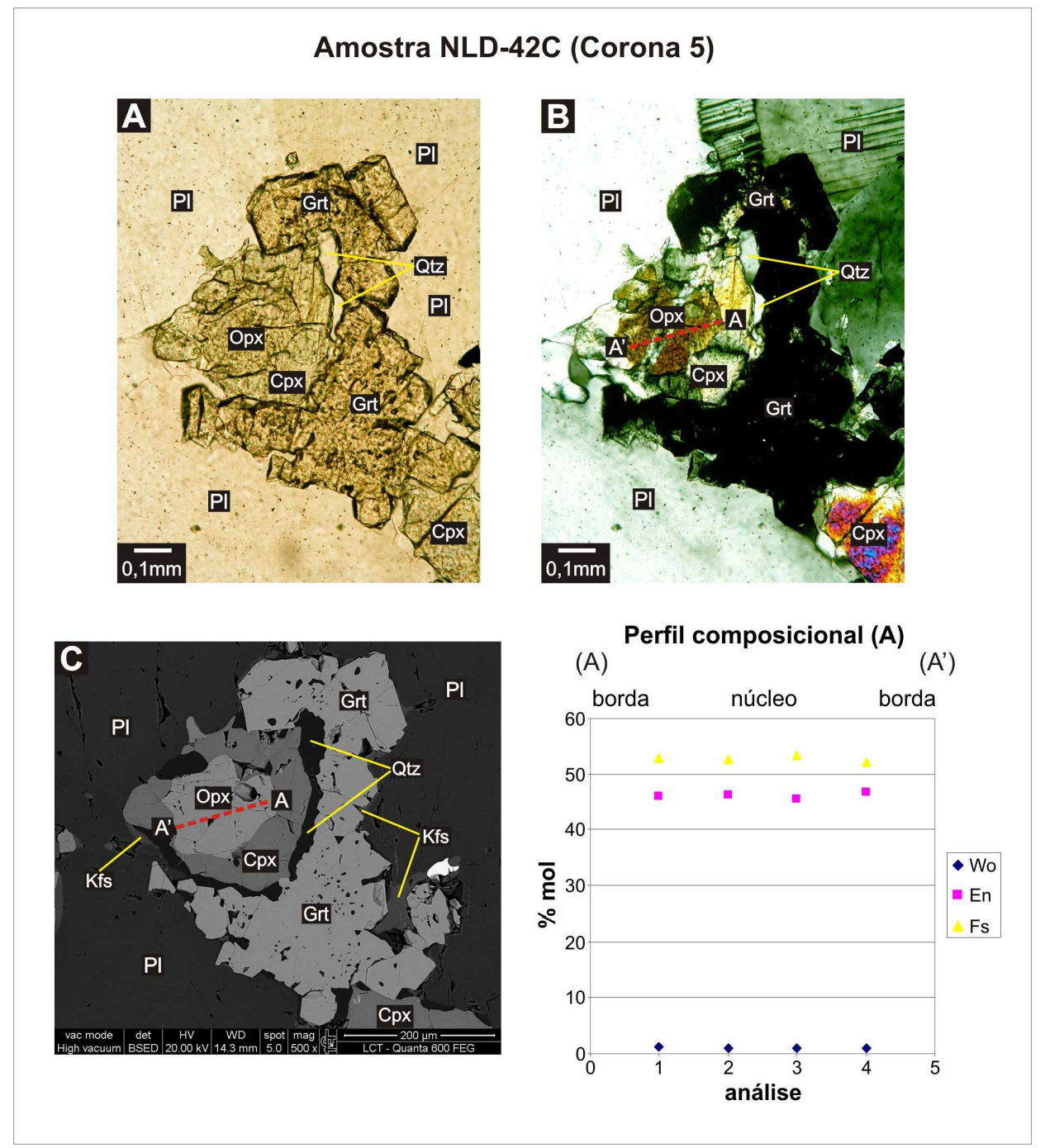

Figura 57: Seção química em cristal de ortopiroxênio manteado por clinopiroxênio, quartzo e granada no contato com o plagioclásio. (A) Polarizadores paralelos, (B) polarizadores cruzados, (C) Imagem retroespalhada obtida em microscópio eletrônico de varredura (MEV). Amostra NLD-42C.

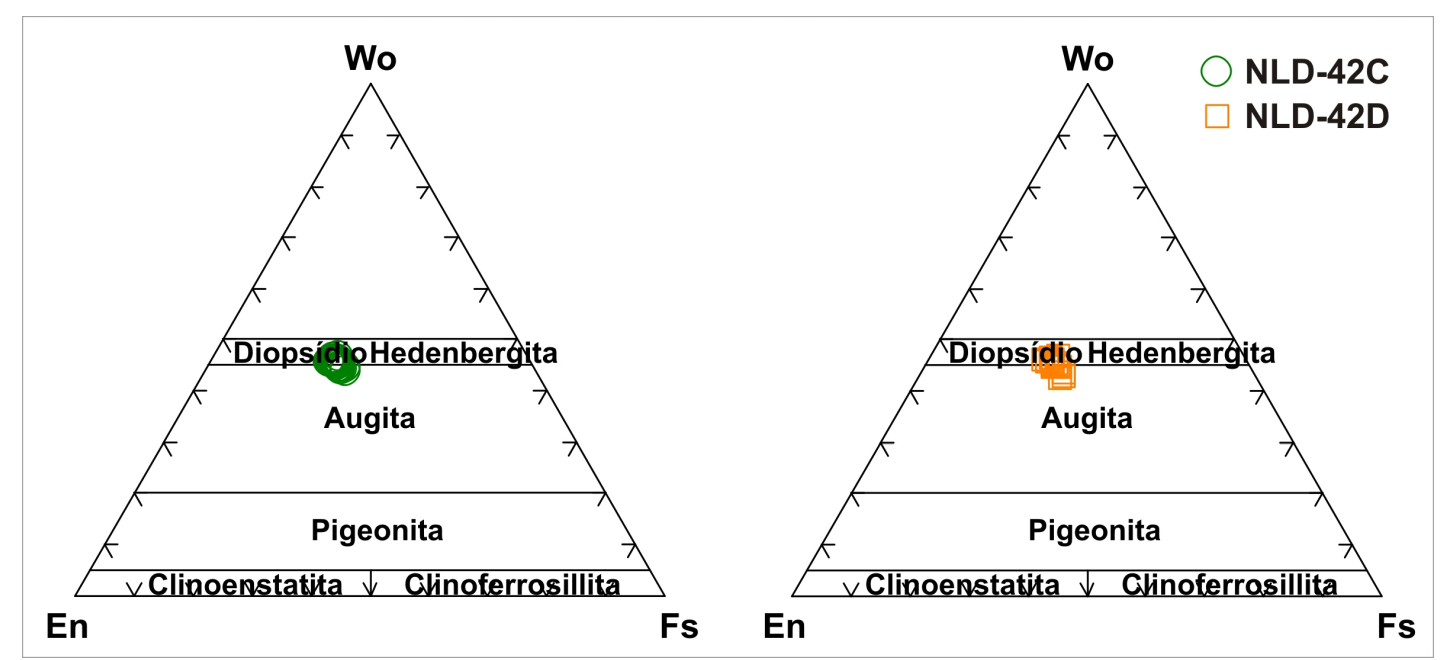

Figura 58: Diagrama para classificação de clinopiroxênios no sistema $\mathrm{Mg}_{2} \mathrm{Si}_{2} \mathrm{O} 6-\mathrm{Fe}_{2} \mathrm{Si}_{2} \mathrm{O}_{6}-\mathrm{CaFeSi}_{2} \mathrm{O}_{6}$ (En-Fs-Wo). 


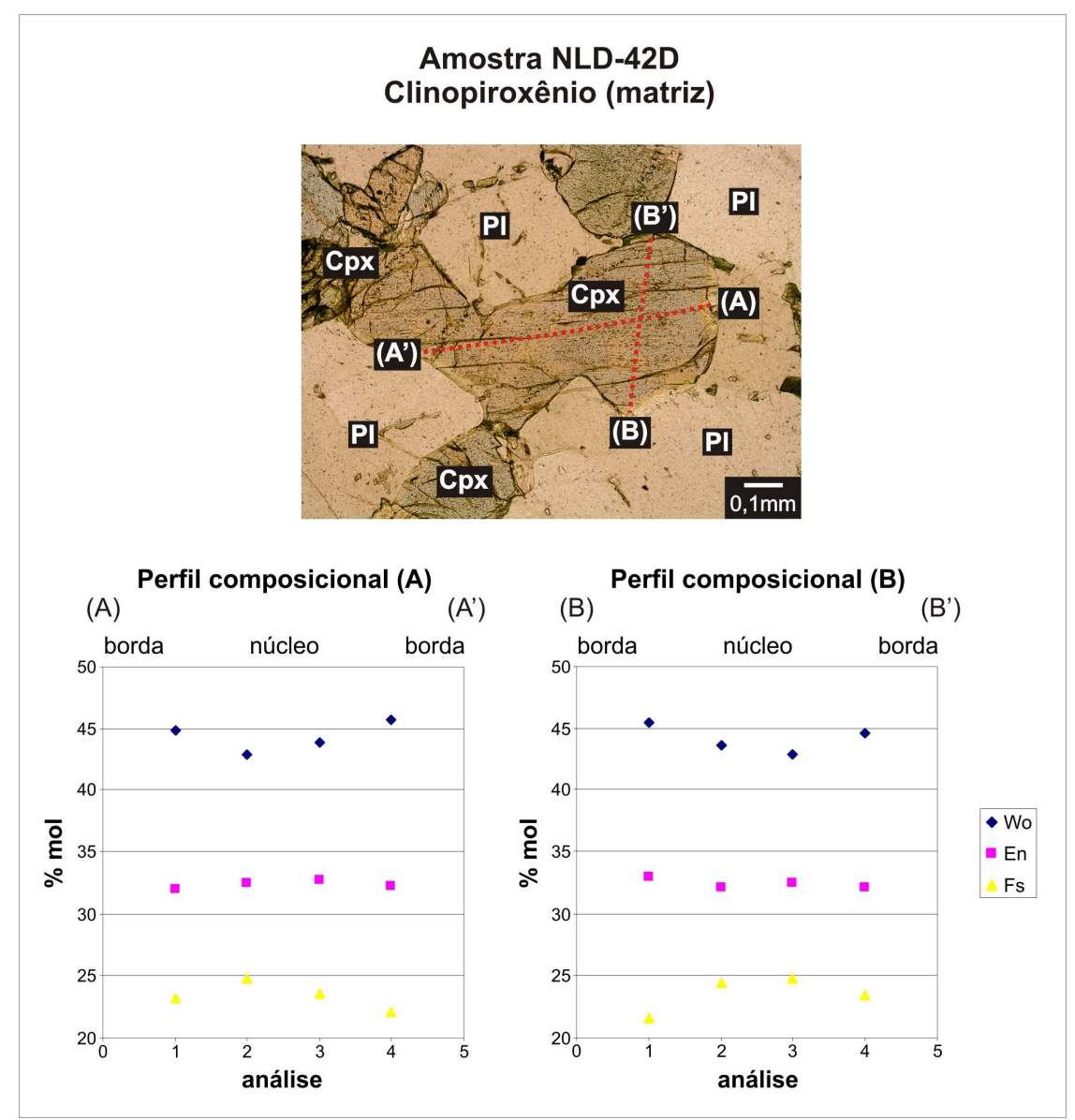

Figura 59: Seção química (A-A’) em cristal de clinopiroxênio da matriz. Polarizadores paralelos. Amostra NLD-42D.

\subsubsection{Anfibólio}

Os anfibólios da amostra NLD-42C são subeuédricos a anédricos, com pleocroísmo variando de verde-amarelado a verde-escuro, freqüentemente substituindo os piroxênios pelas bordas e/ou manteando opacos. São classificados como ferropargasita, de acordo com a nomenclatura proposta por Leake et al., (1997) e Hawthorne \& Oberti (2007) (Figura 60). A distribuição catiônica foi calculada para 23 oxigênios. As variações nos conteúdos de elementos maiores são controladas pelas seguintes substituições catiônicas: troca de edenita $\left[{ }^{\mathrm{T}} \mathrm{Si}+{ }^{\mathrm{A}} \square \leftrightarrow{ }^{\mathrm{T}} \mathrm{Al}+{ }^{\mathrm{A}}(\mathrm{Na}+\mathrm{K})\right]$ e troca tschermakítica ( $\left.{ }^{\mathrm{T}} \mathrm{Si}+{ }^{\mathrm{M} 1-\mathrm{M} 3} \mathrm{Mn} \leftrightarrow{ }^{\mathrm{T}} \mathrm{Al}+{ }^{\mathrm{M} 1-\mathrm{M} 3} \mathrm{Ti}\right)$. A combinação das duas substituições anteriores resulta na troca pargasítica $\left[\mathrm{Al}_{2} \mathrm{AlNa} \leftrightarrow \mathrm{Si}_{2}(\mathrm{Mg}, \mathrm{Fe}) \square\right]$. A razão $[\mathrm{Mg} * 100 /(\mathrm{Mg}+\mathrm{Fe})$ é mais baixa na pargasita $(\mathrm{Mg} \#=39,7-45,4)$. O teor de $\mathrm{Al}$ varia de 1,41-2,27 Al p.f.u. 


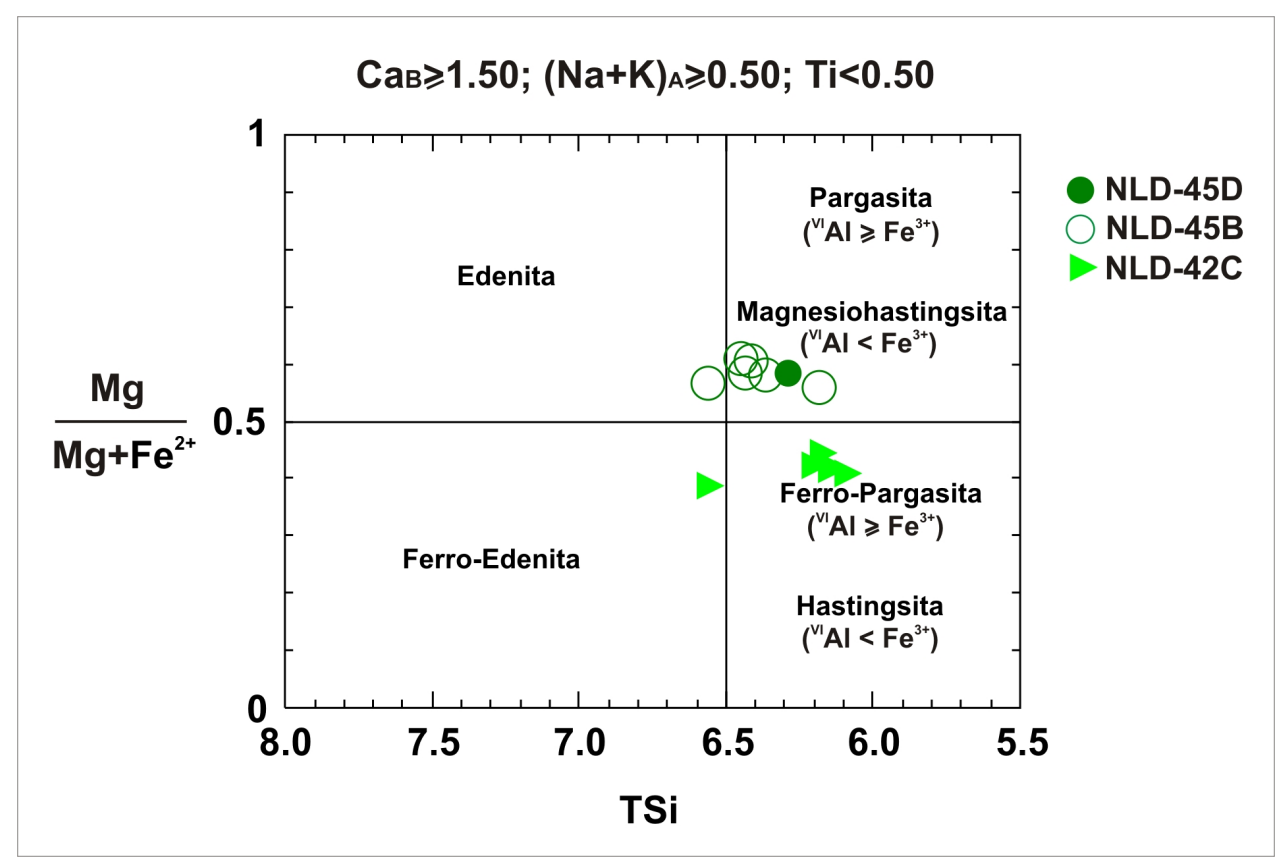

Figura 60: Diagrama de classificação para o grupo de anfibólios cálcicos com $\mathrm{Ca}_{\mathrm{B}}>=1.50 ;(\mathrm{Na}+\mathrm{K})_{\mathrm{A}}>=0.5$; Ti<0.5 (Leake et al., 1997; Hawthorne \& Oberti, 2007).

\subsubsection{Rochas charnockíticas}

\subsubsection{Descrição sucinta das amostras}

\section{- NLD-45B}

A rocha apresenta estrutura predominantemente maciça, com textura granoblástica, inequigranular fina a grossa $(0.1-5 \mathrm{~mm})$. A rocha é caracterizada pelo desenvolvimento de coronas poliminerálicas de $\mathrm{Grt}+\mathrm{Cpx} \pm \mathrm{Qtz} \pm \mathrm{Pl}$ ao redor de cristais de ortopiroxênio e plagioclásio, da associação ígnea pretérita. Os cristais de ortopiroxênio (15-18\%) são euédricos a subeuédricos, de granulação grossa (até $5 \mathrm{~mm}$ ), freqüentemente substituídos por biotita $(<5 \%)$ ou por intercrescimentos de Bt + Qtz. Também ocorre a substituição discreta por hornblenda $(<1 \%)$ nas bordas. O plagioclásio (55-60\%) ocorre na forma de porfiroclastos de até $4 \mathrm{~mm}$, com geminações curvadas e contatos irregulares, e em grãos poligonizados finos, na forma de agregados granoblásticos monominerálicos. O plagioclásio dominante é a andesina $\left(\mathrm{An}_{30-40}\right)$, com poucos grãos de oligoclásio $\left(\mathrm{An}_{20-30}\right)$ isolados. O feldspato potássico (5-10\%) é não- 
geminado e alguns grãos encontram-se poligonizados. O clinopiroxênio (10-15\%) é subeuédrico, com pouca substituição por hornblenda nas bordas. Ocorre na matriz ou compondo coronas com granada idioblástica (5-7\%) e quartzo (7-10\%) ao redor de ortopiroxênio e plagioclásio. Outros minerais acessórios são: apatita $(<5 \%)$, zircão $(<1 \%)$, rutilo $(<1 \%)$ e calcita $(<1 \%)$.

\section{- NLD-45D}

A rocha apresenta estrutura foliada e textura granoblástica a lepidogranoblástica, nas porções mais ricas em biotita. Localmente é caracterizada por uma textura porfiroclástica, constituída predominantemente por cristais reliquiares ígneos de ortopiroxênio e plagioclásio de granulação grossa (até $5 \mathrm{~mm}$ ) em matriz inequigranular fina a média $(0.1-2 \mathrm{~mm})$, composta por grãos de plagioclásio poligonizados, quartzo, granada, clinopiroxênio e biotita. Também são freqüentes as texturas coroníticas constituídas por Grt $+\mathrm{Cpx} \pm \mathrm{Qtz} \pm \mathrm{Pl}$ ao redor de ortopiroxênio e plagioclásio. $\mathrm{O}$ ortopiroxênio (10-20\%) é subeuédrico, de granulação grossa (até $5 \mathrm{~mm}$ ), por vezes intensamente fraturados e penetrados por cristais de biotita de até $5 \mathrm{~mm}$, na forma de escamas (5-10\%) e/ou por intercrescimentos esqueletais de Bt + Qtz. Os cristais de clinopiroxênio (10-15\%) possuem granulação fina a média. Estão geralmente inclusos em ortopiroxênio ou compõem coronas com Grt e Qtz. Também ocorrem alguns grãos de piroxênio com substituição discreta por hornblenda $(<1 \%)$ nas bordas ou ao longo de fraturas e clivagens. A granada (5-10\%) é subidioblástica a idioblástica fina, localmente com inclusões goticulares de quartzo e/ou opacos $(<2 \%)$. O plagioclásio $(45-55 \%)$ ocorre na forma de porfiroclastos de até $4 \mathrm{~mm}$ (grãos reliquiares ígneos), com geminações curvadas e contatos irregulares, e em grãos poligonizados finos, na forma de agregados granoblásticos monominerálicos. O plagioclásio dominante é a andesina $\left(\mathrm{An}_{30-40}\right)$, com poucos grãos de feldspato potássico $(<5 \%)$ não-geminados. Outros minerais acessórios são: apatita $(<5 \%)$, zircão $(<1 \%)$ e calcita $(<1 \%)$. 


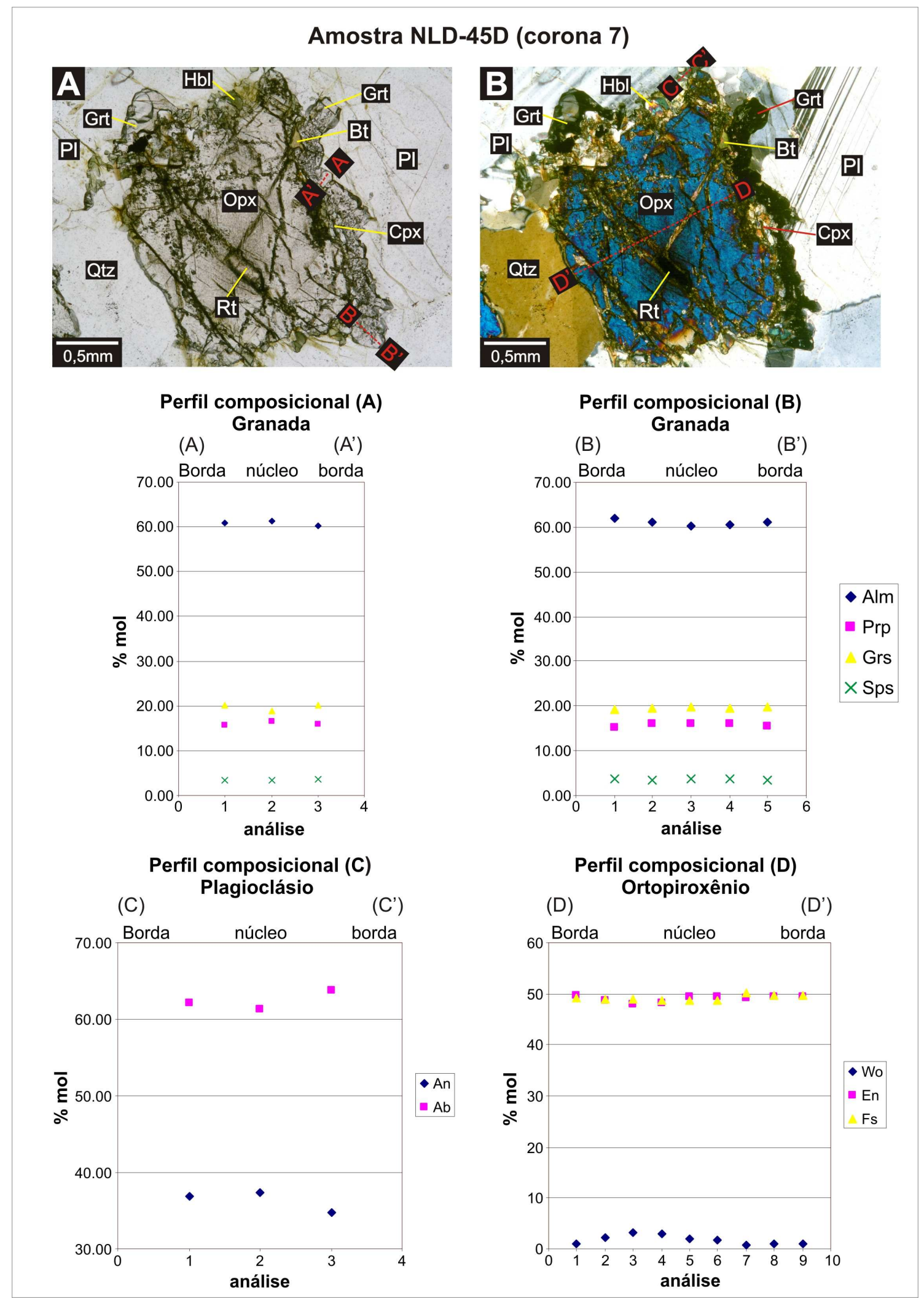

Figura 61: Perfil composicional em cristal de granada (seções A-A' e B-B'), plagioclásio (seção C-C') e ortopiroxênio (seção D-D'). (A) Polarizadores paralelos, (B) polarizadores cruzados. Amostra NLD-45D. 


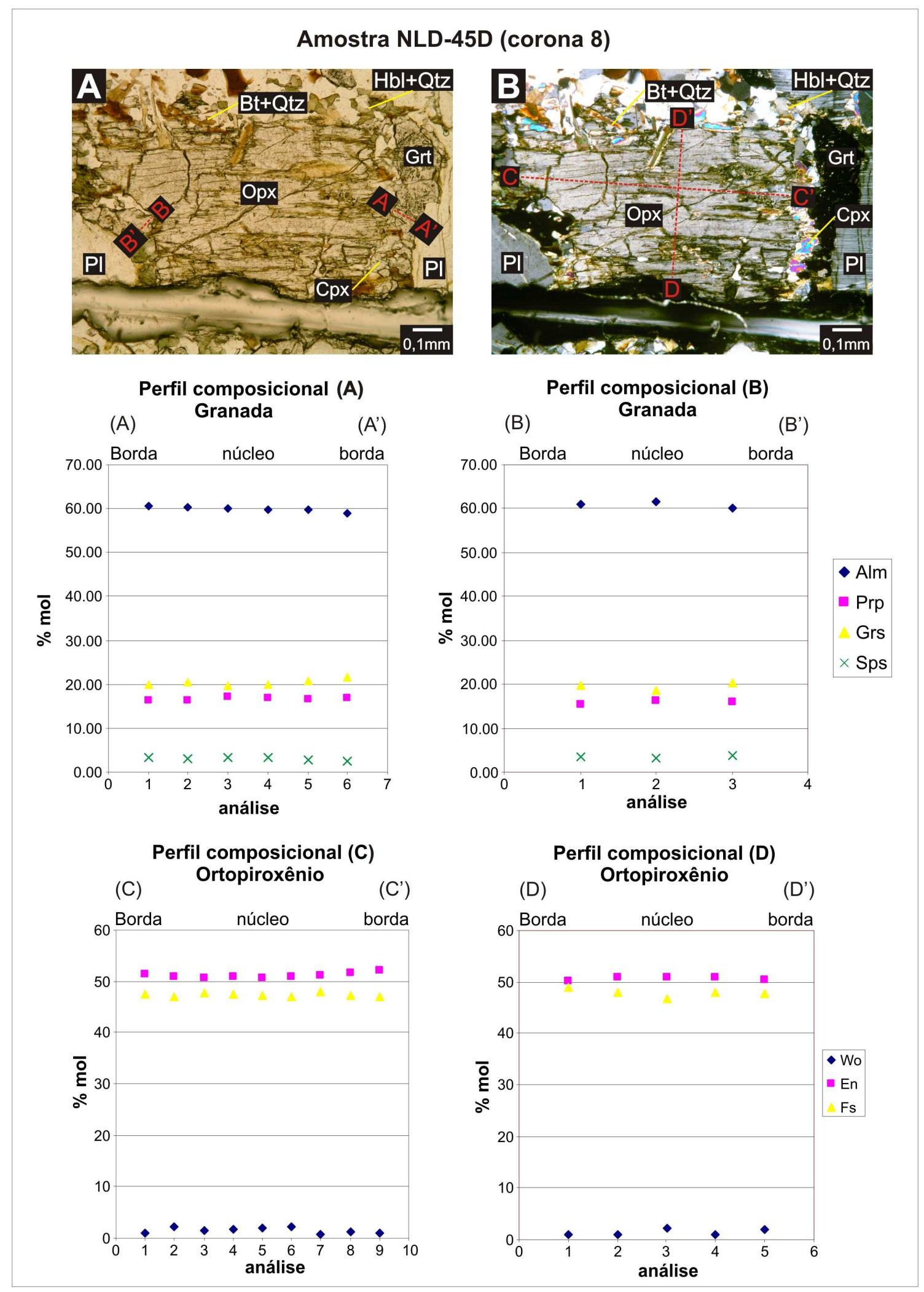

Figura 62: Perfil composicional em cristal de granada (seções A-A' e B-B') e ortopiroxênio (seções C-C' e D-D'). (A) Polarizadores paralelos, (B) polarizadores cruzados. Amostra NLD-45D. 


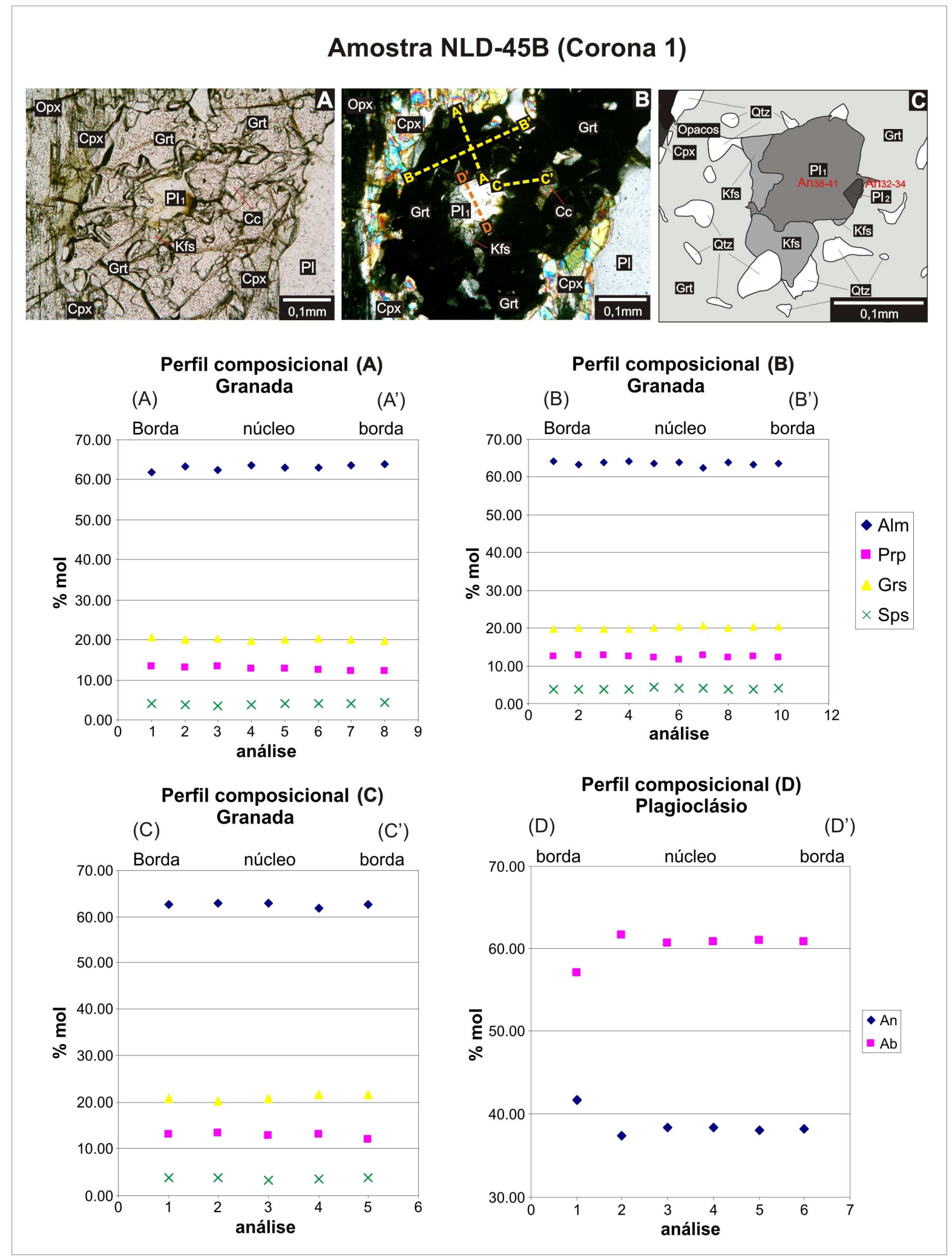

63: Perfil composicional em cristal de granada (seções A-A', B-B' e C-C') e plagioclásio (seção D-D') da corona 1. (A) Polarizadores paralelos, (B) polarizadores cruzados, (C) Esboço sobre a imagem obtida em microscópio eletrônico de varredura (MEV). Amostra NLD-45B. 


\subsubsection{Granada}

Os cristais de granada são em geral subidioblásticos, de granulação fina, comumente na forma de moats, compondo coronas com clinopiroxênio + quartzo \pm plagioclásio no contato entre cristais reliquiares ígneos de ortopiroxênio e plagioclásio. São ricos em inclusões de quartzo e/ou opacos, com terminações idioblásticas límpidas em direção ao plagioclásio coronítico.

A composição química é homogênea, exibindo perfis composicionais relativamente planos. Na amostra NLD-45D foram analisados grãos de granada em duas coronas distintas. Na corona 6 (Figura 61) foram analisados um cristal idioblástico, isento de inclusões, adjacente à augita (seção A-A') e um cristal subidioblástico com inclusões de quartzo, adjacente ao diopsídio (seção B-B'). No perfil composicional AA' da corona 6 (Figura 61) ocorre um pequeno aumento no conteúdo de grossulária nas bordas, acompanhado por uma diminuição no conteúdo de piropo e um leve empobrecimento em almandina, possivelmente relacionado com a difusão com cristal de augita adjacente. No perfil composicional B-B' da mesma corona (Figura 61) ocorre um aumento em almandina do núcleo em direção às bordas, acompanhado por uma diminuição em piropo, devido à troca $\mathrm{Fe}-\mathrm{Mg}$ com cristal de diopsídio adjacente. $\mathrm{Na}$ corona 8 (Figura 62), a granada apresenta um enriquecimento em grossulária, acompanhado por uma diminuição nos conteúdos de piropo. A almandina permanece constante, exceto na seção A-A' em que ocorre um pequeno aumento no teor de Fe no contato com o ortopiroxênio.

$\mathrm{Na}$ amostra NLD-45B, a granada apresenta o mesmo padrão de zoneamento químico, com um leve aumento nos conteúdos de almandina, acompanhado por uma diminuição nos conteúdos de piropo em direção ao contato com o clinopiroxênio devido à difusão química facilitada pelo resfriamento (seções A-A', B-B' e C-C'; Figura 63).

Apresenta as seguintes proporções entre os membros-finais:

- Amostra NLD-45B: (Alm $\left.61,6-64,1 \operatorname{Prp}_{11,6-14,2} \mathrm{Grs}_{19,3-22,5} \mathrm{Sps}_{2,8-4,3}\right)$

- Amostra NLD-45D: (Alm $\left.{ }_{59,1-61,9} \operatorname{Prp}_{15,2-17,1} \mathrm{Grs}_{18,7-20,8} \operatorname{Sps}_{2,7-3,7}\right)$

\subsubsection{Feldspato}

Ocorrem cristais de plagioclásio subeuédricos, reliquiares da textura ígnea pretérita, de granulação média a grossa, levemente deformados, com geminações curvadas e grãos equigranulares poligonizados, de granulação fina. São classificados como andesina $\left(\mathrm{An}_{33-42}\right)$ (Figura 64). 


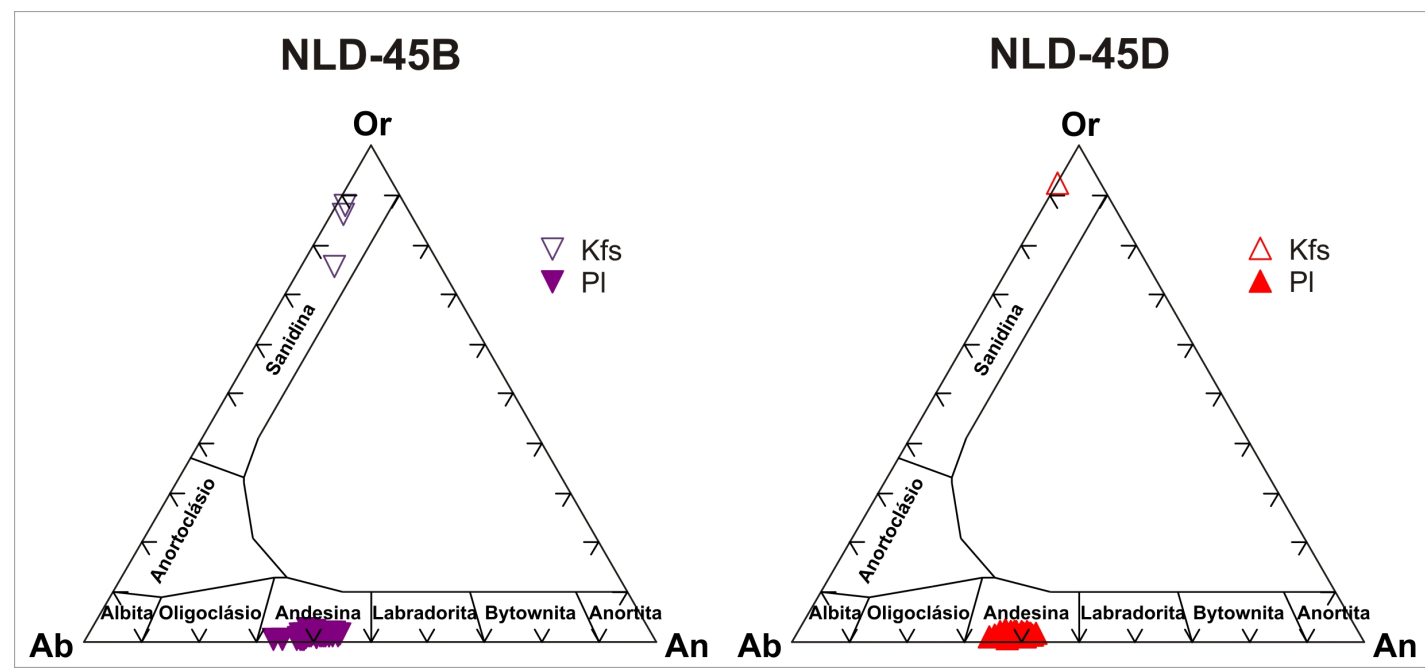

Figura 64: Diagrama para classificação de feldspatos no sistema $\mathrm{CaO}-\mathrm{Na}_{2} \mathrm{O}-\mathrm{K}_{2} \mathrm{O}$ (An-Ab-Or) (MINPET 2.02 - Richard, 1995).

Apresenta as seguintes proporções entre os membros-finais:

$$
\begin{aligned}
& \text { - NLD-45B: } \mathrm{An}_{32,7-43,9} \mathrm{Ab}_{54,5-66,5} \mathrm{Or}_{0,7-2,7} \\
& \text { - NLD-45D: } \mathrm{An}_{34-41,9} \mathrm{Ab}{ }_{56,4-63,8} \mathrm{Or}_{0,8-2}
\end{aligned}
$$

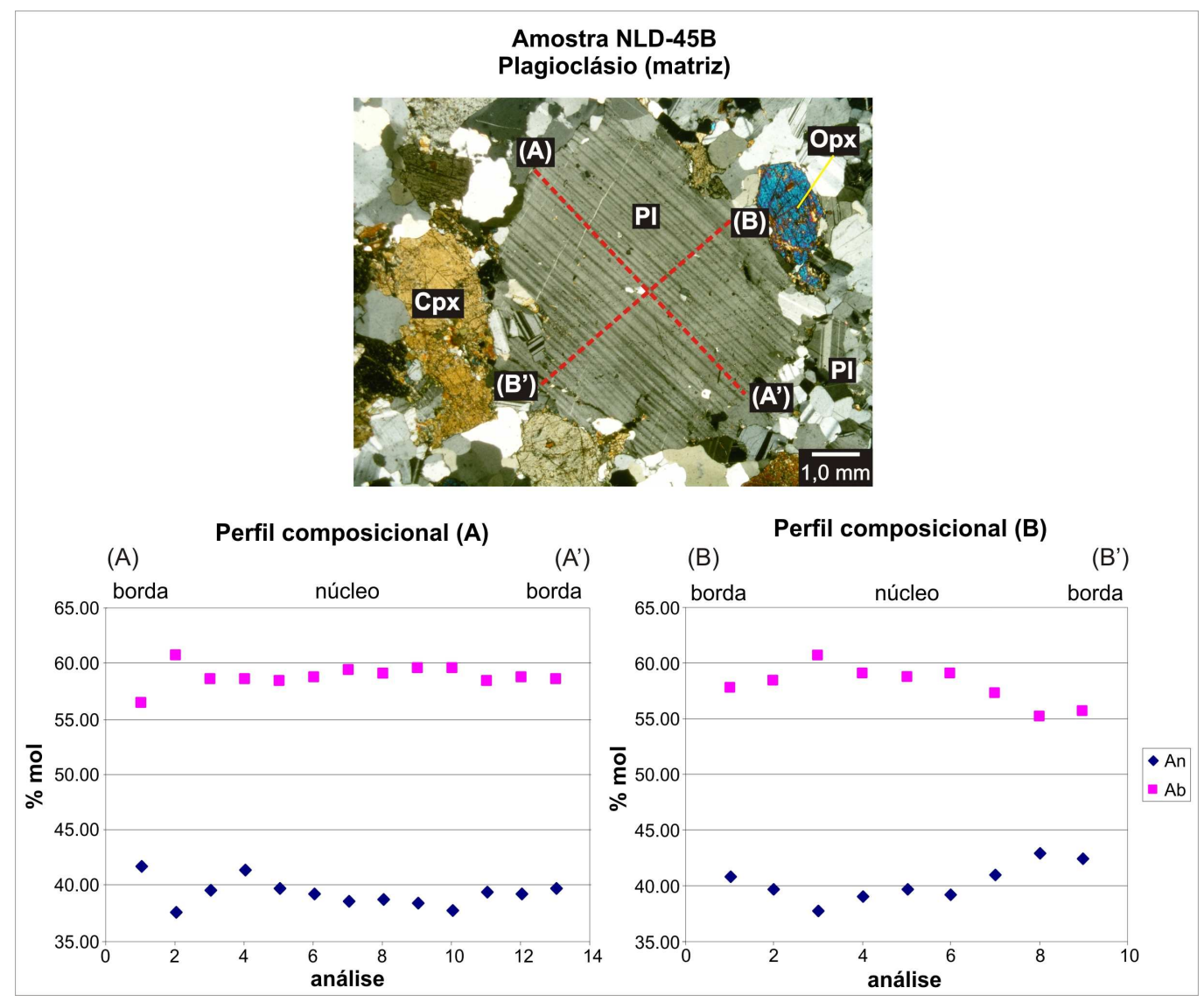

Figura 65: Perfil composicional em cristal de plagioclásio da matriz (seções A-A' e B-B'). Polarizadores cruzados. Amostra NLD-45B. 
O plagioclásio da matriz apresenta um enriquecimento no teor de anortita do núcleo em direção às bordas (Figura 65). Na seção A-A' ocorre um enriquecimento em albita na borda interna e borda externa mais cálcica. Os cristais adjacentes à corona apresentam um leve incremento em albita no contato com a granada, enquanto que os cristais coroníticos exibem perfis composicionais relativamente planos. Na corona $1 \mathrm{da}$ amostra NLD-45B ocorre um grão de plagioclásio neoformado, mais rico em albita $\left(\mathrm{An}_{32-34}\right)$ do que o plagioclásio coronítico $\left(\mathrm{An}_{38-41}\right)$ (Figura 63).

Os cristais de feldspato potássico são não-geminados, subeuédricos a anédricos, de granulação média. Localmente ocorrem no interior das coronas, no contato entre o plagioclásio e os anéis de granada, com quartzo associado possivelmente mimetizando um líquido silicático (Figura 63). Apresenta as seguintes proporções entre os membrosfinais: $\mathrm{An}_{1,5-6,1} \mathrm{Ab}_{7,5-18,2} \mathrm{Or}_{75,7-92,6}$

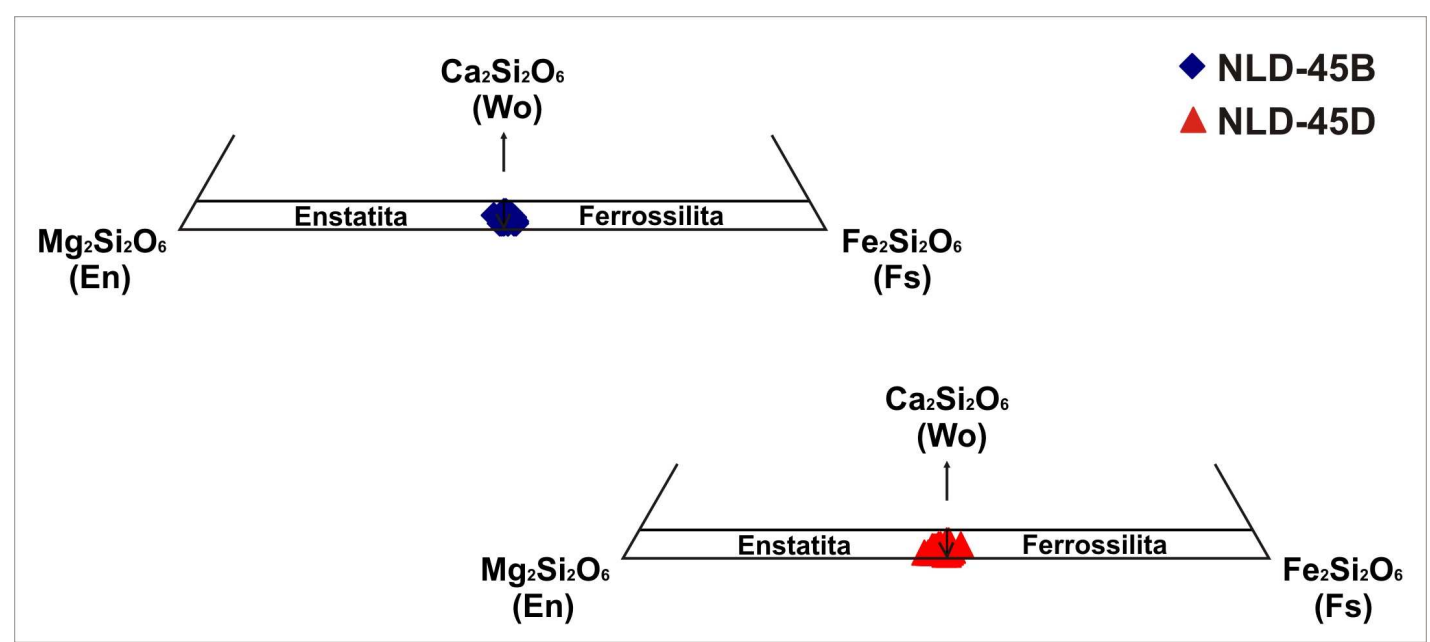

Figura 66: Diagrama para classificação de ortopiroxênios no sistema $\mathrm{Mg}_{2} \mathrm{Si}_{2} \mathrm{O} 6-\mathrm{Fe}_{2} \mathrm{Si}_{2} \mathrm{O}_{6}-\mathrm{CaFeSi}_{2} \mathrm{O}_{6}(\mathrm{En}-$ Fs-Wo).

\subsubsection{Ortopiroxênio}

Os cristais de ortopiroxênio são euédricos a subeuédricos, de granulação média a grossa, bastante fraturados, com pleocroísmo médio variando de bege rosado a incolor. Estão freqüentemente substituídos por coronas de granada + clinopiroxênio \pm quartzo no contato com o plagioclásio. Alguns grãos estão parcialmente substituídos por hornblenda e/ou intercrescimentos de biotita + quartzo nas bordas ou ao longo de fraturas. Localmente a substituição direta de ortopiroxênio por biotita é total. Estão situados no limite composicional enstatita/ferrossilita, de acordo com a classificação de 
Morimoto (1988) (Figura 66). Apresenta as seguintes proporções entre os membros finais: $\mathrm{Wo}_{0,7-3,3} \mathrm{En}_{46,4-52,9} \mathrm{Fs}_{46,1-51,4}$.

A composição química é aproximadamente homogênea, com $\mathrm{Mg \#}=48-53$ e teor de Al entre 0.023-0.037 p.f.u. Os maiores valores de Mg\# são nas bordas, principalmente nos cristais ígneos reliquiares de dimensão maior. Geralmente ocorre um pequeno incremento nos conteúdos de enstatita do núcleo em direção às bordas, acompanhado por uma diminuição nos teores de ferrossilita (Figuras 62, 67).

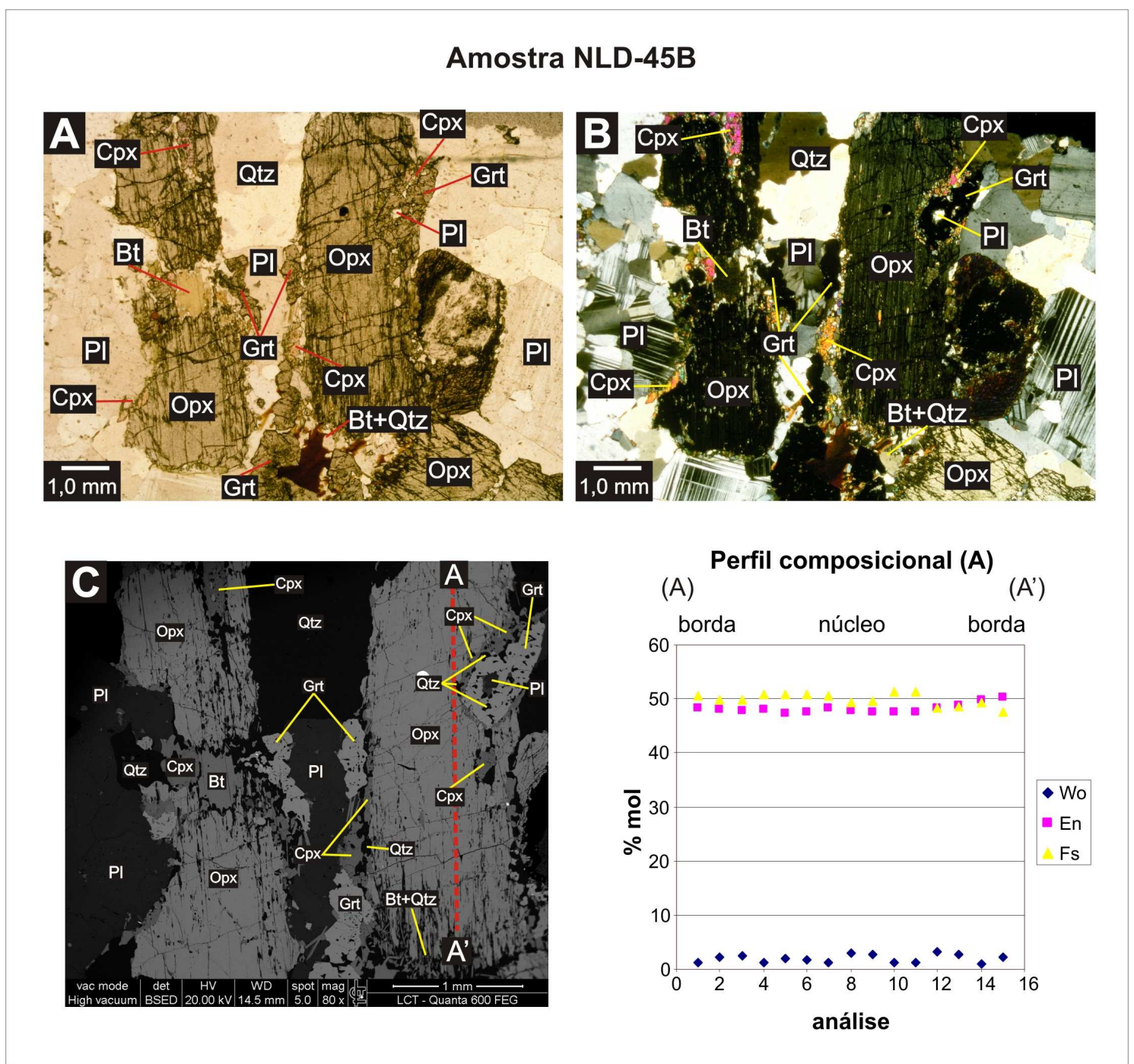

Figura 67: Perfil composicional em cristal de ortopiroxênio ígneo reliquiar. (A) Polarizadores paralelos, (B) polarizadores cruzados, (C) Imagem retroespalhada obtida através do MEV. Amostra NLD-45B.

\subsubsection{Clinopiroxênio}

Cristais ígneos reliquiares de granulação média a grossa estão bem preservados, com substituição discreta de hornblenda e/ou biotita nas bordas ou ao longo de fraturas 
e clivagens. Os cristais menores (dimensão milimétrica) ocorrem inclusos em ortopiroxênio ou compondo coronas com granada.

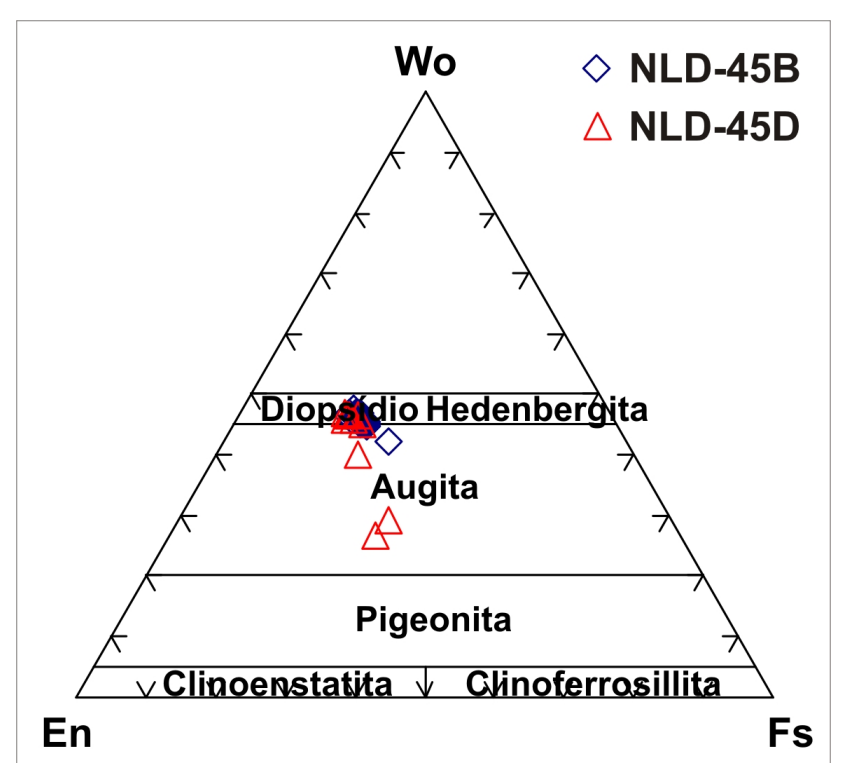

Figura 68: Diagrama para classificação de clinopiroxênios no sistema $\mathrm{Mg}_{2} \mathrm{Si}_{2} \mathrm{O} 6-\mathrm{Fe}_{2} \mathrm{Si}_{2} \mathrm{O}_{6}-\mathrm{CaFeSi}_{2} \mathrm{O}_{6}$ (En-Fs-Wo).

Apresenta as seguintes proporções entre os membros-finais:

- Amostra NLD-45B: $\mathrm{Wo}_{42,1-47,7} \mathrm{En}_{34,1-37,7} \mathrm{Fs}_{15,9-23-8}$

- Amostra NLD-45D: $\mathrm{Wo}_{26,7-46,4} \mathrm{En}_{36,3-43,6} \mathrm{Fs}_{15,2-30,2}$

O clinopiroxênio é classificado como diopsídio, de acordo com a classificação proposta por Morimoto (1988), exceto alguns grãos localizados nas coronas que plotam no campo da augita (Figura 68). A composição química é variável, com Mg\# = 62-77. Os teores de Al variam de 0.028-0.051 Al p.f.u. na maioria dos cristais analisados. Localmente ocorrem valores bastante elevados de $\mathrm{Al}$ em cristais de clinopiroxênio que compõem coronas com granada e quartzo no contato entre o ortopiroxênio e o plagioclásio (0.114-0.218 Al p.f.u. na amostra NLD-45B e 0.462 Al p.f.u. na amostra NLD-45D), refletindo condições de alto grau.

Os grãos são pouco zonados, geralmente apresentando um incremento nos conteúdos de enstatita do núcleo em direção às bordas. Os conteúdos de jadeíta variam de 0-1.5 na amostra NLD-45B e atingem as maiores concentrações na amostra NLD45D (0-8.5). Geralmente com os teores mais elevados de jadeíta ocorrem no núcleo, 
exceto para os grãos de augita em que os maiores valores se concentram nas bordas dos cristais.

\subsubsection{Biotita}

Os cristais de biotita presentes nas rochas charnockíticas ocorrem preferencialmente substituindo o ortopiroxênio, com quartzo associado. São geralmente subeuédricos a euédricos e fortemente pleocróicos, variando de marrom claro a marrom avermelhado, porém apresentam algumas variações texturais, relacionadas com variações composicionais. A razão $[\mathrm{Mg} * 100 /(\mathrm{Mg}+\mathrm{Fe})]$ varia de $\mathrm{Mg} \#=48-58$ e o teor de Ti de 0.21-0.33 Ti p.f.u.

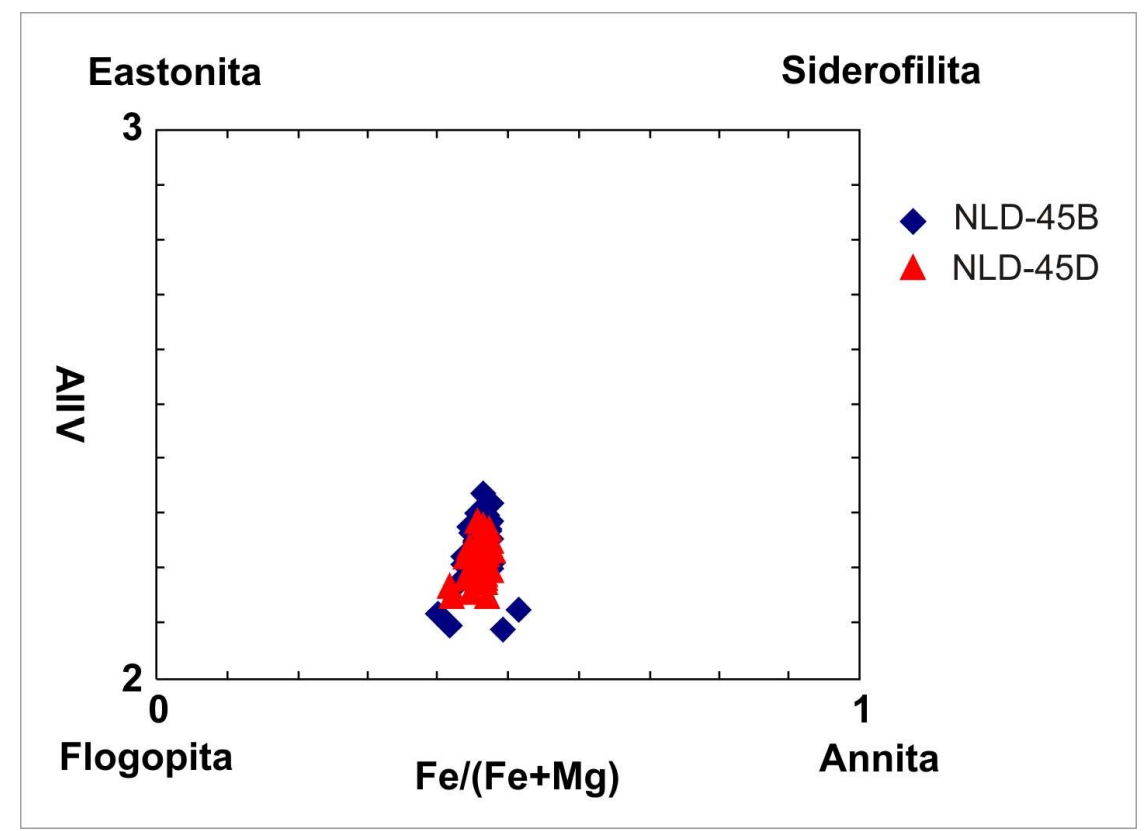

Figura 69: Diagrama para classificação de biotita (MINPET 2.02 - Richard, 1995).

$\mathrm{Na}$ amostra NLD-45B ocorrem grãos de biotita de granulação grossa na matriz, freqüentemente associados com granada subidiomórfica, rica em inclusões de opacos. Nestes grãos ocorrem os maiores teores de Ti registrados nesta amostra (0.30-0.32 Ti p.f.u.). Há uma geração posterior de biotita, caracterizada por grãos idiomórficos finos, com teores menores de Ti (0.21-0.23 Ti p.f.u.) e conteúdos mais expressivos de flogopita $(\mathrm{Mg \#} \mathrm{=} \mathrm{55-57).} \mathrm{Poucos} \mathrm{grãos} \mathrm{exibem} \mathrm{zoneamento} \mathrm{químico.} \mathrm{Ocorre} \mathrm{um} \mathrm{cristal}$ de biotita substituindo ortopiroxênio coronítico ao longo de fraturas (Figura 67), exibindo um leve enriquecimento no membro-final flogopita do núcleo em direção às bordas, possivelmente devido à troca $\mathrm{Fe}-\mathrm{Mg} \operatorname{com} \mathrm{o}$ ortopiroxênio durante $\mathrm{o}$ 
resfriamento. Os grãos de biotita inclusos em ortopiroxênio apresentam $\mathrm{Mg \#}=54-56 \mathrm{e}$ teor de Ti elevado (0.29-0.33 Ti p.f.u.).

A biotita da amostra NLD-45D apresenta composição mais homogênea, com razões $[\mathrm{Mg} * 100 /(\mathrm{Mg}+\mathrm{Fe})]$ variando entre 52-58 e teor de $\mathrm{Ti}=0.25-0.29$ Ti p.f.u. Um cristal de biotita da matriz, de granulação grossa apresenta um leve zoneamento químico, exibindo o núcleo mais rico no membro-final flogopita, seguido por borda interna rica no membro-final annita e borda externa com conteúdos mais elevados em flogopita (Figura 69). A biotita idiomórfica que ocorre associada com o quartzo na substituição do piroxênio apresenta os maiores conteúdos de $\mathrm{Mg}(\mathrm{Mg \#}=58)$ e os menores teores de Ti registrados nesta amostra (0.25 Ti p.f.u.).

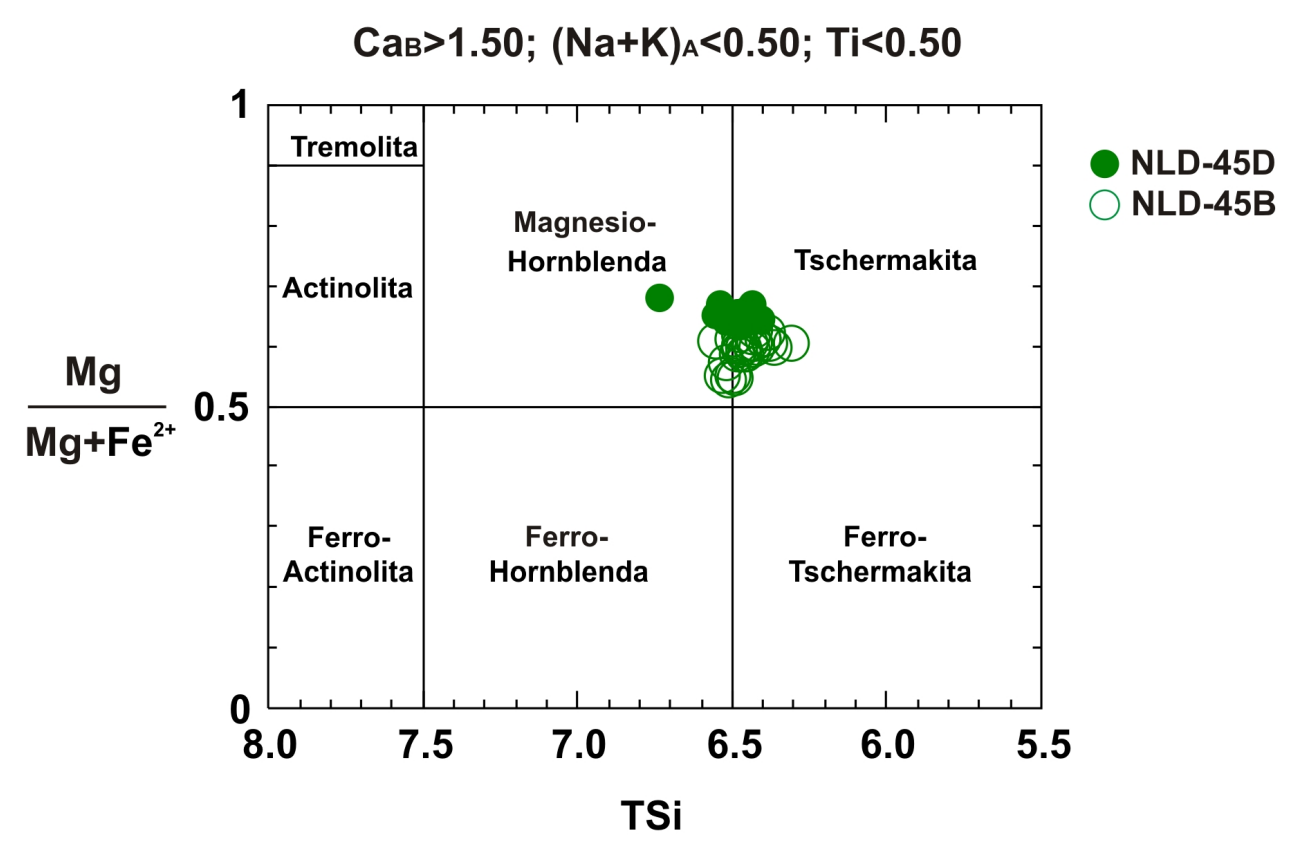

Figura 70: Diagrama de classificação para o grupo de anfibólios cálcicos com $\mathrm{Ca}_{\mathrm{B}}>=1.50 ;(\mathrm{Na}+\mathrm{K})_{\mathrm{A}}<=0.5$; Ti<0.5 (Leake et al., 1997; Hawthorne \& Oberti, 2007).

\subsubsection{Anfibólio}

Os anfibólios das rochas charnockíticas são classificados em anfibólios cálcicos e estão situados no limite entre os campos da hornblenda tschermakítica e magnésiohornblenda, com predomínio de hornblenda tschermakítica (nomeclatura de Leake et al., 1997; Hawthorne \& Oberti, 2007) (Figura 70). Os cristais são subeuédricos, de granulação fina, com pleocroísmo médio variando de verde-pálido a verde-escuro, geralmente substituindo os piroxênios pelas bordas ou ao longo de fraturas. Também 
ocorrem associados com a biotita ou opacos. Na amostra NLD-45B ocorrem cristais de magnésio-hastingsita (Figura 60), subeuédricos a anédricos, de granulação fina, com pleocroísmo médio variando de verde-amarelado a verde-azulado.

$\mathrm{Na}$ amostra NLD-45B, a razão $[\mathrm{Mg} * 100 /(\mathrm{Mg}+\mathrm{Fe})]$ varia de 55-62.5, atingindo valores mais elevados na amostra NLD-45D $(\mathrm{Mg} \#=62.7-67)$. O teor de $\mathrm{Al}$ varia de 1.85-2.40 Al p.f.u. na amostra NLD-45B, com maiores concentrações na hornblenda tschermakítica e menores conteúdos de Al na magnésio-hastingsita. Na amostra NLD45D, com predomínio de magnésio-hornblenda e hornblenda tschermakítica, o teor de $\mathrm{Al}$ varia de 1.41-2.27 Al p.f.u. 


\subsection{GEOTERMOBAROMETRIA}

\subsubsection{Considerações iniciais}

A determinação das condições de formação das associações minerais são aspectos fundamentais de pesquisa em terrenos metamórficos (Essene, 1989; Powell \& Holland, 2008). A geotermobarometria baseia-se na determinação das condições de formação de uma rocha, a partir de cálculos de temperatura e pressão utilizando a composição química dos minerais. A princípio, a associação mineral selecionada para os cálculos deve estar em equilíbrio termodinâmico. A calibração de uma rocha pode ser feita através de geotermobarometria otimizada, com a utilização de programas como o THERMOCALC (Powell \& Holland, 1988) e TWEEQU (Thermobarometry With Estimation of EQUilibrium state) (Berman, 1991) ou através da geotermobarometria clássica. A geotermobarometria de rochas em fácies granulito apresenta complexidades adicionais, pois os processos de fusão parcial atuantes e a difusão química facilitada por altas temperaturas dificultam a preservação de composições minerais de pico metamórfico (Powell \& Holland, 2008).

O THERMOCALC (Powell \& Holland, 1988) é um programa que foi desenvolvido para realizar uma série de cálculos termodinâmicos, utilizando um banco de dados termodinâmicos internamente consistentes (Holland \& Powell, 1998). O banco de dados envolve incertezas nos parâmetros termodinâmicos, gerando, portanto, incertezas a serem calculadas sobre os resultados obtidos (geotermômetros e geobarômetros). O cálculo de rochas envolve a combinação simultânea de "quadrados mínimos" de condições calculadas para um set de reações linearmente independentes, que podem ser expressas entre os membros-finais nos minerais constituintes da rocha e nos dados termodinâmicos. Neste trabalho foi utilizada a versão 3.26 do THERMOCALC (Powell \& Holland, 1988) para cálculos geotermobarométricos em paragnaisses, rochas metabásicas e rochas charnockíticas e a versão 1.02 do TWEEQU (Berman, 1991), para cálculos complementares nas rochas metabásicas.

Os resultados obtidos no THERMOCALC para os paragnaisses apresentaram-se satisfatórios, com erros relativamente baixos. Estes dados foram complementados com dados obtidos através da geotermobarometria clássica, com a utilização dos geotermômetros granada-biotita (Ferry \& Spear, 1978; Indares \& Martignole,1985) e de zircônio-em-rutilo (Watson, 2006; Tomkins et al., 2007) e do geobarômetro GASP (Newton \& Haselton, 1981; Koziol \& Newton, 1988; Koziol, 1989). 
Nas rochas metabásicas e rochas charnockíticas são comuns as texturas coroníticas e a difusão química intensa provocou um grande desequilíbrio termodinâmico entre os minerais. Em muitos casos não foi possível obter um número mínimo de reações linearmente independentes entre todos os membros-finais da associação mineral, impossibilitando um cálculo confiável. Desta forma, a maior parte dos dados foi obtida através da geotermobarometria convencional, com a utilização do geotermômetro granada-clinopiroxênio (Ganguly, 1979; Sengupta et al., 1989) e do geobarômetro granada-clinopiroxênio-plagioclásio (Eckert et al., 1991).

A geotermobarometria convencional foi realizada através da utilização da planilha Excel GPT (Reche \& Martinez, 1996) para os paragnaisses e do software PTMAFIC 2.0 (Soto \& Soto, 1995) para as rochas metabásicas. O PTMAFIC é um programa que executa uma extensa série de cálculos estequiométricos e termodinâmicos a partir de arquivos ASCII de análises químicas normalizadas em anfibólios, granada, epídoto, ilmenita, muscovita, ortopiroxênio, clinopiroxênio, olivina, plagioclásio e espinélio.

Os cálculos geotermobarométricos foram realizados no litotipos em que foram obtidas análises químicas quantitativas e qualitativas. Desta forma, a descrição sucinta das amostras está apresentada no subitem 6.2 (Química Mineral).

\subsubsection{Diagramas de compatibilidade}

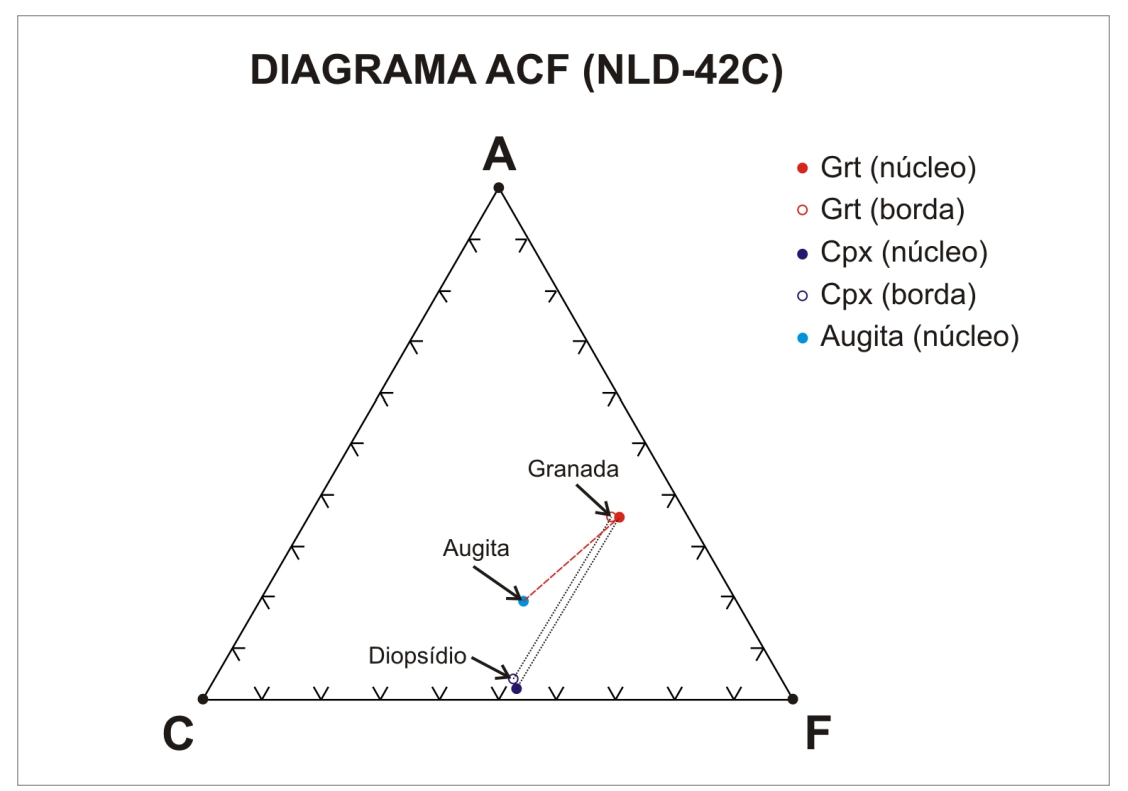

Figura 71: Diagrama ACF para metagabronorito (amostra NLD-42C). Parâmetros: $A=\mathrm{Al}_{2} \mathrm{O}_{3}+\mathrm{Fe}_{2} \mathrm{O}_{3^{-}}$ $\left(\mathrm{Na}_{2} \mathrm{O}+\mathrm{K}_{2} \mathrm{O}\right) ; \mathrm{C}=\mathrm{CaO} ; \mathrm{F}=\mathrm{FeO}+\mathrm{MgO}+\mathrm{MnO}$. 
Nas rochas metabásicas e nas rochas charnockíticas são bastante freqüentes as texturas coroníticas, que representam reações metamórficas incompletas entre as fases minerais ígneas reliquiares (e.g. ortopiroxênio, plagioclásio) produzindo granada + clinopiroxênio + quartzo. Foi utilizado o diagrama de compatibilidade ACF para auxiliar no reconhecimento das composições de granada e clinopiroxênio em equilíbrio. A associação mineral neoformada constituída por Grt + Cpx está representada por linhas de conexão (tie-lines) pontilhadas em preto (Figuras 71 a 75). O quartzo não plota neste diagrama, pois é considerada uma fase em excesso.

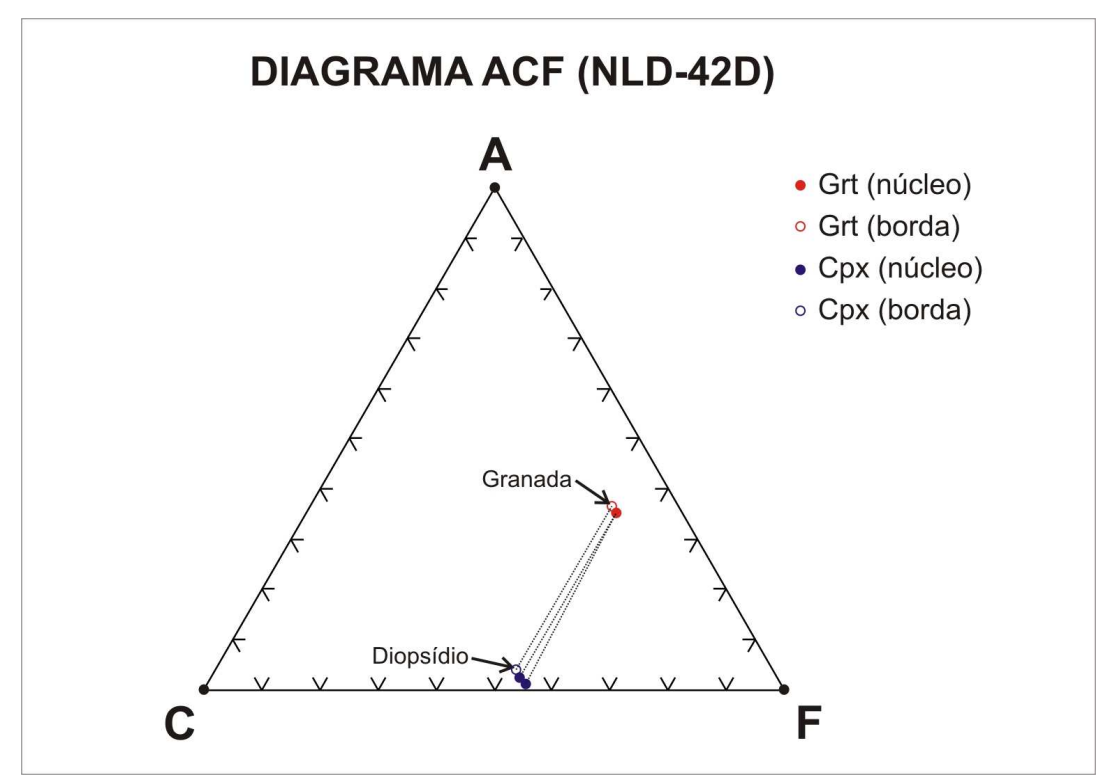

Figura 72: Diagrama ACF para metagabronorito (amostra NLD-42D). Parâmetros: $A=\mathrm{Al}_{2} \mathrm{O}_{3}+\mathrm{Fe}_{2} \mathrm{O}_{3^{-}}$ $\left(\mathrm{Na}_{2} \mathrm{O}+\mathrm{K}_{2} \mathrm{O}\right) ; \mathrm{C}=\mathrm{CaO} ; \mathrm{F}=\mathrm{FeO}+\mathrm{MgO}+\mathrm{MnO}$.

Nas coronas ocorre a formação de cristais diminutos de clinopiroxênio, com composições que variam de diopsídio a augita. Nos diagramas de compatibilidade ACF das rochas metabásicas (Figuras 71 e 72), as composições de núcleo e borda de diopsídio configuram linhas de conexão paralelas com as composições de núcleo e borda da granada, o que sugere condições de equilíbrio para estes pares de Grt-Cpx. A linha de conexão que une a granada à augita, representada por uma linha tracejada vermelha na Figura 71, cruza as demais linhas de conexão entre granada e diopsídio, o que indica que a augita está em desequilíbrio termodinâmico com a granada.

Nos diagramas de compatibilidade ACF das rochas charnockíticas, as linhas de conexão que unem o diopsídio e a granada também são paralelas, indicando equilíbrio termodinâmico entre ambos e são cruzadas pelas linhas de conexão que unem a granada 
à augita (Figuras 73 a 75). Desta forma, a composição do par granada-augita não pode ser aplicada para geotermobarometria. Portanto, foram considerados apenas os pares de granada-diopsídio para os cálculos termobarométricos nas coronas das rochas metabásicas e das rochas charnockíticas.

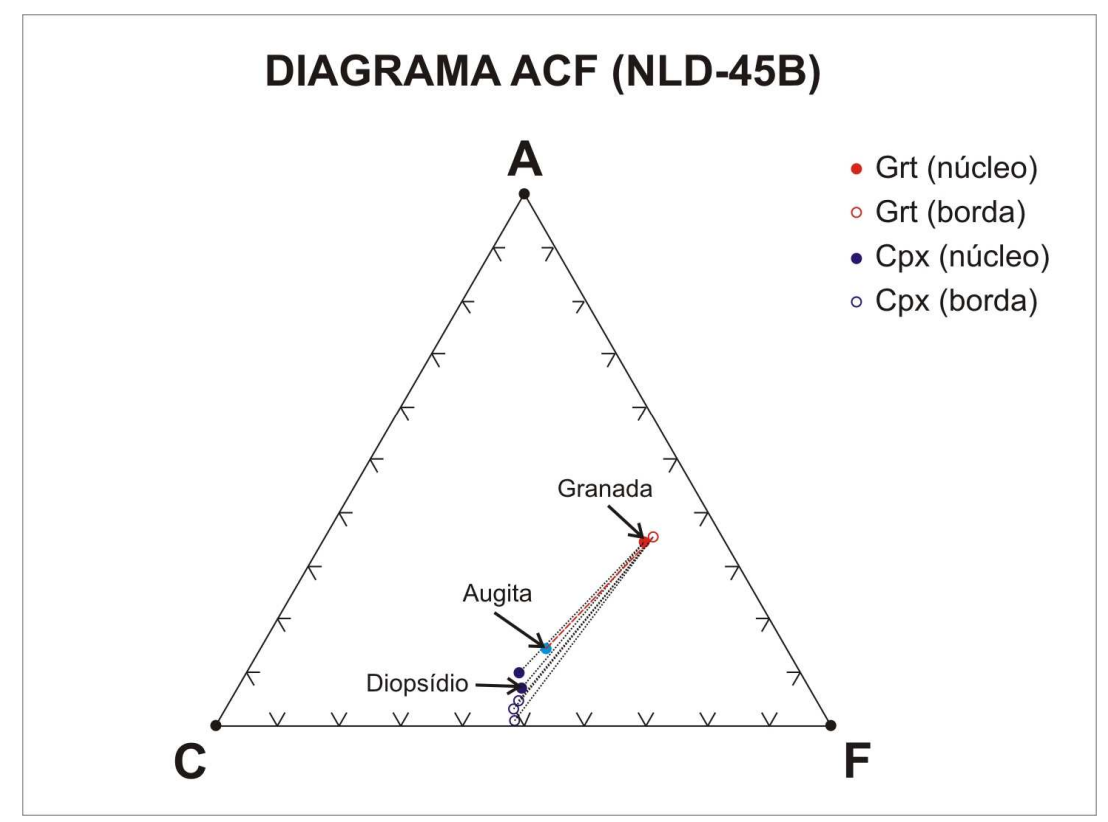

Figura 73: Diagrama ACF para metacharnockito anidro (amostra NLD-45B). Parâmetros: $\mathrm{A}=\mathrm{Al}_{2} \mathrm{O}_{3}+\mathrm{Fe}_{2} \mathrm{O}_{3}-\left(\mathrm{Na}_{2} \mathrm{O}+\mathrm{K}_{2} \mathrm{O}\right) ; \mathrm{C}=\mathrm{CaO} ; \mathrm{F}=\mathrm{FeO}+\mathrm{MgO}+\mathrm{MnO}$.

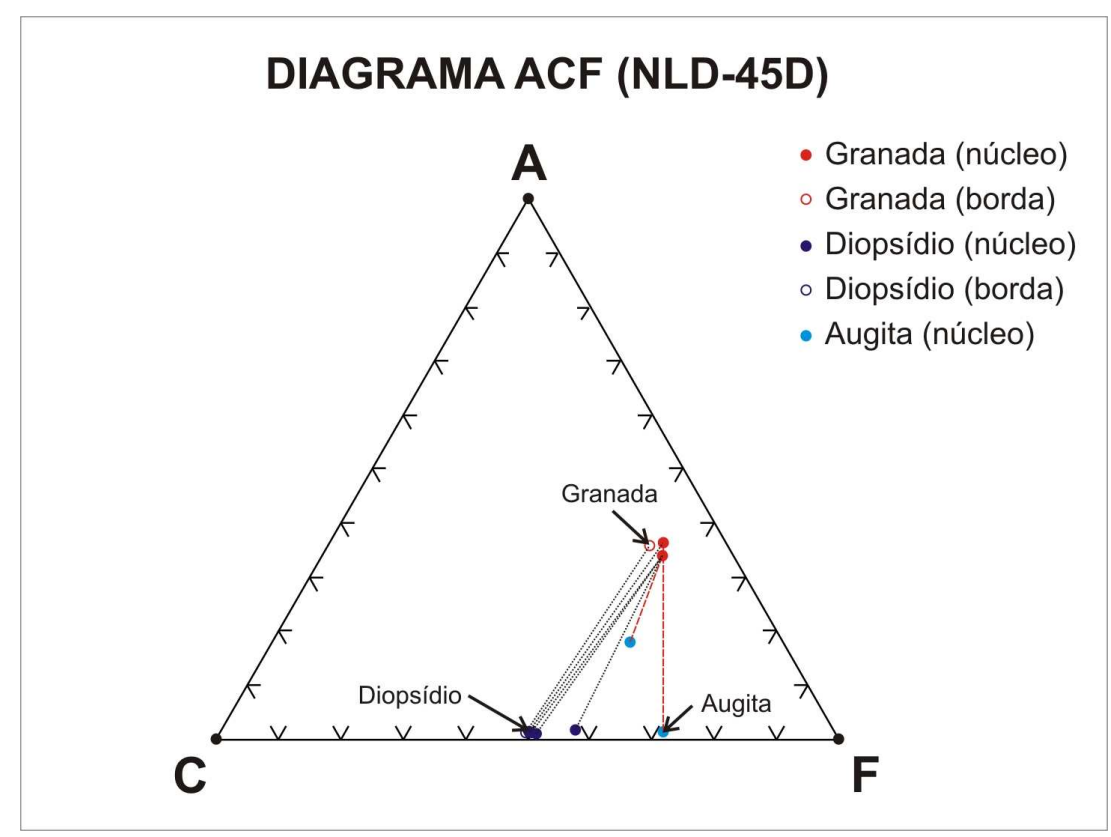

Figura 74: Diagrama ACF para metacharnockito hidratado (amostra NLD-45D). Parâmetros: $\mathrm{A}=\mathrm{Al}_{2} \mathrm{O}_{3}+\mathrm{Fe}_{2} \mathrm{O}_{3}-\left(\mathrm{Na}_{2} \mathrm{O}+\mathrm{K}_{2} \mathrm{O}\right) ; \mathrm{C}=\mathrm{CaO} ; \mathrm{F}=\mathrm{FeO}+\mathrm{MgO}+\mathrm{MnO}$. 


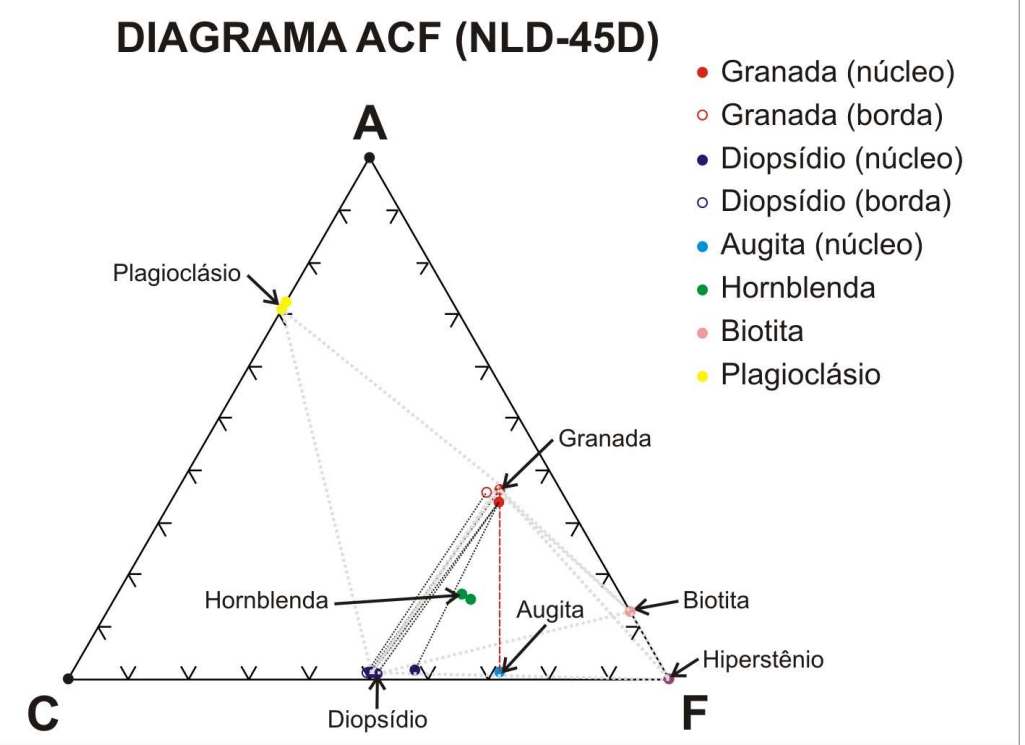

Figura 75: Diagrama ACF para metacharnockito hidratado (amostra NLD-45D). Parâmetros: $\mathrm{A}=\mathrm{Al}_{2} \mathrm{O}_{3}+\mathrm{Fe}_{2} \mathrm{O}_{3}-\left(\mathrm{Na}_{2} \mathrm{O}+\mathrm{K}_{2} \mathrm{O}\right) ; \mathrm{C}=\mathrm{CaO} ; \mathrm{F}=\mathrm{FeO}+\mathrm{MgO}+\mathrm{MnO}$.

\subsubsection{Geotermobarometria dos paragnaisses}

\subsubsection{Banco de dados internamente consistentes (THERMOCALC)}

Paragnaisses- THERMOCALC (Holland \& Powell, 1988)

\begin{tabular}{cccccc}
\hline Amostra & Assoc. Mineral & Localização & $\mathbf{T}\left({ }^{\circ} \mathbf{C}\right)$ & $\mathbf{P}$ (Kbar) & corr \\
\hline OL-II-112B & Grt-Bt-Sil-Kfs-IIm-Rt & inclusão & $791 \pm 28$ & $8.4 \pm 1$ & 0.884 \\
OL-II-112B & Grt-Bt-Sil-Kfs-IIm-Rt & inclusão & $789 \pm 27$ & $8.4 \pm 1.2$ & 0.802 \\
OL-II-112B & Grt-Bt-Sil-Kfs-IIm-Rt & inclusão & $820 \pm 43$ & $8.6 \pm 1.5$ & 0.874 \\
OL-II-112B & Grt-Bt-Sil-Kfs-IIm-Rt & inclusão & $827 \pm 44$ & $8.2 \pm 1.8$ & 0.809 \\
OL-II-112B & Grt-Bt-Sil-Kfs-IIm-Rt & inclusão & $810 \pm 31$ & $8.1 \pm 1.3$ & 0.801 \\
OL-II-112B & Grt-Bt-Ky-Sil-Kfs-IIm & inclusão & $806 \pm 26$ & $10 \pm 0.6$ & 0.981 \\
OL-II-112B & Grt-Bt-Ky-Sil-Kfs-IIm & inclusão & $807 \pm 25$ & $10 \pm 0.6$ & 0.981 \\
OL-II-112B & Grt-Bt-Ky-Sil-Kfs-IIm & inclusão & $779 \pm 58$ & $9.4 \pm 1.3$ & 0.979 \\
OL-II-112B & Grt-Bt-Sil-Ms-Kfs-IIm-Rt & matriz & $751 \pm 51$ & $7 \pm 1.3$ & 0.512 \\
OL-II-112B & Grt-Bt-Sil-Ms-Kfs-IIm-Rt & matriz & $758 \pm 53$ & $7 \pm 1.2$ & 0.54 \\
OL-III-39A & Grt-Bt-PI-IIm-Rt & inclusão & $591 \pm 125$ & $5.3 \pm 1.3$ & 0.712 \\
OL-III-39A & Grt-Bt-PI-IIm-Rt & inclusão & $677 \pm 136$ & $6.2 \pm 1.5$ & 0.754 \\
OL-III-39A & Grt-Bt-PI-IIm-Rt & inclusão & $605 \pm 100$ & $5.7 \pm 1.1$ & 0.724 \\
OL-III-39A & Grt-Bt-PI-IIm-Rt & inclusão & $610 \pm 141$ & $5.5 \pm 1.4$ & 0.723 \\
OL-III-39A & Grt-Bt-PI-IIm-Rt & inclusão & $666 \pm 114$ & $6.2 \pm 1.2$ & 0.757 \\
OL-III-39A & Grt-Bt-PI-IIm-Rt & inclusão & $698 \pm 160$ & $6.8 \pm 1.7$ & 0.786 \\
OL-III-39A & Grt-Bt-PI-Sil & matriz & $676 \pm 140$ & $5.8 \pm 2.1$ & 0.781 \\
OL-III-39A & Grt-Bt-Pl-Sil & matriz & $628 \pm 128$ & $5.2 \pm 1.9$ & 0.768 \\
\hline
\end{tabular}

Tabela 1: Resultados dos cálculos termobarométricos obtidos no THERMOCALC (Holland \& Powell, 1988) para os paragnaisses. 
A preservação de inclusões minerais associadas com a cianita em porfiroblasto de granada na amostra OL-II-112B permitiu a determinação das condições de pico metamórfico dos paragnaisses. Os cálculos termobarométricos foram realizados utilizando o método de banco de dados internamente consistentes, através do THERMOCALC (Powell \& Holland, 1988). As condições de pico bárico foram calculadas através da associação envolvendo cianita (Grt-Ms-Bt-Kfs-Ky-Sil-Ilm-Rt), com pressão máxima de $10 \pm 0.6 \mathrm{kbar}$, para temperatura de $807 \pm 25^{\circ} \mathrm{C}$ (Tabela 1 , Figura 76).

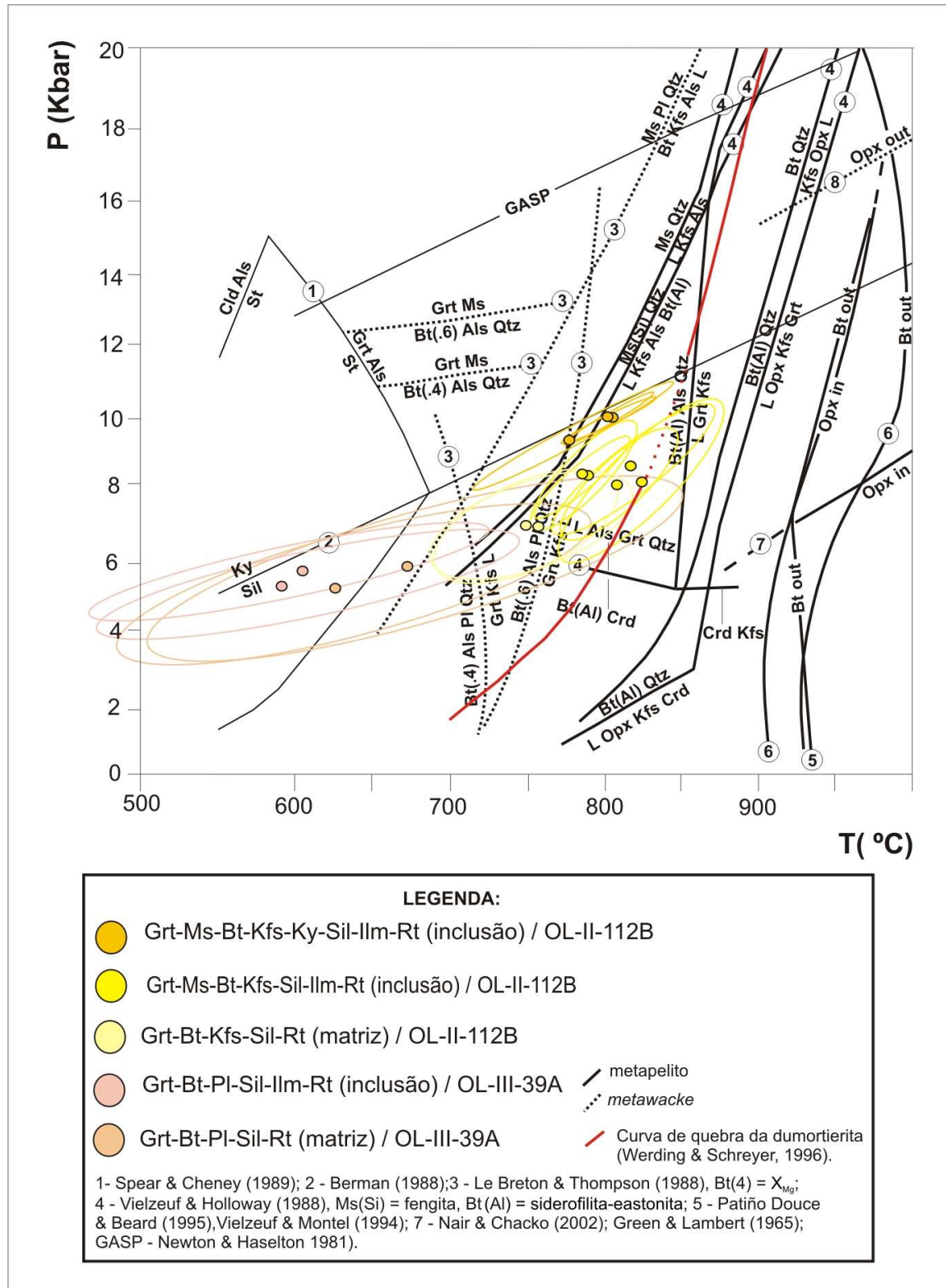

Figura 76: Dados de temperatura e pressão dos paragnaisses obtidos no THERMOCALC (Powell \& Holland, 1988), com os erros dos cálculos representados pelas elipses (amostras OL-II-112B e OL-III39A). 
O pico térmico foi calculado com associação mineral envolvendo sillimanita (Grt-Ms-Bt-Kfs-Sil-Ilm-Rt), em que a temperatura máxima obtida foi de $827 \pm 44^{\circ} \mathrm{C}$, para pressão de $8.2 \pm 1.8$, no limite da curva de quebra da dumortierita (Figura 76). As condições obtidas com cálculos envolvendo fases minerais da matriz na amostra OL-II112B são da ordem de $758 \pm 53^{\circ} \mathrm{C}$ para pressão de $7 \pm 1.2 \mathrm{kbar}$. Os cálculos realizados na amostra OL-III-39A não foram satisfatórios, pois apresentaram erros grandes para temperatura. As inclusões de granada na amostra OL-III-39A indicam temperaturas máximas de $698 \pm 160^{\circ} \mathrm{C}$ para pressão de $6.8 \pm 1.7 \mathrm{kbar}$, enquanto que na matriz a temperatura máxima é da ordem de $676 \pm 140$, para pressão de $5.8 \pm 2.1$ kbar.

\subsubsection{Geotermobarometria clássica}

\subsection{Geotermômetro granada-biotita (Grt-Bt)}

O geotermômetro granada-biotita desenvolvido por Ferry \& Spear (1978) é um dos mais amplamente utilizados em rochas de composição pelítica. Sua calibração é baseada na troca Fe-Mg (exchange reaction) entre cristais de granada e biotita coexistentes, através da seguinte reação:

$$
\begin{array}{ccc}
1 / 3 \mathrm{Fe}_{3} \mathrm{Al}_{2} \mathrm{Si}_{3} \mathrm{O}_{12} & +1 / 3 \mathrm{KMg}_{3} \mathrm{AlSi}_{3} \mathrm{O}_{10}(\mathrm{OH})_{2}=\underset{3}{1 / 3 \mathrm{Mg}_{3} \mathrm{Al}_{2} \mathrm{Si}_{3} \mathrm{O}_{12}}+\underset{3}{1 / 3 \mathrm{KFe}_{3}} \mathrm{AlSi}_{3} \mathrm{O}_{10}(\mathrm{OH})_{2} \\
\text { (almandina) } & \text { (flogopita) } & \text { (piropo) }
\end{array}
$$

Neste trabalho foram utilizadas as calibrações de Ferry \& Spear (1978) e Indares \& Martignole (1985), devido à sua aplicação para rochas em fácies granulito. Os cálculos obtidos na amostra OL-II-112B com as inclusões de biotita na granada e com as composições do núcleo do porfiroblasto de granada forneceram temperaturas máximas de $654.3^{\circ} \mathrm{C}$ (Ferry \& Spear, 1978) e $572.8^{\circ} \mathrm{C}$ (Indares \& Martignole, 1985), para pressão de $10 \mathrm{Kbar}$. Os resultados obtidos com biotita da matriz e composições da borda da granada na mesma amostra forneceram temperaturas máximas de $778.9^{\circ} \mathrm{C}$ (Ferry \& Spear, 1978) e $645.3^{\circ} \mathrm{C}$ (Indares \& Martignole, 1985). Na amostra OL-III-39A os cálculos foram feitos para pressão de $7 \mathrm{Kbar}$ e forneceram temperaturas inferiores àquelas obtidas na amostra OL-II-112B. Os dados obtidos a partir de pares de granada e biotita da matriz também forneceram temperaturas mais elevadas do que os cálculos obtidos a partir das inclusões (Tabela 2). 


\begin{tabular}{ccc}
\multicolumn{3}{c}{ Paragnaisses } \\
\hline \multicolumn{3}{c}{ Geotermômetro Grt-Bt (Para P=10Kbar) } \\
\hline & $\begin{array}{c}\text { Ferry \& } \\
\text { Spear (1978) }\end{array}$ & $\begin{array}{c}\text { Indares \& } \\
\text { Martignole (1985) }\end{array}$ \\
Amostra & $\mathrm{T}\left({ }^{\circ} \mathrm{C}\right)$ & $\mathrm{T}\left({ }^{\circ} \mathrm{C}\right)$ \\
\hline Inclusões na granada \\
OL-II-112B & 624.1 & 510.1 \\
OL-II-112B & 631.6 & 519.2 \\
OL-II-112B & 654.3 & 572.8 \\
OL-II-112B & Matriz \\
OL-II-112B & 745.1 & 616 \\
OL-II-112B & 778.9 & 645.3 \\
& 705.1 & 593
\end{tabular}

\begin{tabular}{|c|c|c|}
\hline \multicolumn{3}{|c|}{ Paragnaisses } \\
\hline \multicolumn{3}{|c|}{ Geotermômetro Grt-Bt (Para P=7Kbar) } \\
\hline & $\begin{array}{c}\text { Ferry \& } \\
\text { Spear (1978) }\end{array}$ & $\begin{array}{c}\text { Indares \& } \\
\text { Martignole (1985) }\end{array}$ \\
\hline Amostra & $\mathrm{T}\left({ }^{\circ} \mathrm{C}\right)$ & $\mathrm{T}\left({ }^{\circ} \mathrm{C}\right)$ \\
\hline \multicolumn{3}{|c|}{ Inclusões na granada } \\
\hline OL-III-39A & 538.4 & 489.9 \\
\hline OL-III-39A & 548.1 & 500.5 \\
\hline \multicolumn{3}{|c|}{ Matriz } \\
\hline OL-III-39A & 666.1 & 581.8 \\
\hline OL-III-39A & 619.9 & 536.1 \\
\hline OL-III-39A & 634.8 & 553.9 \\
\hline
\end{tabular}

Tabela 2: Resultados obtidos através do geotermômetro granada-biotita (Grt-Bt).

\subsection{Geotermômetro Zr-em-rutilo}

Foram obtidas análises de rutilo em duas amostras dos paragnaisses (OL-II112B e OL-III-39A), para aplicação do geotermômetro de Zr-em-rutilo. Este método baseia-se no aumento do conteúdo de zircônio no rutilo com o aumento da temperatura e na mudança de volume necessária para a substituição catiônica de $\mathrm{Zr}^{4+}$ por $\mathrm{Ti}^{4+}$, sugerindo uma pressão-dependência do termômetro (diminuição do zircônio com o aumento da pressão).

Tomkins et al. (2007) realizaram experimentos a 10, 20 e 30 Kbar para a determinação termodinâmica dos membros-finais da reação $\mathrm{ZrSiO}_{4}(\mathrm{Zrc})=\mathrm{ZrO}_{2}(\mathrm{Bd}$ em $\mathrm{Rt})+\mathrm{SiO}_{2}(\mathrm{Qtz})$ e de novas equações termométricas. Para o cálculo da temperatura foram utilizadas as equações obtidas através de calibração experimental de Watson et al. (2006) e Tomkins et al. (2007). Os resultados obtidos estão apresentados na Figura 77 e nas Tabelas 3 e 4.

(1) Watson et al. (2006):

$$
\mathrm{T}\left({ }^{\circ} \mathrm{C}\right)=\frac{4470 \pm 120}{(7.36 \pm 0.1)-\log (\mathrm{Zr})}-273
$$

(2) Tomkins et al. (2007):

$$
\mathrm{T}\left({ }^{\circ} \mathrm{C}\right)=\frac{83.9+0.410 \mathrm{P}}{0.1428-\mathrm{R} \ln (\mathrm{Zr})}-273 \quad \text { Onde: } \mathrm{R}=\text { constante dos gases }(0.0083144 \mathrm{~kJ} / \mathrm{K})
$$$$
\mathrm{Zr}=\mathrm{ppm} \mathrm{Zr}
$$

Foram utilizados para os cálculos grãos de rutilo inclusos em porfiroblastos de granada. Os maiores conteúdos de zircônio estão preservados em grãos de rutilo 
localizados no núcleo do porfiroblasto de granada da amostra OL-II-112B, que forneceram temperaturas máximas de $748.5^{\circ} \mathrm{C}$ (Figura 71). Na amostra OL-III-39A não foram identificados cristais de rutilo inclusos no núcleo de granada, somente nas bordas. A temperatura máxima obtida nesta amostra é da ordem de $686.6^{\circ} \mathrm{C}$.

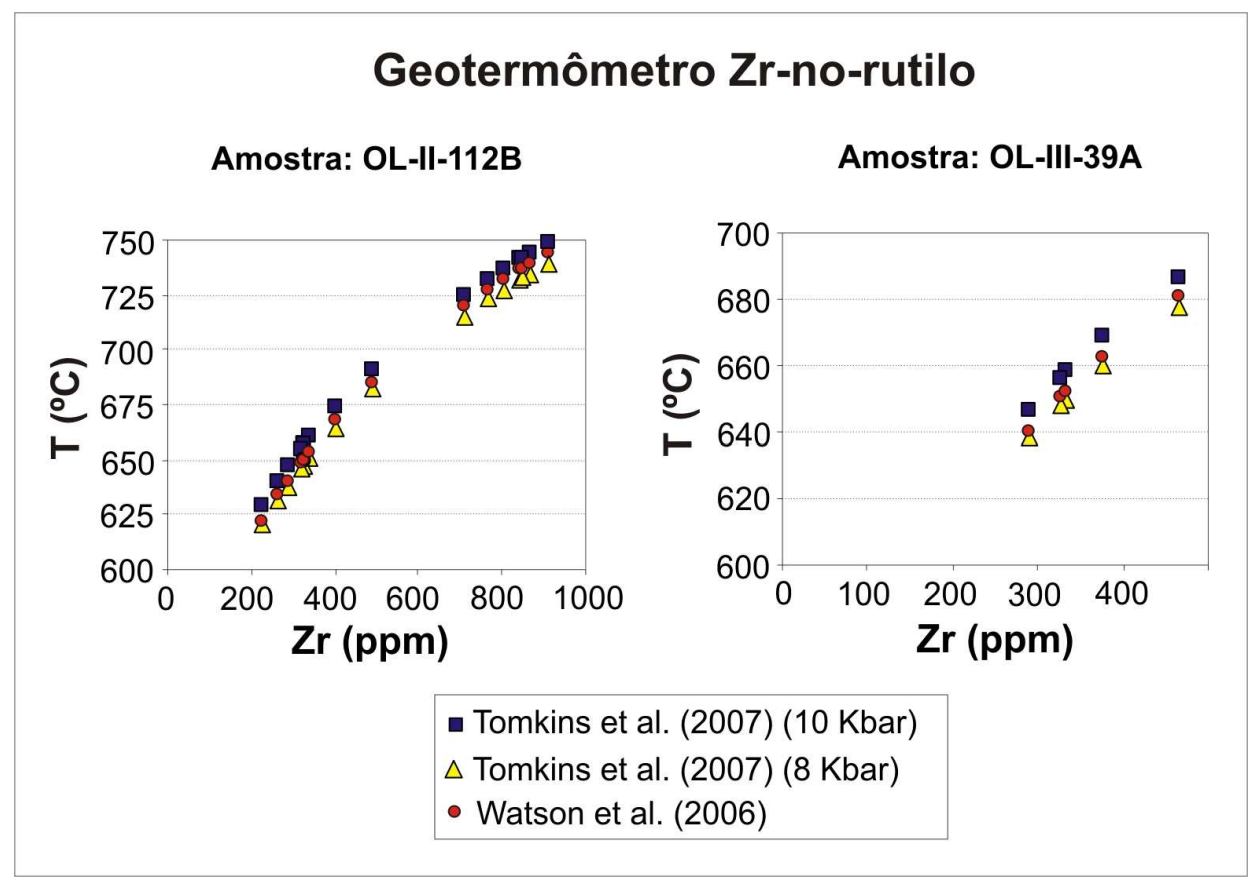

Figura 77: Gráfico de temperatura versus ppm Zr com os resultados da termometria de $\mathrm{Zr}$ no rutilo para os paragnaisses, segundo Tomkins et al. (2007) e Watson et al. (2006).

Resultados de Termometria de Zr em Rutilo (Amostra OL-II-112B)

\begin{tabular}{cccccccc}
\hline Localização & $\mathbf{Z r}_{2} \mathbf{O}_{3}$ & ppm $\mathbf{Z r}$ & $\begin{array}{c}\text { Watson } \\
\mathbf{( 2 0 0 6 )}\end{array}$ & $\mathbf{P}$ (Kbar) & $\begin{array}{c}\text { Tomkins } \\
\text { et al. (2007) }\end{array}$ & $\mathbf{P}$ (Kbar) & $\begin{array}{c}\text { Tomkins } \\
\text { et al. (2007) }\end{array}$ \\
\hline borda & 0.044 & 325.7 & 649.6 & 8 & 647.7 & 10 & 656.3 \\
borda & 0.036 & 266.5 & 633.3 & 8 & 631.7 & 10 & 640.2 \\
borda & 0.054 & 399.8 & 666.8 & 8 & 664.5 & 10 & 673.3 \\
borda & 0.039 & 288.7 & 639.7 & 8 & 638.0 & 10 & 646.6 \\
borda & 0.046 & 340.5 & 653.3 & 8 & 651.3 & 10 & 660.0 \\
borda & 0.066 & 488.6 & 684.4 & 8 & 681.7 & 10 & 690.6 \\
borda & 0.031 & 229.5 & 636.2 & 8 & 620.2 & 10 & 628.6 \\
borda & 0.044 & 325.7 & 649.6 & 8 & 647.7 & 10 & 656.3 \\
borda & 0.043 & 318.3 & 648.6 & 8 & 645.8 & 10 & 654.5 \\
núcleo & 0.117 & 866.2 & 738.3 & 8 & 734.2 & 10 & 743.6 \\
núcleo & 0.114 & 843.9 & 735.7 & 8 & 731.6 & 10 & 741.1 \\
núcleo & 0.115 & 851.3 & 736.6 & 8 & 732.5 & 10 & 741.9 \\
núcleo & 0.096 & 710.7 & 723.1 & 8 & 715.4 & 10 & 724.7 \\
núcleo & 0.123 & 910.6 & 743.3 & 8 & 739.0 & 10 & 748.5 \\
núcleo & 0.104 & 769.9 & 730.6 & 8 & 722.9 & 10 & 732.3 \\
núcleo & 0.109 & 806.9 & 731.3 & 8 & 727.3 & 10 & 736.8 \\
núcleo & 0.123 & 910.6 & 743.3 & 8 & 739.0 & 10 & 748.5 \\
\hline
\end{tabular}

Tabela 3: Resultados obtidos com a termometria de zircônio no rutilo (Watson, 2006; Tomkins et al., 2007) para a amostra OL-II-112B. 
Resultados de Termometria de Zr em Rutilo (Amostra OL-III-39A)

\begin{tabular}{cccccccc}
\hline Localização & $\mathbf{Z r}_{\mathbf{2}} \mathbf{O}_{\mathbf{3}}$ & ppm Zr & $\begin{array}{c}\text { Watson } \\
\mathbf{( 2 0 0 6 )}\end{array}$ & $\mathbf{P}$ (Kbar) & $\begin{array}{c}\text { Tomkins } \\
\text { et al. (2007) }\end{array}$ & P (Kbar) & $\begin{array}{c}\text { Tomkins } \\
\text { et al. (2007) }\end{array}$ \\
\hline borda & 0.045 & 333.1 & 651.4 & 8 & 649.5 & 10 & 658.2 \\
borda & 0.063 & 466.4 & 680.3 & 8 & 677.6 & 10 & 686.6 \\
borda & 0.044 & 325.7 & 656.7 & 8 & 647.7 & 10 & 656.3 \\
borda & 0.039 & 288.7 & 639.7 & 8 & 638.0 & 10 & 646.6 \\
borda & 0.051 & 377.6 & 662.0 & 8 & 659.8 & 10 & 668.5 \\
\hline
\end{tabular}

Tabela 4: Resultados obtidos com a termometria de zircônio no rutilo (Watson, 2006; Tomkins et al., 2007) para a amostra OL-III-39A.

\subsection{Geobarômetro GASP}

O geobarômetro granada-aluminossilicato-quartzo-plagioclásio (GASP) é aplicável para rochas de composição pelítica em fácies anfibolito, granulito e eclogito, e baseia-se na seguinte reação de transferência de rede (net-transfer-reaction):

$$
\begin{gathered}
3 \mathrm{CaAl}_{2} \mathrm{Si}_{2} \mathrm{O}_{8} \\
\text { (anortita) }
\end{gathered}
$$

Foram utilizadas as calibrações de Newton \& Haselton (1981), Koziol \& Newton (1988) e Koziol (1989) na amostra OL-III-39A. Os cálculos foram realizados para temperatura de $800^{\circ} \mathrm{C}$ e a pressão máxima obtida foi de 7.2Kbar (Koziol, 1989) para composições da matriz. Os resultados obtidos com composições de núcleo de granada e inclusões de plagioclásio forneceram pressões máximas de 6.9Kbar (Koziol, 1989) (Tabela 5). Não foi possível aplicar este geobarômetro na amostra OL-II-112B devido à ausência de plagioclásio.

\begin{tabular}{cccc}
\multicolumn{4}{c}{ Paragnaisses } \\
\hline \multicolumn{4}{c}{ Geobarômetro GASP (Para T=800 $\mathrm{C}$ ) } \\
$\begin{array}{c}\text { Newton \& } \\
\text { Haselton (1981) }\end{array}$ & $\begin{array}{c}\text { Koziol \& } \\
\text { Newton (1988) }\end{array}$ & Koziol (1989) \\
Amostra & P (kbar) & P (Kbar) & P (Kbar) \\
\hline \multicolumn{4}{c}{ Inclusões na granada } \\
OI-III-39A & 5.7 & 6.2 \\
OI-III-39A & 5.2 & 5.8 & 6.9 \\
OI-III-39A & 5.8 & 6.3 & 6.4 \\
OI-III-39A & 6 & 6.5 & 7.1 \\
\hline
\end{tabular}

Tabela 5: Resultados obtidos através do geobarômetro granada-aluminossilicato-quartzo-plagioclásio (GASP). 


\subsubsection{Geotermobarometria das rochas metabásicas}

\subsubsection{Banco de dados internamente consistentes (THERMOCALC)}

As fases minerais presentes nas rochas metabásicas foram fortemente afetadas por processos retrometamórficos, o que facilitou a difusão química nas associações minerais de pico metamórfico. Os cálculos termobarométricos realizados através do método de banco de dados internamente consistentes utilizando a versão 3.26 do THERMOCALC (Powell \& Holland, 1988) apresentaram-se relativamente satisfatórios (Tabela 6).

Rochas metabásicas - THERMOCALC (Holland \& Powell, 1988)

\begin{tabular}{|c|c|c|c|c|}
\hline Amostra & Assoc. Mineral & $\mathrm{T}\left({ }^{\circ} \mathrm{C}\right)$ & $P$ (Kbar) & corr \\
\hline NLD-7D & Grt-Cpx-Opx-PI-Hbl & $890 \pm 41$ & $9.26 \pm 1.93$ & 0.612 \\
\hline NLD-7D & Grt-Cpx-Opx-PI-Hbl & $784 \pm 111$ & $6.92 \pm 1.67$ & 0.516 \\
\hline NLD-7D & Grt-Cpx-Opx-PI-Hbl & $683 \pm 70$ & $8.35 \pm 1.2$ & 0.535 \\
\hline NLD-7D & Grt-Cpx-Opx-PI-Hbl & $731 \pm 83$ & $8.67 \pm 1.26$ & 0.523 \\
\hline NLD-7D & Grt-Cpx-Opx-PI-Hbl & $717 \pm 77$ & 8.93 & 0.54 \\
\hline NLD-7D & Grt-Cpx-Opx-PI-Hbl & $757 \pm 78$ & $8.7 \varepsilon$ & 0.54 \\
\hline NLD-20A & Grt-Cpx-P & $709 \pm 66$ & 8.3 & 0.614 \\
\hline NLD-20A & Grt-Cpx- & $690 \pm 63$ & $8.6=$ & 0.617 \\
\hline NLD-20A & Grt-Cpx & $731 \pm 66$ & $9 \pm$ & 0.618 \\
\hline NLD-20A & Grt-Cpx-PI-Hbl & $768 \pm 90$ & $8.8 \pm 1.5$ & 0.519 \\
\hline NLD-20A & Grt-Cpx-PI-Hbl & $699 \pm 85$ & $8 \pm 1.4$ & 0.519 \\
\hline NLD-20A & Grt-Cpx-PI-Hbl & $714 \pm 81$ & $8.8 \pm 1.4$ & 0.545 \\
\hline NLD-42D & Grt-Cpx-PI-Qtz-IIm & $662 \pm 66$ & $7.3 \pm 0.8$ & 0.727 \\
\hline NLD-42D & Grt-Cpx-PI-Qtz-IIm & $794 \pm 167$ & $8.8 \pm 2.0$ & 0.683 \\
\hline NLD-42D & Grt-Cpx-PI-Qtz-IIm & $680 \pm 64$ & $7.3 \pm 0.8$ & 0.717 \\
\hline NLD-42D & Grt-Cpx-PI-Qtz-IIm & $674 \pm 76$ & $7.1 \pm 0.9$ & 0.7 \\
\hline
\end{tabular}

Tabela 6: Resultados dos cálculos termobarométricos obtidos no THERMOCALC (Holland \& Powell, 1988) para as rochas metabásicas.

As condições de pico metamórfico das rochas metabásicas estão preservadas no granada-granulito (amostra NLD-7D). Os cálculos envolvendo a associação Grt-CpxOpx-Pl-Hbl forneceram temperatura máxima de $890 \pm 41^{\circ} \mathrm{C}$ para pressão de $9.26 \pm 1.93$ kbar (Figura 78). Foram realizados cálculos adicionais envolvendo associações com ortopiroxênio, porém com valores de temperatura e pressão inferiores, possivelmente devido à maior difusão química (temperatura de $784 \pm 111^{\circ} \mathrm{C}$, a $6.92 \pm 1.67 \mathrm{kbar}$ ). $\mathrm{O}$ hornblenda metagabro inserido nos ortognaisses do Complexo Mantiqueira registra temperatura máxima de $768 \pm 90^{\circ} \mathrm{C}$, a $8.8 \pm 1.5 \mathrm{kbar}$.

Os metagabronoritos intercalados nas rochas charnockíticas associadas ao Complexo Mantiqueira preservam texturas coroníticas relacionadas ao pico 
metamórfico, porém os intensos processos de difusão química modificaram as composições originais da associação granada-clinopiroxênio-plagioclásio. Os resultados obtidos através do THERMOCALC na amostra NLD-42C foram considerados inconsistentes e não foram apresentados neste trabalho, pois os dados de temperatura estavam com erros muito elevados. Na amostra NLD-42D, a temperatura máxima obtida é da ordem de $794 \pm 167^{\circ} \mathrm{C}$, a $8.8 \pm 2.0$ kbar. Os cálculos que envolveram os menores erros, expressos em elipses mais estreitas na Figura 78, foram de $680 \pm 64^{\circ} \mathrm{C}$, para pressão de $7.3 \pm 0.8$ kbar.

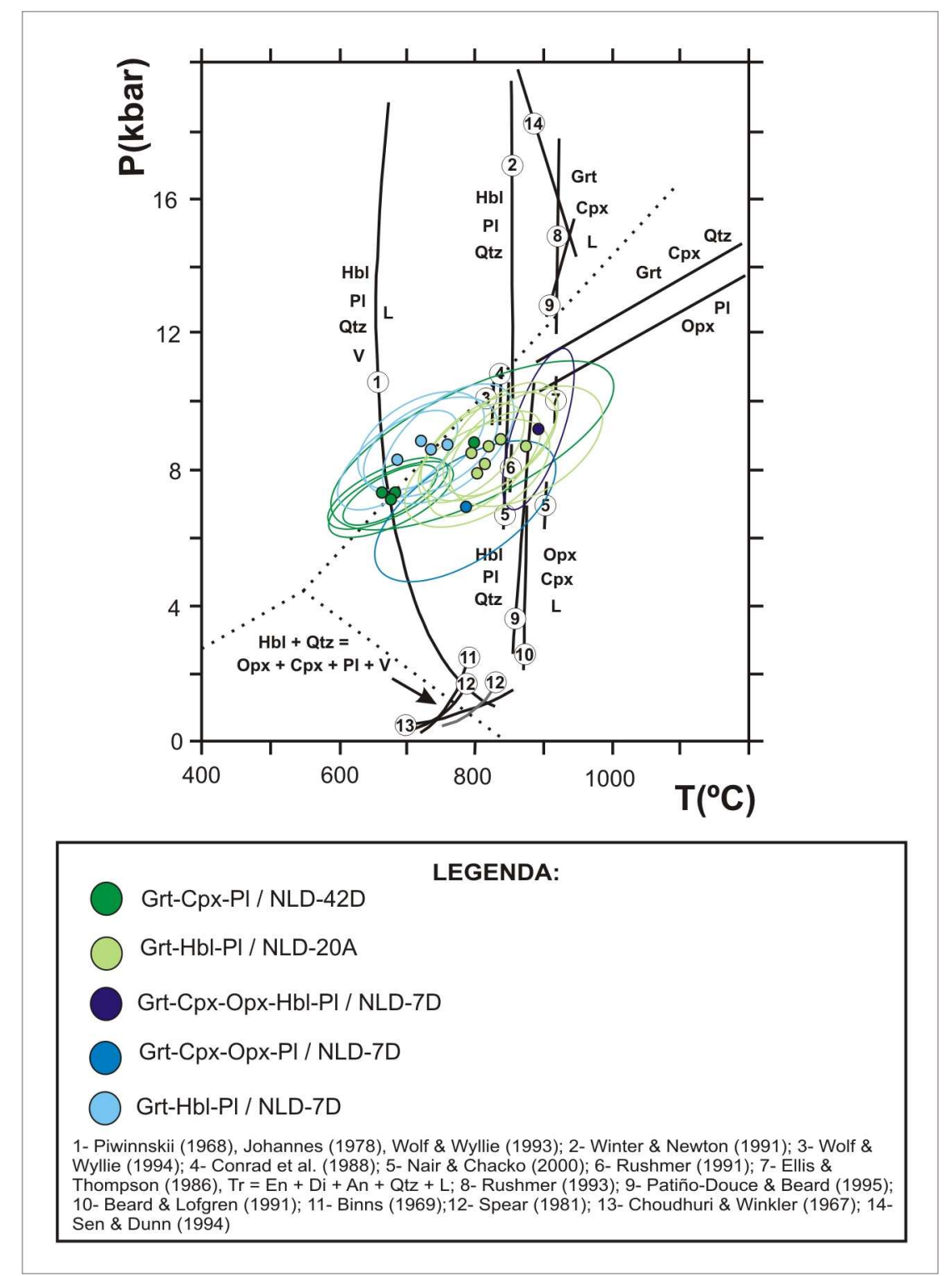

Figura 78: Dados de temperatura e pressão das rochas metabásicas obtidos no THERMOCALC (Powell \& Holland, 1988), com os erros dos cálculos representados pelas elipses (amostras NLD-42D, NLD-20A e NLD-7D). 


\subsubsection{Banco de dados internamente consistentes (TWEEQU)}

Foram realizados cálculos termobarométricos complementares nas rochas metabásicas utilizando o banco de dados internamente consistentes do TWEEQU (Thermobarometry With Estimation of EQUilibrium state), versão 1.02 (Berman, 1988, 1991). Este software calcula os estados de equilíbrio das associações minerais a partir da utilização de modelos de atividades dependentes de P-T, provenientes de dados experimentais e aplicados a associações naturais. Os modelos de atividades utilizados na versão 1.02 foram: Fuhrman \& Lindsley (1988) para o plagioclásio, Berman (1990) para a granada e Newton (1983) para os piroxênios. As condições de pico metamórfico estão registradas no granada granulito (NLD-7D). Cálculos envolvendo a associação de fácies granulito $\mathrm{Grt}+\mathrm{Cpx}+\mathrm{Opx}+\mathrm{Pl}+\mathrm{Qtz}$ forneceram temperaturas de $801^{\circ} \mathrm{C}$, a $9.6 \mathrm{kbar}$ (Figura 79). Os resultados obtidos no TWEEQU para o granada granulito foram considerados satisfatórios, pois corroboram com os resultados obtidos através de outros métodos, como o THERMOCALC e a geotermobarometria convencional.

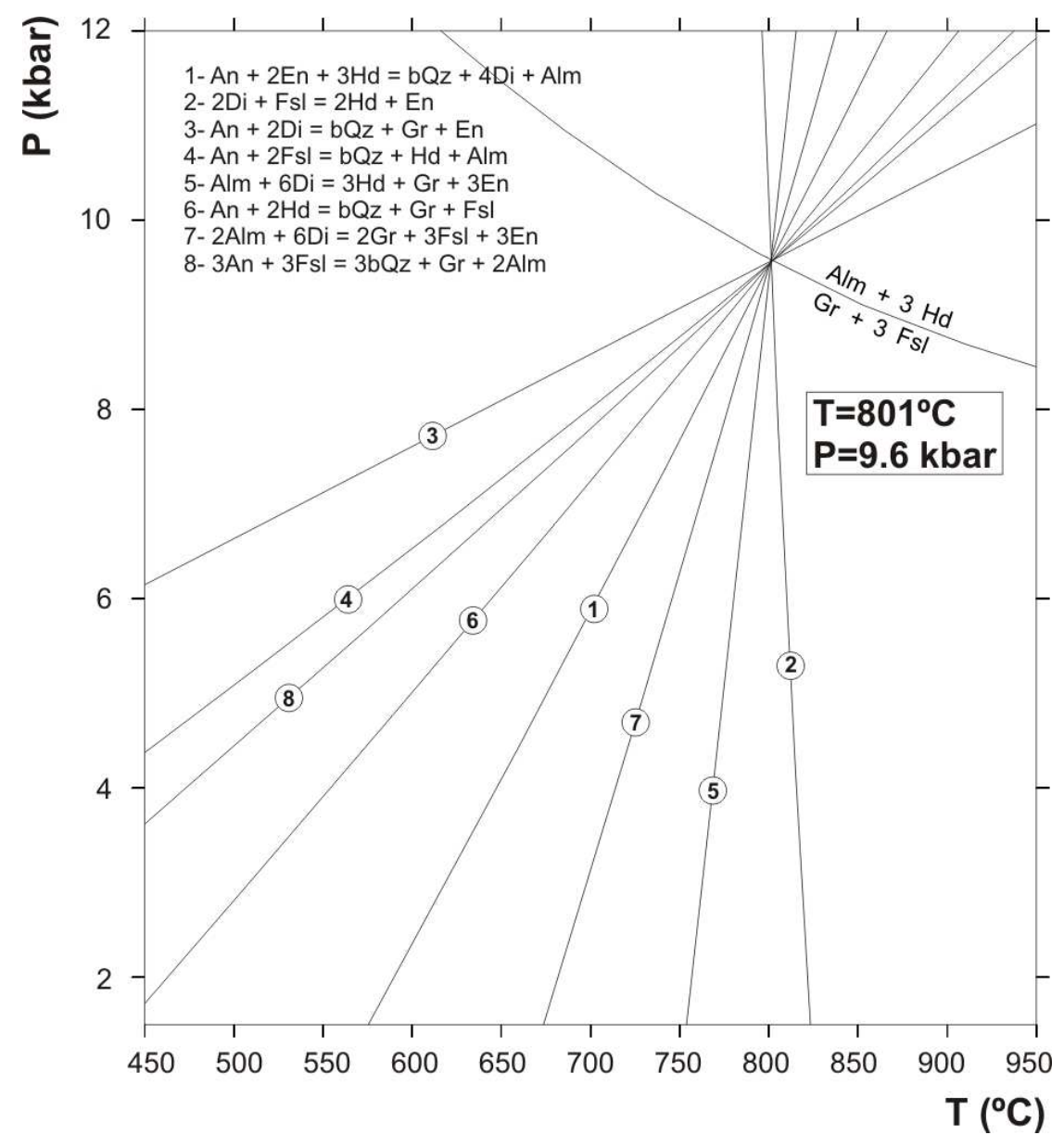

Figura 79: Dados de temperatura e pressão para granada granulito obtidos no TWEEQU (Berman, 1991), (amostra NLD-7D). 


\subsubsection{Geotermobarometria convencional}

\subsection{Geotermômetro Grt-Cpx}

O método de Ganguly (1979) consiste na integração dos dados termodinâmicos disponíveis de granada e clinopiroxênio com dados termoquímicos e experimentais para expressar o coeficiente de distribuição de $\mathrm{Fe}-\mathrm{Mg}\left(\mathrm{K}_{\mathrm{D}}\right)$ entre essas fases avaliando o efeito de $\mathrm{Mn}$ e $\mathrm{Ca}$ no $\mathrm{K}_{\mathrm{D}}^{\mathrm{Fe}-\mathrm{Mg}}$, em função da pressão, temperatura e composição química. Devido à ausência de dados adequados na propriedade de mistura de jadeíta com diopsídio e hedenbergita, a aplicação do geotermômetro é restrita a composições pobres em Na. $\mathrm{O}$ modelo de dependência composicional do $K_{\mathrm{D}}$ é restrita à pares naturais de Grt-Cpx no sistema $\mathrm{FeO}-\mathrm{MgO}-\mathrm{CaO}-\mathrm{MnO}-\mathrm{Al}_{2} \mathrm{O}_{3}-\mathrm{SiO}_{2}$. O coeficiente de distribuição $\left(\mathrm{K}_{\mathrm{D}}\right)$ envolve o $\mathrm{Fe}^{2+}$ e não leva em consideração o conteúdo total de ferro da granada e clinopiroxênio. Como o estado de valência não pode ser determinado através de análises de microssonda eletrônica, o ferro total é freqüentemente equacionado com $\mathrm{FeO}$.

O método de Sengupta et al. (1989) consiste em uma extensão da formulação original de Ellis \& Green (1979), incorporando os termos associados aos coeficientes de atividade dos cátions $\mathrm{Fe}^{2+} \mathrm{e} \mathrm{Mg}$, o que permite obter resultados mais consistentes tanto em granulitos de crosta normal, como em rochas ricas em $\mathrm{Mn}$. A troca $\mathrm{Fe}^{2+}-\mathrm{Mg}$ entre a granada e o clinopiroxênio é baseada na seguinte reação de troca (exchange reaction):

$$
\begin{gathered}
\frac{1 / 3}{\mathrm{Mg}_{3} \mathrm{Al}_{2} \mathrm{Si}_{3} \mathrm{O}_{12}}+\mathrm{CaFeSi}_{2} \mathrm{O}_{6} \leftrightarrow 1 / 3 \mathrm{Fe}_{3} \mathrm{Al}_{2} \mathrm{Si}_{3} \mathrm{O}_{12}+\mathrm{CaMgSi}_{2} \mathrm{O}_{6} \\
\text { (piropo) (hedenbergita) } \quad \text { (almandina) (diopsídio) }
\end{gathered}
$$

A formulação de Ellis \& Green (1979) foi extendida para obter a seguinte expressão termométrica:

$$
\mathrm{T}\left({ }^{\circ} \mathrm{K}\right)=\frac{3030+10.86 \mathrm{P}(\mathrm{Kbar})}{\ln \mathrm{K}_{\mathrm{D}}+1.9034+\left(\ln _{\gamma \mathrm{Fe}}\right)^{\mathrm{Grt}}-\left(\ln _{\gamma \mathrm{Mg}}\right)^{\mathrm{Grt}}}
$$

Foram utilizados os geotermômetros de granada-clinopiroxênio de Ganguly (1979) e Sengupta et al. (1989) por serem mais adequados para rochas em fácies granulito superior. O granada-granulito (amostra NLD-7D) apresenta condições de pico térmico em torno de $799.6^{\circ} \mathrm{C}$ (Ganguly, 1979) e $768.6^{\circ} \mathrm{C}$ (Sengupta et al., 1989), a 10 kbar. 
Metagabronoritos

\begin{tabular}{|c|c|c|}
\hline \multicolumn{3}{|c|}{ Geotermômetro Grt-Cpx (Para $\mathrm{P}=10 \mathrm{Kbar}$ ) } \\
\hline & $\begin{array}{l}\text { Ganguly } \\
\text { (1979) }\end{array}$ & $\begin{array}{c}\text { Sengupta et al. } \\
(1989)\end{array}$ \\
\hline Amostra & $\mathrm{T}\left({ }^{\circ} \mathrm{C}\right)$ & $\mathrm{T}\left({ }^{\circ} \mathrm{C}\right)$ \\
\hline \multicolumn{3}{|c|}{ Corona 2} \\
\hline NLD-42C & 769.45 & 757.06 \\
\hline \multicolumn{3}{|c|}{ Corona 5} \\
\hline NLD-42C & 787.35 & 783.15 \\
\hline NLD-42C & 783.67 & 781.05 \\
\hline \multicolumn{3}{|c|}{ Corona 6} \\
\hline NLD-42C & 779.42 & 783.64 \\
\hline NLD-42C & 802.72 & 808.44 \\
\hline \multicolumn{3}{|c|}{ Corona 7} \\
\hline NLD-42C & 795.37 & 792.02 \\
\hline NLD-42C & 793.81 & 793.29 \\
\hline \multicolumn{3}{|c|}{ Corona 1} \\
\hline NLD-42D & 798.59 & 816.97 \\
\hline NLD-42D & 801.02 & 822.2 \\
\hline \multicolumn{3}{|c|}{ Corona 3} \\
\hline NLD-42D & 798.48 & 787.81 \\
\hline NLD-42D & 801.09 & 799.33 \\
\hline \multicolumn{3}{|c|}{ Veio Grt+Cpx+Qtz } \\
\hline NLD-42D & 826.06 & 831.79 \\
\hline NLD-42D & 821.08 & 827.85 \\
\hline
\end{tabular}

\begin{tabular}{ccc}
\multicolumn{3}{c}{ Metabásicas } \\
\hline \multicolumn{3}{c}{ Geotermômetro Grt-Cpx (Para P=10Kbar) } \\
\hline & $\begin{array}{c}\text { Ganguly } \\
\mathbf{( 1 9 7 9 )}\end{array}$ & $\begin{array}{c}\text { Sengupta et al. } \\
(\mathbf{1 9 8 9 )}\end{array}$ \\
Amostra & $\mathrm{T}\left({ }^{\circ} \mathrm{C}\right)$ & $\mathrm{T}\left({ }^{\circ} \mathrm{C}\right)$ \\
\hline NLD-7D & 778.6 & 751.4 \\
NLD-7D & 790.6 & 763.1 \\
NLD-7D & 798.6 & 753.3 \\
NLD-7D & 799.6 & 768.6 \\
NLD-7D & 778.6 & 744.1 \\
\hline
\end{tabular}

Metabásicas

\begin{tabular}{ccc}
\multicolumn{3}{c}{ Metabásicas } \\
\hline \multicolumn{3}{c}{ Geotermômetro Grt-Cpx } \\
\hline & $\begin{array}{c}\text { Ganguly } \\
(\mathbf{1 9 7 9 )}\end{array}$ & $\begin{array}{c}\text { Sengupta et al. } \\
(\mathbf{1 9 8 9 )}\end{array}$ \\
Amostra & $\mathrm{T}\left({ }^{\circ} \mathrm{C}\right)$ & $\mathrm{T}\left({ }^{\circ} \mathrm{C}\right)$ \\
\hline NLD-20A & 732.9 & 682.6 \\
NLD-20A & 750.3 & 702 \\
NLD-20A & 735.2 & 683.2 \\
NLD-20A & 689.6 & 615.9 \\
NLD-20A & 734.9 & 667.6 \\
\hline
\end{tabular}

Metagabronoritos

\begin{tabular}{|c|c|}
\hline \multicolumn{2}{|c|}{ Geobarômetro Grt-Cpx-PI (Para $\mathrm{P}=780^{\circ} \mathrm{C}$} \\
\hline & $\begin{array}{c}\text { Eckert et al. } \\
\quad(1991)\end{array}$ \\
\hline Amostra & $\mathrm{T}\left({ }^{\circ} \mathrm{C}\right)$ \\
\hline \multicolumn{2}{|c|}{ Corona 2} \\
\hline NLD-42C & $10.47 \pm 1.9$ \\
\hline NLD-42C & $10.37 \pm 1.9$ \\
\hline \multicolumn{2}{|c|}{ Corona 5} \\
\hline NLD-42C & $10.22 \pm 1.9$ \\
\hline NLD-42C & $10.32 \pm 1.9$ \\
\hline \multicolumn{2}{|c|}{ Corona 6} \\
\hline NLD-42C & $9.9 \pm 1.9$ \\
\hline \multicolumn{2}{|c|}{ Corona 7} \\
\hline NLD-42C & $9.85 \pm 1.9$ \\
\hline NLD-42C & $9.94 \pm 1.9$ \\
\hline \multicolumn{2}{|c|}{ Corona 1} \\
\hline NLD-42D & $10.87 \pm 1.9$ \\
\hline NLD-42D & $10.79 \pm 1.9$ \\
\hline \multicolumn{2}{|c|}{ Corona 3} \\
\hline NLD-42D & $10.51 \pm 1.9$ \\
\hline NLD-42D & $10.12 \pm 1.9$ \\
\hline \multicolumn{2}{|c|}{ Veio Grt+Cpx+Qtz } \\
\hline NLD-42D & $10.73 \pm 1.9$ \\
\hline NLD-42D & $10.89 \pm 1.9$ \\
\hline
\end{tabular}

\begin{tabular}{lcc}
\multicolumn{3}{c}{ Metabásicas } \\
\hline Geobarômetro Grt-Cpx-PI (Para T=680 $\left.{ }^{\circ} \mathrm{C}\right)$ \\
\hline & $\begin{array}{c}\text { Eckert } \text { et } \text { al. } \\
(\mathbf{1 9 9 1 )}\end{array}$ \\
Amostra & $\mathrm{T}\left({ }^{\circ} \mathrm{C}\right)$ & $\mathrm{P}$ (Kbar) \\
\hline NLD-7D & $775.9 \pm 23$ & $9.1 \pm 1.9$ \\
NLD-7D & $784.1 \pm 15$ & $9.4 \pm 1.9$ \\
NLD-7D & 750 & $9.22 \pm 1.9$ \\
NLD-7D & 750 & $8.78 \pm 1.9$ \\
NLD-7D & 750 & $8.98 \pm 1.9$ \\
NLD-20A & $707.7 \pm 25$ & $8.1 \pm 1.9$ \\
NLD-20A & $709.2 \pm 26$ & $6.3 \pm 1.9$ \\
NLD-20A & 750 & $9.1 \pm 1.9$ \\
NLD-20A & 750 & $8.0 \pm 1.9$ \\
NLD-20A & 750 & $8.4 \pm 1.9$ \\
\hline
\end{tabular}

Tabela 7: Resultados dos cálculos obtidos através do termômetro granada-clinopiroxênio (Ganguly, 1979; Sengupta et al., 1989) e do barômetro granada-clinopiroxênio-plagioclásio (Eckert et al., 1991) para as rochas metabásicas. 
No hornblenda-metagabro da amostra NLD-20A, a temperatura máxima obtida é da ordem de $750.3^{\circ} \mathrm{C}$, a 9 kbar (Ganguly, 1979). Nos metagabronoritos, as condições de pico metamórfico estão registradas nos veios constituídos por granada-clinopiroxênioquartzo-opacos, com temperaturas máximas de $826.06^{\circ} \mathrm{C}$ (Ganguly, 1979) e $831.79^{\circ} \mathrm{C}$ (Sengupta et al., 1989), a 10 kbar. Na amostra NLD-42C, as temperaturas máximas obtidas são de $808.44^{\circ} \mathrm{C}$ (Sengupta et al., 1989) e de $802.72^{\circ} \mathrm{C}$ (Ganguly, 1979).

\subsection{Geobarômetro Grt-Cpx-PI}

Os geobarômetros mais utilizados para rochas em fácies granulito são granadaclinopiroxênio-plagioclásio e granada-ortopiroxênio-plagioclásio. São baseados nas seguintes reações:

- Grt-Cpx-Pl (GADS):

$$
\begin{aligned}
& \mathrm{CaAl}_{2} \mathrm{Si}_{2} \mathrm{O}_{8}+\mathrm{CaMgSi}_{2} \mathrm{O}_{6} \leftrightarrow 2 / 3 \mathrm{Ca}_{3} \mathrm{Al}_{2} \mathrm{Si}_{3} \mathrm{O}_{12}+1 / 2 \mathrm{Mg}_{3} \mathrm{Al}_{2} \mathrm{Si}_{3} \mathrm{O}_{12}+\mathrm{SiO}_{2} \\
& \begin{array}{lllll}
\text { (anortita) } & \text { (diopsídio) } & \text { (grossulária) } & \text { (piropo) }
\end{array}
\end{aligned}
$$

\section{- Grt-Opx-Pl (GAPES):}

$$
\begin{aligned}
& \mathrm{CaAl}_{2} \mathrm{Si}_{2} \mathrm{O}_{8}+\mathrm{Mg}_{2} \mathrm{Si}_{2} \mathrm{O}_{6} \leftrightarrow 2 / 3 \mathrm{Mg}_{3} \mathrm{Al}_{2} \mathrm{Si}_{3} \mathrm{O}_{12}+1 / 2 \mathrm{Ca}_{3} \mathrm{Al}_{2} \mathrm{Si}_{3} \mathrm{O}_{12}+\mathrm{SiO}_{2} \\
& \text { (anortita) (enstatita) (piropo) (grossulária) (quartzo) }
\end{aligned}
$$

Estas reações foram calibradas a partir dos dados termodinâmicos de Perkins \& Newton (1981). A entalpia da reação é uma das maiores fontes de incerteza na calibração destes barômetros. $\mathrm{O}$ presente estudo redetermina o $\Delta \mathrm{H}_{\mathrm{R}}$ do geobarômetro para as reações GADS e GAPES, utilizando a técnica de calorimetria de solução. A dissolução dos reagentes e produtos dá o $\Delta \mathrm{H}_{\mathrm{R}}$ diretamente por subtração. Os resultados calorimétricos obtidos por Eckert et al. (1991) definem o $\Delta \mathrm{H}^{\circ}{ }_{\mathrm{R}}$ das reações GADS e GAPES. Através dos novos valores de $\Delta H_{R}$, as equações de Perkins \& Newton (1981) foram reformuladas para:

- Grt-Cpx-Pl (GADS):

$$
\text { (1) } \mathrm{P}(\mathrm{Kbar})=3.47+0.01307 \mathrm{~T}\left({ }^{\circ} \mathrm{K}\right)+0.003504 \mathrm{~T}\left({ }^{\circ} \mathrm{K}\right) \ln \mathrm{K}_{\mathrm{A}}( \pm 1.55 \mathrm{Kbar})
$$

- Grt-Opx-Pl (GAPES):

$$
2 \mathrm{P}(\mathrm{Kbar})=2.60+0.01718 \mathrm{~T}\left({ }^{\circ} \mathrm{K}\right)+0.003596 \mathrm{~T}\left({ }^{\circ} \mathrm{K}\right) \ln \mathrm{K}_{\mathrm{B}}( \pm 1.9 \mathrm{Kbar})
$$


No presente trabalho, foi utilizada a reação GADS para o cálculo da pressão. A pressão máxima calculada através do método de Eckert et al. (1991) para o granada granulito da amostra NLD-7D é da ordem de $9.4 \pm 1.9 \mathrm{kbar}$, para temperatura de $784.1^{\circ} \mathrm{C}$. As condições de pressão calculadas para o hornblenda-metagabro foram da ordem de $9.1 \pm 1.9 \mathrm{Kbar}$ a $750^{\circ} \mathrm{C}$ (Eckert et al., 1991). Os valores mais elevados de pressão foram obtidos nos metagabronoritos intercalados nas rochas charnockíticas associadas ao Complexo Mantiqueira. Os cálculos foram realizados para temperatura de $780^{\circ} \mathrm{C}$. As condições obtidas foram de $10.89 \pm 1.9$ kbar (amostra NLD-42D) e $10.47 \pm$ 1.9 kbar, na corona 2 da amostra NLD-42C (Tabela 7).

\subsubsection{Geotermobarometria das rochas charnockíticas}

\subsubsection{Banco de dados internamente consistentes (THERMOCALC)}

Os minerais presentes nas rochas charnockíticas foram bastante afetados por processos de difusão química, o que dificulta a preservação de composições relacionadas ao pico metamórfico. Além disso, o número reduzido de fases minerais em equilíbrio dificulta a utilização do método de banco de dados internamente consistentes, resultando em dados de temperatura com erros grandes (Tabela 8). As maiores temperaturas registradas foram obtidas através de cálculos realizados com a associação mineral Grt-Cpx-Opx-Pl na amostra NLD-45D. As condições calculadas são $771 \pm$ $166^{\circ} \mathrm{C}$, a $11.8 \pm 2.4 \mathrm{kbar}$ (Figura 80). Os cálculos realizados com a associação mineral Grt-Cpx-Opx-Pl-Kfs na amostra NLD-45B forneceram temperatura máxima de $554 \pm$ $192^{\circ} \mathrm{C}$ para pressão de $7.2 \pm 2.7 \mathrm{kbar}$.

\begin{tabular}{ccccc}
\multicolumn{5}{c}{ Rochas charnockiticas - THERMOCALC (Holland \& Powell, 1988) } \\
\hline Amostra & Assoc. Mineral & T $\left({ }^{\circ} \mathbf{C}\right)$ & P (Kbar) & corr \\
NLD-45B & Grt-Cpx-Opx-PI-Kfs & $552 \pm 189$ & $7.0 \pm 2.7$ & 0.689 \\
NLD-45B & Grt-Cpx-Opx-PI-Kfs & $537 \pm 204$ & $6.6 \pm 2.9$ & 0.672 \\
NLD-45B & Grt-Cpx-Opx-PI-Kfs & $554 \pm 192$ & $7.2 \pm 2.7$ & 0.697 \\
NLD-45D & Grt-Cpx-Opx-PI & $679 \pm 136$ & $10.2 \pm 2.0$ & 0.779 \\
NLD-45D & Grt-Cpx-Opx-PI & $765 \pm 160$ & $11.4 \pm 2.3$ & 0.776 \\
NLD-45D & Grt-Cpx-Opx-PI & $683 \pm 141$ & $10.5 \pm 2.1$ & 0.787 \\
NLD-45D & Grt-Cpx-Opx-PI & $771 \pm 166$ & $11.8 \pm 2.4$ & 0.785
\end{tabular}

Tabela 8: Resultados dos cálculos termobarométricos obtidos no THERMOCALC (Holland \& Powell, 1988) para as rochas charnockíticas. 


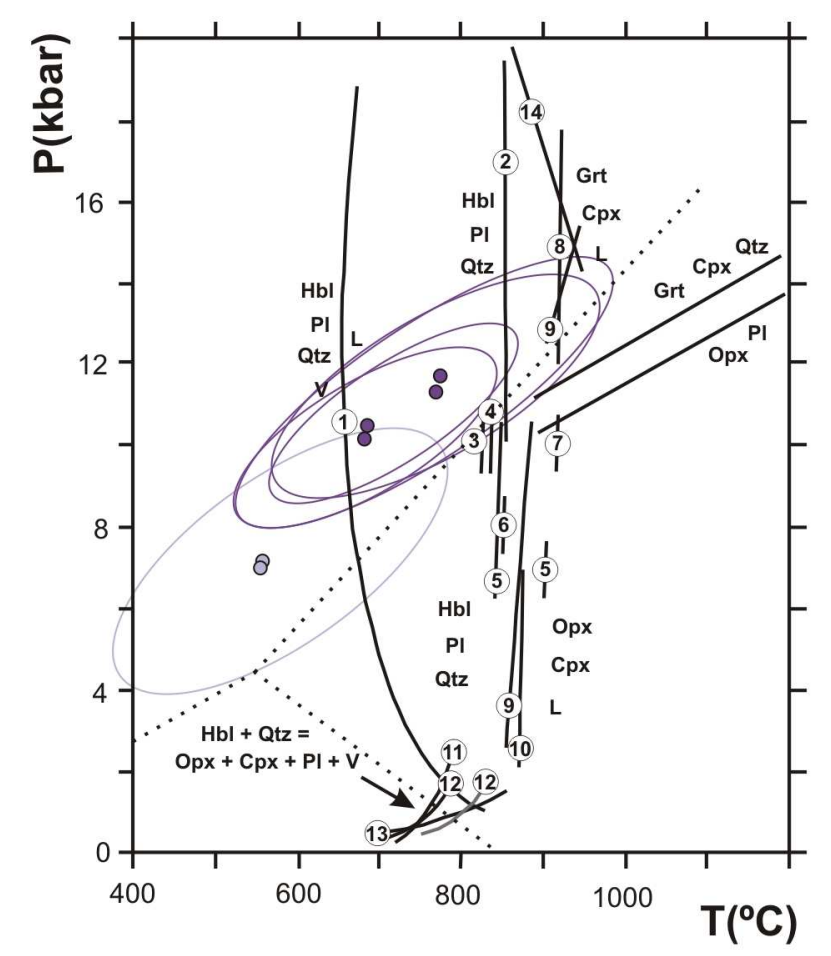

Grt-Cpx-PI / NLD-45B

LEGENDA:

Grt-Cpx-Opx-PI / NLD-45D

1- Piwinnskii (1968), Johannes (1978), Wolf \& Wyllie (1993); 2- Winter \& Newton (1991); 3- Wolf \& Wyllie (1994); 4- Conrad et al. (1988); 5- Nair \& Chacko (2000); 6- Rushmer (1991); 7- Ellis \&

Thompson (1986), Tr = En + Di + An + Qtz + L; 8- Rushmer (1993); 9- Patiño-Douce \& Beard (1995);

10- Beard \& Lofgren (1991); 11- Binns (1969);12- Spear (1981); 13- Choudhuri \& Winkler (1967); 14-
Sen \& Dunn (1994)

Figura 80: Dados de temperatura e pressão das rochas charnockíticas obtidos no THERMOCALC (Powell \& Holland, 1988), com os erros dos cálculos representados pelas elipses (amostras NLD-45B e NLD45D).

\subsubsection{Geotermobarometria convencional}

\subsection{Geotermômetro Grt-Cpx}

A utilização do geotermômetro granada-clinopiroxênio de Ganguly (1979) e Sengupta et al. (1989) permitiu a determinação das condições de pico térmico das rochas charnockíticas. Os cálculos de temperatura foram realizados para pressão de 10 kbar. A corona 8 da amostra NLD-45D (Fotomicrografias 97 e 98) registra as temperaturas mais elevadas, da ordem de $885.17^{\circ} \mathrm{C}$ (Ganguly, 1979) E $901.06^{\circ} \mathrm{C}$ (Sengupta et al., 1989). Na amostra NLD-45B, a temperatura máxima obtida é de 722.86 (Ganguly, 1979). Os resultados estão apresentados na Tabela 9. 
Metacharnockitos

\begin{tabular}{ccc}
\hline Geotermômetro Grt-Cpx (Para P=10Kbar) \\
\hline & $\begin{array}{c}\text { Ganguly } \\
(\mathbf{1 9 7 9 )}\end{array}$ & $\begin{array}{c}\text { Sengupta et al. } \\
(\mathbf{1 9 8 9 )}\end{array}$ \\
Amostra & $\mathrm{T}\left({ }^{\circ} \mathrm{C}\right)$ & $\mathrm{T}\left({ }^{\circ} \mathrm{C}\right)$ \\
\hline \multicolumn{3}{c}{ Corona 1 } \\
NLD-45B & 716.72 & 673.53 \\
NLD-45B & 722.86 & 678.64 \\
NLD-45B & 710.98 & 660.42 \\
NLD-45B & 713.15 & 662.6 \\
& Corona 6 & \\
NLD-45D & 854.87 & 840.06 \\
NLD-45D & 762.7 & 697.75 \\
NLD-45D & 860.68 & 851.12 \\
& Corona 7 & \\
NLD-45D & 881.04 & 898.25 \\
NLD-45D & 775.01 & 726.03 \\
NLD-45D & 885.17 & 901.06 \\
NLD-45D & 778.11 & 728.07
\end{tabular}

Metacharnockitos

Geobarômetro Grt-Cpx-PI (Para T=680

Eckert et al.

(1991)

\begin{tabular}{lrl} 
Amostra & $\mathrm{T}\left({ }^{\circ} \mathrm{C}\right)$ \\
Corona 1 \\
NLD-45B & 10.24 & \pm 1.9 \\
NLD-45B & 10.19 & \pm 1.9 \\
NLD-45B & 10.31 & \pm 1.9 \\
\multicolumn{4}{c}{ Corona 6} \\
NLD-45D & 10.64 & \pm 1.9 \\
NLD-45D & 12.86 & \pm 1.9 \\
NLD-45D & 13.38 & \pm 1.9 \\
NLD-45D & 12.8 & \pm 1.9 \\
\multicolumn{4}{c}{ Corona 7} \\
NLD-45D & 14.34 & \pm 1.9 \\
NLD-45D & 14.36 & \pm 1.9 \\
NLD-45D & 14.01 & \pm 1.9 \\
NLD-45D & 10.59 & \pm 1.9
\end{tabular}

Tabela 9: Resultados dos cálculos obtidos através do termômetro granada-clinopiroxênio (Ganguly, 1979; Sengupta et al., 1989) e do barômetro granada-clinopiroxênio-plagioclásio (Eckert et al., 1991) para as rochas charnockíticas.

\subsection{Geobarômetro Grt-Cpx-PI}

As condições de pico bárico nas rochas charnockíticas foram obtidas através de cálculos envolvendo a associação mineral granada-clinopiroxênio-plagioclásio, utilizando o geobarômetro de Eckert et al. (1991). Os cálculos de pressão foram realizados para temperatura de $680^{\circ} \mathrm{C}$. As condições de pressão máxima calculadas para a amostra NLD-45D foram de $14.36 \pm 1.9 \mathrm{kbar}$, a $680^{\circ} \mathrm{C}$ (Tabela 9). Na amostra NLD45B, a pressão máxima obtida é da ordem de 10.31 kbar. 


\subsection{EVOLUÇÃO METAMÓRFICA}

\subsubsection{Considerações iniciais}

A determinação de uma trajetória P-T-t é um dos objetivos principais na petrologia metamórfica, pois representa a variação nas condições P-T com o tempo para um terreno metamórfico (Vernon \& Clarke, 2008). Diferentes trajetórias P-T-t podem ser inferidas para diferentes unidades, o que aumenta a complexidade das interpretações tectonometamórficas (Spear et al., 1984). Existem dois tipos principais de trajetórias PT: trajetórias "horárias" (England \& Richardson, 1977; Holland \& Richardson, 1979; Hollister et al., 1979, Earle, 1980; England \& Thompson, 1984a) e "anti-horárias" (Vernon, 1982; England \& Thompson, 1984b; Schumacher et al., 1990). Orógenos colisionais são caracterizados por trajetórias P-T-t horárias, com aumento significativo de pressão como resultado do avanço das nappes, seguido por um período de relaxamento termal, em que a temperatura aumenta em direção à geoterma cratônica. As temperaturas máximas são atingidas durante a exumação (England \& Thompson, 1984a). Nas trajetórias anti-horárias o pico bárico e o pico termal ocorrem simultaneamente (England \& Thompson, 1984a). São geralmente características de terrenos submetidos a um aumento de temperatura proveniente de calor magmático, através da acresção de magma basáltico na base da crosta (Harley, 1989; Vernon \& Clarke, 2008).

Segundo Harley (1989), granulitos que registram trajetórias do tipo ITD (descompressão isotermal) estão relacionadas com ambientes colisionais com espessamento de crosta, em que a exumação tectônica promove um adelgaçamento rápido, com taxas moderadas (1-2mm/ano). Os granulitos que exibem trajetórias do tipo IBC (resfriamento isobárico) são formados em diferentes contextos tectônicos. Aqueles que mostram trajetórias anti-horárias foram formados próximo de áreas com grande acresção de magma máfico na base da crosta (underplating) (Harley, 1989; Bohlen \& Mezger, 1989). Muitos granulitos em níveis crustais profundos com trajetórias tipo IBC, devem ter sido submetidos a um adelgaçamento extensional muito rápido ( $5 \mathrm{~mm} / \mathrm{ano})$, subseqüente à colisão. Harley (1989) propõe que as altas temperaturas atingidas no metamorfismo de fácies granulito são provenientes de uma fonte externa de calor, como a de um magma. 
Partes de uma trajetória P-T podem ser inferidas através de inclusões minerais (Wells, 1979), inclusões fluidas (Hollister, 1969; Hollister et al., 1979; Selverstone et al., 1984) ou zoneamento composicional dos minerais (Holland \& Richardson, 1979; Spear et al., 1984; Selverstone et al., 1984). Muitos terrenos granulíticos contêm rochas com texturas ígneas primárias preservadas em condições anidras e de baixo strain, que registram o metamorfismo progressivo em trajetórias horárias com descompressão isotermal inicial (Bohlen, 1991).

Um dos maiores problemas na determinação das condições P-T em rochas granulíticas está relacionado à grande dificuldade em determinar as condições reais de pico metamórfico devido à intensa difusão química ocorrida durante o resfriamento, que foi nomeado por Frost \& Chacko (1989) como o "Princípio da incerteza dos granulitos". No entanto, é possível fazer estimativas realísticas das condições P-T de rochas que mostram evidência de desequilíbrio em escala microscópica, através de uma interpretação cuidadosa das relações texturais e de uma seleção rigorosa de associações para termobarometria (Indares \& Rivers, 1995).

As rochas de composição charnockítica, enderbítica e composições cálcioalcalinas sob condições metamórficas de alta pressão estão associadas com limites de placas convergentes e possuem grande potencial para registrar evidência de subducção/colisão profunda (Bhowmik et al., 2009). O principal mecanismo de produção e preservação de associações de alta pressão em rochas félsicas é relacionado à deformação e disponibilidade de $\mathrm{H}_{2} \mathrm{O}$ (Proyer, 2003). Zonas de cisalhamento podem canalizar fluidos, promovendo o transporte de elementos e podem agir tanto como um catalisador da reação ou participar de reações minerais (Rubie, 1983; Guiraud et al., 2001; Proyer, 2003). O grau de influxo de fluidos durante o evento de hidratação inicial dificulta a preservação de mineralogia e texturas ígneas. Para hidratação limitada, granitóides com Opx preservam ortopiroxênio parcialmente substituído por biotita (Bhowmik et al., 2009). A preservação de associações ígneas pretéritas e o desenvolvimento de texturas coroníticas resultam da transformação metamórfica incompleta devido às baixas taxas de difusão em comparação com as taxas de mudança nas condições P-T (Mongkoltip \& Ashworth, 1983).

\subsubsection{Paragnaisses}

A associação mineral predominante nos paragnaisses da Nappe Lima Duarte é: granada + biotita + sillimanita + muscovita + plagioclásio + quartzo + ilmenita + rutilo. 
Ocorrem paragnaisses sob a klippe quartzítica da Serra Negra, com raras inclusões de cianita associada com feldspato potássico em porfiroblastos intercinemáticos de granada (OL-II-112B) e paragnaisses com cianita e sillimanita na matriz (NLD-61). O metamorfismo progressivo nos paragnaisses é caracterizado pelas reações de quebra da muscovita, localmente com a geração de feldspato potássico (Le Breton \& Thompson, 1988; Vielzeuf \& Holloway, 1988) (reação 1.1):

$$
\mathrm{Ms}+\mathrm{PI}+\mathrm{Qtz}=\mathrm{Bt}+\mathrm{Sil}+\mathrm{Kfs}+\mathrm{L}
$$

A ocorrência de ortoclásio com aspecto de filme, aparentemente mimetizando um líquido silicático (Holness \& Sawyer, 2008) e envolvendo as inclusões de Ky, Sil, Bt, Ms, Ilm e Zrc na amostra OL-II-112B, sugere que a cristalização do porfiroblasto de granada se deu em presença de feldspato potássico e líquido. As reações de quebra de muscovita nos paragnaisses também são evidenciadas pela presença de bolsões de leucossoma, sugerindo anatexia in-situ e presença de cristais prismáticos de sillimanita.

$\mathrm{Na}$ amostra OL-II-112B, ocorre inclusão de cianita em paragênese com biotita e muscovita e em associação com $\mathrm{Bt}+\mathrm{Ms}+\mathrm{Sil}+\mathrm{Kfs}+\mathrm{Ilm}$, indicando que o pico bárico está associado ao campo de estabilidade da cianita, que seguido de descompressão, atingiu o campo de estabilidade da sillimanita. As condições de pico bárico foram obtidas no THERMOCALC (Powell \& Holland, 1988) através da realização de cálculos envolvendo a associação com cianita, com pressão máxima de $10 \pm 0.6$ kbar, para temperatura de $807 \pm 25^{\circ} \mathrm{C}$.

O pico térmico foi obtido no THERMOCALC (Powell \& Holland, 1988) com a associação mineral envolvendo sillimanita (Grt-Ms-Bt-Kfs-Sil-Ilm-Rt). A temperatura máxima obtida foi de $827 \pm 44^{\circ} \mathrm{C}$, para pressão de $8.2 \pm 1.8$, no limite da curva de quebra da dumortierita (Werding \& Schreyer, 1996). Foi descrita uma ocorrência de dumortierita nos paragnaisses da Serra Negra (LD-III-219), em equilíbrio com a sillimanita.

As principais texturas presentes nos paragnaisses são relacionadas à retrogressão. A granada é parcialmente consumida para formar biotita ou intercrescimentos de $\mathrm{Bt}+$ Sil nas bordas ou ao longo de fraturas. Localmente essa substituição é total, resultando em pseudomorfos de granada totalmente substituídos por Bt + Sil (Le Breton \& Thompson, 1988) (reação 1.2): 
Nas rochas onde essa substituição é bastante freqüente (e.g. OL-III-39A) houve um reequilíbrio maior das composições de borda de granada e dos minerais presentes na matriz, resultando em temperaturas máximas registradas em torno de $680-750^{\circ} \mathrm{C}$, a $6-7$ kbar (THERMOCALC, Powell \& Holland, 1988).

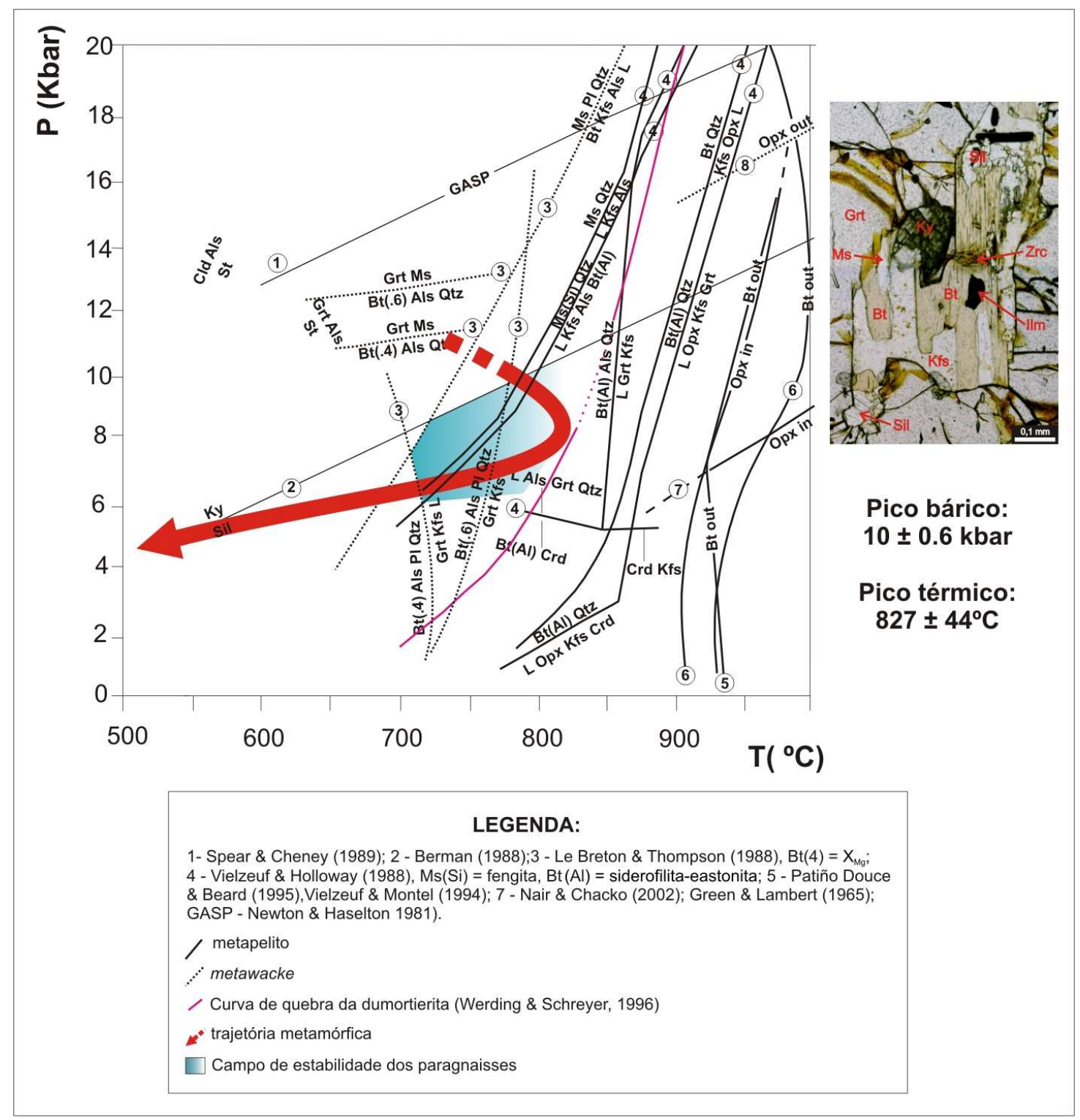

Figura 81: Trajetória P-T para os paragnaisses, utilizando as grades petrogenéticas de Spear \& Cheney (1989), Berman (1988), Le Breton \& Thompson (1988), Vielzeuf \& Holloway (1988), Patino Douce \& Beard (1995), Vielzeuf \& Montel (1994), Nair \& Chacko (2002), Green \& Lambert (1965), Newton \& Haselton (1981) e Werding \& Schreyer (1996). 
No metamorfismo retrógrado ocorre a formação de sillimanita fibrosa pseudomorfizando sillimanita prismática. Também são bastante comuns as texturas de volta das reações de quebra de muscovita, através da subtituição parcial de sillimanita, ortoclásio e/ou cianita, quando presente, por cristais de muscovita tardia na foliação principal, ou dispersa na matriz. A biotita pode estar substituída por muscovita e clorita.

Os paragnaisses da Nappe Lima Duarte encontram-se sob condições de temperatura máxima de $827^{\circ} \mathrm{C}$, no campo bárico da sillimanita, cordierita ausente, sugerindo condições de pressão entre 6 e 8 Kbar. Apresentam uma trajetória metamórfica de descompressão, no sentido horário, saindo do campo de estabilidade da cianita e passando para o campo da sillimanita (Figura 81). No entanto, não foi possível determinar as condições P-T dos paragnaisses com cianita na matriz, o que poderia sugerir pressões um pouco mais elevadas do que o pico bárico de $10 \pm 0.6$ kbar obtido no THERMOCALC para o paragnaisse com inclusão de cianita na granada (OL-II112B).

\subsubsection{Rochas metabásicas}

As rochas metabásicas inseridas nos ortognaisses do Complexo Mantiqueira apresentam a associação granada + clinopiroxênio + plagioclásio + quartzo \pm ortopiroxênio + hornblenda, estável em temperaturas entre $750-890^{\circ} \mathrm{C}$ e pressões em torno de 8 - $11 \mathrm{kbar}$, envolvendo fases anidras (Pattison, 2003). A associação mineral constituída por granada + clinopiroxênio + quartzo em rochas metabásicas de composição intermediária é diagnóstica de metamorfismo de fácies granulito de alta pressão (superior a 9 kbar), segundo Green \& Ringwood (1967) e Rushmer (1993). A pressão exata em que a associação Grt + Cpx + Qtz se torna dominante com o desaparecimento de ortopiroxênio é controlada pela composição do protólito (Green \& Ringwood, 1967; Patiño-Douce \& Beard, 1995).

O fácies granulito foi subdividido por De Waard, (1965a) baseado no aparecimento da granada a partir da reação entre ortopiroxênio e plagioclásio, sendo que composições quartzo-toleiíticas definem a entrada no campo dos granulitos de alta pressão, enquanto que composições basálticas insaturadas definem o limite entre os campos do granulito de baixa pressão e granulito de pressão intermediária (De Waard, 1965a, b; O’Brien \& Rötzler, 2003). As associações minerais transicionais entre granulitos de baixa pressão e associações de eclogitos abrangem composições basálticas desde quartzo normativo até picrito e são caracterizadas pela associação $\mathrm{Grt}+\mathrm{Cpx}+\mathrm{Pl}$ 
+ Qtz \pm Opx (Green \& Ringwood, 1967). Ocorre um aumento progressivo de granada e desaparecimento do plagioclásio com o aumento de pressão, com mudanças mineralógicas graduais durante a transição (Green \& Ringwood, 1967). As principais reações que controlam a presença de granada e clinopiroxênio, bem como as suas composições, são as seguintes (O’Brien \& Rötzler, 2003):

$$
\begin{gathered}
\text { Opx + Pl = Grt + Qtz } \\
\text { Opx + Pl = Grt }+ \text { Cpx + Qtz } \\
\text { Cpx + Pl = Grt + Qtz } \\
\text { An }(\text { in } \mathbf{P l})=\text { CaTs }(\text { in } \text { Cpx })+\text { Qtz }
\end{gathered}
$$

Em rochas metapelíticas e metagraníticas, a entrada para o campo dos granulitos de alta pressão é controlado pelas seguintes reações (O’Brien \& Rötzler, 2003):

$$
\begin{gathered}
\text { Ms }+ \text { Qtz }=\text { Kfs }+ \text { Ky }+ \text { fundido } \\
\text { Bt }+ \text { Ky }+ \text { Qtz }=\text { Grt }+ \text { Kfs }+ \text { fundido } \\
\text { Bt }+ \text { Qtz }=\text { Opx }+ \text { Grt }+ \text { Kfs + fundido }
\end{gathered}
$$

Nas rochas metabásicas inseridas nos ortognaisses do Complexo Mantiqueira, são bastante comuns as texturas coroníticas de Grt $+\mathrm{Cpx} \pm$ Qtz ou de Grt \pm Qtz ao redor de cristais de ortopiroxênio, plagioclásio e/ou opacos, aparentemente de origem ígnea. Coronas anidras de Grt $+\mathrm{Cpx} \pm \mathrm{Qtz}$ ao redor de minerais da associação magmática pretérita (Opx e Pl), similares àquelas descritas por Baldwin et al., (2003) e Nicollet \& Goncalves, (2005), sugerem a passagem pelas reações 2.1 e 2.2. A reação 2.2 marca a passagem do campo dos granulitos de pressão intermediária para o campo dos granulitos de alta pressão (Green \& Ringwood, 1967; Baldwin et al., 2003; O’Brien \& Rötzler, 2003). A ocorrência de leitos milimétricos a subcentimétricos constituídos por granada xenoblástica intercrescida com clinopiroxênio, quartzo e opacos, com calcita preenchendo os interstícios entre os grãos de granada e clinopiroxênio (NLD-42D) é sugestiva de que essa textura tenha sido gerada a partir da percolação de um fluido. A preservação da associação mineral anidra Grt $+\mathrm{Cpx}+\mathrm{Qtz} \pm \mathrm{Pl}$ foi possivelmente facilitada pela infiltração de um fluido rico em $\mathrm{CO}_{2}$, devido à presença de calcita intersticial entre os grãos de granada e clinopiroxênio. 
A aplicação de geotermobarometria em terrenos granulíticos indica que as condições de pico registradas nos granulitos são de $700-1000^{\circ} \mathrm{C}$ e $4-12 \mathrm{Kbar}$ (Newton \& Perkins, 1982; Bohlen et al., 1983; Harley, 1989). A maioria dos terrenos granulíticos regionais registra condições P-T de $800 \pm 50^{\circ} \mathrm{C}$, a $7.5 \pm 1$ kbar (Bohlen, 1987), porém segundo Harley, (1989) mais de metade dos granulitos apresentam pressão baixa (<6kbar) ou mais alta (>9kbar). A estimativa das condições de pico a partir de termometria envolvendo a troca $\mathrm{Fe}-\mathrm{Mg}$ é geralmente subestimada, devido à troca difusional (Pattison \& Begin, 1994). Pode-se assumir equilíbrio local na interface entre a corona e os agregados de minerais adjacentes que substituem as fases ígneas, o que permite estimar as condições de pico metamórfico (Indares \& Rivers, 1995). No presente trabalho, as estimativas P-T nas rochas metabásicas e charnockíticas foram feitas a partir das composições mais refratárias dos minerais, utilizando as composições de núcleo dos minerais da corona ou de associações minerais granoblásticas, de acordo com a metodologia proposta por Pattison \& Bégin (1994), Cox \& Indares (1999), Baldwin et al., (2003).

Nos metagabronoritos, as condições máximas de metamorfismo estão preservadas nos veios constituídos por Grt + Cpx + Qtz + opacos (NLD-42D) com temperaturas máximas de $826.06^{\circ} \mathrm{C}$ (Ganguly, 1979) e $831.79^{\circ} \mathrm{C}$ (Sengupta et al., 1989), a 10 kbar. As condições de pressão máxima foram obtidas através do geobarômetro GrtCpx-Pl de Eckert et al. (1991), que forneceram pressões em torno de $10.89 \pm 1.9 \mathrm{kbar}$, a $780^{\circ} \mathrm{C}$. As condições calculadas através do THERMOCALC são $794 \pm 167^{\circ} \mathrm{C}$ a $8.8 \pm$ 2.0 kbar.

O granada granulito também preserva as condições relacionadas ao pico metamórfico. As condições calculadas para o granada granulito através do THERMOCALC são $890 \pm 41^{\circ} \mathrm{C}$, a $9.26 \pm 1.93$ kbar. Cálculos realizados através do TWEEQU forneceram condições de equilíbrio de $801^{\circ} \mathrm{C}$ a $9.6 \mathrm{kbar}$ para a associação de fácies granulito Grt+Cpx+Opx+Pl+Qtz na amostra NLD-7D, onde ocorre o ponto de intersecção entre as reações. O pico termal no granada granulito obtido através do geotermômetro Grt-Cpx é de $799.6^{\circ} \mathrm{C}$ (Ganguly, 1979) e $768.6^{\circ} \mathrm{C}$ (Sengupta et al., 1989), a 10 kbar, enquanto que a pressão máxima calculada através do método de Eckert et al. (1991) para o granada granulito da amostra NLD-7D é da ordem de $9.4 \pm$ 1.9 kbar, para temperatura de $784.1^{\circ} \mathrm{C}$. No hornblenda-metagabro da amostra NLD20A, a temperatura máxima obtida é da ordem de $750.3^{\circ} \mathrm{C}$, a 9 kbar (Ganguly, 1979) e a pressão é da ordem de $9.1 \pm 1.9 \mathrm{Kbar}$, a $750^{\circ} \mathrm{C}$ (Eckert et al., 1991). Assim, as rochas 
metabásicas estão situadas no limite entre o fácies granulito e o fácies anfibolito, mas possivelmente foram formadas sob condições de fácies granulito de pressão intermediária a alta (Figura 82). Os dados de temperatura obtidos indicam temperaturas inferiores ao campo de estabilidade do ortopiroxênio, que pode ser devido à presença de fluidos associados à geração de líquido silicático (Pattison, 2003) ou difusão química das fases minerais ferro-magnesianas durante o resfriamento (Pattison \& Begin, 1994; Frost \& Chacko, 2000).

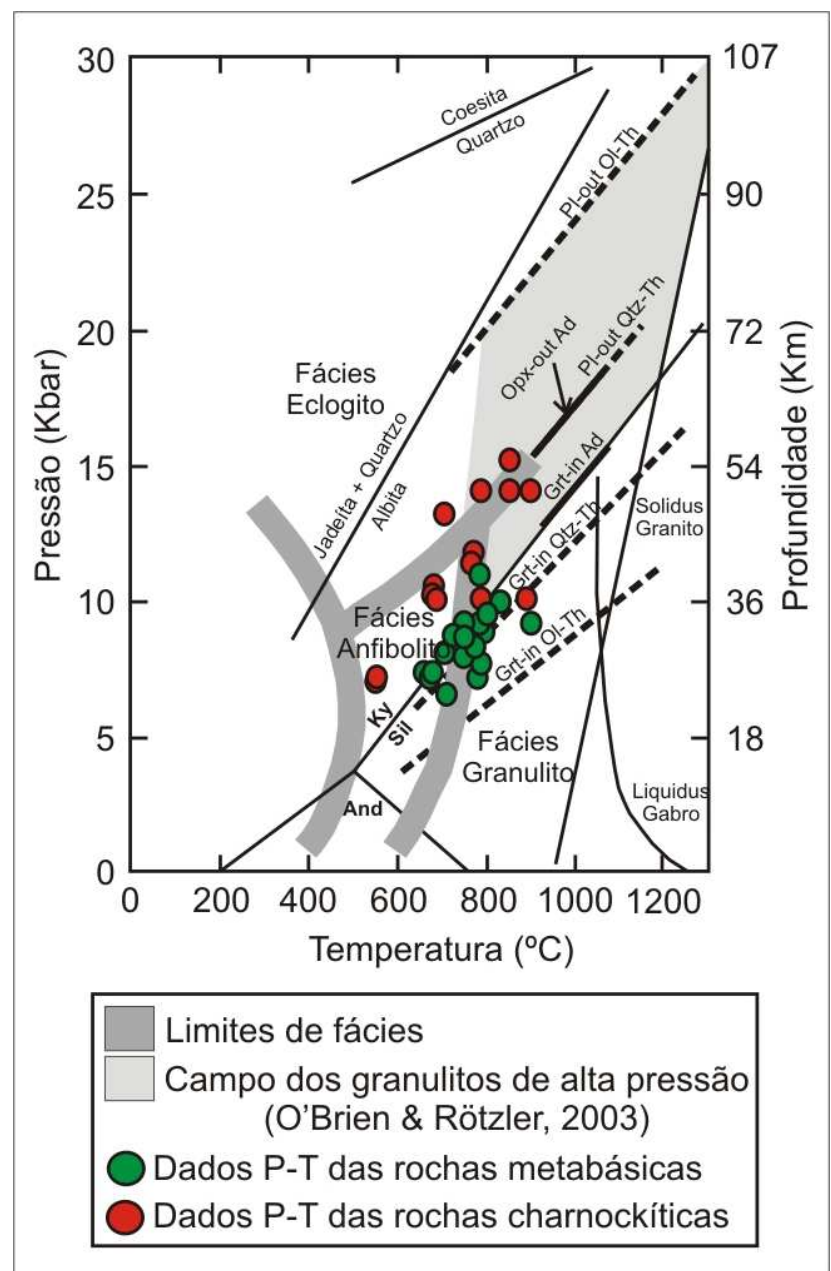

Figura 82: Grid P-T extraído de O’Brien \& Rötzler (2003), com os dados de temperatura e pressão das rochas metabásicas e rochas charnockíticas. Foram utilizadas as grades petrogenéticas de Green \& Ringwood (1967), Ito \& Kennedy (1971), Hansen (1981), Green \& Lambert (1965) e Johannes \& Holtz (1996). Os limites dos campos dos fácies anfibolito, granulito e eclogito foram extraídos de Spear (1993).

As rochas metabásicas com bordas mais deformadas e cisalhadas tiveram uma circulação de fluidos maior, o que resultou em processos retrometamórficos mais intensos, principalmente através da substituição de minerais anidros (e.g. piroxênio) por fases hidratadas (e.g. hornblenda, biotita). São bastante comuns as substituições dos 
piroxênios por hornblenda e/ou por intercrescimentos de Hbl+Qtz, sendo que nos locais onde o retrometamorfismo foi mais intenso, ou com maior percolação de fluidos, essa substituição é quase total. Desta forma, o evento de hidratação subseqüente, responsável pela substituição da associação mineral anidra por minerais hidratados, possivelmente é controlado pelas reações (Pattison, 2003):

$$
\begin{gathered}
\text { Opx + Cpx + Pl + L = Hbl + Qtz } \\
\text { Opx + Cpx + Pl + L = Hbl + Grt + Qtz }
\end{gathered}
$$

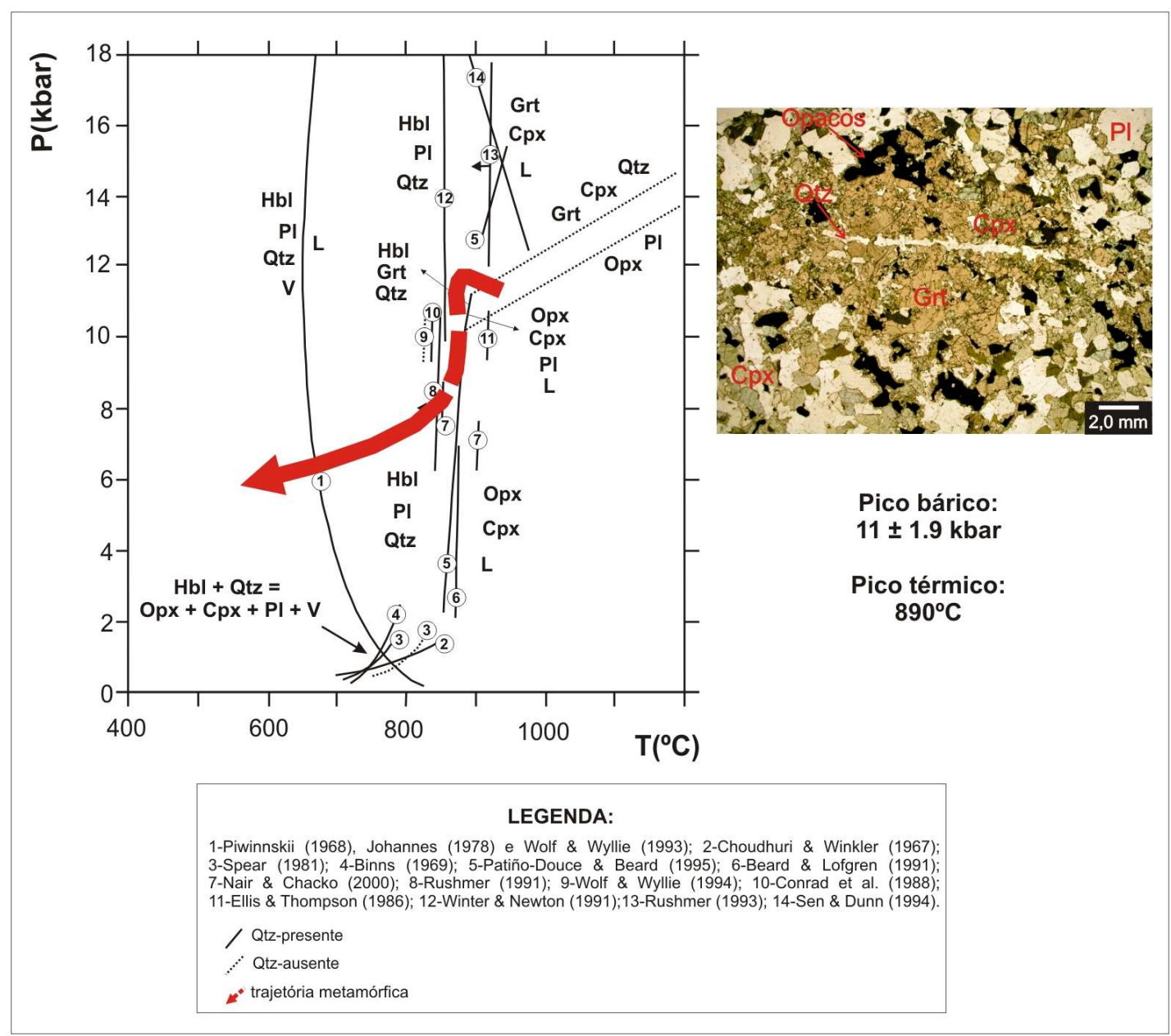

Figura 83: Trajetória P-T para as rochas metabásicas, utilizando as grades petrogenéticas de Piwinskii (1968), Johannes (1978), Wyllie \& Wolf (1993), Choudhuri \& Winkler (1967), Spear (1981), Binns (1969), Patiño-Douce \& Beard (1995), Beard \& Lofgren (1991), Nair \& Chacko (2000), Rushmer (1991), Wolf \& Wyllie (1994), Conrad et al. (1988), Ellis \& Thompson (1986), Winter \& Newton (1991), Rushmer (1993), Sen \& Dunn (1994).

A formação de texturas coroníticas constituídas por Grt $+\mathrm{Cpx}+\mathrm{Qtz}$ ao redor de Opx + Qtz foram interpretadas como sendo resultantes de uma reação progressiva 
(reação 2.2), que marca a passagem do campo de estabilidade do ortopiroxênio e do plagioclásio para o campo de estabilidade dos granulitos de alta pressão (associação Grt + Cpx +Qtz). Desta forma, no presente trabalho, é proposta uma trajetória anti-horária para as rochas metabásicas (Figura 83), seguida de resfriamento quase isobárico.

\subsubsection{Rochas charnockíticas}

A associação mineral predominante nas rochas charnockíticas intrusivas nos ortognaisses do Complexo Mantiqueira é: ortopiroxênio + plagioclásio + quartzo + granada + clinopiroxênio + biotita \pm feldspato potássico \pm hornblenda \pm opacos. São caracterizados pelo desenvolvimento de coronas constituídas por Grt $+\mathrm{Cpx}+\mathrm{Qtz}$ ao redor de cristais ígneos reliquiares de Opx e Pl, que sugerem a passagem pelas reações 2.1 e 2.2 .

As rochas charnockíticas e enderbíticas registram um evento de hidratação anterior ao evento de geração das coronas, através das substituições parciais de ortopiroxênio por intercrescimentos de $\mathrm{Bt}+\mathrm{Qtz}$, aliado à natureza titanífera da biotita, sugere o consumo parcial de ilmenita através da reação (Bhowmik et al., 2009):

\section{Ortopiroxênio + K-feldspato + ilmenita $+\mathrm{H}_{2} \mathrm{O}=$ biotita \pm quartzo}

A substituição de ortopiroxênio por uralita é anterior à substituição por biotita e deve estar relacionada a reações de hidratação durante estágios magmáticos tardios. Localmente esta substituição é quase total, chegando a pseudomorfizar os cristais de ortopiroxênio.

As associações caracterizadas pela persistência do plagioclásio com o aumento de pressão irão apresentar composições de plagioclásio progressivamente mais sódicas, até que parte do sódio seja incorporado pelo clinopiroxênio formando moléculas jadeíticas $[\mathrm{Ab}($ in $\mathrm{Pl})=\mathrm{Jd}($ in $\mathrm{Cpx})+\mathrm{Qtz}]\left(\mathrm{O}^{\prime}\right.$ Brien \& Rötzler, 2003). A pressão necessária para eliminar o plagioclásio em composições basálticas de olivina-toleiíto é de aproximadamente $13.5 \mathrm{kbar}$, enquanto que em composições quartzo-toleiíticas são necessários $20.5 \mathrm{kbar}$, a $1100^{\circ} \mathrm{C}$ para eliminar o plagioclásio (Green \& Ringwood, 1967). A combinação de composições de núcleo de granada e clinopiroxênio com composições mais sódicas do plagioclásio, como por exemplo, o cristal neoformado na corona 9 (NLD-45B), possivelmente representam as condições mais próximas ao pico bárico, mas no entanto não devem representar o pico termal pois a associação Opx+P1 
pode persistir em temperaturas mais elevadas (Baldwin et al., 2003). Esta associação envolvendo plagioclásio sódico neoformado, provavelmente resulta da seguinte reação (Baldwin et al., 2003):

$$
\mathrm{Opx}+\mathrm{Pl}_{1}=\mathbf{G r t}+\mathbf{C p x}+\mathbf{P l}_{2}+\mathbf{Q t z}
$$

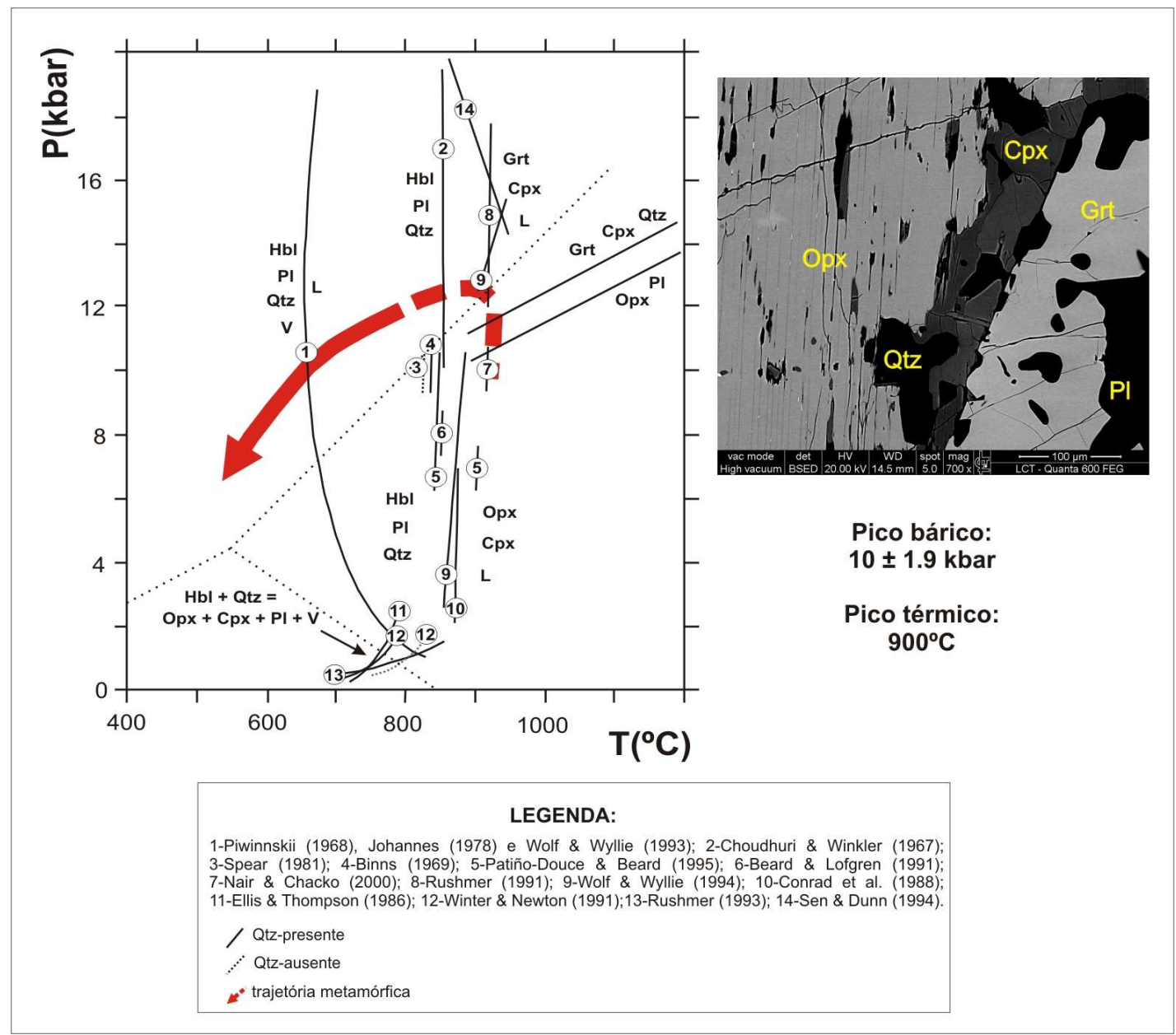

Figura 84: Trajetória P-T para as rochas charnockíticas, utilizando as grades petrogenéticas de Piwinskii (1968), Johannes (1978), Wyllie \& Wolf (1993), Choudhuri \& Winkler (1967), Spear (1981), Binns (1969), Patiño-Douce \& Beard (1995), Beard \& Lofgren (1991), Nair \& Chacko (2000), Rushmer (1991), Wolf \& Wyllie (1994), Conrad et al. (1988), Ellis \& Thompson (1986), Winter \& Newton (1991), Rushmer (1993), Sen \& Dunn (1994).

Nas rochas charnockíticas, as condições mais próximas ao pico metamórfico foram obtidas através de cálculos envolvendo a associação mineral granadaclinopiroxênio-plagioclásio, utilizando o geobarômetro de Eckert et al. (1991). A pressão máxima obtida é de $14.36 \pm 1.9 \mathrm{kbar}$, a $680^{\circ} \mathrm{C}$ (Eckert et al., 1991). Na amostra NLD-45B, a pressão máxima obtida é da ordem de 10.31 kbar. A corona 8 (NLD-45D), 
constituída por Grt $+\mathrm{Cpx}+\mathrm{Qtz} \pm \mathrm{Hbl}$ ao redor de ortopiroxênio magmático no contato com o plagioclásio da matriz, registra as temperaturas mais elevadas, da ordem de $885.17^{\circ} \mathrm{C}$ (Ganguly, 1979) e $901.06^{\circ} \mathrm{C}$ (Sengupta et al., 1989). Na amostra NLD-45B, a temperatura máxima obtida é de 722.86 (Ganguly, 1979). As condições mais próximas ao pico metamórfico também foram calculadas através do THERMOCALC, que forneceu temperatura de $771 \pm 166^{\circ} \mathrm{C}$, a $11.8 \pm 2.4$ kbar (Figura 82).

A evolução metamórfica prossegue com um estágio de decomposição da associação mineral hidratada através de reações de quebra de biotita. A associação de feldspato potássico lobado, aparentemente mimetizando um líquido silicático aproximadamente contemporâneo ao desenvolvimento das coronas, no contato entre plagioclásio e cristais subidioblásticos de granada. É uma textura bastante freqüente, tanto nas rochas charnockíticas como nas rochas metabásicas, e sugere as seguintes reações de desidratação:

$$
\begin{gathered}
\text { Biotita }+ \text { plagioclásio }+ \text { quartzo }=\text { granada }+ \text { K-feldspato }+ \text { fundido } \\
\text { Biotita }+ \text { quartzo }=\text { granada }+ \text { K-feldspato }+ \text { fundido }
\end{gathered}
$$

Segundo Frost \& Frost (1987), Clemens (1992) e Harley et al., (2008), os processos de intrusão de magmas máficos-charnockíticos, fusão parcial e influxo de fluidos com baixa atividade de $\mathrm{H}_{2} \mathrm{O}$ estão intimamente relacionados com a formação de granulitos e devem ocorrem em proximidade em terrenos metamórficos de alto grau. Assume-se que fluidos ricos em $\mathrm{CO}_{2}$ estejam relacionados com o metamorfismo de fácies granulito nas rochas metabásicas e nas rochas charnockíticas, o que permitiu a preservação das paragêneses anidras (Grt-Cpx-Qtz), geralmente em associação com calcita intersticial.

As texturas coroníticas constituídas por Grt $+\mathrm{Cpx}+\mathrm{Qtz}$ ao redor de Opx + Qtz bastante comuns nas rochas charnockíticas foram interpretadas como sendo resultantes de uma reação progressiva (reação 2.2), que marca a passagem do campo de estabilidade do ortopiroxênio e do plagioclásio para o campo de estabilidade dos granulitos de alta pressão (associação Grt $+\mathrm{Cpx}+\mathrm{Qtz}$ ). Desta forma, no presente trabalho, é proposta uma trajetória anti-horária para as rochas charnockíticas (Figura 84), seguida de resfriamento quase isobárico, porém com pressões ligeiramente mais elevadas do que as rochas metabásicas. 


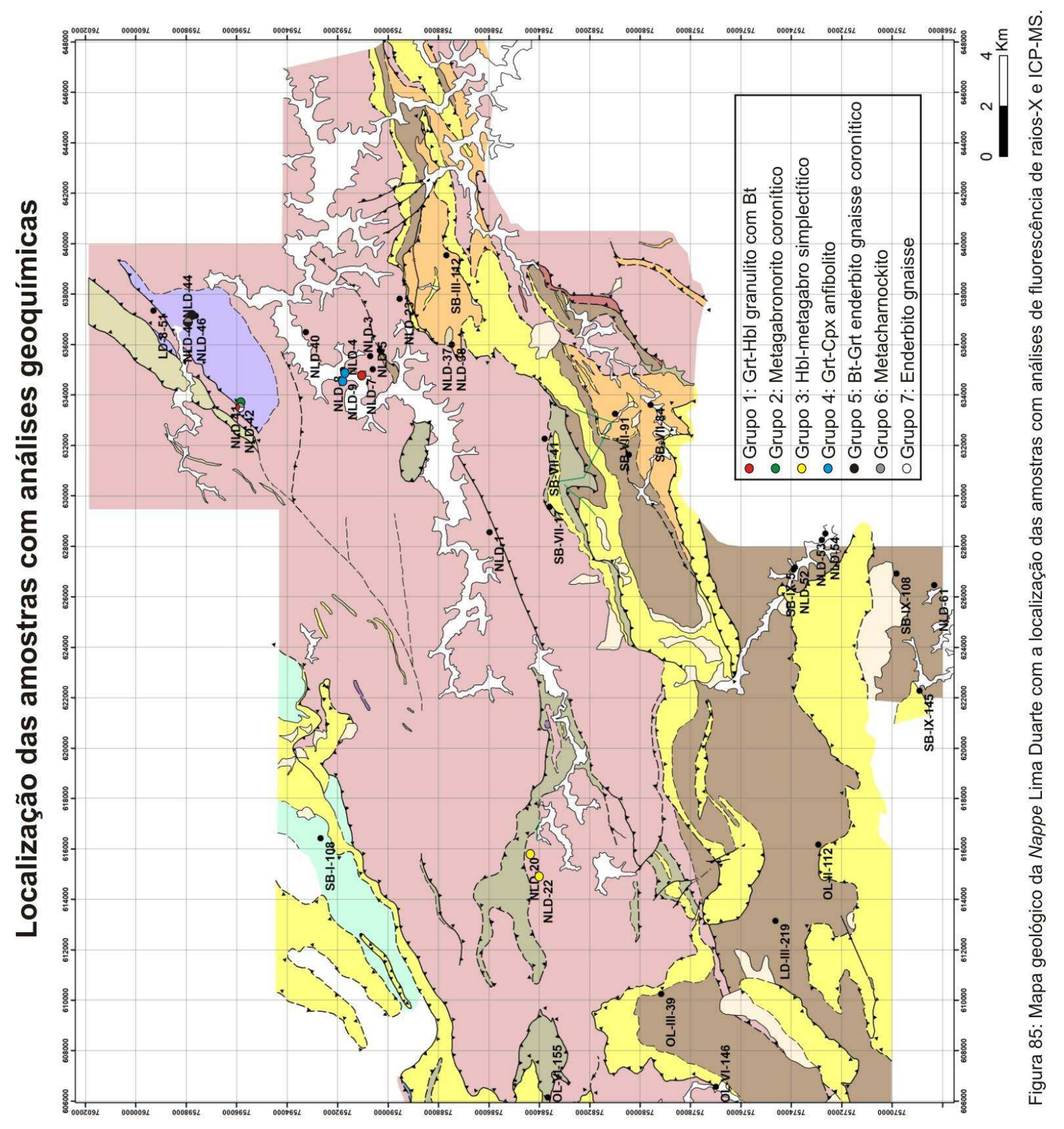




\section{LITOGEOQUÍMICA}

\subsection{Considerações iniciais}

As amostras selecionadas para as análises químicas foram preparadas no Laboratório de Tratamento de Amostras (LTA), do Departamento de Mineralogia e Petrologia (DMP) do Instituto de Geociências, da Universidade de São Paulo (IGcUSP). A determinação dos elementos maiores $\left(\mathrm{SiO}_{2}, \mathrm{TiO}_{2}, \mathrm{Al}_{2} \mathrm{O}_{3}, \mathrm{Fe}_{2} \mathrm{O}_{3 \mathrm{~T}}, \mathrm{MnO}, \mathrm{MgO}\right.$, $\mathrm{CaO}, \mathrm{Na}_{2} \mathrm{O}, \mathrm{K}_{2} \mathrm{O}, \mathrm{P}_{2} \mathrm{O}_{5}$ ), elementos menores e elementos traço ( $\mathrm{Ba}, \mathrm{Co}, \mathrm{Cr}, \mathrm{Cu}, \mathrm{F}, \mathrm{Nb}$, $\mathrm{Nd}, \mathrm{Ni}, \mathrm{Pb}, \mathrm{Rb}, \mathrm{S}, \mathrm{Sc}, \mathrm{Sr}, \mathrm{Th}, \mathrm{U}, \mathrm{V}, \mathrm{Y}, \mathrm{Zn}, \mathrm{Zr}$ ) foram realizados através de espectrometria de fluorescência de raios-X utilizando um equipamento automático Phillips, modelo PW2400, de acordo com o método descrito por Mori et al. (1999), no Laboratório de Química e no Laboratório de Fluorescência de Raios-X, Instituto de Geociências, Universidade de São Paulo (IGc-USP). Os erros analíticos para os elementos maiores são entre 2-5\%, e para os elementos traço são inferiores a 10\%. Para a utilização dos dados obtidos de elementos maiores, os valores foram recalculados para $100 \%$ na base anidra (sem a perda ao fogo - Loi). Foram selecionadas 16 amostras de rochas metabásicas e rochas charnockíticas para estudos de litogeoquímica (NLD-7A, NLD-7B, NLD-7E, NLD-8A, NLD-9A, NLD-20A, NLD-22A, NLD-41A, NLD-41F, NLD-41G, NLD-42A, NLD-42C, NLD-42E, NLD-44A, NLD-45A e NLD-45D).

A determinação de 14 elementos terras raras (La, Ce, Pr, Nd, Sm, Eu, Gd, Tb, Dy, Ho, Er, Tm, Yb, Lu) e 11 elementos traço (Rb, Sr, Y, Zr, Nb, Cs, Ba, Hf, Pb, Th, U) foi realizada por espectrometria de massa com plasma induzido acoplado (Inductively Coupled Plasma-Mass Spectrometry) (ICP-MS), dotado de espectrômetro do tipo quadrupolo, modelo ELAN 6100DRC da PerkinElmer/Sciex, no Laboratório de Química e ICP-MS, do Instituto de Geociências, Universidade de São Paulo (IGc-USP). Os resultados obtidos estão apresentados na Tabela 10. Foram selecionadas 11 amostras para realização de análises por ICP-MS (NLD-7B, NLD-7E, NLD-8A, NLD9A, NLD-20A, NLD-22A, NLD-41F, NLD-41G, NLD-42C, NLD-45A e NLD-45D). Os dados obtidos foram tratados através da utilização do software PetroGraph 1.0.5 (Petrelli, 2005) e a interpretação dos dados foi feita a partir de Rollinson (1993), Sun \& Mc Donough (1989) e Pearce et al., (1984). As amostras foram agrupadas de acordo com critérios mineralógicos, texturais e estruturais, totalizando 7 grupos distintos, descritos a seguir: 


\subsection{Grupos de rochas metabásicas e rochas charnockíticas}

- GRUPO 1: Granada-hornblenda granulito (NLD-7B, NLD-7E, NLD-41A)

A rocha possui estrutura predominantemente maciça, com textura granoblástica inequigranular fina a média $(0,1-1,5 \mathrm{~mm})$, caracterizada pela presença de cristais bem formados de clinopiroxênio e ortopiroxênio substituídos por hornblenda nas bordas (NLD-7B e NLD-7E). Em algumas amostras (NLD-41A) desenvolve-se a textura nematogranoblástica, definida pela orientação preferencial de hornblenda na foliação. Os piroxênios estão freqüentemente substituídos por intercrescimentos simplectíticos de Hbl+Qtz. Também ocorrem pseudomorfos de piroxênio parcial a totalmente substituídos por Hbl. Localmente ocorrem coronas de Grt $+\mathrm{Cpx}+\mathrm{Pl} \pm$ Qtz nos contatos entre o ortopiroxênio e plagioclásio de dimensão maior (1-1.5mm). Esta textura é obliterada pela substituição posterior de Hbl+Qtz.

Mineralogia: hornblenda (15-45\%), plagioclásio (25-45\%), clinopiroxênio (10-30\%), ortopiroxênio $(10-20 \%)$, granada $(1-5 \%)$, opacos $(<7 \%)$, quartzo $(<5 \%)$, apatita $(<3 \%)$, actinolita $(<1 \%)$, biotita $(<1 \%)$, rutilo $(<1 \%)$, calcita $(<1 \%)$.

\section{- GRUPO 2: Metagabronorito coronítico (NLD-42A, NLD-42C, NLD-42E)}

O metagabronorito (NLD-42A, NLD-42C, NLD-42E) apresenta textura predominantemente granoblástica, com leitos nematogranoblásticos caracterizados pela presença de piroxênios (clinopiroxênio e ortopiroxênio) e anfibólios orientados. São muito freqüentes as texturas coroníticas, comumente com agregados de opacos manteados por granada. As coronas de granada se desenvolvem preferencialmente nos contatos entre opacos e plagioclásio e/ou entre opacos e clinopiroxênio. Ocorrem grãos de clinopiroxênio ricos em inclusões de plagioclásio \pm quartzo.

Mineralogia: plagioclásio (35-45\%), clinopiroxênio (20-30\%), ortopiroxênio (10-20\%), granada (10-20\%), hornblenda (5-10\%), opacos (5-10\%), apatita $(<3 \%)$, zircão $(<3 \%)$, calcita $(<2 \%)$, rutilo $(<1 \%)$ e epídoto $(<1 \%)$.

\section{- GRUPO 3: Hornblenda-metagabro simplectítico (NLD-20A, NLD-22A)}

A rocha apresenta uma estrutura predominantemente maciça, sem uma foliação

bem definida, sendo caracterizada por uma textura hipidiomórfica reliquiar, inequigranular fina a muito fina, com cristais ripiformes de plagioclásio e textura simplectítica de $\mathrm{Hbl}+\mathrm{Pl}+$ Qtz posterior, que substitui os piroxênios. A hornblenda é o 
mineral máfico dominante. Localmente ocorrem texturas coroníticas de granada subidioblástica manteando o plagioclásio ou os opacos, que por sua vez é envolvida por hornblenda.

Mineralogia: hornblenda (50-60\%), plagioclásio (15-30\%), clinopiroxênio (5-15\%), ortopiroxênio $(<10 \%)$, quartzo $(5-10 \%)$, granada $(<5 \%)$, opacos $(<5 \%)$, apatita $(<3 \%)$, titanita $(<1 \%)$.

- GRUPO 4: granada-clinopiroxênio anfibolito (NLD-8A), clinopiroxêniogranada anfibolito simplectítico (NLD-9A)

O granada-clinopiroxênio anfibolito (NLD-8A) é caracterizado por uma estrutura protomilonítica, com textura granonematoblástica, inequigranular fina a média. A hornblenda constitui a fase principal e define a foliação principal $\mathrm{S}_{2}$, localmente dobrada. Os cristais de plagioclásio estão bastante estirados. Ocorrem cristais de granada sin a tardi-cinemáticos, xenoblásticos e cristais pós-cinemáticos idioblásticos, que formam texturas do tipo moat, manteando o plagioclásio e eventualmente os opacos, e sendo envolvida por hornblenda.

Mineralogia: hornblenda (55-65\%), granada (15-20\%), clinopiroxênio (5-10\%), plagioclásio (5-10\%), quartzo $(5 \%)$, opacos $(<5 \%)$, apatita $(<1 \%)$, zircão $(<1 \%)$.

O clinopiroxênio-granada anfibolito simplectítico (NLD-9A) é inequigranular fino a médio, pouco foliado, cuja característica principal é a presença de texturas simplectíticas de $\mathrm{Hbl}+\mathrm{Pl}+\mathrm{Qtz}$, substituindo os piroxênios. A granada é idioblástica a subidioblástica, comumente associada ao plagioclásio e a hornblenda, porém sem formar coronas. Ocorrem alguns cristais poiquiloblásticos, englobando quartzo e hornblenda. O plagioclásio predominante é andesina $\left(\mathrm{An}_{45-50}\right)$, na forma de cristais poligonizados na matriz, associados com quartzo e apatita, localmente saussuritizados. A biotita é tardia, idioblástica a subidioblástica, substituindo a hornblenda.

Mineralogia: hornblenda (55-60\%), plagioclásio (25-30\%), granada (5-10\%), clinopiroxênio $(5-10 \%)$, biotita $(5-10 \%)$, ortopiroxênio $(<5 \%)$, opacos $(<5 \%)$, quartzo $(<5 \%)$, apatita $(<1 \%)$.

\section{- GRUPO 5: Metacharnockito (Meta Opx-granito) (NLD-41F)}

A rocha apresenta estrutura bandada, alternando leitos granoblásticos e nematogranoblásticos, de dimensão milimétrica a subcentimétrica, com textura 
dominantemente granoblástica, inequigranular fina a média $(0,1-2,5 \mathrm{~mm})$. Nas bandas ricas em minerais máficos, ocorrem grãos de ortopiroxênio muito fraturados e substituídos por intercrescimentos esqueletais de Bt + Qtz e/ou por anfibólio fibroso (uralita). A granada forma coronas incompletas ao redor de opacos, nos contatos com o feldspato. Frequientemente ocorrem mirmequitas nos contatos entre os grãos de plagioclásio e feldspato potássico. Ocorrem pertitas com lamelas de exsolução de plagioclásio de dimensão submilimétrica $(0,01-0,05 \mathrm{~mm})$ e localmente ocorre antipertita, com lamelas de exsolução de dimensão milimétrica (0,1-0,2mm). É muito comum nos feldspatos a presença de microfraturas preenchidas por clorita, responsável pela coloração esverdeada típica dos feldspatos em rochas charnockíticas.

Mineralogia: feldspato potássico (35-40\%), plagioclásio (25-30\%), quartzo (20-25\%), biotita $(7-10 \%)$, ortopiroxênio $(5-7 \%)$, hornblenda $(<5 \%)$, apatita $(<4 \%)$, opacos $(<3 \%)$, granada $(<1 \%)$, zircão $(<1 \%)$, clorita $(<1 \%)$.

\section{- GRUPO 6: Enderbito gnaisse (Opx-tonalito gnaisse) (NLD-41G, NLD-45A)}

Apresenta estrutura foliada, com textura nematogranoblástica a lepidonematogranoblástica, inequigranular fina a média $(0,1-2,0 \mathrm{~mm})$, com cristais subidioblásticos de hornblenda e biotita orientados na foliação, localmente com megacristais de feldspato de até $4 \mathrm{~mm}$. Localmente ocorrem mirmequitas no contato entre os grãos de plagioclásio e feldspato potássico. O ortopiroxênio ocorre concentrado em leitos de dimensão subcentimétrica, geralmente substituído por anfibólio fibroso (uralita), intercrescimentos esqueletais de $\mathrm{Bt}+\mathrm{Qtz}$ e/ou por hornblenda nas bordas. Quando esta substituição é total, forma leitos lepidonematogranoblásticos, ricos em hornblenda, biotita e plagioclásio.

Mineralogia: plagioclásio (40-45\%), hornblenda (30-35\%), ortopiroxênio (5-10\%), biotita $(5-10 \%)$, quartzo $(5-7 \%)$, clinopiroxênio $(<5 \%)$, apatita $(<5 \%)$, opacos $(<5 \%)$, feldspato potássico $(<2 \%)$, zircão $(<2 \%)$, clorita $(<2 \%)$, rutilo $(<1 \%)$.

- GRUPO 7: Biotita-granada enderbito gnaisse coronítico (Biotita-granada Opx-tonalito gnaisse coronítico) (NLD-44A, NLD-45D)

A rocha é caracterizada por uma textura blastoporfirítica, constituída predominantemente por cristais reliquiares ígneos de ortopiroxênio e plagioclásio de granulação grossa em matriz inequigranular fina a média, composta por grãos de plagioclásio poligonizados, quartzo, granada, clinopiroxênio e biotita. Localmente 
ocorrem porções lepidogranoblásticas, ricas em biotita. São bastante freqüientes as texturas coroníticas de Grt $+\mathrm{Cpx} \pm \mathrm{Qtz} \pm \mathrm{PL}$ no contato entre os cristais de ortopiroxênio e plagioclásio. O ortopiroxênio também está parcial a totalmente substituído por $\mathrm{Bt} \pm$ Qtz pelas bordas ou ao longo de fraturas.

Mineralogia: plagioclásio (45-60\%), ortopiroxênio (10-20\%), clinopiroxênio (10-15\%), granada $(5-10 \%)$, biotita $(5-10 \%)$, feldspato potássico $(<5 \%)$, apatita $(<5 \%)$, quartzo $(<2 \%)$, hornblenda $(<1 \%)$, zircão $(<1 \%)$, rutilo $(<1 \%)$, calcita $(<1 \%)$.

\subsection{Rochas metabásicas}

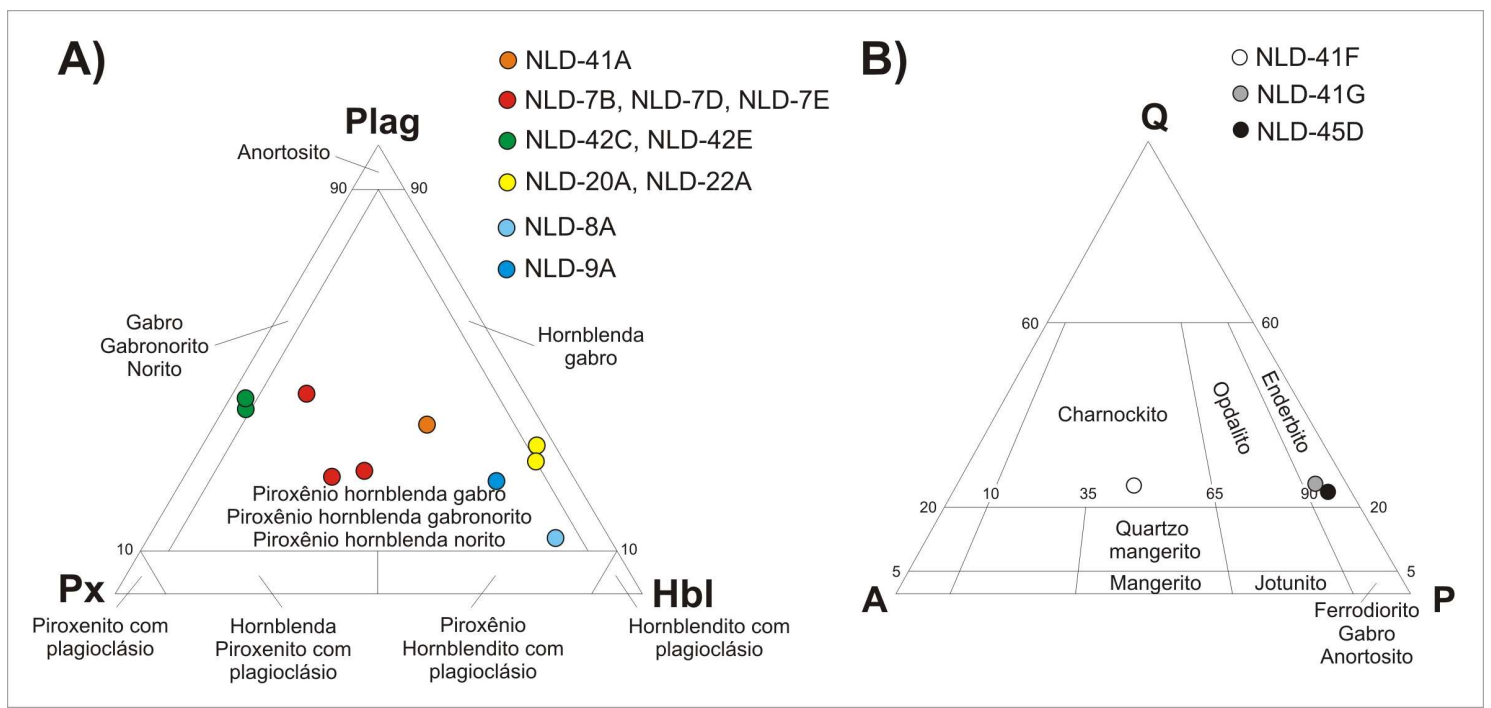

Figura 86: A) Diagrama de classificação de rochas gabróicas (Le Maitre, 1989); B) Diagrama QAP com os nomes das rochas na série charnockítica (Le Maitre, 1989).

\subsubsection{Classificação das rochas metabásicas}

As rochas metabásicas inseridas nos ortognaisses e nas rochas charnockíticas do Complexo Mantiqueira ocorrem preferencialmente na forma de boudins, corpos alongados formando bandas transpostas ao longo da foliação principal, ou ainda na forma de enclaves máficos. A estrutura e a dimensão dos corpos máficos condicionam o grau de hidratação das rochas, pois nos núcleos de boudins de dimensão maior o acesso de fluidos é mais restrito, o que permite a preservação de paragêneses anidras, enquanto que nas bordas cisalhadas dos boudins ou em estruturas de dimensão menor os processos retrometamórficos são facilitados por uma maior circulação de fluidos, resultando na substituição dos minerais anidros por minerais hidratados, como hornblenda e/ou biotita. Piroxênio, plagioclásio e hornblenda são os principais minerais 
constituintes das rochas metabásicas e ocorrem em proporções variadas, resultando em litotipos máficos distintos (Figura 86). As rochas metabásicas investigadas no presente trabalho apresentam estrutura, textura e mineralogia distintas, e possivelmente apontam para diferentes fontes e processos evolutivos que atuaram na formação destas rochas.

No diagrama de classificação de rochas vulcânicas de Le Bas et al. (1986), o teor relativo de sílica varia entre 45.7-50.3 $\mathrm{SiO}_{2}$ (\% peso) e todas as amostras plotam no campo do basalto, situado também no campo definido para as rochas subalcalinas, dado pelos baixos valores de álcalis (Figura 87A). No diagrama binário $(\mathrm{FeOt} / \mathrm{MgO})$ de Miyashiro (1974) (Figura 87B) e no diagrama ternário AFM de Irvine \& Baragar (1971) (Figura 88A) observa-se que os litotipos estudados têm afinidade predominantemente toleí́tica. É possível reconhecer que os metagabronoritos do grupo 2 e granada-clinopiroxênio anfibolitos do grupo 4 apresentam uma tendência evolutiva de ferro-basalto. Estes dois grupos apresentam os menores valores de Mg\# (34-35.6).

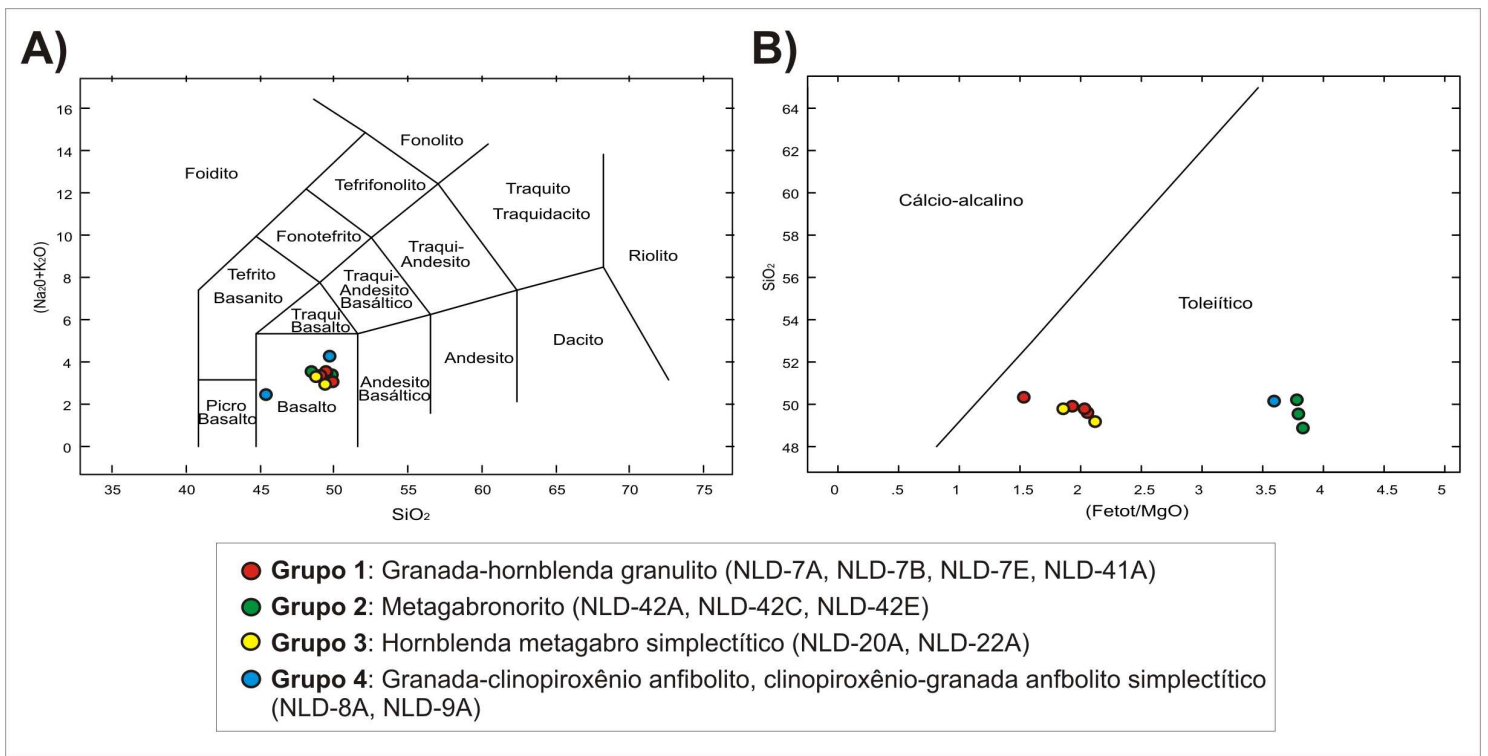

Figura 87: A) Diagrama de classificação de rochas vulcânicas (Le Bas et al., 1986); B) Diagrama binário FeOt/Mg vs. $\mathrm{SiO}_{2}$, segundo Miyashiro (1974).

Segundo Pearce \& Cann (1971, 1973), é possível utilizar a geoquímica para distinguir basaltos produzidos em diferentes contextos tectônicos conhecidos, através de diagramas de discriminação tectono-magmática. Os elementos discriminantes mais efetivos entre basaltos gerados em diferentes ambientes tectônicos são Ti, $\mathrm{Zr}, \mathrm{Y}$ e $\mathrm{Nb}$, por serem elementos traço relativamente imóveis e estáveis sob condições de hidrotermalismo, intemperismo de fundo oceânico e grau metamórfico médio. A 
estabilidade sobre estes elementos em grau metamórfico alto ainda é pouco conhecida. As rochas metabásicas são classificadas como MORB no diagrama discriminante [Ti$\mathrm{Zr}-\mathrm{Sr}$ ] de Pearce \& Cann (1973) (Figura 88B). O diagrama [Ti-Zr-Y] de Pearce \& Cann (1973) discrimina basaltos intraplaca (ilha oceânica ou toleíitos intraplaca) e outros tipos de basaltos. Neste diagrama, quase todas as amostras plotam no campo do MORB (Figura 88C).

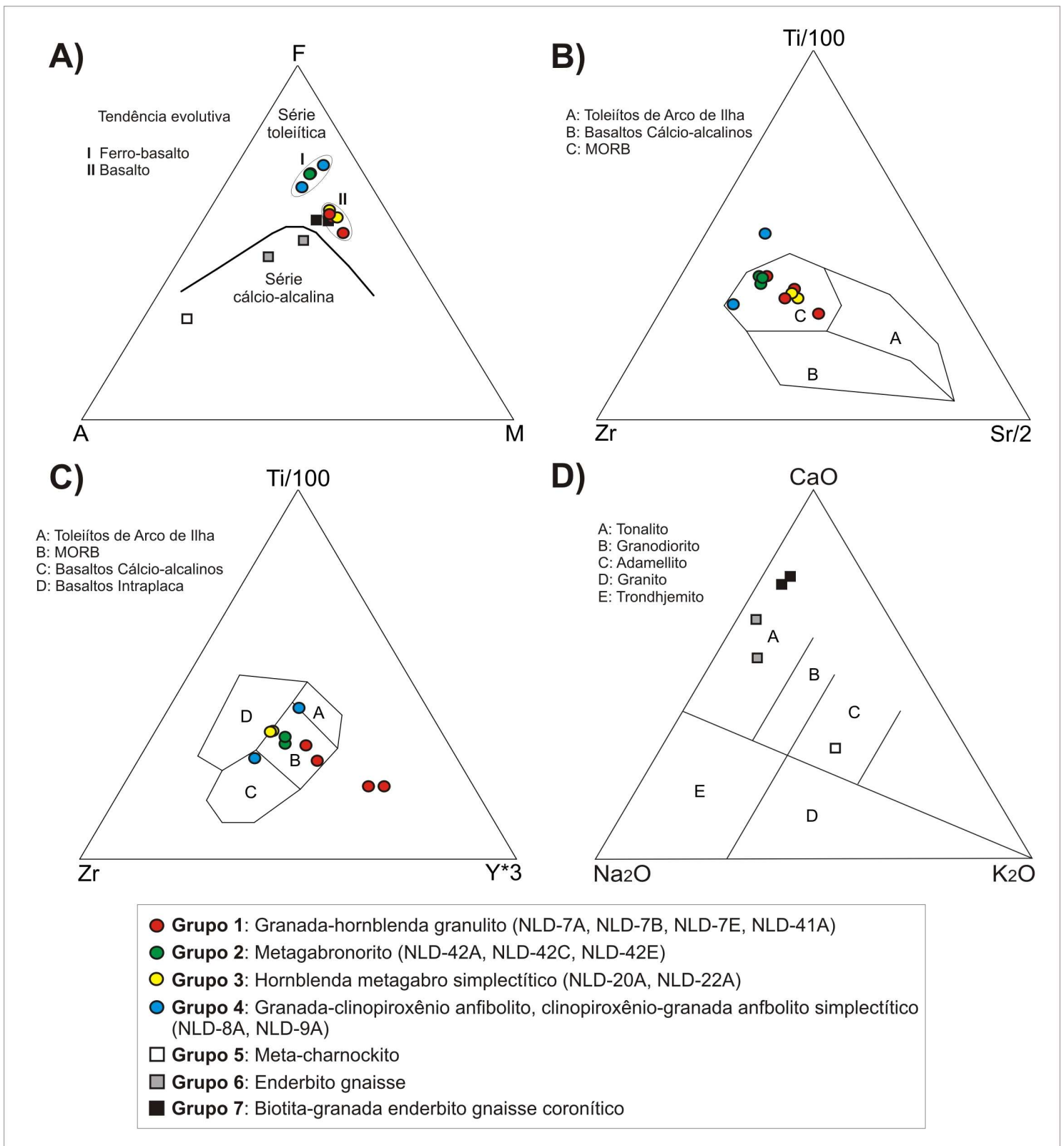

Figura 88: A) Diagrama ternário AFM, com a divisão dos campos toleiítico e cálcio-alcalino, (Irvine \& Baragar, 1971); B) Diagrama discriminatório [Ti-Zr-Sr], (Pearce \& Cann, 1973); C) Diagrama discriminatório [Ti-Zr-Y], (Pearce \& Cann, 1973); D) Diagrama de classificação de granulitos félsicos e intermediários [CaO-Na $\left.\mathrm{N}_{2} \mathrm{O}-\mathrm{K}_{2} \mathrm{O}\right]$ (Glikson, 1979). 


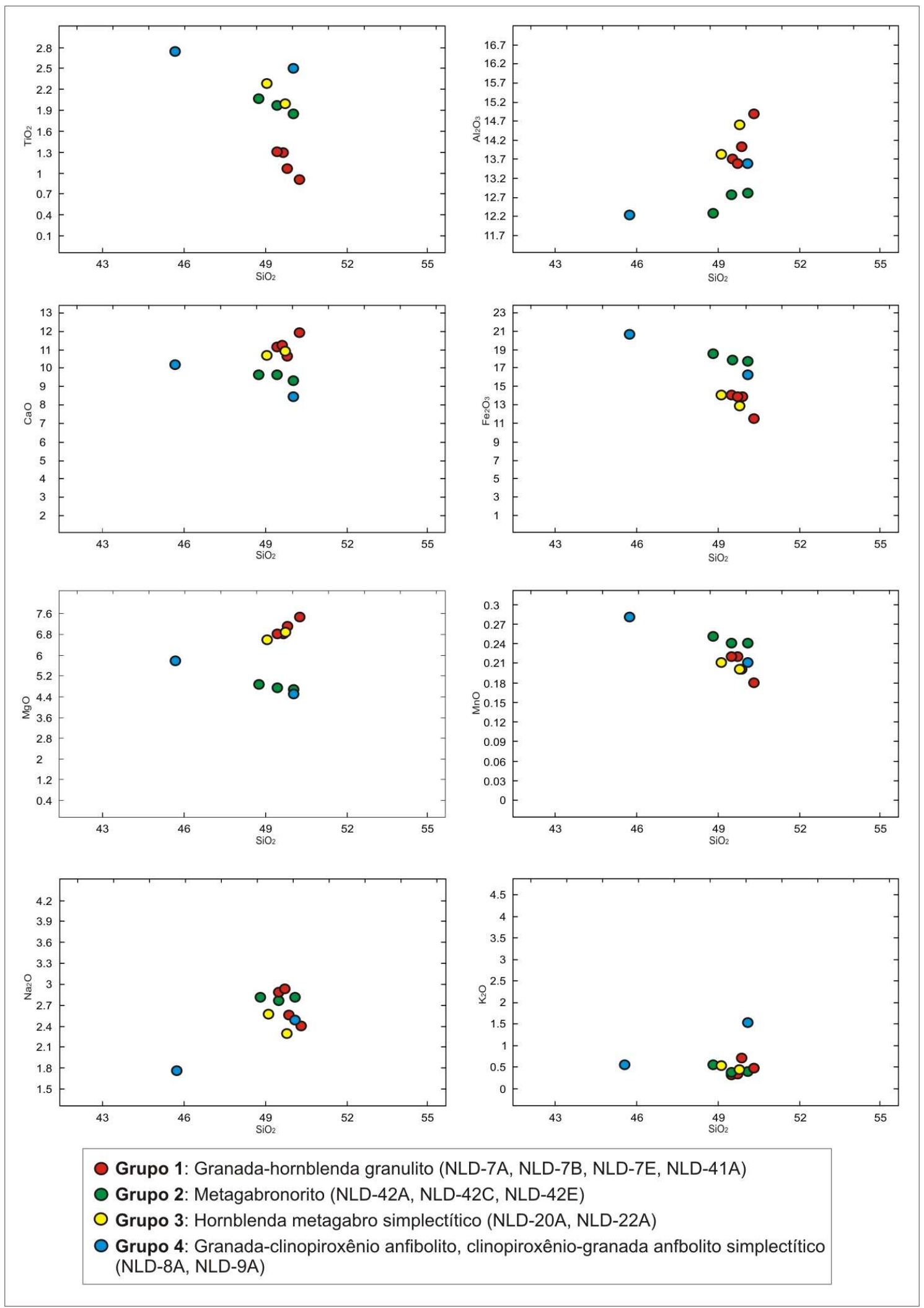

Figura 89: Diagramas de Harker dos elementos maiores (expressos em \% peso) para as rochas metabásicas. 

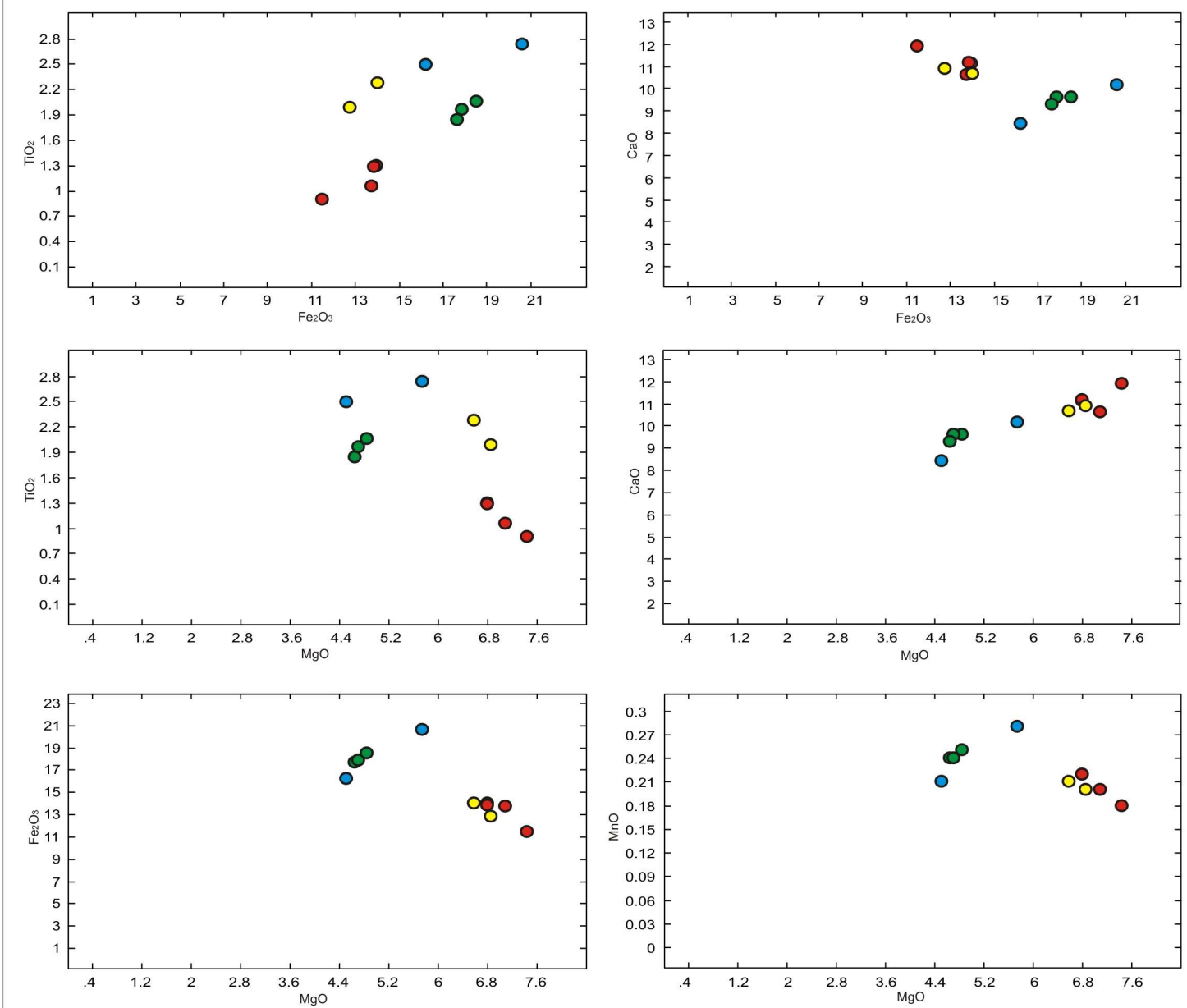

- Grupo 1: Granada-hornblenda granulito (NLD-7A, NLD-7B, NLD-7E, NLD-41A)

- Grupo 2: Metagabronorito (NLD-42A, NLD-42C, NLD-42E)

O Grupo 3: Hornblenda metagabro simplectítico (NLD-20A, NLD-22A)

O Grupo 4: Granada-clinopiroxênio anfibolito, clinopiroxênio-granada anfbolito simplectítico (NLD-8A, NLD-9A)

Figura 90: Diagramas de Harker dos elementos maiores (expressos em \% peso) para as rochas metabásicas.

O hornblenda-metagabro simplectítico do grupo 3 plota no limite do campo MORB com o campo dos basaltos intraplaca, porém apresenta elevadas razões Sr/Y em comparação com as outras rochas metabásicas, o que sugere que parte significativa do $\mathrm{Y}$ tenha sido retida na granada da fonte. Além disto, a preservação de texturas ígneas reliquiares (plagioclásio ripiforme) nos litotipos deste grupo os diferencia dos demais e sugere uma origem intraplaca para o protólito basáltico. O caráter anidro dos metagabronoritos e biotita-granada enderbito gnaisses é confirmado pelos baixos valores de perda ao fogo (Loi) (Tabela 10). Nessas amostras as texturas são mais bem preservadas e possivelmente as razões $\mathrm{CO}_{2} / \mathrm{H}_{2} \mathrm{O}$ são mais elevadas, evidenciado também pela freqüente presença de carbonatos intersticiais tardios. O hornblenda 
metagabro simplectítico apresenta os maiores conteúdos de voláteis e é o litotipo mais afetado por retrometamorfismo.
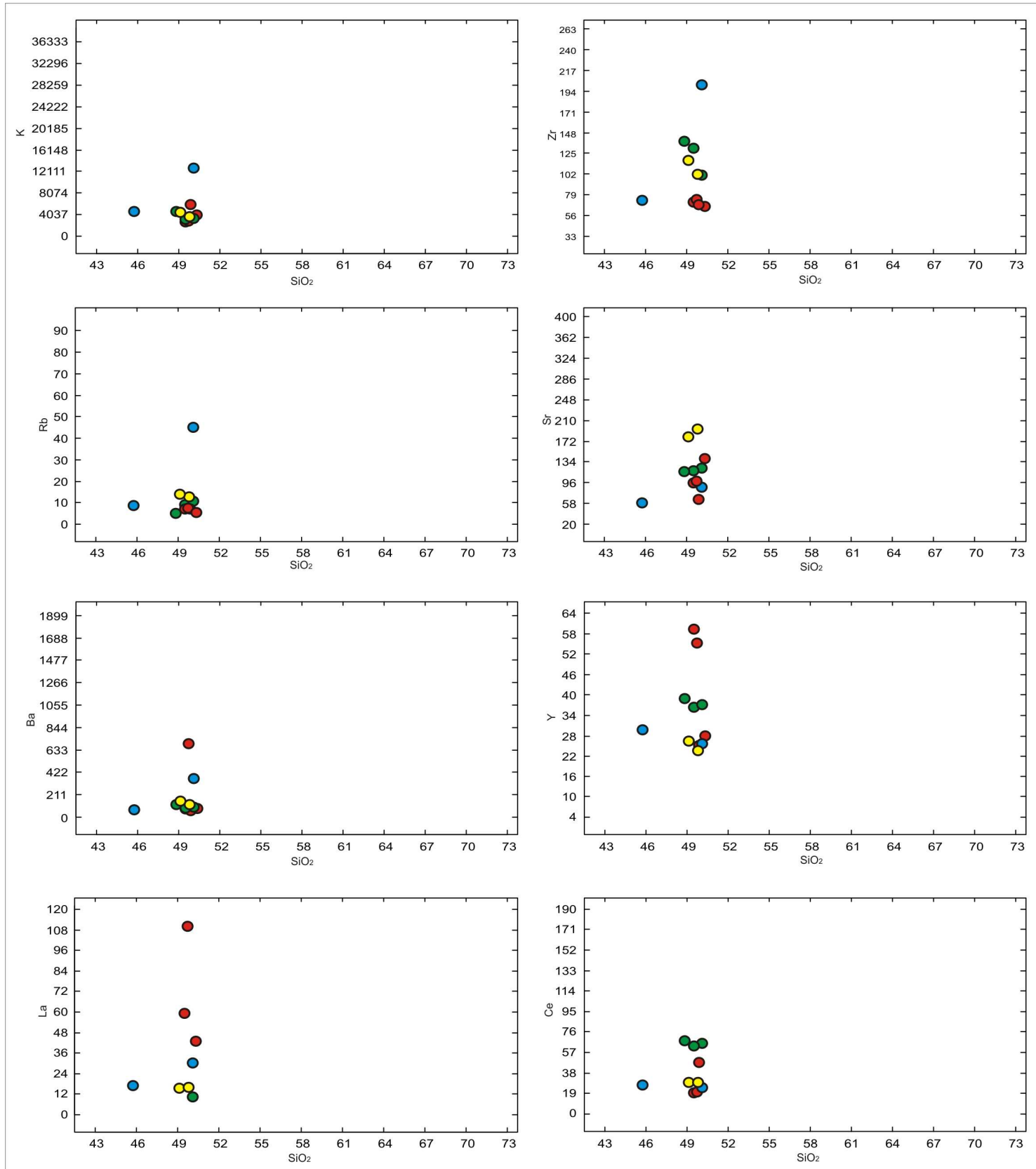

- Grupo 1: Granada-hornblenda granulito (NLD-7A, NLD-7B, NLD-7E, NLD-41A)

- Grupo 2: Metagabronorito (NLD-42A, NLD-42C, NLD-42E)

O Grupo 3: Hornblenda metagabro simplectítico (NLD-20A, NLD-22A)

- Grupo 4: Granada-clinopiroxênio anfibolito, clinopiroxênio-granada anfbolito simplectítico (NLD-8A, NLD-9A)

Figura 91: Diagramas de Harker dos elementos menores e traço (expressos em ppm) para as rochas metabásicas. 


\begin{tabular}{|c|c|c|c|c|c|c|c|c|c|c|c|c|c|c|c|c|}
\hline \multirow{3}{*}{$\begin{array}{c}\text { Amostras } \\
\mathrm{SiO} 2\end{array}$} & \multirow{3}{*}{\begin{tabular}{|c|} 
NLD-41A \\
49.91
\end{tabular}} & \multirow{2}{*}{\multicolumn{2}{|c|}{$\begin{array}{c}\text { NLD-7A NLD-7B } \\
\text { Granada granulito } \\
\end{array}$}} & \multirow{2}{*}{ NLD-7E } & \multirow{2}{*}{\multicolumn{3}{|c|}{\begin{tabular}{|c|} 
NLD-42A NLD-42C NLD-42E \\
Metagabronorito
\end{tabular}}} & \multirow{2}{*}{\multicolumn{2}{|c|}{\begin{tabular}{|c|} 
NLD-8A NLD-9A \\
Grt-cpx \\
anfibolito
\end{tabular}}} & \multicolumn{4}{|c|}{\begin{tabular}{|l|l|} 
NLD-20A NLD-22A & NLD-44A NLD-45D \\
\end{tabular}} & \multirow{3}{*}{\begin{tabular}{|c|} 
NLD-41F \\
$\begin{array}{c}\text { Meta } \\
\text { charnockito }\end{array}$ \\
69.53
\end{tabular}} & \multirow{2}{*}{\multicolumn{2}{|c|}{$\begin{array}{c}\text { NLD-45A NLD-41G } \\
\begin{array}{c}\text { Enderbito } \\
\text { gnaisse }\end{array}\end{array}$}} \\
\hline & & & & & & & & & & $\begin{array}{l}\text { Horn } \\
\text { met }\end{array}$ & $\begin{array}{l}\text { enda } \\
\text { ubro }\end{array}$ & $\begin{array}{r}\text { Biotita } \\
\text { enderbi }\end{array}$ & $\begin{array}{l}\text { ranada } \\
\text { gnaisse }\end{array}$ & & & \\
\hline & & 50.32 & & 49.75 & 48.87 & 50.16 & 49.49 & 45.76 & 50.15 & 49.79 & 49.15 & 51.59 & 51.92 & & 57.43 & 60.09 \\
\hline TiO2 & 1.06 & 0.9 & 1.3 & 1.28 & 2.06 & 1.84 & 1.96 & 2.74 & 2.49 & 1.98 & 2.27 & 1.11 & 1.27 & 0.43 & 0.72 & 0.83 \\
\hline $\mathrm{Al} 2 \mathrm{O} 3$ & 14.02 & 14.88 & 13.71 & 13.58 & 12.28 & 12.80 & 12.75 & 12.23 & 13.57 & 14.6 & 13.81 & 13.09 & 15.08 & 14.89 & 15.59 & 16.46 \\
\hline $\mathrm{Fe} 2 \mathrm{O} 3(\mathrm{t})$ & 13.76 & 11.48 & 14 & 13.85 & 18.55 & 17.64 & 17.90 & 20.61 & 16.26 & 12.78 & 14.02 & 12.54 & 11.57 & 3.40 & 8.84 & 7.41 \\
\hline $\mathrm{Fe} 2 \mathrm{O} 3$ & 1.38 & 1.15 & 1.40 & 1.39 & 1.86 & 1.77 & 1.79 & 2.06 & 1.63 & 1.28 & 1.40 & 1.26 & 1.16 & 0.34 & 0.89 & 0.74 \\
\hline $\mathrm{FeO}$ & 12.38 & 10.33 & 12.60 & 12.46 & 16.69 & 15.87 & 16.11 & 18.55 & 14.63 & 11.50 & 12.62 & 11.28 & 10.41 & 3.06 & 7.95 & 6.67 \\
\hline MnO & 0.20 & 0.18 & 0.22 & 0.22 & 0.25 & 0.24 & 0.24 & 0.28 & 0.21 & 0.2 & 0.21 & 0.20 & 0.19 & 0.03 & 0.15 & 0.08 \\
\hline $\mathrm{MgO}$ & 7.08 & 7.44 & 6.79 & 6.8 & 4.84 & 4.65 & 4.71 & 5.75 & 4.51 & 6.86 & 6.59 & 6.47 & 5.36 & 1.20 & 4.51 & 3.24 \\
\hline $\mathrm{CaO}$ & 10.63 & 11.88 & 11.12 & 11.17 & 9.60 & 9.31 & 9.62 & 10.16 & 8.41 & 10.91 & 10.64 & 11.55 & 10.83 & 3.02 & 8.55 & 6.24 \\
\hline $\mathrm{Na} 2 \mathrm{O}$ & 2.55 & 2.39 & 2.88 & 2.92 & 2.81 & 2.80 & 2.76 & 1.75 & 2.48 & 2.29 & 2.56 & 2.68 & 3.07 & 3.13 & 3.39 & 4.05 \\
\hline K2O & 0.70 & 0.47 & 0.32 & 0.33 & 0.54 & 0.39 & 0.38 & 0.55 & 1.52 & 0.44 & 0.53 & 0.67 & 0.56 & 4.21 & 0.70 & 1.39 \\
\hline P2O5 & 0.09 & 0.05 & 0.11 & 0.11 & 0.19 & 0.18 & 0.18 & 0.18 & 0.4 & 0.18 & 0.22 & 0.11 & 0.16 & 0.17 & 0.13 & 0.22 \\
\hline Loi & 0.42 & 0.26 & 0.20 & 0.18 & 0.00 & 0.00 & 0.00 & 0.04 & 0.28 & 0.44 & 0.34 & 0.00 & 0.00 & 0.38 & 0.24 & 0.38 \\
\hline Total & 100 & 100 & 100 & 100 & 100 & 100 & 100 & 100 & 100 & 100 & 100 & 100 & 100 & 100 & 100 & 100 \\
\hline $\mathrm{Ba}$ & 58 & 81 & 76.7 & 695 & 110 & 92.2 & 82 & 65.5 & 361 & 115 & 146 & 300 & 117 & 1742 & 183 & 290 \\
\hline $\mathrm{Ce}$ & 47 & $<35$ & 19.2 & 20.0 & 67 & 24.5 & 63 & 26.7 & 65.1 & 28.6 & 29.1 & 61 & 29.9 & 174 & 27.5 & 125 \\
\hline Co & 53 & 51 & 44 & 41 & 44 & 43 & 41 & 93 & 46 & 38 & 50 & 42 & 36 & 6 & 25 & 16 \\
\hline $\mathrm{Cr}$ & 226 & 212 & 101 & 103 & 71 & 74 & 66 & 67 & 80 & 179 & 182 & 234 & 230 & $<13$ & 165 & 47 \\
\hline $\mathrm{Cu}$ & 104 & 124 & 64 & 86 & 45 & 39 & 44 & 192 & 164 & 159 & 164 & 77 & 29 & 13 & 92 & 23 \\
\hline Ga & 17 & 16 & 17 & 16 & 20 & 20 & 18 & 20 & 21 & 19 & 20 & 16 & 22 & 18 & 22 & 23 \\
\hline La & $<28$ & 43 & 59.0 & 110 & $<28$ & 10.1 & $<28$ & 16.6 & 30.2 & 15.6 & 15.3 & $<28$ & 12.2 & 108 & 12.2 & 50.6 \\
\hline Nb & $<9$ & $<9$ & 5.5 & 5.34 & 9 & 5.81 & $<9$ & 6.84 & 11.4 & 9.64 & 11.4 & $<9$ & 6.26 & 3.2 & 7.39 & 11.5 \\
\hline Nd & 24 & 84 & 36.8 & 63.3 & 54 & 15.7 & 66 & 24.1 & 35.9 & 18.7 & 20.8 & 42 & 19.3 & 54.8 & 16.0 & 71.6 \\
\hline $\mathrm{Ni}$ & 129 & 96 & 49.7 & 51 & 57 & 56 & 54 & 88 & 60 & 79 & 104 & 91 & 42 & 11 & 42 & 28 \\
\hline $\mathrm{Pb}$ & 18 & 19 & 2.1 & 1.98 & 19 & 2.19 & 15 & 4.13 & 7.15 & 3.19 & 2.05 & 17 & 7.78 & 17.8 & 7.38 & 10.1 \\
\hline $\mathrm{Rb}$ & 7 & 5 & 7.0 & 7.20 & 5 & 10.4 & 9 & 8.38 & 44.8 & 12.3 & 13.8 & 20 & 13.0 & 87.3 & 21.4 & 26.6 \\
\hline $\mathrm{Sc}$ & 39 & 45 & 47.4 & 47 & 39 & 37 & 38 & 45 & 35 & 38 & 39 & 42 & 32 & $<14$ & 27 & 19 \\
\hline $\mathrm{Sr}$ & 65 & 140 & 94.3 & 97.5 & 116 & 87.6 & 117 & 58.0 & 123 & 193 & 179 & 229 & 310 & 364 & 321 & 312 \\
\hline Th & $<7$ & $<7$ & 0.8 & 0.92 & 9 & 1.24 & 8 & 0.70 & 4.97 & 1.59 & 1.70 & $<7$ & 1.34 & 16.6 & 0.85 & 0.93 \\
\hline U & 5 & 5 & 0.24 & 0.28 & 9 & 0.34 & 8 & 0.28 & 1.06 & 0.35 & 0.38 & 6 & 0.84 & 0.41 & 0.33 & 0.26 \\
\hline v & 278 & 278 & 316.9 & 336 & 301 & 276 & 282 & 528 & 330 & 340 & 353 & 311 & 269 & 35 & 202 & 114 \\
\hline $\mathrm{Y}$ & 25 & 28 & 59.1 & 55.0 & 39 & 25.7 & 36 & 29.6 & 37.0 & 23.7 & 26.2 & 28 & 20.0 & 9.8 & 13.4 & 43.3 \\
\hline $\mathrm{Zn}$ & 108 & 84 & 128.0 & 129 & 148 & 148 & 145 & 183 & 145 & 99 & 111 & 112 & 119 & 44 & 101 & 89 \\
\hline $\mathrm{Zr}$ & 67 & 65 & 70.2 & 73.0 & 138 & 100 & 130 & 72.8 & 201 & 102 & 117 & 56 & 80.9 & 241 & 57.4 & 118 \\
\hline Cs & - & - & 0.13 & 0.19 & - & 0.10 & - & 0.08 & 1.51 & 0.15 & 0.15 & - & 0.33 & 0.33 & 0.50 & 0.66 \\
\hline $\mathrm{Pr}$ & - & - & 9.11 & 17.0 & - & 3.26 & - & 5.16 & 8.26 & 4.11 & 4.46 & - & 4.21 & 16.7 & 3.61 & 16.7 \\
\hline Sm & - & - & 8.21 & 11.4 & - & 4.53 & - & 6.17 & 8.46 & 4.74 & 5.46 & - & 5.10 & 7.03 & 4.45 & 16.2 \\
\hline $\mathrm{Eu}$ & - & - & 2.68 & 3.32 & - & 1.50 & - & 2.07 & 2.18 & 1.64 & 1.85 & - & 1.31 & 1.43 & 1.09 & 2.15 \\
\hline Gd & - & - & 10.90 & 12.5 & - & 5.60 & - & 7.13 & 8.76 & 5.28 & 6.15 & - & 5.05 & 3.78 & 4.27 & 13.4 \\
\hline $\mathrm{Tb}$ & - & - & 1.76 & 1.85 & - & 0.96 & - & 1.11 & 1.39 & 0.84 & 0.98 & - & 0.78 & 0.46 & 0.64 & 1.97 \\
\hline Dy & - & - & 10.80 & 10.9 & - & 5.93 & - & 6.59 & 8.18 & 4.90 & 5.71 & - & 4.45 & 2.19 & 3.30 & 10.5 \\
\hline Ho & - & - & 2.57 & 2.53 & - & 1.35 & - & 1.48 & 1.77 & 1.06 & 1.22 & - & 0.93 & 0.40 & 0.60 & 2.09 \\
\hline $\mathrm{Er}$ & - & - & 6.72 & 6.54 & - & 3.62 & - & 3.92 & 4.77 & 2.80 & 3.18 & - & 2.33 & 0.99 & 1.39 & 5.18 \\
\hline $\mathrm{Tm}$ & - & - & 0.99 & 0.96 & - & 0.54 & - & 0.59 & 0.71 & 0.40 & 0.46 & - & 0.34 & 0.12 & 0.18 & 0.68 \\
\hline $\mathrm{Yb}$ & - & - & 6.35 & 6.17 & - & 3.47 & - & 3.69 & 4.43 & 2.43 & 2.79 & - & 2.09 & 0.71 & 1.07 & 3.83 \\
\hline Lu & - & - & 1.00 & 0.96 & - & 0.51 & - & 0.55 & 0.65 & 0.36 & 0.41 & - & 0.30 & 0.11 & 0.15 & 0.50 \\
\hline Hf & - & - & 2.06 & 2.15 & - & 3.32 & - & 2.26 & 5.95 & 2.95 & 3.58 & - & 2.35 & 6.54 & 1.31 & 3.38 \\
\hline Mg\# & 50.47 & 56.21 & 49.00 & 49.30 & 34.07 & 34.30 & 34.26 & 35.59 & 35.46 & 51.53 & 48.21 & 50.54 & 47.85 & 41.14 & 50.26 & 46.41 \\
\hline ACNK & 0.58 & 0.57 & 0.54 & 0.53 & 0.54 & 0.58 & 0.57 & 0.56 & 0.65 & 0.61 & 0.57 & 0.50 & 0.59 & 0.98 & 0.71 & 0.84 \\
\hline ANK & 2.83 & 3.35 & 2.70 & 2.63 & 2.36 & 2.55 & 2.57 & 3.52 & 2.37 & 3.44 & 2.89 & 2.55 & 2.67 & 1.53 & 2.46 & 2.02 \\
\hline NK & 5.54 & 7.73 & 13.68 & 13.45 & 7.91 & 10.91 & 11.04 & 4.84 & 2.48 & 7.91 & 7.34 & 6.08 & 8.33 & 1.13 & 7.36 & 4.43 \\
\hline $\mathrm{FeO} / \mathrm{MgO}$ & 1.75 & 1.39 & 1.86 & 1.83 & 3.45 & 3.41 & 3.42 & 3.23 & 3.24 & 1.68 & 1.91 & 1.74 & 1.94 & 2.55 & 1.76 & 2.06 \\
\hline $\mathrm{Na} 2 \mathrm{O} / \mathrm{K} 2 \mathrm{O}$ & 3.64 & 5.09 & 9.00 & 8.85 & 5.20 & 7.18 & 7.26 & 3.18 & 1.63 & 5.20 & 4.83 & 4.00 & 5.48 & 0.74 & 4.84 & 2.91 \\
\hline $\mathrm{Na} 2 \mathrm{O}+\mathrm{K} 2 \mathrm{O}$ & 3.25 & 2.86 & 3.20 & 3.25 & 3.35 & 3.19 & 3.14 & 2.30 & 4.00 & 2.73 & 3.09 & 3.35 & 3.63 & 7.34 & 4.09 & 5.44 \\
\hline K/Rb & 867.4 & 765.1 & 379.5 & 380.5 & 953.8 & 311.3 & 354.5 & 544.9 & 281.9 & 296.0 & 319.8 & 275.4 & 358.2 & 400.5 & 272.2 & 434.3 \\
\hline $\mathrm{Y}+\mathrm{Nb}$ & - & - & 65 & 60 & 48 & 31 & - & 36 & 48 & 33 & 38 & - & 26 & 13 & 21 & 55 \\
\hline $\mathrm{Zr} / \mathrm{Y}$ & 2.69 & 2.35 & 1.19 & 1.33 & 3.55 & 3.90 & 3.58 & 2.46 & 5.43 & 4.29 & 4.44 & 2.00 & 4.05 & 24.70 & 4.29 & 2.72 \\
\hline La/Yb & - & - & 6.28 & 12.11 & - & 1.96 & - & 3.04 & 4.6 & 4.32 & 3.72 & - & 3.94 & 103.29 & 7.71 & 8.93 \\
\hline $\mathrm{La} / \mathrm{Sm}$ & - & - & 4.53 & 6.09 & - & 1.40 & - & 1.69 & 2.24 & 2.07 & 1.77 & - & 1.50 & 9.71 & 1.73 & 1.97 \\
\hline $\mathbf{G d} / Y \mathbf{b}$ & - & - & 1.4 & 1.64 & - & 1.31 & - & 1.57 & 1.6 & 1.76 & 1.79 & - & 1.96 & 4.32 & 3.22 & 2.83 \\
\hline $\mathrm{Eu} / \mathrm{Eu}^{*}$ & . & - & 0.87 & 0.85 & - & 0.91 & - & 0.95 & 0.78 & 1 & 0.97 & - & 0.79 & 0.85 & 0.77 & 0.45 \\
\hline
\end{tabular}

Tabela 10: Resultados analíticos de geoquímica de rocha-total, com elementos maiores expressos em \% peso e os elementos menores, traço e terras-raras expressos em ppm. As análises de elementos maiores e menores foram obtidas por FRX e as análises de elementos traço e terras-raras foram obtidas por ICP-MS. Loi $=$ Loss on ignition (perda ao fogo).

\subsubsection{Elementos maiores, menores e traço}

Os metagabronoritos e granada-clinopiroxênio anfibolitos apresentam conteúdos mais elevados de $\mathrm{Fe}_{2} \mathrm{O}_{3}$ (16.3-20.6\%), $\mathrm{TiO}_{2}(1.8-2.7 \%)$ e $\mathrm{MnO}(0.21-0.28 \%)$ e menores concentrações de $\mathrm{Al}_{2} \mathrm{O}_{3}(12.2-13.6 \%) \mathrm{CaO}$ (8.4-10.1\%) e $\mathrm{MgO}$ (4.5-5.7\%) do que as rochas metabásicas dos grupos 1 e $3\left(11.5-14 \% \mathrm{Fe}_{2} \mathrm{O}_{3} ; 0.9-2.3 \% \mathrm{TiO}_{2} ; 0.18-0.22 \%\right.$ $\left.\mathrm{MnO} ; 13.6-14.8 \% \mathrm{Al}_{2} \mathrm{O}_{3} ; 10.6-11.8 \% \mathrm{CaO} ; 6.6-7.5 \% \mathrm{MgO}\right)$. Os elevados teores de $\mathrm{Ti}$ 
(2-2.3\% $\left.\mathrm{TiO}_{2}\right)$ no hornblenda metagabro pode ser atribuído à presença de minerais portadores de $\mathrm{Ti}$, como ilmenita e titanita, além de conteúdos elevados de $\mathrm{Ti}$ nos anfibólios. Os quatro diferentes grupos de rochas metabásicas apresentam uma distribuição concentrada dos elementos maiores com o aumento de $\mathrm{SiO}_{2}$. Os diagramas de variação dos metagabronoritos e granada-clinopiroxênio anfibolitos dos grupos 2 e 4 mostram uma diminuição nos conteúdos de $\mathrm{TiO}_{2}, \mathrm{CaO}, \mathrm{Fe}_{2} \mathrm{O}_{3}, \mathrm{MgO}$ e $\mathrm{MnO}$ com o aumento de $\mathrm{SiO}_{2}$. Os diagramas de variação do granada-hornblenda granulito e o hornblenda metagabro dos grupos 1 e 3 apresentam um aumento nos conteúdos de $\mathrm{CaO}$ e $\mathrm{MgO}$ com o aumento de $\mathrm{SiO}_{2}$, acompanhado por uma diminuição em $\mathrm{TiO}_{2}, \mathrm{Fe}_{2} \mathrm{O}_{3}$ e $\mathrm{MnO}$ (Figura 89).

Nos diagramas de variação da Figura 90, observa-se que os metagabronoritos e granada-clinopiroxênio anfibolitos apresentam um aumento nas concentrações de $\mathrm{TiO}_{2}$, $\mathrm{Fe}_{2} \mathrm{O}_{3}, \mathrm{CaO}$ e $\mathrm{MnO}$ com o aumento progressivo de $\mathrm{MgO}$. O granada-hornblenda granulito e o hornblenda metagabro apresentam uma relação inversa, com diminuição de $\mathrm{TiO}_{2}, \mathrm{Fe}_{2} \mathrm{O}_{3}$ e $\mathrm{MnO}$ com o aumento de $\mathrm{MgO}$, enquanto que o $\mathrm{CaO}$ aumenta. $\mathrm{O}$ conteúdo de $\mathrm{K}_{2} \mathrm{O}$ apresenta variações muito pequenas e comportamento constante em todas as amostras, exceto no granada-clinopiroxênio anfibolito do grupo 4, que apresenta um aumento de $\mathrm{K}_{2} \mathrm{O}\left(1.52 \% \mathrm{~K}_{2} \mathrm{O}\right)$ com o aumento de $\mathrm{SiO}_{2}$.

Segundo Rollinson \& Windley (1980) e Rudnick et al., (1985), muitos granulitos apresentam concentrações baixas de elementos LILE ( $\mathrm{K}, \mathrm{Rb}, \mathrm{Ba}, \mathrm{Cs}$ ), incompatíveis ( $\mathrm{U}, \mathrm{Th}, \mathrm{Ti}, \mathrm{Zr}$ ) e altas razões $\mathrm{K} / \mathrm{Rb}$, possivelmente devido ao empobrecimento nestes elementos durante o metamorfismo de fácies granulito. As rochas metabásicas consideradas neste estudo apresentam baixas concentrações em elementos LILE (Rb<10 ppm) (Figura 91) e uma grande variação nas razões $\mathrm{K} / \mathrm{Rb}$, podendo ser separada em dois grupos distintos: um de baixas razões $\mathrm{K} / \mathrm{Rb}$, com valores entre 282-380; e outro grupo com razões $\mathrm{K} / \mathrm{Rb}$ mais elevadas, com valores entre 545953 (granada-hornblenda granulito e metagabronorito). Segundo Rudnick (1992), o empobrecimento em elementos LILE e altas razões $\mathrm{K} / \mathrm{Rb}$ são características esperadas para resíduos de fusão parcial. O granada-hornblenda granulito do grupo 1 apresenta as concentrações mais baixas de elementos incompatíveis $(\mathrm{Zr}<73 \mathrm{ppm}$, Th $<0.9 \mathrm{ppm})$ e conteúdos relativamente elevados de La (30-110 ppm) e Y (25-59 ppm), também exibindo as menores razões $\mathrm{Zr} / \mathrm{Y}(1.1-2.7)$.

De modo geral, as amostras apresentam um comportamento similiar, exceto o clinopiroxênio-granada anfibolito simplectítico (NLD-9A) que exibe um padrão 
distinto, enriquecido em elementos LILE (1.52\% $\mathrm{K}_{2} \mathrm{O} ; 45 \mathrm{ppm} \mathrm{Rb;} 361 \mathrm{ppm} \mathrm{Ba;} 151$ ppm Cs) e elementos incompatíveis como Ti, $\mathrm{Zr}$ e $\mathrm{Th}\left(2.5 \% \mathrm{TiO}_{2} ; 201\right.$ ppm Zr; 5 ppm Th) (Figura 91), com elevadas razões $\mathrm{Zr} / \mathrm{Y}(\mathrm{Zr} / \mathrm{Y}=5.43)$. Os maiores conteúdos de $\mathrm{Sr}$ nas rochas metabásicas foram encontrados no hornblenda metagabro do grupo 2 ( $\mathrm{Sr}=$ 180-193 ppm) e devem estar associados com o fracionamento de plagioclásio no protólito ígneo. Rochas granulíticas que apresentam grande variação geoquímica possivelmente foram formadas por diferentes processos geológicos. As rochas de origem metamórfica que são acompanhadas por reações de desidratação e perda de voláteis tendem a ser mais empobrecidas em elementos LILE (Rollinson \& Windley, 1980).

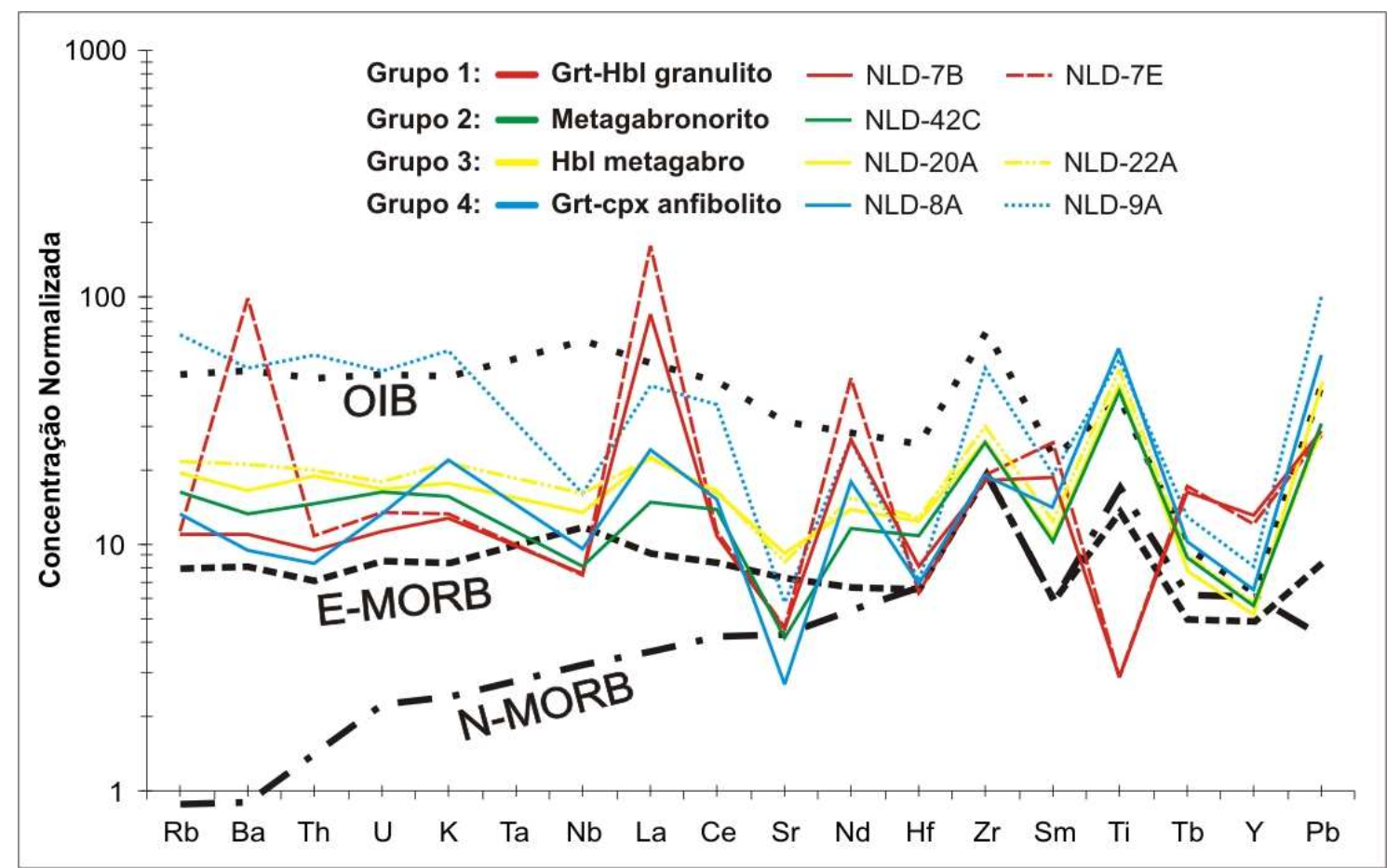

Figura 92: Diagrama multi-elementar das rochas metabásicas, normalizadas pelo manto primitivo de Sun \& Mc Donough (1989), comparados com os padrões OIB, E-MORB e N-MORB de Sun \& Mc Donough (1989). OIB = basalto de ilha oceânica, N-MORB = basalto normal de cadeia meso oceânica, E-MORB = basalto enriquecido de cadeia meso oceânica.

O diagrama multi-elementar de elementos traço das rochas metabásicas, normalizado pelo manto primitivo de Sun \& Mc Donough (1989) (Figura 92) mostra que todos os grupos são caracterizados por um empobrecimento seletivo de alguns elementos HFSE (Th, Nb, Hf e Y) e de Sr e de um relativo enriquecimento em K e Nd. O grupo 1 apresenta conteúdos mais elevados de La, Nd, Sm, Tb e Y em relação aos 
outros grupos. Exibe uma anomalia negativa de Ti que se destaca, pois os demais grupos de rochas metabásicas são caracterizados por um enriquecimento em Ti (Figura 92). A amostra NLD-7E possui teores de Ba anômalos em relação a outra amostra representativa do grupo (NLD-7B). Os grupos 2, 3 e 4 apresentam um padrão de distribuição mais homogêneo, mais enriquecido em elementos LILE $\left(0.4-1.5 \% \mathrm{~K}_{2} \mathrm{O}\right.$; 8.4-45 ppm Rb; 0.1-1.5 ppm Cs) e incompatíveis (0.3-1 ppm U; 0.7-5 ppm Th; 2-2.5\% $\left.\mathrm{TiO}_{2} ; 73-200 \mathrm{ppm} \mathrm{Zr}\right)$ do que o granada-hornblenda granulito do grupo $1\left(0.3 \% \mathrm{~K}_{2} \mathrm{O} ; 7\right.$ ppm Rb; 0.1 ppm Cs; 0.2 ppm U; 0.9 ppm Th; 1.3\% TiO $;$;0-73 ppm Zr). A amostra NLD-9A do grupo 4 apresenta um padrão de distribuição distinto dos demais, caracterizado por um enriquecimento mais elevado em elementos LILE ( $\mathrm{K}, \mathrm{Rb}, \mathrm{Ba})$ e incompatíveis (U, Th, Ti, Zr) (Figura 92). Elevadas concentrações em elementos LILE podem ser produto do enriquecimento destes elementos em processos retrometamórficos (Sighinolfi et al., 1981), o que é consistente para a amostra NLD-9A, onde grande parte dos piroxênios foi substituída por intercrescimentos de Hbl+Qtz no metamorfismo retrógrado.

A comparação dos padrões de distribuição de elementos traço das amostras analisadas com os padrões de distribuição de OIB, E-MORB e N-MORB de Sun \& Mc Donough (1989) mostra que os grupos 2, 3 e 4 apresentam padrões que se assemelham com os padrões de E-MORB, porém com enriquecimento maior nos elementos traço em geral. A semelhança dos padrões aponta para fontes compatíveis com E-MORB, embora enriquecidas em relação a este padrão. Fontes similares ao MORB identificada nos diagramas de variação multi-elementares estão de acordo com os diagramas de discriminação de ambientes tectônicos de Pearce \& Cann (1973) onde a fonte MORB é também sugerida.

\subsubsection{Elementos terras-raras}

No geral, as rochas metabásicas apresentam padrões de elementos terras-raras (ETR) fracamente fracionados (tipo-flat), o que é indicado pelos baixos valores de razões $\mathrm{La} / \mathrm{Yb}$. Os conteúdos e os padrões de distribuição de elementos terras-raras quando normalizadas ao condrito (Taylor \& Mc Lennan, 1985), permitem identificar 3 comportamentos distintos (Figura 93). Os granulitos máficos do grupo 1 são enriquecidos em ETRL (elementos terras-raras leves) em comparação às outras rochas metabásicas (razões $\mathrm{La}_{\mathrm{N}} / \mathrm{Yb}_{\mathrm{N}}=6.3-12, \mathrm{La}_{\mathrm{N}} / \mathrm{Sm}_{\mathrm{N}}=4.5-6, \mathrm{Gd}_{\mathrm{N}} / \mathrm{Yb}_{\mathrm{N}}=1.4-1.6, \mathrm{Eu} / \mathrm{Eu}^{*}=$ 
0.85-0.87), e exibem uma forte anomalia negativa de Ce e uma leve anomalia negativa de Eu (Figura 94A).

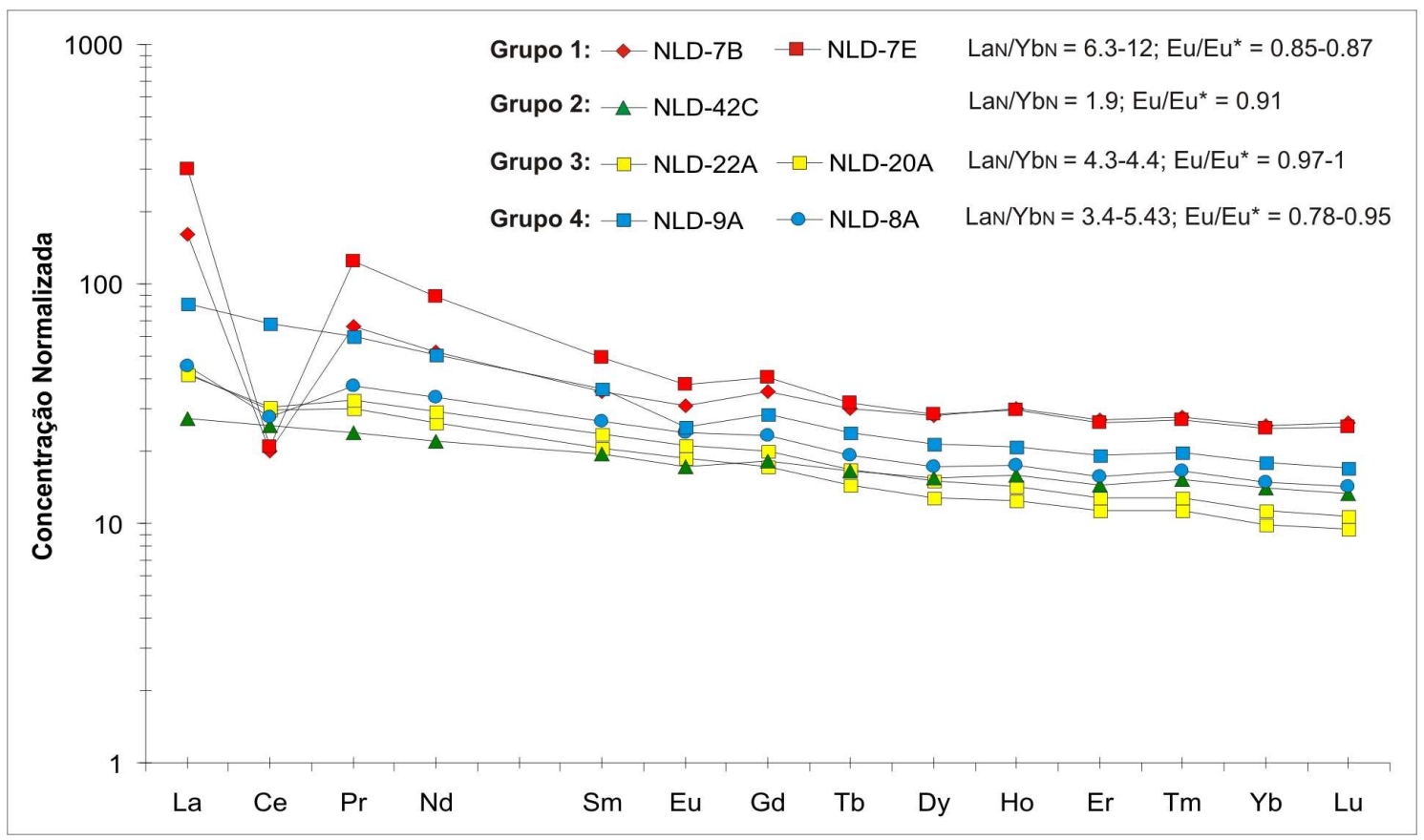

Figura 93: Padrões de ETR das rochas metabásicas, normalizados ao condrito de Taylor \& Mc Lennan (1985).

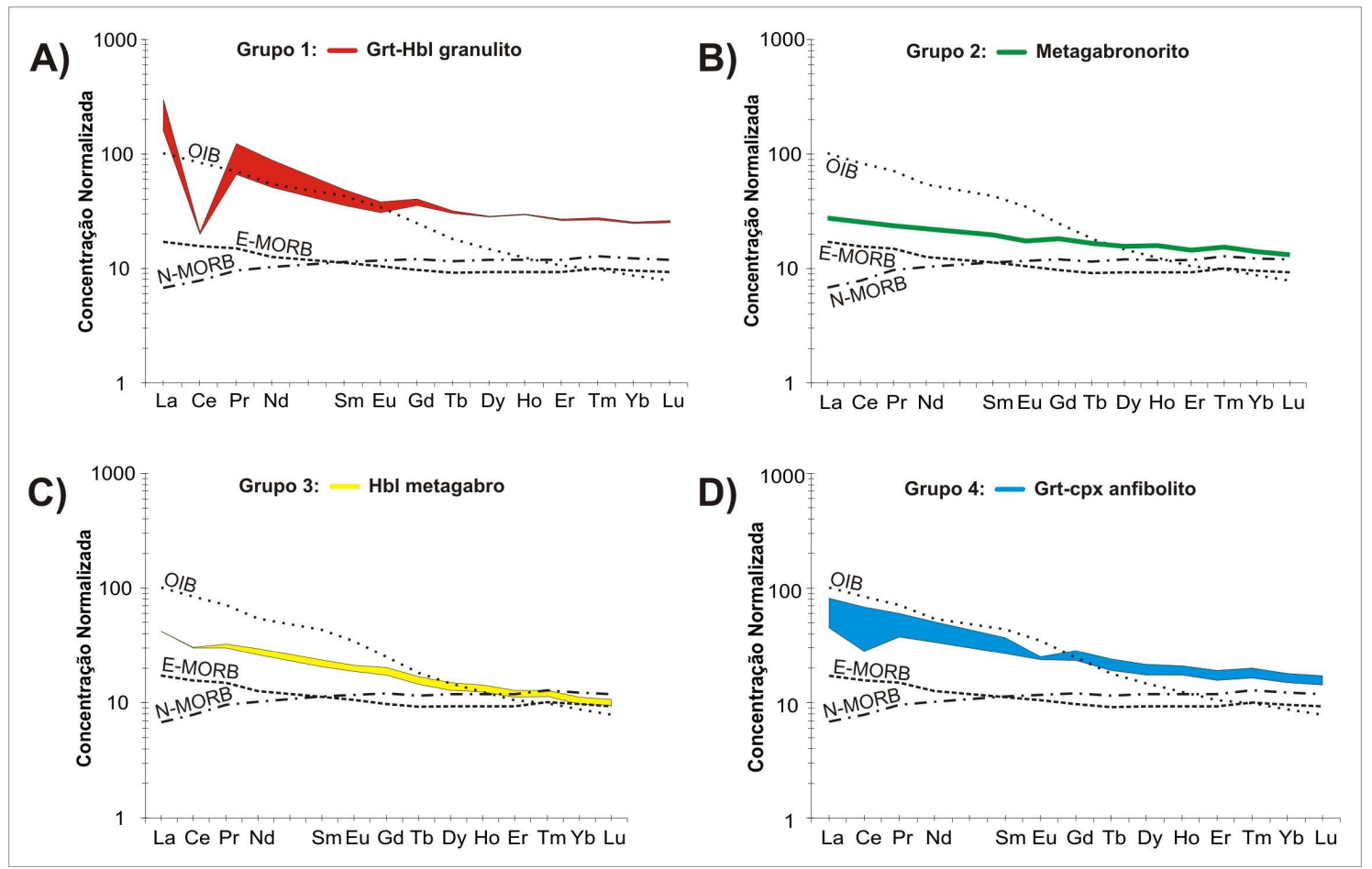

Figura 94: (A), (B), (C), (D) Padrões de ETR das rochas metabásicas normalizados ao condrito de Taylor \& Mc Lennan (1985) comparados com os padrões OIB, E-MORB e N-MORB de Sun \& Mc Donough (1989). OIB = basalto de ilha oceânica, N-MORB = basalto normal de cadeia meso oceânica, E-MORB = basalto enriquecido de cadeia meso oceânica. 
O enriquecimento em ETRL pode apontar para fontes mantélicas enriquecidas. Os padrões de distribuição dos ETR da água do mar tendem a mostrar um enriquecimento nas concentrações de ETRP, freqüentemente acompanhado por uma anomalia negativa de Ce bem marcada (Elderfield \& Greaves, 1981, 1982). A anomalia negativa de $\mathrm{Ce}$ ocorre devido à oxidação de $\mathrm{Ce}^{3+}$ para $\mathrm{Ce}^{4+}$ e a precipitação de $\mathrm{Ce}^{4+} \mathrm{a}$ partir de uma solução de $\mathrm{CeO}_{2}$. $\mathrm{O}$ granada-hornblenda granulito do grupo 1 apresenta uma anomalia negativa de Ce acentuada (Figura 93), o que sugere a atuação de processos hidrotermais na oxidação do $\mathrm{Ce}$, resultando um padrões de ETR com anomalias negativas de Ce (Rollinson, 1993). Diversos autores reconheceram enriquecimento em ETR e anomalias negativas de Ce em rochas toleiíticas e em álcalibasaltos (Frey \& Roy, 1978; Mc Donough \& Sun, 1985; Green, 1978; Fodor et al., 1987).

Os metagabronoritos do grupo 2 apresentam as menores concentrações em elementos terras-raras, mostrando um padrão de distribuição horizontal (razões LaN $/ \mathrm{Yb}_{\mathrm{N}}$ $\left.=1.9, \mathrm{La}_{\mathrm{N}} / \mathrm{Sm}_{\mathrm{N}}=1.4, \mathrm{Gd}_{\mathrm{N}} / \mathrm{Yb}_{\mathrm{N}}=1.3, \mathrm{Eu} / \mathrm{Eu}^{*}=0.91\right)$, semelhante ao padrão de basaltos enriquecidos de cadeia meso oceânica (Figura 94B). O hornblenda metagabro do grupo 3 e o granada-clinopiroxênio anfibolito do grupo 4 apresentam padrões de distribuição semelhantes (razões $\mathrm{La}_{N} / \mathrm{Yb}_{\mathrm{N}}=3.0-4.6, \mathrm{La}_{\mathrm{N}} / \mathrm{Sm}_{\mathrm{N}}=1.7-2.2, \mathrm{Gd}_{\mathrm{N}} / \mathrm{Yb}_{\mathrm{N}}=$ 1.6-1.8, $\left.\mathrm{Eu} / \mathrm{Eu}^{*}=0.78-1\right)$, inclinados em relação ao condrito, que também se assemelham com o padrão de basaltos tipo E-MORB (Figuras 94C e 94D), embora o conteúdo de ETRL seja mais elevado e estes litotipos apresentem uma discreta anomalia negativa de Ce.

O hornblenda metagabro apresenta razões constantes de [La/ $\left.\mathrm{Yb}_{\mathrm{N}}\right](4.3-4.4)$ e razões $\mathrm{Eu} / \mathrm{Eu}^{*}$ próximas de 1, o que reflete ausência de anomalias de Eu para as rochas deste grupo. Também representa as rochas mais empobrecidas em ETRP de todo o conjunto, o que sugere que a granada tenha sido retida na fonte, uma vez que a granada é um mineral concentrador de ETRP. O clinopiroxênio-granada anfibolito simplectítico (NLD-9A) do grupo 4 se distingue dos demais pelo fato de não apresentar anomalia negativa de Ce. Apresenta um padrão de distribuição horizontalizado, mas com anomalia de Eu, embora discreta, mais pronunciada de todo o conjunto de amostras $\left(\mathrm{Eu} / \mathrm{Eu}^{*}=0.78\right)$.

A amostra NLD-8A tem um padrão muito similar ao grupo 3, embora seja levemente mais enriquecida em ETRP. Até mesmo a discreta anomalia de Ce do grupo 3 é igual nesta amostra (Figuras 93 e 94D). Isso reflete uma disparidade intra-grupo na 
distribuição de ETR, o que pode refletir fontes ou processos evolutivos diversos para estas duas amostras representativas deste grupo. O espalhamento do campo ilustrado em azul para os litotipos do grupo 4 (Figura 94D) se dá devido à heterogeneidade intragrupo, o que resulta em padrões de distribuição similares ao E-MORB para a amostra NLD-8A, enquanto que na amostra NLD-9A os padrões de ETRL se assemelham a fontes do tipo OIB, por ser mais enriquecida em ETRL.

A comparação dos padrões de distribuição dos ETR das amostras analisadas com os padrões OIB, E-MORB e N-MORB de Sun \& Mc Donough (1989) mostra que a maioria das rochas metabásicas neste estudo apresenta fontes similares as do tipo EMORB (basalto enriquecido de cadeia meso oceânica), conforme indicado nos diagramas de ETR (Figuras 93 e 94). No diagrama multi-elementar de elementos traço (Figura 92), bem como no diagrama de discriminação tectônica de Pearce \& Cann (1973) (Figura 88B, 88C), embora sempre com enriquecimento para todos os ETR em relação a esse tipo de fonte, o que sugere fontes mais enriquecidas com relação ao EMORB para a formação destas rochas.

\begin{tabular}{|c|c|c|c|c|c|c|c|c|c|c|c|}
\hline & NLD-7B & NLD-7E & NLD-42C & NLD-8A & NLD-9A & NLD-20A & NLD-22A & NLD-45D & NLD-41F & NLD-45A & NLD-41G \\
\hline La & 160.84 & 300.97 & 27.46 & 45.20 & 82.15 & 42.37 & 41.82 & 33.18 & 295.33 & 33.31 & 137.83 \\
\hline $\mathrm{Ce}$ & 20.04 & 20.91 & 25.61 & 27.94 & 68.00 & 29.90 & 30.42 & 31.26 & 182.26 & 28.78 & 130.61 \\
\hline $\operatorname{Pr}$ & 66.50 & 123.77 & 23.80 & 37.66 & 60.26 & 30.01 & 32.54 & 30.75 & 122.08 & 26.36 & 122.23 \\
\hline $\mathrm{Nd}$ & 51.72 & 89.05 & 22.08 & 33.85 & 50.55 & 26.31 & 29.32 & 27.09 & 77.11 & 22.51 & 100.73 \\
\hline $\mathrm{Sm}$ & 35.54 & 49.45 & 19.61 & 26.70 & 36.64 & 20.51 & 23.65 & 22.08 & 30.41 & 19.26 & 70.04 \\
\hline $\mathrm{Eu}$ & 30.84 & 38.22 & 17.25 & 23.77 & 25.10 & 18.81 & 21.24 & 15.02 & 16.39 & 12.55 & 24.68 \\
\hline $\mathrm{Gd}$ & 35.72 & 40.83 & 18.31 & 23.30 & 28.61 & 17.26 & 20.10 & 16.50 & 12.36 & 13.94 & 43.75 \\
\hline $\mathrm{Tb}$ & 30.28 & 31.94 & 16.47 & 19.12 & 23.90 & 14.42 & 16.83 & 13.48 & 7.88 & 11.01 & 33.89 \\
\hline Dy & 28.30 & 28.67 & 15.56 & 17.31 & 21.46 & 12.86 & 14.99 & 11.69 & 5.74 & 8.67 & 27.55 \\
\hline $\mathrm{Ho}$ & 30.23 & 29.74 & 15.85 & 17.41 & 20.85 & 12.47 & 14.33 & 10.91 & 4.69 & 7.09 & 24.60 \\
\hline $\mathrm{Er}$ & 26.99 & 26.28 & 14.52 & 15.74 & 19.15 & 11.23 & 12.77 & 9.37 & 3.97 & 5.60 & 20.82 \\
\hline $\mathrm{Tm}$ & 27.94 & 26.92 & 15.30 & 16.45 & 19.86 & 11.27 & 12.83 & 9.46 & 3.32 & 5.12 & 19.07 \\
\hline $\mathrm{Yb}$ & 25.60 & 24.86 & 14.00 & 14.89 & 17.85 & 9.80 & 11.25 & 8.42 & 2.86 & 4.32 & 15.44 \\
\hline Lu & 26.28 & 25.09 & 13.26 & 14.33 & 17.1 & 9.44 & 10.65 & 7.87 & 2.88 & 3.92 & 13.23 \\
\hline$L a / Y b$ & 6.28 & 12.11 & 1.96 & 3.04 & 4.6 & 4.32 & 3.72 & 3.94 & 103.29 & 7.71 & 8.93 \\
\hline $\mathrm{La} / \mathrm{Sm}$ & 4.53 & 6.09 & 1.40 & 1.69 & 2.24 & 2.07 & 1.77 & 1.50 & 9.71 & 1.73 & 1.97 \\
\hline$G d / Y b$ & 1.4 & 1.64 & 1.31 & 1.57 & 1.6 & 1.76 & 1.79 & 1.96 & 4.32 & 3.22 & 2.83 \\
\hline$E u / E u^{*}$ & 0.87 & 0.85 & 0.91 & 0.95 & 0.78 & 1 & 0.97 & 0.79 & 0.85 & 0.77 & 0.45 \\
\hline
\end{tabular}

Tabela 11: Análises de elementos terras-raras normalizadas ao condrito (Normalização aos valores de Taylor \& McLennan, 1985).

\subsection{Rochas charnockíticas/enderbíticas}

\subsubsection{Classificação das rochas charnockíticas}

O termo "charnockito" foi inicialmente proposto por Holland (1900) para descrever rochas graníticas portadoras de ortopiroxênio, na região dos Madras, sul da India. Howie (1955) introduziu o conceito de metamorfismo plutônico. Os diferentes 
modos de ocorrência e contextos estruturais em que se inserem os charnockitos ao redor do mundo, deram início ao debate sobre a origem ígnea ou metamórfica (Pichamuthu, 1960; Ravich, 1972). A natureza homogênea e maciça de alguns charnockitos, e em alguns casos, a existência de contatos intrusivos, xenólitos e texturas magmáticas, são consistentes com uma origem ígnea (Holland, 1900). A cristalização de magmas charnockíticos ocorre sob condições anidras no fácies granulito, e pode ser derivado da fusão parcial do manto ou de rochas da crosta inferior (Newton, 1992a). A origem metamórfica é atribuída à presença de texturas metamórficas, estrutura bandada e eventualmente, a intercalação de rochas metassedimentares (De Waard, 1969). Rochas charnockíticas de origem metamórfica são geradas a partir de reações metamórficas em estado-sólido, sob condições de fácies granulito (Bohlen, 1991). Alguns autores defendem uma origem metassomática para os charnockitos, através do influxo de $\mathrm{CO}_{2}$ ou queda na pressão de fluidos (Newton, 1992a).

Segundo Frost \& Frost (2008), o termo charnockito só deve ser aplicado para rochas de origem ígnea. Os autores sugerem uma simplificação na nomenclatura de rochas charnockíticas e propõem que termos como enderbito e mangerito devem ser eliminados e substituídos pelo prefixo "Opx" na classificação de rochas ígneas da IUGS, resultando em nomes como Opx-tonalito e Opx-monzonito, respectivamente. No entanto, um trabalho recente realizado por Bhattacharya (2010) propõe que o termo charnockito deve ser adotado para qualquer rocha quartzo-feldspática com ortopiroxênio, independente de seu modo de ocorrência, contexto estrutural ou origem. No presente trabalho, foi adotada a nomenclatura proposta por Bhattacharya (2010) e os nomes da série charnockítica inicialmente proposta por Le Maitre (1989) foram complementados pela nomenclatura recomendada por Frost \& Frost (2008). As rochas charnockíticas presentes na região de Pedro Teixeira (MG) apresentam composição química variável e são classificadas como enderbitos (Opx-tonalito) e charnockitos (Opx-granito) (Figura 86B).

No diagrama de classificação de rochas plutônicas de Cox et al. (1979) (Figura 95A), o meta-charnockito bandado do grupo 5 apresenta o maior teor relativo de sílica e álcalis, plotando no campo do granito. O enderbito gnaisse (Grupo 6) apresenta composição intermediária, correspondente ao campo do diorito. O biotita-granada enderbito gnaisse coronítico (Grupo 7) possui o menor teor relativo de sílica, e plota no campo do gabro. O conteúdo de sílica nas rochas charnockíticas varia de 51.6-69.5\% $\mathrm{SiO}_{2}$. 
No diagrama AFM de Irvine \& Baragar (1971) (Figura 88A), observa-se que os litotipos têm afinidade predominantemente cálcio-alcalina, com típico empobrecimento em FeOt em relação aos álcalis. Porém o biotita-granada enderbito gnaisse situa-se no campo toleí́tico, próximo ao limite com o campo cálcio-alcalino. No diagrama de classificação química de granulitos félsicos e intermediários de Glikson (1979), não foram identificadas amostras com composições trondhjemíticas (Figura 88D). No diagrama discriminante de Pearce et al., (1984), a maioria das amostras caem no campo dos granitóides de arco vulcânico (Figura 95B). O enderbito gnaisse (NLD-41G) plota no limite entre os campos dos granitóides intra-placa e granitóides de arco vulcânico.

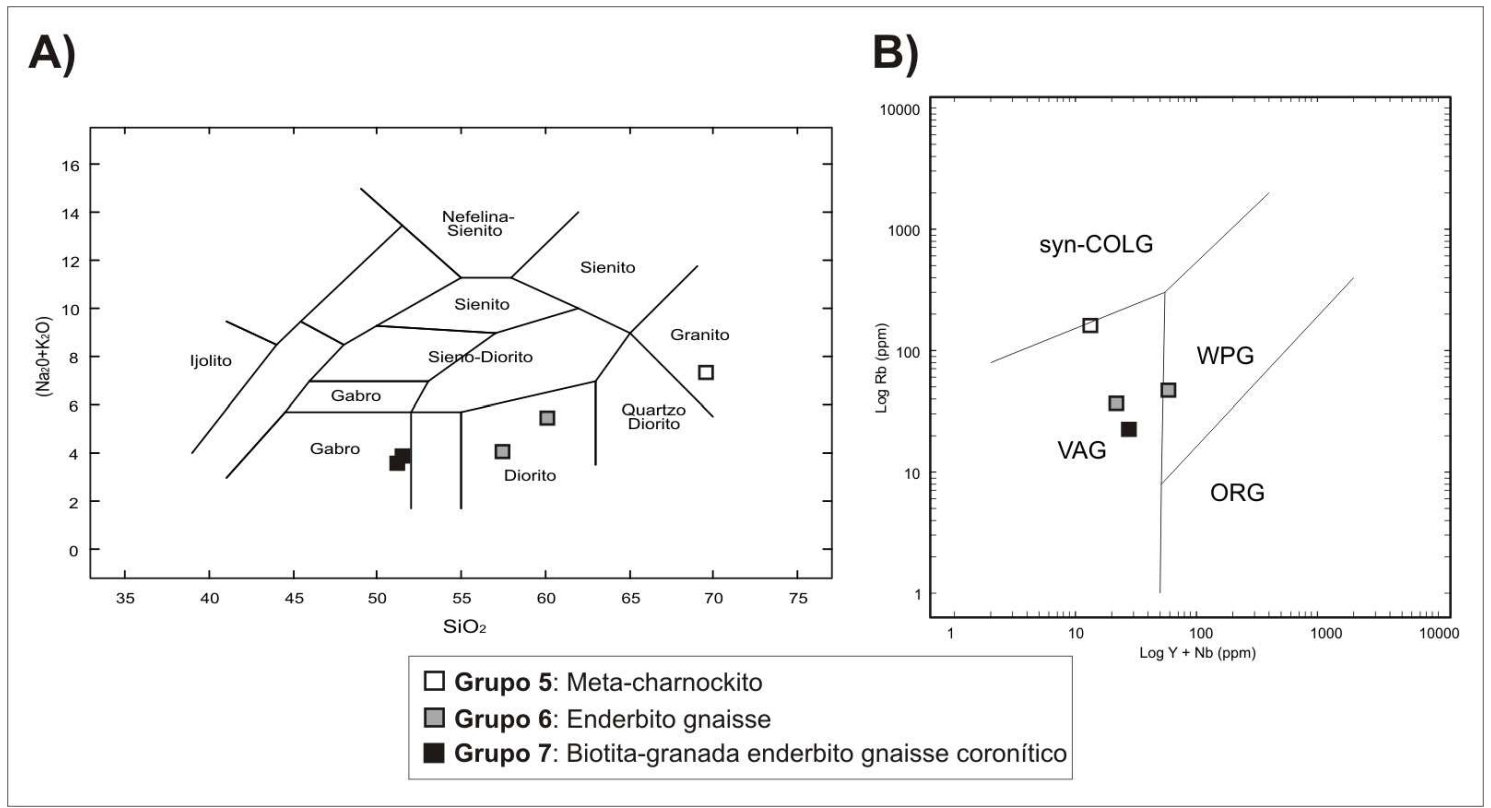

Figura 95: A) Diagrama de classificação de rochas plutônicas (Cox et al., 1979); B) Diagrama discriminante $\mathrm{Rb}$ vs. $(\mathrm{Y}+\mathrm{Nb})$ de Pearce et al., (1984). Syn-COLG = granitóides sin-colisionais; WPG = granitóides intra-placa; VAG = granitóides de arco vulcânico; ORG = granitóides das dorsais oceânicas .

\subsubsection{Elementos maiores, menores e traço}

Os diagramas de variação de elementos maiores, menores e traço apontam trends relativamente homogêneos. Embora o conjunto de amostras seja diminuto, as rochas félsicas estudadas apresentam trends de evolução normal de granitos em relação à maioria dos elementos maiores e traço. Ocorre uma diminuição nos conteúdos de $\mathrm{TiO}_{2}, \mathrm{CaO}, \mathrm{Fe}_{2} \mathrm{O}_{3}, \mathrm{MgO}$ e $\mathrm{MnO}$ com o aumento de $\mathrm{SiO}_{2}$, enquanto que as concentrações em $\mathrm{K}_{2} \mathrm{O}, \mathrm{Rb}, \mathrm{Ba}, \mathrm{La}$, Ce tendem a aumentar (Figura 96). Há uma dispersão nos valores de $\mathrm{Al}_{2} \mathrm{O}_{3}$ e $\mathrm{Na}_{2} \mathrm{O}$. 
$\mathrm{O}$ metacharnockito bandado apresenta os menores conteúdos de $\mathrm{TiO}_{2}, \mathrm{CaO}$, $\mathrm{Fe}_{2} \mathrm{O}_{3}, \mathrm{MgO}$ e $\mathrm{MnO}\left(0.4 \% \mathrm{TiO}_{2}, 3 \% \mathrm{CaO}, 3 \% \mathrm{Fe}_{2} \mathrm{O}_{3}, 1 \% \mathrm{MgO}\right.$ e $\left.0.1 \% \mathrm{MnO}\right)$ em comparação com os enderbitos $\left(0.7-1.3 \% \mathrm{TiO}_{2}, 6-11 \% \mathrm{CaO}, 7-12 \% \mathrm{Fe}_{2} \mathrm{O}_{3}, 3-5 \% \mathrm{MgO}\right.$ e $0.1-0.2 \% \mathrm{MnO})$ e são enriquecidos em elementos LILE (4.2\% $\mathrm{K}_{2} \mathrm{O} ; 87 \mathrm{ppm} \mathrm{Rb}$ ), exibindo concentrações bastante elevadas de $\mathrm{Ba}(1742 \mathrm{ppm})$ e em alguns elementos incompatíveis. Apresenta teores relativamente altos em Zr (241 ppm) (Figura 97), e as menores concentrações de elementos de transição (6 ppm Co; <13 ppm Cr; 13 ppm Cu; 10 ppm Zn; 11 ppm Ni; 35 ppm V). Os enderbito gnaisses dos grupos 6 e 7 exibem um comportamento geoquímico oposto ao metacharnockito bandado (Figuras 96 e 97), mostrando empobrecimento em elementos LILE (0.6-1.4\% $\left.\mathrm{K}_{2} \mathrm{O} ; 13-26 \mathrm{ppm} \mathrm{Rb}\right)$ e incompatíveis (57-118 ppm Zr; Th < 0.9 ppm) e maiores concentrações em elementos de transição (16-36 ppm Co; 47-230 ppm Cr; 23-92 ppm Cu; 90-120 ppm Zn; 28-42 ppm Ni; 114-270 ppm V).

As rochas charnockíticas apresentam razões $\mathrm{K} / \mathrm{Rb}$ relativamente baixas em comparação com os granulitos máficos, com valores entre 272-434. As baixas razões $\mathrm{K} / \mathrm{Rb}$ sugere uma origem ígnea para as rochas charnockíticas da região de Pedro Teixeira (Shaw, 1968).

Os diagramas multi-elementares para as rochas charnockíticas normalizado ao manto primitivo de Taylor \& Mc Lennan (1985) (Figuras 98 e 99) mostram que o metacharnockito do grupo 5 exibe um enriquecimento em elementos LILE ( $\mathrm{K}, \mathrm{Rb}, \mathrm{Ba}$, Cs) e incompatíveis (Zr, Th) em relação aos demais litotipos e apresenta concentrações mais elevadas de ETRL e menos expressivas de ETRP. Segundo Allen et al., (1984), há uma tendência no empobrecimento de $\mathrm{Rb}, \mathrm{Cs}$, Th e U nos charnockitos de alta pressão do sul da India. As amostras NLD-41F e NLD-41G exibem anomalias negativas de U, $\mathrm{Nb}$ e $\mathrm{Sr}$. Todos os litotipos analisados são caracterizados por anomalias positivas de $\mathrm{Pb}$, negativa de $\mathrm{Y}$ e uma discreta anomalia negativa de $\mathrm{Eu}$. $\mathrm{O} \mathrm{Pb}$ geralmente é transportado em fluidos ricos em $\mathrm{CO}_{2} \operatorname{com} \mathrm{Cl}$, e pequenas modificações no $\mathrm{pH}$ ou na composição do fluido dissociam complexos clorados com $\mathrm{Pb}$, o que pode resultar em empobrecimento em $\mathrm{Pb}$ durante o metamorfismo de fácies granulito, que eventualmente retorna no retrometamorfismo (Condie \& Allen, 1984). As baixas concentrações de Y e Yb pode ser atribuída à substituição de $\mathrm{Fe}^{2+} \mathrm{e} \mathrm{Mg}$ por estes elementos nos piroxênios (Allen $e t$ al., 1984). 


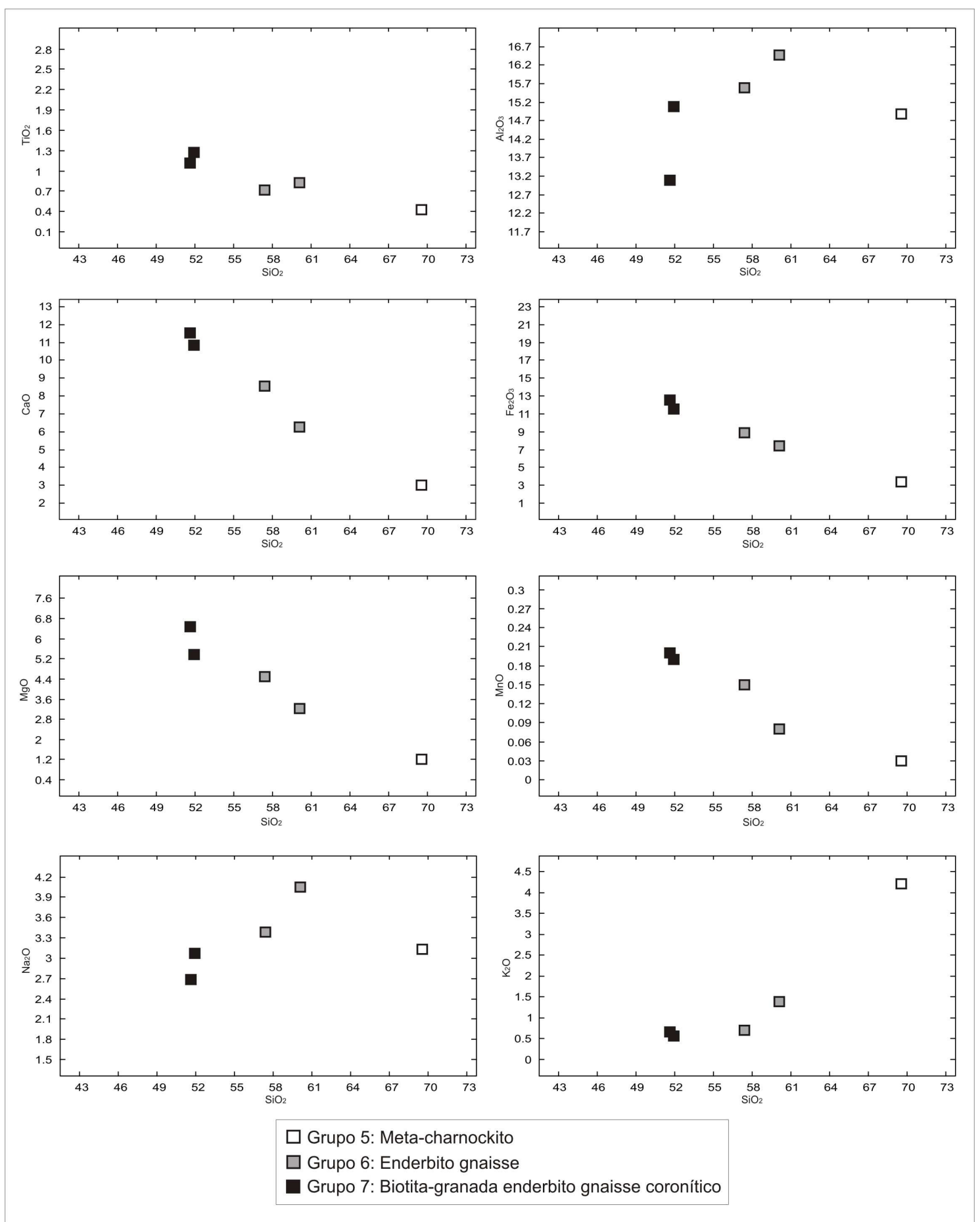

Figura 96: Diagramas de Harker dos elementos maiores (expressos em porcentagem de peso) para as rochas charnockíticas. 


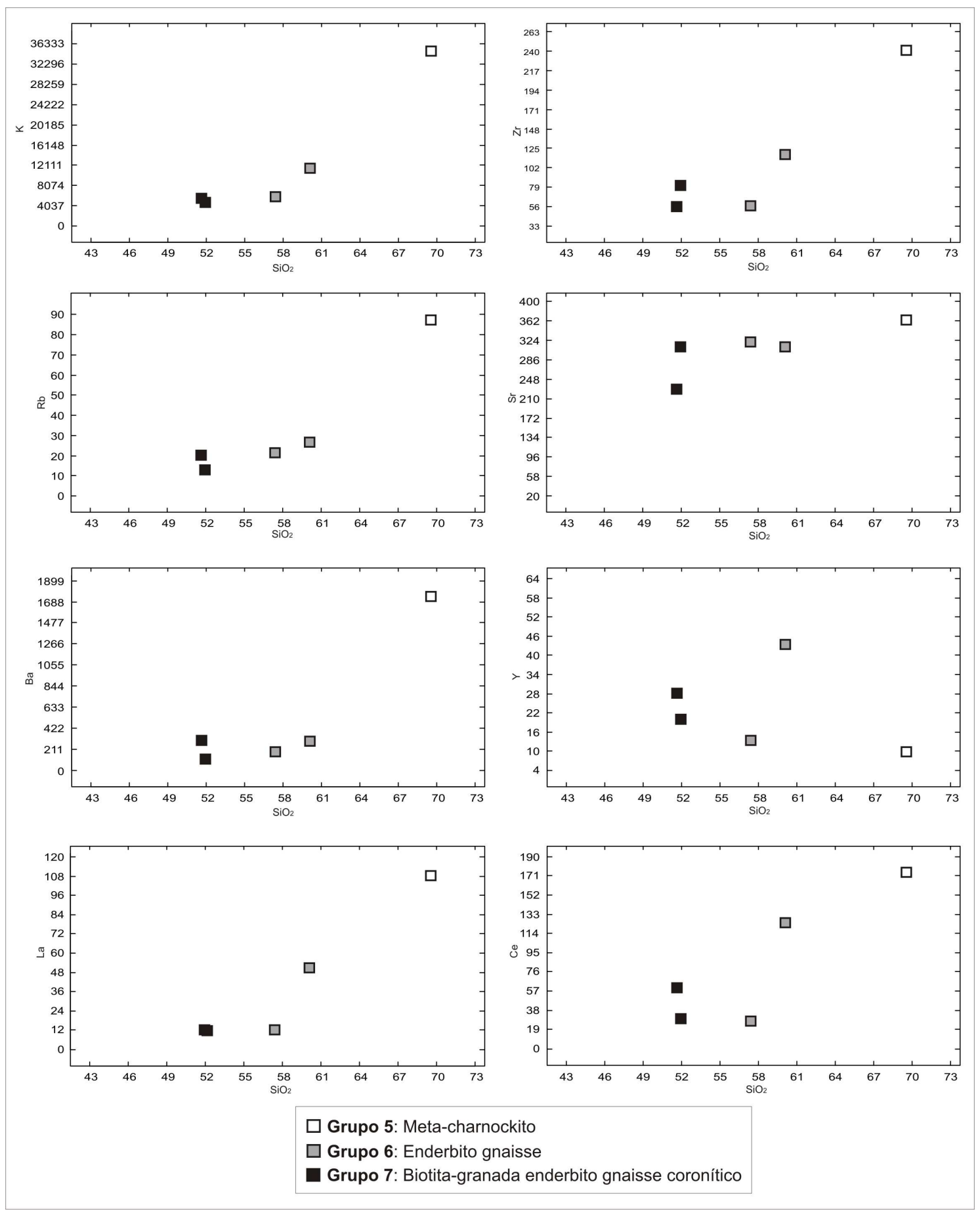

Figura 97: Diagramas de Harker dos elementos menores e traço (expressos em ppm) para as rochas charnockíticas. 


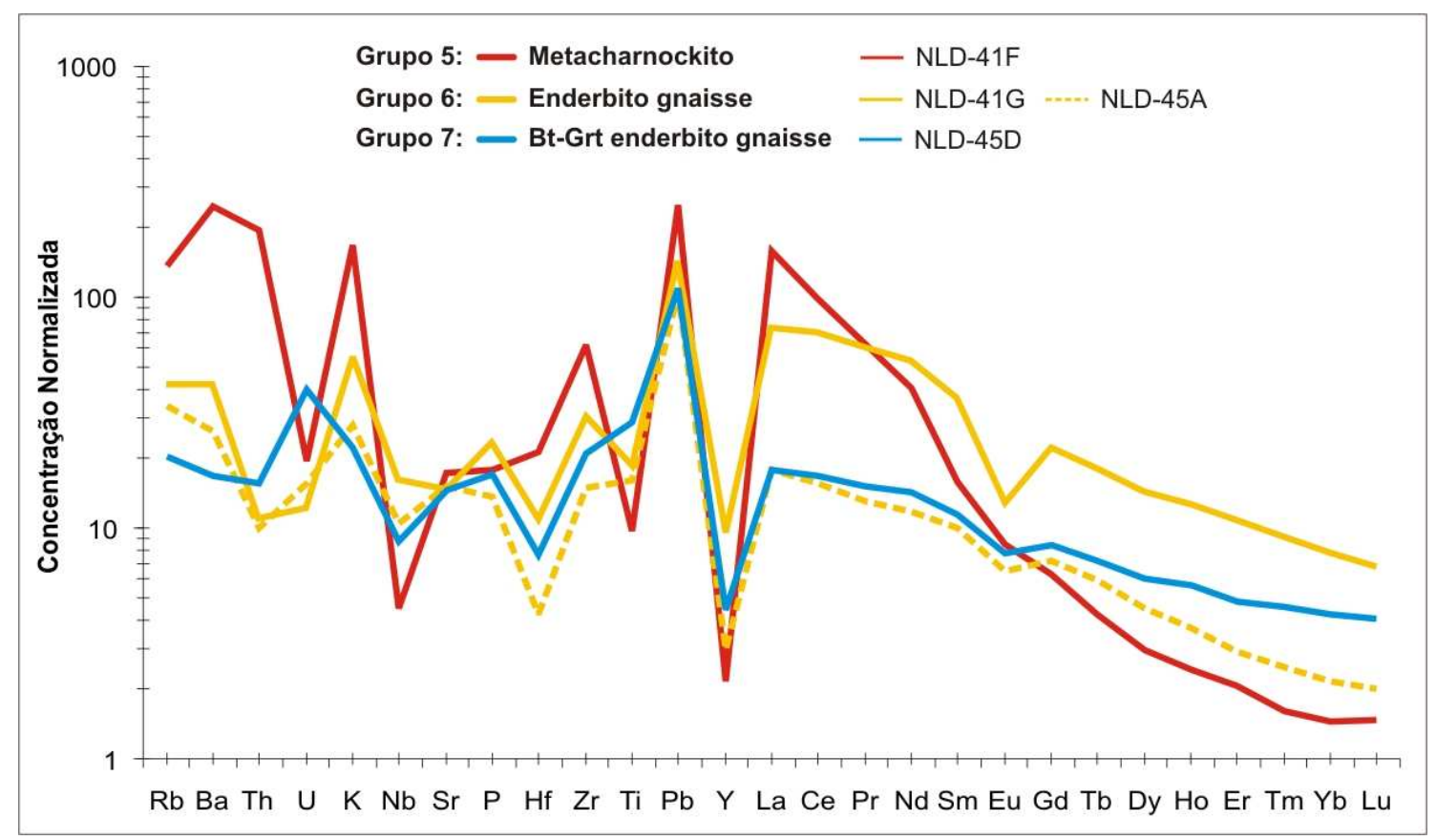

Figura 98: Diagrama multi-elementar das rochas charnockíticas, normalizadas pelo manto primitivo de Sun \& Mc Donough (1989).

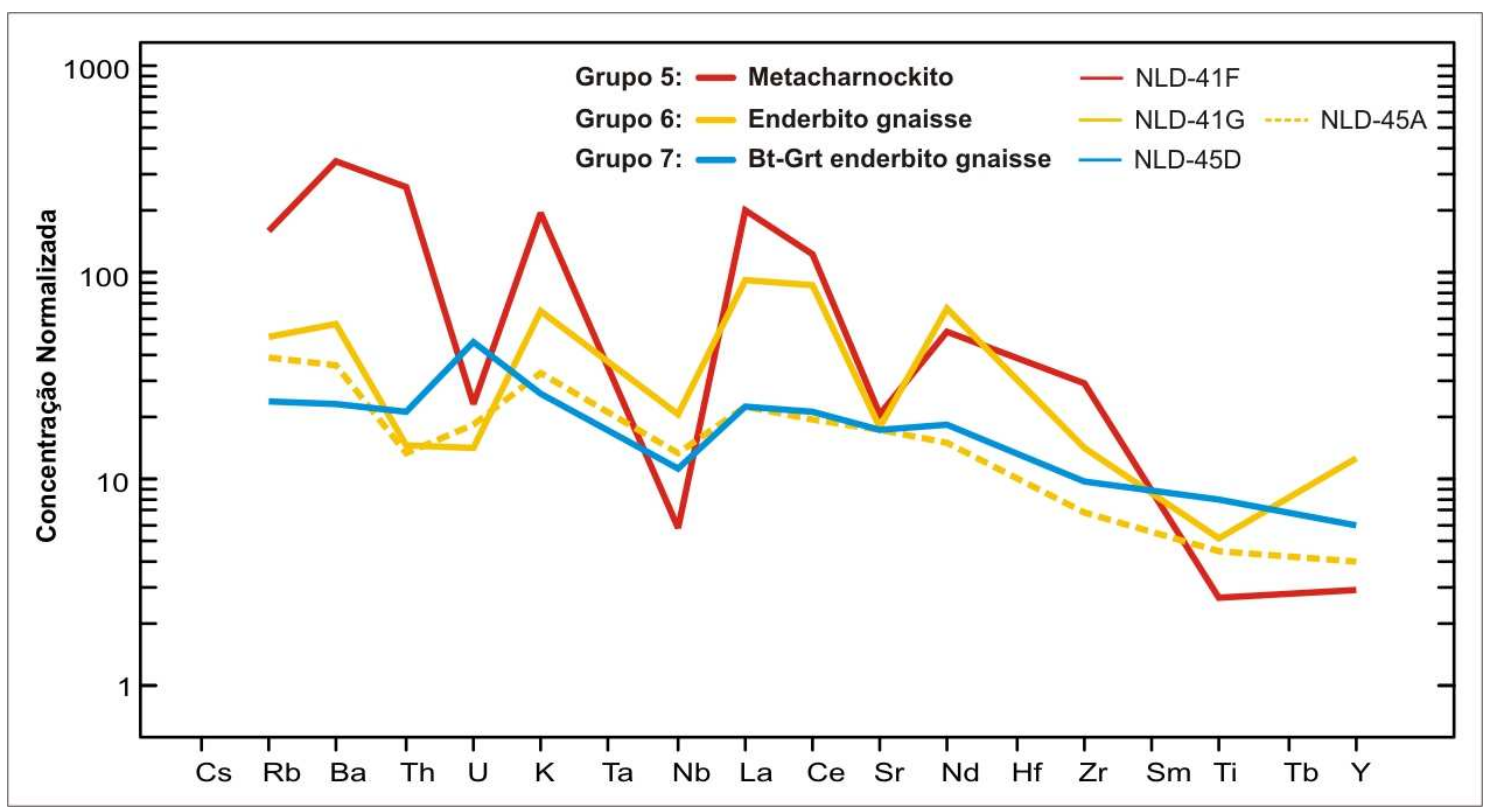

Figura 99: Diagrama multi-elementar das rochas charnockíticas, normalizadas pelo manto primitivo de Taylor \& Mc Lennan (1985).

\subsubsection{Elementos terras-raras}

As rochas charnockíticas apresentam padrões de fracionamento normais de evolução de granitos, sendo que as rochas menos diferenciadas são menos fracionadas (menores razões $[\mathrm{La} / \mathrm{Yb}]_{\mathrm{N}}$ ) e com anomalias de Eu menos pronunciadas (NLD-41F). No diagrama de ETR normalizado ao condrito de Taylor \& Mc Lennan (1985) (Figura 
100) são reconhecidos dois padrões distintos de elementos terras-raras. As rochas enderbíticas (grupos 6 e 7) são caracterizadas por um fracionamento moderado $\left([\mathrm{La} / \mathrm{Yb}]_{\mathrm{N}}=4-9\right)$, e a anomalia negativa de $\mathrm{Eu}$ aumenta com $\mathrm{SiO}_{2}$, sendo mais pronunciada na amostra NLD-41G $\left(\mathrm{Eu} / \mathrm{Eu}^{*}=0.45\right)$. O metacharnockito bandado do grupo 5 apresenta as razões $\left[\mathrm{La} / \mathrm{Yb}_{\mathrm{N}}\right]$ mais elevadas (103.3), o que remete a um alto fracionamento de elementos terras-raras. Os litotipos mais ricos em sílica (NLD-41F e NLD-41G - 60-69.5 $\mathrm{SiO}_{2} \%$ peso) apresentam conteúdo total de ETR mais elevados (260-320 ppm) do que aqueles com menores teores de $\mathrm{SiO}_{2}(68-75 \mathrm{ppm})$ (Figura 100). Essas características apontam para fontes diversas para o metacharnockito, possivelmente retendo granada ou plagioclásio na fonte. As rochas enderbíticas também sugerem uma origem a partir de fontes e/ou processos evolutivos diversos, pois embora os padrões sejam similares, a amostra NLD-41G é muito mais enriquecida em ETR total do que os demais enderbitos (Figura 101A).

Os padrões de ETR das rochas charnockíticas analisadas foram comparados com os padrões de ETR dos charnockitos do batólito de Louis Lake, Wyoming, de composição cálcio-alcalina e formados em limite convergente de placas, que são notadamente de origem ígnea (Frost et al., 2000). O metacharnockito bandado (NLD41F) exibe padrões de distribuição de ETR mais fracionados, enquanto que as rochas de composição enderbítica exibem padrões menos fracionados em comparação com os padrões dos charnockitos de Louis Lake. O metacharnockito bandado apresenta razões $\left[\mathrm{La} / \mathrm{Yb}_{\mathrm{N}}\right]$ mais elevadas, assim os padrões de distribuição de ETR se distinguem dos padrões do charnockito de Louis Lake, sobretudo no enriquecimento relativo de ETRL (Figura 101B).

Os diagramas de variação multi-elementares normalizados ao ORG de Pearce $e t$ al., (1984) foram comparados com análises de Pearce et al., (1984) de granitos de diferentes contextos tectônicos. O metacharnockito bandado (NLD-41F) e os enderbito gnaisses dos grupos 6 e 7 foram comparados com os granitos de arco vulcânico das regiões de Omã, Chile e Jamaica (Figura 102). O enderbito gnaisse da amostra NLD$41 \mathrm{G}$ também foi comparado com os granitos intra-placa das regiões de Sabaloka, Mull, Ascension Islands, Skaergaard e Rift de Oslo (Figura 102B), pois no diagrama discriminante de Pearce et al., (1984), esta amostra plota no limite entre os campos dos granitos de arco vulcânico e granitos intra-placa. A maioria das amostras mostrou padrões similares aos padrões do Chile e da Jamaica, exceto que o metacharnockito 
bandado (NLD-41F) apresenta concentrações mais elevadas em Ba (Figura 102A), o que sugere fontes similares às de arco vulcânico.

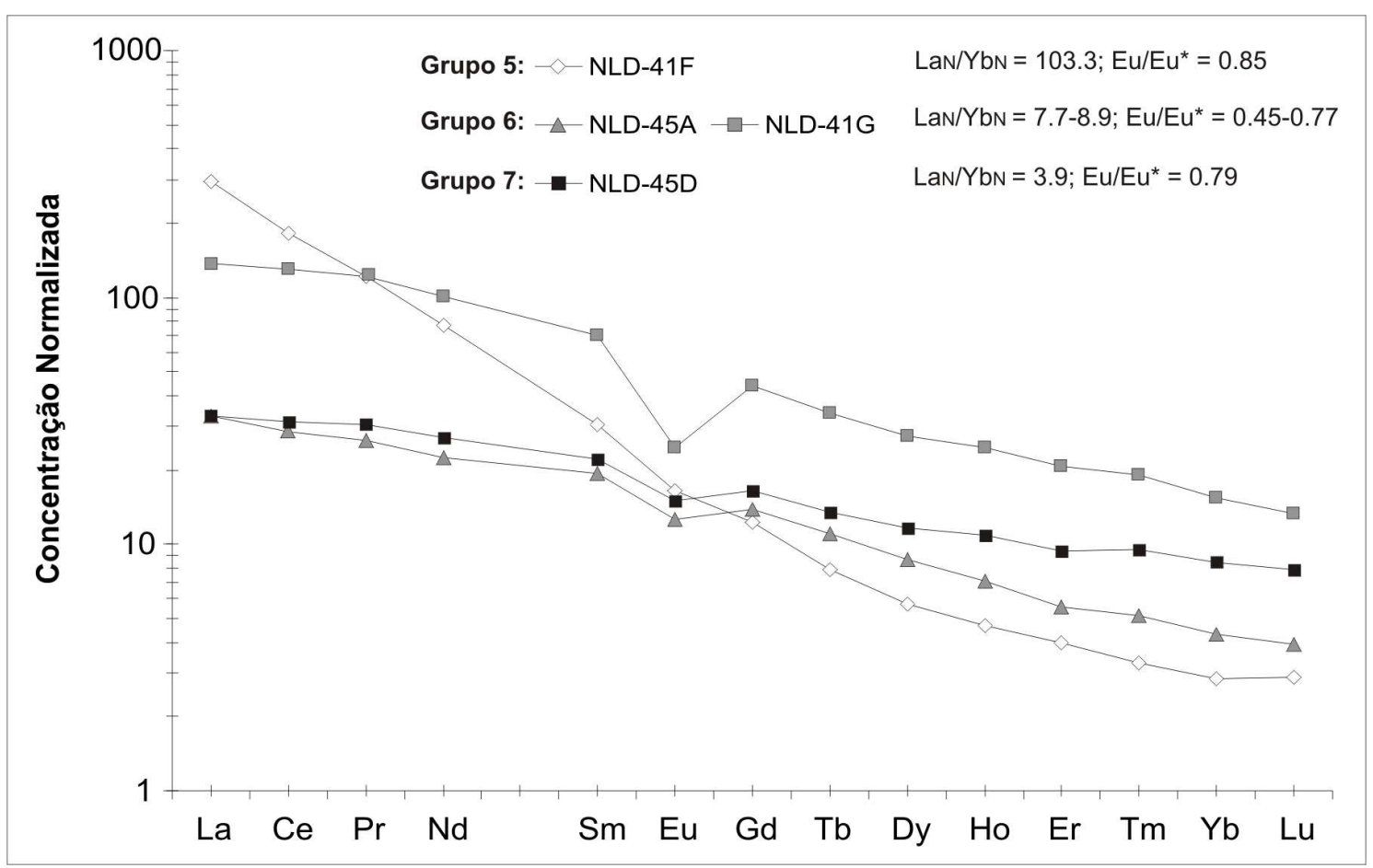

Figura 100: Padrões de ETR das rochas charnockíticas, normalizados ao condrito de Taylor \& Mc Lennan (1985).

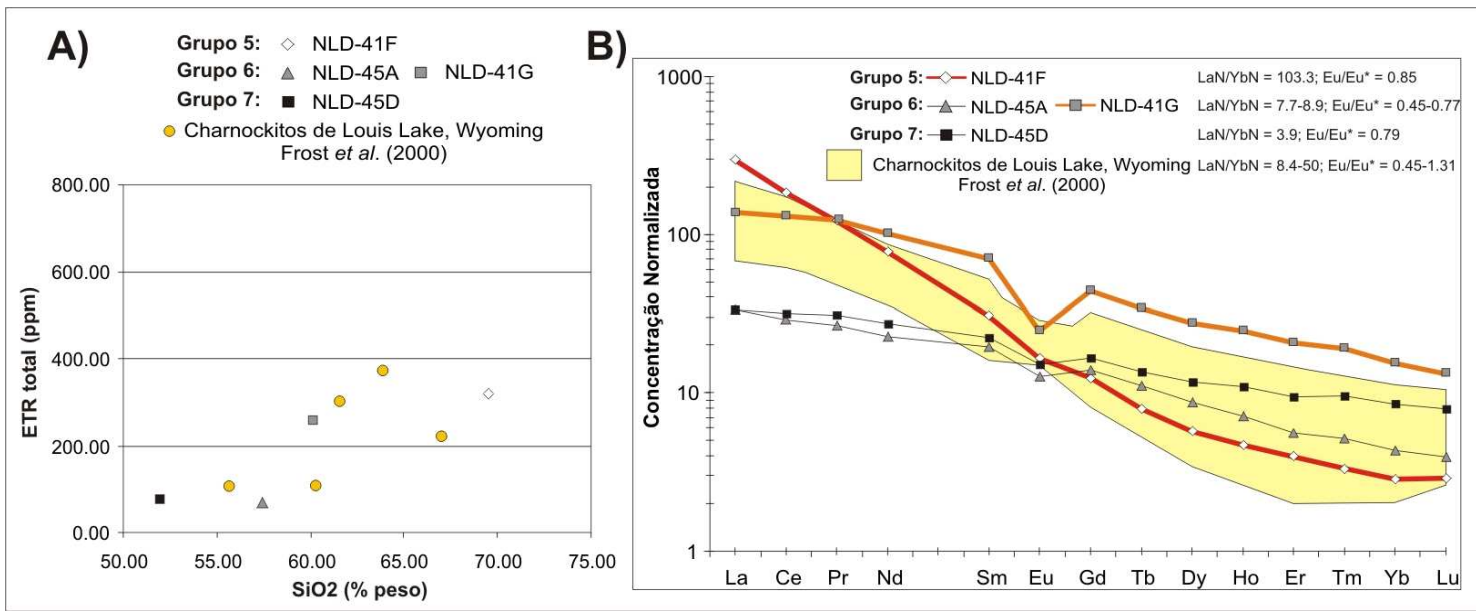

Figura 101: A) Diagrama binário de ETR total vs. $\mathrm{SiO}_{2}$ para as rochas charnockíticas do Complexo Mantiqueira. Dados do charnockito do Batólito de Louis Lake (Wyoming) de Frost et al., (2000) são mostrados para comparação; B) Diagramas de ETR normalizados ao condrito de Taylor \& Mc Lennan (1985), comparados com os padrões de ETR do charnockito de Louis Lake (Wyoming).

Processos de fusão parcial e de cristalização fracionada em rochas ígneas levam a um enriquecimento relativo em ETRL na fase líquida de sistemas silicáticos cristal- 
líquido (Figueiredo, 1995), desse modo há um enriquecimento de ETRL em rochas crustais, principalmente nas mais félsicas. Geralmente há poucas modificações dos padrões de ETR durante o metamorfismo, o que permite estudar os padrões de ETR como referentes ao protólito (Cullers et al., 1974; Muecke et al., 1979).

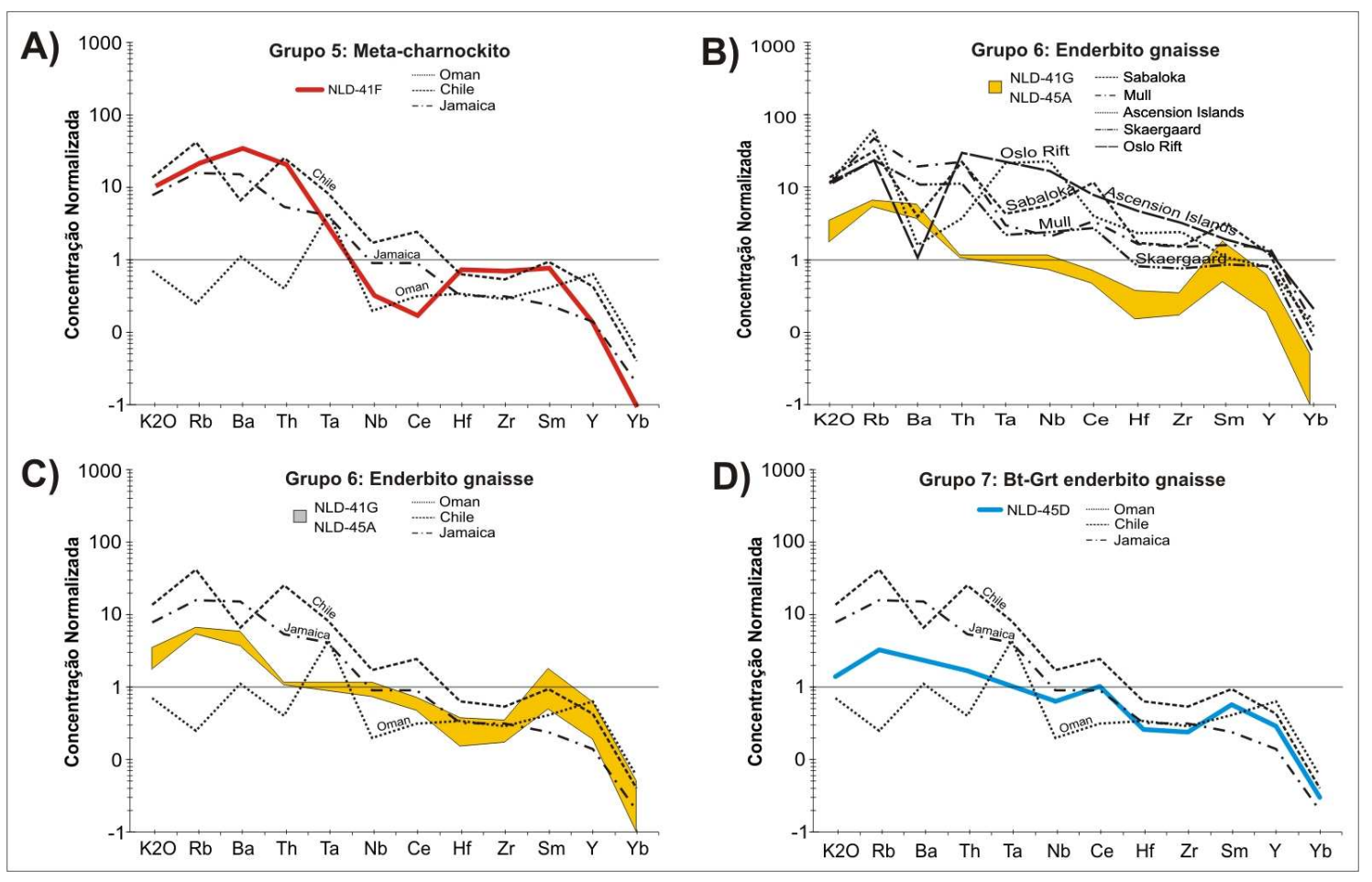

Figura 102: A), B), C), D) Diagramas de variação multi-elementar para as rochas charnockíticas, normalizados para o ORG (ocean ridge granites) de Pearce et al. (1984).

O modelamento geoquímico realizado por Duarte et al., (2004) aponta que o processo petrogenético associado com a formação das rochas do Complexo Mantiqueira é a fusão parcial. Os processos de fusão parcial típicos de contextos tectônicos associados com a geração de rochas cálcio-alcalinas tendem a envolver condições oxidantes, o que é corroborado nos resultados obtidos no modelamento geoquímico de Duarte et al., (2004). Segundo Figueiredo et al., (1992) e Figueiredo \& Teixeira (1996), o Complexo Mantiqueira é constituído de duas suítes cálcio-alcalinas distintas: uma suíte cálcio-alcalina de baixo-K que inclui rochas básicas a ácidas, possivelmente resultantes do retrabalhamento do embasamento arqueano; e uma suíte cálcio-alcalina de alto-K, rica em elementos (LILE), que inclui rochas intermediárias a ácidas, componentes de um arco magmático maduro do Paleoproterozóico.

Os dados geoquímicos (diagramas de variação multi-elementares, de ETR e diagramas de Pearce \& Cann (1973)) apontam fontes do tipo E-MORB (basalto de 
cadeia meso oceânica enriquecido) para grande parte das rochas metabásicas inseridas nos ortognaisses e rochas charnockíticas do Complexo Mantiqueira, embora sempre com enriquecimento em ETR maior, o que é sugestivo de fontes mais enriquecidas. $\mathrm{O}$ granada-clinopiroxênio anfibolito simplectítico (NLD-9A) apresenta assinaturas geoquímicas bastante distintas das demais rochas metabásicas, com enriquecimento maior em elementos LILE e ETRL, o que sugere uma origem a partir de fontes OIB (basalto de ilha oceânica). Não foi possível determinar se ocorreu um magmatismo anidro, pois os processos metamórficos e magmáticos ocorrem simultaneamente durante uma orogenia e modificações da mineralogia e, conseqüentemente da geoquímica, são muitas vezes inevitáveis. Embora as evidências petrográficas (preservação de texturas magmáticas) e de campo apontem para uma origem ígnea para as rochas charnockíticas, a cristalização possivelmente se deu em níveis crustais profundos, em ambiente metamórfico de alta pressão. As rochas charnockíticas podem ter sido originadas a partir de processo de fusão parcial, conforme postulado por Duarte et al., (2004). Os padrões de ETR e diagramas de variação multi-elementares de elementos traço sugerem que as rochas charnockíticas têm fontes relacionadas à ambientes de arco vulcânico, exceto o litotipo félsico de composição enderbítica (NLD-41G) que pode ter fontes relacionadas à ambiente de arco vulcânico ou intra-placa. 


\section{CONCLUSÕES}

A Nappe Lima Duarte está inserida na porção oriental do Sistema Orogênico Brasília Meridional, no sul de Minas Gerais. É constituída predominantemente por paragnaisses migmatíticos com granada, sillimanita, biotita e muscovita, e ortoquartzitos grossos, com intercalações esparsas de anfibolitos e gnaisses calciossilicáticos. O Complexo Mantiqueira, infra-estrutura alóctone da nappe, ocorre na forma de lascas tectonicamente imbricadas na mesma. É constituído por ortognaisses migmatíticos e polimetamórficos, tipo TTG, com diferentes gerações de leucossoma. Apresentam intercalações de rochas metabásicas de dimensões e composições variadas, na forma de enclaves máficos alongados e boudins, geralmente concordantes com a foliação principal. Também ocorrem rochas charnockíticas associadas aos ortognaisses, que são aparentemente intrusivas nos mesmos, porém estão afetadas por zonas de cisalhamento, que localmente definem o contato com os ortognaisses do Complexo Mantiqueira e com a seqüência metassedimentar da Nappe Lima Duarte. As rochas charnockíticas apresentam estrutura maciça a foliada e são comumente cortadas por injeções tonalíticas de dimensões variadas (milimétrica a decimétrica) e possuem rochas metabásicas associadas, tanto na forma de boudins ou enclaves máficos.

A associação mineral observada nos paragnaisses $(\mathrm{Grt}+\mathrm{Bt}+\mathrm{Sil}+\mathrm{Pl}+\mathrm{Rt}+\mathrm{Ilm}$ $+\mathrm{Qtz} \pm \mathrm{Ms} \pm \mathrm{Kfs} \pm \mathrm{Ky}$ ) é relacionada a um metamorfismo progressivo de fácies anfibolito superior. Sob a klippe quartzítica da Serra Negra ocorrem paragnaisses com raras inclusões de cianita associada com feldspato potássico em porfiroblastos intercinemáticos de granada (OL-II-112B) e também paragnaisses com cianita e sillimanita na matriz (NLD-61). O metamorfismo progressivo nos paragnaisses é caracterizado pelas reações de quebra da muscovita, localmente com a geração de feldspato potássico (Le Breton \& Thompson, 1988; Vielzeuf \& Holloway, 1988). A ocorrência de inclusões de feldspato potássico com aspecto de filme nos porfiroblastos de granada, aparentemente mimetizando um líquido silicático (Holness \& Sawyer, 2008) e envolvendo as inclusões de Ky, Sil, Bt, Ms, Ilm e Zrc sugere que a cristalização do porfiroblasto de granada se deu em presença de feldspato potássico e líquido. Nos paragnaisses, a ocorrência de conteúdos mais elevados em grossulária no porfiroblasto de granada, nas proximidades de inclusão de cianita sugere que as condições do pico bárico foram atingidas no campo de estabilidade da cianita, que seguido de 
descompressão, atingiu o campo de estabilidade da sillimanita. As condições de pico bárico foram obtidas no THERMOCALC (Powell \& Holland, 1988) através da realização de cálculos envolvendo a associação com cianita, com pressão máxima de 10 $\pm 0.6 \mathrm{kbar}$, para temperatura de $807 \pm 25^{\circ} \mathrm{C}$.

O pico térmico de $827 \pm 44^{\circ} \mathrm{C}$, para pressão de $8.2 \pm 1.8$, no limite da curva de quebra da dumortierita (Werding \& Schreyer, 1996), foi obtido no THERMOCALC (Powell \& Holland, 1988) com a associação mineral envolvendo sillimanita. A temperatura máxima obtida com o geotermômetro de Zr-em-rutilo (Watson et al., 2006; Tomkins et al., 2007) foi de $748.5^{\circ} \mathrm{C}$, no núcleo do porfiroblasto de granada da amostra OL-II-112B, possivelmente registrando uma etapa de descompressão no limite Ky/Sil. No retrometamorfismo ocorreu a substituição parcial a total de porfiroblastos de granada por intercrescimentos de Bt + Sil (Le Breton \& Thompson, 1988), além da substituição da sillimanita, cianita (quando presente) e feldspatos por muscovita, representando a volta das reações de quebra da muscovita (Le Breton \& Thompson, 1988; Vielzeuf \& Holloway, 1988). No metamorfismo retrógrado também ocorre a formação de sillimanita fibrosa pseudomorfizando sillimanita prismática. Os paragnaisses da Nappe Lima Duarte apresentam uma trajetória metamórfica no sentido horário, saindo do campo de estabilidade da cianita e passando para o campo da sillimanita.

As rochas metabásicas inseridas nos ortognaisses do Complexo Mantiqueira e as rochas charnockíticas associadas apresentam a associação granada + clinopiroxênio + plagioclásio + quartzo \pm ortopiroxênio + hornblenda, que é diagnóstica de metamorfismo de fácies granulito de alta pressão (>9 kbar) (Green \& Ringwood, 1967; Rushmer, 1993). As rochas metabásicas e as rochas charnockíticas são caracterizadas pela presença de texturas coroníticas progressivas constituídas por Grt $+\mathrm{Cpx} \pm \mathrm{Qtz}$ ou de Grt \pm Qtz nos contatos entre ortopiroxênio, plagioclásio e/ou opacos, aparentemente de origem ígnea, que marca a passagem do campo dos granulitos de pressão intermediária para o campo dos granulitos de alta pressão (Green \& Ringwood, 1967; Baldwin et al., 2003; O’Brien \& Rötzler, 2003).

Nos metagabronoritos, as condições máximas de metamorfismo estão preservadas nos veios constituídos por Grt + Cpx + Qtz + opacos (NLD-42D) com temperatura máxima de $831.79^{\circ} \mathrm{C}$ (Sengupta et al., 1989), a $10 \mathrm{kbar}$. As condições de pressão máxima foram obtidas através do geobarômetro Grt-Cpx-Pl de Eckert et al. 
(1991), que forneceram pressões em torno de $10.89 \pm 1.9 \mathrm{kbar}$, a $780^{\circ} \mathrm{C}$. As condições calculadas através do THERMOCALC são $794 \pm 167^{\circ} \mathrm{C}$ a $8.8 \pm 2.0$ kbar.

O granada granulito também preserva as condições relacionadas ao pico metamórfico. As condições calculadas através do THERMOCALC são $890 \pm 41^{\circ} \mathrm{C}$, a $9.26 \pm 1.93$ kbar. Cálculos realizados através do TWEEQU forneceram condições de equilíbrio de $801^{\circ} \mathrm{C}$ a 9.6kbar para a associação de fácies granulito $\mathrm{Grt}+\mathrm{Cpx}+\mathrm{Opx}+\mathrm{Pl}+\mathrm{Qtz}$ na amostra NLD-7D, onde ocorre o ponto de intersecção entre as reações. A temperatura máxima no granada granulito obtida através do geotermômetro Grt-Cpx é de $799.6^{\circ} \mathrm{C}$ (Ganguly, 1979) e $768.6^{\circ} \mathrm{C}$ (Sengupta et al., 1989), a 10 kbar, e a pressão é da ordem de $9.4 \pm 1.9 \mathrm{kbar}$, a $785^{\circ} \mathrm{C}$ (Eckert et al., 1991). No hornblenda-metagabro da amostra NLD-20A, a temperatura máxima obtida é da ordem de $750.3^{\circ} \mathrm{C}$, a $9 \mathrm{kbar}$ (Ganguly, 1979) e a pressão é da ordem de $9.1 \pm 1.9 \mathrm{Kbar}$, a $750^{\circ} \mathrm{C}$ (Eckert et al., 1991).

As condições mais próximas ao pico metamórfico nas rochas charnockíticas foram obtidas através de cálculos envolvendo a associação mineral Grt-Cpx-Pl, que forneceram pressão máxima de $14.36 \pm 1.9 \mathrm{kbar}$, a $680^{\circ} \mathrm{C}$ (Eckert et al., 1991). As temperaturas máximas registradas são da ordem de $885.17^{\circ} \mathrm{C}$ (Ganguly, 1979) e $901.06^{\circ} \mathrm{C}$ (Sengupta et al., 1989). Cálculos realizados no THERMOCALC forneceram temperatura de $771 \pm 166^{\circ} \mathrm{C}$, a $11.8 \pm 2.4$ kbar. São bastante comuns nas rochas charnockíticas as reações de quebra de biotita, acompanhadas pela formação de feldspato potássico lobado, aparentemente mimetizando um líquido silicático e aproximadamente contemporâneo ao desenvolvimento das coronas. Essa textura ocorre tanto nas rochas charnockíticas, de composição intermediária, como nas rochas metabásicas. Propõe-se no presente trabalho uma trajetória anti-horária para as rochas charnockíticas e para as rochas metabásicas, seguida de resfriamento quase isobárico, porém com pressões ligeiramente mais elevadas nas rochas charnockíticas, em nível crustal mais profundo.

As rochas metabásicas intercaladas nos ortognaisses e rochas charnockíticas do Complexo Mantiqueira apresentam baixas concentrações de elementos LILE, possivelmente associadas com o empobrecimento destes elementos durante $\mathrm{o}$ metamorfismo, através de perdas por reações de desidratação. Somente o clinopiroxênio-granada anfibolito simplectítico é enriquecido em elementos LILE e incompatíveis. Os dados geoquímicos apontam fontes do tipo E-MORB (basalto de cadeia meso oceânica enriquecido) para grande parte das rochas metabásicas inseridas 
nos ortognaisses e rochas charnockíticas do Complexo Mantiqueira, embora sempre com enriquecimento em ETR maior, o que é sugestivo de fontes mais enriquecidas. $\mathrm{O}$ granada-clinopiroxênio anfibolito simplectítico (NLD-9A) apresenta assinaturas geoquímicas bastante distintas das demais rochas metabásicas, com enriquecimento maior em elementos LILE e ETRL, o que sugere uma origem a partir de fontes OIB (basalto de ilha oceânica). Os padrões de ETR e diagramas de variação multielementares de elementos traço sugerem que as rochas charnockíticas têm fontes relacionadas à ambientes de arco vulcânico, exceto o litotipo félsico de composição enderbítica (NLD-41G) que pode ter fontes relacionadas à ambiente de arco vulcânico ou intra-placa.

Os paragnaisses registram uma trajetória inicial horária, descompressiva ao campo da sillimanita, que se distingue da trajetória inicial anti-horária exibida pelas rochas metabásicas e charnockíticas. A freqüente presença de texturas coroníticas de Grt-Cpx-Qtz nas rochas metabásicas e charnockíticas registra o metamorfismo progressivo, de fácies granulito de alta pressão. Sugere-se que esse relativo aumento de pressão tenha sido condicionado pela colocação dos metassedimentos da Nappe Lima Duarte sobre as rochas do Complexo Mantiqueira, porém no mesmo campo de temperatura. Desta forma, o avanço da nappe metassedimentar pode ter sido responsável pelo soterramento das rochas metabásicas e charnockíticas relacionadas ao Complexo Mantiqueira, o que justifica pressões mais elevadas nestes litotipos. A etapa de exumação foi compartilhada por ambas, o que é evidenciado através das condições semelhantes de metamorfismo entre os paragnaisses da Nappe Lima Duarte e rochas do Complexo Mantiqueira, que registram uma trajetória de resfriamento quase isobárico, porém com os metassedimentos em nível crustal mais raso. 


\section{REFERÊNCIAS BIBLIOGRÁFICAS}

Allen, P., Condie, K.C. \& Narayana, B.L. 1984. The geochemistry of prograde and retrograde charnockite-gneiss reactions in southern India. Geochimica et Cosmochimica Acta, 49: 323-336.

Almeida, F.F.M. 1978. Regimes tectônicos arqueanos na evolução proterozóica e mineralização do leste brasileiro. Anais da Academia Brasileira de Ciências, Rio de Janeiro, 50(4): 601-602.

Almeida, F.F.M.; Hasui, Y., Davino, A.; Haraly, N.L.E. 1980. Informações geofísicas do oeste mineiro e seu significado tectônico. Anais da Academia Brasileira de Ciências, Rio de Janeiro, 52(1): 49-60.

Andreis, R.R., Ribeiro, A. \& Paciullo, F.V.P. 1989. Ciclos deposicionais no proterozóico das folhas Barbacena e Divinópolis (setor sul), 1:250.000. In: Simp. Geol. Sudeste, I, Rio de Janeiro, 1989, Bol. Res., p.97-98.

Appleyard, C.M., Bell, D.R., Le Roux, A.P. 2007. Petrology and geochemistry of eclogite xenoliths from the Rietfontein Kimberlite, Northern Cape, South Africa. Contributions to Mineralogy and Petrology, 154: 309-333.

Ashworth, J.R., Sheplev, V.S., Bryxina, N.A., Kolobov, V.Y. \& Reverdatto, V.V. 1998. Diffusion-controlled corona reaction and overstepping of equilibrium in a garnet granulite, Yenisey Ridge, Siberia. Journal of metamorphic Geology, 16: 231-246.

Ashworth, J.R., Sheplev, V.S., Khlestov, V.V. \& Ananyev, A. A. 2001. Geothermometry using minerals at non-equilibrium: a corona example. European Journal of Mineralogy, 13: 1153-1161.

Baldwin, J.A., Bowring, S.A. \& Williams, M.L. 2003. Petrological and geochronological constraints on high pressure, high temperature metamorphism in the Snowbird tectonic zone, Canada. Journal of metamorphic Geology, 21: 81-98.

Barbosa, A.L.M. \& Grossi Sad, J.H. 1983a. Reinterpretação das "séries" Juiz de Fora e Paraíba, em Minas Gerais e Rio de Janeiro. In: SBG, Simpósio Geologia de Minas Gerais, 2, Belo Horizonte, Anais, 3: 1-15.

Barbosa, A.L.M. \& Grossi Sad, J.H. 1983b. Petrografia dos charnockitos e rochas afins ao longo da divisa Minas Gerais-Rio de Janeiro. In: SBG, Simpósio Geologia de Minas Gerais, 2, Belo Horizonte, Anais, 3: 63-74. 
Barbosa, A.L.M. \& Grossi Sad, J.H. 1983c. Geoquímica e Petrologia dos charnockitos e rochas afins do Complexo Juiz de Fora, MG-RJ. In: SBG, Simpósio Geologia de Minas Gerais, 2, Belo Horizonte, Anais, 3: 75-82.

Barbosa, O. 1954. Evolution du Geosynclinal Espinhaço. In: Congress Geol. Inter., 19, Alger, Comptes Rendus, 14: 17-36.

Bard, J.P. 1986. Microtextures of igneous and metamorphic rocks (Petrology and Structural geology). D. Reidel Publishing Company. 264 p.

Beard, J.S. \& Lofgren, G.E. 1991. Dehydration melting and water-saturated melting of basaltic and andesitic greenstones and amphibolites at 1, 3 and 6.9 kbar. Journal of Petrology, 32: 365-401.

Bendoraitis, D.P. 2007. De nappe sin-metamórfica a sistema de cavalgamento: evolução estrutural de uma seção da Nappe Lima Duarte, sul do cráton do São Francisco. Monografia de Trabalho de Formatura, IGc-USP, 48p.

Berman, R.G. 1988. Internally-consistent thermodynamic data for minerals in the system $\mathrm{Na}_{2} \mathrm{O}-\mathrm{K}_{2} \mathrm{O}-\mathrm{CaO}-\mathrm{MgO}-\mathrm{FeO}-\mathrm{Fe}_{2} \mathrm{O}_{3}-\mathrm{Al}_{2} \mathrm{O}_{3}-\mathrm{SiO}_{2}-\mathrm{TiO}_{2}-\mathrm{H}_{2} \mathrm{O}-\mathrm{CO}_{2}$. Journal of Petrology, 29: 445-522.

Berman, R.G. 1990. Mixing properties of Ca-Mg-Fe-Mn garnets. American Mineralogist, 75: 328-344.

Berman, R.G. 1991. Thermobarometry using multi-equilibrium calculations: a new technique, with petrological applications. Canadian Mineralogist, 29: 833-855.

Bhattacharya, S. 2010. Review: the charnockite problem, a twenty first century perspective. Natural Science, 2: 402-408.

Bhowmik, S.K., Saha, L., Dasgupta, S. \& Fukuoka, M. 2009. Metamorphic phase relations in orthopyroxene-bearing granitoids: implication for high-pressure metamorphism and prograde melting in the continental crust. Journal of metamorphic Geology, 27: 295-315.

Binns, R.A. 1969. Hydrothermal investigations of the amphibolite-granulite facies boundary. Special Publication of the Geological Society of Australia, 2: 341-344.

Bohlen, S.R., Wall, V.J. \& Boettcher, A.L. 1983. Geobarometry in granulites. In: Advances in Physical Geochemistry, 3 (ed. Saxena, S.K.), pp. 141-171. SpringVerlag, New York.

Bohlen, S.R. 1987. Pressure-Temperature-time paths and a tectonic model for the evolution of granulites. Journal of Geology, 95: 617-632. 
Bohlen, S.R. \& Mezger, K. 1989. Origin of granulite terranes and the formation of the lowermost continental crust. Science, 244: 326-329.

Bohlen, S.R. 1991. On the formation of granulites. Journal of metamorphic Geology, 9: 223-229.

Brito Neves, B.B., Campos Neto, M.C. \& Fuck, R.A., 1999. From Rodinia to Western Gondwana: An approach to the Brasiliano-Pan African cycle and orogenic collage. Episodes, 22 (3): 155-166.

Campos Neto, M.C., Basei, M.A.S., Siga Junior, O., Bergmann, M., Figueiredo, M.C.H., Lima, G.A., Almeida, L.E.G., Braghi, A., Miller, A.D., Mayerhofer, C.E.S., Foz Neto, C.R., Shimizu, D., Cagnon, F.A., Bazzon, F., Fernandes, F., Franzaglia, G.C., Moragas, G.M., Vilela, L.G.G., Marcelino, M.B., Galvão, M.C.S., Rondani, M.E., Santos Filho, M.G., Ando, M.H., Espindola, R.S. \& Torres, S.I. 1996a. Mapa geológico 1:50 000 da região de Lima Duarte (MG). In: SBG, Congresso Brasileiro de Geologia, 39, Salvador, Anais, 1: 70-71.

Campos Neto, M.C., Lima, G.A., Basei, M.A.S., Siga Junior, O., Figueiredo, M.C.H. 1996b. Controle metamórfico e estrutural entre terrenos da borda SE do cráton do São Francisco e os terrenos Juiz de Fora: região de Lima Duarte - Rio Preto Valença (MG-RJ). In: SBG, Congresso Brasileiro de Geologia, 39, Salvador, Anais, 6: 95-97.

Campos Neto, M.C. \& Caby, R., 1999. Neoproterozoic high-pressure metamorphism and tectonic constraint from the nappe system south of the São Francisco craton, southeast Brazil. Precambrian Research, 97: 3-26

Campos Neto, M.C. \& Caby, R., 2000. Terrane accretion and upward extrusion of highpressure granulites in the Neoproterozoic nappes of Southeast Brazil: Petrologial and structural constraints. Tectonics, 14 (4): 669-687.

Campos Neto, M.C., 2000. Orogenic System from Southwestern Gondwana: An approach to Brasiliano-Pan African cycle and orogenic collage in Southeastern Brazil. In: Cordani, U.G., Milani, E.J., Thomaz Filho, A. e Campos, D.A. TECTONIC EVOLUTION OF SOUTH AMERICA, $31^{\text {ST }}$ International Geological Congress: 335-365.

Campos Neto, M.C., Basei, M..A., Vlach, S.R.F., Caby, R., Szabó, AJ. \& Vasconcelos, P., 2004. Migração de orógenos e superposição de orogêneses: um esboço da colagem brasiliana no sul do Cráton do São Francisco, SE-Brasil, 2004. Geologia USP, Série Científica, 4 (1): 13-40. 
Campos Neto, M.C., Janasi, V.A., Basei, M.A.S. \& Siga Junior, O. 2007. Sistema de Nappes Andrelândia, setor oriental: litoestratigrafia e posição estratigráfica. Revista Brasileira de Geociências, 37 (suplemento nº4): 47-60.

Campos Neto, M.C., Cioffi, C.R., Moraes, R., Motta, R.G., Siga Jr., O. \& Basei, M.A.S. 2010. Structural and metamorphic control on the exhumation of high-P granulites: The Carvalhos Klippe example, from the oriental Andrelândia Nappe System, southern portion of the Brasília Orogen, Brazil. Precambrian Research, 180: 125142.

Carswell, D.A. \& O’Brien, P.J. 1993. Thermobarometry and geotectonic significance of high-pressure granulites: Examples from the Moldanubian zone of the Bohemian Massif in lower Austria. Journal of Petrology, 119: 30-42.

Choudhuri, A. \& Winkler, H.G.F. 1967. Anthophyllit und Hornblende in einigen metamorphen Reaktionen. Contributions to Mineralogy and Petrology, 14: 293315.

Clemens, J.D. 1992. Partial melting and granulitic genesis: a partisan overview. Precambrian Research, 55: 297-301.

Condie, K.C. \& Allen, P. 1984. Origin of Archean charnockites from southern India. In: Archean Geochemistry (eds. A. Kroner, A.M. Goodwin and G.M. Hanson), Springer-Verlag, Berlin.

Conrad, W.K., Nicholls, I.A. \& Wall, V.J. 1988. Water-saturated and undersaturated melting of metaluminous and peraluminous crustal compositions at 10 kbar: evidence for the origin of silicic magmas in the Taupo Volcanic Zone, New Zealand, and other occurrences. Journal of Petrology, 29: 765-803.

Costa, A.G. 1998. The granulite-facies rocks of the northern segment of the Ribeira Belt, eastern Minas Gerais, SE Brazil. Gondwana Research, 1: 367-372.

Cox, K.G., Bell, J.D. \& Pankhurst, R.J. 1979. The interpretation of igneous rocks. London, Allen \& Unwin, $450 \mathrm{p}$.

Cox, R.A. \& Indares, A. 1999. Transformation of Fe-Ti gabbro to coronite, eclogite and amphibolite in the Baie Du Nord segment, Manicouagan Imbricate Zone, eastern Grenville Province. Journal of metamorphic Geology, 17: 537-555.

Currie, C.A., Beaumont, C. \& Huismans, R.S., 2007. The fate of subducted sediments: A case for backarc intrusion and underplating. Geology, 35, (12): 1111-1114.

De Waard, D. 1965a. A proposed subdivision of the granulite fácies. American Journal of Science, 263: 455-461. 
De Waard, D. 1965b. The occurrence of garnet in the granulite-facies terrane of the Adirondack Highlands. Journal of Petrology, 6(1): 165-191.

De Waard, D. 1969. The occurrence of charnockite in the Adirondacks: a note on the origin and definition of charnockite. Am. J. Set., 267: 983-987.

Duarte, B.P., Figueiredo, M.C.H., Campos Neto, M.C. \& Heilbron, M. 1997. Geochemistry of granulite fácies orthogneisses of the Juiz de Fora Complex, Central Segmento of the Ribeira Belt, Southeastern Brazil. Revista Brasileira de Geociências, 27(1): 67-82.

Duarte, B.P. 1998. Evolução tectônica dos ortognaisses dos complexos Juiz de Fora e Mantiqueira na região de Juiz de Fora, MG: geologia, petrologia e geoquímica. Instituto de Geociências, Universidade de São Paulo, Tese de Doutoramento, 280p.

Duarte, B.P., Valente, S.C., Heilbron, M. \& Campos Neto, M.C. 2004. Petrogenesis of the Orthogneisses of the Mantiqueira Complex, Central Ribeira Belt, SE Brazil: An Archaean to Paleoproterozoic Basement Unit Reworked During the PanAfrican Orogeny. Gondwana Research, 7: 437-450.

Duarte, B.P., Heilbron, M., Ragatky, D. \& Valente, S.C. 2005. Mantiqueira and Juiz de For a Complexes: reworked basement units within a Western Gondwana mobile belt in Brazil. In: Abstracts, Gondwana 12. Academia Nacional de Ciências, Mendoza, Argentina, p. 142.

Earle, M.M. 1980. A note on the relationship between inclined isothermal surfaces and subduction-zone metamorphism. Bulletin of the Geological Society of America, 68: $313-324$.

Ebert, H. 1954. Relatório de Atividades. Relatório Anual do Diretor, DGM, DNPM, ano 1953, Rio de Janeiro, p.55-57.

Ebert, H. 1955. Relatório de Atividades. Relatório Anual do Diretor, DGM, DNPM, ano 1954, Rio de Janeiro, p.79-89.

Ebert, H. 1956a. Relatório de Atividades. Relatório Anual do Diretor, DGM, DNPM, ano 1955, Rio de Janeiro, p.62-81.

Ebert, H. 1956b. Relatório de Atividades. Relatório Annual do Diretor, DGM, DNPM, ano 1956, Rio de Janeiro, p.97-107.

Ebert, H. 1958. Discordâncias precambrianas em Carandaí (MG). Boletim 183, DGM, DNPM, Rio de Janeiro, 48p. 
Ebert, H. 1968. Ocorrência da fácies granulítica no sul de Minas Gerais e em áreas adjacentes, em dependência de sua estrutura orgânica: Hipótese sobre sua origem. Anais da Academia Brasileira de Ciências(suplemento), Rio de Janeiro, 40: 215229.

Ebert, H. 1971. Os Paraibides entre São João Del Rey, Minas Gerais, e Itapira, São Paulo, e a bifurcação entre Paraibides e Araxaides. In: SBG, Congresso Brasileiro de Geologia, 25, São Paulo, Resumo das Comunicações, 1: 177-178.

Eckert, J.O. Jr., Newton, R.C. \& Kleppa, O. J. 1991. The $\Delta H$ of reaction and recalibration of garnet-pyroxene-plagioclase-quartz geobarometers in the CMAS system by solution calorimetry: American Mineralogist, 76: 148-160.

Elderfield, H. \& Greaves, M.J. 1981. Negative cerium anomalies in the rare earth element patterns of oceanic ferromanganese nodules. Earth Planet. Sci. Lett., 55: 163-170.

Elderfield, H. \& Greaves, M.J. 1982. The rare earth element elements in seawater. Nature, 296: 214-219.

Ellis, D.J. \& Green, D.H. 1985. Garnet-forming reactions in mafic granulites from Enderby Land, Antarctica - Implications for geothermometry and geobarometry. Journal of Petrology, 26: 633-662.

Ellis, D.J. \& Thompson, A.B. 1986. Subsolidus and partial melting reactions in the quartz-excess $\mathrm{CaO}+\mathrm{MgO}+\mathrm{Al}_{2} \mathrm{O}_{3}+\mathrm{SiO}_{2}+\mathrm{H}_{2} \mathrm{O}$ system under water-excess and water-deficient conditions to $10 \mathrm{~kb}$ : some implications for the origin of peraluminous melts from mafic rocks. Journal of Petrology, 27: 91-121.

England, P.C. \& Richardson, S.W. 1977. The influence of erosion upon the mineral facies of rocks from different metamorphic environments. Journal of the Geological Society of London, 134: 201-213.

England, P.C. \& Thompson, A.B. 1984a. Pressure-Temperature-Time Paths of Regional Metamorphism I. Heat Transfer during the Evolution of Regions of Thickened Continental Crust. Journal of Petrology, 25 (4): 894-928.

England, P.C. \& Thompson, A.B. 1984b. Pressure-Temperature-Time Paths of Regional Metamorphism II. Their inference and interpretation using mineral assemblages in metamorphic rocks. Journal of Petrology, 25 (4): 929-955.

Essene, E.J. 1989. The current status of thermobarometry in metamorphic rocks. In: Daly, J.S., Cliff, R.A. \& Yardley, B.W.D. (eds). Evolution of Metamorphic Belts, Geological Society Special Publication, 43: 1-44. 
Ferry, J.M. \& Spear, F.S. 1978. Experimental calibration of the partitioning of Fe and $\mathrm{Mg}$ between biotite and garnet. Contributions to Mineralogy and Petrology, 66: 113-117.

Figueiredo, M.C.H. \& Teixeira, W. 1996. The Mantiqueira metamorphic complex, eastern Minas Gerais State: preliminary geochronological and geochemical results. Anais da Academia Brasileira de Ciências, 68: 223-246.

Fischel, D.P., Pimentel, M.M., Fuck, R.A., Costa, A.G \& Rosière, C.A. 1998. Geology and Sm-Nd isotopic data for the Mantiqueira and Juiz de Fora complex (Ribeira Belt) in the Abre Campo-Manhuaçu region, Minas Gerais, Brazil. In: $14^{\text {th }}$ International Conference on Basement Tectonics, 1998, Ouro Preto, Brazil, Abstracts, 21-23.

Fodor, R.V., Bauer, G.R., Jacobs, R.S. \& Bornhorst, T.J. 1987. Kahoolawe Island, Hawaii: tholeiitic, alkalic and unusual hydrothermal (?) "enrichment" characteristics. Journal of Volcanology and Geothermal Research, 31: 171-176.

Frey, F.A. \& Roy, S.D. 1978. Integrated models of basalts petrogenesis: a study of quartz tholeiites to olivine melilitites from South Eastern Australia utilizing geochemical and experimental petrological data. Journal of Petrology, 19: 463513.

Frost, B.R. \& Chacko, T. 1989. The granulite uncertainty principle: limitations on thermobarometry in granulites. Journal of Geology, 97: 435-450.

Frost, B.R., Frost, C.D., Hulsebosch, T.P. \& Swapp, S.M. 2000. Origin of the Charnockites of the Louis Lake Batholith, Wind River Range, Wyoming. Journal of Petrology, 41(12): 1759-1776.

Frost, B.R. \& Frost, C.D. 2008. On charnockites. Gondwana Research, 13: 30-44.

Fuhrman, M.L. \& Lindsley, D.H. 1988. Ternary-feldspar modeling and thermometry. American Mineralogist, 73: 201-215.

Ganguly, J. 1979. Garnet and clinopyroxene solid solutions, and geothermometry based on Fe-Mg distribution coefficient. Geochem. Cosmochim. Acta, 43: 1021-1029.

Guiraud, M., Powell, R. \& Rebay, G. 2001. H2O in metamorphism and unexpected behavior in the preservation of metamorphic mineral assemblages. Journal of metamorphic Geology, 19: 445-454.

Glikson, J.A. 1979. Primitive archean element distribution patterns: chemical evidence and geotectonic significance. Earth Planet. Sci. Lett., 12: 309-320. 
Green, D. H \& Lambert, I. B. 1965. Experimental crystalization of anhydrous granite at high pressure and temperatures. Journal of Geophysical Research, 70: 52595268.

Green, D.H. \& Ringwood, A.E. 1967. An experimental investigation of the gabbro to eclogite transformation and its petrological applications. Geochimica et Cosmochimica Acta, 31: 767-833.

Green, D.H. \& Ringwood, A.E. 1972. A comparison of recent experimental data on the gabbro-garnet granulite-eclogite transition. Journal of Geology, 80: 277-288.

Green, T.H. 1978. Rare earth geochemistry of basalts from Norfolk Island and implications for mantle inhomogeneity in the rare earth elements. Geochemical Journal, 12: 165-172.

Hansen, B. 1981. The transition from pyroxene granulite facies to garnet clinopyroxene granulite facies: Experiments in the system $\mathrm{CaO}-\mathrm{MgO}-\mathrm{Al}_{2} \mathrm{O}_{3}-\mathrm{SiO}_{2}$. Contributions to Mineralogy and Petrology, 76: 234-242.

Haraly, N.L.E., Hasui, Y., Mioto, J.A., Hamza, V.M. \& Rodrigues, C.R. 1985. Ensaio sobre a estruturação crustal do Estado de Minas Gerais com base na informação geofísica. Boletim Especial da Sociedade Brasileira de Geologia, Belo Horizonte: 71-93.

Harley, S.L. 1989. The origins of granulite: a metamorphic perspective. Geological Magazine, 126 (3): 215-247.

Hasui, Y. 1982. The Mantiqueira Province: Archean structure and Proterozoic evolution. Revista Brasileira de Geociências (International Symposium of Archean and Early Proterozoic Geological Evolution and Metallogenesis, Salvador, Anais), 12(1-3): 167-171.

Hawthorne, F.C. \& Oberti, R. 2007. Classification of the Amphiboles. Reviews in Mineralogy \& Geochemistry, 67: 55-88.

Heilbron, M., 1985. O metamorfismo da área de Itutinga- Madre de Deus de Minas MG. In: SBG, $3^{\circ}$ Simpósio de Geologia de Minas Gerais, Anais, 219-233.

Heilbron, M. 1993. Evolução tectono-metamórfica da seção Bom Jardim de Minas-MG - Barra do Piraí-RJ, setor central da Faixa Ribeira. Tese de Doutoramento, IG/USP. 268p.

Heilbron, M., Valeriano, C.M., Valladares, C.S. \& Machado, N. 1995. A Orogênese Brasiliana no segmento central da Faixa Ribeira, Brasil. Revista Brasileira de Geociências, 25(4): 249-266. 
Heilbron, M., Machado, N. \& Duarte, B.P. 2001. Evolution of the Paleoproterozoic Transamazonian Orogen in SE Brazil: a view from the Neoproterozoic Ribeira Belt. In: Abastracts, GAC-MAC Joint Annual Meeting, St. Johns, Canada, 26: p.61.

Hofmann, A.W. \& White, W.M. 1982. Mantle plumes from ancient oceanic crust. Earth and Planetary Science Letters, 57: 421-436.

Holland, T.H. 1900. The charnockite series, a group of Archaean hypersthenic rocks in Peninsular India. Memoirs of the Geological Survey of India, 28: 119-249.

Holland, T.J.B. \& Richardson, S.W. 1979. Amphibole zonation in metabasites as a guide to the evolution of metamorphic conditions. Contributions to Mineralogy and Petrology, 70: 143-148.

Hollister, L.S., Burruss, R.C., Henry, D.L. \& Hendel, E.-M. 1979. Physical conditions during uplift of metamorphic terranes, as recorded by fluid inclusions. Bulletin of the Geological Society of America, 80: 2465-2494.

Holness, M.B. \& Sawyer, E.W. 2008. On the pseudomorphing of melt-filled pores during the crystallization of migmatites. Journal of Petrology, 49: 1343-1363.

Howie, R.A. 1954. The geochemistry of the charnockite series of Madras, India. Transactions of the Royal Society of Edinburgh, 62: 725-768.

Indares, A. \& Martignole, J. 1985. Biotite-garnet geothermometry in granulite-facies rocks: evaluation of equilibrium criteria. Canadian Mineralogist, 23: 187-193.

Indares, A. \& Rivers, T. 1995. Textures, metamorphic reactions and thermobarometry of eclogitized metagabbros: a Proterozoic example. European Journal of Mineralogy, 7: 43-56.

Indares, A. 1995. Metamorphic interpretation of high-pressure-temperature metapelites with preserved growth zoning in garnet, eastern Greenville Province, Canadian Shield. Journal of metamorphic Geology, 13: 475-486.

Indares, A. \& Dunning, G. 1997. Coronitc metagabbro and eclogite from the Greenville Province of western Quebec; interpretation of U-Pb geochronology and metamorphism. Canadian Journal of Earth Sciences, 34: 891-901.

Indares, A. \& Dunning, G. 2001. Partial melting of high P-T metapelites from the Tshenukutish terrane (Greenville Province): Petrology and U-Pb geochronology. Journal of Petrology, 42: 1547-1565.

Irvine, T.N. \& Baragar, W.R.A. 1971. A guide to the chemical classification of the common volcanic rocks. Canadian Journal of Earth Science, 8: 523-548. 
Ito, K. \& Kennedy, G. C. 1971. An experimental study of the basalt-garnet granuliteeclogite transition. In: The Structure and Physical properties of the Earth's Crust, Monograph no.14 (ed. Heacock, J. G.), pp. 303-314. American Geophysical Union, Washington DC.

Johannes, W. 1978. Melting of plagioclase in the system Ab-An- $\mathrm{H}_{2} \mathrm{O}$ and Qz-Ab-An$\mathrm{H}_{2} \mathrm{O}$ at $\mathrm{PH}_{2} \mathrm{O}=5 \mathrm{kbar}$, an equilibrium problem. Contributions to Mineralogy and Petrology, 66: 295-303.

Johannes, W. \& Holtz, F. 1996. Petrogenesis and Experimental Petrology of Granitic Rocks. Spring-Verlag, Heidelberg.

Koziol, A.M. \& Newton, R.C. 1988. Redetermination of the anorthite breakdown reaction improvement of the plagioclase-garnet- $\mathrm{Al}_{2} \mathrm{SiO}_{5}$-quartz geobarometer. American Mineralogist, 73: 216-223.

Koziol, A.M. 1989. Recalibration of the garnet-plagioclase- $\mathrm{Al}_{2} \mathrm{SiO}_{5}$-quartz (GASP) geobarometer and applications to natural parageneses. EOS, 70: p. 493.

Kröner, A., O’Brien, P.J., Nemchin, A.A. \& Pidgeon, R.T. 2000. Zircon ages for high pressure granulites from South Bohemia, Czech Republic, and their connection to Carboniferous high temperature processes. Contributions to Mineralogy and Petrology, 138: 127-142.

Leake, B.E., Woolley, A.R., Arps, C.E.S., Birch, W.D., Gilbert, M.C., Grice, J.D., Hawthorne, F.C., Kato, A., Kisch, H.J., Krivovichev, V.G., Linthout, K., Laird, J., Mandarino, J.A., Maresch, W.V., Nickel, E.H., Rock, N.M.S., Schumacher, J.C., Smith, D.C., Stephenson, N.C.N., Ungaretti, L., Whittaker, E.J.W. \& Youzhi, G. 1997. Nomenclature of amphiboles: report of the subcommittee on amphiboles of the international mineralogical association, commission on new minerals and mineral names. The Canadian Mineralogist, 35: 219-246.

Le Bas, M.J., Le Maitre, R.W., Streckeisen, AA. \& Zanettin, B. 1986. A chemical classification of volcanic rocks based on the total alkali-silica diagram. Journal of Petrology, 27: 745-750.

Le Breton, N. \& Thompson, A.B. 1988. Fluid-absent (dehydration) melting of biotite in metapelites in early stages of crustal anatexis. Contributions to Mineralogy and Petrology, 99: 226-237.

Le Maitre, R.W. (Ed.) 1989. A Classification of Igneous Rocks and Glossary of Terms. Recommendations of the IUGS Commission on the Systematics of Igneous Rocks. Blackwell Scientific Publications, Oxford. 
Liu, Y. \& Zhong, D. 1997. Petrology of high-pressure granulites from the eastern Himalayan syntaxis. Journal of metamorphic Geology, 15: 451-466.

Machado, N., Valladares, C., Heilbron, M. \& Valeriano, C. 1996. U-Pb geochronology of the central Ribeira belt (Brazil) and implications for the evolution of the Brazilian Orogeny. Precambrian Research, 69: 347-361.

Mc Donough, W.F. \& Sun, S-s. 1985. Isotopic and geochemical systematics in TertiaryRecent basalts from south eastern Australia and implications for the evolution of the sub-continental lithosphere. Geochimica et Cosmochimica Acta, 49: 20512067.

Meschede, M. 1986. A method of discriminating between different types of mid-ocean ridge basalts and continental toleiites with the $\mathrm{Nb}-\mathrm{Zr}-\mathrm{Y}$ diagram. Chem. Geol, 56: $207-218$.

Miyashiro, A. 1974. Classification, characteristics and origin of ophiolites. Journal of Geology, 83 (2): 249-81.

Mongkoltip, P. \& Ashworth, J.P. 1983. Quantitative estimation of an open-system symplectite-forming reaction: restricted diffusion of $\mathrm{Al}$ and $\mathrm{Si}$ in coronas around olivine. Journal of Petrology, 24: 635-661.

Mora, J.M.G. 2010. Metamorfismo das rochas ultramáficas de Olaria e Lima Duarte, Minas Gerais. Dissertação de Mestrado, IG-USP: 102 pp.

Mori, P.E., Reeves, S., Correia, C.T. \& Haukka, M. 1999. Development of fused glass disc XRF facility and comparison with pressed powder pellet technique at Instituto de Geociências, São Paulo University. Revista Brasileira de Geociências, 29 (3): 441-446.

Morimoto, N., Fabries, J., Ferguson, A.K., Ginzburg, I.V., Ross, M., Seifert, F.A., Zussman, J., Aoki, K. \& Gottardi, G. 1988. Nomenclature of pyroxenes. American Mineralogist, 73: 1123-1133.

Nair, R. \& Chacko, T. 2000. Fluid-absent melting of two high grade amphibolites: constraints on the conditions required for orthopyroxene formation. Geological Association of Canada - Mineralogical Association of Canada Annual Meeting, Abstracts with program, 24: 2121-2042.

Nair, R. \& Chacko, T. 2002. Fluid-absent melting of High-grade Semi-pelites: P-T Constraints on Orthopyroxene Formation and Implications for Granulite Genesis. Journal of Petrology, 43: 2121-2142. 
Newson, H.E., White, W.M., Jochum, K.P. \& Hofmann, A.W. 1986. Siderophile and chalcophile elements abundances in oceanic basalts, $\mathrm{Pb}$ isotope evolution and growth of the Earth's core. Earth and Planetary Science Letters, 80: 299-313.

Newton, R.C., \& Haselton, H.T. 1981. Thermodynamics of the Garnet-Plagioclase$\mathrm{Al}_{2} \mathrm{SiO}_{5}$-Quartz geobarometer. In: Newton, R.C., Navrostsky, A. \& Wood, B.J. (eds). Thermodynamics of minerals and melts. Springer, Berlim: p.129-145.

Newton, R.C. \& Perkins, D. 1982. Thermodynamic calibration of geobarometers based on the assemblages garnet-plagioclase-orthopyroxene (clinopyroxene)-quartz. American Mineralogist, 67: 203-222.

Newton, R.C. 1983. Geobarometry of high-grade metamorphic rocks. American Journal of Science, 283-A: 1-28.

Newton, R.C. 1992a. An overview of charnockite. Precambrian Research, 55: 399-405.

Nicollet, C. \& Goncalves, P. Two contrasted P-T-time paths of coronitic metanorites of the French Massif Central: are reaction textures reliable guides to metamorphic histories? Journal of metamorphic Geology, 23: 97-105.

Noce, C.M.; Pedrosa-Soares, A. C.; Silva, L.C.; Armstrong, R. \& Piuzana, D. 2007. Evolution of polycyclic basement complexes in the Araçuaí Orogen, based on U$\mathrm{Pb}$ SHRIMP data: Implications for Brazil-Africa links in Paleoproterozoic time. Precambrian Research, 159: 60-78.

Nummer, A.R. 1990. Estratigrafia e estruturas do Grupo Andrelândia na região de Santa Rita do Ibitipoca - Lima Duarte (sul de MG). In: SBG, Congresso Brasileiro de Geologia, 36, Natal, Anais, 6: 2786-2787.

Nummer, A.R. 1992. Modelamento de uma megaestrutura do Grupo Andrelândia na região de Santa Rita do Ibitipoca - Lima Duarte (sul de MG). In: SBG, Congresso Brasileiro de Geologia, 37, São Paulo, Boletim de Resumos Expandidos, 2: 341343.

O’Brien, P.J. \& Rötzler, J. 2003. High-pressure granulites: formation, recovery of peak conditions and implications for tectonics. Journal of metamorphic Geology, 21: 320.

O’Brien, P.J. 2008. Challenges in high-pressure granulite metamorphism in the era of pseudosections: reaction textures, compositional zoning and tectonic interpretation with examples from the Bohemian Massif. Journal of metamorphic Geology, 26: 235-251. 
Paciullo, F.V.P., Trouw, R.A.J. \& Ribeiro, A. 2002. Geologia da Folha Andrelândia. In: Pedrosa-Soares, A.C., Noce, C.M., Trouw, R.A.J., Heilbron, M. (orgs.) Geologia e Recursos Minerais do Sudeste Mineiro, Projeto Sul de Minas, 1: 84120.

Paciullo, F.V.P., Trouw, R.A.J., Ribeiro, A., Simões, L.A., Lopes, M. 2003a. Mapa Geológico - Folha Andrelândia. Escala 1:100 000. Pedrosa-Soares, A.C., Noce, C.M., Trouw, R.A.J., Heilbron, M. (coord.) Geologia e Recursos Minerais do Sudeste Mineiro, 1, Belo Horizonte, COMIG, 1 CD-ROM.

Paterson, S.R., Vernon, R.H. \& Tobisch, O.T. 1989: A review of criteria for the identification of magmatic and tectonic foliations in granitoids. Journal of Strucutral Geology, 11: 349-363.

Patiño Douce, A.E. \& Beard, J.S. 1995. Dehydration-melting of Biotite Gneiss and Quartz Amphibolite from 3 to 15 Kbar. Journal of Petrology, 36: 707-738.

Pattison, D.R.M. 2003. Petrogenetic significance of orthopyroxene-free garnet+clinopyroxene+plagioclase \pm quartz-bearing metabasites with respect to the amphibolite and granulite facies. Journal of metamorphic Geology, 21: 21-34.

Pattison, D.R.M., Chacko, T., Farquhar, J. \& McFarlane, C.R.M. 2003. Temperatures of granulite-facies metamorphism; constraints from experimental phase equilibria and thermobarometry corrected for retrograde exchange. Journal of Petrology, 44: 867-900.

Pearce, J.A. \& Cann, J.R. 1971. Ophiolites origin investigated by discriminant analysis using Ti, Zr and Y. Earth Planet. Sci. Lett., 12: 339-349.

Pearce, J.A. \& Cann, J.R. 1973. Tectonic setting of basic volcanic rocks determined using trace elements analysis. Earth Planet. Sci. Lett., 19: 290-300.

Pearce, J.A., Harris, N.B.W \& Tindle, A.G. 1984. Trace element discrimination diagrams for the tectonic interpretation of granitic rocks. Journal of Petrology, 25 : 956-983.

Pedrosa-Soares, A.C. \& Noce, C.M., 1998. Where is the suture zone of the Neoproterozoic Araçuaí-West Congo Orogen. In: $14^{\text {th }}$ International Conference on Basement Tectonics, 1998, Ouro Preto, Brazil, Abstracts, 35-37.

Perkins, D. \& Newton, R.C. 1981. Charnockite geobarometers based on coexisting garnet - pyroxene - plagioclase - quartz. Nature, 292: 144-146. 
Petrelli, M., Poli, G., Perugini, D. \& Pecerillo, A. 2005. PetroGraph: a new software to visualize, model, and present geochemical data in igneous petrology. Geochemistry, Geophysics, Geosystems, 6: 1-15.

Pichamuthu, C.S. 1960. Charnockite in the making. Nature, 188: 135-136.

Pinto, C.P. (org)., Brandalise, L.A., Souza, H.A., Vasconcellos, R.M., Barreto, E.L., Dias Gomes, R.A.A., Carvalhaes, J.B., Padilha, A.V., Heineck, C.A. \& Grossi Sad, J.H. 1991. Lima Duarte, Folha SF-23-X-C-VI, Estado de Minas Gerais, Escala 1:100 000. MIE-DNPM, Programa Levantamentos Geológicos Básicos do Brasil, CPRM, Belo Horizonte, Mapas e texto explicativo, 224p.

Piwinskii, A.J. 1968. Experimental studies of igneous rocks series central Sierra Nevada Batholith, California. Journal of Geology, 76: 548-570.

Powell, R. \& Holland, T.J.B. 1988. An internally consistent thermodynamic dataset with uncertainties and correlations. III. Applications methods, worked example and a computer program. Journal of metamorphic Geology, 6 (2): 173-204.

Powell, R. \& Holland, T.J.B. 2008. On thermobarometry. Journal of metamorphic Geology, 26: 155-179.

Proyer, A. 2003. The preservation of high-pressure rocks during exhumation: metagranites and metapelites. Lithos, 70: 183-194.

Quéméneur, J. J.G., Ribeiro, A., Paciullo, F.V.P., Heilbron, M., Trouw, R.A.J., Valença, J.G. \& Noce, C.M. 2002. Mapa Geológico-Folha Lavras, escala 1:100.000. COMIG,UFRJ,UFMG, Projeto Sul de Minas-Etapa I.

Ravich, M.G. 1972. The charnockite problem. In. Adie, R.J., ed., Antarctic Geology and Geophysics, Scandinavian University Books, Oslo, 523-526.

Reche, J. \& Martinez, F.J. 1996. GPT: an Excel spreadsheet for thermobarometric calculations in metapelitic rocks. Computers \& Geosciences, 22(7): 775-784.

Ribeiro, A. \& Heilbron, M. 1982. Estratigrafia e metamorfismo dos Grupos Carrancas e Andrelândia, sul de Minas Gerais. In : SBG, Congresso Brasileiro de Geologia, 32, Salvador, Anais, 1: 177-186.

Ribeiro, A., Trouw, R.A.J., Andreis, R.R., Paciullo, F.V.P. \& Valença, J. 1995. Evolução das bacias Proterozóicas e o termo-tectonismo Brasiliano na margem sul do cráton do São Francisco. Revista Brasileira de Geociências, 25: 235-248.

Ribeiro, A., Paciullo, F.V.P., Noce, C.M., Valeriano, C.M., Valença, J.G., Ávila, C. A., Trouw, R.A.J. \& Silva, M.A., 2002. Mapa Geológico-Folha São João Del Rei, escala 1:100.000. COMIG,UFRJ,UFMG, Projeto Sul de Minas-Etapa I. 
Richard, L. 1995. Minpet for Windows. Version 2.02 (software).

Rieder, M., Cavazzini, G., D’Yakonov, Y.S., Frank-Kamenetskii, V.A., Gottardi, G., Guggenheim, S., Koval, P.V., Müller, G., Neiva, A.M.R., Radoslovich, E.W., Robert, J.L., Sassi, F.P., Takeda, H., Weiss, Z. \& Wones, D.R. 1998. Nomenclature of the micas. The Canadian Mineralogist, 36: 905-912.

Rocha, B.C., 2007. Assinaturas metamórficas contrastantes: granulitos máficos de alta pressão e metatexitos pelíticos da Nappe Lima Duarte, sul do Cráton do São Francisco, MG. Monografia de Trabalho de Formatura, IGc-USP, 74p.

Rocha, B.C., Campos Neto, M.C. \& Bendoraitis, D.P. 2007. Assinaturas metamórficas contrastantes: granulitos máficos e paragnaisses da Nappe Lima Duarte, borda sul do cráton do São Francisco, MG. In: XIV Simpósio de Geologia de Minas Gerais e X Simpósio de Geologia do Sudeste, 2007, Diamantina. Boletim de Resumos, Diamantina: Sociedade Brasileira de Geologia - Núcleos Minas Gerais, Rio de Janeiro-Espírito Santo e São Paulo, 2007, p. 23-23.

Rocha, B.C \& Campos Neto, M.C. 2008. Condições metamórficas da Nappe Lima Duarte, borda sul do cráton do São Francisco. In: $44^{\circ}$ Congresso Brasileiro de Geologia, 2008, Curitiba. XLIV CBG Anais. Curitiba-Paraná: Sociedade Brasileira de Geologia - Núcleo Paraná, 2008, v. único, p. 8-8.

Rollinson, H.R. \& Windley, B.F. 1980. Selective elemental depletion during metamorphism of Archaean granulites, Scourie, NW Scotland. Contributions to Mineralogy and Petrology, 72: 257-263.

Rollinson, H.R. 1993. Using geochemical data. Essex, England: Longman Scientific \& Technical, New York: John Willey \& Sons, Inc., 352p.

Rosier, G.F. 1965. Pesquisa geológica na parte oriental do RJ e a parte vizinha de MG. Boletim 222, DGM, DNPM, 41p.

Rudnick, R.L., Mc Lennan, S.M. \& Taylor, S.R. 1985. Large ion lithophile elements in rocks from high-pressure granulite facies terrains. Geochimica et Cosmochimica Acta, 49: 1645-1655.

Rubie, D.C. 1983. Reaction-enhanced ductility: the role of solid-solid invariant reactions in deformation of the crust and mantle. Tectonophysics, 96: 331-352.

Rudnick, R.L. 1992. Restites, Eu anomalies and the lower continental crust. Geochimica et Cosmochimica Acta, 56: 963-970. 
Rushmer, T. 1991. Partial melting of two amphibolites: contrasting experimental results under fluid-absent conditions. Contributions to Mineralogy and Petrology, 107: 41-59.

Rushmer, T. 1993. Experimental high pressure granulites: some applications to natural mafic xenolith suites and Archean granulite terranes. Geology, 21: 411-414.

Schumacher, J.C., Hollocher, K.T., Robinson, P. \& Tracy, R.J. 1990. Progressive reactions and melting in the Acadian metamorphic high of central Massachusetts and southwestern New Hampshire, USA. In: Ashworth, J.R. \& Brown, M. (eds.): High-temperature Metamorphism and Crustal Anatexis. London: Unwin Hyman, p.198-234.

Selverstone, J., Spear, F.S., Franz, G. \& Morteani, G. 1984. High-pressure metamorphism in the SW Tauern Window, Austria: P-T paths from hornblendekyanite-staurolite schists. Journal of Petrology, 25: 501-531.

Sem, C. \& Dunn, T. 1994. Dehydration melting of a basaltic composition amphibolite at 1.5 and 2.0 GPa: implications for the origin of adakites. . Contributions to Mineralogy and Petrology, 117: 394-409.

Sengupta, P., Dasgupta, S., Bhattacharya, P. K. \& Hariya, Y. 1989. Mixing behavior in quaternary garnet solid solution and an extended Ellis and Green garnetclinopyroxene geothermometer. Contributions to Mineralogy and Petrology, 103: 223-227.

Shaw, D.M. 1968. A review of K-Rb fractionation trends by covariance analysis. Geochem. Cosmochim. Acta, 32: 573-601.

Sighinolfi, G.P., Figueiredo, M.C.H., Fyfe, W.S., Kronberg, B.I. \& Tanner Oliveira, M.A.F. 1981.Geochemistry and petrology of the Jequié granulitic complex (Brazil): an Archean basement complex. Contributions to Mineralogy and Petrology, 78: 263-271.

Silva, L.C., Armstrong, R., Noce, C.M., Carneiro, M.A., Pimentel, M.M., PedrosaSoares, A.C., Leite, C.A., Vieira, V.S., Silva, M.A, Paes, V.J.C. \& Cardoso-Filho, J.M. 2002.Reavaliação da evolução geológica em terrenos pré-cambrianos brasileiros com base em novos dados U-Pb SHRIMP. Parte II. Orógeno Araçuaí, Cinturão Mineiro e Cráton São Francisco Meridional. Revista Brasileira de Geociências, 32: 513-528.

Silva, L.C., Mc Naughton, N.J., Armstrong, R., Hartmann, L.A. \& Fletcher, I.R. 2005a. The Neoproterozoic Mantiqueira Province and its African connections: a zircon 
based U-Pb geochronology subdivision for the Brasiliano/Pan-African systems of orogens. Precambrian Research, 136: 203-240.

Soto, J.I. \& Soto, V.M. 1995. PTMAFIC: Software package for thermometry, barometry and activity calculations in mafic rocks using an IBM-compatible computer. Computers \& Geosciences, 21: 619-652.

Spear, F.S., Selverstone, J., Hickmott, D., Crowley, P. \& Hodges, K.V. 1984. P-T paths from garnet zoning: A new technique for deciphering tectonic processes in crystalline terranes. Geology, 12: 87-90.

Spear, F.S. 1981. An experimental study of hornblende stability and compositional variability in amphibolite. American Journal of Science, 281: 697-734.

Spear, F.S. 1995. Metamorphic Phase Equilibria and Pressure-Temperature-Time Paths. Mineralogical Society of America, Washington, D.C. Second edition, Book Crafters, 799p.

Sun, S-s. \& Mc Donough. 1989. Chemical and isotopic systematics of oceanic basalts: implications for mantle compositions and processes. In: A.D. Saunders and M.J. Norry (editors). Magmatism in the ocean basins. Geological Society. London. 313-345.

Taylor, S.R. \& McLennan, S.M. 1985. The Continental Crust: Its Composition and Evolution. Blackwell.

Thompson, A.B. \& England, P.C. 1984. Pressure-Temperature-Time Paths of Regional Metamorphism II. Their Inference and Interpretation using Mineral Assemblages in Metamorphic Rocks. Journal of Petrology, 25 (4): 929-955.

Tomkins, H.S., Powell, R. \& Ellis, D.J. 2007. The pressure dependence of the zirconium-in-rutile thermometer. Journal of metamorphic Geology, 25: 703-713.

Trouw, R.A.J., Paciullo, F.V.P., Chrispim, S.J. \& Dayan, H. 1982. Análise da deformação numa area a SE de Lavras, Minas Gerais. In: SBG, Congresso Brasileiro de Geologia, 32, Salvador, Anais, 1: 187-198.

Trouw, R.A.J., Ribeiro, A. \& Paciullo, F.V.P. 1983. Geologia estrutural dos Grupos São João del Rei, Carrancas e Andrelândia, Sul de Minas Gerais. Anais da Academia Brasileira de Ciências, 55 (1): 71-85.

Trouw, R.A.J., Ribeiro, A. \& Paciullo, F.V.P. 1986. Contribuição à geologia da Folha Barbacena - 1:250.000. In: SBG, Congresso Brasileiro de Geologia, 34, Goiânia, Anais: 974-986. 
Trouw, R.A.J. 1992. Evolução tectônica ao sul do cráton do São Francisco, baseada em análise metamórfica. In: SBG, Congresso Brasileiro de Geologia, 37, São Paulo, Boletim de Resumos Expandidos, 1, p.327.

Trouw, R.A.J., Heilbron, M., Ribeiro, A., Paciullo, F., Valeriano, C.M., Almeida, J.C.H., Tupinambá, M. \& Andreis, R.R. 2000. The central segment of Ribeira Belt. Tectonic Evolution of South America, Rio de Janeiro, 2000: 287-310.

Trouw, R.A.J., Paciullo, Ribeiro, F.V.P., Bittar, S. \& Almeida, J.C.H. 2002. Mapa Geológico Folha Caxambu, escala 1:100.000. COMIG,UFRJ,UFMG, Projeto Sul de Minas-Etapa I.

Trouw, R.A.J., Trouw, C.C., Peternel, R. \& Tohver, E. 2008. Novas idades SHRIMP de zircões da zona de interferência entre as faixas Brasília e Ribeira. In: SBG, Congresso Brasileiro de Geologia, 44, Curitiba, Anais, p.29.

Vernon, R.H. 1982. Isobaric cooling of two regional metamorphic complexes related to igneous intrusions in southeastern Australia. Geology, 10: 76-81.

Vernon, R.H. 1996. Problems with inferring P-T-t paths in low-P granulite facies rocks. Journal of metamorphic Geology, 14: 143-153.

Vernon, R.H. 2000a. Review of microstructural evidence of magmatic and solid-state flow. Electronic Geosciences, 5: 2.

Vernon, R.H. 2004. A Practical Guide to Rock Microstructure. Cambridge: Cambridge University Press.

Vernon, R,H., White, R.W. \& Clarke, G.L. 2008. False metamorphic events inferred from misinterpretation of microstructural evidence and P-T data. Journal of metamorphic Geology, 26: 437-449.

Vernon, R.H. \& Clarke, G.L. 2008. Principles of Metamorphic Petrology. Cambridge University Press, New York, 446p.

Vielzeuf, D. \& Holloway, J.R. 1988. Experimental determination of the fluid-absent melting relations in the pelitic system. Contributions to Mineralogy and Petrology, 98: 257-276.

Vielzeuf, D. \& Pin, C. 1989. Geodynamic implications of granulite rocks in the Hercynian Belt. Geological Society Special Publications, 43: 343-348.

Vielzeuf, D. \& Montel, J.M. 1994. Partial melting of metagreywackes. Fluid-absent experiments and phase relationships. Contributions to Mineralogy and Petrology, 117: $375-393$. 
Vilela, L.G.G. 2000. Petrografia, geotermobarometria e evolução metamórfica de granulitos básicos de alta pressão e rochas transicionais para fácies eclogito na região de Lima Duarte, MG. Dissertação de Mestrado, IG-USP: 180 pp.

Waters, D.J. 2001. The significance of prograde and retrograde quartz-bearing intergrowth microstructures in partially melted granulite-facies rocks. Lithos, 56: 97-110.

Watson, E.B., Wark, D.A. \& Thomas, J.B. 2006. Crystallization thermometers for zircon and rutile. Contributions to Mineralogy and Petrology, 151: 413-433.

Werding, G. \& Schreyer, W. 1996. Experimental studies on borosilicates and selected borates. Reviews in Mineralogy and Geochemistry, 33: 117-163.

Whitney, P.R. \& McLelland, J.M. 1973. Origin of Coronas in Metagabbros of the Adirondacks Mts., N.Y. Contributions to Mineralogy and Petrology, 39: 81-98.

Winther, K.T. \& Newton, R.C. 1991. Experimental melting of hydrous low-K tholeiite: evidence on the origin of Archaean cratons. Bulletin of the Geological Society of Denmark, 39: 213-228.

Wolf, M.B. \& Wyllie, P.J. 1994. Dehydration-melting of amphibole at 10kbar: the effects of temperature and time. Contributions to Mineralogy and Petrology, 115: 369-383.

Wyllie, P.J. \& Wolf, M.B. 1993. Amphibolite dehydration-melting: sorting out the solidus. In: Magmatic Processes and Plate Tectonics. Special Publication, 76, (Prichard, H.M., Alabaster, T., Harris, N.B.W. \& Neary, C.R., eds), 405-416. Geological Society, London.

Zhao, G.C., Cawood, P.A., Wilde, S.A. \& Lu, L.Z. 2001. High-pressure granulites (retrograded eclogites) from the Hengsham Complex, North China Craton: Petrology and tectonic implications. Journal of Petrology, 42: 1141-1170.

Zingg, A. 1990. The Ivrea crustal cross-section (northern Italy and southern Switzerland). Exposed cross-sections of the continental crust; proceedings. NATO Advanced Study Institute on Exposed Cross-Sections of the Continental Crust, 317: 1-19. 
ANEXOS 
ANEXO I

MAPA GEOLÓGICO 


\section{MAPA GEOLÓGICO DA NAPPE LIMA DUARTE}

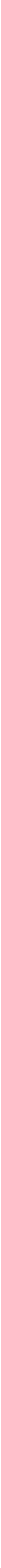


ANEXO II

\section{TABELA DE PONTOS}




\section{RELAÇÃO DAS AMOSTRAS ANALISADAS}

\begin{tabular}{|c|c|c|c|c|c|}
\hline \multicolumn{6}{|c|}{ Relação de amostras - Paragnaisses } \\
\hline & Petrografia & Microssonda & MEV & FRX & \multirow{3}{*}{ ICP-MS } \\
\hline OL-II-112B & $\mathrm{x}$ & $\mathrm{x}$ & \multirow[t]{2}{*}{$x$} & & \\
\hline OL-III-39A & $x$ & $x$ & & & \\
\hline \multicolumn{6}{|c|}{ Relação de amostras - Rochas metabásicas } \\
\hline & Petrografia & Microssonda & MEV & FRX & ICP-MS \\
\hline NLD-7A & $\mathrm{x}$ & & & $\mathrm{x}$ & \\
\hline NLD-7B & $\mathrm{x}$ & & & $\mathrm{x}$ & $\mathrm{x}$ \\
\hline NLD-7D & $\mathrm{x}$ & $\mathrm{x}$ & & & \\
\hline NLD-7E & $\mathrm{x}$ & & & $\mathrm{x}$ & $\mathrm{x}$ \\
\hline NLD-8A & $\mathrm{x}$ & & & $\mathrm{x}$ & $\mathrm{x}$ \\
\hline NLD-9A & $\mathrm{x}$ & & & $\mathrm{x}$ & $\mathrm{x}$ \\
\hline NLD-20A & $\mathrm{x}$ & $\mathrm{x}$ & & $\mathrm{x}$ & $\mathrm{x}$ \\
\hline NLD-22A & $\mathrm{x}$ & & & $\mathrm{x}$ & $\mathrm{x}$ \\
\hline NLD-42A & $\mathrm{x}$ & & & $\mathrm{x}$ & \\
\hline NLD-42C & $\mathrm{x}$ & $\mathrm{x}$ & $\mathrm{x}$ & $\mathrm{x}$ & $\mathrm{x}$ \\
\hline NLD-42D & $\mathrm{x}$ & $\mathrm{x}$ & $\mathrm{x}$ & & \\
\hline NLD-42E & $\mathrm{x}$ & & & $\mathrm{x}$ & \\
\hline \multicolumn{6}{|c|}{ Relação de amostras - Rochas charnockíticas } \\
\hline & Petrografia & Microssonda & MEV & FRX & ICP-MS \\
\hline NLD-41A & $\mathrm{x}$ & & & $\mathrm{x}$ & \\
\hline NLD-41F & $x$ & & & $x$ & $x$ \\
\hline NLD-41G & $x$ & & & $x$ & $x$ \\
\hline NLD-44A & $x$ & & & $x$ & \\
\hline NLD-45A & $x$ & & & $x$ & $x$ \\
\hline NLD-45B & $x$ & $\mathrm{x}$ & $\mathrm{x}$ & & \\
\hline NLD-45D & $x$ & $\mathrm{x}$ & $x$ & $x$ & $x$ \\
\hline
\end{tabular}




\section{ANEXO III}

\section{TABELAS DE ANÁLISES QUÍMICAS}




\section{QUÍMICA MINERAL DOS PARAGNAISSES}

Amostras OL-II-112B e OL-III-39A

(Granada, feldspato, biotita, rutilo) 


\section{Nappe Lima Duarte (Amostra OL-III-39A)}

GRANADA

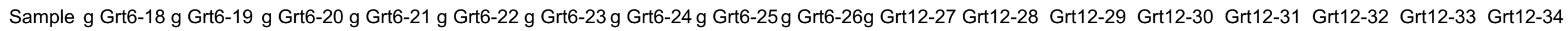

\begin{tabular}{|c|c|c|c|c|c|c|c|c|c|c|c|c|c|c|c|c|c|}
\hline $\mathrm{SiO} 2$ & 37.59 & 37.89 & 37.68 & 37.84 & 38.48 & 37.66 & 38.33 & 38.16 & 37.93 & 37.26 & 37.8 & 38.05 & 37.9 & 37.91 & 37.56 & 37.91 & 37.66 \\
\hline $\mathrm{TiO} 2$ & 0 & 0.06 & 0 & 0.02 & 0.05 & 0 & 0.06 & 0.05 & 0.04 & 0.07 & 0.05 & 0 & 0.05 & 0.04 & 0.14 & 0 & 0.05 \\
\hline $\mathrm{Al} 2 \mathrm{O} 3$ & 21.91 & 22.06 & 22.04 & 22.23 & 22.37 & 22.28 & 22.23 & 22.31 & 22.22 & 22.14 & 22.03 & 22.22 & 22.05 & 22.26 & 22.07 & 22.14 & 21.92 \\
\hline Cr2O3 & 0 & 0 & 0 & 0 & 0 & 0 & 0 & 0 & 0 & 0 & 0 & 0 & 0 & 0 & 0 & 0 & 0 \\
\hline $\mathrm{Fe} 2 \mathrm{O} 3$ & 0 & 0 & 0 & 0 & 0 & 0 & 0 & 0 & 0 & 0 & 0 & 0 & 0 & 0 & 0 & 0 & 0 \\
\hline $\mathrm{FeO}$ & 30.66 & 32.4 & 31.03 & 31.4 & 30.99 & 32.32 & 31.4 & 31.06 & 31.11 & 31.86 & 31.48 & 31 & 31.42 & 31.32 & 30.92 & 31.29 & 31.14 \\
\hline $\mathrm{MnO}$ & 4.34 & 4.16 & 4.27 & 4.4 & 4.25 & 4.28 & 4.17 & 4.25 & 4.1 & 3.78 & 4.33 & 4.49 & 4.61 & 4.57 & 4.6 & 2.16 & 2.16 \\
\hline $\mathrm{MgO}$ & 2.3 & 2.29 & 2.26 & 2.32 & 2.3 & 2.23 & 2.24 & 2.2 & 2.21 & 2.63 & 2.24 & 2.09 & 2.17 & 2.06 & 2.15 & 4.74 & 4.61 \\
\hline $\mathrm{CaO}$ & 1.33 & 1.36 & 1.36 & 1.37 & 1.46 & 1.41 & 1.46 & 1.36 & 1.41 & 1.25 & 1.27 & 1.31 & 1.28 & 1.24 & 1.29 & 1.28 & 1.34 \\
\hline $\mathrm{Na} 2 \mathrm{O}$ & 0 & 0 & 0 & 0 & 0 & 0 & 0 & 0 & 0 & 0 & 0 & 0 & 0 & 0 & 0 & 0 & 0 \\
\hline $\mathrm{K} 2 \mathrm{O}$ & 0 & 0 & 0 & 0 & 0 & 0 & 0 & 0 & 0 & 0 & 0 & 0 & 0 & 0 & 0 & 0 & 0 \\
\hline Totals & 98.13 & 100.22 & 98.65 & 99.59 & 99.89 & 100.18 & 99.88 & 99.38 & 99.01 & 98.99 & 99.2 & 99.15 & 99.47 & 99.4 & 98.73 & 99.53 & 98.88 \\
\hline Oxygens & 12 & 12 & 12 & 12 & 12 & 12 & 12 & 12 & 12 & 12 & 12 & 12 & 12 & 12 & 12 & 12 & 12 \\
\hline $\mathrm{Si}$ & 3.045 & 3.024 & 3.04 & 3.028 & 3.056 & 3.009 & 3.051 & 3.05 & 3.045 & 3.003 & 3.038 & 3.051 & 3.039 & 3.039 & 3.031 & 3.004 & 3.006 \\
\hline $\mathrm{Ti}$ & 0 & 0.003 & 0 & 0.001 & 0.003 & 0 & 0.003 & 0.003 & 0.002 & 0.004 & 0.003 & 0 & 0.003 & 0.002 & 0.008 & 0 & 0.003 \\
\hline $\mathrm{Al}$ & 2.093 & 2.076 & 2.096 & 2.097 & 2.094 & 2.098 & 2.086 & 2.102 & 2.103 & 2.104 & 2.087 & 2.101 & 2.084 & 2.103 & 2.1 & 2.069 & 2.063 \\
\hline $\mathrm{Cr}$ & 0 & 0 & 0 & 0 & 0 & 0 & 0 & 0 & 0 & 0 & 0 & 0 & 0 & 0 & 0 & 0 & 0 \\
\hline Fe3 & 0 & 0 & 0 & 0 & 0 & 0 & 0 & 0 & 0 & 0 & 0 & 0 & 0 & 0 & 0 & 0 & 0 \\
\hline $\mathrm{Fe} 2$ & 2.078 & 2.162 & 2.093 & 2.102 & 2.058 & 2.16 & 2.091 & 2.076 & 2.089 & 2.147 & 2.116 & 2.079 & 2.107 & 2.1 & 2.087 & 2.074 & 2.079 \\
\hline $\mathrm{Mn}$ & 0.298 & 0.281 & 0.292 & 0.298 & 0.286 & 0.29 & 0.281 & 0.288 & 0.279 & 0.258 & 0.295 & 0.305 & 0.313 & 0.311 & 0.315 & 0.145 & 0.146 \\
\hline $\mathrm{Mg}$ & 0.278 & 0.272 & 0.272 & 0.277 & 0.273 & 0.265 & 0.266 & 0.262 & 0.264 & 0.316 & 0.268 & 0.25 & 0.259 & 0.246 & 0.258 & 0.56 & 0.548 \\
\hline $\mathrm{Ca}$ & 0.116 & 0.116 & 0.118 & 0.118 & 0.125 & 0.121 & 0.124 & 0.116 & 0.121 & 0.108 & 0.11 & 0.112 & 0.11 & 0.107 & 0.112 & 0.109 & 0.114 \\
\hline $\mathrm{Na}$ & 0 & 0 & 0 & 0 & 0 & 0 & 0 & 0 & 0 & 0 & 0 & 0 & 0 & 0 & 0 & 0 & 0 \\
\hline $\mathrm{K}$ & 0 & 0 & 0 & 0 & 0 & 0 & 0 & 0 & 0 & 0 & 0 & 0 & 0 & 0 & 0 & 0 & 0 \\
\hline Sum & 7.908 & 7.935 & 7.912 & 7.922 & 7.894 & 7.942 & 7.902 & 7.896 & 7.90 & 7.94 & 7.92 & 7.90 & 7.92 & 7.91 & 7.91 & 7.96 & 7.96 \\
\hline Alm & 75.02 & 76.37 & 75.42 & 75.21 & 75.05 & 76.16 & 75.71 & 75.71 & 75.88 & 75.89 & 75.87 & 75.71 & 75.55 & 75.98 & 75.29 & 71.81 & 72.01 \\
\hline Prp & 10.04 & 9.61 & 9.80 & 9.91 & 9.96 & 9.34 & 9.63 & 9.56 & 9.59 & 11.17 & 9.61 & 9.10 & 9.29 & 8.90 & 9.31 & 19.39 & 18.98 \\
\hline Grs & 4.19 & 4.10 & 4.25 & 4.22 & 4.56 & 4.27 & 4.49 & 4.23 & 4.40 & 3.82 & 3.94 & 4.08 & 3.94 & 3.87 & 4.04 & 3.77 & 3.95 \\
\hline \multirow[t]{2}{*}{ Sps } & 10.76 & 9.93 & 10.52 & 10.66 & 10.43 & 10.23 & 10.17 & 10.50 & 10.13 & 9.12 & 10.58 & 11.11 & 11.22 & 11.25 & 11.36 & 5.02 & 5.06 \\
\hline & 100 & 100 & 100 & 100 & 100 & 100 & 100 & 100 & 100 & 100 & 100 & 100 & 100 & 100 & 100 & 100 & 100 \\
\hline
\end{tabular}




\section{Nappe Lima Duarte (Amostra OL-III-39A)}

GRANADA

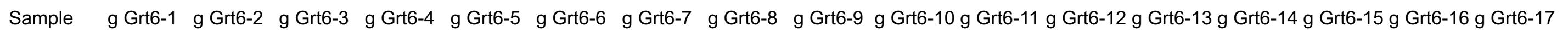

\begin{tabular}{|c|c|c|c|c|c|c|c|c|c|c|c|c|c|c|c|c|c|}
\hline $\mathrm{SiO} 2$ & 37.95 & 37.76 & 37.9 & 37.95 & 38.06 & 37.99 & 37.73 & 37.4 & 37.34 & 37.6 & 37.79 & 37.95 & 38.02 & 37.22 & 37.51 & 37.87 & 37.26 \\
\hline TiO2 & 0.01 & 0.07 & 0 & 0.03 & 0.01 & 0 & 0 & 0 & 0 & 0.06 & 0 & 0.03 & 0 & 0 & 0 & 0 & 0 \\
\hline $\mathrm{Al} 2 \mathrm{O} 3$ & 22.15 & 22.16 & 22.25 & 22.07 & 21.98 & 22.22 & 22.23 & 22.06 & 22.05 & 22.09 & 22 & 22.08 & 21.97 & 21.88 & 22.06 & 21.87 & 21.68 \\
\hline Cr2O3 & 0 & 0 & 0 & 0 & 0 & 0 & 0 & 0 & 0 & 0 & 0 & 0 & 0 & 0 & 0 & 0 & 0 \\
\hline $\mathrm{Fe} 2 \mathrm{O} 3$ & 0 & 0 & 0 & 0 & 0 & 0 & 0 & 0 & 0 & 0 & 0 & 0 & 0 & 0 & 0 & 0 & 0 \\
\hline $\mathrm{FeO}$ & 31.84 & 31.41 & 31.72 & 31.98 & 32.23 & 31.41 & 31.56 & 31.32 & 31.29 & 31.89 & 31.84 & 31.73 & 31.62 & 30.8 & 31.49 & 31.72 & 31.1 \\
\hline $\mathrm{MnO}$ & 2.62 & 2.31 & 2.23 & 2.33 & 2.33 & 2.34 & 2.34 & 2.38 & 2.28 & 2.35 & 2.31 & 2.38 & 2.22 & 2.21 & 4.42 & 4.37 & 4.09 \\
\hline $\mathrm{MgO}$ & 3.99 & 4.28 & 4.28 & 4.34 & 4.43 & 4.36 & 4.22 & 4.38 & 4.28 & 4.05 & 4.14 & 4.09 & 4.16 & 4.26 & 2.29 & 2.29 & 2.38 \\
\hline $\mathrm{CaO}$ & 1.28 & 1.22 & 1.26 & 1.29 & 1.22 & 1.28 & 1.34 & 1.54 & 1.7 & 1.69 & 1.72 & 1.69 & 1.74 & 1.71 & 1.47 & 1.43 & 1.54 \\
\hline $\mathrm{Na} 2 \mathrm{O}$ & 0 & 0 & 0 & 0 & 0 & 0 & 0 & 0 & 0 & 0 & 0 & 0 & 0 & 0 & 0 & 0 & 0 \\
\hline $\mathrm{K} 2 \mathrm{O}$ & 0 & 0 & 0 & 0 & 0 & 0 & 0 & 0 & 0 & 0 & 0 & 0 & 0 & 0 & 0 & 0 & 0 \\
\hline Totals & 99.83 & 99.2 & 99.65 & 99.98 & 100.27 & 99.59 & 99.43 & 99.07 & 98.93 & 99.73 & 99.8 & 99.94 & 99.73 & 98.1 & 99.23 & 99.56 & 98.06 \\
\hline Oxygens & 12 & 12 & 12 & 12 & 12 & 12 & 12 & 12 & 12 & 12 & 12 & 12 & 12 & 12 & 12 & 12 & 12 \\
\hline $\mathrm{Si}$ & 3.011 & 3.007 & 3.006 & 3.005 & 3.008 & 3.011 & 3.001 & 2.988 & 2.988 & 2.991 & 3.002 & 3.007 & 3.016 & 2.998 & 3.019 & 3.038 & 3.031 \\
\hline $\mathrm{Ti}$ & 0.001 & 0.004 & 0 & 0.002 & 0.001 & 0 & 0 & 0 & 0 & 0.003 & 0 & 0.002 & 0 & 0 & 0 & 0 & 0 \\
\hline $\mathrm{Al}$ & 2.072 & 2.08 & 2.081 & 2.061 & 2.048 & 2.077 & 2.085 & 2.078 & 2.08 & 2.072 & 2.06 & 2.063 & 2.054 & 2.078 & 2.093 & 2.068 & 2.079 \\
\hline $\mathrm{Cr}$ & 0 & 0 & 0 & 0 & 0 & 0 & 0 & 0 & 0 & 0 & 0 & 0 & 0 & 0 & 0 & 0 & 0 \\
\hline $\mathrm{Fe} 3$ & 0 & 0 & 0 & 0 & 0 & 0 & 0 & 0 & 0 & 0 & 0 & 0 & 0 & 0 & 0 & 0 & 0 \\
\hline $\mathrm{Fe} 2$ & 2.113 & 2.091 & 2.104 & 2.118 & 2.13 & 2.082 & 2.099 & 2.093 & 2.094 & 2.121 & 2.115 & 2.103 & 2.097 & 2.075 & 2.12 & 2.128 & 2.116 \\
\hline $\mathrm{Mn}$ & 0.176 & 0.156 & 0.15 & 0.156 & 0.156 & 0.157 & 0.157 & 0.161 & 0.154 & 0.158 & 0.155 & 0.16 & 0.149 & 0.151 & 0.301 & 0.297 & 0.282 \\
\hline $\mathrm{Mg}$ & 0.472 & 0.508 & 0.506 & 0.512 & 0.522 & 0.515 & 0.501 & 0.521 & 0.51 & 0.48 & 0.49 & 0.483 & 0.492 & 0.512 & 0.275 & 0.274 & 0.288 \\
\hline $\mathrm{Ca}$ & 0.109 & 0.104 & 0.107 & 0.109 & 0.104 & 0.109 & 0.114 & 0.132 & 0.146 & 0.144 & 0.146 & 0.143 & 0.148 & 0.148 & 0.126 & 0.123 & 0.134 \\
\hline $\mathrm{Na}$ & 0 & 0 & 0 & 0 & 0 & 0 & 0 & 0 & 0 & 0 & 0 & 0 & 0 & 0 & 0 & 0 & 0 \\
\hline $\mathrm{K}$ & 0 & 0 & 0 & 0 & 0 & 0 & 0 & 0 & 0 & 0 & 0 & 0 & 0 & 0 & 0 & 0 & 0 \\
\hline Sum & 7.953 & 7.95 & 7.954 & 7.963 & 7.968 & 7.951 & 7.957 & 7.973 & 7.972 & 7.97 & 7.969 & 7.96 & 7.957 & 7.962 & 7.934 & 7.928 & 7.93 \\
\hline Alm & 73.62 & 73.14 & 73.39 & 73.16 & 73.15 & 72.72 & 73.11 & 72.00 & 72.11 & 73.06 & 72.78 & 72.79 & 72.66 & 71.90 & 75.12 & 75.41 & 75.04 \\
\hline Prp & 16.45 & 17.77 & 17.65 & 17.69 & 17.93 & 17.99 & 17.45 & 17.92 & 17.56 & 16.53 & 16.86 & 16.72 & 17.05 & 17.74 & 9.74 & 9.71 & 10.21 \\
\hline Grs & 3.80 & 3.64 & 3.73 & 3.77 & 3.57 & 3.81 & 3.97 & 4.54 & 5.03 & 4.96 & 5.02 & 4.95 & 5.13 & 5.13 & 4.46 & 4.36 & 4.75 \\
\hline \multirow[t]{2}{*}{ Sps } & 6.13 & 5.46 & 5.23 & 5.39 & 5.36 & 5.48 & 5.47 & 5.54 & 5.30 & 5.44 & 5.33 & 5.54 & 5.16 & 5.23 & 10.67 & 10.52 & 10.00 \\
\hline & 100 & 100 & 100 & 100 & 100 & 100 & 100 & 100 & 100 & 100 & 100 & 100 & 100 & 100 & 100 & 100 & 100 \\
\hline
\end{tabular}




\section{Nappe Lima Duarte (Amostra OL-III-39A)}

\section{GRANADA}

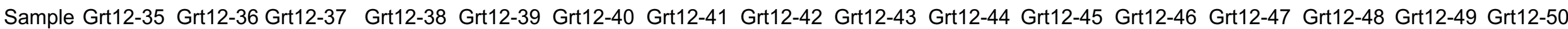

\begin{tabular}{|c|c|c|c|c|c|c|c|c|c|c|c|c|c|c|c|c|}
\hline $\mathrm{SiO} 2$ & 37.87 & 38.02 & 37.42 & 38.28 & 37.98 & 38.13 & 38.37 & 37.86 & 37.97 & 37.2 & 38.08 & 37.8 & 37.42 & 37.71 & 37.84 & 37.56 \\
\hline $\mathrm{TiO} 2$ & 0 & 0 & 0.07 & 0.04 & 0.08 & 0 & 0.04 & 0 & 0 & 0.04 & 0.07 & 0.09 & 0.15 & 0.07 & 0 & 0 \\
\hline $\mathrm{Al} 2 \mathrm{O} 3$ & 21.93 & 22.27 & 21.93 & 22.19 & 21.82 & 22.12 & 22.05 & 22.02 & 21.96 & 21.77 & 22.06 & 21.87 & 21.75 & 21.94 & 21.69 & 22.04 \\
\hline Cr2O3 & 0 & 0 & 0 & 0 & 0 & 0 & 0 & 0 & 0 & 0 & 0 & 0 & 0 & 0 & 0 & 0 \\
\hline Fe2O3 & 0 & 0 & 0 & 0 & 0 & 0 & 0 & 0 & 0 & 0 & 0 & 0 & 0 & 0 & 0 & 0 \\
\hline $\mathrm{FeO}$ & 31.01 & 31.24 & 30.65 & 31.59 & 31.09 & 30.58 & 31.58 & 31.14 & 30.52 & 29.66 & 31.61 & 30.75 & 31.57 & 31.56 & 30.86 & 31 \\
\hline $\mathrm{MnO}$ & 2.05 & 2.14 & 2.12 & 2.07 & 2.01 & 2.14 & 2.14 & 2.02 & 2.19 & 2.19 & 2.25 & 2.22 & 2.43 & 2.29 & 2.19 & 2.2 \\
\hline $\mathrm{MgO}$ & 4.52 & 4.55 & 4.58 & 4.49 & 4.62 & 4.76 & 4.7 & 4.5 & 4.43 & 4.54 & 4.36 & 4.31 & 3.97 & 4.32 & 4.65 & 4.16 \\
\hline $\mathrm{CaO}$ & 1.47 & 1.36 & 1.38 & 1.42 & 1.41 & 1.34 & 1.32 & 1.47 & 1.33 & 1.41 & 1.35 & 1.31 & 1.32 & 1.39 & 1.34 & 1.29 \\
\hline $\mathrm{Na} 2 \mathrm{O}$ & 0 & 0 & 0 & 0 & 0 & 0 & 0 & 0 & 0 & 0 & 0 & 0 & 0 & 0 & 0 & 0 \\
\hline $\mathrm{K} 2 \mathrm{O}$ & 0 & 0 & 0 & 0 & 0 & 0 & 0 & 0 & 0 & 0 & 0 & 0 & 0 & 0 & 0 & 0 \\
\hline Totals & 98.85 & 99.58 & 98.16 & 100.07 & 99.01 & 99.07 & 100.2 & 99.01 & 98.4 & 96.81 & 99.78 & 98.36 & 98.61 & 99.27 & 98.57 & 98.25 \\
\hline Oxygens & 12 & 12 & 12 & 12 & 12 & 12 & 12 & 12 & 12 & 12 & 12 & 12 & 12 & 12 & 12 & 12 \\
\hline $\mathrm{Si}$ & 3.02 & 3.009 & 3.004 & 3.017 & 3.023 & 3.024 & 3.021 & 3.015 & 3.034 & 3.018 & 3.015 & 3.027 & 3.007 & 3.005 & 3.026 & 3.015 \\
\hline $\mathrm{Ti}$ & 0 & 0 & 0.004 & 0.002 & 0.005 & 0 & 0.002 & 0 & 0 & 0.002 & 0.004 & 0.006 & 0.009 & 0.004 & 0 & 0 \\
\hline $\mathrm{Al}$ & 2.061 & 2.078 & 2.076 & 2.062 & 2.048 & 2.069 & 2.047 & 2.067 & 2.069 & 2.083 & 2.059 & 2.065 & 2.061 & 2.061 & 2.045 & 2.086 \\
\hline $\mathrm{Cr}$ & 0 & 0 & 0 & 0 & 0 & 0 & 0 & 0 & 0 & 0 & 0 & 0 & 0 & 0 & 0 & 0 \\
\hline Fe3 & 0 & 0 & 0 & 0 & 0 & 0 & 0 & 0 & 0 & 0 & 0 & 0 & 0 & 0 & 0 & 0 \\
\hline $\mathrm{Fe} 2$ & 2.068 & 2.068 & 2.058 & 2.083 & 2.07 & 2.029 & 2.079 & 2.074 & 2.039 & 2.013 & 2.093 & 2.059 & 2.122 & 2.103 & 2.064 & 2.082 \\
\hline $\mathrm{Mn}$ & 0.138 & 0.143 & 0.144 & 0.138 & 0.136 & 0.144 & 0.143 & 0.136 & 0.148 & 0.151 & 0.151 & 0.151 & 0.165 & 0.155 & 0.148 & 0.15 \\
\hline $\mathrm{Mg}$ & 0.537 & 0.537 & 0.548 & 0.527 & 0.548 & 0.562 & 0.551 & 0.533 & 0.527 & 0.549 & 0.515 & 0.514 & 0.475 & 0.513 & 0.554 & 0.498 \\
\hline $\mathrm{Ca}$ & 0.126 & 0.116 & 0.119 & 0.12 & 0.12 & 0.114 & 0.111 & 0.126 & 0.114 & 0.123 & 0.114 & 0.113 & 0.114 & 0.119 & 0.115 & 0.111 \\
\hline $\mathrm{Na}$ & 0 & 0 & 0 & 0 & 0 & 0 & 0 & 0 & 0 & 0 & 0 & 0 & 0 & 0 & 0 & 0 \\
\hline $\mathrm{K}$ & 0 & 0 & 0 & 0 & 0 & 0 & 0 & 0 & 0 & 0 & 0 & 0 & 0 & 0 & 0 & 0 \\
\hline Sum & 7.95 & 7.95 & 7.95 & 7.95 & 7.95 & 7.94 & 7.95 & 7.95 & 7.93 & 7.94 & 7.95 & 7.94 & 7.95 & 7.96 & 7.95 & 7.94 \\
\hline Alm & 72.08 & 72.21 & 71.73 & 72.63 & 72.03 & 71.22 & 72.09 & 72.29 & 72.10 & 70.98 & 72.85 & 72.58 & 73.78 & 72.77 & 71.64 & 73.28 \\
\hline Prp & 18.72 & 18.75 & 19.10 & 18.38 & 19.07 & 19.73 & 19.11 & 18.58 & 18.64 & 19.36 & 17.93 & 18.12 & 16.52 & 17.75 & 19.23 & 17.53 \\
\hline Grs & 4.39 & 4.05 & 4.15 & 4.18 & 4.18 & 4.00 & 3.85 & 4.39 & 4.03 & 4.34 & 3.97 & 3.98 & 3.96 & 4.12 & 3.99 & 3.91 \\
\hline \multirow[t]{2}{*}{ Sps } & 4.81 & 4.99 & 5.02 & 4.81 & 4.73 & 5.05 & 4.96 & 4.74 & 5.23 & 5.32 & 5.26 & 5.32 & 5.74 & 5.36 & 5.14 & 5.28 \\
\hline & 100 & 100 & 100 & 100 & 100 & 100 & 100 & 100 & 100 & 100 & 100 & 100 & 100 & 100 & 100 & 100 \\
\hline
\end{tabular}




\section{Nappe Lima Duarte (Amostra OL-III-39A)}

GRANADA

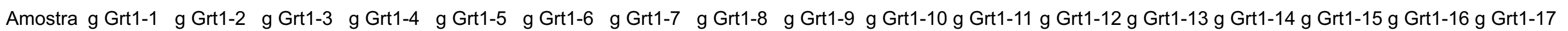

\begin{tabular}{|c|c|c|c|c|c|c|c|c|c|c|c|c|c|c|c|c|c|}
\hline $\mathrm{SiO} 2$ & 37.77 & 37.97 & 37.5 & 37.62 & 37.38 & 37.69 & 37.48 & 37.33 & 37.26 & 36.77 & 37.08 & 37.39 & 37.05 & 37.3 & 37.45 & 37.21 & 37.36 \\
\hline TiO2 & 0.03 & 0.1 & 0.04 & 0 & 0.03 & 0 & 0.05 & 0.03 & 0.08 & 0.01 & 0 & 0.05 & 0.02 & 0 & 0.07 & 0.05 & 0.07 \\
\hline $\mathrm{Al} 2 \mathrm{O} 3$ & 21.94 & 21.96 & 21.98 & 22.03 & 21.93 & 22.08 & 21.98 & 22.03 & 22.06 & 21.97 & 22.04 & 21.84 & 21.73 & 21.95 & 21.71 & 22.05 & 21.95 \\
\hline Cr2O3 & 0 & 0 & 0 & 0 & 0 & 0 & 0 & 0 & 0 & 0 & 0 & 0 & 0 & 0 & 0 & 0 & 0 \\
\hline Fe2O3 & 0 & 0 & 0 & 0 & 0 & 0 & 0 & 0 & 0 & 0 & 0 & 0 & 0 & 0 & 0 & 0 & 0 \\
\hline $\mathrm{FeO}$ & 34.39 & 34.62 & 34.2 & 33.53 & 34.09 & 33.37 & 33.63 & 33.21 & 33.34 & 32.47 & 33.74 & 33.31 & 32.61 & 34.37 & 34.19 & 33.96 & 33.77 \\
\hline $\mathrm{MnO}$ & 1.84 & 1.51 & 1.31 & 1.3 & 1.23 & 1.22 & 1.27 & 1.23 & 1.16 & 1.16 & 1.46 & 1.2 & 1.41 & 1.69 & 0.83 & 1.02 & 0.84 \\
\hline $\mathrm{MgO}$ & 2.36 & 2.44 & 2.89 & 2.76 & 2.69 & 2.61 & 2.63 & 2.53 & 2.54 & 2.6 & 2.5 & 2.55 & 2.52 & 2.41 & 2.72 & 2.73 & 2.77 \\
\hline $\mathrm{CaO}$ & 1.27 & 1.91 & 1.98 & 2.18 & 2.59 & 3.21 & 2.77 & 2.9 & 3.01 & 2.89 & 2.03 & 2.96 & 2.55 & 1.64 & 2.67 & 2.72 & 2.38 \\
\hline $\mathrm{Na} 2 \mathrm{O}$ & 0 & 0 & 0 & 0 & 0 & 0 & 0 & 0 & 0 & 0 & 0 & 0 & 0 & 0 & 0 & 0 & 0 \\
\hline $\mathrm{K} 2 \mathrm{O}$ & 0 & 0 & 0 & 0 & 0 & 0 & 0 & 0 & 0 & 0 & 0 & 0 & 0 & 0 & 0 & 0 & 0 \\
\hline Totals & 99.6 & 100.52 & 99.9 & 99.43 & 99.94 & 100.18 & 99.82 & 99.26 & 99.44 & 97.86 & 98.84 & 99.31 & 97.89 & 99.36 & 99.63 & 99.72 & 99.15 \\
\hline Oxygens & 12 & 12 & 12 & 12 & 12 & 12 & 12 & 12 & 12 & 12 & 12 & 12 & 12 & 12 & 12 & 12 & 12 \\
\hline $\mathrm{Si}$ & 3.03 & 3.02 & 2.999 & 3.014 & 2.992 & 3.001 & 2.998 & 2.999 & 2.99 & 2.991 & 2.996 & 3.005 & 3.014 & 3.006 & 3.004 & 2.982 & 3.003 \\
\hline $\mathrm{Ti}$ & 0.002 & 0.006 & 0.002 & 0 & 0.002 & 0 & 0.003 & 0.002 & 0.005 & 0.001 & 0 & 0.003 & 0.001 & 0 & 0.004 & 0.003 & 0.004 \\
\hline $\mathrm{Al}$ & 2.075 & 2.06 & 2.072 & 2.08 & 2.07 & 2.073 & 2.073 & 2.087 & 2.087 & 2.107 & 2.1 & 2.069 & 2.084 & 2.084 & 2.053 & 2.083 & 2.08 \\
\hline $\mathrm{Cr}$ & 0 & 0 & 0 & 0 & 0 & 0 & 0 & 0 & 0 & 0 & 0 & 0 & 0 & 0 & 0 & 0 & 0 \\
\hline Fe3 & 0 & 0 & 0 & 0 & 0 & 0 & 0 & 0 & 0 & 0 & 0 & 0 & 0 & 0 & 0 & 0 & 0 \\
\hline $\mathrm{Fe} 2$ & 2.307 & 2.303 & 2.287 & 2.247 & 2.282 & 2.223 & 2.25 & 2.231 & 2.238 & 2.209 & 2.28 & 2.239 & 2.219 & 2.316 & 2.294 & 2.276 & 2.27 \\
\hline $\mathrm{Mn}$ & 0.125 & 0.102 & 0.088 & 0.088 & 0.084 & 0.082 & 0.086 & 0.084 & 0.079 & 0.08 & 0.1 & 0.081 & 0.097 & 0.115 & 0.057 & 0.069 & 0.057 \\
\hline $\mathrm{Mg}$ & 0.282 & 0.29 & 0.345 & 0.33 & 0.321 & 0.31 & 0.314 & 0.302 & 0.304 & 0.315 & 0.301 & 0.306 & 0.305 & 0.289 & 0.325 & 0.326 & 0.332 \\
\hline $\mathrm{Ca}$ & 0.109 & 0.163 & 0.169 & 0.187 & 0.222 & 0.274 & 0.238 & 0.25 & 0.259 & 0.252 & 0.176 & 0.255 & 0.222 & 0.141 & 0.229 & 0.233 & 0.205 \\
\hline $\mathrm{Na}$ & 0 & 0 & 0 & 0 & 0 & 0 & 0 & 0 & 0 & 0 & 0 & 0 & 0 & 0 & 0 & 0 & 0 \\
\hline $\mathrm{K}$ & 0 & 0 & 0 & 0 & 0 & 0 & 0 & 0 & 0 & 0 & 0 & 0 & 0 & 0 & 0 & 0 & 0 \\
\hline Sum & 7.93 & 7.94 & 7.96 & 7.95 & 7.97 & 7.96 & 7.96 & 7.96 & 7.96 & 7.95 & 7.95 & 7.96 & 7.94 & 7.95 & 7.97 & 7.97 & 7.95 \\
\hline Alm & 81.72 & 80.58 & 79.16 & 78.79 & 78.45 & 76.95 & 77.91 & 77.82 & 77.71 & 77.35 & 79.80 & 77.72 & 78.05 & 80.95 & 78.97 & 78.37 & 79.26 \\
\hline Prp & 9.99 & 10.15 & 11.94 & 11.57 & 11.03 & 10.73 & 10.87 & 10.53 & 10.56 & 11.03 & 10.54 & 10.62 & 10.73 & 10.10 & 11.19 & 11.23 & 11.59 \\
\hline Grs & 3.86 & 5.70 & 5.85 & 6.56 & 7.63 & 9.48 & 8.24 & 8.72 & 8.99 & 8.82 & 6.16 & 8.85 & 7.81 & 4.93 & 7.88 & 8.02 & 7.16 \\
\hline \multirow[t]{2}{*}{ Sps } & 4.43 & 3.57 & 3.05 & 3.09 & 2.89 & 2.84 & 2.98 & 2.93 & 2.74 & 2.80 & 3.50 & 2.81 & 3.41 & 4.02 & 1.96 & 2.38 & 1.99 \\
\hline & 100 & 100 & 100 & 100 & 100 & 100 & 100 & 100 & 100 & 100 & 100 & 100 & 100 & 100 & 100 & 100 & 100 \\
\hline
\end{tabular}




\section{Nappe Lima Duarte (Amostra OL-III-39A)}

GRANADA

Amostra $\quad$ g Grt1-18 g Grt1-19 g Grt1-20 g Grt1-21 g Grt1-22 g Grt1-23 g Grt1-24 g Grt1-25 g Grt1-26 g Grt1-27 g Grt1-28 g Grt1-29 g Grt1-30 g Grt1-31 g Grt1-32 g Grt1-33 g Grt1-3

\begin{tabular}{|c|c|c|c|c|c|c|c|c|c|c|c|c|c|c|c|c|c|}
\hline $\mathrm{SiO} 2$ & 37.74 & 37.19 & 37.04 & 37.53 & 37.18 & 37.27 & 37.66 & 37.31 & 36.99 & 37.24 & 37.36 & 37.32 & 37.3 & 37.34 & 37.49 & 36.83 & 37.52 \\
\hline TiO2 & 0.07 & 0 & 0 & 0.08 & 0 & 0.08 & 0.02 & 0 & 0.1 & 0 & 0.05 & 0.07 & 0.02 & 0 & 0.1 & 0.01 & 0.07 \\
\hline $\mathrm{Al} 2 \mathrm{O} 3$ & 22.07 & 21.95 & 21.98 & 21.93 & 21.88 & 21.9 & 21.76 & 22.05 & 21.91 & 21.86 & 21.93 & 21.86 & 21.86 & 21.79 & 21.98 & 21.76 & 21.95 \\
\hline $\mathrm{Cr} 2 \mathrm{O} 3$ & 0 & 0 & 0 & 0 & 0 & 0 & 0 & 0 & 0 & 0 & 0 & 0 & 0 & 0 & 0 & 0 & 0 \\
\hline $\mathrm{Fe} 2 \mathrm{O} 3$ & 0 & 0 & 0 & 0 & 0 & 0 & 0 & 0 & 0 & 0 & 0 & 0 & 0 & 0 & 0 & 0 & 0 \\
\hline $\mathrm{MnO}$ & 0.92 & 1.63 & 1.74 & 1.53 & 1.43 & 1.06 & 1.07 & 1.37 & 1.82 & 1.78 & 1.45 & 1.39 & 1.29 & 1.52 & 1.25 & 1.28 & 1.35 \\
\hline $\mathrm{MgO}$ & 2.9 & 2.31 & 2.21 & 2.5 & 2.58 & 2.84 & 2.99 & 2.69 & 2.3 & 2.4 & 2.67 & 2.62 & 2.68 & 2.5 & 2.54 & 2.57 & 2.45 \\
\hline $\mathrm{CaO}$ & 2.39 & 1.78 & 1.46 & 1.87 & 1.85 & 1.97 & 1.72 & 1.59 & 0.86 & 1.32 & 1.49 & 2.02 & 2.72 & 1.49 & 3.28 & 3.15 & 3.21 \\
\hline $\mathrm{Na} 2 \mathrm{O}$ & 0 & 0 & 0 & 0 & 0 & 0 & 0 & 0 & 0 & 0 & 0 & 0 & 0 & 0 & 0 & 0 & 0 \\
\hline $\mathrm{K} 2 \mathrm{O}$ & 0 & 0 & 0 & 0 & 0 & 0 & 0 & 0 & 0 & 0 & 0 & 0 & 0 & 0 & 0 & 0 & 0 \\
\hline Oxygens & 12 & 12 & 12 & 12 & 12 & 12 & 12 & 12 & 12 & 12 & 12 & 12 & 12 & 12 & 12 & 12 & 12 \\
\hline $\mathrm{Si}$ & 3.008 & 2.999 & 3.002 & 3.007 & 2.992 & 2.994 & 3.013 & 2.992 & 2.987 & 3.013 & 2.996 & 3.005 & 3.005 & 3.009 & 3.001 & 2.972 & 3.014 \\
\hline $\mathrm{Ti}$ & 0.004 & 0 & 0 & 0.005 & 0 & 0.005 & 0.001 & 0 & 0.006 & 0 & 0.003 & 0.004 & 0.001 & 0 & 0.006 & 0.001 & 0.004 \\
\hline $\mathrm{Al}$ & 2.073 & 2.087 & 2.1 & 2.071 & 2.076 & 2.074 & 2.053 & 2.084 & 2.086 & 2.085 & 2.073 & 2.075 & 2.076 & 2.07 & 2.075 & 2.07 & 2.078 \\
\hline $\mathrm{Cr}$ & 0 & 0 & 0 & 0 & 0 & 0 & 0 & 0 & 0 & 0 & 0 & 0 & 0 & 0 & 0 & 0 & 0 \\
\hline $\mathrm{Fe} 3$ & 0 & 0 & 0 & 0 & 0 & 0 & 0 & 0 & 0.00 & 0.00 & 0.00 & 0.00 & 0.00 & 0.00 & 0.00 & 0.00 & 0.00 \\
\hline $\mathrm{Fe} 2$ & 2.256 & 2.329 & 2.334 & 2.307 & 2.334 & 2.308 & 2.316 & 2.337 & 2.41 & 2.32 & 2.35 & 2.29 & 2.23 & 2.34 & 2.20 & 2.28 & 2.19 \\
\hline $\mathrm{Mn}$ & 0.062 & 0.111 & 0.119 & 0.104 & 0.097 & 0.072 & 0.073 & 0.093 & 0.13 & 0.12 & 0.10 & 0.09 & 0.09 & 0.10 & 0.09 & 0.09 & 0.09 \\
\hline $\mathrm{Na}$ & 0 & 0 & 0 & 0 & 0 & 0 & 0 & 0 & 0 & 0 & 0 & 0 & 0 & 0 & 0 & 0 & 0 \\
\hline $\mathrm{K}$ & 0 & 0 & 0 & 0 & 0 & 0 & 0 & 0 & 0 & 0 & 0 & 0 & 0 & 0 & 0 & 0 & 0 \\
\hline Sum & 7.95 & 7.96 & 7.95 & 7.95 & 7.97 & 7.96 & 7.96 & 7.97 & 7.96 & 7.94 & 7.97 & 7.95 & 7.96 & 7.96 & 7.96 & 7.99 & 7.94 \\
\hline Alm & 78.69 & 81.09 & 82.01 & 80.38 & 80.46 & 79.86 & 80.06 & 80.92 & 83.50 & 81.49 & 81.20 & 79.71 & 77.55 & 81.50 & 76.68 & 77.30 & 76.77 \\
\hline Prp & 12.03 & 9.68 & 9.35 & 10.42 & 10.69 & 11.76 & 12.31 & 11.11 & 9.60 & 10.19 & 10.99 & 10.95 & 11.21 & 10.43 & 10.55 & 10.47 & 10.30 \\
\hline Grs & 7.12 & 5.36 & 4.46 & 5.57 & 5.52 & 5.88 & 5.12 & 4.74 & 2.57 & 4.04 & 4.42 & 6.07 & 8.18 & 4.45 & 9.82 & 9.25 & 9.70 \\
\hline \multirow[t]{2}{*}{ Sps } & 2.16 & 3.86 & 4.18 & 3.62 & 3.34 & 2.49 & 2.52 & 3.22 & 4.33 & 4.29 & 3.39 & 3.28 & 3.06 & 3.62 & 2.96 & 2.98 & 3.23 \\
\hline & 100 & 100 & 100 & 100 & 100 & 100 & 100 & 100 & 100 & 100 & 100 & 100 & 100 & 100 & 100 & 100 & 100 \\
\hline
\end{tabular}




\section{Nappe Lima Duarte (Amostra OL-III-39A)}

\section{GRANADA}

Sample g Grt1-35 g Grt1-36 g Grt1-37 g Grt1-38 g Grt1-39 g Grt1-40 g Grt1-41 g Grt1-42 g Grt1-43 g Grt1-44 g Grt1-45 g Grt1-46 g Grt1-47 g Grt1-48

\begin{tabular}{|c|c|c|c|c|c|c|c|c|c|c|c|c|c|c|}
\hline $\mathrm{SiO} 2$ & 37.53 & 37.37 & 37.32 & 37.54 & 37.51 & 37.74 & 37.43 & 37.85 & 37.62 & 37.39 & 36.83 & 37.36 & 37.17 & 37.01 \\
\hline TiO2 & 0 & 0.02 & 0.01 & 0 & 0 & 0.04 & 0 & 0.02 & 0 & 0.12 & 0 & 0 & 0.04 & 0.06 \\
\hline $\mathrm{Al} 2 \mathrm{O} 3$ & 21.82 & 21.79 & 21.94 & 21.87 & 22.14 & 21.82 & 22.02 & 21.74 & 22.11 & 21.86 & 22.05 & 21.83 & 21.89 & 21.78 \\
\hline $\mathrm{Cr} 2 \mathrm{O} 3$ & 0 & 0 & 0 & 0 & 0 & 0 & 0 & 0 & 0 & 0 & 0 & 0 & 0 & 0 \\
\hline $\mathrm{Fe} 2 \mathrm{O} 3$ & 0 & 0 & 0 & 0 & 0 & 0 & 0 & 0 & 0 & 0 & 0 & 0 & 0 & 0 \\
\hline $\mathrm{FeO}$ & 33.08 & 33.45 & 32.61 & 33.23 & 33.89 & 33.6 & 34.83 & 33.84 & 34.31 & 34.43 & 35.45 & 34.58 & 35 & 35.72 \\
\hline $\mathrm{MnO}$ & 1.2 & 1.26 & 1.3 & 1.16 & 1.18 & 1.2 & 1.27 & 1.17 & 1.38 & 1.42 & 1.41 & 1.6 & 1.7 & 1.76 \\
\hline $\mathrm{MgO}$ & 2.63 & 2.42 & 2.59 & 2.5 & 2.5 & 2.55 & 2.92 & 2.73 & 2.88 & 2.82 & 2.67 & 2.57 & 2.4 & 2.46 \\
\hline $\mathrm{CaO}$ & 3.24 & 3.11 & 3.14 & 3.23 & 3.17 & 3.06 & 1.83 & 2.51 & 1.78 & 1.66 & 1.4 & 1.27 & 1.1 & 0.8 \\
\hline $\mathrm{Na} 2 \mathrm{O}$ & 0 & 0 & 0 & 0 & 0 & 0 & 0 & 0 & 0 & 0 & 0 & 0 & 0 & 0 \\
\hline $\mathrm{K} 2 \mathrm{O}$ & 0 & 0 & 0 & 0 & 0 & 0 & 0 & 0 & 0 & 0 & 0 & 0 & 0 & 0 \\
\hline Totals & 99.5 & 99.42 & 98.91 & 99.53 & 100.39 & 100.01 & 100.3 & 99.87 & 100.07 & 99.7 & 99.81 & 99.22 & 99.3 & 99.59 \\
\hline Oxygens & 12 & 12 & 12 & 12 & 12 & 12 & 12 & 12 & 12 & 12 & 12 & 12 & 12 & 12 \\
\hline Si & 3.008 & 3.004 & 3.005 & 3.009 & 2.988 & 3.013 & 2.988 & 3.023 & 3.002 & 2.999 & 2.966 & 3.013 & 3.002 & 2.99 \\
\hline $\mathrm{Ti}$ & 0 & 0.001 & 0.001 & 0 & 0 & 0.002 & 0 & 0.001 & 0 & 0.007 & 0 & 0 & 0.002 & 0.004 \\
\hline $\mathrm{Al}$ & 2.062 & 2.065 & 2.082 & 2.067 & 2.079 & 2.053 & 2.072 & 2.048 & 2.08 & 2.067 & 2.094 & 2.076 & 2.084 & 2.074 \\
\hline $\mathrm{Cr}$ & 0 & 0 & 0 & 0 & 0 & 0 & 0 & 0 & 0 & 0 & 0 & 0 & 0 & 0 \\
\hline $\mathrm{Fe} 3$ & 0.00 & 0.00 & 0.00 & 0.00 & 0.00 & 0.00 & 0.00 & 0.00 & 0.00 & 0.00 & 0.00 & 0.00 & 0.00 & 0.00 \\
\hline $\mathrm{Fe} 2$ & 2.22 & 2.25 & 2.20 & 2.23 & 2.26 & 2.24 & 2.33 & 2.26 & 2.29 & 2.31 & 2.39 & 2.33 & 2.36 & 2.41 \\
\hline $\mathrm{Mn}$ & 0.08 & 0.09 & 0.09 & 0.08 & 0.08 & 0.08 & 0.09 & 0.08 & 0.09 & 0.10 & 0.10 & 0.11 & 0.12 & 0.12 \\
\hline $\mathrm{Mg}$ & 0.32 & 0.29 & 0.31 & 0.30 & 0.30 & 0.30 & 0.35 & 0.33 & 0.34 & 0.34 & 0.32 & 0.31 & 0.29 & 0.30 \\
\hline $\mathrm{Ca}$ & 0.28 & 0.27 & 0.27 & 0.28 & 0.27 & 0.26 & 0.16 & 0.21 & 0.15 & 0.14 & 0.12 & 0.11 & 0.10 & 0.07 \\
\hline $\mathrm{Na}$ & 0 & 0 & 0 & 0 & 0 & 0 & 0 & 0 & 0 & 0 & 0 & 0 & 0 & 0 \\
\hline $\mathrm{K}$ & 0 & 0 & 0 & 0 & 0 & 0 & 0 & 0 & 0 & 0 & 0 & 0 & 0 & 0 \\
\hline Sum & 7.96 & 7.96 & 7.95 & 7.96 & 7.97 & 7.96 & 7.98 & 7.95 & 7.96 & 7.96 & 7.99 & 7.95 & 7.95 & 7.97 \\
\hline Alm & 76.66 & 77.74 & 76.62 & 77.27 & 77.73 & 77.61 & 79.73 & 78.53 & 79.56 & 80.04 & 81.67 & 81.51 & 82.54 & 83.27 \\
\hline Prp & 10.89 & 10.02 & 10.82 & 10.34 & 10.22 & 10.52 & 11.93 & 11.29 & 11.89 & 11.68 & 10.94 & 10.80 & 10.09 & 10.21 \\
\hline Grs & 9.61 & 9.26 & 9.46 & 9.65 & 9.29 & 9.07 & 5.38 & 7.43 & 5.32 & 4.95 & 4.10 & 3.84 & 3.32 & 2.38 \\
\hline \multirow[t]{2}{*}{ Sps } & 2.84 & 2.97 & 3.11 & 2.74 & 2.75 & 2.80 & 2.95 & 2.74 & 3.23 & 3.33 & 3.28 & 3.84 & 4.05 & 4.14 \\
\hline & 100 & 100 & 100 & 100 & 100 & 100 & 100 & 100 & 100 & 100 & 100 & 100 & 100 & 100 \\
\hline
\end{tabular}


Nappe Lima Duarte (Amostra OL-II-112B)

FELDSPATO

$\begin{array}{ccccccccccc}\text { Sample } & \text { Kfs1 } & \text { Kfs2 } & \text { Kfs3 } & \text { Kfs4 } & \text { Kfs5 } & \text { Kfs6 } & \text { Kfs7 } & \text { Kfs8 } & \text { Kfs9 } & \text { Kfs10 } \\ \text { SiO2 } & 64.28 & 64.36 & 62.44 & 62.05 & 64.55 & 64.48 & 64.44 & 63.79 & 63.32 & 64.54 \\ \mathrm{TiO} 2 & 0.04 & 0.18 & 0 & 0 & 0 & 0.03 & 0.01 & 0.01 & 0 & 0 \\ \mathrm{Al} 2 \mathrm{O} 3 & 18.92 & 18.75 & 18.25 & 18.5 & 18.84 & 19.13 & 18.77 & 18.99 & 18.75 & 18.88 \\ \mathrm{Cr} 2 \mathrm{O} 3 & 0 & 0 & 0 & 0 & 0 & 0 & 0 & 0 & 0 & 0 \\ \mathrm{Fe} 2 \mathrm{O} 3 & 0 & 0 & 0 & 0 & 0 & 0 & 0 & 0 & 0 & 0 \\ \mathrm{FeO} & 0 & 0 & 0 & 0 & 0 & 0 & 0 & 0 & 0 & 0 \\ \mathrm{MnO} & 0 & 0.02 & 0 & 0 & 0 & 0.01 & 0.01 & 0.01 & 0 & 0 \\ \mathrm{MgO} & 0 & 0 & 0.02 & 0.01 & 0 & 0.01 & 0 & 0.01 & 0 & 0.01 \\ \mathrm{CaO} & 0.01 & 0.01 & 0.03 & 0 & 0.01 & 0.02 & 0.01 & 0 & 0 & 0.01 \\ \mathrm{Na} 2 \mathrm{O} & 1.4 & 1.27 & 0.45 & 1.49 & 1.86 & 2.03 & 1.67 & 2.08 & 2.23 & 1.91 \\ \mathrm{~K} 2 \mathrm{O} & 14.71 & 14.84 & 16.13 & 14.45 & 14.28 & 13.83 & 14.31 & 13.69 & 13.46 & 14.3 \\ \mathrm{Totals} & 99.38 & 99.44 & 97.33 & 96.52 & 99.56 & 99.55 & 99.23 & 98.58 & 97.77 & 99.66 \\ \mathrm{Oxygens} & 8 & 8 & 8 & 8 & 8 & 8 & 8 & 8 & 8 & 8 \\ \mathrm{Si} & 2.97 & 2.972 & 2.967 & 2.964 & 2.979 & 2.97 & 2.981 & 2.967 & 2.968 & 2.977 \\ \mathrm{Ti} & 0.001 & 0.006 & 0 & 0 & 0 & 0.001 & 0 & 0 & 0 & 0 \\ \mathrm{Al} & 1.03 & 1.021 & 1.023 & 1.042 & 1.025 & 1.039 & 1.024 & 1.041 & 1.036 & 1.026 \\ \mathrm{Cr} & 0 & 0 & 0 & 0 & 0 & 0 & 0 & 0 & 0 & 0 \\ \mathrm{Fe} 3 & 0.01 & 0.011 & 0.013 & 0 & 0.001 & 0 & 0.002 & 0.002 & 0.004 & 0 \\ \mathrm{Fe} 2 & 0 & 0 & 0 & 0 & 0 & 0 & 0 & 0 & 0 & 0 \\ \mathrm{Mn} & 0 & 0.001 & 0 & 0 & 0 & 0 & 0 & 0 & 0 & 0 \\ \mathrm{Mg} & 0 & 0 & 0.001 & 0.001 & 0 & 0 & 0 & 0 & 0 & 0 \\ \mathrm{Ca} & 0 & 0 & 0.001 & 0 & 0 & 0.001 & 0.001 & 0 & 0 & 0 \\ \mathrm{Na} & 0.125 & 0.114 & 0.042 & 0.138 & 0.167 & 0.181 & 0.15 & 0.188 & 0.202 & 0.171 \\ \mathrm{~K} & 0.867 & 0.875 & 0.978 & 0.881 & 0.841 & 0.813 & 0.845 & 0.812 & 0.805 & 0.842 \\ \mathrm{Sum} & 5.005 & 5 & 5.025 & 5.025 & 5.013 & 5.007 & 5.003 & 5.012 & 5.016 & 5.017 \\ \mathrm{An} & 0 & 0 & 0.10 & 0.00 & 0.00 & 0.10 & 0.10 & 0.00 & 0.00 & 0.00 \\ \mathrm{Ab} & 12.60 & 11.53 & 4.11 & 13.54 & 16.57 & 18.19 & 15.06 & 18.80 & 20.06 & 16.88 \\ \mathrm{Or} & 87.40 & 88.47 & 95.79 & 86.46 & 83.43 & 81.71 & 84.84 & 81.20 & 79.94 & 83.12 \\ \mathrm{Total} & 100 & 100 & 100 & 100 & 100 & 100 & 100 & 100 & 100 & 100\end{array}$

\section{Nappe Lima Duarte (Amostra OL-III-39A)}

$\begin{array}{cccccccccc}\text { Sample } & \text { Plag1 } & \text { Plag2 } & \text { Plag3 } & \text { Plag4 } & \text { Plag5 } & \text { Plag6 } & \text { Plag7 } & \text { Plag8 } & \text { Plag9 } \\ \mathrm{SiO} 2 & 56.9 & 58.41 & 60.27 & 60.28 & 60.8 & 60.6 & 61.16 & 61.35 & 61.31 \\ \mathrm{TiO} 2 & 0 & 0.03 & 0.01 & 0.03 & 0 & 0 & 0 & 0 & 0 \\ \mathrm{Al} 2 \mathrm{O} 3 & 27.28 & 26.39 & 24.8 & 24.48 & 24.63 & 24.65 & 24.76 & 24.78 & 24.67 \\ \mathrm{Cr} 2 \mathrm{O} 3 & 0 & 0 & 0 & 0 & 0 & 0 & 0 & 0 & 0 \\ \mathrm{Fe} 2 \mathrm{O} 3 & 0 & 0 & 0 & 0 & 0 & 0 & 0 & 0 & 0 \\ \mathrm{FeO} & 0 & 0 & 0 & 0 & 0 & 0 & 0 & 0 & 0 \\ \mathrm{MnO} & 0 & 0.05 & 0.01 & 0.01 & 0.01 & 0 & 0 & 0.01 & 0.02 \\ \mathrm{MgO} & 0.01 & 0.01 & 0 & 0 & 0 & 0 & 0 & 0 & 0 \\ \mathrm{CaO} & 9.22 & 8.02 & 6.14 & 5.81 & 5.46 & 6 & 5.75 & 5.87 & 5.88 \\ \mathrm{Na} 2 \mathrm{O} & 6.17 & 6.83 & 7.92 & 8.2 & 8.36 & 8.17 & 8.36 & 8.32 & 8.25 \\ \mathrm{~K} 2 \mathrm{O} & 0.05 & 0.05 & 0.1 & 0.13 & 0.14 & 0.08 & 0.13 & 0.14 & 0.15 \\ \mathrm{Totals} & 99.62 & 99.78 & 99.24 & 98.94 & 99.39 & 99.51 & 100.17 & 100.48 & 100.28 \\ \mathrm{Oxygens} & 8 & 8 & 8 & 8 & 8 & 8 & 8 & 8 & 8 \\ \mathrm{Si} & 2.555 & 2.608 & 2.695 & 2.703 & 2.708 & 2.704 & 2.71 & 2.71 & 2.714 \\ \mathrm{Ti} & 0 & 0.001 & 0 & 0.001 & 0 & 0 & 0 & 0 & 0 \\ \mathrm{Al} & 1.444 & 1.389 & 1.307 & 1.294 & 1.293 & 1.296 & 1.294 & 1.291 & 1.288 \\ \mathrm{Cr} & 0 & 0 & 0 & 0 & 0 & 0 & 0 & 0 & 0 \\ \mathrm{Fe} 3 & 0.007 & 0.011 & 0.005 & 0.007 & 0.012 & 0.004 & 0.002 & 0.003 & 0.001 \\ \mathrm{Fe} 2 & 0 & 0 & 0 & 0 & 0 & 0 & 0 & 0 & 0 \\ \mathrm{Mn} & 0 & 0.002 & 0 & 0 & 0 & 0 & 0 & 0 & 0.001 \\ \mathrm{Mg} & 0.001 & 0 & 0 & 0 & 0 & 0 & 0 & 0 & 0 \\ \mathrm{Ca} & 0.444 & 0.383 & 0.294 & 0.279 & 0.26 & 0.287 & 0.273 & 0.278 & 0.279 \\ \mathrm{Na} & 0.537 & 0.592 & 0.687 & 0.713 & 0.722 & 0.707 & 0.719 & 0.713 & 0.708 \\ \mathrm{~K} & 0.003 & 0.003 & 0.005 & 0.007 & 0.008 & 0.005 & 0.008 & 0.008 & 0.008 \\ \mathrm{Sum} & 4.989 & 4.988 & 4.994 & 5.005 & 5.003 & 5.002 & 5.005 & 5.003 & 4.999 \\ \mathrm{An} & 45.12 & 39.16 & 29.82 & 27.93 & 26.26 & 28.73 & 27.30 & 27.83 & 28.04 \\ \mathrm{Ab} & 54.57 & 60.53 & 69.68 & 71.37 & 72.93 & 70.77 & 71.90 & 71.37 & 71.16 \\ \mathrm{Or} & 0.30 & 0.31 & 0.51 & 0.70 & 0.81 & 0.50 & 0.80 & 0.80 & 0.80 \\ \mathrm{Total} & 100 & 100 & 100 & 100 & 100 & 100 & 100 & 100 & 100\end{array}$




\section{Nappe Lima Duarte (Amostra OL-II-112B)}

BIOTITA

\begin{tabular}{|c|c|c|c|c|c|c|c|c|c|c|c|c|c|c|c|c|c|c|c|c|}
\hline $\mathrm{SiO} 2$ & 34.5 & 34.48 & 34.84 & 35.08 & 34.42 & 35.33 & 34.07 & 34.79 & 35.12 & 33.89 & 34.46 & 34.63 & 35.08 & 34.38 & 35.12 & 35.65 & 34.9 & 34.86 & 34.53 & 34.39 \\
\hline TiO2 & 4.72 & 4.72 & 3.91 & 3.69 & 4.19 & 4.1 & 3.91 & 3.59 & 3.69 & 3.63 & 5.1 & 3.46 & 4.02 & 2.37 & 2.69 & 2.86 & 3.86 & 3.48 & 3.34 & 3.89 \\
\hline $\mathrm{Al} 2 \mathrm{O} 3$ & 18.48 & 18.46 & 19 & 18.85 & 19.46 & 19.4 & 20.69 & 18.96 & 18.98 & 18.96 & 19.28 & 19.72 & 19.17 & 19.06 & 19.84 & 20.2 & 18.93 & 19.21 & 19.11 & 18.73 \\
\hline $\mathrm{FeO}$ & 20.47 & 20.48 & 20.64 & 20.36 & 20.28 & 20.54 & 20.57 & 21.45 & 19.94 & 20.11 & 20.12 & 20.86 & 20.8 & 20.5 & 20.77 & 20.24 & 21.55 & 22.39 & 21.93 & 23.55 \\
\hline $\mathrm{MnO}$ & 0.03 & 0.03 & 0 & 0.02 & 0.03 & 0.03 & 0.05 & 0.03 & 0.04 & 0.05 & 0.03 & 0.01 & 0.03 & 0.03 & 0.01 & 0.04 & 0.02 & 0.05 & 0.01 & 0.04 \\
\hline $\mathrm{MgO}$ & 7.55 & 7.55 & 7.62 & 7.68 & 7.17 & 7.53 & 7.9 & 7.08 & 7.39 & 7.55 & 8.05 & 7.55 & 7.56 & 8.49 & 7.57 & 7.63 & 6.55 & 6.68 & 6.4 & 6 \\
\hline $\mathrm{CaO}$ & 0 & 0 & 0 & 0 & 0.01 & 0 & 0.01 & 0 & 0 & 0 & 0.01 & 0 & 0 & 0.01 & 0 & 0 & 0 & 0 & 0 & 0 \\
\hline $\mathrm{Na} 2 \mathrm{O}$ & 0.07 & 0.07 & 0.12 & 0.08 & 0.18 & 0.1 & 0.28 & 0.18 & 0.16 & 0.12 & 0.24 & 0.34 & 0.18 & 0.29 & 0.11 & 0.17 & 0.11 & 0.19 & 0.13 & 0.14 \\
\hline $\mathrm{K} 2 \mathrm{O}$ & 9.77 & 9.77 & 9.92 & 9.99 & 9.83 & 9.85 & 9.46 & 9.73 & 9.59 & 9.34 & 9.34 & 9.35 & 9.4 & 9.03 & 9.62 & 9.87 & 9.6 & 9.51 & 9.53 & 9.67 \\
\hline Totals & 95.6 & 95.57 & 96.05 & 95.77 & 95.58 & 96.87 & 96.95 & 95.84 & 94.92 & 93.65 & 96.64 & 95.94 & 96.25 & 94.16 & 95.74 & 96.67 & 95.52 & 96.37 & 95 & 96.43 \\
\hline $\mathrm{Si}$ & 2.645 & 2.645 & 2.001 & 2.00 & 2.000 & 2.663 & 2.568 & 2.668 & 2.050 & 2.040 & 2.601 & 2.639 & 2.002 & 2.665 & & & & 2.665 & & \\
\hline $\mathrm{Ti}$ & 0.272 & 0.272 & 0.224 & 0.212 & 0.241 & 0.232 & 0.222 & 0.207 & 0.213 & 0.213 & 0.29 & 0.198 & 0.229 & 0.138 & 0.154 & 0.162 & 0.223 & 0.2 & 0.195 & 0.226 \\
\hline $\mathrm{Al}$ & 1.671 & 1.669 & 1.709 & 1.698 & 1.757 & 1.724 & 1.839 & 1.715 & 1.717 & 1.745 & 1.716 & 1.771 & 1.715 & 1.742 & 1.784 & 1.793 & 1.715 & 1.731 & 1.746 & 1.70 \\
\hline $\mathrm{Fe} 2$ & 1.313 & 1.314 & 1.317 & 1.301 & 1.298 & 1.295 & 1.297 & 1.376 & 1.28 & 1.312 & 1.27 & 1.329 & 1.32 & 1.329 & 1.324 & 1.275 & 1.385 & 1.432 & 1.421 & 1.518 \\
\hline $\mathrm{Mn}$ & 0.002 & 0.002 & 0 & 0.001 & 0.002 & 0.002 & 0.003 & 0.002 & 0.002 & 0.003 & 0.002 & 0.001 & 0.002 & 0.002 & 0.001 & 0.003 & 0.001 & 0.003 & 0.001 & 0.00 \\
\hline $\mathrm{Mg}$ & 0.863 & 0.863 & 0.867 & 0.875 & 0.818 & 0.846 & 0.887 & 0.81 & 0.846 & 0.878 & 0.906 & 0.858 & 0.855 & 0.981 & 0.86 & 0.856 & 0.75 & 0.761 & 0.739 & 0.68 \\
\hline $\mathrm{Ca}$ & 0.00 & 0.00 & 0.00 & 0.00 & 0.00 & 0.00 & 0.00 & 0.00 & 0.00 & 0.00 & 0.00 & 0.00 & 0.00 & 0.00 & 0.00 & 0.00 & 0.00 & 0.00 & 0.00 & 0.00 \\
\hline $\mathrm{K}$ & 0.955 & 0.956 & 0.965 & 0.974 & 0.96 & 0.948 & 0.91 & 0.952 & 0.939 & 0.93 & 0.899 & 0.909 & 0.91 & 0.893 & 0.935 & 0.948 & 0.942 & 0.928 & 0.942 & 0.95 \\
\hline Sum & 7.731 & 7.732 & 7.756 & 7.753 & 7.739 & 7.724 & 7.767 & 7.757 & 7.715 & 7.745 & 7.72 & 7.757 & 7.72 & 7.795 & 7.753 & 7.744 & 7.716 & 7.748 & 7.738 & 7.76 \\
\hline $\mathrm{XMg}$ & 0.40 & 0.40 & 0.40 & 0.40 & 0.39 & 0.40 & 0.41 & 0.37 & 0.40 & 0.40 & 0.42 & 0.39 & 0.39 & 0.42 & 0.39 & 0.40 & 0.35 & 0.35 & 0.34 & 0.31 \\
\hline
\end{tabular}


Nappe Lima Duarte (Amostra OL-III-39A) BIOTITA

\begin{tabular}{|c|c|c|c|c|c|c|c|c|c|c|c|c|c|c|c|c|c|}
\hline $\mathrm{SiO} 2$ & 35.32 & 35.76 & 35.4 & 35.51 & 35.5 & 35.8 & 35.7 & 35.82 & 36.43 & 36.11 & 37.03 & 35.65 & 36.22 & 36.44 & 36.18 & 36.29 & 35.8 \\
\hline $\mathrm{TiO} 2$ & 2.86 & 2.95 & 2.7 & 2.66 & 2.83 & 2.86 & 2.68 & 2.75 & 2.72 & 3.02 & 2.92 & 2.43 & 3.37 & 2.79 & 3.12 & 2.36 & 2.47 \\
\hline $\mathrm{Al} 2 \mathrm{O} 3$ & 19.06 & 19.26 & 19.13 & 18.91 & 19.23 & 19.12 & 19.18 & 19.09 & 19.23 & 19.22 & 19.24 & 19.25 & 19.33 & 19.33 & 19.34 & 19.85 & 20.03 \\
\hline $\mathrm{FeO}$ & 17.02 & 17.31 & 17.01 & 17.3 & 17.14 & 17.23 & 17.26 & 17.08 & 17.16 & 17.44 & 15.13 & 17.65 & 16.21 & 16.66 & 16.42 & 14.96 & 16.13 \\
\hline $\mathrm{MnO}$ & 0.05 & 0.06 & 0.04 & 0.03 & 0.06 & 0.05 & 0.07 & 0.02 & 0.05 & 0.02 & 0.02 & 0.04 & 0.03 & 0.04 & 0.04 & 0.01 & 0.01 \\
\hline $\mathrm{MgO}$ & 10.88 & 10.66 & 10.4 & 10.68 & 10.73 & 10.82 & 10.69 & 10.66 & 10.84 & 10.73 & 10.5 & 10.4 & 10.53 & 10.82 & 11.24 & 11.95 & 11.17 \\
\hline $\mathrm{CaO}$ & 0 & 0 & 0.01 & 0.01 & 0 & 0 & 0 & 0 & 0.01 & 0 & 0.02 & 0.04 & 0 & 0.01 & 0.01 & 0.01 & 0 \\
\hline $\mathrm{Na} 2 \mathrm{O}$ & 0.17 & 0.17 & 0.16 & 0.18 & 0.19 & 0.18 & 0.21 & 0.18 & 0.19 & 0.17 & 0.04 & 0.19 & 0.24 & 0.19 & 0.22 & 0.23 & 0.24 \\
\hline $\mathrm{K} 2 \mathrm{O}$ & 9.31 & 9.5 & 9.41 & 9.35 & 9.26 & 9.34 & 9.36 & 9.52 & 9.36 & 9.38 & 9.4 & 9.27 & 9.29 & 9.34 & 9.36 & 9.41 & 9.52 \\
\hline Totals & 94.68 & 95.68 & 94.27 & 94.65 & 94.95 & 95.4 & 95.16 & 95.13 & 95.99 & 96.11 & 94.3 & 94.92 & 95.23 & 95.62 & 95.95 & 95.08 & 95.36 \\
\hline Si & 2.675 & 2.682 & 2.692 & 2.693 & 2.68 & 2.689 & 2.691 & 2.699 & 2.714 & 2.693 & 2.774 & 2.697 & 2.708 & 2.718 & 2.69 & 2.701 & 2.676 \\
\hline $\mathrm{Ti}$ & 0.163 & 0.166 & 0.154 & 0.152 & 0.161 & 0.162 & 0.152 & 0.156 & 0.153 & 0.169 & 0.164 & 0.138 & 0.189 & 0.157 & 0.175 & 0.132 & 0.139 \\
\hline $\mathrm{Al}$ & 1.702 & 1.703 & 1.715 & 1.691 & 1.711 & 1.694 & 1.704 & 1.696 & 1.689 & 1.69 & 1.699 & 1.717 & 1.704 & 1.699 & 1.695 & 1.742 & 1.765 \\
\hline Fe2 & 1.078 & 1.086 & 1.082 & 1.097 & 1.082 & 1.082 & 1.088 & 1.077 & 1.069 & 1.088 & 0.948 & 1.117 & 1.013 & 1.039 & 1.021 & 0.931 & 1.008 \\
\hline $\mathrm{Mn}$ & 0.003 & 0.004 & 0.003 & 0.002 & 0.004 & 0.003 & 0.004 & 0.001 & 0.003 & 0.001 & 0.001 & 0.003 & 0.002 & 0.002 & 0.003 & 0.001 & 0 \\
\hline $\mathrm{Mg}$ & 1.228 & 1.192 & 1.179 & 1.207 & 1.207 & 1.211 & 1.201 & 1.198 & 1.203 & 1.193 & 1.172 & 1.172 & 1.174 & 1.203 & 1.246 & 1.325 & 1.244 \\
\hline $\mathrm{Ca}$ & 0 & 0 & 0.001 & 0.001 & 0 & 0 & 0 & 0 & 0.001 & 0 & 0.002 & 0.003 & 0 & 0.001 & 0.001 & 0.001 & 0 \\
\hline $\mathrm{Na}$ & 0.025 & 0.025 & 0.024 & 0.027 & 0.028 & 0.026 & 0.031 & 0.027 & 0.027 & 0.025 & 0.006 & 0.028 & 0.035 & 0.027 & 0.032 & 0.034 & 0.034 \\
\hline $\mathrm{K}$ & 0.9 & 0.909 & 0.913 & 0.904 & 0.892 & 0.895 & 0.899 & 0.915 & 0.889 & 0.893 & 0.898 & 0.894 & 0.886 & 0.888 & 0.888 & 0.893 & 0.908 \\
\hline Sum & 7.774 & 7.767 & 7.765 & 7.775 & 7.764 & 7.764 & 7.771 & 7.769 & 7.748 & 7.752 & 7.664 & 7.769 & 7.712 & 7.734 & 7.749 & 7.76 & 7.775 \\
\hline XMg & 0.53 & 0.52 & 0.52 & 0.52 & 0.53 & 0.53 & 0.52 & 0.53 & 0.53 & 0.52 & 0.55 & 0.51 & 0.54 & 0.54 & 0.55 & 0.59 & 0.55 \\
\hline
\end{tabular}


Nappe Lima Duarte (Amostra OL-III-39A) BIOTITA

$\begin{array}{ccccccccccc}\mathrm{SiO} 2 & 36.52 & 36.47 & 36.07 & 36.31 & 36.34 & 35.7 & 36.22 & 36.31 & 35.45 & 35.41 \\ \mathrm{TiO} 2 & 2.62 & 2.12 & 2.69 & 2.71 & 2.17 & 3.04 & 2.79 & 3.06 & 2.95 & 2.84 \\ \mathrm{Al} 2 \mathrm{O} 3 & 19.51 & 20.04 & 19.28 & 19.55 & 19.89 & 19.67 & 19.63 & 19.66 & 19.75 & 18.98 \\ \mathrm{FeO} & 14.97 & 14.48 & 16.59 & 16.4 & 14.07 & 16.2 & 15.38 & 14.79 & 13.72 & 16.84 \\ \mathrm{MnO} & 0.01 & 0.03 & 0.02 & 0.02 & 0.02 & 0.05 & 0.02 & 0.03 & 0.02 & 0.07 \\ \mathrm{MgO} & 12.4 & 12.67 & 11.04 & 10.95 & 12.7 & 10.71 & 11.44 & 12.03 & 11.7 & 10.48 \\ \mathrm{CaO} & 0 & 0.04 & 0.02 & 0 & 0 & 0.01 & 0.01 & 0 & 0.02 & 0.02 \\ \mathrm{Na} 2 \mathrm{O} & 0.32 & 0.33 & 0.22 & 0.16 & 0.32 & 0.24 & 0.24 & 0.25 & 0.18 & 0.21 \\ \mathrm{~K} 2 \mathrm{O} & 9.21 & 9.09 & 9.12 & 9.44 & 9.28 & 9.5 & 9.3 & 9.37 & 9.62 & 9.16 \\ \mathrm{Totals} & 95.57 & 95.27 & 95.06 & 95.55 & 94.81 & 95.14 & 95.04 & 95.52 & 93.41 & 94.02 \\ \mathrm{Si} & 2.702 & 2.697 & 2.705 & 2.708 & 2.7 & 2.678 & 2.702 & 2.689 & 2.68 & 2.696 \\ \mathrm{Ti} & 0.146 & 0.118 & 0.152 & 0.152 & 0.121 & 0.172 & 0.157 & 0.171 & 0.168 & 0.162 \\ \mathrm{Al} & 1.702 & 1.747 & 1.705 & 1.719 & 1.742 & 1.74 & 1.727 & 1.716 & 1.76 & 1.704 \\ \mathrm{Fe} 2 & 0.926 & 0.896 & 1.041 & 1.023 & 0.874 & 1.017 & 0.96 & 0.916 & 0.867 & 1.072 \\ \mathrm{Mn} & 0.001 & 0.002 & 0.001 & 0.001 & 0.001 & 0.003 & 0.001 & 0.002 & 0.001 & 0.004 \\ \mathrm{Mg} & 1.368 & 1.396 & 1.233 & 1.217 & 1.406 & 1.198 & 1.272 & 1.328 & 1.318 & 1.189 \\ \mathrm{Ca} & 0 & 0.003 & 0.002 & 0 & 0 & 0.001 & 0.001 & 0 & 0.001 & 0.001 \\ \mathrm{Na} & 0.046 & 0.048 & 0.033 & 0.023 & 0.046 & 0.035 & 0.035 & 0.036 & 0.026 & 0.031 \\ \mathrm{~K} & 0.869 & 0.858 & 0.872 & 0.898 & 0.879 & 0.909 & 0.885 & 0.886 & 0.928 & 0.89 \\ \mathrm{Sum} & 7.76 & 7.765 & 7.744 & 7.742 & 7.771 & 7.753 & 7.739 & 0.744 & 7.749 & 7.75 \\ \mathrm{XMg} & 0.60 & 0.61 & 0.54 & 0.54 & 0.62 & 0.54 & 0.57 & 0.59 & 0.60 & 0.53 \\ & & & & & & & & & & \end{array}$


Nappe Lima Duarte (Amostra OL-III-39A)

BIOTITA

$\begin{array}{ccccccccccc}\mathrm{SiO} 2 & 36.52 & 36.47 & 36.07 & 36.31 & 36.34 & 35.7 & 36.22 & 36.31 & 35.45 & 35.41 \\ \mathrm{TiO} 2 & 2.62 & 2.12 & 2.69 & 2.71 & 2.17 & 3.04 & 2.79 & 3.06 & 2.95 & 2.84 \\ \mathrm{Al} 2 \mathrm{O} 3 & 19.51 & 20.04 & 19.28 & 19.55 & 19.89 & 19.67 & 19.63 & 19.66 & 19.75 & 18.98 \\ \mathrm{FeO} & 14.97 & 14.48 & 16.59 & 16.4 & 14.07 & 16.2 & 15.38 & 14.79 & 13.72 & 16.84 \\ \mathrm{MnO} & 0.01 & 0.03 & 0.02 & 0.02 & 0.02 & 0.05 & 0.02 & 0.03 & 0.02 & 0.07 \\ \mathrm{MgO} & 12.4 & 12.67 & 11.04 & 10.95 & 12.7 & 10.71 & 11.44 & 12.03 & 11.7 & 10.48 \\ \mathrm{CaO} & 0 & 0.04 & 0.02 & 0 & 0 & 0.01 & 0.01 & 0 & 0.02 & 0.02 \\ \mathrm{Na} 2 \mathrm{O} & 0.32 & 0.33 & 0.22 & 0.16 & 0.32 & 0.24 & 0.24 & 0.25 & 0.18 & 0.21 \\ \mathrm{~K} 2 \mathrm{O} & 9.21 & 9.09 & 9.12 & 9.44 & 9.28 & 9.5 & 9.3 & 9.37 & 9.62 & 9.16 \\ \mathrm{Totals} & 95.57 & 95.27 & 95.06 & 95.55 & 94.81 & 95.14 & 95.04 & 95.52 & 93.41 & 94.02 \\ \mathrm{Si} & 2.702 & 2.697 & 2.705 & 2.708 & 2.7 & 2.678 & 2.702 & 2.689 & 2.68 & 2.696 \\ \mathrm{Ti} & 0.146 & 0.118 & 0.152 & 0.152 & 0.121 & 0.172 & 0.157 & 0.171 & 0.168 & 0.162 \\ \mathrm{Al} & 1.702 & 1.747 & 1.705 & 1.719 & 1.742 & 1.74 & 1.727 & 1.716 & 1.76 & 1.704 \\ \mathrm{Fe} 2 & 0.926 & 0.896 & 1.041 & 1.023 & 0.874 & 1.017 & 0.96 & 0.916 & 0.867 & 1.072 \\ \mathrm{Mn} & 0.001 & 0.002 & 0.001 & 0.001 & 0.001 & 0.003 & 0.001 & 0.002 & 0.001 & 0.004 \\ \mathrm{Mg} & 1.368 & 1.396 & 1.233 & 1.217 & 1.406 & 1.198 & 1.272 & 1.328 & 1.318 & 1.189 \\ \mathrm{Ca} & 0 & 0.003 & 0.002 & 0 & 0 & 0.001 & 0.001 & 0 & 0.001 & 0.001 \\ \mathrm{Na} & 0.046 & 0.048 & 0.033 & 0.023 & 0.046 & 0.035 & 0.035 & 0.036 & 0.026 & 0.031 \\ \mathrm{~K} & 0.869 & 0.858 & 0.872 & 0.898 & 0.879 & 0.909 & 0.885 & 0.886 & 0.928 & 0.89 \\ \mathrm{Sum} & 7.76 & 7.765 & 7.744 & 7.742 & 7.771 & 7.753 & 7.739 & 7.744 & 7.749 & 7.75 \\ \mathrm{XMg} & 0.60 & 0.61 & 0.54 & 0.54 & 0.62 & 0.54 & 0.57 & 0.59 & 0.60 & 0.53\end{array}$

\section{Nappe Lima Duarte (Amostra OL-II-112B) RUTILO}

$\begin{array}{ccccccccccc} & \text { Rt5 - 1 } & \text { Rt5 - 2 } & \text { Rt12 - 3 } & \text { Rt12 - 4 } & \text { Rt7 - 5 } & \text { Rt7 - 6 } & \text { Rt7 - 7 } & \text { Rt9 - 8 } & \text { Rt9- 9 } & \text { Rt9 - 10 } \\ \text { TiO2 } & 97.432 & 97.785 & 96.135 & 97.259 & 98.559 & 97.558 & 99.446 & 98.684 & 89.557 & 95.562 \\ \mathrm{SiO} 2 & 0.009 & 0.006 & 0.013 & 0.052 & 0.009 & 0.016 & 0.02 & 0.019 & 0.023 & 0.037 \\ \mathrm{Cr} 2 \mathrm{O} 3 & 0.063 & 0.066 & 0.072 & 0.069 & 0.098 & 0.098 & 0.101 & 0.107 & 0.072 & 0.087 \\ \mathrm{Al2O} 3 & 0.098 & 0.11 & 0.091 & 0.138 & 0.087 & 0.1 & 0.107 & 0.077 & 8.39 & 0.081 \\ \mathrm{Nb} 2 \mathrm{O} 5 & 0.37 & 0.398 & 0.377 & 0.372 & 0.472 & 0.479 & 0.488 & 0.354 & 0.35 & 0.328 \\ \mathrm{FeO} & 0.687 & 0.545 & 0.599 & 0.732 & 0.698 & 0.714 & 0.913 & 0.706 & 1.234 & 1.448 \\ \mathrm{~V} 2 \mathrm{O} 5 & 0.402 & 0.41 & 0.44 & 0.432 & 0.55 & 0.545 & 0.521 & 0.463 & 0.436 & 0.444 \\ \text { ZrO2 } & 0.044 & 0.036 & 0.054 & 0.039 & 0.117 & 0.114 & 0.115 & 0.096 & 0.123 & 0.104 \\ \text { Total } & 99.106 & 99.357 & 97.78 & 99.093 & 100.591 & 99.624 & 101.71 & 100.506 & 100.185 & 98.091\end{array}$

Rt9 - 11 Rt11 - 12 Rt14 - 13 Rt14 -14 Rt13 -15 Rt19 - 16 Rt19 - 17

$\begin{array}{cccccccc}\mathrm{TiO} 2 & 96.5 & 97.139 & 94.909 & 95.55 & 98.501 & 94.879 & 94.548 \\ \mathrm{SiO} 2 & 0.036 & 0.022 & 0.025 & 0.012 & 0.021 & 0.017 & 0.007 \\ \mathrm{Cr} 2 \mathrm{O} 3 & 0.075 & 0.075 & 0.064 & 0.089 & 0.085 & 0.045 & 0.073 \\ \mathrm{Al} 2 \mathrm{O} 3 & 0.101 & 0.064 & 0.116 & 0.093 & 0.101 & 0.078 & 0.097 \\ \mathrm{Nb} 2 \mathrm{O} 5 & 0.335 & 0.328 & 0.405 & 0.509 & 0.424 & 0.331 & 0.389 \\ \mathrm{FeO} & 1.302 & 0.877 & 1.112 & 0.746 & 1.032 & 0.674 & 0.532 \\ \mathrm{~V} 2 \mathrm{O} 5 & 0.437 & 0.547 & 0.453 & 0.439 & 0.393 & 0.378 & 0.398 \\ \mathrm{ZrO} 2 & 0.109 & 0.046 & 0.123 & 0.066 & 0.031 & 0.044 & 0.043 \\ \text { Total } & 98.896 & 99.098 & 97.208 & 97.505 & 100.589 & 96.446 & 96.087\end{array}$

Nappe Lima Duarte (Amostra OL-III-39A) RUTILO

$\begin{array}{ccllll} & \mathrm{Rt}-1 & \mathrm{Rt} 22-2 & \mathrm{Rt} 20-3 & \mathrm{Rt} 20-4 & \mathrm{Rt} 1-5 \\ \mathrm{TiO} 2 & 94.502 & 97.088 & 94.752 & 98.642 & 96.469 \\ \mathrm{SiO} 2 & 0.028 & 0.038 & 0.024 & 0.017 & 0.024 \\ \mathrm{Cr} 2 \mathrm{O} 3 & 0.078 & 0.059 & 0.292 & 0.289 & 0.062 \\ \mathrm{Al2O} 3 & 0.099 & 0.083 & 0.097 & 0.082 & 0.082 \\ \mathrm{Nb} 2 \mathrm{O} 5 & 0.557 & 0.437 & 1.244 & 1.222 & 1.106 \\ \mathrm{FeO} & 0.791 & 0.608 & 0.785 & 0.901 & 0.998 \\ \mathrm{~V} 2 \mathrm{O} 5 & 0.591 & 0.535 & 0.568 & 0.531 & 0.544 \\ \text { ZrO2 } & 0.045 & 0.063 & 0.044 & 0.039 & 0.051 \\ \text { Total } & 96.691 & 98.911 & 97.807 & 101.725 & 99.335\end{array}$




\section{QUÍMICA MINERAL DAS ROCHAS METABÁSICAS}

\section{Amostras NLD-7D, NLD-20A, NLD-42C e NLD-42D}

\section{(Granada, feldspato, ortopiroxênio, clinopiroxênio, anfibólio)}


Complexo Mantiqueira - Rochas metabásicas (Amostra NLD-7D)

\section{GRANADA}

\begin{tabular}{|c|c|c|c|c|c|c|c|c|c|c|c|c|c|c|}
\hline NLD7D & NLD7D & NLD7D & NLD7D & NLD7D & NLD7D & NLD7D & NLD7D & NLD7D & NLD7D & NLD7D & NLD7D & NLD7D & NLD7D & NLD7D \\
\hline 37.7 & 37.79 & 38.13 & 37.68 & 37.7 & 37.6 & 37.66 & 38.14 & 37.25 & 37.59 & 37.55 & 37.76 & 37.39 & 37.97 & 37.71 \\
\hline 0.03 & 0.07 & 0.05 & 0.09 & 0.01 & 0.04 & 0.01 & 0 & 0.03 & 0.05 & 0.03 & 0.05 & 0.07 & 0.01 & 0.01 \\
\hline 21.4 & 21.54 & 21.39 & 21.36 & 21.8 & 21.36 & 21.64 & 21.71 & 21.67 & 21.4 & 21.87 & 21.51 & 21.43 & 21.75 & 21.8 \\
\hline 0.51 & 0.89 & 0.21 & 0.87 & 1.55 & 0.78 & 0.03 & 0 & 1.17 & 2.38 & 0.84 & 0.83 & 1.08 & 0.86 & 1.18 \\
\hline 27.82 & 27.81 & 28.29 & 27.72 & 27.45 & 27.18 & 27.56 & 26.96 & 27.17 & 27.38 & 27.56 & 27.38 & 27.18 & 27.91 & 27.51 \\
\hline 2.03 & 2.17 & 2.1 & 2.22 & 2.12 & 2.05 & 2.26 & 2.18 & 2.08 & 2.19 & 2.18 & 2.36 & 2.19 & 2.15 & 2.23 \\
\hline 3.65 & 3.56 & 3.62 & 3.49 & 3.56 & 3.67 & 3.43 & 3.61 & 3.56 & 3.52 & 3.42 & 3.53 & 3.58 & 3.55 & 3.49 \\
\hline 6.81 & 6.95 & 6.85 & 6.98 & 7.14 & 7.18 & 7.08 & 7.19 & 6.98 & 7.1 & 7.08 & 7.13 & 7.03 & 7.02 & 7.1 \\
\hline 99.95 & 100.79 & 100.65 & 100.43 & 101.33 & 99.87 & 99.66 & 99.79 & 99.92 & 101.63 & 100.54 & 100.55 & 99.96 & 101.21 & 101.03 \\
\hline 12 & 12 & 12 & 12 & 12 & 12 & 12 & 12 & 12 & 12 & 12 & 12 & 12 & 12 & 12 \\
\hline 2.984 & 2.971 & 2.999 & 2.974 & 2.949 & 2.977 & 2.987 & 3.008 & 2.951 & 2.94 & 2.958 & 2.974 & 2.962 & 2.971 & 2.957 \\
\hline 0.002 & 0.004 & 0.003 & 0.006 & 0.001 & 0.002 & 0 & 0 & 0.002 & 0.003 & 0.002 & 0.003 & 0.004 & 0 & 0 \\
\hline 1.998 & 1.996 & 1.983 & 1.988 & 2.01 & 1.994 & 2.024 & 2.019 & 2.024 & 1.974 & 2.031 & 1.997 & 2.002 & 2.007 & 2.015 \\
\hline 0.03 & 0.053 & 0.013 & 0.052 & 0.091 & 0.046 & 0.002 & 0 & 0.07 & 0.14 & 0.05 & 0.049 & 0.064 & 0.051 & 0.069 \\
\hline 1.842 & 1.828 & 1.861 & 1.83 & 1.795 & 1.8 & 1.829 & 1.778 & 1.8 & 1.791 & 1.815 & 1.803 & 1.801 & 1.826 & 1.804 \\
\hline 0.136 & 0.145 & 0.14 & 0.148 & 0.14 & 0.138 & 0.152 & 0.146 & 0.139 & 0.145 & 0.145 & 0.158 & 0.147 & 0.142 & 0.148 \\
\hline 0.431 & 0.417 & 0.424 & 0.411 & 0.415 & 0.433 & 0.405 & 0.424 & 0.421 & 0.411 & 0.402 & 0.414 & 0.422 & 0.414 & 0.408 \\
\hline 0.578 & 0.586 & 0.578 & 0.591 & 0.599 & 0.61 & 0.602 & 0.608 & 0.593 & 0.596 & 0.598 & 0.603 & 0.597 & 0.589 & 0.597 \\
\hline 8 & 8 & 8 & 8 & 8 & 8 & 8 & 7.983 & 8 & 8 & 8 & 8 & 8 & 8 & 8 \\
\hline 61.67 & 61.42 & 61.97 & 61.41 & 60.87 & 60.38 & 61.21 & 60.15 & 60.95 & 60.86 & 61.32 & 60.54 & 60.70 & 61.46 & 61.01 \\
\hline 14.43 & 14.01 & 14.12 & 13.79 & 14.07 & 14.53 & 13.55 & 14.34 & 14.26 & 13.97 & 13.58 & 13.90 & 14.22 & 13.93 & 13.80 \\
\hline 19.35 & 19.69 & 19.25 & 19.83 & 20.31 & 20.46 & 20.15 & 20.57 & 20.08 & 20.25 & 20.20 & 20.25 & 20.12 & 19.82 & 20.19 \\
\hline 4.55 & 4.87 & 4.66 & 4.97 & 4.75 & 4.63 & 5.09 & 4.94 & 4.71 & 4.93 & 4.90 & 5.31 & 4.95 & 4.78 & 5.01 \\
\hline
\end{tabular}


Complexo Mantiqueira - Rochas metabásicas (Amostra NLD-7D)

\section{GRANADA}

\begin{tabular}{|c|c|c|c|c|c|c|c|c|c|c|c|c|c|c|}
\hline NLD7D & NLD7D & NLD7D & NLD7D & NLD7D & NLD7D & NLD7D & NLD7D & NLD7D & NLD7D & NLD7D & NLD7D & NLD7D & NLD7D & NLD7D \\
\hline 37.69 & 37.41 & 37.81 & 37.73 & 37.54 & 37.88 & 37.86 & 37.6 & 38.19 & 37.67 & 37.54 & 37.97 & 37.82 & 37.45 & 37.81 \\
\hline 0.09 & 0.07 & 0.01 & 0.03 & 0 & 0.02 & 0.02 & 0.03 & 0 & 0.06 & 0.04 & 0.01 & 0.01 & 0.03 & 0.08 \\
\hline 21.71 & 21.29 & 21.73 & 21.49 & 21.62 & 21.91 & 21.67 & 21.86 & 21.87 & 21.7 & 21.77 & 21.6 & 21.63 & 21.47 & 21.81 \\
\hline 1.15 & 0.28 & 0.82 & 1.45 & 1.15 & 0.66 & 0.06 & 0.57 & 0 & 1.16 & 0.99 & 0.79 & 0.23 & 0 & 0 \\
\hline 27.7 & 27.11 & 26.97 & 27.68 & 27.59 & 28.3 & 27.86 & 27.66 & 28.09 & 26.49 & 26.78 & 27.57 & 27.64 & 26.81 & 27.07 \\
\hline 2.09 & 2.17 & 2.2 & 2.19 & 2.24 & 2.35 & 2.12 & 2.24 & 2.3 & 2.01 & 1.91 & 2.17 & 2.09 & 2.16 & 2.1 \\
\hline 3.5 & 3.63 & 3.72 & 3.45 & 3.39 & 3.29 & 3.63 & 3.51 & 3.47 & 4.15 & 4.04 & 3.68 & 3.66 & 3.54 & 3.58 \\
\hline 7.09 & 7.05 & 7.33 & 7.1 & 7.02 & 6.84 & 6.88 & 6.87 & 6.85 & 7.16 & 7.03 & 7.1 & 6.98 & 7.2 & 7.17 \\
\hline 101.03 & 99.01 & 100.61 & 101.12 & 100.55 & 101.26 & 100.1 & 100.35 & 100.78 & 100.41 & 100.11 & 100.89 & 100.06 & 98.66 & 99.64 \\
\hline 12 & 12 & 12 & 12 & 12 & 12 & 12 & 12 & 12 & 12 & 12 & 12 & 12 & 12 & 12 \\
\hline 2.956 & 2.986 & 2.969 & 2.961 & 2.961 & 2.967 & 2.988 & 2.965 & 2.995 & 2.958 & 2.957 & 2.977 & 2.986 & 2.993 & 2.99 \\
\hline 0.005 & 0.004 & 0.001 & 0.002 & 0 & 0.001 & 0.001 & 0.002 & 0 & 0.003 & 0.002 & 0.001 & 0.001 & 0.002 & 0.005 \\
\hline 2.008 & 2.003 & 2.012 & 1.989 & 2.011 & 2.024 & 2.017 & 2.033 & 2.022 & 2.008 & 2.022 & 1.997 & 2.013 & 2.022 & 2.033 \\
\hline 0.068 & 0.017 & 0.049 & 0.085 & 0.068 & 0.039 & 0.003 & 0.034 & 0 & 0.069 & 0.059 & 0.046 & 0.014 & 0 & 0 \\
\hline 1.818 & 1.809 & 1.771 & 1.817 & 1.82 & 1.854 & 1.84 & 1.824 & 1.842 & 1.739 & 1.764 & 1.808 & 1.825 & 1.792 & 1.79 \\
\hline 0.139 & 0.146 & 0.147 & 0.146 & 0.149 & 0.156 & 0.142 & 0.15 & 0.153 & 0.134 & 0.127 & 0.144 & 0.14 & 0.146 & 0.141 \\
\hline 0.409 & 0.431 & 0.435 & 0.403 & 0.398 & 0.384 & 0.427 & 0.412 & 0.406 & 0.486 & 0.475 & 0.43 & 0.431 & 0.422 & 0.422 \\
\hline 0.597 & 0.603 & 0.617 & 0.597 & 0.594 & 0.575 & 0.583 & 0.581 & 0.576 & 0.603 & 0.594 & 0.597 & 0.591 & 0.617 & 0.608 \\
\hline 8 & 8 & 8 & 8 & 8 & 8 & 8 & 8 & 7.994 & 8 & 8 & 8 & 8 & 7.994 & 7.989 \\
\hline 61.36 & 60.52 & 59.63 & 61.32 & 61.47 & 62.45 & 61.50 & 61.48 & 61.87 & 58.71 & 59.59 & 60.69 & 61.10 & 60.19 & 60.45 \\
\hline 13.80 & 14.42 & 14.65 & 13.60 & 13.44 & 12.93 & 14.27 & 13.89 & 13.64 & 16.41 & 16.05 & 14.43 & 14.43 & 14.18 & 14.25 \\
\hline 20.15 & 20.17 & 20.77 & 20.15 & 20.06 & 19.37 & 19.49 & 19.58 & 19.35 & 20.36 & 20.07 & 20.04 & 19.79 & 20.73 & 20.53 \\
\hline 4.69 & 4.88 & 4.95 & 4.93 & 5.03 & 5.25 & 4.75 & 5.06 & 5.14 & 4.52 & 4.29 & 4.83 & 4.69 & 4.90 & 4.76 \\
\hline
\end{tabular}




\section{Complexo Mantiqueira - Rochas metabásicas (Amostra NLD-7D)}

\section{GRANADA}

\begin{tabular}{|c|c|c|c|c|c|c|c|c|c|c|c|c|c|c|}
\hline NLD7D & NLD7D & NLD7D & NLD7D & NLD7D & NLD7D & NLD7D & NLD7D & NLD7D & NLD7D & NLD7D & NLD7D & NLD7D & NLD7D & NLD7D \\
\hline 38.21 & 37.79 & 35.51 & 37.22 & 37.9 & 37.61 & 38.14 & 37.9 & 37.43 & 37.69 & 37.72 & 37.99 & 37.6 & 37.78 & 37.3 \\
\hline 0 & 0.04 & 0.01 & 0.05 & 0.04 & 0.12 & 0.08 & 0.08 & 0.11 & 0.03 & 0.07 & 0.06 & 0.08 & 0.01 & 0.08 \\
\hline 21.93 & 21.82 & 22.44 & 21.28 & 21.69 & 21.69 & 21.53 & 21.57 & 21.82 & 21.27 & 21.48 & 21.57 & 21.38 & 21.74 & 21.6 \\
\hline 0 & 0.74 & 3.05 & 1.21 & 0.75 & 1.38 & 1.32 & 0.53 & 0.57 & 0 & 1.2 & 0.47 & 0.34 & 0.15 & 0 \\
\hline 28.05 & 27.41 & 25.08 & 26.73 & 27.57 & 26.72 & 27.12 & 27.35 & 26.76 & 26.55 & 27.15 & 27.93 & 27.5 & 28.02 & 27.48 \\
\hline 2.23 & 2.24 & 2.2 & 2.14 & 2.17 & 1.99 & 2.16 & 1.95 & 2.13 & 2.14 & 2.06 & 2.08 & 2.23 & 2.25 & 2.12 \\
\hline 3.48 & 3.57 & 3.44 & 3.61 & 3.61 & 3.75 & 3.64 & 3.77 & 3.75 & 3.57 & 3.65 & 3.55 & 3.38 & 3.52 & 3.41 \\
\hline 7.11 & 7.17 & 7.04 & 7.2 & 7.14 & 7.53 & 7.71 & 7.3 & 7.23 & 7.69 & 7.35 & 7.11 & 7.22 & 6.72 & 6.76 \\
\hline 101.02 & 100.78 & 98.78 & 99.45 & 100.88 & 100.8 & 101.7 & 100.46 & 99.8 & 98.94 & 100.69 & 100.76 & 99.73 & 100.2 & 98.74 \\
\hline 12 & 12 & 12 & 12 & 12 & 12 & 12 & 12 & 12 & 12 & 12 & 12 & 12 & 12 & 12 \\
\hline 2.99 & 2.966 & 2.847 & 2.962 & 2.972 & 2.95 & 2.969 & 2.98 & 2.959 & 3.003 & 2.965 & 2.984 & 2.984 & 2.983 & 2.983 \\
\hline 0 & 0.002 & 0.001 & 0.003 & 0.002 & 0.007 & 0.005 & 0.005 & 0.007 & 0.002 & 0.004 & 0.004 & 0.005 & 0.001 & 0.005 \\
\hline 2.023 & 2.019 & 2.121 & 1.997 & 2.005 & 2.005 & 1.976 & 1.999 & 2.034 & 1.998 & 1.99 & 1.997 & 2.001 & 2.024 & 2.037 \\
\hline 0 & 0.043 & 0.184 & 0.073 & 0.044 & 0.081 & 0.077 & 0.031 & 0.034 & 0 & 0.071 & 0.028 & 0.02 & 0.009 & 0 \\
\hline 1.836 & 1.799 & 1.681 & 1.779 & 1.808 & 1.752 & 1.765 & 1.798 & 1.769 & 1.769 & 1.785 & 1.835 & 1.825 & 1.851 & 1.838 \\
\hline 0.148 & 0.149 & 0.149 & 0.144 & 0.144 & 0.132 & 0.143 & 0.13 & 0.142 & 0.144 & 0.137 & 0.138 & 0.15 & 0.15 & 0.144 \\
\hline 0.405 & 0.418 & 0.411 & 0.428 & 0.422 & 0.439 & 0.423 & 0.442 & 0.442 & 0.424 & 0.428 & 0.416 & 0.4 & 0.414 & 0.407 \\
\hline 0.597 & 0.603 & 0.605 & 0.614 & 0.601 & 0.634 & 0.643 & 0.616 & 0.613 & 0.657 & 0.62 & 0.599 & 0.615 & 0.569 & 0.58 \\
\hline 7.999 & 8 & 8 & 8 & 8 & 8 & 8 & 8 & 8 & 7.997 & 8 & 8 & 8 & 8 & 7.993 \\
\hline 61.49 & 60.59 & 59.07 & 60.00 & 60.77 & 59.25 & 59.35 & 60.21 & 59.64 & 59.08 & 60.10 & 61.41 & 61.04 & 62.03 & 61.91 \\
\hline 13.56 & 14.08 & 14.44 & 14.44 & 14.18 & 14.85 & 14.22 & 14.80 & 14.90 & 14.16 & 14.41 & 13.92 & 13.38 & 13.87 & 13.71 \\
\hline 19.99 & 20.31 & 21.26 & 20.71 & 20.20 & 21.44 & 21.62 & 20.63 & 20.67 & 21.94 & 20.88 & 20.05 & 20.57 & 19.07 & 19.54 \\
\hline 4.96 & 5.02 & 5.24 & 4.86 & 4.84 & 4.46 & 4.81 & 4.35 & 4.79 & 4.81 & 4.61 & 4.62 & 5.02 & 5.03 & 4.85 \\
\hline
\end{tabular}


Complexo Mantiqueira - Rochas metabásicas (Amostra NLD-7D)

GRANADA

$\begin{array}{ccccccccccc}\text { NLD7D } & \text { NLD7D } & \text { NLD7D } & \text { NLD7D } & \text { NLD7D } & \text { NLD7D } & \text { NLD7D } & \text { NLD7D } & \text { NLD7D } & \text { NLD7D } & \text { NLD7D } \\ & & & & & & & & & & \\ 38.01 & 37.77 & 38.16 & 37.65 & 38.69 & 38.06 & 37.71 & 38.27 & 38.27 & 38.28 & 37.48 \\ 0 & 0.16 & 0.02 & 0.08 & 0 & 0.08 & 0.04 & 0.08 & 0.09 & 0.03 & 0.07 \\ 21.99 & 21.78 & 21.68 & 21.59 & 21.91 & 22.29 & 21.7 & 21.98 & 22.02 & 21.8 & 21.63 \\ 0.31 & 0.12 & 0.51 & 0.49 & 0.13 & 0 & 0.58 & 0 & 0 & 0 & 0.52 \\ 28.36 & 27.8 & 28.39 & 27.88 & 29.15 & 28.41 & 27.62 & 27.81 & 27.84 & 28.3 & 27.49 \\ 2.23 & 2.36 & 2.3 & 2.27 & 2.43 & 2.35 & 2.17 & 2.28 & 2.4 & 2.27 & 2.2 \\ 3.49 & 3.46 & 3.54 & 3.54 & 3.33 & 3.11 & 3.49 & 3.36 & 3.5 & 3.38 & 3.27 \\ 6.72 & 6.99 & 6.72 & 6.71 & 6.8 & 6.87 & 7.1 & 7.02 & 6.85 & 6.98 & 7.29 \\ 101.12 & 100.44 & 101.33 & 100.21 & 102.45 & 101.19 & 100.4 & 100.81 & 100.98 & 101.04 & 99.96 \\ 12 & 12 & 12 & 12 & 12 & 12 & 12 & 12 & 12 & 12 & 12 \\ & & & & & & & & & & \\ 2.976 & 2.975 & 2.984 & 2.975 & 2.996 & 2.977 & 2.972 & 2.997 & 2.992 & 2.997 & 2.97 \\ 0 & 0.01 & 0.001 & 0.005 & 0 & 0.005 & 0.002 & 0.005 & 0.005 & 0.002 & 0.004 \\ 2.03 & 2.023 & 1.999 & 2.011 & 2 & 2.055 & 2.017 & 2.029 & 2.029 & 2.012 & 2.02 \\ 0.018 & 0.007 & 0.03 & 0.029 & 0.008 & 0 & 0.034 & 0 & 0 & 0 & 0.031 \\ 1.857 & 1.832 & 1.857 & 1.842 & 1.888 & 1.858 & 1.82 & 1.821 & 1.821 & 1.853 & 1.821 \\ 0.148 & 0.157 & 0.152 & 0.152 & 0.16 & 0.156 & 0.145 & 0.151 & 0.159 & 0.15 & 0.147 \\ 0.407 & 0.406 & 0.413 & 0.417 & 0.384 & 0.363 & 0.41 & 0.392 & 0.408 & 0.395 & 0.386 \\ 0.564 & 0.59 & 0.564 & 0.569 & 0.565 & 0.577 & 0.6 & 0.59 & 0.575 & 0.586 & 0.62 \\ 8 & 8 & 8 & 8 & 8 & 7.99 & 8 & 7.984 & 7.989 & 7.995 & 8 \\ 62.40 & 61.37 & 62.19 & 61.81 & 63.00 & 62.90 & 61.18 & 61.65 & 61.46 & 62.10 & 61.23 \\ 13.68 & 13.60 & 13.83 & 13.99 & 12.81 & 12.29 & 13.78 & 13.27 & 13.77 & 13.24 & 12.98 \\ 18.95 & 19.77 & 18.89 & 19.09 & 18.85 & 19.53 & 20.17 & 19.97 & 19.41 & 19.64 & 20.85 \\ 4.97 & 5.26 & 5.09 & 5.10 & 5.34 & 5.28 & 4.87 & 5.11 & 5.37 & 5.03 & 4.94\end{array}$

\section{Complexo Mantiqueira - Rochas metabásicas (Amostra NLD-20A) GRANADA}

Sample NLD20A NLD20A NLD20A NLD20A NLD20A NLD20A NLD20A

$\begin{array}{cccccccc}\mathrm{SiO} 2 & 38.04 & 37.35 & 37.93 & 37.52 & 38.43 & 34.77 & 37.71 \\ \mathrm{TiO} 2 & 0.04 & 0.02 & 0.05 & 0.01 & 0.05 & 0 & 0.03 \\ \mathrm{Al} 2 \mathrm{O} 3 & 21.69 & 21.72 & 21.95 & 21.81 & 21.69 & 26.44 & 21.61 \\ \mathrm{Fe} 2 \mathrm{O} 3 & 0.12 & 0 & 0 & 0 & 0 & 0.2 & 0 \\ \mathrm{FeO} & 27.31 & 26.3 & 26.52 & 26.89 & 25.62 & 24.61 & 26.57 \\ \mathrm{MnO} & 1.86 & 2.35 & 2.32 & 2.55 & 2.35 & 2.59 & 2.64 \\ \mathrm{MgO} & 3.57 & 3.32 & 3.19 & 3.16 & 3.04 & 2.76 & 3.04 \\ \mathrm{CaO} & 7.78 & 7.58 & 8.02 & 7.28 & 8.75 & 7.36 & 8.15 \\ \mathrm{Totals} & 100.4 & 98.65 & 99.99 & 99.22 & 99.93 & 98.73 & 99.76 \\ & & & & & & & \\ \mathrm{Si} & & & & & & & \\ \mathrm{Ti} & 2.989 & 2.984 & 2.99 & 2.986 & 3.022 & 2.758 & 2.989 \\ \mathrm{Al} & 0.002 & 0.001 & 0.003 & 0.001 & 0.003 & 0 & 0.002 \\ \mathrm{Fe} 3 & 2.009 & 2.046 & 2.039 & 2.046 & 2.011 & 2.472 & 2.019 \\ \mathrm{Fe} 2 & 0.007 & 0 & 0 & 0 & 0 & 0.012 & 0.001 \\ \mathrm{Mn} & 1.795 & 1.757 & 1.748 & 1.79 & 1.685 & 1.632 & 1.76 \\ \mathrm{Mg} & 0.124 & 0.159 & 0.155 & 0.172 & 0.156 & 0.174 & 0.177 \\ \mathrm{Ca} & 0.418 & 0.395 & 0.375 & 0.374 & 0.356 & 0.326 & 0.36 \\ \mathrm{Sum} & 0.656 & 0.649 & 0.678 & 0.621 & 0.738 & 0.626 & 0.692 \\ \mathrm{Alm} & 7.993 & 7.991 & 7.988 & 7.99 & 7.97 & 8 & 8 \\ \mathrm{Prp} & 59.97 & 59.36 & 59.13 & 60.53 & 57.41 & 59.17 & 58.88 \\ \mathrm{Grs} & 13.97 & 13.34 & 12.69 & 12.65 & 12.13 & 11.82 & 12.04 \\ \mathrm{Sps} & 21.92 & 21.93 & 22.94 & 21.00 & 25.14 & 22.70 & 23.15 \\ \mathrm{Ha} & 4.14 & 5.37 & 5.24 & 5.82 & 5.32 & 6.31 & 5.92\end{array}$




\section{Complexo Mantiqueira - Rochas metabásicas (Amostra NLD-20A)}

\section{GRANADA}

\begin{tabular}{|c|c|c|c|c|c|c|c|c|c|c|c|c|c|c|}
\hline NLD20A & NLD20A & NLD20A & NLD20A & NLD20A & NLD20A & NLD20A & NLD20A & NLD20A & NLD20A & NLD20A & NLD20A & NLD20A & NLD20A & NLD20A \\
\hline 37.84 & 37.75 & 37.75 & 37.81 & 37.75 & 37.94 & 37.47 & 37.87 & 39.29 & 37.38 & 37.89 & 40.08 & 37.01 & 46.23 & 37.44 \\
\hline 0 & 0.03 & 0.06 & 0 & 0.03 & 0 & 0.03 & 0.06 & 0.07 & 0 & 0.05 & 0.01 & 0.03 & 0 & 0.03 \\
\hline 22.01 & 21.86 & 21.92 & 21.73 & 21.67 & 21.63 & 21.77 & 21.43 & 21.27 & 21.65 & 21.66 & 20.86 & 24.09 & 19.83 & 21.62 \\
\hline 0 & 0.69 & 0.51 & 0 & 0.18 & 0.16 & 0.22 & 0.05 & 0 & 0.04 & 0 & 0 & 0 & 0 & 0 \\
\hline 27.02 & 27.23 & 27.59 & 27.07 & 26.41 & 25.9 & 25.87 & 26.71 & 26.41 & 26.03 & 25.62 & 24.62 & 25.74 & 23.35 & 26.55 \\
\hline 1.87 & 2.45 & 2.96 & 3.13 & 2.75 & 2.87 & 2.88 & 2.81 & 2.94 & 3 & 3.02 & 2.91 & 2.98 & 2.85 & 2.93 \\
\hline 3.32 & 3.16 & 3.09 & 2.9 & 2.77 & 2.67 & 2.73 & 2.88 & 2.85 & 2.65 & 2.49 & 2.52 & 2.33 & 1.92 & 2.77 \\
\hline 7.74 & 7.66 & 7.1 & 7.18 & 8.62 & 9.21 & 8.73 & 8.31 & 7.73 & 8.51 & 9.05 & 8.88 & 7.92 & 8.75 & 8.05 \\
\hline 99.81 & 100.85 & 100.97 & 99.84 & 100.17 & 100.4 & 99.7 & 100.14 & 100.57 & 99.26 & 99.78 & 99.9 & 100.12 & 102.94 & 99.41 \\
\hline 2.987 & 2.965 & 2.966 & 2.997 & 2.983 & 2.99 & 2.973 & 2.995 & 3.073 & 2.981 & 3 & 3.135 & 2.909 & 3.431 & 2.983 \\
\hline 0 & 0.002 & 0.003 & 0 & 0.002 & 0 & 0.002 & 0.004 & 0.004 & 0 & 0.003 & 0.001 & 0.002 & 0 & 0.002 \\
\hline 2.048 & 2.024 & 2.031 & 2.031 & 2.019 & 2.01 & 2.036 & 1.998 & 1.961 & 2.036 & 2.022 & 1.924 & 2.232 & 1.735 & 2.031 \\
\hline 0 & 0.041 & 0.03 & 0 & 0.01 & 0.009 & 0.013 & 0.003 & 0 & 0.002 & 0 & 0 & 0 & 0 & 0.001 \\
\hline 1.784 & 1.789 & 1.813 & 1.795 & 1.746 & 1.707 & 1.717 & 1.767 & 1.727 & 1.736 & 1.697 & 1.61 & 1.692 & 1.449 & 1.769 \\
\hline 0.125 & 0.163 & 0.197 & 0.21 & 0.184 & 0.192 & 0.194 & 0.188 & 0.195 & 0.203 & 0.203 & 0.193 & 0.199 & 0.179 & 0.197 \\
\hline 0.391 & 0.37 & 0.362 & 0.343 & 0.326 & 0.314 & 0.322 & 0.34 & 0.332 & 0.315 & 0.293 & 0.294 & 0.273 & 0.212 & 0.329 \\
\hline 0.655 & 0.645 & 0.598 & 0.611 & 0.731 & 0.778 & 0.743 & 0.705 & 0.649 & 0.728 & 0.768 & 0.745 & 0.668 & 0.696 & 0.688 \\
\hline 7.989 & 8 & 8 & 7.987 & 8 & 8 & 8 & 8 & 7.942 & 8 & 7.986 & 7.902 & 7.973 & 7.702 & 8 \\
\hline 60.37 & 60.30 & 61.04 & 60.66 & 58.45 & 57.07 & 57.69 & 58.90 & 59.49 & 58.22 & 57.31 & 56.65 & 59.75 & 57.14 & 59.30 \\
\hline 13.23 & 12.47 & 12.19 & 11.59 & 10.91 & 10.50 & 10.82 & 11.33 & 11.44 & 10.56 & 9.90 & 10.34 & 9.64 & 8.36 & 11.03 \\
\hline 22.17 & 21.74 & 20.13 & 20.65 & 24.47 & 26.01 & 24.97 & 23.50 & 22.36 & 24.41 & 25.94 & 26.21 & 23.59 & 27.44 & 23.06 \\
\hline 4.23 & 5.49 & 6.63 & 7.10 & 6.16 & 6.42 & 6.52 & 6.27 & 6.72 & 6.81 & 6.86 & 6.79 & 7.03 & 7.06 & 6.60 \\
\hline
\end{tabular}


Complexo Mantiqueira - Rochas metabásicas (Amostra NLD-20A)

\section{GRANADA}

\begin{tabular}{|c|c|c|c|c|c|c|c|c|c|c|c|c|c|c|}
\hline NLD20A & NLD20A & NLD20A & NLD20A & NLD20A & NLD20A & NLD20A & NLD20A & NLD20A & NLD20A & NLD20A & NLD20A & NLD20A & NLD20A & NLD20A \\
\hline 37.96 & 37.97 & 37.67 & 37.64 & 37.73 & 37.74 & 37.43 & 33.91 & 37.44 & 37.67 & 37.34 & 37.68 & 37.46 & 37.81 & 37.46 \\
\hline 0 & 0.03 & 0.04 & 0 & 0.06 & 0.05 & 0 & 0.04 & 0 & 0.04 & 0.02 & 0.03 & 0 & 0.01 & 0.01 \\
\hline 21.85 & 22.34 & 21.88 & 21.88 & 22 & 21.73 & 21.44 & 26.91 & 21.84 & 21.92 & 21.65 & 21.84 & 22.08 & 21.64 & 21.76 \\
\hline 0 & 0 & 0 & 0 & 0 & 0 & 0 & 0 & 0.17 & 0 & 0 & 0 & 0 & 0 & 0.66 \\
\hline 26.88 & 24.85 & 25.11 & 26.03 & 24.04 & 25.13 & 24.54 & 21.85 & 25.18 & 26.48 & 26.2 & 25.08 & 25.54 & 26.43 & 26.62 \\
\hline 2.67 & 2.66 & 2.91 & 2.96 & 2.74 & 3.01 & 2.83 & 2.61 & 2.98 & 2.75 & 2.92 & 2.95 & 2.88 & 2.84 & 2.71 \\
\hline 3.05 & 2.85 & 2.78 & 2.82 & 2.5 & 2.85 & 2.52 & 2.31 & 2.67 & 2.98 & 2.98 & 2.88 & 2.88 & 2.9 & 3.09 \\
\hline 7.45 & 8.33 & 8.84 & 8.38 & 10.78 & 8.67 & 9.77 & 9.27 & 9.22 & 7.93 & 7.95 & 8.9 & 8.7 & 8.3 & 7.75 \\
\hline 99.87 & 99.03 & 99.24 & 99.73 & 99.85 & 99.19 & 98.53 & 96.91 & 99.51 & 99.78 & 99.06 & 99.37 & 99.55 & 99.93 & 100.07 \\
\hline 3 & 3.004 & 2.99 & 2.983 & 2.975 & 2.997 & 2.996 & 2.725 & 2.973 & 2.982 & 2.98 & 2.988 & 2.969 & 2.992 & 2.964 \\
\hline 0 & 0.002 & 0.003 & 0 & 0.003 & 0.003 & 0 & 0.002 & 0 & 0.002 & 0.001 & 0.002 & 0 & 0.001 & 0.001 \\
\hline 2.036 & 2.083 & 2.048 & 2.044 & 2.046 & 2.034 & 2.023 & 2.55 & 2.044 & 2.046 & 2.037 & 2.042 & 2.063 & 2.019 & 2.03 \\
\hline 0 & 0 & 0 & 0 & 0 & 0 & 0 & 0 & 0.01 & 0 & 0.001 & 0 & 0 & 0 & 0.039 \\
\hline 1.777 & 1.644 & 1.667 & 1.725 & 1.586 & 1.669 & 1.642 & 1.468 & 1.672 & 1.754 & 1.749 & 1.663 & 1.693 & 1.749 & 1.762 \\
\hline 0.179 & 0.178 & 0.195 & 0.199 & 0.183 & 0.203 & 0.192 & 0.178 & 0.201 & 0.185 & 0.197 & 0.198 & 0.193 & 0.19 & 0.182 \\
\hline 0.359 & 0.336 & 0.328 & 0.333 & 0.294 & 0.338 & 0.301 & 0.276 & 0.316 & 0.351 & 0.354 & 0.341 & 0.341 & 0.342 & 0.365 \\
\hline 0.631 & 0.707 & 0.753 & 0.713 & 0.911 & 0.739 & 0.838 & 0.799 & 0.785 & 0.673 & 0.68 & 0.757 & 0.74 & 0.705 & 0.658 \\
\hline 7.982 & 7.953 & 7.984 & 7.996 & 7.999 & 7.983 & 7.992 & 7.998 & 8 & 7.993 & 8 & 7.99 & 7.999 & 7.998 & 8 \\
\hline 60.32 & 57.38 & 56.64 & 58.08 & 53.33 & 56.60 & 55.23 & 53.95 & 56.22 & 59.20 & 58.69 & 56.20 & 57.06 & 58.57 & 59.39 \\
\hline 12.19 & 11.73 & 11.15 & 11.21 & 9.89 & 11.46 & 10.12 & 10.14 & 10.63 & 11.85 & 11.88 & 11.52 & 11.49 & 11.45 & 12.30 \\
\hline 21.42 & 24.68 & 25.59 & 24.01 & 30.63 & 25.06 & 28.19 & 29.36 & 26.40 & 22.71 & 22.82 & 25.58 & 24.94 & 23.61 & 22.18 \\
\hline 6.08 & 6.21 & 6.63 & 6.70 & 6.15 & 6.88 & 6.46 & 6.54 & 6.76 & 6.24 & 6.61 & 6.69 & 6.50 & 6.36 & 6.13 \\
\hline
\end{tabular}


Complexo Mantiqueira - Rochas metabásicas (Amostra NLD-20A) GRANADA

\begin{tabular}{|c|c|c|c|c|c|c|c|c|c|c|c|c|c|c|}
\hline NLD20A & NLD20A & NLD20A & NLD20A & NLD20A & NLD20A & NLD20A & NLD20A & NLD20A & NLD20A & NLD20A & NLD20A & NLD20A & NLD20A & NLD20A \\
\hline 37.74 & 37.83 & 43.66 & 38.02 & 37.22 & 37.61 & 37.82 & 37.63 & 37.85 & 37.78 & 36.8 & 37.94 & 37.71 & 37.81 & 37.82 \\
\hline 0.03 & 0.02 & 1.02 & 0.04 & 0.04 & 0 & 0 & 0.03 & 0.03 & 0.04 & 0.03 & 0.07 & 0.03 & 0 & 0.03 \\
\hline 21.45 & 21.52 & 12.02 & 21.65 & 21.73 & 21.55 & 21.6 & 21.64 & 21.68 & 21.52 & 21.32 & 21.73 & 21.55 & 21.85 & 21.89 \\
\hline 0.08 & 0 & 0 & 0 & 0.33 & 0.37 & 0.26 & 0 & 0 & 0 & 0 & 0 & 0 & 0 & 0 \\
\hline 26.75 & 26.01 & 15.88 & 24.66 & 26.67 & 26.83 & 26.86 & 25.67 & 26.05 & 26.4 & 26.34 & 28.53 & 27.64 & 27.2 & 27.1 \\
\hline 2.73 & 2.72 & 0.19 & 2.74 & 2.89 & 2.79 & 2.83 & 2.87 & 2.72 & 2.66 & 2.7 & 2.05 & 2.59 & 2.48 & 1.82 \\
\hline 3.1 & 3.01 & 9.82 & 2.44 & 3.05 & 3.12 & 2.97 & 2.85 & 2.88 & 3.21 & 2.95 & 3.77 & 3.08 & 3.12 & 3.58 \\
\hline 7.9 & 8.28 & 11.83 & 10.27 & 7.42 & 7.62 & 7.96 & 8.39 & 8.54 & 7.66 & 7.15 & 5.63 & 7.13 & 7.11 & 7.75 \\
\hline 99.8 & 99.4 & 94.43 & 99.83 & 99.36 & 99.9 & 100.31 & 99.09 & 99.75 & 99.27 & 97.3 & 99.72 & 99.74 & 99.59 & 99.99 \\
\hline 2.993 & 3.003 & 3.473 & 3.002 & 2.967 & 2.982 & 2.987 & 2.996 & 2.996 & 3.002 & 2.989 & 3.002 & 2.994 & 2.997 & 2.981 \\
\hline 0.002 & 0.001 & 0.061 & 0.002 & 0.003 & 0 & 0 & 0.002 & 0.002 & 0.003 & 0.002 & 0.004 & 0.002 & 0 & 0.002 \\
\hline 2.005 & 2.014 & 1.127 & 2.015 & 2.042 & 2.014 & 2.011 & 2.031 & 2.023 & 2.017 & 2.041 & 2.027 & 2.018 & 2.042 & 2.034 \\
\hline 0.005 & 0 & 0 & 0 & 0.02 & 0.022 & 0.015 & 0 & 0 & 0 & 0 & 0 & 0 & 0 & 0.002 \\
\hline 1.774 & 1.727 & 1.056 & 1.629 & 1.778 & 1.779 & 1.774 & 1.709 & 1.724 & 1.754 & 1.79 & 1.888 & 1.835 & 1.803 & 1.784 \\
\hline 0.184 & 0.183 & 0.013 & 0.183 & 0.195 & 0.188 & 0.189 & 0.193 & 0.182 & 0.179 & 0.186 & 0.137 & 0.174 & 0.167 & 0.121 \\
\hline 0.366 & 0.356 & 1.164 & 0.287 & 0.362 & 0.368 & 0.35 & 0.338 & 0.339 & 0.38 & 0.357 & 0.445 & 0.364 & 0.369 & 0.421 \\
\hline 0.672 & 0.705 & 1.009 & 0.87 & 0.635 & 0.648 & 0.674 & 0.717 & 0.725 & 0.653 & 0.623 & 0.477 & 0.607 & 0.605 & 0.655 \\
\hline 8 & 7.989 & 7.903 & 7.988 & 8 & 8 & 8 & 7.987 & 7.991 & 7.987 & 7.988 & 7.981 & 7.994 & 7.983 & 7.998 \\
\hline 59.21 & 58.13 & 32.57 & 54.87 & 59.87 & 59.64 & 59.39 & 57.80 & 58.05 & 59.14 & 60.55 & 64.07 & 61.58 & 61.24 & 59.85 \\
\hline 12.22 & 11.98 & 35.90 & 9.67 & 12.19 & 12.34 & 11.72 & 11.43 & 11.41 & 12.81 & 12.08 & 15.10 & 12.21 & 12.53 & 14.12 \\
\hline 22.43 & 23.73 & 31.12 & 29.30 & 21.38 & 21.72 & 22.56 & 24.25 & 24.41 & 22.02 & 21.08 & 16.19 & 20.37 & 20.55 & 21.97 \\
\hline 6.14 & 6.16 & 0.40 & 6.16 & 6.57 & 6.30 & 6.33 & 6.53 & 6.13 & 6.04 & 6.29 & 4.65 & 5.84 & 5.67 & 4.06 \\
\hline
\end{tabular}




\section{Rochas metabásicas (Amostra NLD-42C)}

\section{GRANADA}

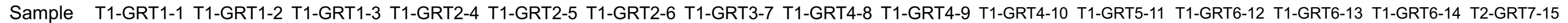
Minera

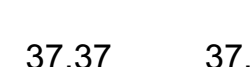

$\mathrm{TiO}$

$\mathrm{Al} 2 \mathrm{O} 3$

$\mathrm{Cr} 2 \mathrm{O} 3$

$\mathrm{Fe} 2 \mathrm{O} 3$

$\mathrm{FeO}$

$\mathrm{MnO}$

$\mathrm{MgO}$

$\mathrm{CaO}$

$\mathrm{Na} 2 \mathrm{O}$

$\mathrm{K} 2 \mathrm{O}$

Tota

Oxygens $\quad 12.0$

$\mathrm{Fe} 3$

Fe2

$\mathrm{M}$

$\mathrm{Mg}$

$\mathrm{C}$

$\mathrm{Na}$

Sum

Alm

Prp

Grs

Sps

TOTAL

\section{$37.37 \quad 37.23$}

$\begin{array}{ll}0.20 & 0.00 \\ & 21.52\end{array}$

1.16

28.28

1.89

2.94

7.35

0.00

0.00

100.58

$12.00 \quad 12.00$

2.96

0.01

2.00

0.00

0.07

1.87

0.13

0.35

0.62

0.00

0.00

8

63.07

11.66

20.99

4.28

100.00
2.14

2.16

3.03

7.38

0.00

0.00

100.91

$12.00 \quad 12.00$

2.94

0.00

2.00

0.00

0.13

1.81

0.14

0.36

0.62

0.00

0.00

8

61.72

12.13

21.25

4.90

100.00

62.10

12.24

21.06

4.60

100.00

$$
\mathrm{g}
$$$$
\mathrm{g}
$$

$$
\mathrm{g}
$$

$$
\mathrm{g}
$$$$
\mathrm{g}
$$$$
\mathrm{g}
$$

$$
\mathrm{g}
$$$$
\mathrm{g}
$$$$
\mathrm{g}
$$$$
\mathrm{g}
$$$$
\mathrm{g}
$$$$
\mathrm{g}
$$

$\begin{array}{ccccc}37.68 & 37.18 & 37.09 & 37.16 & 37.23 \\ 0.00 & 0.00 & 0.00 & 0.09 & 0.20 \\ 21.36 & 21.86 & 21.43 & 21.49 & 21.31\end{array}$

37.11

0.00

21.12

0.02

0.83

1.62

1.83

27.51

1.87

3.10

7.42

0.00

0.00

$\begin{array}{lll}0.02 & 0.00 & 0.00 \\ 1.02 & 1.46 & 1.86\end{array}$

$\begin{array}{lll}27.17 & 27.73 & 28.28\end{array}$

1.86

3.10

7.63

0.00

0.00

99.31

12.00

12.00

\subsection{6}

0.00

2.02

0.00

0.06

1.81

0.13

0.37

0.65

0.00

0.00

8

8

8

$$
8
$$

62.68

12.23

20.60

4.49

100.00

\subsection{9}

12.45

21.39

4.26
100.00

\subsection{6}

28.28
2.06

27.93

2.01

2.96

7.12

0.00

7.06

0.00

0.00

0.00

0.00

37.36

0.00

37.47

37.47
0.00
21.33

37.18

0.01

1.25

21.33

3.02
21.01

37.05

0.04

37.72

28.28

1.73

0.00

1.70

21.65

0.00
2.66

27.25

2.00

27.71

27.96

2.11

2.97

7.10

0.00

325

7.21

0.00

7.08

2.08

3.17

7.28

0.00

0.00

0.00

100.47

100.77

100.03

101.18

12.00

12.00

12.00

12.00

12.00

12.00

12.00

$\begin{array}{lll}2.95 & 2.94 & 2.98\end{array}$

0.01

2.01

0.01

1.99

0.00

0.11

0.09

1.84

0.15

0.36

0.60

0.00

0.00

0.14

0.34

0.61

0.00

0.00

2.98
0.00

2.96

0.00

2.96

0.00

1.98

2.00

0.00
0.05

1.87

0.14

0.35

0.61

0.00

0.00

0.00

0.07

1.87

0.13

0.35

0.60

0.00

0.00

8

8

8

8

61.28

62.33

63.29

62.97

11.51

22.03

4.26

20.33

20.52 


\section{Rochas metabásicas (Amostra NLD-42C)}

\section{GRANADA}

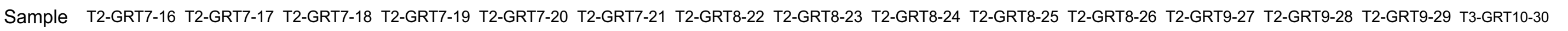

\begin{tabular}{|c|c|c|c|c|c|c|c|c|c|c|c|c|c|c|c|}
\hline Mineral & $g$ & g & g & $g$ & g & $g$ & g & $g$ & g & $g$ & g & $g$ & g & g & g \\
\hline $\mathrm{SiO} 2$ & 37.18 & 37.52 & 37.52 & 37.75 & 37.57 & 37.22 & 37.92 & 37.30 & 37.44 & 37.70 & 37.75 & 37.82 & 37.65 & 37.43 & 37.59 \\
\hline TiO2 & 0.00 & 0.00 & 0.11 & 0.09 & 0.00 & 0.02 & 0.04 & 0.00 & 0.15 & 0.04 & 0.07 & 0.00 & 0.07 & 0.00 & 0.13 \\
\hline $\mathrm{Al} 2 \mathrm{O} 3$ & 21.47 & 21.59 & 21.66 & 21.63 & 21.39 & 21.39 & 21.11 & 21.94 & 21.54 & 21.32 & 21.55 & 21.65 & 21.57 & 21.70 & 21.65 \\
\hline Cr2O3 & 0.00 & 0.01 & 0.01 & 0.00 & 0.04 & 0.00 & 0.00 & 0.03 & 0.01 & 0.01 & 0.01 & 0.00 & 0.00 & 0.01 & 0.01 \\
\hline $\mathrm{Fe} 2 \mathrm{O} 3$ & 2.01 & 0.71 & 1.01 & 0.22 & 0.03 & 1.51 & 0.00 & 1.28 & 1.07 & 0.46 & 0.33 & 0.45 & 0.73 & 1.86 & 1.04 \\
\hline $\mathrm{FeO}$ & 27.66 & 28.17 & 28.50 & 28.13 & 28.36 & 27.58 & 28.38 & 27.90 & 28.10 & 28.43 & 28.25 & 28.27 & 28.17 & 27.88 & 28.19 \\
\hline $\mathrm{MnO}$ & 1.59 & 1.90 & 1.63 & 1.84 & 1.64 & 1.79 & 1.62 & 1.71 & 1.78 & 1.69 & 1.70 & 1.70 & 1.78 & 1.81 & 1.84 \\
\hline $\mathrm{MgO}$ & 3.25 & 3.15 & 3.16 & 3.11 & 3.15 & 3.22 & 2.96 & 3.26 & 3.19 & 3.20 & 3.06 & 3.05 & 3.28 & 3.19 & 3.17 \\
\hline $\mathrm{CaO}$ & 7.32 & 7.14 & 7.15 & 7.55 & 7.24 & 7.33 & 7.68 & 7.14 & 7.27 & 7.23 & 7.62 & 7.63 & 7.22 & 7.30 & 7.30 \\
\hline $\mathrm{Na} 2 \mathrm{O}$ & 0.00 & 0.00 & 0.00 & 0.00 & 0.00 & 0.00 & 0.00 & 0.00 & 0.00 & 0.00 & 0.00 & 0.00 & 0.00 & 0.00 & 0.00 \\
\hline $\mathrm{K} 2 \mathrm{O}$ & 0.00 & 0.00 & 0.00 & 0.00 & 0.00 & 0.00 & 0.00 & 0.00 & 0.00 & 0.00 & 0.00 & 0.00 & 0.00 & 0.00 & 0.00 \\
\hline Total & 100.49 & 100.19 & 100.75 & 100.32 & 99.42 & 100.07 & 99.72 & 100.55 & 100.54 & 100.08 & 100.33 & 100.56 & 100.46 & 101.18 & 100.93 \\
\hline Oxygens & 12.00 & 12.00 & 12.00 & 12.00 & 12.00 & 12.00 & 12.00 & 12.00 & 12.00 & 12.00 & 12.00 & 12.00 & 12.00 & 12.00 & 12.00 \\
\hline $\mathrm{Si}$ & 2.94 & 2.97 & 2.96 & 2.98 & 2.99 & 2.95 & 3.01 & 2.94 & 2.96 & 2.99 & 2.98 & 2.98 & 2.97 & 2.94 & 2.96 \\
\hline $\mathrm{Ti}$ & 0.00 & 0.00 & 0.01 & 0.01 & 0.00 & 0.00 & 0.00 & 0.00 & 0.01 & 0.00 & 0.00 & 0.00 & 0.00 & 0.00 & 0.01 \\
\hline $\mathrm{Al}$ & 2.00 & 2.02 & 2.01 & 2.01 & 2.01 & 2.00 & 1.98 & 2.04 & 2.01 & 1.99 & 2.01 & 2.01 & 2.01 & 2.01 & 2.01 \\
\hline $\mathrm{Cr}$ & 0.00 & 0.00 & 0.00 & 0.00 & 0.00 & 0.00 & 0.00 & 0.00 & 0.00 & 0.00 & 0.00 & 0.00 & 0.00 & 0.00 & 0.00 \\
\hline Fe3 & 0.12 & 0.04 & 0.06 & 0.01 & 0.00 & 0.09 & 0.00 & 0.08 & 0.06 & 0.03 & 0.02 & 0.03 & 0.04 & 0.11 & 0.06 \\
\hline $\mathrm{Fe} 2$ & 1.83 & 1.87 & 1.88 & 1.86 & 1.89 & 1.83 & 1.89 & 1.84 & 1.86 & 1.89 & 1.87 & 1.86 & 1.86 & 1.83 & 1.86 \\
\hline $\mathrm{Mn}$ & 0.11 & 0.13 & 0.11 & 0.12 & 0.11 & 0.12 & 0.11 & 0.11 & 0.12 & 0.11 & 0.11 & 0.11 & 0.12 & 0.12 & 0.12 \\
\hline $\mathrm{Mg}$ & 0.38 & 0.37 & 0.37 & 0.37 & 0.37 & 0.38 & 0.35 & 0.38 & 0.38 & 0.38 & 0.36 & 0.36 & 0.39 & 0.37 & 0.37 \\
\hline $\mathrm{Ca}$ & 0.62 & 0.61 & 0.60 & 0.64 & 0.62 & 0.62 & 0.65 & 0.60 & 0.62 & 0.61 & 0.65 & 0.64 & 0.61 & 0.61 & 0.62 \\
\hline $\mathrm{Na}$ & 0.00 & 0.00 & 0.00 & 0.00 & 0.00 & 0.00 & 0.00 & 0.00 & 0.00 & 0.00 & 0.00 & 0.00 & 0.00 & 0.00 & 0.00 \\
\hline $\mathrm{K}$ & 0.00 & 0.00 & 0.00 & 0.00 & 0.00 & 0.00 & 0.00 & 0.00 & 0.00 & 0.00 & 0.00 & 0.00 & 0.00 & 0.00 & 0.00 \\
\hline Sum & 8 & 8 & 8 & 8 & 8 & 8 & 7.995 & 8 & 8 & 8 & 8 & 8 & 8 & 8 & 8 \\
\hline Alm & 62.24 & 62.83 & 63.43 & 62.24 & 63.18 & 61.98 & 62.87 & 62.60 & 62.61 & 63.02 & 62.54 & 62.53 & 62.52 & 62.31 & 62.58 \\
\hline Prp & 13.03 & 12.53 & 12.52 & 12.25 & 12.46 & 12.86 & 11.70 & 13.02 & 12.64 & 12.64 & 12.05 & 12.04 & 12.97 & 12.72 & 12.55 \\
\hline Grs & 21.09 & 20.37 & 20.38 & 21.39 & 20.65 & 21.09 & 21.80 & 20.50 & 20.73 & 20.53 & 21.59 & 21.60 & 20.50 & 20.88 & 20.75 \\
\hline Sps & 3.64 & 4.28 & 3.68 & 4.12 & 3.71 & 4.06 & 3.63 & 3.88 & 4.01 & 3.81 & 3.82 & 3.82 & 4.00 & 4.08 & 4.12 \\
\hline TOTAL & 100.00 & 100.00 & 100.00 & 100.00 & 100.00 & 100.00 & 100.00 & 100.00 & 100.00 & 100.00 & 100.00 & 100.00 & 100.00 & 100.00 & 100.00 \\
\hline
\end{tabular}




\section{Rochas metabásicas (Amostra NLD-42C)}

\section{GRANADA}

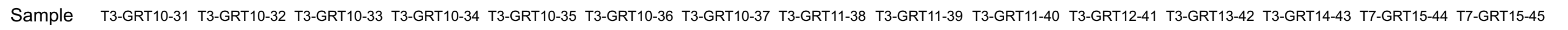

\begin{tabular}{|c|c|c|c|c|c|c|c|c|c|c|c|c|c|c|c|}
\hline Mineral & $g$ & $g$ & g & g & g & g & $g$ & g & g & g & g & g & g & g & g \\
\hline $\mathrm{SiO} 2$ & 37.65 & 37.96 & 37.87 & 37.46 & 37.52 & 37.12 & 37.66 & 37.59 & 37.37 & 43.20 & 37.26 & 37.40 & 37.47 & 37.49 & 37.82 \\
\hline TiO2 & 0.00 & 0.13 & 0.00 & 0.00 & 0.00 & 0.00 & 0.00 & 0.00 & 0.07 & 0.11 & 0.35 & 0.04 & 0.04 & 0.00 & 0.00 \\
\hline $\mathrm{Al} 2 \mathrm{O} 3$ & 21.34 & 21.57 & 21.44 & 21.48 & 21.44 & 21.57 & 21.53 & 21.31 & 21.43 & 20.00 & 21.50 & 21.15 & 21.43 & 21.26 & 21.41 \\
\hline $\mathrm{Cr} 2 \mathrm{O} 3$ & 0.01 & 0.00 & 0.00 & 0.00 & 0.01 & 0.00 & 0.00 & 0.03 & 0.00 & 0.01 & 0.00 & 0.02 & 0.01 & 0.00 & 0.00 \\
\hline $\mathrm{Fe} 2 \mathrm{O} 3$ & 1.10 & 0.76 & 0.94 & 1.26 & 1.17 & 0.88 & 1.79 & 1.05 & 1.94 & 0.00 & 0.39 & 2.05 & 1.35 & 0.62 & 0.58 \\
\hline $\mathrm{FeO}$ & 27.99 & 28.63 & 28.26 & 27.81 & 28.00 & 27.90 & 28.01 & 28.36 & 27.55 & 25.79 & 29.11 & 27.39 & 28.18 & 28.43 & 28.60 \\
\hline $\mathrm{MnO}$ & 1.84 & 1.75 & 1.75 & 1.78 & 1.67 & 1.84 & 1.98 & 1.88 & 1.74 & 1.69 & 1.67 & 1.87 & 1.99 & 1.77 & 1.82 \\
\hline $\mathrm{MgO}$ & 3.18 & 3.19 & 3.18 & 3.28 & 3.14 & 2.99 & 3.16 & 3.04 & 3.25 & 2.84 & 2.91 & 3.19 & 3.01 & 3.06 & 3.05 \\
\hline $\mathrm{CaO}$ & 7.41 & 7.35 & 7.48 & 7.27 & 7.47 & 7.24 & 7.31 & 7.22 & 7.52 & 6.78 & 6.92 & 7.64 & 7.24 & 7.13 & 7.28 \\
\hline $\mathrm{Na} 2 \mathrm{O}$ & 0.00 & 0.00 & 0.00 & 0.00 & 0.00 & 0.00 & 0.00 & 0.00 & 0.00 & 0.00 & 0.00 & 0.00 & 0.00 & 0.00 & 0.00 \\
\hline $\mathrm{K} 2 \mathrm{O}$ & 0.00 & 0.00 & 0.00 & 0.00 & 0.00 & 0.00 & 0.00 & 0.00 & 0.00 & 0.00 & 0.00 & 0.00 & 0.00 & 0.00 & 0.00 \\
\hline Total & 100.52 & 101.33 & 100.91 & 100.35 & 100.43 & 99.55 & 101.45 & 100.49 & 100.86 & 100.41 & 100.10 & 100.75 & 100.72 & 99.77 & 100.56 \\
\hline Oxygens & 12.00 & 12.00 & 12.00 & 12.00 & 12.00 & 12.00 & 12.00 & 12.00 & 12.00 & 12.00 & 12.00 & 12.00 & 12.00 & 12.00 & 12.00 \\
\hline Si & 2.97 & 2.97 & 2.98 & 2.96 & 2.97 & 2.96 & 2.95 & 2.97 & 2.94 & 3.31 & 2.96 & 2.95 & 2.96 & 2.98 & 2.99 \\
\hline $\mathrm{Ti}$ & 0.00 & 0.01 & 0.00 & 0.00 & 0.00 & 0.00 & 0.00 & 0.00 & 0.00 & 0.01 & 0.02 & 0.00 & 0.00 & 0.00 & 0.00 \\
\hline $\mathrm{Al}$ & 1.99 & 1.99 & 1.99 & 2.00 & 2.00 & 2.03 & 1.99 & 1.99 & 1.99 & 1.81 & 2.01 & 1.97 & 2.00 & 2.00 & 1.99 \\
\hline $\mathrm{Cr}$ & 0.00 & 0.00 & 0.00 & 0.00 & 0.00 & 0.00 & 0.00 & 0.00 & 0.00 & 0.00 & 0.00 & 0.00 & 0.00 & 0.00 & 0.00 \\
\hline $\mathrm{Fe} 3$ & 0.07 & 0.04 & 0.06 & 0.07 & 0.07 & 0.05 & 0.11 & 0.06 & 0.11 & 0.00 & 0.02 & 0.12 & 0.08 & 0.04 & 0.03 \\
\hline $\mathrm{Fe} 2$ & 1.85 & 1.88 & 1.86 & 1.84 & 1.85 & 1.86 & 1.84 & 1.88 & 1.82 & 1.65 & 1.94 & 1.81 & 1.86 & 1.89 & 1.89 \\
\hline $\mathrm{Mn}$ & 0.12 & 0.12 & 0.12 & 0.12 & 0.11 & 0.12 & 0.13 & 0.13 & 0.12 & 0.11 & 0.11 & 0.13 & 0.13 & 0.12 & 0.12 \\
\hline $\mathrm{Mg}$ & 0.38 & 0.37 & 0.37 & 0.39 & 0.37 & 0.36 & 0.37 & 0.36 & 0.38 & 0.32 & 0.35 & 0.38 & 0.35 & 0.36 & 0.36 \\
\hline $\mathrm{Ca}$ & 0.63 & 0.62 & 0.63 & 0.62 & 0.63 & 0.62 & 0.61 & 0.61 & 0.64 & 0.56 & 0.59 & 0.65 & 0.61 & 0.61 & 0.62 \\
\hline $\mathrm{Na}$ & 0.00 & 0.00 & 0.00 & 0.00 & 0.00 & 0.00 & 0.00 & 0.00 & 0.00 & 0.00 & 0.00 & 0.00 & 0.00 & 0.00 & 0.00 \\
\hline $\mathrm{K}$ & 0.00 & 0.00 & 0.00 & 0.00 & 0.00 & 0.00 & 0.00 & 0.00 & 0.00 & 0.00 & 0.00 & 0.00 & 0.00 & 0.00 & 0.00 \\
\hline Sum & 8 & 8 & 8 & 8 & 8 & 8 & 8 & 8 & 8 & 7.776 & 8 & 8 & 8 & 8 & 8 \\
\hline Alm & 62.17 & 62.94 & 62.42 & 62.12 & 62.44 & 62.87 & 62.23 & 63.11 & 61.60 & 62.51 & 64.92 & 61.20 & 62.86 & 63.46 & 63.27 \\
\hline Prp & 12.61 & 12.47 & 12.49 & 13.07 & 12.47 & 12.03 & 12.53 & 12.04 & 12.92 & 12.24 & 11.57 & 12.69 & 11.95 & 12.17 & 12.02 \\
\hline Grs & 21.08 & 20.69 & 21.16 & 20.80 & 21.31 & 20.91 & 20.80 & 20.61 & 21.54 & 21.09 & 19.75 & 21.89 & 20.70 & 20.38 & 20.62 \\
\hline Sps & 4.14 & 3.89 & 3.93 & 4.02 & 3.78 & 4.19 & 4.44 & 4.24 & 3.93 & 4.16 & 3.76 & 4.23 & 4.49 & 3.99 & 4.08 \\
\hline TOTAL & 100.00 & 100.00 & 100.00 & 100.00 & 100.00 & 100.00 & 100.00 & 100.00 & 100.00 & 100.00 & 100.00 & 100.00 & 100.00 & 100.00 & 100.00 \\
\hline
\end{tabular}




\section{Rochas metabásicas (Amostra NLD-42C)}

\section{GRANADA}

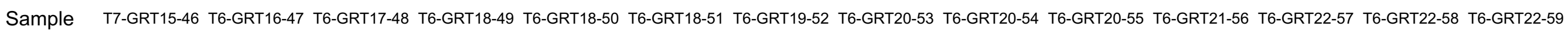

$\mathrm{SiO} 2$

$\mathrm{TiO} 2$

$\begin{array}{ll}37.85 & 36.65 \\ 0.00 & 0.02\end{array}$

$$
\begin{gathered}
\mathrm{g} \\
36.96
\end{gathered}
$$

$$
\mathrm{g}
$$

$\mathrm{Al} 2 \mathrm{O} 3$

$36.96 \quad 36.54$$$
21.29
$$

0.02
20.84

$\mathrm{Cr} 2 \mathrm{O} 3$

0.00

20.84
0.03

0.00
21.07

$\begin{array}{cc}36.54 & 37.02 \\ 0.00 & 0.02 \\ 21.14 & 21.12\end{array}$

$21.07 \quad 21.14$

0.02

$\mathrm{Fe} 2 \mathrm{O} 3$

0.00

1.32

$\mathrm{FeO}$

$\mathrm{MnO}$

$\mathrm{CaO}$
$\mathrm{Na} 2 \mathrm{O}$

$\mathrm{K} 2 \mathrm{O}$

1.73

3.10

27.57

2.21

27.57

2.77

27.20

0.02
2.59

2.59
27.50

$\begin{array}{ll}1.72 & 1.62 \\ 3.07 & 3.14\end{array}$

3.07
7.07

0.00

0.00

0.00

3.14
7.32

1.51
3.01

3.01
7.48

1.61
3.22

3.22
7.35

$\begin{array}{ll}0.00 & 0.00 \\ 0.00 & 0.00\end{array}$

0.00

0.00

0.00

$\mathrm{g}$
37.21

0.04

21.45

37.08

21.49

28.00

1.55
3.16

3.16
7.27

7.27
0.00

0.00

$\begin{array}{lll}\text { Total } & 99.70 \quad 98.28\end{array}$

Oxygens $\quad 12.00 \quad 12.00$

99.92

99.66

100.45

100.79

12.00

12.00

12.00

12.00

2.93

2.92

2.94

0.00

$0.00 \quad 0.00$

1.98

0.00

0.00

0.00

0.08

1.87

0.13

1.84

0.00

0.17

1.82

0.10

0.36

0.64

0.37

0.37

0.63

0.64

0.61
0.00

0.00

0.00

0.00

0.00

2.93
0.00

2.94

0.00

$1.97 \quad 2.00$
0.00

0.00

0.15

1.82

0.11

0.38

0.62

0.00

0.00

0.00

0.12

1.85

0.10

0.37

0.62

0.00

0.00

8

8

8

62.29
12.26
21.95

$62.11 \quad 62.89$

12.95

21.26

$\begin{array}{ccc}3.49 & 3.68 & 3.54 \\ 100.00 & 100.00 & 100.00\end{array}$

12.65
20.92

Sps $\quad 3.90$

TOTAL $\quad 100.00$

3.70

100.00

1.56
28.25

$\begin{array}{cc}g & g \\ 36.90 & 36.71 \\ 0.07 & 0.00 \\ 21.07 & 20.99 \\ 0.00 & 0.00 \\ 2.77 & 3.29 \\ 27.58 & 27.55 \\ 1.64 & 1.62 \\ 3.13 & 3.09 \\ 7.29 & 7.16 \\ 0.00 & 0.00 \\ 0.00 & 0.00\end{array}$

$\mathrm{g}$
37.41
0.00
21.65
0.01
2.15
28.33
1.59
3.08
7.25
0.00
0.00

$\mathrm{g}$
37.38
0.02
20.92
0.04
2.06
28.40
1.65
2.90
7.38
0.00
0.00

$\begin{array}{ccc}g & g & g \\ 36.95 & 36.98 & 37.17 \\ 0.13 & 0.07 & 0.13 \\ 21.32 & 21.15 & 21.21 \\ 0.03 & 0.03 & 0.00 \\ 2.77 & 2.42 & 0.85 \\ 27.24 & 27.54 & 28.12 \\ 1.70 & 1.63 & 1.67 \\ 3.19 & 3.20 & 3.06 \\ 7.53 & 7.32 & 7.26 \\ 0.00 & 0.00 & 0.00 \\ 0.00 & 0.00 & 0.00\end{array}$

100.10

$100.45 \quad 100.41$

101.47

12.00

12.00

12.00

12.00

2.95

2.93

2.92

0.00

0.00

0.00

2.94

0.00

2.01

0.09

1.88

1.97

0.00
0.17

0.17
1.83

1.97

0.00
0.20

0.20
1.83

$0.11 \quad 0.11$

0.36

0.60

0.37

0.62

0.37

0.61

0.00

0.00

0.00

2.00

0.00

0.13

1.86

0.11

0.36

0.61

0.00

100.76

100.86

100.33

99.46

12.00

12.00

12.00

12.00

$\begin{array}{llll}2.96 & 2.92 & 2.93 & 2.97 \\ 0.00 & 0.01 & 0.00 & 0.01\end{array}$

0.01

$\begin{array}{llll}1.95 & 1.98 & 1.98 & 2.00 \\ 0.00 & 0.00 & 0.00 & 0.00\end{array}$

$\begin{array}{llll}0.00 & 0.00 & 0.00 & 0.00 \\ 0.12 & 0.16 & 0.14 & 0.05\end{array}$

$\begin{array}{llll}0.12 & 0.16 & 0.14 & 0.05\end{array}$

$\begin{array}{llll}1.88 & 1.80 & 1.83 & 1.88\end{array}$

$\begin{array}{llll}0.11 & 0.11 & 0.11 & 0.11\end{array}$

$\begin{array}{llll}0.34 & 0.38 & 0.38 & 0.36\end{array}$

0.63

0.00

0.64

0.00

0.00

0.62

0.00

0.00

0.62

$$
8
$$

8

8

63.71
12.36
20.37

20.37

62.47
12.62

12.62
21.15

3.56
$\begin{array}{cc}3.56 & 3.75 \\ 100.00 & 100.00\end{array}$

62.80
12.55
20.91
3.74

8

8

3.74
100.00

$\begin{array}{cc}63.33 & 63.53 \\ 12.29 & 11.58 \\ 20.77 & 21.14 \\ 3.61 & 3.75 \\ 100.00 & 100.00\end{array}$

$\begin{array}{ccc}8 & 8 & 8 \\ 61.50 & 62.22 & 63.12 \\ 12.82 & 12.87 & 12.23 \\ 21.78 & 21.20 & 20.86 \\ 3.90 & 3.71 & 3.80 \\ 100.00 & 100.00 & 100.00\end{array}$


Rochas metabásicas (Amostra NLD-42D)

GRANADA

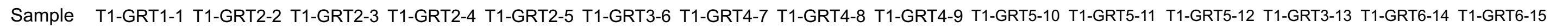

\begin{tabular}{|c|c|c|c|c|c|c|c|c|c|c|c|c|c|c|c|}
\hline Mineral & $g$ & $g$ & $g$ & g & $g$ & g & $g$ & $g$ & g & $g$ & $g$ & g & $g$ & g & g \\
\hline $\mathrm{SiO} 2$ & 37.68 & 37.44 & 37.83 & 37.38 & 37.66 & 37.19 & 37.45 & 37.40 & 37.94 & 37.62 & 37.62 & 37.93 & 37.31 & 36.96 & 37.57 \\
\hline $\mathrm{TiO} 2$ & 0.04 & 0.00 & 0.04 & 0.07 & 0.07 & 0.04 & 0.00 & 0.04 & 0.07 & 0.00 & 0.00 & 0.00 & 0.09 & 0.04 & 0.02 \\
\hline $\mathrm{Al} 2 \mathrm{O} 3$ & 21.45 & 21.29 & 21.72 & 21.72 & 21.11 & 21.68 & 21.21 & 21.40 & 21.61 & 21.57 & 21.62 & 21.91 & 21.49 & 21.23 & 21.27 \\
\hline Cr2O3 & 0.00 & 0.00 & 0.00 & 0.00 & 0.03 & 0.00 & 0.04 & 0.00 & 0.03 & 0.00 & 0.01 & 0.01 & 0.01 & 0.04 & 0.03 \\
\hline $\mathrm{Fe} 2 \mathrm{O} 3$ & 0.58 & 1.73 & 0.40 & 1.25 & 0.23 & 1.02 & 1.34 & 0.56 & 0.37 & 1.15 & 0.46 & 0.00 & 1.82 & 1.22 & 1.01 \\
\hline $\mathrm{FeO}$ & 28.49 & 28.53 & 29.31 & 28.18 & 28.89 & 28.29 & 28.28 & 28.54 & 29.11 & 28.62 & 28.54 & 28.98 & 28.26 & 27.71 & 29.46 \\
\hline $\mathrm{MnO}$ & 1.36 & 1.28 & 1.17 & 1.45 & 1.43 & 1.17 & 1.19 & 1.21 & 1.31 & 1.38 & 1.17 & 1.23 & 1.26 & 1.13 & 1.11 \\
\hline $\mathrm{MgO}$ & 3.36 & 3.32 & 3.32 & 3.37 & 3.27 & 3.07 & 3.22 & 3.16 & 3.18 & 3.23 & 3.24 & 3.20 & 3.28 & 3.08 & 2.86 \\
\hline $\mathrm{CaO}$ & 7.20 & 7.05 & 6.92 & 7.09 & 6.96 & 7.46 & 7.46 & 7.30 & 7.27 & 7.17 & 7.40 & 6.97 & 7.26 & 7.70 & 7.21 \\
\hline $\mathrm{Na} 2 \mathrm{O}$ & 0.00 & 0.00 & 0.00 & 0.00 & 0.00 & 0.00 & 0.00 & 0.00 & 0.00 & 0.00 & 0.00 & 0.00 & 0.00 & 0.00 & 0.00 \\
\hline $\mathrm{K} 2 \mathrm{O}$ & 0.00 & 0.00 & 0.00 & 0.00 & 0.00 & 0.00 & 0.00 & 0.00 & 0.00 & 0.00 & 0.00 & 0.00 & 0.00 & 0.00 & 0.00 \\
\hline Total & 100.17 & 100.63 & 100.71 & 100.51 & 99.64 & 99.92 & 100.18 & 99.62 & 100.89 & 100.75 & 100.06 & 100.23 & 100.79 & 99.12 & 100.54 \\
\hline Oxygens & 12.00 & 12.00 & 12.00 & 12.00 & 12.00 & 12.00 & 12.00 & 12.00 & 12.00 & 12.00 & 12.00 & 12.00 & 12.00 & 12.00 & 12.00 \\
\hline $\mathrm{Si}$ & 2.98 & 2.958 & 2.978 & 2.949 & 2.998 & 2.952 & 2.968 & 2.977 & 2.983 & 2.964 & 2.978 & 2.992 & 2.942 & 2.958 & 2.975 \\
\hline $\mathrm{Ti}$ & 0.00 & 0.00 & 0.00 & 0.00 & 0.00 & 0.00 & 0.00 & 0.00 & 0.00 & 0.00 & 0.00 & 0.00 & 0.01 & 0.00 & 0.00 \\
\hline $\mathrm{Al}$ & 2.00 & 1.98 & 2.02 & 2.02 & 1.98 & 2.03 & 1.98 & 2.01 & 2.00 & 2.00 & 2.02 & 2.04 & 2.00 & 2.00 & 1.99 \\
\hline $\mathrm{Cr}$ & 0.00 & 0.00 & 0.00 & 0.00 & 0.00 & 0.00 & 0.00 & 0.00 & 0.00 & 0.00 & 0.00 & 0.00 & 0.00 & 0.00 & 0.00 \\
\hline $\mathrm{Fe} 3$ & 0.03 & 0.10 & 0.02 & 0.07 & 0.01 & 0.06 & 0.08 & 0.03 & 0.02 & 0.07 & 0.03 & 0.00 & 0.11 & 0.07 & 0.06 \\
\hline $\mathrm{Fe} 2$ & 1.89 & 1.89 & 1.93 & 1.86 & 1.92 & 1.88 & 1.88 & 1.90 & 1.91 & 1.89 & 1.89 & 1.91 & 1.86 & 1.86 & 1.95 \\
\hline $\mathrm{Mn}$ & 0.09 & 0.09 & 0.08 & 0.10 & 0.10 & 0.08 & 0.08 & 0.08 & 0.09 & 0.09 & 0.08 & 0.08 & 0.08 & 0.08 & 0.08 \\
\hline $\mathrm{Mg}$ & 0.40 & 0.39 & 0.39 & 0.40 & 0.39 & 0.36 & 0.38 & 0.38 & 0.37 & 0.38 & 0.38 & 0.38 & 0.39 & 0.37 & 0.34 \\
\hline $\mathrm{Ca}$ & 0.61 & 0.60 & 0.58 & 0.60 & 0.59 & 0.63 & 0.63 & 0.62 & 0.61 & 0.61 & 0.63 & 0.59 & 0.61 & 0.66 & 0.61 \\
\hline $\mathrm{Na}$ & 0.00 & 0.00 & 0.00 & 0.00 & 0.00 & 0.00 & 0.00 & 0.00 & 0.00 & 0.00 & 0.00 & 0.00 & 0.00 & 0.00 & 0.00 \\
\hline $\mathrm{K}$ & 0.00 & 0.00 & 0.00 & 0.00 & 0.00 & 0.00 & 0.00 & 0.00 & 0.00 & 0.00 & 0.00 & 0.00 & 0.00 & 0.00 & 0.00 \\
\hline Sum & 8,000 & 8,000 & 8,000 & 8,000 & 8,000 & 8,000 & 8,000 & 8,000 & 8,000 & 8,000 & 8,000 & 7,989 & 8,000 & 8,000 & 8,000 \\
\hline Alm & 63.21 & 63.73 & 64.77 & 63.01 & 64.09 & 63.61 & 63.17 & 63.76 & 64.08 & 63.64 & 63.45 & 64.59 & 63.27 & 62.65 & 65.57 \\
\hline Prp & 13.28 & 13.18 & 13.05 & 13.41 & 12.92 & 12.29 & 12.80 & 12.58 & 12.49 & 12.82 & 12.83 & 12.74 & 13.07 & 12.43 & 11.35 \\
\hline Grs & 20.46 & 20.18 & 19.56 & 20.29 & 19.79 & 21.46 & 21.33 & 20.91 & 20.52 & 20.44 & 21.10 & 19.90 & 20.81 & 22.32 & 20.56 \\
\hline Sps & 3.05 & 2.91 & 2.62 & 3.29 & 3.20 & 2.64 & 2.70 & 2.75 & 2.91 & 3.10 & 2.62 & 2.77 & 2.85 & 2.60 & 2.52 \\
\hline TOTAL & 100.00 & 100.00 & 100.00 & 100.00 & 100.00 & 100.00 & 100.00 & 100.00 & 100.00 & 100.00 & 100.00 & 100.00 & 100.00 & 100.00 & 100.00 \\
\hline
\end{tabular}


Rochas metabásicas (Amostra NLD-42D)

GRANADA

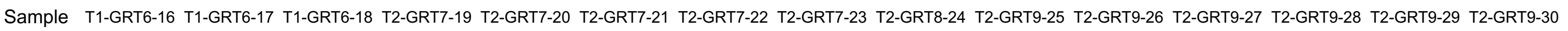
Mineral

\begin{tabular}{|c|c|c|c|c|c|c|c|c|c|c|c|c|c|c|c|}
\hline $\mathrm{SiO} 2$ & 37.93 & 37.75 & 37.59 & 37.40 & 37.24 & 37.27 & 37.64 & 37.29 & 37.30 & 37.73 & 37.29 & 37.86 & 37.57 & 37.41 & 37.23 \\
\hline $\mathrm{TiO} 2$ & 0.09 & 0.22 & 0.00 & 0.04 & 0.04 & 0.11 & 0.04 & 0.13 & 0.28 & 0.02 & 0.02 & 0.13 & 0.00 & 0.15 & 0.00 \\
\hline $\mathrm{Al} 2 \mathrm{O} 3$ & 21.12 & 23.66 & 21.37 & 21.20 & 21.39 & 21.74 & 21.45 & 21.70 & 21.39 & 21.16 & 21.39 & 21.08 & 21.36 & 20.93 & 21.45 \\
\hline Cr2O3 & 0.02 & 0.03 & 0.01 & 0.02 & 0.00 & 0.00 & 0.02 & 0.00 & 0.01 & 0.01 & 0.00 & 0.00 & 0.02 & 0.05 & 0.00 \\
\hline $\mathrm{Fe} 2 \mathrm{O} 3$ & 0.00 & 0.00 & 1.30 & 1.47 & 1.45 & 1.25 & 0.66 & 0.51 & 1.12 & 0.57 & 1.83 & 1.50 & 0.31 & 0.30 & 1.20 \\
\hline $\mathrm{FeO}$ & 29.24 & 28.46 & 28.71 & 27.90 & 28.33 & 28.60 & 28.89 & 28.52 & 29.33 & 28.68 & 28.15 & 28.30 & 28.40 & 28.15 & 27.86 \\
\hline $\mathrm{MnO}$ & 1.00 & 1.03 & 1.05 & 1.10 & 1.17 & 1.17 & 1.14 & 1.16 & 1.15 & 1.29 & 1.23 & 1.17 & 1.25 & 1.31 & 1.25 \\
\hline $\mathrm{MgO}$ & 2.85 & 2.88 & 3.24 & 3.06 & 3.27 & 3.24 & 3.31 & 3.36 & 3.00 & 3.45 & 3.45 & 3.54 & 3.43 & 3.50 & 3.47 \\
\hline $\mathrm{CaO}$ & 7.30 & 6.86 & 7.33 & 8.02 & 7.20 & 7.11 & 7.09 & 7.04 & 7.04 & 7.01 & 7.06 & 7.47 & 7.14 & 7.14 & 7.18 \\
\hline $\mathrm{Na} 2 \mathrm{O}$ & 0.00 & 0.00 & 0.00 & 0.00 & 0.00 & 0.00 & 0.00 & 0.00 & 0.00 & 0.00 & 0.00 & 0.00 & 0.00 & 0.00 & 0.00 \\
\hline $\mathrm{K} 2 \mathrm{O}$ & 0.00 & 0.00 & 0.00 & 0.00 & 0.00 & 0.00 & 0.00 & 0.00 & 0.00 & 0.00 & 0.00 & 0.00 & 0.00 & 0.00 & 0.00 \\
\hline Total & 99.55 & 100.89 & 100.60 & 100.22 & 100.10 & 100.48 & 100.24 & 99.71 & 100.63 & 99.92 & 100.42 & 101.06 & 99.48 & 98.94 & 99.63 \\
\hline Oxygens & 12.00 & 12.00 & 12.00 & 12.00 & 12.00 & 12.00 & 12.00 & 12.00 & 12.00 & 12.00 & 12.00 & 12.00 & 12.00 & 12.00 & 12.00 \\
\hline $\mathrm{Si}$ & 3.019 & 2.941 & 2.967 & 2.963 & 2.954 & 2.944 & 2.977 & 2.961 & 2.952 & 2.992 & 2.948 & 2.972 & 2.989 & 2.994 & 2.959 \\
\hline $\mathrm{Ti}$ & 0.01 & 0.01 & 0.00 & 0.00 & 0.00 & 0.01 & 0.00 & 0.01 & 0.02 & 0.00 & 0.00 & 0.01 & 0.00 & 0.01 & 0.00 \\
\hline $\mathrm{Al}$ & 1.98 & 2.17 & 1.99 & 1.98 & 2.00 & 2.02 & 2.00 & 2.03 & 2.00 & 1.98 & 1.99 & 1.95 & 2.00 & 1.97 & 2.01 \\
\hline $\mathrm{Cr}$ & 0.00 & 0.00 & 0.00 & 0.00 & 0.00 & 0.00 & 0.00 & 0.00 & 0.00 & 0.00 & 0.00 & 0.00 & 0.00 & 0.00 & 0.00 \\
\hline Fe3 & 0.00 & 0.00 & 0.08 & 0.09 & 0.09 & 0.07 & 0.04 & 0.03 & 0.07 & 0.03 & 0.11 & 0.09 & 0.02 & 0.02 & 0.07 \\
\hline $\mathrm{Fe} 2$ & 1.95 & 1.85 & 1.90 & 1.85 & 1.88 & 1.89 & 1.91 & 1.90 & 1.94 & 1.90 & 1.86 & 1.86 & 1.89 & 1.88 & 1.85 \\
\hline $\mathrm{Mn}$ & 0.07 & 0.07 & 0.07 & 0.07 & 0.08 & 0.08 & 0.08 & 0.08 & 0.08 & 0.09 & 0.08 & 0.08 & 0.08 & 0.09 & 0.08 \\
\hline $\mathrm{Mg}$ & 0.34 & 0.34 & 0.38 & 0.36 & 0.39 & 0.38 & 0.39 & 0.40 & 0.35 & 0.41 & 0.41 & 0.42 & 0.41 & 0.42 & 0.41 \\
\hline $\mathrm{Ca}$ & 0.62 & 0.57 & 0.62 & 0.68 & 0.61 & 0.60 & 0.60 & 0.60 & 0.60 & 0.60 & 0.60 & 0.63 & 0.61 & 0.61 & 0.61 \\
\hline $\mathrm{Na}$ & 0.00 & 0.00 & 0.00 & 0.00 & 0.00 & 0.00 & 0.00 & 0.00 & 0.00 & 0.00 & 0.00 & 0.00 & 0.00 & 0.00 & 0.00 \\
\hline $\mathrm{K}$ & 0.00 & 0.00 & 0.00 & 0.00 & 0.00 & 0.00 & 0.00 & 0.00 & 0.00 & 0.00 & 0.00 & 0.00 & 0.00 & 0.00 & 0.00 \\
\hline Sum & 7,984 & 7,959 & 8,000 & 8,000 & 8,000 & 8,000 & 8,000 & 8,000 & 8,000 & 8,000 & 8,000 & 8,000 & 8,000 & 8,000 & 8,000 \\
\hline Alm & 65.42 & 65.51 & 63.90 & 62.35 & 63.58 & 64.05 & 64.16 & 63.80 & 65.41 & 63.56 & 63.14 & 62.36 & 63.23 & 62.76 & 62.60 \\
\hline Prp & 11.36 & 11.84 & 12.84 & 12.20 & 13.09 & 12.91 & 13.12 & 13.40 & 11.89 & 13.63 & 13.77 & 13.92 & 13.62 & 13.89 & 13.89 \\
\hline Grs & 20.93 & 20.25 & 20.90 & 22.95 & 20.70 & 20.40 & 20.17 & 20.17 & 20.11 & 19.91 & 20.28 & 21.10 & 20.34 & 20.39 & 20.68 \\
\hline Sps & 2.28 & 2.40 & 2.36 & 2.49 & 2.64 & 2.64 & 2.55 & 2.63 & 2.59 & 2.91 & 2.81 & 2.62 & 2.81 & 2.96 & 2.84 \\
\hline TOTAL & 100.00 & 100.00 & 100.00 & 100.00 & 100.00 & 100.00 & 100.00 & 100.00 & 100.00 & 100.00 & 100.00 & 100.00 & 100.00 & 100.00 & 100.00 \\
\hline
\end{tabular}


Rochas metabásicas (Amostra NLD-42D)

GRANADA

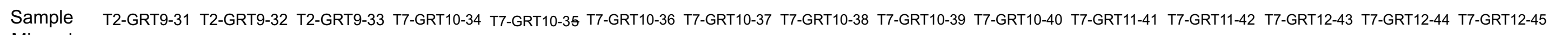

\begin{tabular}{|c|c|c|c|c|c|c|c|c|c|c|c|c|c|c|c|}
\hline Mineral & $g$ & $g$ & g & $g$ & $g$ & g & $g$ & g & g & g & g & $g$ & $g$ & g & g \\
\hline $\mathrm{SiO} 2$ & 37.63 & 37.40 & 37.40 & 37.28 & 37.51 & 37.58 & 37.27 & 37.26 & 36.98 & 37.39 & 37.50 & 37.26 & 37.63 & 37.46 & 37.49 \\
\hline TiO2 & 0.28 & 0.13 & 0.20 & 0.00 & 0.04 & 0.15 & 0.39 & 0.22 & 0.09 & 0.00 & 0.31 & 0.11 & 0.04 & 0.15 & 0.07 \\
\hline $\mathrm{Al} 2 \mathrm{O} 3$ & 21.13 & 20.89 & 21.10 & 21.49 & 21.27 & 21.19 & 21.26 & 21.14 & 21.09 & 21.46 & 21.20 & 21.63 & 21.57 & 21.50 & 21.69 \\
\hline Cr2O3 & 0.04 & 0.00 & 0.04 & 0.00 & 0.01 & 0.03 & 0.02 & 0.02 & 0.03 & 0.00 & 0.00 & 0.05 & 0.01 & 0.02 & 0.01 \\
\hline $\mathrm{Fe} 2 \mathrm{O} 3$ & 1.56 & 1.32 & 1.72 & 1.28 & 0.54 & 1.62 & 1.86 & 0.81 & 1.81 & 0.35 & 0.90 & 1.08 & 0.41 & 0.76 & 1.14 \\
\hline $\mathrm{FeO}$ & 28.75 & 28.23 & 28.09 & 28.18 & 28.07 & 27.99 & 27.44 & 27.47 & 27.23 & 28.31 & 28.42 & 28.31 & 29.31 & 28.61 & 28.85 \\
\hline $\mathrm{MnO}$ & 1.20 & 1.31 & 1.25 & 1.03 & 1.05 & 0.99 & 0.99 & 1.05 & 1.02 & 0.99 & 1.06 & 1.06 & 0.94 & 1.01 & 1.01 \\
\hline $\mathrm{MgO}$ & 3.35 & 3.35 & 3.47 & 2.85 & 2.89 & 3.03 & 3.09 & 3.06 & 3.09 & 2.86 & 3.34 & 3.23 & 3.13 & 3.23 & 3.21 \\
\hline $\mathrm{CaO}$ & 7.26 & 7.25 & 7.30 & 8.03 & 8.28 & 8.33 & 8.56 & 8.40 & 8.21 & 8.03 & 7.55 & 7.42 & 7.18 & 7.44 & 7.25 \\
\hline $\mathrm{Na} 2 \mathrm{O}$ & 0.00 & 0.00 & 0.00 & 0.00 & 0.00 & 0.00 & 0.00 & 0.00 & 0.00 & 0.00 & 0.00 & 0.00 & 0.00 & 0.00 & 0.00 \\
\hline $\mathrm{K} 2 \mathrm{O}$ & 0.00 & 0.00 & 0.00 & 0.00 & 0.00 & 0.00 & 0.00 & 0.00 & 0.00 & 0.00 & 0.00 & 0.00 & 0.00 & 0.00 & 0.00 \\
\hline Total & 101.19 & 99.89 & 100.56 & 100.13 & 99.65 & 100.91 & 100.89 & 99.42 & 99.54 & 99.40 & 100.28 & 100.14 & 100.23 & 100.19 & 100.72 \\
\hline Oxygens & 12.00 & 12.00 & 12.00 & 12.00 & 12.00 & 12.00 & 12.00 & 12.00 & 12.00 & 12.00 & 12.00 & 12.00 & 12.00 & 12.00 & 12.00 \\
\hline $\mathrm{Si}$ & 2.958 & 2.974 & 2.954 & 2.958 & 2.984 & 2.959 & 2.935 & 2.969 & 2.948 & 2.981 & 2.967 & 2.95 & 2.979 & 2.965 & 2.955 \\
\hline $\mathrm{Ti}$ & 0.02 & 0.01 & 0.01 & 0.00 & 0.00 & 0.01 & 0.02 & 0.01 & 0.01 & 0.00 & 0.02 & 0.01 & 0.00 & 0.01 & 0.00 \\
\hline $\mathrm{Al}$ & 1.96 & 1.96 & 1.96 & 2.01 & 2.00 & 1.97 & 1.97 & 1.99 & 1.98 & 2.02 & 1.98 & 2.02 & 2.01 & 2.01 & 2.02 \\
\hline $\mathrm{Cr}$ & 0.00 & 0.00 & 0.00 & 0.00 & 0.00 & 0.00 & 0.00 & 0.00 & 0.00 & 0.00 & 0.00 & 0.00 & 0.00 & 0.00 & 0.00 \\
\hline $\mathrm{Fe} 3$ & 0.09 & 0.08 & 0.10 & 0.08 & 0.03 & 0.10 & 0.11 & 0.05 & 0.11 & 0.02 & 0.05 & 0.06 & 0.02 & 0.05 & 0.07 \\
\hline $\mathrm{Fe} 2$ & 1.89 & 1.88 & 1.86 & 1.87 & 1.87 & 1.84 & 1.81 & 1.83 & 1.82 & 1.89 & 1.88 & 1.88 & 1.94 & 1.89 & 1.90 \\
\hline $\mathrm{Mn}$ & 0.08 & 0.09 & 0.08 & 0.07 & 0.07 & 0.07 & 0.07 & 0.07 & 0.07 & 0.07 & 0.07 & 0.07 & 0.06 & 0.07 & 0.07 \\
\hline $\mathrm{Mg}$ & 0.39 & 0.40 & 0.41 & 0.34 & 0.34 & 0.36 & 0.36 & 0.36 & 0.37 & 0.34 & 0.39 & 0.38 & 0.37 & 0.38 & 0.38 \\
\hline $\mathrm{Ca}$ & 0.61 & 0.62 & 0.62 & 0.68 & 0.71 & 0.70 & 0.72 & 0.72 & 0.70 & 0.69 & 0.64 & 0.63 & 0.61 & 0.63 & 0.61 \\
\hline $\mathrm{Na}$ & 0.00 & 0.00 & 0.00 & 0.00 & 0.00 & 0.00 & 0.00 & 0.00 & 0.00 & 0.00 & 0.00 & 0.00 & 0.00 & 0.00 & 0.00 \\
\hline $\mathrm{K}$ & 0.00 & 0.00 & 0.00 & 0.00 & 0.00 & 0.00 & 0.00 & 0.00 & 0.00 & 0.00 & 0.00 & 0.00 & 0.00 & 0.00 & 0.00 \\
\hline Sum & 8,000 & 8,000 & 8,000 & 8,000 & 8,000 & 8,000 & 8,000 & 8,000 & 8,000 & 8,000 & 8,000 & 8,000 & 8,000 & 8,000 & 8,000 \\
\hline Alm & 63.56 & 63.00 & 62.58 & 63.22 & 62.56 & 62.13 & 61.10 & 61.41 & 61.51 & 63.37 & 63.02 & 63.42 & 65.09 & 63.69 & 64.28 \\
\hline Prp & 13.21 & 13.32 & 13.79 & 11.39 & 11.45 & 11.96 & 12.27 & 12.17 & 12.42 & 11.37 & 13.17 & 12.88 & 12.37 & 12.81 & 12.74 \\
\hline Grs & 20.54 & 20.73 & 20.84 & 23.06 & 23.61 & 23.69 & 24.40 & 24.04 & 23.73 & 23.01 & 21.44 & 21.30 & 20.42 & 21.22 & 20.68 \\
\hline Sps & 2.69 & 2.95 & 2.80 & 2.33 & 2.38 & 2.22 & 2.23 & 2.38 & 2.34 & 2.25 & 2.38 & 2.40 & 2.11 & 2.29 & 2.30 \\
\hline TOTAL & 100.00 & 100.00 & 100.00 & 100.00 & 100.00 & 100.00 & 100.00 & 100.00 & 100.00 & 100.00 & 100.00 & 100.00 & 100.00 & 100.00 & 100.00 \\
\hline
\end{tabular}


Rochas metabásicas (Amostra NLD-42D)

GRANADA

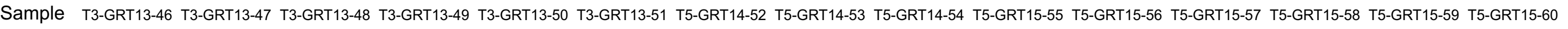

\begin{tabular}{|c|c|c|c|c|c|c|c|c|c|c|c|c|c|c|c|}
\hline Mineral & g & g & $g$ & g & g & 9 & g & $g$ & g & g & g & g & g & g & g \\
\hline $\mathrm{SiO} 2$ & 37.40 & 37.95 & 37.55 & 37.84 & 37.13 & 37.52 & 36.75 & 37.21 & 37.85 & 37.63 & 37.13 & 37.12 & 37.51 & 37.55 & 36.82 \\
\hline TiO2 & 0.00 & 0.07 & 0.07 & 0.00 & 0.11 & 0.00 & 0.20 & 0.00 & 0.00 & 0.00 & 0.00 & 0.13 & 0.00 & 0.00 & 0.09 \\
\hline $\mathrm{Al} 2 \mathrm{O} 3$ & 21.18 & 21.47 & 21.37 & 21.45 & 21.46 & 21.03 & 21.53 & 21.46 & 21.59 & 21.44 & 21.35 & 21.68 & 21.59 & 21.28 & 21.29 \\
\hline Cr2O3 & 0.01 & 0.03 & 0.00 & 0.00 & 0.01 & 0.00 & 0.01 & 0.02 & 0.00 & 0.00 & 0.05 & 0.00 & 0.01 & 0.04 & 0.01 \\
\hline $\mathrm{Fe} 2 \mathrm{O} 3$ & 1.07 & 0.10 & 0.71 & 0.07 & 1.71 & 0.37 & 1.31 & 1.74 & 0.00 & 0.64 & 1.10 & 1.37 & 0.00 & 0.55 & 0.87 \\
\hline $\mathrm{FeO}$ & 27.72 & 28.44 & 28.15 & 28.40 & 27.72 & 28.44 & 27.92 & 27.69 & 28.18 & 28.50 & 27.29 & 27.82 & 28.59 & 28.83 & 27.94 \\
\hline $\mathrm{MnO}$ & 1.90 & 1.86 & 1.87 & 1.79 & 1.77 & 1.74 & 1.79 & 1.76 & 1.75 & 1.75 & 1.78 & 1.74 & 1.75 & 1.77 & 1.83 \\
\hline $\mathrm{MgO}$ & 3.24 & 3.19 & 3.26 & 3.25 & 3.23 & 3.19 & 3.09 & 3.24 & 3.27 & 3.14 & 3.40 & 3.35 & 2.88 & 3.02 & 3.09 \\
\hline $\mathrm{CaO}$ & 7.26 & 7.34 & 7.11 & 7.22 & 7.19 & 7.00 & 6.92 & 7.21 & 7.25 & 7.13 & 7.20 & 6.99 & 7.02 & 6.94 & 6.85 \\
\hline $\mathrm{Na} 2 \mathrm{O}$ & 0.00 & 0.00 & 0.00 & 0.00 & 0.00 & 0.00 & 0.00 & 0.00 & 0.00 & 0.00 & 0.00 & 0.00 & 0.00 & 0.00 & 0.00 \\
\hline $\mathrm{K} 2 \mathrm{O}$ & 0.00 & 0.00 & 0.00 & 0.00 & 0.00 & 0.00 & 0.00 & 0.00 & 0.00 & 0.00 & 0.00 & 0.00 & 0.00 & 0.00 & 0.00 \\
\hline Total & 99.77 & 100.45 & 100.09 & 100.00 & 100.34 & 99.29 & 99.53 & 100.34 & 99.91 & 100.21 & 99.32 & 100.20 & 99.34 & 99.97 & 98.81 \\
\hline Oxygens & 12.00 & 12.00 & 12.00 & 12.00 & 12.00 & 12.00 & 12.00 & 12.00 & 12.00 & 12.00 & 12.00 & 12.00 & 12.00 & 12.00 & 12.00 \\
\hline $\mathrm{Si}$ & 2.975 & 2.994 & 2.977 & 2.997 & 2.941 & 2.998 & 2.935 & 2.946 & 2.997 & 2.98 & 2.962 & 2.94 & 2.993 & 2.986 & 2.959 \\
\hline $\mathrm{Ti}$ & 0.00 & 0.00 & 0.00 & 0.00 & 0.01 & 0.00 & 0.01 & 0.00 & 0.00 & 0.00 & 0.00 & 0.01 & 0.00 & 0.00 & 0.01 \\
\hline $\mathrm{Al}$ & 1.99 & 2.00 & 2.00 & 2.00 & 2.00 & 1.98 & 2.03 & 2.00 & 2.02 & 2.00 & 2.01 & 2.02 & 2.03 & 1.99 & 2.02 \\
\hline $\mathrm{Cr}$ & 0.00 & 0.00 & 0.00 & 0.00 & 0.00 & 0.00 & 0.00 & 0.00 & 0.00 & 0.00 & 0.00 & 0.00 & 0.00 & 0.00 & 0.00 \\
\hline Fe3 & 0.06 & 0.01 & 0.04 & 0.00 & 0.10 & 0.02 & 0.08 & 0.10 & 0.00 & 0.04 & 0.07 & 0.08 & 0.00 & 0.03 & 0.05 \\
\hline $\mathrm{Fe} 2$ & 1.84 & 1.88 & 1.88 & 1.88 & 1.84 & 1.90 & 1.87 & 1.83 & 1.87 & 1.89 & 1.82 & 1.84 & 1.91 & 1.92 & 1.88 \\
\hline $\mathrm{Mn}$ & 0.13 & 0.12 & 0.13 & 0.12 & 0.12 & 0.12 & 0.12 & 0.12 & 0.12 & 0.12 & 0.12 & 0.12 & 0.12 & 0.12 & 0.13 \\
\hline $\mathrm{Mg}$ & 0.38 & 0.38 & 0.39 & 0.38 & 0.38 & 0.38 & 0.37 & 0.38 & 0.39 & 0.37 & 0.41 & 0.40 & 0.34 & 0.36 & 0.37 \\
\hline $\mathrm{Ca}$ & 0.62 & 0.62 & 0.60 & 0.61 & 0.61 & 0.60 & 0.59 & 0.61 & 0.62 & 0.61 & 0.62 & 0.59 & 0.60 & 0.59 & 0.59 \\
\hline $\mathrm{Na}$ & 0.00 & 0.00 & 0.00 & 0.00 & 0.00 & 0.00 & 0.00 & 0.00 & 0.00 & 0.00 & 0.00 & 0.00 & 0.00 & 0.00 & 0.00 \\
\hline $\mathrm{K}$ & 0.00 & 0.00 & 0.00 & 0.00 & 0.00 & 0.00 & 0.00 & 0.00 & 0.00 & 0.00 & 0.00 & 0.00 & 0.00 & 0.00 & 0.00 \\
\hline Sum & 8,000 & 8,000 & 8,000 & 8,000 & 8,000 & 8,000 & 8,000 & 8,000 & 7,996 & 8,000 & 8,000 & 8,000 & 7,992 & 8,000 & 8,000 \\
\hline Alm & 61.98 & 62.63 & 62.80 & 62.78 & 62.31 & 63.42 & 63.28 & 62.23 & 62.51 & 63.36 & 61.48 & 62.52 & 64.29 & 64.20 & 63.37 \\
\hline Prp & 12.91 & 12.51 & 12.85 & 12.78 & 12.96 & 12.67 & 12.49 & 13.00 & 12.93 & 12.42 & 13.67 & 13.40 & 11.52 & 11.99 & 12.51 \\
\hline Grs & 20.81 & 20.72 & 20.17 & 20.43 & 20.69 & 19.97 & 20.12 & 20.77 & 20.60 & 20.30 & 20.80 & 20.12 & 20.22 & 19.83 & 19.90 \\
\hline Sps & 4.30 & 4.14 & 4.17 & 4.01 & 4.04 & 3.93 & 4.11 & 4.00 & 3.95 & 3.93 & 4.05 & 3.97 & 3.98 & 3.99 & 4.22 \\
\hline TOTAL & 100.00 & 100.00 & 100.00 & 100.00 & 100.00 & 100.00 & 100.00 & 100.00 & 100.00 & 100.00 & 100.00 & 100.00 & 100.00 & 100.00 & 100.00 \\
\hline
\end{tabular}


Rochas metabásicas (Amostra NLD-42D)

GRANADA

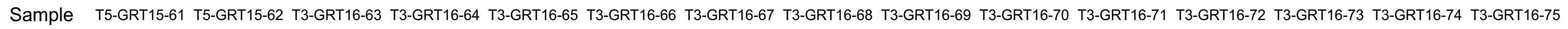

\begin{tabular}{|c|c|c|c|c|c|c|c|c|c|c|c|c|c|c|c|}
\hline Mineral & $\mathrm{g}$ & g & g & $g$ & g & g & g & g & g & g & g & g & $\mathrm{g}$ & $g$ & g \\
\hline $\mathrm{SiO} 2$ & 37.38 & 36.82 & 37.49 & 37.48 & 37.20 & 37.30 & 38.12 & 37.77 & 37.80 & 37.80 & 37.45 & 37.63 & 37.66 & 37.87 & 37.53 \\
\hline $\mathrm{TiO} 2$ & 0.09 & 0.00 & 0.17 & 0.26 & 0.39 & 0.20 & 0.24 & 0.00 & 0.04 & 0.02 & 0.04 & 0.11 & 0.04 & 0.00 & 0.15 \\
\hline $\mathrm{Al} 2 \mathrm{O} 3$ & 21.34 & 21.70 & 21.38 & 21.27 & 20.99 & 21.27 & 21.60 & 21.55 & 21.67 & 21.48 & 21.57 & 21.19 & 21.47 & 21.64 & 21.48 \\
\hline Cr2O3 & 0.00 & 0.03 & 0.03 & 0.00 & 0.00 & 0.05 & 0.03 & 0.02 & 0.00 & 0.01 & 0.00 & 0.01 & 0.03 & 0.06 & 0.00 \\
\hline $\mathrm{Fe} 2 \mathrm{O} 3$ & 1.27 & 1.27 & 1.57 & 0.00 & 1.27 & 1.68 & 0.07 & 0.06 & 0.72 & 0.62 & 1.42 & 1.47 & 0.37 & 0.77 & 2.58 \\
\hline $\mathrm{FeO}$ & 28.72 & 28.18 & 29.57 & 28.93 & 28.56 & 27.96 & 28.80 & 28.47 & 28.41 & 28.05 & 27.92 & 28.06 & 28.17 & 28.02 & 27.67 \\
\hline $\mathrm{MnO}$ & 1.88 & 1.88 & 1.02 & 1.03 & 1.22 & 1.29 & 1.38 & 1.33 & 1.22 & 1.16 & 0.99 & 0.99 & 1.12 & 1.11 & 1.08 \\
\hline $\mathrm{MgO}$ & 3.01 & 2.91 & 3.22 & 3.14 & 3.13 & 3.41 & 3.63 & 3.34 & 3.48 & 3.64 & 3.62 & 3.75 & 3.50 & 3.58 & 3.66 \\
\hline $\mathrm{CaO}$ & 6.85 & 6.83 & 6.74 & 7.31 & 7.38 & 7.36 & 7.12 & 7.32 & 7.33 & 7.41 & 7.36 & 7.29 & 7.42 & 7.61 & 7.58 \\
\hline $\mathrm{Na} 2 \mathrm{O}$ & 0.00 & 0.00 & 0.00 & 0.00 & 0.00 & 0.00 & 0.00 & 0.00 & 0.00 & 0.00 & 0.00 & 0.00 & 0.00 & 0.00 & 0.00 \\
\hline $\mathrm{K} 2 \mathrm{O}$ & 0.00 & 0.00 & 0.00 & 0.00 & 0.00 & 0.00 & 0.00 & 0.00 & 0.00 & 0.00 & 0.00 & 0.00 & 0.00 & 0.00 & 0.00 \\
\hline Total & 100.54 & 99.62 & 101.18 & 99.42 & 100.13 & 100.52 & 100.99 & 99.86 & 100.67 & 100.18 & 100.38 & 100.50 & 99.79 & 100.66 & 101.75 \\
\hline Oxygens & 12.00 & 12.00 & 12.00 & 12.00 & 12.00 & 12.00 & 12.00 & 12.00 & 12.00 & 12.00 & 12.00 & 12.00 & 12.00 & 12.00 & 12.00 \\
\hline $\mathrm{Si}$ & 2.961 & 2.94 & 2.951 & 2.987 & 2.956 & 2.947 & 2.986 & 2.992 & 2.972 & 2.982 & 2.953 & 2.966 & 2.983 & 2.974 & 2.928 \\
\hline $\mathrm{Ti}$ & 0.01 & 0.00 & 0.01 & 0.02 & 0.02 & 0.01 & 0.01 & 0.00 & 0.00 & 0.00 & 0.00 & 0.01 & 0.00 & 0.00 & 0.01 \\
\hline $\mathrm{Al}$ & 1.99 & 2.04 & 1.98 & 2.00 & 1.97 & 1.98 & 2.00 & 2.01 & 2.01 & 2.00 & 2.01 & 1.97 & 2.01 & 2.00 & 1.98 \\
\hline $\mathrm{Cr}$ & 0.00 & 0.00 & 0.00 & 0.00 & 0.00 & 0.00 & 0.00 & 0.00 & 0.00 & 0.00 & 0.00 & 0.00 & 0.00 & 0.00 & 0.00 \\
\hline $\mathrm{Fe} 3$ & 0.08 & 0.08 & 0.09 & 0.00 & 0.08 & 0.10 & 0.00 & 0.00 & 0.04 & 0.04 & 0.08 & 0.09 & 0.02 & 0.05 & 0.15 \\
\hline $\mathrm{Fe} 2$ & 1.90 & 1.88 & 1.95 & 1.93 & 1.90 & 1.85 & 1.89 & 1.89 & 1.87 & 1.85 & 1.84 & 1.85 & 1.87 & 1.84 & 1.81 \\
\hline $\mathrm{Mn}$ & 0.13 & 0.13 & 0.07 & 0.07 & 0.08 & 0.09 & 0.09 & 0.09 & 0.08 & 0.08 & 0.07 & 0.07 & 0.08 & 0.07 & 0.07 \\
\hline $\mathrm{Mg}$ & 0.36 & 0.35 & 0.38 & 0.37 & 0.37 & 0.40 & 0.42 & 0.39 & 0.41 & 0.43 & 0.43 & 0.44 & 0.41 & 0.42 & 0.43 \\
\hline $\mathrm{Ca}$ & 0.58 & 0.58 & 0.57 & 0.62 & 0.63 & 0.62 & 0.60 & 0.62 & 0.62 & 0.63 & 0.62 & 0.62 & 0.63 & 0.64 & 0.63 \\
\hline $\mathrm{Na}$ & 0.00 & 0.00 & 0.00 & 0.00 & 0.00 & 0.00 & 0.00 & 0.00 & 0.00 & 0.00 & 0.00 & 0.00 & 0.00 & 0.00 & 0.00 \\
\hline $\mathrm{K}$ & 0.00 & 0.00 & 0.00 & 0.00 & 0.00 & 0.00 & 0.00 & 0.00 & 0.00 & 0.00 & 0.00 & 0.00 & 0.00 & 0.00 & 0.00 \\
\hline Sum & 8,000 & 8,000 & 8,000 & 7,998 & 8,000 & 8,000 & 8,000 & 8,000 & 8,000 & 8,000 & 8,000 & 8,000 & 8,000 & 8,000 & 8,000 \\
\hline Alm & 64.18 & 64.04 & 65.75 & 64.41 & 63.71 & 62.45 & 62.92 & 63.07 & 62.82 & 62.05 & 62.30 & 62.25 & 62.53 & 61.90 & 61.49 \\
\hline Prp & 11.97 & 11.77 & 12.73 & 12.45 & 12.45 & 13.59 & 14.10 & 13.17 & 13.71 & 14.35 & 14.42 & 14.80 & 13.86 & 14.09 & 14.47 \\
\hline Grs & 19.60 & 19.87 & 19.22 & 20.83 & 21.08 & 21.05 & 19.91 & 20.79 & 20.74 & 21.02 & 21.05 & 20.73 & 21.10 & 21.52 & 21.59 \\
\hline Sps & 4.25 & 4.32 & 2.30 & 2.30 & 2.75 & 2.91 & 3.07 & 2.97 & 2.72 & 2.58 & 2.23 & 2.22 & 2.51 & 2.49 & 2.45 \\
\hline TOTAL & 100.00 & 100.00 & 100.00 & 100.00 & 100.00 & 100.00 & 100.00 & 100.00 & 100.00 & 100.00 & 100.00 & 100.00 & 100.00 & 100.00 & 100.00 \\
\hline
\end{tabular}




\section{Rochas metabásicas (Amostra NLD-42D)}

\section{GRANADA}

\begin{tabular}{|c|c|c|c|c|c|c|c|c|c|c|}
\hline Sample & T3-GRT16-76 & T3-GRT16-77 & T3-GRT16-78 & T3-GRT16-79 & T3-GRT16-80 & T3-GRT16-81 & T3-GRT16-82 & T3-GRT16-83 & T3-GRT16-84 & T3-GRT16-8 \\
\hline Mineral & $g$ & $g$ & $g$ & g & g & $g$ & $g$ & g & $g$ & g \\
\hline $\mathrm{SiO} 2$ & 37.30 & 37.28 & 37.29 & 37.27 & 37.43 & 37.52 & 37.42 & 37.90 & 37.57 & 37.80 \\
\hline TiO2 & 0.20 & 0.00 & 0.13 & 0.13 & 0.00 & 0.24 & 0.02 & 0.07 & 0.02 & 0.07 \\
\hline $\mathrm{Al} 2 \mathrm{O} 3$ & 21.21 & 21.46 & 21.18 & 21.36 & 22.21 & 21.61 & 21.45 & 21.55 & 21.19 & 21.40 \\
\hline $\mathrm{Cr} 2 \mathrm{O} 3$ & 0.00 & 0.04 & 0.01 & 0.00 & 0.00 & 0.01 & 0.02 & 0.00 & 0.04 & 0.00 \\
\hline $\mathrm{Fe} 2 \mathrm{O} 3$ & 0.87 & 1.87 & 2.78 & 0.68 & 1.56 & 1.65 & 0.57 & 0.00 & 2.21 & 0.49 \\
\hline $\mathrm{FeO}$ & 27.42 & 27.33 & 27.03 & 27.56 & 27.31 & 28.12 & 27.83 & 28.28 & 28.18 & 29.08 \\
\hline $\mathrm{MnO}$ & 0.98 & 0.97 & 1.10 & 1.14 & 1.14 & 0.95 & 1.06 & 1.24 & 1.25 & 1.19 \\
\hline $\mathrm{MgO}$ & 3.46 & 3.73 & 3.43 & 3.42 & 3.62 & 3.73 & 3.79 & 3.65 & 3.50 & 3.17 \\
\hline $\mathrm{CaO}$ & 7.97 & 7.49 & 8.14 & 7.69 & 7.68 & 7.29 & 7.11 & 7.21 & 7.22 & 7.26 \\
\hline $\mathrm{Na} 2 \mathrm{O}$ & 0.00 & 0.00 & 0.00 & 0.00 & 0.00 & 0.00 & 0.00 & 0.00 & 0.00 & 0.00 \\
\hline $\mathrm{K} 2 \mathrm{O}$ & 0.00 & 0.00 & 0.00 & 0.00 & 0.00 & 0.00 & 0.00 & 0.00 & 0.00 & 0.00 \\
\hline Total & 99.40 & 100.18 & 101.10 & 99.26 & 100.94 & 101.12 & 99.27 & 99.90 & 101.19 & 100.47 \\
\hline Oxygens & 12.00 & 12.00 & 12.00 & 12.00 & 12.00 & 12.00 & 12.00 & 12.00 & 12.00 & 12.00 \\
\hline $\mathrm{Si}$ & 2.968 & 2.944 & 2.929 & 2.969 & 2.93 & 2.939 & 2.976 & 2.994 & 2.951 & 2.985 \\
\hline $\mathrm{Ti}$ & 0.01 & 0.00 & 0.01 & 0.04 & 0.00 & 0.01 & 0.00 & 0.00 & 0.00 & 0.00 \\
\hline $\mathrm{Al}$ & 1.99 & 2.00 & 1.96 & 2.01 & 2.05 & 2.00 & 2.01 & 2.01 & 1.96 & 1.99 \\
\hline $\mathrm{Cr}$ & 0.00 & 0.00 & 0.00 & 0.00 & 0.00 & 0.00 & 0.00 & 0.00 & 0.00 & 0.00 \\
\hline Fe3 & 0.05 & 0.11 & 0.16 & 0.04 & 0.09 & 0.10 & 0.03 & 0.00 & 0.13 & 0.03 \\
\hline $\mathrm{Fe} 2$ & 1.83 & 1.81 & 1.78 & 1.84 & 1.79 & 1.84 & 1.85 & 1.87 & 1.85 & 1.92 \\
\hline $\mathrm{Mn}$ & 0.07 & 0.07 & 0.07 & 0.08 & 0.08 & 0.06 & 0.07 & 0.08 & 0.08 & 0.08 \\
\hline $\mathrm{Mg}$ & 0.41 & 0.44 & 0.40 & 0.41 & 0.42 & 0.44 & 0.45 & 0.43 & 0.41 & 0.37 \\
\hline $\mathrm{Ca}$ & 0.68 & 0.63 & 0.69 & 0.66 & 0.64 & 0.61 & 0.61 & 0.61 & 0.61 & 0.62 \\
\hline $\mathrm{Na}$ & 0.00 & 0.00 & 0.00 & 0.00 & 0.00 & 0.00 & 0.00 & 0.00 & 0.00 & 0.00 \\
\hline $\mathrm{K}$ & 0.00 & 0.00 & 0.00 & 0.00 & 0.00 & 0.00 & 0.00 & 0.00 & 0.00 & 0.00 \\
\hline Sum & 8,000 & 8,000 & 8,000 & 8,000 & 8,000 & 8,000 & 8,000 & 7,998 & 8,000 & 8,000 \\
\hline Alm & 61.24 & 61.32 & 60.50 & 61.71 & 61.04 & 62.39 & 62.19 & 62.47 & 62.72 & 64.28 \\
\hline Prp & 13.76 & 14.94 & 13.69 & 13.64 & 14.41 & 14.76 & 15.08 & 14.37 & 13.88 & 12.47 \\
\hline Grs & 22.79 & 21.53 & 23.32 & 22.07 & 21.99 & 20.72 & 20.35 & 20.39 & 20.59 & 20.57 \\
\hline Sps & 2.21 & 2.21 & 2.49 & 2.59 & 2.56 & 2.13 & 2.38 & 2.77 & 2.81 & 2.68 \\
\hline TOTAL & 100.00 & 100.00 & 100.00 & 100.00 & 100.00 & 100.00 & 100.00 & 100.00 & 100.00 & 100.00 \\
\hline
\end{tabular}




\section{Rochas metabásicas (Amostra NLD-7D)}

\section{PLAGIOCLÁSIO}

\begin{tabular}{|c|c|c|c|c|c|c|c|c|c|c|c|c|c|c|c|c|c|}
\hline Sample & NLD-7D & NLD-7D & NLD-7D & NLD-7D & NLD-7D & NLD-7D & NLD-7D & NLD-7D & NLD-7D & NLD-7D & NLD-7D & NLD-7D & NLD-7D & NLD-7D & NLD-7D & NLD-7D & NLD-7D \\
\hline $\mathrm{SiO} 2$ & 56.78 & 57.73 & 56.71 & 57.43 & 57.14 & 54.86 & 57.06 & 57.64 & 58.38 & 56.59 & 57.51 & 55.15 & 57.66 & 56.27 & 56.87 & 57.22 & 51.05 \\
\hline TiO2 & 26.95 & 27.23 & 27 & 27.14 & 26.98 & 27.7 & 26.96 & 27.04 & 26.92 & 26.23 & 26.99 & 27.29 & 26.97 & 27.1 & 27.19 & 27.21 & 31.05 \\
\hline $\mathrm{Al} 2 \mathrm{O} 3$ & 0.02 & 0.04 & 0.05 & 0 & 0.04 & 0.01 & 0.03 & 0.01 & 0.01 & 0.03 & 0.05 & 0 & 0.02 & 0 & 0 & 0 & 0.01 \\
\hline $\mathrm{Fe} 2 \mathrm{O} 3$ & 0.26 & 0.09 & 0 & 0.1 & 0 & 0.17 & 0.18 & 0.17 & 0.2 & 0.55 & 0.08 & 0.14 & 0.01 & 0.35 & 0.15 & 0.09 & 0.6 \\
\hline $\mathrm{MnO}$ & 0 & 0.01 & 0 & 0 & 0 & 0.01 & 0 & 0 & 0 & 0.01 & 0 & 0 & 0 & 0.01 & 0 & 0 & 0 \\
\hline $\mathrm{MgO}$ & 0 & 0 & 0 & 0 & 0.01 & 0.01 & 0.01 & 0 & 0 & 0.04 & 0.01 & 0.02 & 0 & 0 & 0 & 0 & 0.11 \\
\hline $\mathrm{CaO}$ & 9.09 & 9.13 & 9.13 & 9.22 & 8.93 & 8.81 & 9.04 & 8.81 & 8.71 & 8.63 & 9.05 & 9.1 & 9.15 & 9.02 & 9.34 & 9.42 & 8.44 \\
\hline $\mathrm{Na} 2 \mathrm{O}$ & 6.41 & 6.38 & 6.31 & 6.21 & 6.39 & 6.3 & 6.44 & 6.46 & 6.31 & 6.5 & 6.52 & 6.25 & 6.34 & 6.54 & 6.22 & 6.36 & 5.17 \\
\hline $\mathrm{K} 2 \mathrm{O}$ & 0.18 & 0.16 & 0.19 & 0.2 & 0.21 & 0.18 & 0.18 & 0.19 & 0.16 & 0.17 & 0.18 & 0.2 & 0.2 & 0.22 & 0.19 & 0.2 & 0.2 \\
\hline Totals & 99.7 & 100.76 & 99.38 & 100.31 & 99.7 & 98.05 & 99.89 & 100.31 & 100.69 & 98.75 & 100.39 & 98.14 & 100.36 & 99.52 & 99.97 & 100.5 & 96.62 \\
\hline $\mathrm{Si}$ & 2.664 & 2.675 & 2.667 & 2.674 & 2.676 & 2.624 & 2.67 & 2.681 & 2.699 & 2.678 & 2.676 & 2.635 & 2.682 & 2.65 & 2.661 & 2.664 & 2.493 \\
\hline $\mathrm{Ti}$ & 0.951 & 0.949 & 0.955 & 0.95 & 0.95 & 0.996 & 0.949 & 0.946 & 0.936 & 0.934 & 0.945 & 0.98 & 0.943 & 0.96 & 0.957 & 0.953 & 1.14 \\
\hline $\mathrm{Al}$ & 0.001 & 0.002 & 0.003 & 0 & 0.002 & 0.001 & 0.001 & 0.001 & 0.001 & 0.002 & 0.003 & 0 & 0.001 & 0 & 0 & 0 & 0 \\
\hline $\mathrm{Fe} 3$ & 0.01 & 0.00 & 0.00 & 0.00 & 0.00 & 0.01 & 0.01 & 0.01 & 0.01 & 0.02 & 0.00 & 0.01 & 0.00 & 0.01 & 0.01 & 0.00 & 0.02 \\
\hline $\mathrm{Mn}$ & 0.00 & 0.00 & 0.00 & 0.00 & 0.00 & 0.00 & 0.00 & 0.00 & 0.00 & 0.00 & 0.00 & 0.00 & 0.00 & 0.00 & 0.00 & 0.00 & 0.00 \\
\hline $\mathrm{Mg}$ & 0 & 0 & 0 & 0 & 0 & 0 & 0.001 & 0 & 0 & 0.003 & 0 & 0.001 & 0 & 0 & 0 & 0 & 0.008 \\
\hline $\mathrm{Ca}$ & 0.457 & 0.453 & 0.46 & 0.46 & 0.448 & 0.451 & 0.453 & 0.439 & 0.431 & 0.438 & 0.451 & 0.466 & 0.456 & 0.455 & 0.468 & 0.47 & 0.441 \\
\hline $\mathrm{Na}$ & 0.583 & 0.573 & 0.576 & 0.561 & 0.58 & 0.584 & 0.584 & 0.583 & 0.566 & 0.596 & 0.588 & 0.578 & 0.572 & 0.598 & 0.564 & 0.574 & 0.489 \\
\hline $\mathrm{K}$ & 0.011 & 0.01 & 0.011 & 0.012 & 0.013 & 0.011 & 0.011 & 0.011 & 0.01 & 0.01 & 0.011 & 0.012 & 0.012 & 0.013 & 0.011 & 0.012 & 0.012 \\
\hline Sum & 4.676 & 4.665 & 4.671 & 4.661 & 4.669 & 4.674 & 4.675 & 4.667 & 4.649 & 4.68 & 4.676 & 4.678 & 4.666 & 4.689 & 4.667 & 4.675 & 4.606 \\
\hline An & 43.5 & 43.7 & 43.9 & 44.5 & 43.0 & 43.1 & 43.2 & 42.5 & 42.8 & 42.0 & 43.0 & 44.1 & 43.8 & 42.7 & 44.9 & 44.5 & 46.8 \\
\hline$A b$ & 55.5 & 55.3 & 55.0 & 54.3 & 55.7 & 55.8 & 55.7 & 56.4 & 56.2 & 57.1 & 56.0 & 54.7 & 55.0 & 56.1 & 54.1 & 54.4 & 51.9 \\
\hline Or & 1.1 & 1.0 & 1.1 & 1.2 & 1.3 & 1.1 & 1.1 & 1.1 & 1.0 & 1.0 & 1.1 & 1.1 & 1.2 & 1.2 & 1.1 & 1.1 & 1.3 \\
\hline
\end{tabular}


Rochas metabásicas (Amostra NLD-7D)

PLAGIOCLÁSIO

$\begin{array}{ccccccccccc}\text { Sample } & \text { NLD-7D } & \text { NLD-7D } & \text { NLD-7D } & \text { NLD-7D } & \text { NLD-7D } & \text { NLD-7D } & \text { NLD-7D } & \text { NLD-7D } & \text { NLD-7D } & \text { NLD-7D } \\ \mathrm{SiO} 2 & 57.31 & 56.86 & 57.24 & 56.48 & 56.34 & 56.44 & 57.21 & 56.98 & 57.02 & 58.01 \\ \mathrm{TiO} 2 & 27.33 & 27.01 & 27.07 & 27.02 & 26.93 & 26.9 & 27.43 & 27.18 & 27.02 & 26.99 \\ \mathrm{Al} 2 \mathrm{O} 3 & 0.01 & 0 & 0 & 0 & 0.02 & 0.03 & 0 & 0.03 & 0.01 & 0 \\ \mathrm{Fe} 2 \mathrm{O} 3 & 0.24 & 0.17 & 0.07 & 0.09 & 0.36 & 0.07 & 0.07 & 0 & 0.06 & 0.25 \\ \mathrm{MnO} & 0.03 & 0.01 & 0.01 & 0.01 & 0 & 0.01 & 0 & 0.01 & 0.02 & 0 \\ \mathrm{MgO} & 0 & 0.01 & 0 & 0 & 0.01 & 0.01 & 0.01 & 0 & 0 & 0 \\ \mathrm{CaO} & 9.22 & 8.81 & 9.07 & 9.21 & 9.04 & 9.3 & 9.36 & 9.39 & 9.31 & 9 \\ \mathrm{Na} 2 \mathrm{O} & 6.3 & 6.51 & 6.25 & 6.22 & 6.29 & 6.07 & 6.22 & 6.16 & 6.17 & 6.2 \\ \mathrm{~K} 2 \mathrm{O} & 0.21 & 0.22 & 0.16 & 0.16 & 0.19 & 0.17 & 0.17 & 0.19 & 0.17 & 0.2 \\ \mathrm{Totals} & 100.67 & 99.6 & 99.86 & 99.19 & 99.19 & 98.97 & 100.47 & 99.93 & 99.78 & 100.65 \\ \mathrm{Si} & 2.663 & 2.669 & 2.675 & 2.662 & 2.658 & 2.665 & 2.662 & 2.665 & 2.67 & 2.688 \\ \mathrm{Ti} & 0.955 & 0.953 & 0.952 & 0.958 & 0.956 & 0.955 & 0.96 & 0.956 & 0.951 & 0.94 \\ \mathrm{Al} & 0.001 & 0 & 0 & 0 & 0.001 & 0.001 & 0 & 0.001 & 0.001 & 0 \\ \mathrm{Fe} 3 & 0.01 & 0.01 & 0.00 & 0.00 & 0.01 & 0.00 & 0.00 & 0.00 & 0.00 & 0.01 \\ \mathrm{Mn} & 0.00 & 0.00 & 0.00 & 0.00 & 0.00 & 0.00 & 0.00 & 0.00 & 0.00 & 0.00 \\ \mathrm{Mg} & 0 & 0.001 & 0 & 0 & 0.001 & 0 & 0 & 0 & 0 & 0 \\ \mathrm{Ca} & 0.459 & 0.443 & 0.454 & 0.465 & 0.457 & 0.471 & 0.467 & 0.471 & 0.467 & 0.447 \\ \mathrm{Na} & 0.568 & 0.592 & 0.567 & 0.569 & 0.576 & 0.555 & 0.561 & 0.558 & 0.56 & 0.557 \\ \mathrm{~K} & 0.013 & 0.013 & 0.01 & 0.01 & 0.011 & 0.01 & 0.01 & 0.012 & 0.01 & 0.012 \\ \mathrm{Sum} & 4.668 & 4.678 & 4.66 & 4.668 & 4.673 & 4.661 & 4.663 & 4.663 & 4.662 & 4.652 \\ \mathrm{An} & 44.1 & 42.3 & 44.0 & 44.5 & 43.8 & 45.5 & 45.0 & 45.2 & 45.0 & 44.0 \\ \mathrm{Ab} & 54.6 & 56.5 & 55.0 & 54.5 & 55.2 & 53.6 & 54.0 & 53.6 & 54.0 & 54.8 \\ \mathrm{Or} & 1.3 & 1.3 & 1.0 & 1.0 & 1.1 & 1.0 & 1.0 & 1.2 & 1.0 & 1.2\end{array}$




\section{Rochas metabásicas (Amostra NLD-20A) PLAGIOCLÁSIO}

\begin{tabular}{|c|c|c|c|c|c|c|c|c|c|c|c|c|c|c|c|c|c|}
\hline nple & NLD-20A & NLD-20A & NLD-20A & NLD-20A & NLD-20A & NLD-20A & NLD-20A & NLD-20A & NLD-20A & NLD-20A & NLD-20A & NLD-20A & NLD-20A & NLD-20A & NLD-20A & NLD-20A & NLD-20A \\
\hline $\mathrm{SiO} 2$ & 54.72 & 55.04 & 54.58 & 57.17 & 53.28 & 50.47 & 53.45 & 53.58 & 55.29 & 54.72 & 53.84 & 55.88 & 54.72 & 54.86 & 55.46 & 52.03 & 50.99 \\
\hline $\mathrm{TiO} 2$ & 28.31 & 28.31 & 28.59 & 26.89 & 28.91 & 30.91 & 29.14 & 28.53 & 28.32 & 28.62 & 28.93 & 27.55 & 27.34 & 27.25 & 27.72 & 30.26 & 29.47 \\
\hline $\mathrm{Al} 2 \mathrm{O} 3$ & 0.01 & 0.03 & 0.01 & 0.07 & 0 & 0.01 & 0.02 & 0.01 & 0 & 0 & 0.01 & 0.01 & 0.07 & 0 & 0.02 & 0.06 & 0 \\
\hline $\mathrm{Fe} 2 \mathrm{O} 3$ & 0.16 & 0.11 & 0 & 0.06 & 0.05 & 0.12 & 0.05 & 0 & 0.13 & 0.13 & 0.13 & 0.17 & 0.04 & 0.27 & 0.27 & 0.23 & 0.36 \\
\hline $\mathrm{MnO}$ & 0 & 0.01 & 0 & 0.03 & 0.02 & 0 & 0.04 & 0 & 0 & 0 & 0.01 & 0 & 0.01 & 0.01 & 0 & 0 & 0.02 \\
\hline $\mathrm{MgO}$ & 0 & 0 & 0 & 0 & 0 & 0.01 & 0 & 0 & 0 & 0 & 0 & 0 & 0.01 & 0.01 & 0.01 & 0 & 0.03 \\
\hline $\mathrm{CaO}$ & 10.56 & 10.7 & 11.09 & 9.04 & 11.41 & 11.05 & 11.67 & 11.57 & 10.68 & 11.03 & 11.54 & 9.85 & 10.06 & 9.77 & 10.14 & 12.74 & 11.51 \\
\hline $\mathrm{Na} 2 \mathrm{O}$ & 5.51 & 5.35 & 5.13 & 6.28 & 4.96 & 4.56 & 4.89 & 4.92 & 5.59 & 5.11 & 5.07 & 5.61 & 5.55 & 5.79 & 5.82 & 4.14 & 4.08 \\
\hline $\mathrm{K} 2 \mathrm{O}$ & 0.12 & 0.1 & 0.09 & 0.14 & 0.1 & 0.07 & 0.11 & 0.03 & 0.11 & 0.14 & 0.07 & 0.15 & 0.14 & 0.11 & 0.16 & 0.12 & 0.34 \\
\hline Totals & 99.4 & 99.64 & 99.48 & 99.69 & 98.72 & 97.21 & 99.37 & 98.63 & 100.12 & 99.75 & 99.59 & 99.23 & 97.92 & 98.06 & 99.6 & 99.59 & 96.79 \\
\hline $\mathrm{Si}$ & 2.591 & 2.597 & 2.582 & 2.677 & 2.549 & 2.463 & 2.543 & 2.563 & 2.598 & 2.583 & 2.553 & 2.637 & 2.621 & 2.625 & 2.616 & 2.482 & 2.498 \\
\hline $\mathrm{Ti}$ & 1.008 & 1.004 & 1.017 & 0.947 & 1.04 & 1.135 & 1.042 & 1.026 & 1.001 & 1.016 & 1.032 & 0.978 & 0.985 & 0.981 & 0.984 & 1.086 & 1.086 \\
\hline $\mathrm{Al}$ & 0 & 0.002 & 0.001 & 0.004 & 0 & 0.001 & 0.001 & 0.001 & 0 & 0 & 0 & 0 & 0.004 & 0 & 0.001 & 0.003 & 0 \\
\hline $\mathrm{Fe} 3$ & 0.01 & 0.00 & 0.00 & 0.00 & 0.00 & 0.01 & 0.00 & 0.00 & 0.01 & 0.01 & 0.01 & 0.01 & 0.00 & 0.01 & 0.01 & 0.01 & 0.01 \\
\hline $\mathrm{Mn}$ & 0 & 0 & 0 & 0.001 & 0.001 & 0 & 0.002 & 0 & 0 & 0 & 0 & 0 & 0 & 0 & 0 & 0 & 0.001 \\
\hline $\mathrm{Mg}$ & 0 & 0 & 0 & 0 & 0 & 0.001 & 0 & 0 & 0 & 0 & 0 & 0 & 0 & 0.001 & 0.001 & 0 & 0.002 \\
\hline $\mathrm{Ca}$ & 0.536 & 0.541 & 0.562 & 0.454 & 0.585 & 0.578 & 0.595 & 0.593 & 0.538 & 0.558 & 0.586 & 0.498 & 0.516 & 0.501 & 0.513 & 0.651 & 0.604 \\
\hline $\mathrm{Na}$ & 0.506 & 0.49 & 0.47 & 0.57 & 0.46 & 0.432 & 0.451 & 0.456 & 0.509 & 0.468 & 0.466 & 0.514 & 0.515 & 0.537 & 0.532 & 0.383 & 0.388 \\
\hline $\mathrm{K}$ & 0.007 & 0.006 & 0.005 & 0.008 & 0.006 & 0.00 & 0.01 & 0.002 & 0.006 & 0.009 & 0.004 & 0.009 & 0.009 & 0.007 & 0.01 & 0.007 & 0.021 \\
\hline Sum & 4.655 & 4.644 & 4.638 & 4.663 & 4.643 & 4.62 & 4.64 & 4.64 & 4.657 & 4.637 & 4.647 & 4.643 & 4.653 & 4.661 & 4.666 & 4.622 & 4.614 \\
\hline An & 51.1 & 52.2 & 54.2 & 44.0 & 55.7 & 57.0 & 56.5 & 56.4 & 51.1 & 53.9 & 55.5 & 48.8 & 49.6 & 47.9 & 48.6 & 62.5 & 59.6 \\
\hline$A b$ & 48.2 & 47.3 & 45.3 & 55.2 & 43.8 & 42.6 & 42.8 & 43.4 & 48.3 & 45.2 & 44.1 & 50.3 & 49.5 & 51.4 & 50.4 & 36.8 & 38.3 \\
\hline Or & 0.7 & 0.6 & 0.5 & 0.8 & 0.6 & 0.4 & 0.7 & 0.2 & 0.6 & 0.9 & 0.4 & 0.9 & 0.9 & 0.7 & 0.9 & 0.7 & 2.1 \\
\hline
\end{tabular}




\section{Rochas metabásicas (Amostra NLD-20A)}

\section{PLAGIOCLÁSIO}

\begin{tabular}{|c|c|c|c|c|c|c|c|c|c|c|c|c|c|c|c|c|}
\hline ple & $U \mathrm{~A}$ & & & & & & & & & & & & & & & \\
\hline $\mathrm{SiO} 2$ & 54.71 & 52.13 & 51.74 & 52.45 & 54.33 & 53.47 & 53.33 & 51.45 & 51.92 & 52.12 & 52.22 & 52.9 & 50.58 & 55.73 & 55.38 & 56.22 \\
\hline TiO2 & 28.15 & 30.64 & 30.24 & 29.76 & 28.66 & 29.25 & 29.53 & 30.37 & 30.39 & 30.22 & 29.89 & 29.42 & 29.16 & 27.72 & 27.81 & 27.76 \\
\hline $\mathrm{Al} 2 \mathrm{O} 3$ & 0.01 & 0 & 0 & 0.01 & 0 & 0 & 0.01 & 0 & 0.01 & 0.03 & 0.05 & 0.04 & 0.04 & 0.01 & 0.01 & 0 \\
\hline $\mathrm{Fe} 2 \mathrm{O} 3$ & 0.14 & 0.08 & 0.14 & 0.11 & 0.21 & 0.1 & 0.15 & 0.12 & 0.09 & 0.01 & 0.12 & 0.04 & 0.14 & 0.11 & 0.18 & 0.1 \\
\hline $\mathrm{MnO}$ & 0.03 & 0.04 & 0 & 0.05 & 0 & 0.01 & 0 & 0.01 & 0 & 0.01 & 0.01 & 0.01 & 0 & 0.01 & 0.02 & 0 \\
\hline $\mathrm{MgO}$ & 0.02 & 0.01 & 0 & 0 & 0 & 0.01 & 0 & 0 & 0 & 0.01 & 0.01 & 0.01 & 0.01 & 0 & 0 & 0 \\
\hline $\mathrm{CaO}$ & 10.76 & 13.26 & 12.78 & 12.54 & 11.03 & 11.87 & 12.29 & 13.24 & 13.1 & 12.97 & 12.76 & 12.03 & 12.16 & 10.12 & 10.1 & 10.24 \\
\hline $\mathrm{Na} 2 \mathrm{O}$ & 5.54 & 4.05 & 4.12 & 4.33 & 5.25 & 4.82 & 4.72 & 3.83 & 3.96 & 4.1 & 4.49 & 4.31 & 4.29 & 5.75 & 5.77 & 5.77 \\
\hline $\mathrm{K} 2 \mathrm{O}$ & 0.16 & 0.04 & 0.08 & 0.07 & 0.09 & 0.1 & 0.07 & 0.09 & 0.1 & 0.1 & 0.07 & 0.08 & 0.1 & 0.15 & 0.14 & 0.16 \\
\hline Totals & 99.51 & 100.26 & 99.1 & 99.33 & 99.59 & 99.63 & 100.09 & 99.12 & 99.57 & 99.57 & 99.63 & 98.84 & 96.47 & 99.61 & 99.41 & 100.24 \\
\hline $\mathrm{Si}$ & 2.59 & 2.473 & 2.481 & 2.504 & 2.572 & 2.538 & 2.524 & 2.469 & 2.478 & 2.486 & 2.491 & 2.529 & 2.49 & 2.625 & 2.616 & 2.63 \\
\hline $\mathrm{Ti}$ & 1.002 & 1.093 & 1.09 & 1.069 & 1.021 & 1.044 & 1.051 & 1.096 & 1.091 & 1.084 & 1.072 & 1.058 & 1.08 & 0.982 & 0.988 & 0.977 \\
\hline $\mathrm{Al}$ & 0.001 & 0 & 0 & 0.001 & 0 & 0 & 0 & 0 & 0.001 & 0.002 & 0.003 & 0.002 & 0.002 & 0.001 & 0.001 & 0 \\
\hline $\mathrm{Fe} 3$ & 0.01 & 0.00 & 0.01 & 0.00 & 0.01 & 0.00 & 0.01 & 0.00 & 0.00 & 0.00 & 0.00 & 0.00 & 0.01 & 0.00 & 0.01 & 0.00 \\
\hline $\mathrm{Mn}$ & 0.001 & 0.002 & 0 & 0.002 & 0 & 0 & 0 & 0.001 & 0 & 0.001 & 0 & 0.001 & 0 & 0.001 & 0.001 & 0 \\
\hline $\mathrm{Mg}$ & 0.001 & 0.001 & 0 & 0 & 0 & 0.001 & 0 & 0 & 0 & 0.001 & 0.001 & 0.001 & 0.001 & 0 & 0 & 0 \\
\hline $\mathrm{Ca}$ & 0.546 & 0.674 & 0.656 & 0.642 & 0.56 & 0.604 & 0.623 & 0.681 & 0.67 & 0.663 & 0.652 & 0.616 & 0.642 & 0.511 & 0.511 & 0.513 \\
\hline $\mathrm{Na}$ & 0.509 & 0.373 & 0.383 & 0.401 & 0.482 & 0.444 & 0.433 & 0.356 & 0.366 & 0.379 & 0.415 & 0.4 & 0.409 & 0.525 & 0.529 & 0.524 \\
\hline $\mathrm{K}$ & 0.01 & 0.003 & 0.005 & 0.005 & 0.005 & 0.006 & 0.004 & 0.005 & 0.006 & 0.006 & 0.005 & 0.005 & 0.006 & 0.009 & 0.008 & 0.01 \\
\hline Sum & 4.664 & 4.62 & 4.621 & 4.627 & 4.647 & 4.641 & 4.641 & 4.613 & 4.615 & 4.621 & 4.644 & 4.613 & 4.635 & 4.658 & 4.661 & 4.657 \\
\hline An & 51.3 & 64.2 & 62.8 & 61.3 & 53.5 & 57.3 & 58.8 & 65.4 & 64.3 & 63.3 & 60.8 & 60.3 & 60.7 & 48.9 & 48.8 & 49.0 \\
\hline$A b$ & 47.8 & 35.5 & 36.7 & 38.3 & 46.0 & 42.1 & 40.8 & 34.2 & 35.1 & 36.2 & 38.7 & 39.2 & 38.7 & 50.2 & 50.5 & 50.0 \\
\hline Or & 0.9 & 0.3 & 0.5 & 0.5 & 0.5 & 0.6 & 0.4 & 0.5 & 0.6 & 0.6 & 0.5 & 0.5 & 0.6 & 0.9 & 0.8 & 1.0 \\
\hline
\end{tabular}




\section{Rochas metabásicas (Amostra NLD-42C)}

FELDSPATO

\begin{tabular}{|c|c|c|c|c|c|c|c|c|c|c|c|c|c|c|c|}
\hline $\begin{array}{l}\text { Sample } \\
\text { Mineral }\end{array}$ & $\begin{array}{l}\text { T6-PL1-1 } \\
\text { fsp }\end{array}$ & $\begin{array}{l}\text { T6-PL1-2 } \\
\text { fsp }\end{array}$ & $\begin{array}{l}\text { T6-PL1-3 } \\
\text { fsp }\end{array}$ & $\begin{array}{l}\text { T6-PL1-4 } \\
\quad \text { fsp }\end{array}$ & $\begin{array}{l}\text { T6-PL2-5 } \\
\text { fsp }\end{array}$ & $\begin{array}{l}\text { T6-PL2-6 } \\
\text { fsp }\end{array}$ & $\begin{array}{l}\text { T6-PL3-7 } \\
\text { fsp }\end{array}$ & $\begin{array}{l}\text { T6-PL3-8 } \\
\text { fsp }\end{array}$ & $\begin{array}{l}\text { T6-PL3-9 } \\
\text { fsp }\end{array}$ & $\begin{array}{l}\text { T6-PL4-10 } \\
\text { fsp }\end{array}$ & $\begin{array}{l}\text { T6-PL5-11 } \\
\text { fsp }\end{array}$ & $\begin{array}{c}\text { T6-PL5-12 } \\
\text { fsp }\end{array}$ & $\begin{array}{l}\text { T6-PL5-13 } \\
\text { fsp }\end{array}$ & $\begin{array}{c}\text { T6-PL6-14 } \\
\text { fsp }\end{array}$ & $\begin{array}{l}\text { T2-KFS1-15 } \\
\text { fsp }\end{array}$ \\
\hline $\mathrm{SiO} 2$ & 57.56 & 57.16 & 57.43 & 56.61 & 56.81 & 58.64 & 58.09 & 57.44 & 58.83 & 59.63 & 58.41 & 59.36 & 58.04 & 57.95 & 63.07 \\
\hline $\mathrm{TiO} 2$ & 0 & 0.09 & 0 & 0 & 0.12 & 0 & 0.02 & 0 & 0.02 & 0 & 0.02 & 0 & 0.07 & 0.07 & 0 \\
\hline $\mathrm{Al} 2 \mathrm{O} 3$ & 26.41 & 26.77 & 26.74 & 26.44 & 26.54 & 26.7 & 27.1 & 27.16 & 26.98 & 26.06 & 26.16 & 25.61 & 26.63 & 27.26 & 19.2 \\
\hline Cr2O3 & 0 & 0 & 0 & 0 & 0 & 0 & 0 & 0 & 0 & 0 & 0 & 0 & 0 & 0 & 0 \\
\hline $\mathrm{Fe} 2 \mathrm{O} 3$ & 0 & 0 & 0 & 0 & 0 & 0 & 0 & 0 & 0 & 0 & 0 & 0 & 0 & 0 & 0 \\
\hline $\mathrm{FeO}$ & 0 & 0 & 0 & 0 & 0 & 0 & 0 & 0 & 0 & 0 & 0 & 0 & 0 & 0 & 0 \\
\hline $\mathrm{MnO}$ & 0 & 0 & 0 & 0.03 & 0.01 & 0 & 0 & 0.01 & 0 & 0.01 & 0.02 & 0 & 0 & 0 & 0.02 \\
\hline $\mathrm{MgO}$ & 0.01 & 0 & 0 & 0.11 & 0.01 & 0 & 0.01 & 0.01 & 0.01 & 0 & 0 & 0 & 0 & 0 & 0.03 \\
\hline $\mathrm{CaO}$ & 7.83 & 8.36 & 8.22 & 8.24 & 7.99 & 8.33 & 8.47 & 8.67 & 8.39 & 7.63 & 7.84 & 6.99 & 8 & 8.39 & 0.13 \\
\hline $\mathrm{Na} 2 \mathrm{O}$ & 6.94 & 6.4 & 6.49 & 6.38 & 6.54 & 6.56 & 6.52 & 6.41 & 6.69 & 7.13 & 6.9 & 6.96 & 6.64 & 6.47 & 0.39 \\
\hline $\mathrm{K} 2 \mathrm{O}$ & 0.17 & 0.18 & 0.17 & 0.18 & 0.28 & 0.28 & 0.25 & 0.23 & 0.28 & 0.32 & 0.26 & 0.31 & 0.3 & 0.34 & 16.2 \\
\hline Total & 98.91 & 98.97 & 99.05 & 97.98 & 98.31 & 100.51 & 100.46 & 99.94 & 101.2 & 100.77 & 99.61 & 99.22 & 99.68 & 100.47 & 99.03 \\
\hline Oxygens & 8 & 8 & 8 & 8 & 8 & 8 & 8 & 8 & 8 & 8 & 8 & 8 & 8 & 8 & 8 \\
\hline Si & 2.6 & 2.58 & 2.588 & 2.577 & 2.582 & 2.604 & 2.584 & 2.571 & 2.596 & 2.638 & 2.617 & 2.658 & 2.598 & 2.576 & 2.948 \\
\hline $\mathrm{Ti}$ & 0 & 0.003 & 0 & 0 & 0.004 & 0 & 0.001 & 0 & 0.001 & 0 & 0.001 & 0 & 0.002 & 0.002 & 0 \\
\hline $\mathrm{Al}$ & 1.406 & 1.424 & 1.42 & 1.419 & 1.422 & 1.398 & 1.421 & 1.433 & 1.404 & 1.359 & 1.381 & 1.352 & 1.405 & 1.428 & 1.058 \\
\hline $\mathrm{Cr}$ & 0 & 0 & 0 & 0 & 0 & 0 & 0 & 0 & 0 & 0 & 0 & 0 & 0 & 0 & 0 \\
\hline Fe3 & 0.002 & 0.005 & 0.006 & 0.014 & 0.005 & 0.005 & 0.004 & 0.005 & 0.006 & 0.006 & 0.006 & 0.007 & 0.007 & 0.009 & 0.004 \\
\hline $\mathrm{Fe} 2$ & 0 & 0 & 0 & 0 & 0 & 0 & 0 & 0 & 0 & 0 & 0 & 0 & 0 & 0 & 0 \\
\hline $\mathrm{Mn}$ & 0 & 0 & 0 & 0.001 & 0.001 & 0 & 0 & 0 & 0 & 0 & 0.001 & 0 & 0 & 0 & 0.001 \\
\hline $\mathrm{Mg}$ & 0.001 & 0 & 0 & 0.007 & 0.001 & 0 & 0 & 0.001 & 0.001 & 0 & 0 & 0 & 0 & 0 & 0.002 \\
\hline $\mathrm{Ca}$ & 0.379 & 0.404 & 0.397 & 0.402 & 0.389 & 0.396 & 0.404 & 0.416 & 0.397 & 0.361 & 0.376 & 0.335 & 0.384 & 0.4 & 0.007 \\
\hline $\mathrm{Na}$ & 0.608 & 0.56 & 0.567 & 0.563 & 0.577 & 0.565 & 0.562 & 0.556 & 0.573 & 0.612 & 0.599 & 0.604 & 0.576 & 0.557 & 0.035 \\
\hline $\mathrm{K}$ & 0.01 & 0.011 & 0.01 & 0.01 & 0.016 & 0.016 & 0.014 & 0.013 & 0.016 & 0.018 & 0.015 & 0.018 & 0.017 & 0.02 & 0.966 \\
\hline Sum & 5.005 & 4.987 & 4.987 & 4.993 & 4.996 & 4.984 & 4.991 & 4.995 & 4.992 & 4.994 & 4.996 & 4.973 & 4.99 & 4.991 & 5.021 \\
\hline An & 38.01 & 41.44 & 40.76 & 41.23 & 39.61 & 40.53 & 41.22 & 42.23 & 40.26 & 36.43 & 37.98 & 35.01 & 39.30 & 40.94 & 0.69 \\
\hline$A b$ & 60.98 & 57.44 & 58.21 & 57.74 & 58.76 & 57.83 & 57.35 & 56.45 & 58.11 & 61.76 & 60.51 & 63.11 & 58.96 & 57.01 & 3.47 \\
\hline Or & 1.00 & 1.13 & 1.03 & 1.03 & 1.63 & 1.64 & 1.43 & 1.32 & 1.62 & 1.82 & 1.52 & 1.88 & 1.74 & 2.05 & 95.83 \\
\hline TOTAL & 100.00 & 100.00 & 100.00 & 100.00 & 100.00 & 100.00 & 100.00 & 100.00 & 100.00 & 100.00 & 100.00 & 100.00 & 100.00 & 100.00 & 100.00 \\
\hline
\end{tabular}




\section{Rochas metabásicas (Amostra NLD-42C)}

FELDSPATO

\begin{tabular}{|c|c|c|c|c|c|c|c|c|c|c|c|c|c|c|c|}
\hline $\begin{array}{l}\text { Sample } \\
\text { Mineral }\end{array}$ & $\begin{array}{c}\text { T2-PL7-16 } \\
\text { fsp }\end{array}$ & $\begin{array}{c}\text { T2-PL7-17 } \\
\text { fsp }\end{array}$ & $\begin{array}{l}\text { T2-PL7-18 } \\
\text { fsp }\end{array}$ & $\begin{array}{l}\text { T2-PL7-19 } \\
\text { fsp }\end{array}$ & $\begin{array}{l}\text { T2-PL7-20 } \\
\text { fsp }\end{array}$ & $\begin{array}{c}\text { T3-PL8-21 } \\
\text { fsp }\end{array}$ & $\begin{array}{l}\text { T3-PL8-22 } \\
\text { fsp }\end{array}$ & $\begin{array}{l}\text { T3-PL8-23 } \\
\text { fsp }\end{array}$ & $\begin{array}{l}\text { T3-PL8-24 } \\
\text { fsp }\end{array}$ & $\begin{array}{c}\text { T3-PL8-25 } \\
\text { fsp }\end{array}$ & $\begin{array}{c}\text { T3-PL8-26 } \\
\text { fsp }\end{array}$ & $\begin{array}{l}\text { T3-PL8-27 } \\
\text { fsp }\end{array}$ & $\begin{array}{c}\text { T3-PL8-28 } \\
\text { fsp }\end{array}$ & $\begin{array}{c}\text { T3-PL8-29 } \\
\text { fsp }\end{array}$ & $\begin{array}{c}9 \text { T3-PL8-30 } \\
\text { fsp }\end{array}$ \\
\hline $\mathrm{SiO} 2$ & 57.25 & 57.19 & 57.17 & 57.04 & 56.87 & 57.87 & 58.07 & 58.08 & 57.34 & 57.56 & 58.42 & 57.94 & 58.05 & 57.53 & 57.48 \\
\hline TiO2 & 0 & 0 & 0.05 & 0.09 & 0.02 & 0.16 & 0.07 & 0.16 & 0.05 & 0 & 0 & 0.02 & 0 & 0 & 0 \\
\hline $\mathrm{Al} 2 \mathrm{O} 3$ & 26.84 & 26.63 & 27.11 & 26.89 & 27.02 & 27 & 27.27 & 27.04 & 26.99 & 26.87 & 26.61 & 26.97 & 26.96 & 27.03 & 26.99 \\
\hline $\mathrm{Cr} 2 \mathrm{O} 3$ & 0 & 0 & 0 & 0 & 0 & 0 & 0 & 0 & 0 & 0 & 0 & 0 & 0 & 0 & 0 \\
\hline $\mathrm{Fe} 2 \mathrm{O} 3$ & 0 & 0 & 0 & 0 & 0 & 0 & 0 & 0 & 0 & 0 & 0 & 0 & 0 & 0 & 0 \\
\hline $\mathrm{FeO}$ & 0 & 0 & 0 & 0 & 0 & 0 & 0 & 0 & 0 & 0 & 0 & 0 & 0 & 0 & 0 \\
\hline $\mathrm{MnO}$ & 0.02 & 0 & 0 & 0.04 & 0.04 & 0 & 0 & 0.02 & 0.02 & 0 & 0.01 & 0.01 & 0 & 0.01 & 0 \\
\hline $\mathrm{MgO}$ & 0 & 0 & 0.03 & 0 & 0.01 & 0.01 & 0 & 0.02 & 0 & 0.01 & 0 & 0 & 0.01 & 0 & 0 \\
\hline $\mathrm{Na} 2 \mathrm{O}$ & 6.59 & 6.56 & 6.41 & 6.32 & 6.56 & 6.57 & 6.47 & 6.62 & 6.31 & 6.62 & 6.86 & 6.74 & 6.74 & 6.46 & 6.36 \\
\hline $\mathrm{K} 2 \mathrm{O}$ & 0.29 & 0.34 & 0.31 & 0.35 & 0.32 & 0.31 & 0.39 & 0.34 & 0.34 & 0.34 & 0.35 & 0.3 & 0.29 & 0.31 & 0.33 \\
\hline Total & 99.55 & 99.1 & 99.69 & 99.39 & 99.57 & 100.69 & 100.84 & 100.9 & 99.83 & 100.15 & 100.44 & 100.71 & 100.54 & 99.71 & 99.93 \\
\hline Oxygens & 8 & 8 & 8 & 8 & 8 & 8 & 8 & 8 & 8 & 8 & 8 & 8 & 8 & 8 & 8 \\
\hline $\mathrm{Si}$ & 2.576 & 2.583 & 2.568 & 2.57 & 2.561 & 2.575 & 2.579 & 2.578 & 2.572 & 2.575 & 2.603 & 2.577 & 2.583 & 2.58 & 2.574 \\
\hline $\mathrm{Ti}$ & 0 & 0 & 0.002 & 0.003 & 0.001 & 0.005 & 0.002 & 0.005 & 0.002 & 0 & 0 & 0.001 & 0 & 0 & 0 \\
\hline $\mathrm{Al}$ & 1.424 & 1.418 & 1.435 & 1.428 & 1.435 & 1.416 & 1.427 & 1.415 & 1.427 & 1.417 & 1.398 & 1.414 & 1.414 & 1.429 & 1.425 \\
\hline $\mathrm{Fe} 2$ & 0 & 0 & 0 & 0 & 0 & 0 & 0 & 0 & 0 & 0 & 0 & 0 & 0 & 0 & 0 \\
\hline $\mathrm{Mn}$ & 0.001 & 0 & 0 & 0.002 & 0.002 & 0 & 0 & 0.001 & 0.001 & 0 & 0 & 0.001 & 0 & 0 & 0 \\
\hline $\mathrm{Mg}$ & 0 & 0 & 0.002 & 0 & 0.001 & 0 & 0 & 0.001 & 0 & 0 & 0 & 0 & 0 & 0 & 0 \\
\hline $\mathrm{Ca}$ & 0.412 & 0.406 & 0.414 & 0.418 & 0.421 & 0.418 & 0.408 & 0.411 & 0.423 & 0.419 & 0.391 & 0.415 & 0.405 & 0.403 & 0.421 \\
\hline $\mathrm{Na}$ & 0.575 & 0.575 & 0.558 & 0.552 & 0.573 & 0.567 & 0.557 & 0.57 & 0.549 & 0.574 & 0.593 & 0.581 & 0.581 & 0.562 & 0.552 \\
\hline $\mathrm{K}$ & 0.016 & 0.02 & 0.018 & 0.02 & 0.019 & 0.018 & 0.022 & 0.019 & 0.019 & 0.019 & 0.02 & 0.017 & 0.016 & 0.018 & 0.019 \\
\hline Sum & 5.006 & 5.004 & 5 & 4.997 & 5.015 & 5.002 & 4.995 & 5.002 & 4.995 & 5.01 & 5.004 & 5.011 & 5.006 & 4.994 & 4.996 \\
\hline An & 41.08 & 40.56 & 41.82 & 42.22 & 41.56 & 41.67 & 41.34 & 41.10 & 42.68 & 41.40 & 38.94 & 40.97 & 40.42 & 41.00 & 42.44 \\
\hline$A b$ & 57.33 & 57.44 & 56.36 & 55.76 & 56.56 & 56.53 & 56.43 & 57.00 & 55.40 & 56.72 & 59.06 & 57.35 & 57.98 & 57.17 & 55.65 \\
\hline Or & 1.60 & 2.00 & 1.82 & 2.02 & 1.88 & 1.79 & 2.23 & 1.90 & 1.92 & 1.88 & 1.99 & 1.68 & 1.60 & 1.83 & 1.92 \\
\hline TOTAL & 100.00 & 100.00 & 100.00 & 100.00 & 100.00 & 100.00 & 100.00 & 100.00 & 100.00 & 100.00 & 100.00 & 100.00 & 100.00 & 100.00 & 100.00 \\
\hline
\end{tabular}




\section{Rochas metabásicas (Amostra NLD-42C)}

FELDSPATO

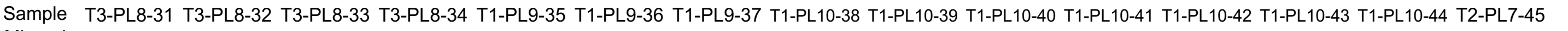

\begin{tabular}{|c|c|c|c|c|c|c|c|c|c|c|c|c|c|c|c|}
\hline Mineral & $\mathrm{fsp}$ & $\mathrm{fsp}$ & $\mathrm{fsp}$ & fsp & fsp & fsp & fsp & fsp & fsp & fsp & fsp & fsp & fsp & fsp & fsp \\
\hline $\mathrm{SiO} 2$ & 56.98 & 57.43 & 57.8 & 56.76 & 57.86 & 57.81 & 57.92 & 57.26 & 57.3 & 57.83 & 57.03 & 57.65 & 57.3 & 57.7 & 58.55 \\
\hline TiO2 & 0.05 & 0.02 & 0.07 & 0.05 & 0 & 0 & 0 & 0 & 0 & 0 & 0.07 & 0 & 0.02 & 0.05 & 0 \\
\hline $\mathrm{Al} 2 \mathrm{O} 3$ & 27.09 & 26.81 & 27.37 & 26.38 & 27 & 27.09 & 27 & 27.16 & 26.86 & 26.92 & 26.99 & 26.98 & 26.93 & 26.91 & 26.18 \\
\hline $\mathrm{Cr} 2 \mathrm{O} 3$ & 0 & 0 & 0 & 0 & 0 & 0 & 0 & 0 & 0 & 0 & 0 & 0 & 0 & 0 & 0 \\
\hline $\mathrm{Fe} 2 \mathrm{O} 3$ & 0 & 0 & 0 & 0 & 0 & 0 & 0 & 0 & 0 & 0 & 0 & 0 & 0 & 0 & 0 \\
\hline $\mathrm{FeO}$ & 0 & 0 & 0 & 0 & 0 & 0 & 0 & 0 & 0 & 0 & 0 & 0 & 0 & 0 & 0 \\
\hline $\mathrm{MnO}$ & 0 & 0.01 & 0 & 0.01 & 0 & 0.01 & 0 & 0 & 0.02 & 0 & 0 & 0 & 0.01 & 0 & 0 \\
\hline $\mathrm{MgO}$ & 0.01 & 0 & 0 & 0.21 & 0 & 0 & 0 & 0 & 0 & 0.01 & 0.01 & 0.01 & 0.16 & 0 & 0.01 \\
\hline $\mathrm{CaO}$ & 8.71 & 8.59 & 8.61 & 8.16 & 8.77 & 8.77 & 8.37 & 8.79 & 8.52 & 8.55 & 8.54 & 8.59 & 8.57 & 8.56 & 7.93 \\
\hline $\mathrm{Na} 2 \mathrm{O}$ & 6.48 & 6.61 & 6.65 & 6.51 & 6.49 & 6.39 & 6.49 & 6.28 & 6.55 & 6.35 & 6.44 & 6.42 & 6.41 & 6.37 & 6.94 \\
\hline $\mathrm{K} 2 \mathrm{O}$ & 0.33 & 0.33 & 0.27 & 0.3 & 0.34 & 0.35 & 0.32 & 0.37 & 0.3 & 0.33 & 0.35 & 0.35 & 0.32 & 0.36 & 0.31 \\
\hline Total & 99.65 & 99.81 & 100.78 & 98.38 & 100.45 & 100.43 & 100.1 & 99.86 & 99.56 & 99.99 & 99.43 & 100 & 99.73 & 99.95 & 99.92 \\
\hline Oxygens & 8 & 8 & 8 & 8 & 8 & 8 & 8 & 8 & 8 & 8 & 8 & 8 & 8 & 8 & 8 \\
\hline Si & 2.563 & 2.577 & 2.567 & 2.567 & 2.579 & 2.577 & 2.587 & 2.567 & 2.578 & 2.586 & 2.569 & 2.579 & 2.567 & 2.583 & 2.617 \\
\hline $\mathrm{Ti}$ & 0.002 & 0.001 & 0.002 & 0.002 & 0 & 0 & 0 & 0 & 0 & 0 & 0.002 & 0 & 0.001 & 0.002 & 0 \\
\hline $\mathrm{Al}$ & 1.436 & 1.419 & 1.433 & 1.407 & 1.419 & 1.424 & 1.422 & 1.435 & 1.425 & 1.419 & 1.434 & 1.423 & 1.422 & 1.42 & 1.379 \\
\hline $\mathrm{Cr}$ & 0 & 0 & 0 & 0 & 0 & 0 & 0 & 0 & 0 & 0 & 0 & 0 & 0 & 0 & 0 \\
\hline Fe3 & 0.004 & 0.003 & 0.005 & 0.033 & 0.004 & 0.003 & 0.002 & 0.005 & 0 & 0.002 & 0.001 & 0.003 & 0.014 & 0.002 & 0.005 \\
\hline $\mathrm{Fe} 2$ & 0 & 0 & 0 & 0 & 0 & 0 & 0 & 0 & 0 & 0 & 0 & 0 & 0 & 0 & 0 \\
\hline $\mathrm{Mn}$ & 0 & 0.001 & 0 & 0 & 0 & 0 & 0 & 0 & 0.001 & 0 & 0 & 0 & 0.001 & 0 & 0 \\
\hline $\mathrm{Mg}$ & 0.001 & 0 & 0 & 0.014 & 0 & 0 & 0 & 0 & 0 & 0 & 0.001 & 0.001 & 0.011 & 0 & 0.001 \\
\hline $\mathrm{Ca}$ & 0.42 & 0.413 & 0.41 & 0.395 & 0.419 & 0.419 & 0.401 & 0.422 & 0.411 & 0.41 & 0.412 & 0.412 & 0.411 & 0.41 & 0.38 \\
\hline $\mathrm{Na}$ & 0.565 & 0.575 & 0.572 & 0.571 & 0.56 & 0.552 & 0.562 & 0.546 & 0.572 & 0.55 & 0.563 & 0.557 & 0.557 & 0.553 & 0.601 \\
\hline $\mathrm{K}$ & 0.019 & 0.019 & 0.015 & 0.017 & 0.02 & 0.02 & 0.018 & 0.021 & 0.017 & 0.019 & 0.02 & 0.02 & 0.018 & 0.021 & 0.018 \\
\hline Sum & 5.008 & 5.008 & 5.005 & 5.004 & 5 & 4.996 & 4.991 & 4.996 & 5.004 & 4.987 & 5.002 & 4.996 & 5.001 & 4.991 & 5 \\
\hline An & 41.83 & 41.01 & 41.12 & 40.18 & 41.94 & 42.28 & 40.88 & 42.67 & 41.10 & 41.88 & 41.41 & 41.66 & 41.68 & 41.67 & 38.04 \\
\hline$A b$ & 56.27 & 57.10 & 57.37 & 58.09 & 56.06 & 55.70 & 57.29 & 55.21 & 57.20 & 56.18 & 56.58 & 56.32 & 56.49 & 56.20 & 60.16 \\
\hline Or & 1.89 & 1.89 & 1.50 & 1.73 & 2.00 & 2.02 & 1.83 & 2.12 & 1.70 & 1.94 & 2.01 & 2.02 & 1.83 & 2.13 & 1.80 \\
\hline TOTAL & 100.00 & 100.00 & 100.00 & 100.00 & 100.00 & 100.00 & 100.00 & 100.00 & 100.00 & 100.00 & 100.00 & 100.00 & 100.00 & 100.00 & 100.00 \\
\hline
\end{tabular}




\section{Rochas metabásicas (Amostra NLD-42D)}

FELDSPATO

\begin{tabular}{|c|c|c|c|c|c|c|c|c|c|c|c|c|c|c|c|}
\hline $\begin{array}{l}\text { Sample } \\
\text { Mineral }\end{array}$ & $\begin{array}{l}\text { T1-PL1-1 } \\
\text { fsp }\end{array}$ & $\begin{array}{l}\text { T1-PL2-2 } \\
\text { fsp }\end{array}$ & $\begin{array}{l}\text { T1-PL2-3 } \\
\text { fsp }\end{array}$ & $\begin{array}{l}\text { T1-PL2-4 } \\
\text { fsp }\end{array}$ & $\begin{array}{l}\text { T1-PL2-5 } \\
\text { fsp }\end{array}$ & $\begin{array}{l}\text { T1-PL2-6 } \\
\text { fsp }\end{array}$ & $\begin{array}{l}\text { T1-PL2-7 } \\
\text { fsp }\end{array}$ & $\begin{array}{l}\text { T1-PL2-8 } \\
\text { fsp }\end{array}$ & $\begin{array}{l}\text { T1-PL2-9 } \\
\text { fsp }\end{array}$ & $\begin{array}{c}\text { T1-PL2-10 } \\
\text { fsp }\end{array}$ & $\begin{array}{l}\text { T1-PL2-11 } \\
\text { fsp }\end{array}$ & $\begin{array}{c}\text { T1-PL2-12 } \\
\text { fsp }\end{array}$ & $\begin{array}{l}\text { T1-KFS1-13 } \\
\text { fsp }\end{array}$ & $\begin{array}{c}\text { T4-PL3-14 } \\
\text { fsp }\end{array}$ & $\begin{array}{l}\text { T4-PL3-15 } \\
\text { fsp }\end{array}$ \\
\hline $\mathrm{SiO} 2$ & 58.31 & 58.28 & 58.3 & 58.85 & 58.32 & 58.52 & 57.39 & 58.43 & 58.62 & 58.95 & 59.51 & 58.48 & 71.37 & 60.43 & 57.3 \\
\hline $\mathrm{TiO} 2$ & 0 & 0 & 0.07 & 0.07 & 0 & 0 & 0.07 & 0 & 0 & 0 & 0 & 0 & 0 & 0.05 & 0 \\
\hline $\mathrm{Al} 2 \mathrm{O} 3$ & 26.01 & 25.95 & 26.18 & 26.34 & 26.03 & 25.93 & 26.49 & 25.97 & 26.09 & 26.43 & 26.5 & 26.16 & 14.75 & 24.13 & 26.67 \\
\hline Cr2O3 & 0 & 0 & 0 & 0 & 0 & 0 & 0 & 0 & 0 & 0 & 0 & 0 & 0 & 0 & 0 \\
\hline $\mathrm{Fe} 2 \mathrm{O} 3$ & 0 & 0 & 0 & 0 & 0 & 0 & 0 & 0 & 0 & 0 & 0 & 0 & 0 & 0 & 0 \\
\hline $\mathrm{FeO}$ & 0 & 0 & 0 & 0 & 0 & 0 & 0 & 0 & 0 & 0 & 0 & 0 & 0 & 0 & 0 \\
\hline $\mathrm{MnO}$ & 0 & 0 & 0.01 & 0 & 0.03 & 0.03 & 0 & 0.02 & 0.03 & 0 & 0 & 0 & 0.01 & 0.01 & 0.02 \\
\hline $\mathrm{MgO}$ & 0 & 0.05 & 0 & 0 & 0 & 0 & 0.04 & 0.01 & 0 & 0 & 0 & 0.05 & 0 & 0.02 & 0.02 \\
\hline $\mathrm{CaO}$ & 7.86 & 7.45 & 7.86 & 7.73 & 7.98 & 7.66 & 7.54 & 7.52 & 7.63 & 7.76 & 7.75 & 7.66 & 0.1 & 5.64 & 7.4 \\
\hline $\mathrm{Na} 2 \mathrm{O}$ & 6.84 & 6.83 & 6.99 & 6.72 & 7.01 & 6.89 & 6.59 & 6.79 & 7.01 & 6.93 & 6.92 & 6.79 & 0.33 & 5.2 & 6.51 \\
\hline $\mathrm{K} 2 \mathrm{O}$ & 0.3 & 0.27 & 0.31 & 0.32 & 0.33 & 0.32 & 0.32 & 0.3 & 0.33 & 0.33 & 0.34 & 0.32 & 12.69 & 5.03 & 0.32 \\
\hline Total & 99.32 & 98.83 & 99.72 & 100.02 & 99.7 & 99.36 & 98.45 & 99.03 & 99.71 & 100.4 & 101.02 & 99.45 & 99.25 & 100.5 & 98.25 \\
\hline Oxygens & 8 & 8 & 8 & 8 & 8 & 8 & 8 & 8 & 8 & 8 & 8 & 8 & 8 & 8 & 8 \\
\hline Si & 2.621 & 2.622 & 2.613 & 2.625 & 2.616 & 2.63 & 2.6 & 2.631 & 2.625 & 2.62 & 2.628 & 2.619 & 3.215 & 2.714 & 2.599 \\
\hline $\mathrm{Ti}$ & 0 & 0 & 0.002 & 0.002 & 0 & 0 & 0.002 & 0 & 0 & 0 & 0 & 0 & 0 & 0.002 & 0 \\
\hline $\mathrm{Al}$ & 1.378 & 1.376 & 1.383 & 1.385 & 1.377 & 1.374 & 1.415 & 1.379 & 1.377 & 1.385 & 1.38 & 1.381 & 0.783 & 1.278 & 1.426 \\
\hline $\mathrm{Cr}$ & 0 & 0 & 0 & 0 & 0 & 0 & 0 & 0 & 0 & 0 & 0 & 0 & 0 & 0 & 0 \\
\hline Fe3 & 0.003 & 0.015 & 0.003 & 0 & 0.002 & 0 & 0.004 & 0.001 & 0.002 & 0.004 & 0.001 & 0.01 & 0.007 & 0.006 & 0.004 \\
\hline $\mathrm{Fe} 2$ & 0 & 0 & 0 & 0 & 0 & 0 & 0 & 0 & 0 & 0 & 0 & 0 & 0 & 0 & 0 \\
\hline $\mathrm{Mn}$ & 0 & 0 & 0 & 0 & 0.001 & 0.001 & 0 & 0.001 & 0.001 & 0 & 0 & 0 & 0 & 0 & 0.001 \\
\hline $\mathrm{Mg}$ & 0 & 0.003 & 0 & 0 & 0 & 0 & 0.002 & 0 & 0 & 0 & 0 & 0.003 & 0 & 0.001 & 0.002 \\
\hline $\mathrm{Ca}$ & 0.378 & 0.359 & 0.377 & 0.369 & 0.384 & 0.369 & 0.366 & 0.363 & 0.366 & 0.37 & 0.367 & 0.368 & 0.005 & 0.271 & 0.36 \\
\hline $\mathrm{Na}$ & 0.596 & 0.596 & 0.607 & 0.581 & 0.61 & 0.6 & 0.579 & 0.593 & 0.609 & 0.597 & 0.593 & 0.589 & 0.029 & 0.452 & 0.572 \\
\hline $\mathrm{K}$ & 0.017 & 0.016 & 0.018 & 0.018 & 0.019 & 0.018 & 0.019 & 0.017 & 0.019 & 0.018 & 0.019 & 0.018 & 0.73 & 0.288 & 0.018 \\
\hline Sum & 4.995 & 4.987 & 5.004 & 4.98 & 5.008 & 4.993 & 4.987 & 4.984 & 4.999 & 4.994 & 4.988 & 4.988 & 4.769 & 5.013 & 4.981 \\
\hline An & 38.14 & 36.97 & 37.62 & 38.12 & 37.91 & 37.39 & 37.97 & 37.31 & 36.82 & 37.56 & 37.49 & 37.74 & 0.65 & 26.81 & 37.89 \\
\hline$A b$ & 60.14 & 61.38 & 60.58 & 60.02 & 60.22 & 60.79 & 60.06 & 60.95 & 61.27 & 60.61 & 60.57 & 60.41 & 3.80 & 44.71 & 60.21 \\
\hline Or & 1.72 & 1.65 & 1.80 & 1.86 & 1.88 & 1.82 & 1.97 & 1.75 & 1.91 & 1.83 & 1.94 & 1.85 & 95.55 & 28.49 & 1.89 \\
\hline TOTAL & 100.00 & 100.00 & 100.00 & 100.00 & 100.00 & 100.00 & 100.00 & 100.00 & 100.00 & 100.00 & 100.00 & 100.00 & 100.00 & 100.00 & 100.00 \\
\hline
\end{tabular}




\section{Rochas metabásicas (Amostra NLD-42D)}

FELDSPATO

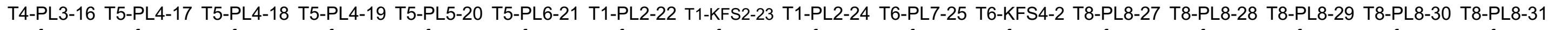

\begin{tabular}{|c|c|c|c|c|c|c|c|c|c|c|c|c|c|c|c|}
\hline fsp & fsp & fsp & fsp & fsp & fsp & fsp & fsp & fsp & fsp & fsp & fsp & fsp & fsp & fsp & fsp \\
\hline 57.59 & 57.1 & 57.55 & 58.3 & 76 & 57.67 & 59.1 & 77.35 & 58.8 & 63.2 & 64.29 & 58.67 & 58.59 & 58.22 & 57.93 & 57.74 \\
\hline 0 & 0 & 0.07 & 0 & 0.02 & 0 & 0 & 0.12 & 0.02 & 0 & 0 & 0 & 0 & 0 & 0 & 0.02 \\
\hline 26.35 & 26.45 & 26.5 & 26.41 & 12.51 & 26.28 & 26.01 & 12.11 & 25.96 & 18.91 & 18.86 & 26.63 & 26.12 & 26.17 & 26.19 & 26.41 \\
\hline 0 & 0 & 0 & 0 & 0 & 0 & 0 & 0 & 0 & 0 & 0 & 0 & 0 & 0 & 0 & 0 \\
\hline 0 & 0 & 0 & 0 & 0 & 0 & 0 & 0 & 0 & 0 & 0 & 0 & 0 & 0 & 0 & 0 \\
\hline 0 & 0 & 0 & 0 & 0 & 0 & 0 & 0 & 0 & 0 & 0 & 0 & 0 & 0 & 0 & 0 \\
\hline 0.03 & 0.01 & 0.01 & 0.01 & 0.03 & 0 & 0.03 & 0 & 0 & 0.01 & 0 & 0 & 0 & 0.01 & 0 & 0 \\
\hline 0.03 & 0 & 0.01 & 0.01 & 0.03 & 0 & 0.01 & 0.02 & 0 & 0.01 & 0 & 0.01 & 0.01 & 0.01 & 0 & 0.01 \\
\hline 7.26 & 7.44 & 7.76 & 7.7 & 0.03 & 7.73 & 7.39 & 1.35 & 7.36 & 0.04 & 0.06 & 7.93 & 7.88 & 7.95 & 7.93 & 7.87 \\
\hline 6.68 & 6.84 & 6.7 & 6.92 & 0.33 & 7.04 & 7.07 & 1.12 & 6.9 & 0.59 & 0.54 & 6.6 & 6.81 & 6.66 & 6.78 & 6.67 \\
\hline 0.36 & 0.23 & 0.25 & 0.28 & 10.78 & 0.23 & 0.32 & 6.59 & 0.39 & 16.32 & 15.71 & 0.37 & 0.37 & 0.35 & 0.35 & 0.34 \\
\hline 98.3 & 98.07 & 98.86 & 99.63 & 99.73 & 98.96 & 99.92 & 98.66 & 99.43 & 99.08 & 99.47 & 100.22 & 99.78 & 99.37 & 99.18 & 99.06 \\
\hline 8 & 8 & 8 & 8 & 8 & 8 & 8 & 8 & 8 & 8 & 8 & 8 & 8 & 8 & 8 & 8 \\
\hline 2.61 & 2.594 & 2.597 & 2.611 & 3.342 & 2.604 & 2.631 & 3.372 & 2.634 & 2.954 & 2.978 & 2.611 & 2.621 & 2.617 & 2.611 & 2.604 \\
\hline 0 & 0 & 0.002 & 0 & 0.001 & 0 & 0 & 0.004 & 0.001 & 0 & 0 & 0 & 0 & 0 & 0 & 0.001 \\
\hline 1.408 & 1.416 & 1.41 & 1.394 & 0.649 & 1.399 & 1.365 & 0.622 & 1.371 & 1.042 & 1.03 & 1.398 & 1.378 & 1.387 & 1.391 & 1.404 \\
\hline 0 & 0 & 0 & 0 & 0 & 0 & 0 & 0 & 0 & 0 & 0 & 0 & 0 & 0 & 0 & 0 \\
\hline 0.005 & 0.012 & 0.007 & 0.006 & 0.013 & 0.004 & 0.015 & 0.014 & 0.006 & 0.008 & 0.005 & 0.004 & 0.005 & 0.002 & 0.002 & 0.002 \\
\hline 0 & 0 & 0 & 0 & 0 & 0 & 0 & 0 & 0 & 0 & 0 & 0 & 0 & 0 & 0 & 0 \\
\hline 0.001 & 0 & 0 & 0 & 0.001 & 0 & 0.001 & 0 & 0 & 0 & 0 & 0 & 0 & 0 & 0 & 0 \\
\hline 0.002 & 0 & 0.001 & 0.001 & 0.002 & 0 & 0.001 & 0.002 & 0 & 0 & 0 & 0.001 & 0.001 & 0 & 0 & 0.001 \\
\hline 0.353 & 0.362 & 0.375 & 0.369 & 0.001 & 0.374 & 0.352 & 0.063 & 0.353 & 0.002 & 0.003 & 0.378 & 0.377 & 0.383 & 0.383 & 0.38 \\
\hline 0.587 & 0.603 & 0.586 & 0.601 & 0.028 & 0.617 & 0.61 & 0.095 & 0.599 & 0.054 & 0.048 & 0.57 & 0.591 & 0.58 & 0.592 & 0.583 \\
\hline 0.021 & 0.014 & 0.015 & 0.016 & 0.605 & 0.014 & 0.018 & 0.366 & 0.022 & 0.973 & 0.929 & 0.021 & 0.021 & 0.02 & 0.02 & 0.02 \\
\hline 4.987 & 5 & 4.992 & 4.997 & 4.641 & 5.01 & 4.992 & 4.535 & 4.987 & 5.035 & 4.993 & 4.983 & 4.993 & 4.989 & 4.999 & 4.994 \\
\hline 36.73 & 36.98 & 38.42 & 37.42 & 0.16 & 37.21 & 35.92 & 12.02 & 36.24 & 0.19 & 0.31 & 39.01 & 38.12 & 38.96 & 38.49 & 38.66 \\
\hline 61.08 & 61.59 & 60.04 & 60.95 & 4.42 & 61.39 & 62.24 & 18.13 & 61.50 & 5.25 & 4.90 & 58.82 & 59.76 & 59.00 & 59.50 & 59.31 \\
\hline 2.19 & 1.43 & 1.54 & 1.62 & 95.43 & 1.39 & 1.84 & 69.85 & 2.26 & 94.56 & 94.80 & 2.17 & 2.12 & 2.03 & 2.01 & 2.03 \\
\hline 100.00 & 100.00 & 100.00 & 100.00 & 100.00 & 100.00 & 100.00 & 100.00 & 100.00 & 100.00 & 100.00 & 100.00 & 100.00 & 100.00 & 100.00 & 100.00 \\
\hline
\end{tabular}


Rochas metabásicas (Amostra NLD-7D)

\section{PIROXÊNIO}

\begin{tabular}{|c|c|c|c|c|c|c|c|c|c|c|c|c|c|c|c|}
\hline sample & NLD-7D & NLD-7D & NLD-7D & NLD-7D & NLD-7D & NLD-7D & NLD-7D & NLD-7D & NLD-7D & NLD-7D & NLD-7D & NLD-7D & NLD-7D & NLD-7D & NLD-7D \\
\hline $\mathrm{SiO} 2$ & 50.805 & 51.173 & 51.824 & 51.039 & 50.773 & 51.45 & 50.729 & 51.325 & 51.397 & 50.886 & 51.011 & 51.366 & 54.914 & 49.431 & 51.545 \\
\hline TiO2 & 0.042 & 0.014 & 0.065 & 0.019 & 0.056 & 0.042 & 0.023 & 0.056 & 0.028 & 0 & 0.079 & 0.037 & 0 & 0.079 & 0.037 \\
\hline $\mathrm{Al} 2 \mathrm{O} 3$ & 0.951 & 0.866 & 0.738 & 0.819 & 0.812 & 0.877 & 3.562 & 1.106 & 0.958 & 0.92 & 1.04 & 1.14 & 0.823 & 3.316 & 0.879 \\
\hline $\mathrm{FeO}$ & 29.179 & 30.66 & 30.098 & 30.32 & 29.766 & 30.777 & 29.305 & 30.439 & 30.231 & 29.87 & 30.121 & 29.212 & 27.295 & 28.834 & 29.304 \\
\hline $\mathrm{MnO}$ & 0.726 & 0.697 & 0.698 & 0.639 & 0.744 & 0.656 & 0.74 & 0.714 & 0.832 & 0.807 & 0.781 & 0.748 & 0.679 & 0.65 & 0.738 \\
\hline $\mathrm{MgO}$ & 17.213 & 16.821 & 16.535 & 16.942 & 16.868 & 16.802 & 15.433 & 16.982 & 16.516 & 16.628 & 16.145 & 16.624 & 15.279 & 16.174 & 16.766 \\
\hline $\mathrm{CaO}$ & 0.435 & 0.426 & 0.326 & 0.425 & 0.433 & 0.456 & 0.601 & 0.473 & 0.516 & 0.597 & 0.453 & 1.116 & 0.358 & 0.42 & 0.427 \\
\hline $\mathrm{Na} 2 \mathrm{O}$ & 0.003 & 0 & 0.015 & 0.052 & 0.013 & 0.018 & 0.021 & 0 & 0 & 0.013 & 0.016 & 0.012 & 0 & 0 & 0 \\
\hline Total & 99.35 & 100.68 & 100.34 & 100.28 & 99.5 & 101.08 & 100.42 & 101.1 & 100.48 & 99.72 & 99.65 & 100.26 & 99.35 & 98.91 & 99.71 \\
\hline TSi & 1.971 & 1.968 & 2.001 & 1.968 & 1.972 & 1.972 & 1.955 & 1.964 & 1.982 & 1.974 & 1.986 & 1.979 & 2.144 & 1.927 & 1.998 \\
\hline TAl & 0.029 & 0.032 & 0 & 0.032 & 0.028 & 0.028 & 0.045 & 0.036 & 0.018 & 0.026 & 0.014 & 0.021 & 0 & 0.073 & 0.002 \\
\hline M1Al & 0.014 & 0.008 & 0.034 & 0.005 & 0.009 & 0.011 & 0.117 & 0.013 & 0.026 & 0.016 & 0.034 & 0.031 & 0.038 & 0.079 & 0.038 \\
\hline M1Ti & 0.001 & 0 & 0.002 & 0.001 & 0.002 & 0.001 & 0.001 & 0.002 & 0.001 & 0 & 0.002 & 0.001 & 0 & 0.002 & 0.001 \\
\hline M1Fe2 & 0 & 0.027 & 0.013 & 0.021 & 0.012 & 0.028 & 0 & 0.016 & 0.024 & 0.022 & 0.027 & 0.013 & 0.073 & 0 & 0 \\
\hline $\mathrm{M} 1 \mathrm{Mg}$ & 0.984 & 0.965 & 0.952 & 0.974 & 0.977 & 0.96 & 0.882 & 0.969 & 0.95 & 0.962 & 0.937 & 0.955 & 0.889 & 0.919 & 0.961 \\
\hline M2Mg & 0.011 & 0 & 0 & 0 & 0 & 0 & 0.004 & 0 & 0 & 0 & 0 & 0 & 0 & 0.021 & 0.007 \\
\hline M2Mn & 0.024 & 0.023 & 0.023 & 0.021 & 0.024 & 0.021 & 0.024 & 0.023 & 0.027 & 0.027 & 0.026 & 0.024 & 0.022 & 0.021 & 0.024 \\
\hline $\mathrm{M} 2 \mathrm{Ca}$ & 0.018 & 0.018 & 0.013 & 0.018 & 0.018 & 0.019 & 0.025 & 0.019 & 0.021 & 0.025 & 0.019 & 0.046 & 0.015 & 0.018 & 0.018 \\
\hline $\mathrm{M} 2 \mathrm{Na}$ & 0 & 0 & 0.001 & 0.004 & 0.001 & 0.001 & 0.002 & 0 & 0 & 0.001 & 0.001 & 0.001 & 0 & 0 & 0 \\
\hline $\mathrm{M} 2 \mathrm{~K}$ & 0 & 0.001 & 0.002 & 0.001 & 0.002 & 0 & 0 & 0 & 0 & 0 & 0 & 0 & 0 & 0 & 0.001 \\
\hline Sum_cat & 4 & 3.999 & 3.998 & 3.999 & 3.998 & 4 & 4 & 4 & 4 & 4 & 4 & 4 & 4 & 4 & 3.999 \\
\hline$\overline{\mathrm{Ca}}$ & 0.911 & 0.882 & 0.688 & 0.882 & 0.907 & 0.943 & 1.32 & 0.977 & 1.081 & 1.252 & 0.963 & 2.343 & 0.824 & 0.914 & 0.904 \\
\hline $\mathrm{Mg}$ & 50.173 & 48.443 & 48.56 & 48.938 & 49.178 & 48.326 & 47.16 & 48.794 & 48.125 & 48.518 & 47.75 & 48.553 & 48.918 & 48.982 & 49.412 \\
\hline Fe2_Mn & 48.915 & 50.675 & 50.751 & 50.18 & 49.915 & 50.731 & 51.52 & 50.229 & 50.794 & 50.231 & 51.287 & 49.104 & 50.259 & 50.104 & 49.684 \\
\hline $\mathrm{JD} 1$ & 0.012 & 0.045 & 0.17 & 0.241 & 0.141 & 0.068 & 0.105 & 0 & 0 & 0.055 & 0.062 & 0.069 & 0 & 0.008 & 0.046 \\
\hline $\mathrm{AE} 1$ & 0 & 0 & 0 & 0.018 & 0 & 0 & 0 & 0 & 0 & 0 & 0 & 0 & 0 & 0 & 0 \\
\hline CTTS1 & 0.063 & 0.021 & 0 & 0.028 & 0.083 & 0.062 & 0.036 & 0.082 & 0.042 & 0 & 0.119 & 0.055 & 0 & 0.119 & 0.056 \\
\hline CATS1 & 0.724 & 0.341 & 0 & 0 & 0.336 & 0.502 & 2.345 & 0.684 & 0.864 & 0.787 & 0.594 & 1.016 & 0 & 3.637 & 0.069 \\
\hline W01 & 0.136 & 0.53 & 0.695 & 0.861 & 0.498 & 0.388 & 0 & 0.222 & 0.19 & 0.481 & 0.262 & 1.299 & 0.834 & 0 & 0.791 \\
\hline EN1 & 50.778 & 48.98 & 49.049 & 49.328 & 49.721 & 48.817 & 47.218 & 49.37 & 48.798 & 49.148 & 48.355 & 49.13 & 49.529 & 48.117 & 50.007 \\
\hline FS1 & 48.288 & 50.083 & 50.086 & 49.523 & 49.221 & 50.163 & 50.298 & 49.642 & 50.107 & 49.528 & 50.608 & 48.431 & 49.637 & 48.121 & 49.032 \\
\hline$Q$ & 1.96 & 1.968 & 1.937 & 1.969 & 1.962 & 1.965 & 1.856 & 1.962 & 1.946 & 1.956 & 1.937 & 1.942 & 1.796 & 1.897 & 1.936 \\
\hline EN & 50.173 & 48.443 & 48.56 & 48.938 & 49.178 & 48.326 & 47.16 & 48.794 & 48.125 & 48.518 & 47.75 & 48.553 & 48.918 & 48.982 & 49.412 \\
\hline FS & 48.915 & 50.675 & 50.751 & 50.18 & 49.915 & 50.731 & 51.52 & 50.229 & 50.794 & 50.231 & 51.287 & 49.104 & 50.259 & 50.104 & 49.684 \\
\hline WEF & 99.977 & 100 & 99.886 & 99.611 & 99.902 & 99.866 & 99.833 & 100 & 100 & 99.901 & 99.877 & 99.909 & 100 & 100 & 100 \\
\hline JD & 0.023 & 0 & 0.114 & 0.389 & 0.098 & 0.134 & 0.167 & 0 & 0 & 0.099 & 0.123 & 0.091 & 0 & 0 & 0 \\
\hline
\end{tabular}


Rochas metabásicas (Amostra NLD-7D)

PIROXÊNIO

\begin{tabular}{|c|c|c|c|c|c|c|c|c|c|c|c|c|c|c|c|c|}
\hline NLD-7D & NLD-7D & NLD-7D & NLD-7D & NLD-7D & NLD-7D & NLD-7D & NLD-7D & NLD-7D & NLD-7D & NLD-7D & NLD-7D & NLD-7D & NLD-7D & NLD-7D & NLD-7D & NLD-7D \\
\hline 51.544 & 51.347 & 50.849 & 51.02 & 51.225 & 51.088 & 50.847 & 52.084 & 51.429 & 52.162 & 52.714 & 52.436 & 51.847 & 52.349 & 51.94 & 52.066 & 52.069 \\
\hline 0.028 & 0.033 & 0.051 & 0.06 & 0.037 & 0.131 & 0.065 & 0.056 & 0.061 & 0.218 & 0.094 & 0.074 & 0.124 & 0.069 & 0.212 & 0.188 & 0.153 \\
\hline 1.093 & 1.041 & 0.966 & 0.877 & 1.071 & 0.981 & 1.03 & 0.914 & 0.941 & 2.136 & 2.104 & 1.906 & 1.815 & 1.947 & 1.893 & 2.138 & 2.216 \\
\hline 30.194 & 29.482 & 31.135 & 30.612 & 29.557 & 29.077 & 29.471 & 29.91 & 30.005 & 11.108 & 11.751 & 12.112 & 10.756 & 11.64 & 12.247 & 11.495 & 11.456 \\
\hline 0.77 & 0.73 & 0.788 & 0.913 & 0.773 & 0.83 & 0.694 & 0.668 & 0.734 & 0.245 & 0.296 & 0.318 & 0.308 & 0.305 & 0.315 & 0.352 & 0.28 \\
\hline 16.647 & 16.599 & 16.509 & 16.462 & 16.638 & 16.949 & 16.716 & 16.624 & 16.567 & 11.992 & 11.851 & 11.978 & 12.172 & 11.983 & 12.059 & 11.652 & 11.719 \\
\hline 0.755 & 1 & 0.518 & 0.444 & 0.593 & 0.466 & 0.477 & 0.442 & 0.491 & 22.276 & 22.31 & 21.941 & 22.924 & 22.15 & 21.977 & 22.186 & 22.131 \\
\hline 0.017 & 0.021 & 0.022 & 0.001 & 0.021 & 0 & 0 & 0.014 & 0 & 0.551 & 0.578 & 0.453 & 0.535 & 0.479 & 0.469 & 0.512 & 0.571 \\
\hline 0.017 & 0.005 & 0.03 & 0 & 0 & 0.1 & 0.007 & 0.012 & 0 & 0 & 0.013 & 0.019 & 0 & 0.004 & 0 & 0 & 0.014 \\
\hline 101.07 & 100.26 & 100.87 & 100.39 & 99.92 & 99.62 & 99.31 & 100.72 & 100.23 & 100.69 & 101.71 & 101.24 & 100.48 & 100.93 & 101.11 & 100.59 & 100.61 \\
\hline 0.026 & 0.02 & 0.044 & 0.028 & 0.018 & 0.021 & 0.021 & 0 & 0.013 & 0.053 & 0.049 & 0.047 & 0.063 & 0.047 & 0.063 & 0.049 & 0.052 \\
\hline 0.023 & 0.027 & 0 & 0.012 & 0.031 & 0.024 & 0.026 & 0.041 & 0.03 & 0.041 & 0.043 & 0.036 & 0.017 & 0.039 & 0.02 & 0.045 & 0.046 \\
\hline 0.001 & 0.001 & 0.001 & 0.002 & 0.001 & 0.004 & 0.002 & 0.002 & 0.002 & 0.006 & 0.003 & 0.002 & 0.003 & 0.002 & 0.006 & 0.005 & 0.004 \\
\hline 0.025 & 0.018 & 0.052 & 0.038 & 0.008 & 0 & 0.002 & 0.005 & 0.014 & 0.285 & 0.3 & 0.296 & 0.302 & 0.293 & 0.304 & 0.299 & 0.296 \\
\hline 0.951 & 0.954 & 0.947 & 0.949 & 0.96 & 0.972 & 0.97 & 0.952 & 0.954 & 0.667 & 0.654 & 0.665 & 0.678 & 0.666 & 0.67 & 0.651 & 0.654 \\
\hline 0 & 0 & 0 & 0 & 0 & 0.006 & 0 & 0 & 0 & 0 & 0 & 0 & 0 & 0 & 0 & 0 & 0 \\
\hline 0.942 & 0.933 & 0.95 & 0.952 & 0.949 & 0.942 & 0.957 & 0.957 & 0.956 & 0.061 & 0.064 & 0.081 & 0.034 & 0.07 & 0.078 & 0.061 & 0.062 \\
\hline 0.025 & 0.024 & 0.026 & 0.03 & 0.025 & 0.027 & 0.023 & 0.022 & 0.024 & 0.008 & 0.009 & 0.01 & 0.01 & 0.01 & 0.01 & 0.011 & 0.009 \\
\hline 0.031 & 0.041 & 0.021 & 0.018 & 0.025 & 0.019 & 0.02 & 0.018 & 0.02 & 0.891 & 0.885 & 0.876 & 0.918 & 0.885 & 0.878 & 0.891 & 0.887 \\
\hline 0.001 & 0.002 & 0.002 & 0 & 0.002 & 0 & 0 & 0.001 & 0 & 0.04 & 0.041 & 0.033 & 0.039 & 0.035 & 0.034 & 0.037 & 0.041 \\
\hline 3.999 & 4 & 3.999 & 4 & 4 & 3.995 & 4 & 3.999 & 4 & 4 & 3.999 & 3.999 & 4 & 4 & 4 & 4 & 3.999 \\
\hline 1.57 & 2.097 & 1.07 & 0.926 & 1.25 & 0.983 & 1.009 & 0.932 & 1.033 & 46.578 & 46.281 & 45.415 & 47.267 & 46.002 & 45.254 & 46.561 & 46.494 \\
\hline 48.161 & 48.434 & 47.446 & 47.754 & 48.814 & 49.752 & 49.185 & 48.75 & 48.485 & 34.888 & 34.206 & 34.496 & 34.92 & 34.627 & 34.55 & 34.025 & 34.256 \\
\hline 50.269 & 49.469 & 51.484 & 51.321 & 49.935 & 49.265 & 49.806 & 50.318 & 50.482 & 18.534 & 19.513 & 20.089 & 17.813 & 19.37 & 20.197 & 19.414 & 19.251 \\
\hline 0.107 & 0.093 & 0 & 0.004 & 0.081 & 0.254 & 0.018 & 0.084 & 0 & 2.051 & 2.165 & 1.723 & 0.844 & 1.787 & 1.013 & 1.919 & 2.168 \\
\hline 0 & 0 & 0.158 & 0 & 0 & 0 & 0 & 0 & 0 & 0 & 0 & 0 & 1.123 & 0 & 0.713 & 0 & 0 \\
\hline 0.041 & 0.049 & 0.075 & 0.089 & 0.055 & 0.196 & 0.098 & 0 & 0.091 & 0.315 & 0.135 & 0.106 & 0.177 & 0.099 & 0.303 & 0.273 & 0.222 \\
\hline 1.097 & 0.982 & 0 & 0.604 & 0.858 & 0.878 & 0.989 & 0 & 0.568 & 0.064 & 0.058 & 0.147 & 0 & 0.191 & 0 & 0.398 & 0.182 \\
\hline 0.45 & 1.09 & 1.007 & 0.247 & 0.352 & 0 & 0 & 0.941 & 0.386 & 45.429 & 45.308 & 44.613 & 46.394 & 45.118 & 44.399 & 45.265 & 45.295 \\
\hline 48.726 & 48.982 & 47.989 & 48.481 & 49.411 & 50.281 & 49.72 & 49.258 & 49.084 & 34.312 & 33.629 & 34.08 & 34.406 & 34.18 & 34.128 & 33.568 & 33.67 \\
\hline 49.579 & 48.804 & 50.771 & 50.575 & 49.242 & 48.391 & 49.175 & 49.717 & 49.87 & 17.83 & 18.706 & 19.332 & 17.056 & 18.626 & 19.444 & 18.577 & 18.464 \\
\hline 1.949 & 1.946 & 1.97 & 1.956 & 1.941 & 1.94 & 1.949 & 1.932 & 1.944 & 1.905 & 1.903 & 1.918 & 1.931 & 1.915 & 1.93 & 1.901 & 1.899 \\
\hline 0.003 & 0.003 & 0.003 & 0 & 0.003 & 0 & 0 & 0.002 & 0 & 0.08 & 0.083 & 0.065 & 0.078 & 0.069 & 0.068 & 0.074 & 0.083 \\
\hline 1.57 & 2.097 & 1.07 & 0.926 & 1.25 & 0.983 & 1.009 & 0.932 & 1.033 & 46.578 & 46.281 & 45.415 & 47.267 & 46.002 & 45.254 & 46.561 & 46.494 \\
\hline 48.161 & 48.434 & 47.446 & 47.754 & 48.814 & 49.752 & 49.185 & 48.75 & 48.485 & 34.888 & 34.206 & 34.496 & 34.92 & 34.627 & 34.55 & 34.025 & 34.256 \\
\hline 50.269 & 49.469 & 51.484 & 51.321 & 49.935 & 49.265 & 49.806 & 50.318 & 50.482 & 18.534 & 19.513 & 20.089 & 17.813 & 19.37 & 20.197 & 19.414 & 19.251 \\
\hline 99.872 & 99.841 & 99.836 & 99.992 & 99.84 & 100 & 100 & 99.893 & 100 & 95.997 & 95.841 & 96.718 & 96.161 & 96.524 & 96.623 & 96.256 & 95.839 \\
\hline 0.128 & 0.159 & 0 & 0.008 & 0.16 & 0 & 0 & 0.107 & 0 & 4.003 & 4.159 & 3.282 & 3.839 & 3.476 & 3.377 & 3.744 & 4.161 \\
\hline
\end{tabular}


Rochas metabásicas (Amostra NLD-7D)

PIROXÊNIO

\begin{tabular}{|c|c|c|c|c|c|c|c|c|c|c|c|c|c|c|c|}
\hline NLD-7D & NLD-7D & NLD-7D & NLD-7D & NLD-7D & NLD-7D & NLD-7D & NLD-7D & NLD-7D & NLD-7D & NLD-7D & NLD-7D & NLD-7D & NLD-7D & NLD-7D & NLD-7D \\
\hline 51.048 & 51.826 & 52.096 & 51.829 & 52.64 & 51.978 & 52.056 & 52.686 & 52.395 & 52.041 & 52.533 & 52.416 & 52.093 & 52.121 & 52.519 & 52.645 \\
\hline 0.508 & 0.183 & 0.094 & 0.124 & 0.049 & 0.148 & 0.188 & 0.148 & 0.089 & 0.178 & 0.158 & 0.128 & 0.153 & 0.133 & 0.099 & 0.129 \\
\hline 1.037 & 1.936 & 1.786 & 2.061 & 1.736 & 2.199 & 2.463 & 1.869 & 1.894 & 1.904 & 1.582 & 1.827 & 1.962 & 1.857 & 1.817 & 1.889 \\
\hline 30.285 & 11.285 & 13.02 & 11.536 & 14.509 & 11.592 & 11.366 & 11.575 & 10.912 & 10.876 & 10.714 & 13.034 & 11.157 & 11.879 & 11.671 & 10.929 \\
\hline 0.778 & 0.304 & 0.329 & 0.334 & 0.395 & 0.303 & 0.323 & 0.274 & 0.361 & 0.283 & 0.301 & 0.373 & 0.245 & 0.294 & 0.286 & 0.288 \\
\hline 16.358 & 11.813 & 12.371 & 11.998 & 12.67 & 11.905 & 11.876 & 12.27 & 12.197 & 12.07 & 12.222 & 12.158 & 11.998 & 12.201 & 12.191 & 12.124 \\
\hline 0.496 & 22.447 & 20.702 & 21.899 & 18.723 & 22.005 & 22.081 & 22.43 & 22.631 & 22.702 & 22.986 & 20.966 & 22.405 & 21.999 & 21.865 & 22.844 \\
\hline 0.044 & 0.44 & 0.474 & 0.546 & 0.509 & 0.507 & 0.507 & 0.51 & 0.498 & 0.509 & 0.458 & 0.524 & 0.543 & 0.458 & 0.453 & 0.565 \\
\hline 0 & 0.003 & 0 & 0 & 0.015 & 0.025 & 0 & 0.026 & 0.007 & 0 & 0 & 0.007 & 0 & 0 & 0 & 0.017 \\
\hline 100.55 & 100.24 & 100.87 & 100.33 & 101.25 & 100.66 & 100.86 & 101.79 & 100.98 & 100.56 & 100.95 & 101.43 & 100.56 & 100.94 & 100.9 & 101.43 \\
\hline 1.97 & 1.947 & 1.948 & 1.943 & 1.965 & 1.944 & 1.942 & 1.947 & 1.949 & 1.944 & 1.955 & 1.95 & 1.947 & 1.944 & 1.959 & 1.95 \\
\hline 0.03 & 0.053 & 0.052 & 0.057 & 0.035 & 0.056 & 0.058 & 0.053 & 0.051 & 0.056 & 0.045 & 0.05 & 0.053 & 0.056 & 0.041 & 0.05 \\
\hline 0.017 & 0.033 & 0.027 & 0.034 & 0.042 & 0.04 & 0.05 & 0.028 & 0.032 & 0.028 & 0.025 & 0.031 & 0.034 & 0.026 & 0.039 & 0.032 \\
\hline 0.015 & 0.005 & 0.003 & 0.003 & 0.001 & 0.004 & 0.005 & 0.004 & 0.002 & 0.005 & 0.004 & 0.004 & 0.004 & 0.004 & 0.003 & 0.004 \\
\hline 0.027 & 0.3 & 0.281 & 0.292 & 0.252 & 0.292 & 0.284 & 0.292 & 0.289 & 0.294 & 0.293 & 0.291 & 0.293 & 0.292 & 0.28 & 0.295 \\
\hline 0.941 & 0.662 & 0.69 & 0.671 & 0.705 & 0.664 & 0.66 & 0.676 & 0.676 & 0.672 & 0.678 & 0.674 & 0.669 & 0.678 & 0.678 & 0.669 \\
\hline 0 & 0 & 0 & 0 & 0 & 0 & 0 & 0 & 0 & 0 & 0 & 0 & 0 & 0 & 0 & 0 \\
\hline 0.025 & 0.01 & 0.01 & 0.011 & 0.012 & 0.01 & 0.01 & 0.009 & 0.011 & 0.009 & 0.009 & 0.012 & 0.008 & 0.009 & 0.009 & 0.009 \\
\hline 0.021 & 0.904 & 0.829 & 0.88 & 0.749 & 0.882 & 0.883 & 0.888 & 0.902 & 0.909 & 0.917 & 0.836 & 0.897 & 0.879 & 0.874 & 0.906 \\
\hline 0.003 & 0.032 & 0.034 & 0.04 & 0.037 & 0.037 & 0.037 & 0.037 & 0.036 & 0.037 & 0.033 & 0.038 & 0.039 & 0.033 & 0.033 & 0.041 \\
\hline 0 & 0 & 0 & 0 & 0.001 & 0.001 & 0 & 0.001 & 0 & 0 & 0 & 0 & 0 & 0 & 0 & 0.001 \\
\hline 4 & 4 & 4 & 4 & 3.999 & 3.999 & 4 & 3.999 & 4 & 4 & 4 & 4 & 4 & 4 & 4 & 3.999 \\
\hline 1.044 & 46.831 & 42.828 & 45.755 & 39.015 & 45.981 & 46.26 & 46.007 & 46.754 & 47.091 & 47.304 & 43.362 & 46.676 & 45.378 & 45.398 & 47.129 \\
\hline 47.906 & 34.291 & 35.61 & 34.88 & 36.735 & 34.612 & 34.618 & 35.017 & 35.06 & 34.836 & 34.996 & 34.987 & 34.778 & 35.017 & 35.219 & 34.802 \\
\hline 51.05 & 18.878 & 21.563 & 19.365 & 24.25 & 19.407 & 19.121 & 18.976 & 18.186 & 18.073 & 17.7 & 21.651 & 18.546 & 19.605 & 19.384 & 18.069 \\
\hline 0.169 & 1.649 & 1.353 & 1.752 & 1.932 & 1.951 & 1.896 & 1.431 & 1.639 & 1.441 & 1.258 & 1.563 & 1.727 & 1.31 & 1.681 & 1.63 \\
\hline 0 & 0 & 0.399 & 0.281 & 0 & 0 & 0 & 0.496 & 0.216 & 0.443 & 0.427 & 0.389 & 0.287 & 0.379 & 0 & 0.485 \\
\hline 0.756 & 0.265 & 0.135 & 0.179 & 0.071 & 0.214 & 0.273 & 0.21 & 0.127 & 0.256 & 0.226 & 0.183 & 0.22 & 0.19 & 0.143 & 0.184 \\
\hline 0.72 & 0.04 & 0 & 0 & 0.204 & 0.131 & 0.699 & 0 & 0 & 0 & 0 & 0 & 0 & 0 & 0.331 & 0 \\
\hline 0 & 45.985 & 42.17 & 44.894 & 38.237 & 44.966 & 44.656 & 45.111 & 46.031 & 46.164 & 46.51 & 42.593 & 45.701 & 44.636 & 44.371 & 46.166 \\
\hline 48.247 & 33.895 & 35.175 & 34.36 & 36.262 & 34.108 & 34.145 & 34.496 & 34.614 & 34.339 & 34.576 & 34.514 & 34.216 & 34.592 & 34.79 & 34.227 \\
\hline 50.109 & 18.165 & 20.768 & 18.533 & 23.295 & 18.631 & 18.332 & 18.255 & 17.372 & 17.358 & 17.003 & 20.757 & 17.849 & 18.893 & 18.684 & 17.308 \\
\hline 1.939 & 1.92 & 1.926 & 1.912 & 1.907 & 1.908 & 1.898 & 1.922 & 1.918 & 1.921 & 1.928 & 1.916 & 1.915 & 1.928 & 1.916 & 1.914 \\
\hline 47.906 & 34.291 & 35.61 & 34.88 & 36.735 & 34.612 & 34.618 & 35.017 & 35.06 & 34.836 & 34.996 & 34.987 & 34.778 & 35.017 & 35.219 & 34.802 \\
\hline 51.05 & 18.878 & 21.563 & 19.365 & 24.25 & 19.407 & 19.121 & 18.976 & 18.186 & 18.073 & 17.7 & 21.651 & 18.546 & 19.605 & 19.384 & 18.069 \\
\hline 99.666 & 96.784 & 96.572 & 96.035 & 96.303 & 96.307 & 96.298 & 96.352 & 96.41 & 96.319 & 96.701 & 96.225 & 96.067 & 96.694 & 96.708 & 95.952 \\
\hline 0.334 & 3.216 & 3.428 & 3.965 & 3.697 & 3.693 & 3.702 & 3.648 & 3.59 & 3.681 & 3.299 & 3.775 & 3.933 & 3.306 & 3.292 & 4.048 \\
\hline
\end{tabular}




\section{QUÍMICA MINERAL DAS ROCHAS CHARNOCKÍTICAS}

Amostras NLD-45B e NLD-45D

(Granada, feldspato, ortopiroxênio, clinopiroxênio, biotita, anfibólio) 


\section{Complexo Mantiqueira - Rochas charnockíticas (Amostra NLD-45B) \\ GRANADA}

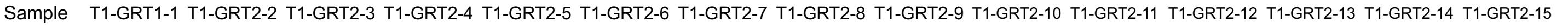

\begin{tabular}{|c|c|c|c|c|c|c|c|c|c|c|c|c|c|c|c|}
\hline $\mathrm{SiO} 2$ & 37.73 & 37.46 & 37.95 & 37.81 & 37.68 & 37.49 & 37.64 & 40.08 & 38.2 & 37.96 & 37.97 & 37.99 & 38.89 & 37.88 & 37.83 \\
\hline TiO2 & 0.01 & 0.1 & 0 & 0.09 & 0.12 & 0 & 0 & 0.04 & 0.07 & 0 & 0.03 & 0.04 & 0.07 & 0 & 0.06 \\
\hline $\mathrm{Al} 2 \mathrm{O} 3$ & 21.46 & 21.27 & 21.34 & 21.33 & 21.43 & 21.64 & 21.29 & 21.12 & 21.47 & 21.88 & 21.46 & 21.63 & 21.25 & 21.54 & 21.48 \\
\hline $\mathrm{Cr} 2 \mathrm{O} 3$ & 0.04 & 0.02 & 0.05 & 0.02 & 0.04 & 0.02 & 0.02 & 0 & 0.04 & 0.06 & 0 & 0.01 & 0.01 & 0.02 & 0.01 \\
\hline $\mathrm{Fe} 2 \mathrm{O} 3$ & 1.07 & 0.01 & 0.16 & 0.17 & 0.06 & 0.1 & 0.23 & 0 & 0.03 & 0 & 0.06 & 0.48 & 0 & 0.24 & 0 \\
\hline $\mathrm{FeO}$ & 27.77 & 28.54 & 28.96 & 28.1 & 28.55 & 28.3 & 28.56 & 28.06 & 28.87 & 28.91 & 28.62 & 28.97 & 28.32 & 28.76 & 28.41 \\
\hline $\mathrm{MnO}$ & 1.46 & 1.5 & 1.4 & 1.62 & 1.68 & 1.42 & 1.53 & 1.53 & 1.73 & 1.63 & 1.59 & 1.57 & 1.76 & 1.71 & 1.64 \\
\hline $\mathrm{MgO}$ & 3.6 & 3.09 & 3.14 & 3.28 & 3.37 & 3.32 & 3.28 & 3.3 & 3.47 & 3.37 & 3.42 & 3.32 & 3.39 & 3.31 & 3.32 \\
\hline $\mathrm{CaO}$ & 7.38 & 7.27 & 7.33 & 7.57 & 6.95 & 7.16 & 7.05 & 6.82 & 6.96 & 6.84 & 7.1 & 7 & 7.17 & 6.94 & 7.01 \\
\hline $\mathrm{Na} 2 \mathrm{O}$ & 0 & 0 & 0 & 0 & 0 & 0 & 0 & 0 & 0 & 0 & 0 & 0 & 0 & 0 & 0 \\
\hline $\mathrm{K} 2 \mathrm{O}$ & 0 & 0 & 0 & 0 & 0 & 0 & 0 & 0 & 0 & 0 & 0 & 0 & 0 & 0 & 0 \\
\hline Total & 100.52 & 99.26 & 100.33 & 99.99 & 99.87 & 99.45 & 99.61 & 100.94 & 100.83 & 100.65 & 100.26 & 101.02 & 100.85 & 100.4 & 99.75 \\
\hline Oxygens & 12 & 12 & 12 & 12 & 12 & 12 & 12 & 12 & 12 & 12 & 12 & 12 & 12 & 12 & 12 \\
\hline $\mathrm{Si}$ & 2.971 & 2.992 & 3 & 2.994 & 2.989 & 2.982 & 2.994 & 3.112 & 3 & 2.985 & 2.998 & 2.982 & 3.043 & 2.99 & 2.999 \\
\hline $\mathrm{Ti}$ & 0.001 & 0.006 & 0 & 0.005 & 0.007 & 0 & 0 & 0.003 & 0.004 & 0 & 0.002 & 0.003 & 0.004 & 0 & 0.003 \\
\hline $\mathrm{Al}$ & 1.992 & 2.003 & 1.989 & 1.991 & 2.003 & 2.029 & 1.997 & 1.933 & 1.988 & 2.029 & 1.997 & 2.002 & 1.96 & 2.005 & 2.008 \\
\hline $\mathrm{Cr}$ & 0.002 & 0.001 & 0.003 & 0.001 & 0.002 & 0.001 & 0.002 & 0 & 0.002 & 0.004 & 0 & 0.001 & 0.001 & 0.001 & 0 \\
\hline $\mathrm{Fe} 3$ & 0.063 & 0 & 0.009 & 0.01 & 0.003 & 0.006 & 0.013 & 0 & 0.001 & 0 & 0.003 & 0.028 & 0 & 0.014 & 0 \\
\hline $\mathrm{Fe} 2$ & 1.829 & 1.905 & 1.915 & 1.861 & 1.894 & 1.883 & 1.901 & 1.822 & 1.897 & 1.901 & 1.89 & 1.903 & 1.853 & 1.9 & 1.884 \\
\hline $\mathrm{Mn}$ & 0.097 & 0.102 & 0.094 & 0.109 & 0.113 & 0.096 & 0.103 & 0.1 & 0.115 & 0.109 & 0.106 & 0.105 & 0.116 & 0.114 & 0.11 \\
\hline $\mathrm{Mg}$ & 0.423 & 0.368 & 0.37 & 0.387 & 0.398 & 0.393 & 0.389 & 0.382 & 0.406 & 0.395 & 0.403 & 0.389 & 0.396 & 0.389 & 0.392 \\
\hline $\mathrm{Ca}$ & 0.622 & 0.622 & 0.621 & 0.642 & 0.591 & 0.61 & 0.601 & 0.567 & 0.586 & 0.576 & 0.601 & 0.589 & 0.601 & 0.587 & 0.596 \\
\hline $\mathrm{Na}$ & 0 & 0 & 0 & 0 & 0 & 0 & 0 & 0 & 0 & 0 & 0 & 0 & 0 & 0 & 0 \\
\hline $\mathrm{K}$ & 0 & 0 & 0 & 0 & 0 & 0 & 0 & 0 & 0 & 0 & 0 & 0 & 0 & 0 & 0 \\
\hline Sum & 8 & 8 & 8 & 8 & 8 & 8 & 8 & 7.919 & 8 & 7.999 & 8 & 8 & 7.973 & 8 & 7.993 \\
\hline Alm & 61.56 & 63.56 & 63.83 & 62.05 & 63.22 & 63.15 & 63.49 & 63.46 & 63.15 & 63.77 & 63.00 & 63.73 & 62.47 & 63.55 & 63.18 \\
\hline Prp & 14.24 & 12.28 & 12.33 & 12.90 & 13.28 & 13.18 & 12.99 & 13.31 & 13.52 & 13.25 & 13.43 & 13.03 & 13.35 & 13.01 & 13.15 \\
\hline Grs & 20.94 & 20.75 & 20.70 & 21.41 & 19.73 & 20.46 & 20.07 & 19.75 & 19.51 & 19.32 & 20.03 & 19.73 & 20.26 & 19.63 & 19.99 \\
\hline Sps & 3.26 & 3.40 & 3.13 & 3.63 & 3.77 & 3.22 & 3.44 & 3.48 & 3.83 & 3.66 & 3.53 & 3.52 & 3.91 & 3.81 & 3.69 \\
\hline TOTAL & 100.00 & 100.00 & 100.00 & 100.00 & 100.00 & 100.00 & 100.00 & 100.00 & 100.00 & 100.00 & 100.00 & 100.00 & 100.00 & 100.00 & 100.00 \\
\hline
\end{tabular}




\section{Complexo Mantiqueira - Rochas charnockíticas (Amostra NLD-45B)}

\section{GRANADA}

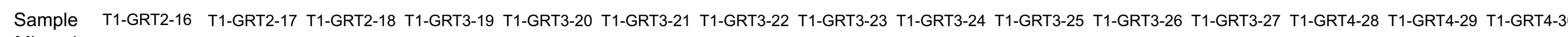

\begin{tabular}{|c|c|c|c|c|c|c|c|c|c|c|c|c|c|c|c|}
\hline Mineral & g & $g$ & g & $g$ & $g$ & $g$ & $g$ & g & $\mathrm{g}$ & g & $g$ & g & g & $g$ & g \\
\hline $\mathrm{SiO} 2$ & 37.82 & 38.53 & 37.95 & 38.01 & 38.11 & 37.7 & 37.67 & 37.93 & 38.35 & 37.86 & 37.76 & 37.93 & 38.18 & 37.5 & 38.21 \\
\hline TiO2 & 0.04 & 0 & 0.08 & 0.03 & 0.09 & 0.07 & 0 & 0.13 & 0 & 0.01 & 0.02 & 0.04 & 0.01 & 0 & 0 \\
\hline $\mathrm{Al} 2 \mathrm{O} 3$ & 21.52 & 21.5 & 21.52 & 21.2 & 21.52 & 21.48 & 21.85 & 21.61 & 21.39 & 21.49 & 21.64 & 21.55 & 21.27 & 21.38 & 21.24 \\
\hline Cr2O3 & 0.07 & 0.01 & 0.02 & 0.04 & 0 & 0.01 & 0.03 & 0.04 & 0.08 & 0.06 & 0.02 & 0 & 0.1 & 0.04 & 0.03 \\
\hline $\mathrm{Fe} 2 \mathrm{O} 3$ & 0.09 & 0 & 0.04 & 0 & 0 & 0 & 0.03 & 0 & 0 & 0 & 0.21 & 0 & 0 & 0.23 & 0 \\
\hline $\mathrm{FeO}$ & 28.46 & 28.71 & 28.95 & 28.82 & 28.93 & 28.55 & 28.45 & 28.47 & 28.07 & 28.89 & 28.3 & 28.69 & 28 & 28.23 & 28.49 \\
\hline $\mathrm{MnO}$ & 1.76 & 1.72 & 1.33 & 1.68 & 1.64 & 1.64 & 1.69 & 1.6 & 1.72 & 1.66 & 1.54 & 1.67 & 1.73 & 1.6 & 1.57 \\
\hline $\mathrm{MgO}$ & 3.38 & 3.3 & 3.26 & 3.06 & 3.43 & 3.26 & 3.37 & 3.34 & 3.11 & 3.18 & 3.45 & 3.12 & 3.26 & 3.38 & 3.3 \\
\hline $\mathrm{CaO}$ & 7.01 & 7.1 & 7.27 & 7.3 & 6.79 & 7 & 6.92 & 6.95 & 6.79 & 6.93 & 7.14 & 7.23 & 6.95 & 6.99 & 7.2 \\
\hline $\mathrm{Na} 2 \mathrm{O}$ & 0 & 0 & 0 & 0 & 0 & 0 & 0 & 0 & 0 & 0 & 0 & 0 & 0 & 0 & 0 \\
\hline $\mathrm{K} 2 \mathrm{O}$ & 0 & 0 & 0 & 0 & 0 & 0 & 0 & 0 & 0 & 0 & 0 & 0 & 0 & 0 & 0 \\
\hline Total & 100.15 & 100.87 & 100.42 & 100.15 & 100.51 & 99.7 & 100.02 & 100.07 & 99.51 & 100.08 & 100.08 & 100.24 & 99.5 & 99.36 & 100.04 \\
\hline Oxygens & 12 & 12 & 12 & 12 & 12 & 12 & 12 & 12 & 12 & 12 & 12 & 12 & 12 & 12 & 12 \\
\hline Si & 2.99 & 3.02 & 2.993 & 3.01 & 3.001 & 2.994 & 2.98 & 2.996 & 3.039 & 2.998 & 2.984 & 2.998 & 3.028 & 2.988 & 3.02 \\
\hline $\mathrm{Ti}$ & 0.003 & 0 & 0.005 & 0.002 & 0.005 & 0.004 & 0 & 0.008 & 0 & 0.001 & 0.001 & 0.003 & 0.001 & 0 & 0 \\
\hline $\mathrm{Al}$ & 2.006 & 1.986 & 2.001 & 1.98 & 1.998 & 2.011 & 2.037 & 2.012 & 1.997 & 2.006 & 2.016 & 2.008 & 1.989 & 2.008 & 1.98 \\
\hline $\mathrm{Cr}$ & 0.004 & 0.001 & 0.001 & 0.003 & 0 & 0 & 0.002 & 0.003 & 0.005 & 0.004 & 0.001 & 0 & 0.006 & 0.003 & 0.002 \\
\hline $\mathrm{Fe} 3$ & 0.005 & 0 & 0.002 & 0 & 0 & 0 & 0.001 & 0 & 0 & 0 & 0.012 & 0 & 0 & 0.013 & 0 \\
\hline $\mathrm{Fe} 2$ & 1.883 & 1.883 & 1.91 & 1.909 & 1.905 & 1.896 & 1.882 & 1.881 & 1.86 & 1.913 & 1.871 & 1.896 & 1.857 & 1.882 & 1.883 \\
\hline $\mathrm{Mn}$ & 0.118 & 0.114 & 0.089 & 0.112 & 0.109 & 0.11 & 0.113 & 0.107 & 0.115 & 0.111 & 0.103 & 0.112 & 0.116 & 0.108 & 0.105 \\
\hline $\mathrm{Mg}$ & 0.398 & 0.386 & 0.384 & 0.362 & 0.402 & 0.386 & 0.397 & 0.393 & 0.367 & 0.375 & 0.407 & 0.367 & 0.385 & 0.401 & 0.389 \\
\hline $\mathrm{Ca}$ & 0.594 & 0.596 & 0.615 & 0.62 & 0.573 & 0.595 & 0.587 & 0.589 & 0.577 & 0.588 & 0.605 & 0.612 & 0.591 & 0.597 & 0.61 \\
\hline $\mathrm{Na}$ & 0 & 0 & 0 & 0 & 0 & 0 & 0 & 0 & 0 & 0 & 0 & 0 & 0 & 0 & 0 \\
\hline $\mathrm{K}$ & 0 & 0 & 0 & 0 & 0 & 0 & 0 & 0 & 0 & 0 & 0 & 0 & 0 & 0 & 0 \\
\hline Sum & 8 & 7.986 & 8 & 7.997 & 7.995 & 7.997 & 8 & 7.989 & 7.96 & 7.997 & 8 & 7.996 & 7.974 & 8 & 7.989 \\
\hline Alm & 62.91 & 63.21 & 63.71 & 63.57 & 63.73 & 63.48 & 63.18 & 63.33 & 63.72 & 64.04 & 62.66 & 63.48 & 62.97 & 62.99 & 63.04 \\
\hline Prp & 13.30 & 12.96 & 12.81 & 12.05 & 13.45 & 12.92 & 13.33 & 13.23 & 12.57 & 12.55 & 13.63 & 12.29 & 13.06 & 13.42 & 13.02 \\
\hline Grs & 19.85 & 20.01 & 20.51 & 20.65 & 19.17 & 19.92 & 19.70 & 19.83 & 19.77 & 19.69 & 20.26 & 20.49 & 20.04 & 19.98 & 20.42 \\
\hline Sps & 3.94 & 3.83 & 2.97 & 3.73 & 3.65 & 3.68 & 3.79 & 3.60 & 3.94 & 3.72 & 3.45 & 3.75 & 3.93 & 3.61 & 3.52 \\
\hline TOTAL & 100.00 & 100.00 & 100.00 & 100.00 & 100.00 & 100.00 & 100.00 & 100.00 & 100.00 & 100.00 & 100.00 & 100.00 & 100.00 & 100.00 & 100.00 \\
\hline
\end{tabular}




\section{Complexo Mantiqueira - Rochas charnockíticas (Amostra NLD-45B)}

\section{GRANADA}

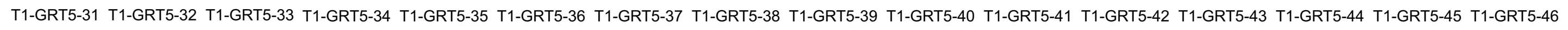

\begin{tabular}{|c|c|c|c|c|c|c|c|c|c|c|c|c|c|c|c|}
\hline g & g & $g$ & g & g & g & g & g & $g$ & g & g & g & g & g & $g$ & $g$ \\
\hline 37.44 & 37.93 & 37.79 & 37.92 & 37.61 & 37.94 & 38.1 & 37.93 & 37.86 & 37.87 & 38.05 & 37.71 & 37.87 & 38.03 & 38.06 & 37.95 \\
\hline 0.03 & 0 & 0 & 0.1 & 0.07 & 0 & 0 & 0.01 & 0 & 0.1 & 0.04 & 0 & 0.04 & 0 & 0.01 & 0 \\
\hline 21.38 & 21.33 & 21.31 & 21.29 & 21.05 & 21.31 & 21.24 & 21.38 & 21.26 & 21.48 & 21.38 & 21.18 & 21.37 & 21.17 & 21.21 & 21.26 \\
\hline 0.03 & 0 & 0.02 & 0 & 0.07 & 0.07 & 0.06 & 0.09 & 0.03 & 0.1 & 0 & 0.09 & 0.09 & 0.12 & 0.03 & 0.01 \\
\hline 0.62 & 0.53 & 0.83 & 0 & 0 & 0.01 & 0 & 0 & 0 & 0 & 0.08 & 0.35 & 0 & 0.02 & 0 & 0.32 \\
\hline 27.66 & 28.65 & 28.26 & 28.37 & 28.26 & 28.65 & 28.29 & 28.47 & 28.62 & 28.22 & 29.04 & 28.94 & 28.6 & 29.11 & 28.34 & 28.96 \\
\hline 1.82 & 1.69 & 1.61 & 1.72 & 1.83 & 1.8 & 1.85 & 1.88 & 1.64 & 1.63 & 1.64 & 1.69 & 1.88 & 1.82 & 1.83 & 1.75 \\
\hline 3.37 & 3.31 & 3.4 & 3.2 & 3.23 & 3.21 & 3.08 & 3.03 & 3.14 & 3.22 & 3.27 & 3.13 & 3.06 & 2.97 & 3.22 & 3.07 \\
\hline 7.24 & 7.1 & 7.21 & 6.92 & 7.02 & 7.16 & 6.96 & 6.88 & 6.86 & 6.94 & 7.03 & 6.91 & 7.06 & 7.19 & 7.29 & 7.15 \\
\hline 0 & 0 & 0 & 0 & 0 & 0 & 0 & 0 & 0 & 0 & 0 & 0 & 0 & 0 & 0 & 0 \\
\hline 0 & 0 & 0 & 0 & 0 & 0 & 0 & 0 & 0 & 0 & 0 & 0 & 0 & 0 & 0 & 0 \\
\hline 99.59 & 100.54 & 100.43 & 99.53 & 99.13 & 100.14 & 99.58 & 99.67 & 99.41 & 99.56 & 100.52 & 99.99 & 99.97 & 100.43 & 100 & 100.47 \\
\hline 12 & 12 & 12 & 12 & 12 & 12 & 12 & 12 & 12 & 12 & 12 & 12 & 12 & 12 & 12 & 12 \\
\hline 2.977 & 2.993 & 2.983 & 3.013 & 3.006 & 3.004 & 3.026 & 3.013 & 3.014 & 3.005 & 3.001 & 2.996 & 3.003 & 3.009 & 3.014 & 3 \\
\hline 0.002 & 0 & 0 & 0.006 & 0.004 & 0 & 0 & 0.001 & 0 & 0.006 & 0.003 & 0 & 0.003 & 0 & 0.001 & 0 \\
\hline 2.004 & 1.984 & 1.983 & 1.995 & 1.984 & 1.989 & 1.988 & 2.002 & 1.996 & 2.009 & 1.988 & 1.983 & 1.998 & 1.975 & 1.98 & 1.981 \\
\hline 0.002 & 0 & 0.001 & 0 & 0.004 & 0.004 & 0.004 & 0.006 & 0.002 & 0.006 & 0 & 0.005 & 0.005 & 0.007 & 0.002 & 0 \\
\hline 0.037 & 0.031 & 0.049 & 0 & 0 & 0 & 0 & 0 & 0 & 0 & 0.004 & 0.02 & 0 & 0.001 & 0 & 0.018 \\
\hline 1.84 & 1.891 & 1.866 & 1.885 & 1.889 & 1.897 & 1.879 & 1.891 & 1.906 & 1.873 & 1.917 & 1.923 & 1.897 & 1.927 & 1.877 & 1.915 \\
\hline 0.122 & 0.113 & 0.108 & 0.116 & 0.124 & 0.121 & 0.124 & 0.126 & 0.111 & 0.109 & 0.11 & 0.114 & 0.126 & 0.122 & 0.123 & 0.117 \\
\hline 0.4 & 0.389 & 0.4 & 0.379 & 0.384 & 0.379 & 0.365 & 0.358 & 0.373 & 0.381 & 0.384 & 0.371 & 0.362 & 0.35 & 0.38 & 0.362 \\
\hline 0.617 & 0.6 & 0.61 & 0.589 & 0.601 & 0.607 & 0.592 & 0.586 & 0.586 & 0.59 & 0.594 & 0.588 & 0.6 & 0.61 & 0.619 & 0.605 \\
\hline 0 & 0 & 0 & 0 & 0 & 0 & 0 & 0 & 0 & 0 & 0 & 0 & 0 & 0 & 0 & 0 \\
\hline 0 & 0 & 0 & 0 & 0 & 0 & 0 & 0 & 0 & 0 & 0 & 0 & 0 & 0 & 0 & 0 \\
\hline 8 & 8 & 8 & 7.984 & 7.996 & 8 & 7.978 & 7.983 & 7.987 & 7.981 & 8 & 8 & 7.993 & 8 & 7.995 & 8 \\
\hline 61.77 & 63.18 & 62.53 & 63.49 & 63.01 & 63.15 & 63.48 & 63.86 & 64.05 & 63.43 & 63.79 & 64.19 & 63.55 & 64.04 & 62.59 & 63.85 \\
\hline 13.43 & 13.00 & 13.40 & 12.77 & 12.81 & 12.62 & 12.33 & 12.09 & 12.53 & 12.90 & 12.78 & 12.38 & 12.13 & 11.63 & 12.67 & 12.07 \\
\hline 20.71 & 20.05 & 20.44 & 19.84 & 20.05 & 20.21 & 20.00 & 19.79 & 19.69 & 19.98 & 19.77 & 19.63 & 20.10 & 20.27 & 20.64 & 20.17 \\
\hline 4.10 & 3.78 & 3.62 & 3.91 & 4.14 & 4.03 & 4.19 & 4.26 & 3.73 & 3.69 & 3.66 & 3.81 & 4.22 & 4.05 & 4.10 & 3.90 \\
\hline 100.00 & 100.00 & 100.00 & 100.00 & 100.00 & 100.00 & 100.00 & 100.00 & 100.00 & 100.00 & 100.00 & 100.00 & 100.00 & 100.00 & 100.00 & 100.00 \\
\hline
\end{tabular}




\section{Complexo Mantiqueira - Rochas charnockíticas (Amostra NLD-45B)}

GRANADA

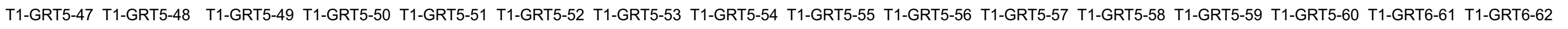

\begin{tabular}{|c|c|c|c|c|c|c|c|c|c|c|c|c|c|c|c|}
\hline$g$ & $g$ & $g$ & $g$ & $g$ & $g$ & $g$ & $g$ & $g$ & $g$ & $g$ & $g$ & $g$ & $g$ & $g$ & $g$ \\
\hline 38.05 & 37.81 & 37.9 & 37.76 & 38.2 & 37.51 & 38.26 & 37.63 & 37.9 & 37.88 & 37.91 & 38.15 & 38.08 & 38.19 & 37.69 & 37.86 \\
\hline 0 & 0 & 0.09 & 0.07 & 0.04 & 0 & 0.03 & 0 & 0.03 & 0.06 & 0 & 0 & 0 & 0.04 & 0 & 0.06 \\
\hline 21.45 & 21.14 & 21.72 & 21.08 & 21.36 & 21.67 & 21.49 & 21.29 & 21.24 & 21.25 & 21.35 & 21.47 & 21.43 & 21.35 & 21.3 & 21.29 \\
\hline 0.06 & 0 & 0 & 0.02 & 0 & 0.01 & 0.05 & 0.1 & 0 & 0.03 & 0.06 & 0.02 & 0.02 & 0 & 0.14 & 0.09 \\
\hline 0 & 0 & 0 & 0 & 0 & 0.55 & 0 & 0 & 0 & 0 & 0.08 & 0 & 0.24 & 0.06 & 0.01 & 0.22 \\
\hline 28.18 & 28.43 & 28.14 & 28.23 & 28.38 & 27.73 & 28.24 & 28.36 & 27.7 & 28.03 & 28.03 & 28.27 & 28.81 & 28.95 & 28.87 & 28.7 \\
\hline 1.66 & 1.79 & 1.68 & 1.62 & 1.51 & 1.56 & 1.64 & 1.55 & 1.61 & 1.72 & 1.83 & 1.66 & 1.8 & 1.67 & 1.72 & 1.59 \\
\hline 3.1 & 3.05 & 3.27 & 3.35 & 3.26 & 3.31 & 3.04 & 3.17 & 3.32 & 3.35 & 3.41 & 3.27 & 3.33 & 3.35 & 3.21 & 3.39 \\
\hline 7.1 & 7.11 & 7.24 & 7.04 & 7.26 & 7.52 & 7.52 & 7.18 & 7.31 & 7.06 & 7.31 & 7.29 & 6.98 & 7.09 & 6.8 & 6.99 \\
\hline 0 & 0 & 0 & 0 & 0 & 0 & 0 & 0 & 0 & 0 & 0 & 0 & 0 & 0 & 0 & 0 \\
\hline 0 & 0 & 0 & 0 & 0 & 0 & 0 & 0 & 0 & 0 & 0 & 0 & 0 & 0 & 0 & 0 \\
\hline 99.6 & 99.34 & 100.05 & 99.17 & 100.01 & 99.86 & 100.28 & 99.28 & 99.12 & 99.38 & 99.96 & 100.12 & 100.7 & 100.71 & 99.74 & 100.19 \\
\hline 12 & 12 & 12 & 12 & 12 & 12 & 12 & 12 & 12 & 12 & 12 & 12 & 12 & 12 & 12 & 12 \\
\hline 3.018 & 3.015 & 2.993 & 3.012 & 3.018 & 2.972 & 3.016 & 3.001 & 3.018 & 3.012 & 3 & 3.012 & 2.998 & 3.005 & 2.997 & 2.995 \\
\hline 0 & 0 & 0.005 & 0.004 & 0.003 & 0 & 0.002 & 0 & 0.002 & 0.003 & 0 & 0 & 0 & 0.003 & 0 & 0.003 \\
\hline 2.005 & 1.988 & 2.022 & 1.982 & 1.99 & 2.024 & 1.997 & 2.002 & 1.994 & 1.992 & 1.992 & 1.998 & 1.989 & 1.981 & 1.997 & 1.986 \\
\hline 0.004 & 0 & 0 & 0.002 & 0 & 0.001 & 0.003 & 0.006 & 0 & 0.002 & 0.003 & 0.001 & 0.001 & 0 & 0.009 & 0.006 \\
\hline 0 & 0 & 0 & 0 & 0 & 0.032 & 0 & 0 & 0 & 0 & 0.004 & 0 & 0.014 & 0.003 & 0 & 0.013 \\
\hline 1.869 & 1.896 & 1.859 & 1.883 & 1.875 & 1.838 & 1.862 & 1.892 & 1.844 & 1.864 & 1.856 & 1.866 & 1.898 & 1.906 & 1.921 & 1.899 \\
\hline 0.112 & 0.121 & 0.112 & 0.11 & 0.101 & 0.105 & 0.11 & 0.105 & 0.109 & 0.116 & 0.122 & 0.111 & 0.12 & 0.111 & 0.116 & 0.107 \\
\hline 0.366 & 0.363 & 0.385 & 0.398 & 0.383 & 0.391 & 0.358 & 0.376 & 0.394 & 0.397 & 0.402 & 0.385 & 0.391 & 0.393 & 0.381 & 0.4 \\
\hline 0.603 & 0.607 & 0.613 & 0.602 & 0.615 & 0.638 & 0.636 & 0.614 & 0.624 & 0.602 & 0.62 & 0.616 & 0.589 & 0.598 & 0.58 & 0.592 \\
\hline 0 & 0 & 0 & 0 & 0 & 0 & 0 & 0 & 0 & 0 & 0 & 0 & 0 & 0 & 0 & 0 \\
\hline 0 & 0 & 0 & 0 & 0 & 0 & 0 & 0 & 0 & 0 & 0 & 0 & 0 & 0 & 0 & 0 \\
\hline 7.978 & 7.991 & 7.99 & 7.993 & 7.985 & 8 & 7.982 & 7.995 & 7.984 & 7.988 & 8 & 7.989 & 8 & 8 & 8 & 8 \\
\hline 63.36 & 63.48 & 62.61 & 62.91 & 63.05 & 61.84 & 62.78 & 63.34 & 62.07 & 62.57 & 61.87 & 62.66 & 63.31 & 63.36 & 64.08 & 63.34 \\
\hline 12.41 & 12.15 & 12.97 & 13.30 & 12.88 & 13.16 & 12.07 & 12.59 & 13.26 & 13.33 & 13.40 & 12.93 & 13.04 & 13.07 & 12.71 & 13.34 \\
\hline 20.44 & 20.32 & 20.65 & 20.11 & 20.68 & 21.47 & 21.44 & 20.56 & 21.00 & 20.21 & 20.67 & 20.69 & 19.65 & 19.88 & 19.35 & 19.75 \\
\hline 3.80 & 4.05 & 3.77 & 3.68 & 3.40 & 3.53 & 3.71 & 3.52 & 3.67 & 3.89 & 4.07 & 3.73 & 4.00 & 3.69 & 3.87 & 3.57 \\
\hline 100.00 & 100.00 & 100.00 & 100.00 & 100.00 & 100.00 & 100.00 & 100.00 & 100.00 & 100.00 & 100.00 & 100.00 & 100.00 & 100.00 & 100.00 & 100.00 \\
\hline
\end{tabular}




\section{Complexo Mantiqueira - Rochas charnockíticas (Amostra NLD-45B)} GRANADA

T1-GRT6-63 T1-GRT7-64 T1-GRT7-65 T1-GRT7-66 T1-GRT7-67 T1-GRT7-68 T1-GRT7-69 T1-GRT7-70

\begin{tabular}{|c|c|c|c|c|c|c|c|}
\hline$g$ & $g$ & $g$ & $g$ & $g$ & $g$ & $g$ & $g$ \\
\hline 38.14 & 38.06 & 38.22 & 38.09 & 37.68 & 37.67 & 38.17 & 37.82 \\
\hline 0.14 & 0.09 & 0.01 & 0.01 & 0.06 & 0.12 & 0.1 & 0.15 \\
\hline 21.44 & 21.38 & 21.53 & 21.47 & 21.44 & 21.06 & 21.41 & 21.26 \\
\hline 0.07 & 0.02 & 0.02 & 0.02 & 0.09 & 0.13 & 0.1 & 0.11 \\
\hline 0 & 0.41 & 0 & 0 & 0 & 0.94 & 0 & 0 \\
\hline 28.41 & 29 & 28.42 & 28.07 & 28.25 & 28.25 & 28.16 & 28.43 \\
\hline 1.68 & 1.48 & 1.47 & 1.71 & 1.44 & 1.25 & 1.42 & 1.33 \\
\hline 3.46 & 3.27 & 3.2 & 3.35 & 3.12 & 3.07 & 3.32 & 3.18 \\
\hline 6.75 & 7.23 & 7.26 & 7.21 & 7.63 & 7.92 & 7.42 & 7.3 \\
\hline 0 & 0 & 0 & 0 & 0 & 0 & 0 & 0 \\
\hline 0 & 0 & 0 & 0 & 0 & 0 & 0 & 0 \\
\hline 100.1 & 100.93 & 100.14 & 99.95 & 99.7 & 100.41 & 100.09 & 99.58 \\
\hline 12 & 12 & 12 & 12 & 12 & 12 & 12 & 12 \\
\hline 3.01 & 2.992 & 3.015 & 3.01 & 2.992 & 2.98 & 3.011 & 3.004 \\
\hline 0.008 & 0.005 & 0.001 & 0.001 & 0.003 & 0.007 & 0.006 & 0.009 \\
\hline 1.995 & 1.981 & 2.002 & 2 & 2.007 & 1.964 & 1.991 & 1.991 \\
\hline 0.004 & 0.001 & 0.001 & 0.001 & 0.006 & 0.008 & 0.006 & 0.007 \\
\hline 0 & 0.024 & 0 & 0 & 0 & 0.055 & 0 & 0 \\
\hline 1.875 & 1.907 & 1.875 & 1.855 & 1.876 & 1.869 & 1.858 & 1.889 \\
\hline 0.112 & 0.098 & 0.098 & 0.115 & 0.097 & 0.084 & 0.095 & 0.089 \\
\hline 0.407 & 0.383 & 0.376 & 0.395 & 0.369 & 0.362 & 0.39 & 0.376 \\
\hline 0.57 & 0.609 & 0.614 & 0.611 & 0.649 & 0.672 & 0.628 & 0.621 \\
\hline 0 & 0 & 0 & 0 & 0 & 0 & 0 & 0 \\
\hline 0 & 0 & 0 & 0 & 0 & 0 & 0 & 0 \\
\hline 7.982 & 8 & 7.983 & 7.989 & 7.999 & 8 & 7.985 & 7.988 \\
\hline 63.26 & 63.63 & 63.28 & 62.33 & 62.72 & 62.57 & 62.54 & 63.50 \\
\hline 13.73 & 12.78 & 12.69 & 13.27 & 12.34 & 12.12 & 13.13 & 12.64 \\
\hline 19.23 & 20.32 & 20.72 & 20.53 & 21.70 & 22.50 & 21.14 & 20.87 \\
\hline 3.78 & 3.27 & 3.31 & 3.86 & 3.24 & 2.81 & 3.20 & 2.99 \\
\hline 100.00 & 100.00 & 100.00 & 100.00 & 100.00 & 100.00 & 100.00 & 100.00 \\
\hline
\end{tabular}

Rochas charnockíticas (Amostra NLD-45D) GRANADA

T2-GRT4-16 T2-GRT4-17 T1-GRT5-18 T1-GRT5-19 T1-GRT5-20

$\begin{array}{ccccc}g & g & g & g & g \\ 37.48 & 37.46 & 36.98 & 37.49 & 37.51 \\ 0.00 & 0.00 & 0.13 & 0.00 & 0.07 \\ 21.96 & 22.03 & 22.07 & 22.26 & 22.26 \\ 0.01 & 0.01 & 0.09 & 0.02 & 0.07 \\ 1.68 & 1.54 & 3.19 & 1.73 & 1.72 \\ 27.46 & 27.01 & 26.91 & 27.16 & 27.37 \\ 1.48 & 1.58 & 1.30 & 1.40 & 1.21 \\ 4.16 & 4.00 & 3.87 & 4.11 & 3.91 \\ 6.58 & 7.06 & 7.18 & 6.95 & 7.29 \\ 0.00 & 0.00 & 0.00 & 0.00 & 0.00 \\ 0.00 & 0.00 & 0.00 & 0.00 & 0.00 \\ & & & & \\ 100.82 & 100.68 & 101.72 & 101.13 & 101.41 \\ & & & & \\ 12.00 & 12.00 & 12.00 & 12.00 & 12.00 \\ & & & & \\ 2.94 & 2.94 & 2.88 & 2.93 & 2.92 \\ 0.00 & 0.00 & 0.01 & 0.00 & 0.00 \\ 2.03 & 2.04 & 2.03 & 2.05 & 2.04 \\ 0.00 & 0.00 & 0.01 & 0.00 & 0.00 \\ 0.10 & 0.09 & 0.19 & 0.10 & 0.10 \\ 1.80 & 1.77 & 1.76 & 1.77 & 1.78 \\ 0.10 & 0.11 & 0.09 & 0.09 & 0.08 \\ 0.49 & 0.47 & 0.45 & 0.48 & 0.45 \\ 0.55 & 0.59 & 0.60 & 0.58 & 0.61 \\ 0.00 & 0.00 & 0.00 & 0.00 & 0.00 \\ 0.00 & 0.00 & 0.00 & 0.00 & 0.00 \\ 8,000 & 8,000 & 8,000 & 8,000 & 8,000 \\ 61.31 & 60.32 & 60.73 & 60.62 & 60.97 \\ 16.55 & 15.91 & 15.54 & 16.34 & 15.52 \\ 18.80 & 20.20 & 20.76 & 19.86 & 20.78 \\ 3.34 & 3.58 & 2.98 & 3.18 & 2.73 \\ 100.00 & 100.00 & 100.00 & 100.00 & 100.00\end{array}$




\section{Complexo Mantiqueira - Rochas charnockíticas (Amostra NLD-45D) \\ GRANADA}

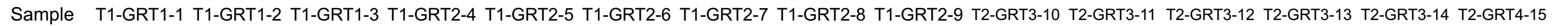

\begin{tabular}{|c|c|c|c|c|c|c|c|c|c|c|c|c|c|c|c|}
\hline Mineral & $g$ & $g$ & $g$ & $g$ & $g$ & $g$ & $g$ & $g$ & $g$ & $g$ & $g$ & g & $g$ & $g$ & g \\
\hline $\mathrm{SiO} 2$ & 37.11 & 37.39 & 37.37 & 37.42 & 37.88 & 38.07 & 37.03 & 37.78 & 37.99 & 37.64 & 37.44 & 37.25 & 37.50 & 37.85 & 37.77 \\
\hline TiO2 & 0.00 & 0.00 & 0.00 & 0.11 & 0.00 & 0.00 & 0.07 & 0.02 & 0.09 & 0.00 & 0.07 & 0.00 & 0.00 & 0.00 & 0.07 \\
\hline $\mathrm{Al} 2 \mathrm{O} 3$ & 21.56 & 21.80 & 21.73 & 22.03 & 21.91 & 21.87 & 22.22 & 22.06 & 22.05 & 21.82 & 21.97 & 22.10 & 21.80 & 21.96 & 21.71 \\
\hline $\mathrm{Cr} 2 \mathrm{O} 3$ & 0.13 & 0.04 & 0.00 & 0.00 & 0.05 & 0.00 & 0.03 & 0.00 & 0.00 & 0.06 & 0.03 & 0.01 & 0.00 & 0.04 & 0.01 \\
\hline $\mathrm{Fe} 2 \mathrm{O} 3$ & 2.00 & 2.04 & 2.06 & 1.52 & 0.81 & 0.20 & 1.05 & 1.51 & 1.36 & 0.08 & 1.35 & 2.33 & 2.11 & 1.44 & 0.46 \\
\hline $\mathrm{FeO}$ & 27.10 & 27.56 & 26.86 & 27.14 & 27.29 & 27.32 & 26.49 & 26.94 & 26.87 & 27.83 & 27.32 & 26.89 & 27.16 & 27.69 & 27.53 \\
\hline $\mathrm{MnO}$ & 1.58 & 1.45 & 1.60 & 1.42 & 1.34 & 1.44 & 1.43 & 1.30 & 1.16 & 1.60 & 1.55 & 1.60 & 1.68 & 1.50 & 1.49 \\
\hline $\mathrm{MgO}$ & 3.85 & 4.11 & 4.00 & 4.09 & 4.13 & 4.37 & 4.22 & 4.23 & 4.31 & 3.84 & 4.04 & 4.04 & 4.07 & 3.97 & 3.98 \\
\hline $\mathrm{CaO}$ & 6.87 & 6.53 & 7.07 & 7.00 & 7.25 & 6.98 & 6.92 & 7.33 & 7.62 & 6.79 & 6.81 & 6.88 & 6.81 & 6.99 & 7.08 \\
\hline $\mathrm{Na} 2 \mathrm{O}$ & 0.00 & 0.00 & 0.00 & 0.00 & 0.00 & 0.00 & 0.00 & 0.00 & 0.00 & 0.00 & 0.00 & 0.00 & 0.00 & 0.00 & 0.00 \\
\hline $\mathrm{K} 2 \mathrm{O}$ & 0.00 & 0.00 & 0.00 & 0.00 & 0.00 & 0.00 & 0.00 & 0.00 & 0.00 & 0.00 & 0.00 & 0.00 & 0.00 & 0.00 & 0.00 \\
\hline Total & 100.20 & 100.92 & 100.70 & 100.73 & 100.66 & 100.26 & 99.47 & 101.18 & 101.44 & 99.65 & 100.58 & 101.09 & 101.13 & 101.45 & 100.09 \\
\hline Oxygens & 12.00 & 12.00 & 12.00 & 12.00 & 12.00 & 12.00 & 12.00 & 12.00 & 12.00 & 12.00 & 12.00 & 12.00 & 12.00 & 12.00 & 12.00 \\
\hline $\mathrm{Si}$ & 2.93 & 2.93 & 2.93 & 2.93 & 2.98 & 2.93 & 2.93 & 2.94 & 2.95 & 2.98 & 2.94 & 2.91 & 2.93 & 2.95 & 2.98 \\
\hline $\mathrm{Ti}$ & 0.00 & 0.00 & 0.00 & 0.01 & 0.00 & 0.00 & 0.00 & 0.00 & 0.01 & 0.00 & 0.00 & 0.00 & 0.00 & 0.00 & 0.00 \\
\hline $\mathrm{Al}$ & 2.01 & 2.02 & 2.01 & 2.04 & 2.02 & 2.02 & 2.07 & 2.03 & 2.02 & 2.04 & 2.03 & 2.04 & 2.01 & 2.02 & 2.02 \\
\hline $\mathrm{Cr}$ & 0.01 & 0.00 & 0.00 & 0.00 & 0.00 & 0.00 & 0.00 & 0.00 & 0.00 & 0.00 & 0.00 & 0.00 & 0.00 & 0.00 & 0.00 \\
\hline $\mathrm{Fe} 3$ & 0.12 & 0.12 & 0.12 & 0.09 & 0.05 & 0.01 & 0.06 & 0.09 & 0.08 & 0.00 & 0.08 & 0.14 & 0.12 & 0.08 & 0.03 \\
\hline $\mathrm{Fe} 2$ & 1.79 & 1.81 & 1.76 & 1.78 & 1.79 & 1.79 & 1.75 & 1.76 & 1.74 & 1.84 & 1.79 & 1.76 & 1.78 & 1.81 & 1.81 \\
\hline $\mathrm{Mn}$ & 0.11 & 0.10 & 0.11 & 0.09 & 0.09 & 0.10 & 0.10 & 0.09 & 0.08 & 0.11 & 0.10 & 0.11 & 0.11 & 0.10 & 0.10 \\
\hline $\mathrm{Mg}$ & 0.45 & 0.48 & 0.47 & 0.48 & 0.48 & 0.51 & 0.50 & 0.49 & 0.50 & 0.45 & 0.47 & 0.47 & 0.47 & 0.46 & 0.47 \\
\hline $\mathrm{Ca}$ & 0.58 & 0.55 & 0.60 & 0.59 & 0.61 & 0.59 & 0.59 & 0.61 & 0.63 & 0.58 & 0.57 & 0.58 & 0.57 & 0.58 & 0.60 \\
\hline $\mathrm{Na}$ & 0.00 & 0.00 & 0.00 & 0.00 & 0.00 & 0.00 & 0.00 & 0.00 & 0.00 & 0.00 & 0.00 & 0.00 & 0.00 & 0.00 & 0.00 \\
\hline $\mathrm{K}$ & 0.00 & 0.00 & 0.00 & 0.00 & 0.00 & 0.00 & 0.00 & 0.00 & 0.00 & 0.00 & 0.00 & 0.00 & 0.00 & 0.00 & 0.00 \\
\hline Sum & 8,000 & 8,000 & 8,000 & 8,000 & 8,000 & 8,000 & 8,000 & 8,000 & 8,000 & 8,000 & 8,000 & 8,000 & 8,000 & 8,000 & 8,000 \\
\hline Alm & 61.12 & 61.65 & 60.12 & 60.57 & 60.26 & 60.02 & 59.75 & 59.65 & 59.06 & 61.85 & 60.98 & 60.38 & 60.59 & 61.21 & 60.91 \\
\hline Prp & 15.45 & 16.38 & 15.95 & 16.24 & 16.23 & 17.12 & 16.98 & 16.69 & 16.90 & 15.21 & 16.04 & 16.17 & 16.16 & 15.63 & 15.68 \\
\hline Grs & 19.82 & 18.70 & 20.28 & 19.99 & 20.51 & 19.64 & 19.99 & 20.77 & 21.47 & 19.34 & 19.48 & 19.81 & 19.47 & 19.80 & 20.08 \\
\hline Sps & 3.62 & 3.28 & 3.65 & 3.20 & 3.00 & 3.22 & 3.27 & 2.89 & 2.57 & 3.59 & 3.50 & 3.64 & 3.78 & 3.36 & 3.32 \\
\hline TOTAL & 100.00 & 100.00 & 100.00 & 100.00 & 100.00 & 100.00 & 100.00 & 100.00 & 100.00 & 100.00 & 100.00 & 100.00 & 100.00 & 100.00 & 100.00 \\
\hline
\end{tabular}




\section{Rochas charnockíticas (Amostra NLD-45B)}

FELDSPATO

\begin{tabular}{|c|c|c|c|c|c|c|c|c|c|c|c|c|c|c|c|}
\hline $\begin{array}{l}\text { Sample } \\
\text { Mineral }\end{array}$ & $\begin{array}{l}\text { T7-PL1-1 } \\
\text { fsp }\end{array}$ & $\begin{array}{l}\text { T7-PL1-2 } \\
\text { fsp }\end{array}$ & $\begin{array}{l}\text { T7-PL2-3 } \\
\text { fsp }\end{array}$ & $\begin{array}{l}\text { T7-PL2-4 } \\
\text { fsp }\end{array}$ & $\begin{array}{l}\text { T7-PL2-5 } \\
\text { fsp }\end{array}$ & $\begin{array}{l}\text { T7-PL2-6 } \\
\text { fsp }\end{array}$ & $\begin{array}{l}\text { T7-PL2-7 } \\
\text { fsp }\end{array}$ & $\begin{array}{l}\text { T7-PL2-8 } \\
\text { fsp }\end{array}$ & $\begin{array}{l}\text { T7-PL2-9 } \\
\text { fsp }\end{array}$ & $\begin{array}{c}\text { T7-PL2-10 } \\
\text { fsp }\end{array}$ & $\begin{array}{l}\text { T7-PL2-11 } \\
\text { fsp }\end{array}$ & $\begin{array}{c}\text { T7-PL2-12 } \\
\text { fsp }\end{array}$ & $\begin{array}{l}\text { T7-PL2-13 } \\
\text { fsp }\end{array}$ & $\begin{array}{l}\text { T7-PL2-14 } \\
\text { fsp }\end{array}$ & $\begin{array}{l}\text { T7-PL2-15 } \\
\text { fsp }\end{array}$ \\
\hline $\mathrm{SiO} 2$ & 56.86 & 58.38 & 56.55 & 56.82 & 57.56 & 57.55 & 56.79 & 58.12 & 57.78 & 57.3 & 57.72 & 57.86 & 57.94 & 58.33 & 57.87 \\
\hline TiO2 & 0.06 & 0 & 0.07 & 0 & 0 & 0 & 0 & 0 & 0 & 0 & 0 & 0 & 0.02 & 0.02 & 0 \\
\hline $\mathrm{Al} 2 \mathrm{O} 3$ & 26.72 & 26.07 & 26.62 & 26.39 & 26.4 & 26.28 & 26.23 & 26.4 & 26.46 & 26.15 & 26.12 & 25.96 & 26.16 & 26.17 & 26.11 \\
\hline $\mathrm{Cr} 2 \mathrm{O} 3$ & 0 & 0 & 0 & 0 & 0 & 0 & 0 & 0 & 0 & 0 & 0 & 0 & 0 & 0 & 0 \\
\hline $\mathrm{Fe} 2 \mathrm{O} 3$ & 0 & 0 & 0 & 0 & 0 & 0 & 0 & 0 & 0 & 0 & 0 & 0 & 0 & 0 & 0 \\
\hline $\mathrm{FeO}$ & 0 & 0 & 0 & 0 & 0 & 0 & 0 & 0 & 0 & 0 & 0 & 0 & 0 & 0 & 0 \\
\hline $\mathrm{MnO}$ & 0.03 & 0.01 & 0.06 & 0.04 & 0.04 & 0.06 & 0.01 & 0.05 & 0.04 & 0.04 & 0.07 & 0.03 & 0.04 & 0.04 & 0.04 \\
\hline $\mathrm{MgO}$ & 0 & 0 & 0 & 0.02 & 0 & 0.01 & 0.01 & 0.02 & 0.01 & 0 & 0 & 0.01 & 0.01 & 0 & 0.03 \\
\hline $\mathrm{CaO}$ & 8.57 & 7.86 & 8.78 & 8.58 & 8.31 & 8.67 & 8.35 & 8.25 & 8.15 & 8.27 & 8.28 & 7.98 & 8.08 & 7.99 & 7.82 \\
\hline $\mathrm{Na} 2 \mathrm{O}$ & 6.41 & 7.03 & 6.49 & 6.54 & 6.8 & 6.55 & 6.73 & 6.7 & 6.75 & 6.67 & 7.04 & 6.85 & 6.79 & 6.84 & 6.83 \\
\hline $\mathrm{K} 2 \mathrm{O}$ & 0.32 & 0.3 & 0.24 & 0.3 & 0.35 & 0.33 & 0.38 & 0.32 & 0.34 & 0.34 & 0.39 & 0.36 & 0.37 & 0.35 & 0.47 \\
\hline Total & 98.97 & 99.66 & 98.8 & 98.69 & 99.47 & 99.45 & 98.5 & 99.86 & 99.53 & 98.77 & 99.63 & 99.05 & 99.41 & 99.73 & 99.16 \\
\hline Oxygens & 8 & 8 & 8 & 8 & 8 & 8 & 8 & 8 & 8 & 8 & 8 & 8 & 8 & 8 & 8 \\
\hline $\mathrm{Si}$ & 2.57 & 2.615 & 2.564 & 2.578 & 2.589 & 2.59 & 2.583 & 2.601 & 2.595 & 2.595 & 2.596 & 2.612 & 2.605 & 2.613 & 2.606 \\
\hline $\mathrm{Ti}$ & 0.002 & 0 & 0.002 & 0 & 0 & 0 & 0 & 0 & 0 & 0 & 0 & 0 & 0.001 & 0.001 & 0 \\
\hline $\mathrm{Al}$ & 1.424 & 1.377 & 1.423 & 1.412 & 1.4 & 1.395 & 1.406 & 1.393 & 1.401 & 1.396 & 1.385 & 1.381 & 1.387 & 1.382 & 1.386 \\
\hline $\mathrm{Cr}$ & 0 & 0 & 0 & 0 & 0 & 0 & 0 & 0 & 0 & 0 & 0 & 0 & 0 & 0 & 0 \\
\hline $\mathrm{Fe} 3$ & 0.009 & 0.008 & 0.007 & 0.006 & 0.009 & 0.007 & 0.006 & 0.006 & 0.006 & 0.007 & 0.006 & 0.004 & 0.007 & 0.004 & 0.011 \\
\hline $\mathrm{Fe} 2$ & 0 & 0 & 0 & 0 & 0 & 0 & 0 & 0 & 0 & 0 & 0 & 0 & 0 & 0 & 0 \\
\hline $\mathrm{Mn}$ & 0.001 & 0.001 & 0.002 & 0.001 & 0.001 & 0.002 & 0.001 & 0.002 & 0.001 & 0.002 & 0.003 & 0.001 & 0.002 & 0.001 & 0.001 \\
\hline $\mathrm{Mg}$ & 0 & 0 & 0 & 0.001 & 0 & 0.001 & 0.001 & 0.001 & 0.001 & 0 & 0 & 0.001 & 0 & 0 & 0.002 \\
\hline $\mathrm{Ca}$ & 0.415 & 0.377 & 0.426 & 0.417 & 0.401 & 0.418 & 0.407 & 0.396 & 0.392 & 0.401 & 0.399 & 0.386 & 0.389 & 0.383 & 0.377 \\
\hline $\mathrm{Na}$ & 0.562 & 0.61 & 0.571 & 0.575 & 0.593 & 0.572 & 0.593 & 0.582 & 0.588 & 0.586 & 0.614 & 0.6 & 0.592 & 0.594 & 0.596 \\
\hline $\mathrm{K}$ & 0.019 & 0.017 & 0.014 & 0.017 & 0.02 & 0.019 & 0.022 & 0.018 & 0.02 & 0.02 & 0.022 & 0.021 & 0.021 & 0.02 & 0.027 \\
\hline Sum & 5.001 & 5.006 & 5.01 & 5.009 & 5.012 & 5.004 & 5.018 & 4.999 & 5.004 & 5.006 & 5.026 & 5.006 & 5.004 & 4.999 & 5.006 \\
\hline An & 41.67 & 37.55 & 42.14 & 41.33 & 39.55 & 41.43 & 39.82 & 39.76 & 39.20 & 39.82 & 38.55 & 38.33 & 38.82 & 38.42 & 37.70 \\
\hline$A b$ & 56.43 & 60.76 & 56.48 & 56.99 & 58.48 & 56.69 & 58.02 & 58.43 & 58.80 & 58.19 & 59.32 & 59.58 & 59.08 & 59.58 & 59.60 \\
\hline Or & 1.91 & 1.69 & 1.38 & 1.68 & 1.97 & 1.88 & 2.15 & 1.81 & 2.00 & 1.99 & 2.13 & 2.09 & 2.10 & 2.01 & 2.70 \\
\hline TOTAL & 100.00 & 100.00 & 100.00 & 100.00 & 100.00 & 100.00 & 100.00 & 100.00 & 100.00 & 100.00 & 100.00 & 100.00 & 100.00 & 100.00 & 100.00 \\
\hline
\end{tabular}




\section{Rochas charnockíticas (Amostra NLD-45B)}

FELDSPATO

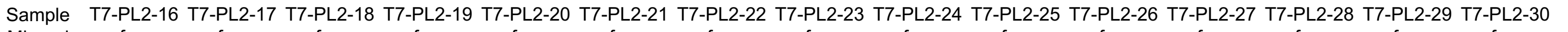

\begin{tabular}{|c|c|c|c|c|c|c|c|c|c|c|c|c|c|c|c|}
\hline Mineral & fsp & fsp & fsp & fsp & fsp & fsp & fsp & fsp & fsp & fsp & fsp & fsp & fsp & fsp & fsp \\
\hline $\mathrm{SiO} 2$ & 58.19 & 57.51 & 57.08 & 57.94 & 57.25 & 57.29 & 58.1 & 57.78 & 57.85 & 57.13 & 58.16 & 57.79 & 57.57 & 56.86 & 56.94 \\
\hline TiO2 & 0.01 & 0.01 & 0 & 0 & 0.04 & 0 & 0 & 0.07 & 0 & 0.05 & 0 & 0.01 & 0 & 0 & 0.02 \\
\hline $\mathrm{Al} 2 \mathrm{O} 3$ & 26.31 & 26.06 & 26.37 & 26.42 & 26.61 & 26.94 & 26.55 & 26.44 & 26.42 & 26.35 & 26.42 & 26.61 & 26.74 & 27.39 & 26.81 \\
\hline Cr2O3 & 0 & 0 & 0 & 0 & 0 & 0 & 0 & 0 & 0 & 0 & 0 & 0 & 0 & 0 & 0 \\
\hline $\mathrm{Fe} 2 \mathrm{O} 3$ & 0 & 0 & 0 & 0 & 0 & 0 & 0 & 0 & 0 & 0 & 0 & 0 & 0 & 0 & 0 \\
\hline $\mathrm{FeO}$ & 0 & 0 & 0 & 0 & 0 & 0 & 0 & 0 & 0 & 0 & 0 & 0 & 0 & 0 & 0 \\
\hline $\mathrm{MnO}$ & 0.07 & 0.03 & 0.06 & 0.03 & 0.04 & 0.02 & 0.03 & 0.01 & 0.01 & 0.04 & 0.06 & 0.03 & 0.04 & 0.04 & 0.06 \\
\hline $\mathrm{MgO}$ & 0.03 & 0 & 0 & 0 & 0 & 0 & 0 & 0.01 & 0 & 0 & 0.02 & 0 & 0.01 & 0.02 & 0.03 \\
\hline $\mathrm{CaO}$ & 8.13 & 8.16 & 8.36 & 8.27 & 8.37 & 8.58 & 8.3 & 7.92 & 8.16 & 8.25 & 8.32 & 8.16 & 8.35 & 9.07 & 8.76 \\
\hline $\mathrm{Na} 2 \mathrm{O}$ & 6.66 & 6.74 & 6.71 & 6.83 & 6.84 & 6.71 & 6.73 & 7.02 & 6.8 & 6.74 & 6.81 & 6.79 & 6.46 & 6.43 & 6.36 \\
\hline $\mathrm{K} 2 \mathrm{O}$ & 0.4 & 0.36 & 0.32 & 0.36 & 0.29 & 0.27 & 0.33 & 0.3 & 0.35 & 0.37 & 0.29 & 0.31 & 0.3 & 0.33 & 0.33 \\
\hline Total & 99.8 & 98.88 & 98.9 & 99.83 & 99.43 & 99.81 & 100.05 & 99.55 & 99.61 & 98.92 & 100.07 & 99.7 & 99.47 & 100.14 & 99.32 \\
\hline Oxygens & 8 & 8 & 8 & 8 & 8 & 8 & 8 & 8 & 8 & 8 & 8 & 8 & 8 & 8 & 8 \\
\hline $\mathrm{Si}$ & 2.605 & 2.6 & 2.584 & 2.597 & 2.578 & 2.571 & 2.596 & 2.595 & 2.598 & 2.587 & 2.601 & 2.591 & 2.587 & 2.548 & 2.567 \\
\hline $\mathrm{Ti}$ & 0 & 0 & 0 & 0 & 0.001 & 0 & 0 & 0.002 & 0 & 0.002 & 0 & 0 & 0 & 0 & 0.001 \\
\hline $\mathrm{Al}$ & 1.389 & 1.389 & 1.408 & 1.396 & 1.413 & 1.425 & 1.398 & 1.4 & 1.399 & 1.406 & 1.393 & 1.407 & 1.417 & 1.447 & 1.425 \\
\hline $\mathrm{Cr}$ & 0 & 0 & 0 & 0 & 0 & 0 & 0 & 0 & 0 & 0 & 0 & 0 & 0 & 0 & 0 \\
\hline Fe3 & 0.008 & 0.009 & 0.005 & 0.005 & 0.007 & 0.005 & 0.008 & 0.006 & 0.004 & 0.004 & 0.003 & 0.006 & 0.004 & 0.005 & 0.007 \\
\hline $\mathrm{Fe} 2$ & 0 & 0 & 0 & 0 & 0 & 0 & 0 & 0 & 0 & 0 & 0 & 0 & 0 & 0 & 0 \\
\hline $\mathrm{Mn}$ & 0.003 & 0.001 & 0.002 & 0.001 & 0.001 & 0.001 & 0.001 & 0 & 0.001 & 0.002 & 0.002 & 0.001 & 0.001 & 0.002 & 0.002 \\
\hline $\mathrm{Mg}$ & 0.002 & 0 & 0 & 0 & 0 & 0 & 0 & 0.001 & 0 & 0 & 0.001 & 0 & 0.001 & 0.001 & 0.002 \\
\hline $\mathrm{Ca}$ & 0.39 & 0.395 & 0.406 & 0.397 & 0.404 & 0.413 & 0.397 & 0.381 & 0.392 & 0.4 & 0.399 & 0.392 & 0.402 & 0.435 & 0.423 \\
\hline $\mathrm{Na}$ & 0.578 & 0.591 & 0.589 & 0.593 & 0.597 & 0.584 & 0.583 & 0.612 & 0.593 & 0.591 & 0.59 & 0.59 & 0.563 & 0.559 & 0.556 \\
\hline $\mathrm{K}$ & 0.023 & 0.021 & 0.018 & 0.02 & 0.017 & 0.015 & 0.019 & 0.017 & 0.02 & 0.021 & 0.017 & 0.018 & 0.017 & 0.019 & 0.019 \\
\hline Sum & 4.996 & 5.006 & 5.012 & 5.009 & 5.017 & 5.013 & 5.002 & 5.014 & 5.007 & 5.013 & 5.005 & 5.005 & 4.993 & 5.015 & 5.002 \\
\hline An & 39.35 & 39.23 & 40.08 & 39.31 & 39.69 & 40.81 & 39.74 & 37.72 & 39.00 & 39.53 & 39.66 & 39.20 & 40.94 & 42.94 & 42.38 \\
\hline$A b$ & 58.32 & 58.69 & 58.14 & 58.71 & 58.64 & 57.71 & 58.36 & 60.59 & 59.00 & 58.40 & 58.65 & 59.00 & 57.33 & 55.18 & 55.71 \\
\hline Or & 2.32 & 2.09 & 1.78 & 1.98 & 1.67 & 1.48 & 1.90 & 1.68 & 1.99 & 2.08 & 1.69 & 1.80 & 1.73 & 1.88 & 1.90 \\
\hline TOTAL & 100.00 & 100.00 & 100.00 & 100.00 & 100.00 & 100.00 & 100.00 & 100.00 & 100.00 & 100.00 & 100.00 & 100.00 & 100.00 & 100.00 & 100.00 \\
\hline
\end{tabular}




\section{Rochas charnockíticas (Amostra NLD-45B) FELDSPATO}

\begin{tabular}{|c|c|c|c|c|c|c|c|c|c|c|c|c|c|c|c|}
\hline $\begin{array}{l}\text { Sample } \\
\text { Mineral }\end{array}$ & $\begin{array}{l}\text { T7-PL2-31 } \\
\text { fsp }\end{array}$ & $\begin{array}{l}\text { T7-PL2-32 } \\
\text { fsp }\end{array}$ & $\begin{array}{l}\text { T7-PL3-33 } \\
\text { fsp }\end{array}$ & $\begin{array}{c}\text { T7-PL3-34 } \\
\text { fsp }\end{array}$ & $\begin{array}{l}\text { T7-PL3-35 } \\
\text { fsp }\end{array}$ & $\begin{array}{l}\text { T7-PL3-36 } \\
\text { fsp }\end{array}$ & $\begin{array}{l}\text { T7-PL3-37 } \\
\text { fsp }\end{array}$ & $\begin{array}{c}\text { T1-PL4-38 } \\
\text { fsp }\end{array}$ & $\begin{array}{c}\text { T1-PL4-39 } \\
\text { fsp }\end{array}$ & $\begin{array}{l}\text { T1-PL4-40 } \\
\text { fsp }\end{array}$ & $\begin{array}{c}\text { T1-PL4-41 } \\
\text { fsp }\end{array}$ & $\begin{array}{c}\text { T1-KFS1-42 } \\
\text { fsp }\end{array}$ & $\begin{array}{l}\text { T1-KFS1-43 } \\
\text { fsp }\end{array}$ & $\begin{array}{l}\text { T1-PL4-44 } \\
\text { fsp }\end{array}$ & $\begin{array}{l}\text { T1-PL4-45 } \\
\text { fsp }\end{array}$ \\
\hline $\mathrm{SiO} 2$ & 57.31 & 57.01 & 57.63 & 56.66 & 56.27 & 56.15 & 56.35 & 58 & 57.56 & 58.02 & 57.96 & 62.59 & 61.77 & 57.83 & 57.05 \\
\hline $\mathrm{TiO} 2$ & 0 & 0.04 & 0.04 & 0 & 0.07 & 0.05 & 0 & 0.01 & 0.06 & 0 & 0.01 & 0 & 0.12 & 0 & 0 \\
\hline $\mathrm{Al} 2 \mathrm{O} 3$ & 26.37 & 26.57 & 26.52 & 26.92 & 26.71 & 26.64 & 26.53 & 26.04 & 26.53 & 26.4 & 26.18 & 19.27 & 20.15 & 26.39 & 26.52 \\
\hline $\mathrm{Cr} 2 \mathrm{O} 3$ & 0 & 0 & 0 & 0 & 0 & 0 & 0 & 0 & 0 & 0 & 0 & 0 & 0 & 0 & 0 \\
\hline $\mathrm{Fe} 2 \mathrm{O} 3$ & 0 & 0 & 0 & 0 & 0 & 0 & 0 & 0 & 0 & 0 & 0 & 0 & 0 & 0 & 0 \\
\hline $\mathrm{FeO}$ & 0 & 0 & 0 & 0 & 0 & 0 & 0 & 0 & 0 & 0 & 0 & 0 & 0 & 0 & 0 \\
\hline $\mathrm{MnO}$ & 0.03 & 0.06 & 0.03 & 0.04 & 0.04 & 0.04 & 0.05 & 0.03 & 0.04 & 0.03 & 0.03 & 0.05 & 0.05 & 0.05 & 0.06 \\
\hline $\mathrm{MgO}$ & 0.02 & 0.01 & 0.03 & 0 & 0.01 & 0.27 & 0.27 & 0 & 0.01 & 0.01 & 0.01 & 0.01 & 0.02 & 0.01 & 0 \\
\hline $\mathrm{CaO}$ & 8.31 & 8.26 & 8.53 & 8.57 & 8.58 & 8.55 & 8.47 & 7.96 & 8 & 8.01 & 8.01 & 0.44 & 1.27 & 7.74 & 7.91 \\
\hline $\mathrm{Na} 2 \mathrm{O}$ & 6.45 & 6.65 & 6.51 & 6.71 & 6.58 & 6.35 & 6.42 & 6.95 & 7.01 & 7.11 & 7.08 & 1.3 & 2.12 & 7.08 & 7.21 \\
\hline $\mathrm{K} 2 \mathrm{O}$ & 0.32 & 0.33 & 0.26 & 0.28 & 0.3 & 0.27 & 0.23 & 0.17 & 0.15 & 0.15 & 0.15 & 15.02 & 13.38 & 0.15 & 0.17 \\
\hline Total & 98.8 & 98.93 & 99.54 & 99.19 & 98.56 & 98.32 & 98.32 & 99.17 & 99.35 & 99.74 & 99.43 & 98.68 & 98.88 & 99.25 & 98.92 \\
\hline Oxygens & 8 & 8 & 8 & 8 & 8 & 8 & 8 & 8 & 8 & 8 & 8 & 8 & 8 & 8 & 8 \\
\hline $\mathrm{Si}$ & 2.593 & 2.579 & 2.587 & 2.561 & 2.559 & 2.548 & 2.554 & 2.609 & 2.587 & 2.598 & 2.601 & 2.925 & 2.874 & 2.598 & 2.579 \\
\hline $\mathrm{Ti}$ & 0 & 0.001 & 0.001 & 0 & 0.002 & 0.002 & 0 & 0 & 0.002 & 0 & 0 & 0 & 0.004 & 0 & 0 \\
\hline $\mathrm{Al}$ & 1.406 & 1.417 & 1.404 & 1.434 & 1.432 & 1.425 & 1.418 & 1.381 & 1.406 & 1.393 & 1.385 & 1.061 & 1.105 & 1.397 & 1.413 \\
\hline $\mathrm{Cr}$ & 0 & 0 & 0 & 0 & 0 & 0 & 0 & 0 & 0 & 0 & 0 & 0 & 0 & 0 & 0 \\
\hline Fe3 & 0.004 & 0.005 & 0.01 & 0.006 & 0.007 & 0.027 & 0.03 & 0.011 & 0.011 & 0.01 & 0.014 & 0.018 & 0.017 & 0.014 & 0.011 \\
\hline $\mathrm{Fe} 2$ & 0 & 0 & 0 & 0 & 0 & 0 & 0 & 0 & 0 & 0 & 0 & 0 & 0 & 0 & 0 \\
\hline $\mathrm{Mn}$ & 0.001 & 0.002 & 0.001 & 0.001 & 0.002 & 0.002 & 0.002 & 0.001 & 0.001 & 0.001 & 0.001 & 0.002 & 0.002 & 0.002 & 0.002 \\
\hline $\mathrm{Mg}$ & 0.001 & 0.001 & 0.002 & 0 & 0 & 0.018 & 0.018 & 0 & 0.001 & 0.001 & 0.001 & 0.001 & 0.002 & 0.001 & 0 \\
\hline $\mathrm{Ca}$ & 0.403 & 0.4 & 0.41 & 0.415 & 0.418 & 0.416 & 0.411 & 0.384 & 0.385 & 0.384 & 0.385 & 0.022 & 0.064 & 0.372 & 0.383 \\
\hline $\mathrm{Na}$ & 0.566 & 0.584 & 0.566 & 0.588 & 0.58 & 0.558 & 0.564 & 0.607 & 0.611 & 0.617 & 0.616 & 0.118 & 0.191 & 0.617 & 0.632 \\
\hline $\mathrm{K}$ & 0.018 & 0.019 & 0.015 & 0.016 & 0.018 & 0.016 & 0.013 & 0.01 & 0.008 & 0.009 & 0.008 & 0.895 & 0.794 & 0.009 & 0.01 \\
\hline Sum & 4.993 & 5.009 & 4.995 & 5.021 & 5.018 & 5.01 & 5.009 & 5.002 & 5.012 & 5.013 & 5.01 & 5.042 & 5.053 & 5.009 & 5.029 \\
\hline An & 40.83 & 39.88 & 41.37 & 40.73 & 41.14 & 42.02 & 41.60 & 38.36 & 38.35 & 38.02 & 38.16 & 2.13 & 6.10 & 37.27 & 37.37 \\
\hline$A b$ & 57.35 & 58.23 & 57.11 & 57.70 & 57.09 & 56.36 & 57.09 & 60.64 & 60.86 & 61.09 & 61.05 & 11.40 & 18.21 & 61.82 & 61.66 \\
\hline Or & 1.82 & 1.89 & 1.51 & 1.57 & 1.77 & 1.62 & 1.32 & 1.00 & 0.80 & 0.89 & 0.79 & 86.47 & 75.69 & 0.90 & 0.98 \\
\hline TOTAL & 100.00 & 100.00 & 100.00 & 100.00 & 100.00 & 100.00 & 100.00 & 100.00 & 100.00 & 100.00 & 100.00 & 100.00 & 100.00 & 100.00 & 100.00 \\
\hline
\end{tabular}




\section{Rochas charnockíticas (Amostra NLD-45B)}

FELDSPATO

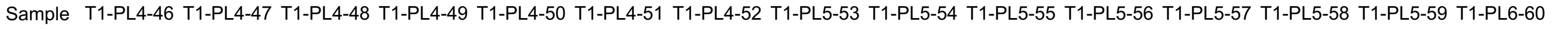

\begin{tabular}{|c|c|c|c|c|c|c|c|c|c|c|c|c|c|c|c|}
\hline Mineral & fsp & fsp & fsp & fsp & fsp & fsp & fsp & fsp & fsp & fsp & fsp & fsp & fsp & fsp & fsp \\
\hline $\mathrm{SiO} 2$ & 58.64 & 57.81 & 57.94 & 57.06 & 63.55 & 56.79 & 59.34 & 56.67 & 56.53 & 57.32 & 57.32 & 57.61 & 57.72 & 57.47 & 56.9 \\
\hline $\mathrm{TiO} 2$ & 0.02 & 0.06 & 0.04 & 0 & 0 & 0.01 & 0.06 & 0.06 & 0 & 0.07 & 0 & 0.02 & 0 & 0.05 & 0 \\
\hline $\mathrm{Al} 2 \mathrm{O} 3$ & 25.91 & 26.47 & 26.54 & 26.5 & 18.86 & 26.25 & 25.44 & 26.78 & 26.7 & 26.51 & 26.6 & 26.75 & 26.52 & 26.79 & 27.1 \\
\hline Cr2O3 & 0 & 0 & 0 & 0 & 0 & 0 & 0 & 0 & 0 & 0 & 0 & 0 & 0 & 0 & 0 \\
\hline $\mathrm{Fe} 2 \mathrm{O} 3$ & 0 & 0 & 0 & 0 & 0 & 0 & 0 & 0 & 0 & 0 & 0 & 0 & 0 & 0 & 0 \\
\hline $\mathrm{FeO}$ & 0 & 0 & 0 & 0 & 0 & 0 & 0 & 0 & 0 & 0 & 0 & 0 & 0 & 0 & 0 \\
\hline $\mathrm{MnO}$ & 0.03 & 0.05 & 0.05 & 0.03 & 0.01 & 0.01 & 0.03 & 0.05 & 0.04 & 0.05 & 0.03 & 0 & 0.02 & 0.01 & 0.04 \\
\hline $\mathrm{MgO}$ & 0.01 & 0.26 & 0 & 0.12 & 0.03 & 0 & 0.08 & 0.01 & 0 & 0 & 0 & 0 & 0 & 0.01 & 0.03 \\
\hline $\mathrm{CaO}$ & 7.09 & 7.6 & 7.98 & 7.78 & 0.3 & 7.69 & 6.6 & 8.21 & 8.46 & 8.05 & 8.21 & 8.11 & 7.98 & 8.22 & 8.45 \\
\hline $\mathrm{Na} 2 \mathrm{O}$ & 7.39 & 6.84 & 7.03 & 7.1 & 1.17 & 7.15 & 7.41 & 6.97 & 6.82 & 6.92 & 6.95 & 7.03 & 6.91 & 6.67 & 6.69 \\
\hline $\mathrm{K} 2 \mathrm{O}$ & 0.13 & 0.12 & 0.15 & 0.14 & 15.35 & 0.14 & 0.13 & 0.3 & 0.24 & 0.28 & 0.27 & 0.27 & 0.23 & 0.18 & 0.26 \\
\hline Total & 99.24 & 99.21 & 99.72 & 98.73 & 99.27 & 98.05 & 99.07 & 99.05 & 98.8 & 99.2 & 99.37 & 99.79 & 99.38 & 99.41 & 99.46 \\
\hline Oxygens & 8 & 8 & 8 & 8 & 8 & 8 & 8 & 8 & 8 & 8 & 8 & 8 & 8 & 8 & 8 \\
\hline $\mathrm{Si}$ & 2.629 & 2.581 & 2.59 & 2.572 & 2.952 & 2.583 & 2.651 & 2.564 & 2.565 & 2.585 & 2.583 & 2.582 & 2.594 & 2.583 & 2.557 \\
\hline $\mathrm{Ti}$ & 0.001 & 0.002 & 0.001 & 0 & 0 & 0 & 0.002 & 0.002 & 0 & 0.002 & 0 & 0.001 & 0 & 0.002 & 0 \\
\hline $\mathrm{Al}$ & 1.369 & 1.393 & 1.398 & 1.408 & 1.033 & 1.407 & 1.34 & 1.429 & 1.428 & 1.409 & 1.413 & 1.414 & 1.405 & 1.419 & 1.436 \\
\hline $\mathrm{Cr}$ & 0 & 0 & 0 & 0 & 0 & 0 & 0 & 0 & 0 & 0 & 0 & 0 & 0 & 0 & 0 \\
\hline $\mathrm{Fe} 3$ & 0.013 & 0.041 & 0.019 & 0.028 & 0.014 & 0.018 & 0.024 & 0.006 & 0.005 & 0.006 & 0.005 & 0.007 & 0.007 & 0.007 & 0.015 \\
\hline $\mathrm{Fe} 2$ & 0 & 0 & 0 & 0 & 0 & 0 & 0 & 0 & 0 & 0 & 0 & 0 & 0 & 0 & 0 \\
\hline $\mathrm{Mn}$ & 0.001 & 0.002 & 0.002 & 0.001 & 0.001 & 0.001 & 0.001 & 0.002 & 0.002 & 0.002 & 0.001 & 0 & 0.001 & 0.001 & 0.001 \\
\hline $\mathrm{Mg}$ & 0.001 & 0.018 & 0 & 0.008 & 0.002 & 0 & 0.005 & 0.001 & 0 & 0 & 0 & 0 & 0 & 0.001 & 0.002 \\
\hline $\mathrm{Ca}$ & 0.341 & 0.363 & 0.382 & 0.376 & 0.015 & 0.375 & 0.316 & 0.398 & 0.412 & 0.389 & 0.396 & 0.39 & 0.384 & 0.396 & 0.407 \\
\hline $\mathrm{Na}$ & 0.643 & 0.592 & 0.609 & 0.621 & 0.105 & 0.63 & 0.642 & 0.611 & 0.6 & 0.605 & 0.607 & 0.611 & 0.603 & 0.581 & 0.583 \\
\hline $\mathrm{K}$ & 0.008 & 0.007 & 0.009 & 0.008 & 0.91 & 0.008 & 0.008 & 0.017 & 0.014 & 0.016 & 0.016 & 0.015 & 0.013 & 0.011 & 0.015 \\
\hline Sum & 5.004 & 4.997 & 5.008 & 5.022 & 5.032 & 5.022 & 4.987 & 5.03 & 5.025 & 5.015 & 5.02 & 5.019 & 5.007 & 4.998 & 5.015 \\
\hline An & 34.38 & 37.73 & 38.20 & 37.41 & 1.46 & 37.02 & 32.71 & 38.79 & 40.16 & 38.51 & 38.86 & 38.39 & 38.40 & 40.08 & 40.50 \\
\hline$A b$ & 64.82 & 61.54 & 60.90 & 61.79 & 10.19 & 62.19 & 66.46 & 59.55 & 58.48 & 59.90 & 59.57 & 60.14 & 60.30 & 58.81 & 58.01 \\
\hline Or & 0.81 & 0.73 & 0.90 & 0.80 & 88.35 & 0.79 & 0.83 & 1.66 & 1.36 & 1.58 & 1.57 & 1.48 & 1.30 & 1.11 & 1.49 \\
\hline TOTAL & 100.00 & 100.00 & 100.00 & 100.00 & 100.00 & 100.00 & 100.00 & 100.00 & 100.00 & 100.00 & 100.00 & 100.00 & 100.00 & 100.00 & 100.00 \\
\hline
\end{tabular}


Rochas charnockíticas (Amostra NLD-45B)

\section{FELDSPATO}

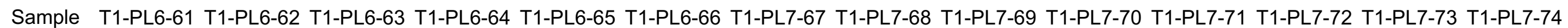

\begin{tabular}{|c|c|c|c|c|c|c|c|c|c|c|c|c|c|c|}
\hline Mineral & $f s p$ & $\mathrm{fsp}$ & fsp & fsp & $f s p$ & $\mathrm{fsp}$ & fsp & fsp & fsp & fsp & fsp & fsp & $\mathrm{fsp}$ & fsp \\
\hline $\mathrm{SiO} 2$ & 56.3 & 56.5 & 56.62 & 56.77 & 57 & 56.63 & 57.15 & 57.86 & 58.18 & 57.9 & 56.4 & 56.86 & 56.8 & 57.29 \\
\hline TiO2 & 0 & 0.05 & 0.01 & 0 & 0.02 & 0 & 0.01 & 0 & 0 & 0.04 & 0.07 & 0 & 0.01 & 0 \\
\hline $\mathrm{Al} 2 \mathrm{O} 3$ & 27.51 & 27.37 & 27.42 & 27.21 & 26.85 & 26.93 & 26.89 & 26.45 & 26.41 & 26.77 & 26.53 & 27.34 & 27.05 & 26.75 \\
\hline $\mathrm{Cr} 2 \mathrm{O} 3$ & 0 & 0 & 0 & 0 & 0 & 0 & 0 & 0 & 0 & 0 & 0 & 0 & 0 & 0 \\
\hline $\mathrm{Fe} 2 \mathrm{O} 3$ & 0 & 0 & 0 & 0 & 0 & 0 & 0 & 0 & 0 & 0 & 0 & 0 & 0 & 0 \\
\hline $\mathrm{FeO}$ & 0 & 0 & 0 & 0 & 0 & 0 & 0 & 0 & 0 & 0 & 0 & 0 & 0 & 0 \\
\hline $\mathrm{MnO}$ & 0.02 & 0.04 & 0.02 & 0.02 & 0.04 & 0.02 & 0.03 & 0.02 & 0.06 & 0.05 & 0.03 & 0.03 & 0.02 & 0.01 \\
\hline $\mathrm{MgO}$ & 0 & 0.05 & 0.01 & 0 & 0 & 0.09 & 0.01 & 0.01 & 0 & 0 & 0.33 & 0 & 0 & 0.19 \\
\hline $\mathrm{CaO}$ & 8.92 & 8.99 & 9.1 & 9.07 & 8.52 & 8.18 & 7.96 & 7.88 & 7.88 & 8.12 & 8.24 & 8.9 & 8.56 & 8.12 \\
\hline $\mathrm{Na} 2 \mathrm{O}$ & 6.41 & 6.19 & 6.29 & 6.22 & 6.51 & 6.6 & 6.71 & 6.75 & 7.22 & 6.76 & 6.48 & 6.56 & 6.47 & 6.82 \\
\hline $\mathrm{K} 2 \mathrm{O}$ & 0.26 & 0.28 & 0.24 & 0.27 & 0.28 & 0.25 & 0.27 & 0.25 & 0.29 & 0.34 & 0.28 & 0.23 & 0.27 & 0.27 \\
\hline Total & 99.42 & 99.47 & 99.71 & 99.56 & 99.22 & 98.68 & 99.02 & 99.21 & 100.03 & 99.97 & 98.35 & 99.91 & 99.18 & 99.45 \\
\hline Oxygens & 8 & 8 & 8 & 8 & 8 & 8 & 8 & 8 & 8 & 8 & 8 & 8 & 8 & 8 \\
\hline Si & 2.538 & 2.545 & 2.545 & 2.554 & 2.57 & 2.563 & 2.58 & 2.604 & 2.601 & 2.59 & 2.559 & 2.551 & 2.563 & 2.572 \\
\hline $\mathrm{Ti}$ & 0 & 0.002 & 0 & 0 & 0.001 & 0 & 0 & 0 & 0 & 0.001 & 0.002 & 0 & 0 & 0 \\
\hline $\mathrm{Al}$ & 1.462 & 1.453 & 1.453 & 1.444 & 1.427 & 1.437 & 1.431 & 1.403 & 1.392 & 1.412 & 1.419 & 1.446 & 1.439 & 1.416 \\
\hline $\mathrm{Cr}$ & 0 & 0 & 0 & 0 & 0 & 0 & 0 & 0 & 0 & 0 & 0 & 0 & 0 & 0 \\
\hline $\mathrm{Fe} 3$ & 0.009 & 0.007 & 0.005 & 0.006 & 0.009 & 0.013 & 0.004 & 0.004 & 0.005 & 0.003 & 0.022 & 0.007 & 0.006 & 0.016 \\
\hline $\mathrm{Fe} 2$ & 0 & 0 & 0 & 0 & 0 & 0 & 0 & 0 & 0 & 0 & 0 & 0 & 0 & 0 \\
\hline $\mathrm{Mn}$ & 0.001 & 0.001 & 0.001 & 0.001 & 0.002 & 0.001 & 0.001 & 0.001 & 0.002 & 0.002 & 0.001 & 0.001 & 0.001 & 0 \\
\hline $\mathrm{Mg}$ & 0 & 0.003 & 0 & 0 & 0 & 0.006 & 0 & 0 & 0 & 0 & 0.023 & 0 & 0 & 0.013 \\
\hline $\mathrm{Ca}$ & 0.431 & 0.434 & 0.438 & 0.437 & 0.412 & 0.396 & 0.385 & 0.38 & 0.377 & 0.389 & 0.401 & 0.428 & 0.414 & 0.391 \\
\hline $\mathrm{Na}$ & 0.561 & 0.541 & 0.549 & 0.543 & 0.569 & 0.579 & 0.588 & 0.589 & 0.626 & 0.587 & 0.57 & 0.57 & 0.566 & 0.593 \\
\hline $\mathrm{K}$ & 0.015 & 0.016 & 0.014 & 0.016 & 0.016 & 0.014 & 0.015 & 0.014 & 0.016 & 0.019 & 0.016 & 0.013 & 0.016 & 0.016 \\
\hline Sum & 5.014 & 5.001 & 5.006 & 5 & 5.004 & 5.008 & 5.004 & 4.994 & 5.021 & 5.004 & 5.01 & 5.015 & 5.004 & 5.016 \\
\hline An & 42.80 & 43.79 & 43.76 & 43.88 & 41.32 & 40.04 & 38.97 & 38.66 & 37.00 & 39.10 & 40.63 & 42.33 & 41.57 & 39.10 \\
\hline$A b$ & 55.71 & 54.59 & 54.85 & 54.52 & 57.07 & 58.54 & 59.51 & 59.92 & 61.43 & 58.99 & 57.75 & 56.38 & 56.83 & 59.30 \\
\hline Or & 1.49 & 1.61 & 1.40 & 1.61 & 1.60 & 1.42 & 1.52 & 1.42 & 1.57 & 1.91 & 1.62 & 1.29 & 1.61 & 1.60 \\
\hline TOTAL & 100.00 & 100.00 & 100.00 & 100.00 & 100.00 & 100.00 & 100.00 & 100.00 & 100.00 & 100.00 & 100.00 & 100.00 & 100.00 & 100.00 \\
\hline
\end{tabular}




\section{Rochas charnockíticas (Amostra NLD-45D) \\ FELDSPATO}

\begin{tabular}{|c|c|c|c|c|c|c|c|c|c|c|c|c|c|c|c|}
\hline $\begin{array}{l}\text { Sample } \\
\text { Mineral }\end{array}$ & $\begin{array}{c}\text { T12-PL1-1 } \\
\text { fsp }\end{array}$ & $\begin{array}{c}\text { T12-PL1-2 } \\
\text { fsp }\end{array}$ & $\begin{array}{c}\text { T12-PL1-3 } \\
\text { fsp }\end{array}$ & $\begin{array}{l}\text { T12-PL1-4 } \\
\text { fsp }\end{array}$ & $\begin{array}{c}\text { T12-PL1-5 } \\
\text { fsp }\end{array}$ & $\begin{array}{c}\text { T12-PL1-6 } \\
\text { fsp }\end{array}$ & $\begin{array}{l}\text { T12-PL2-7 } \\
\text { fsp }\end{array}$ & $\begin{array}{l}\text { T12-PL2-8 } \\
\text { fsp }\end{array}$ & $\begin{array}{c}\text { T12-PL2-9 } \\
\text { fsp }\end{array}$ & $\begin{array}{c}\text { T12-PL3-10 } \\
\mathrm{fsp}\end{array}$ & $\begin{array}{l}\text { T12-PL3-11 } \\
\quad \text { fsp }\end{array}$ & $\begin{array}{c}1 \text { T12-PL3-12 } \\
\mathrm{fsp}\end{array}$ & $\begin{array}{l}\text { T5-PL4-13 } \\
\text { fsp }\end{array}$ & $\begin{array}{l}\text { T1-PL5-14 } \\
\text { fsp }\end{array}$ & $\begin{array}{c}\text { T1-PL6-15 } \\
\text { fsp }\end{array}$ \\
\hline $\mathrm{SiO} 2$ & 58.34 & 58.52 & 58.34 & 58.95 & 58.32 & 57.5 & 58.87 & 58.12 & 57.83 & 58.49 & 57.77 & 58.76 & 57.94 & 58.46 & 57.87 \\
\hline TiO2 & 0.07 & 0.07 & 0.14 & 0 & 0 & 0.05 & 0 & 0.05 & 0.12 & 0 & 0 & 0 & 0.07 & 0 & 0.02 \\
\hline $\mathrm{Al} 2 \mathrm{O} 3$ & 26.97 & 26.8 & 26.81 & 25.92 & 27.01 & 26.84 & 26.97 & 26.97 & 27.11 & 26.65 & 26.7 & 26.88 & 26.68 & 26.84 & 27.11 \\
\hline $\mathrm{Cr} 2 \mathrm{O} 3$ & 0 & 0 & 0 & 0 & 0 & 0 & 0 & 0 & 0 & 0 & 0 & 0 & 0 & 0 & 0 \\
\hline $\mathrm{Fe} 2 \mathrm{O} 3$ & 0 & 0 & 0 & 0 & 0 & 0 & 0 & 0 & 0 & 0 & 0 & 0 & 0 & 0 & 0 \\
\hline $\mathrm{FeO}$ & 0 & 0 & 0 & 0 & 0 & 0 & 0 & 0 & 0 & 0 & 0 & 0 & 0 & 0 & 0 \\
\hline $\mathrm{MnO}$ & 0.01 & 0.01 & 0.01 & 0 & 0 & 0 & 0 & 0.02 & 0.02 & 0 & 0 & 0 & 0 & 0.03 & 0.01 \\
\hline $\mathrm{MgO}$ & 0 & 0.01 & 0 & 0.03 & 0 & 0.01 & 0.05 & 0 & 0 & 0 & 0 & 0.05 & 0.01 & 0.01 & 0 \\
\hline $\mathrm{CaO}$ & 8.5 & 8.15 & 7.74 & 7.39 & 8.5 & 8.5 & 8.42 & 8.38 & 8.64 & 8.33 & 8.33 & 8.36 & 8.27 & 8.6 & 8.53 \\
\hline $\mathrm{Na} 2 \mathrm{O}$ & 6.94 & 6.69 & 7 & 7.23 & 6.93 & 6.56 & 6.74 & 6.67 & 6.67 & 6.69 & 6.71 & 6.95 & 6.8 & 6.77 & 6.64 \\
\hline $\mathrm{K} 2 \mathrm{O}$ & 0.31 & 0.29 & 0.32 & 0.37 & 0.3 & 0.27 & 0.28 & 0.26 & 0.23 & 0.19 & 0.23 & 0.2 & 0.2 & 0.23 & 0.2 \\
\hline Total & 101.14 & 100.55 & 100.35 & 99.89 & 101.06 & 99.72 & 101.33 & 100.48 & 100.61 & 100.36 & 99.73 & 101.21 & 99.97 & 100.94 & 100.39 \\
\hline Oxygens & 8 & 8 & 8 & 8 & 8 & 8 & 8 & 8 & 8 & 8 & 8 & 8 & 8 & 8 & 8 \\
\hline $\mathrm{Si}$ & 2.585 & 2.601 & 2.599 & 2.635 & 2.586 & 2.581 & 2.597 & 2.588 & 2.574 & 2.603 & 2.589 & 2.594 & 2.591 & 2.592 & 2.58 \\
\hline $\mathrm{Ti}$ & 0.002 & 0.002 & 0.005 & 0 & 0 & 0.002 & 0 & 0.002 & 0.004 & 0 & 0 & 0 & 0.002 & 0 & 0.001 \\
\hline $\mathrm{Al}$ & 1.409 & 1.404 & 1.408 & 1.366 & 1.412 & 1.42 & 1.402 & 1.416 & 1.423 & 1.399 & 1.411 & 1.399 & 1.407 & 1.403 & 1.425 \\
\hline $\mathrm{Cr}$ & 0 & 0 & 0 & 0 & 0 & 0 & 0 & 0 & 0 & 0 & 0 & 0 & 0 & 0 & 0 \\
\hline $\mathrm{Fe} 3$ & 0.001 & 0 & 0 & 0.001 & 0 & 0.002 & 0.004 & 0 & 0.002 & 0.003 & 0.005 & 0.008 & 0.003 & 0.002 & 0.001 \\
\hline $\mathrm{Fe} 2$ & 0 & 0 & 0 & 0 & 0 & 0 & 0 & 0 & 0 & 0 & 0 & 0 & 0 & 0 & 0 \\
\hline $\mathrm{Mn}$ & 0 & 0 & 0 & 0 & 0 & 0 & 0 & 0.001 & 0.001 & 0 & 0 & 0 & 0 & 0.001 & 0 \\
\hline $\mathrm{Mg}$ & 0 & 0.001 & 0 & 0.002 & 0 & 0 & 0.003 & 0 & 0 & 0 & 0 & 0.003 & 0.001 & 0.001 & 0 \\
\hline $\mathrm{Ca}$ & 0.403 & 0.388 & 0.37 & 0.354 & 0.404 & 0.409 & 0.398 & 0.4 & 0.412 & 0.397 & 0.4 & 0.396 & 0.396 & 0.409 & 0.407 \\
\hline $\mathrm{Na}$ & 0.597 & 0.577 & 0.604 & 0.627 & 0.596 & 0.571 & 0.577 & 0.576 & 0.576 & 0.577 & 0.583 & 0.595 & 0.59 & 0.582 & 0.574 \\
\hline $\mathrm{K}$ & 0.017 & 0.016 & 0.018 & 0.021 & 0.017 & 0.015 & 0.016 & 0.015 & 0.013 & 0.011 & 0.013 & 0.011 & 0.011 & 0.013 & 0.012 \\
\hline Sum & 5.015 & 4.991 & 5.004 & 5.006 & 5.015 & 4.999 & 4.996 & 4.998 & 5.004 & 4.99 & 5.001 & 5.005 & 5.002 & 5.003 & 5 \\
\hline An & 39.63 & 39.55 & 37.30 & 35.33 & 39.72 & 41.11 & 40.16 & 40.36 & 41.16 & 40.30 & 40.16 & 39.52 & 39.72 & 40.74 & 40.99 \\
\hline$A b$ & 58.70 & 58.82 & 60.89 & 62.57 & 58.60 & 57.39 & 58.22 & 58.12 & 57.54 & 58.58 & 58.53 & 59.38 & 59.18 & 57.97 & 57.80 \\
\hline Or & 1.67 & 1.63 & 1.81 & 2.10 & 1.67 & 1.51 & 1.61 & 1.51 & 1.30 & 1.12 & 1.31 & 1.10 & 1.10 & 1.29 & 1.21 \\
\hline TOTAL & 100.00 & 100.00 & 100.00 & 100.00 & 100.00 & 100.00 & 100.00 & 100.00 & 100.00 & 100.00 & 100.00 & 100.00 & 100.00 & 100.00 & 100.00 \\
\hline
\end{tabular}




\section{Rochas charnockíticas (Amostra NLD-45D) FELDSPATO}

\begin{tabular}{|c|c|c|c|c|c|c|c|c|c|c|c|c|c|c|c|}
\hline $\begin{array}{l}\text { Sample } \\
\text { Mineral }\end{array}$ & $\begin{array}{l}\text { T1-PL6-16 } \\
\text { fsp }\end{array}$ & $\begin{array}{c}\text { T1-PL6-17 } \\
\text { fsp }\end{array}$ & $\begin{array}{c}\text { T1-PL6-18 } \\
\text { fsp }\end{array}$ & $\begin{array}{c}\text { T1-PL6-19 } \\
\text { fsp }\end{array}$ & $\begin{array}{c}\text { T3-PL7-20 } \\
\text { fsp }\end{array}$ & $\begin{array}{l}\text { T3-PL7-21 } \\
\text { fsp }\end{array}$ & $\begin{array}{c}\text { T2-PL8-22 } \\
\text { fsp }\end{array}$ & $\begin{array}{c}\text { T2-PL8-23 } \\
\text { fsp }\end{array}$ & $\begin{array}{c}\text { T2-PL8-24 } \\
\text { fsp }\end{array}$ & $\begin{array}{c}\text { T2-KFS1-25 } \\
\text { fsp }\end{array}$ & $\begin{array}{c}\text { T2-PL8-26 } \\
\text { fsp }\end{array}$ & $\begin{array}{c}\text { T2-PL8-27 } \\
\text { fsp }\end{array}$ & $\begin{array}{c}\text { T2-PL9-28 } \\
\text { fsp }\end{array}$ & $\begin{array}{c}\text { T2-PL9-29 } \\
\text { fsp }\end{array}$ & $\begin{array}{l}\text { 2-PL9- } \\
\text { fsp }\end{array}$ \\
\hline $\mathrm{SiO} 2$ & 58.99 & 58.29 & 58.05 & 58.81 & 57.8 & 57.59 & 56.44 & 56.73 & 56.48 & 63.25 & 58.7 & 59.57 & 58.22 & 57.81 & 56.72 \\
\hline $\mathrm{TiO} 2$ & 0 & 0 & 0 & 0.05 & 0 & 0.09 & 0.01 & 0 & 0.09 & 0.01 & 0 & 0 & 0.06 & 0.02 & 0.04 \\
\hline $\mathrm{Al} 2 \mathrm{O} 3$ & 26.61 & 26.41 & 26.37 & 26.71 & 26.31 & 25.92 & 27 & 27.3 & 27.26 & 18.73 & 26.78 & 25.77 & 26.51 & 26.92 & 27.07 \\
\hline $\mathrm{Cr} 2 \mathrm{O} 3$ & 0 & 0 & 0 & 0 & 0 & 0 & 0 & 0 & 0 & 0 & 0 & 0 & 0 & 0 & 0 \\
\hline $\mathrm{Fe} 2 \mathrm{O} 3$ & 0 & 0 & 0 & 0 & 0 & 0 & 0 & 0 & 0 & 0 & 0 & 0 & 0 & 0 & 0 \\
\hline $\mathrm{FeO}$ & 0 & 0 & 0 & 0 & 0 & 0 & 0 & 0 & 0 & 0 & 0 & 0 & 0 & 0 & 0 \\
\hline $\mathrm{MnO}$ & 0.01 & 0 & 0.01 & 0.01 & 0 & 0.03 & 0.02 & 0.06 & 0.02 & 0.03 & 0.01 & 0.02 & 0.02 & 0.02 & 0.02 \\
\hline $\mathrm{MgO}$ & 0.01 & 0 & 0.29 & 0.04 & 0.25 & 0.46 & 0 & 0.01 & 0.01 & 0.02 & 0.01 & 0.03 & 0.03 & 0 & 0 \\
\hline $\mathrm{CaO}$ & 7.8 & 7.98 & 7.82 & 8.2 & 7.33 & 7.56 & 8.56 & 8.43 & 8.38 & 0 & 7.7 & 7.13 & 7.95 & 8.74 & 8.53 \\
\hline $\mathrm{Na} 2 \mathrm{O}$ & 6.98 & 6.87 & 6.83 & 6.97 & 6.85 & 6.65 & 6.66 & 6.43 & 6.55 & 0.84 & 7.06 & 7.51 & 7.08 & 6.51 & 6.68 \\
\hline $\mathrm{K} 2 \mathrm{O}$ & 0.26 & 0.24 & 0.34 & 0.21 & 0.35 & 0.34 & 0.23 & 0.23 & 0.28 & 16.04 & 0.13 & 0.2 & 0.26 & 0.3 & 0.32 \\
\hline Total & 100.66 & 99.79 & 99.72 & 101 & 98.89 & 98.66 & 98.93 & 99.2 & 99.07 & 98.93 & 100.4 & 100.23 & 100.13 & 100.33 & 99.38 \\
\hline Oxygens & 8 & 8 & 8 & 8 & 8 & 8 & 8 & 8 & 8 & 8 & 8 & 8 & 8 & 8 & 8 \\
\hline $\mathrm{Si}$ & 2.616 & 2.609 & 2.585 & 2.602 & 2.596 & 2.585 & 2.555 & 2.558 & 2.552 & 2.957 & 2.605 & 2.644 & 2.598 & 2.58 & 2.559 \\
\hline $\mathrm{Ti}$ & 0 & 0 & 0 & 0.002 & 0 & 0.003 & 0 & 0 & 0.003 & 0 & 0 & 0 & 0.002 & 0.001 & 0.001 \\
\hline $\mathrm{Al}$ & 1.391 & 1.394 & 1.384 & 1.394 & 1.393 & 1.371 & 1.441 & 1.451 & 1.452 & 1.032 & 1.401 & 1.348 & 1.394 & 1.417 & 1.44 \\
\hline $\mathrm{Cr}$ & 0 & 0 & 0 & 0 & 0 & 0 & 0 & 0 & 0 & 0 & 0 & 0 & 0 & 0 & 0 \\
\hline $\mathrm{Fe} 3$ & 0.001 & 0.002 & 0.037 & 0.003 & 0.027 & 0.048 & 0.007 & 0.006 & 0.007 & 0.012 & 0.01 & 0.013 & 0.008 & 0.003 & 0.004 \\
\hline $\mathrm{Fe} 2$ & 0 & 0 & 0 & 0 & 0 & 0 & 0 & 0 & 0 & 0 & 0 & 0 & 0 & 0 & 0 \\
\hline $\mathrm{Mn}$ & 0 & 0 & 0 & 0 & 0 & 0.001 & 0.001 & 0.002 & 0.001 & 0.001 & 0 & 0.001 & 0.001 & 0.001 & 0.001 \\
\hline $\mathrm{Mg}$ & 0.001 & 0 & 0.02 & 0.002 & 0.016 & 0.031 & 0 & 0.001 & 0 & 0.002 & 0.001 & 0.002 & 0.002 & 0 & 0 \\
\hline $\mathrm{Ca}$ & 0.371 & 0.383 & 0.373 & 0.389 & 0.353 & 0.364 & 0.415 & 0.407 & 0.406 & 0 & 0.366 & 0.339 & 0.38 & 0.418 & 0.412 \\
\hline $\mathrm{Na}$ & 0.6 & 0.596 & 0.59 & 0.598 & 0.596 & 0.579 & 0.585 & 0.563 & 0.574 & 0.077 & 0.608 & 0.646 & 0.613 & 0.563 & 0.585 \\
\hline $\mathrm{K}$ & 0.015 & 0.013 & 0.019 & 0.012 & 0.02 & 0.02 & 0.014 & 0.013 & 0.016 & 0.956 & 0.008 & 0.011 & 0.015 & 0.017 & 0.019 \\
\hline Sum & 4.995 & 4.998 & 5.006 & 5.002 & 5 & 4.999 & 5.018 & 5.001 & 5.01 & 5.037 & 4.997 & 5.004 & 5.012 & 4.999 & 5.02 \\
\hline An & 37.63 & 38.61 & 37.98 & 38.94 & 36.43 & 37.80 & 40.93 & 41.40 & 40.76 & 0.00 & 37.27 & 34.04 & 37.70 & 41.88 & 40.55 \\
\hline$A b$ & 60.85 & 60.08 & 60.08 & 59.86 & 61.51 & 60.12 & 57.69 & 57.27 & 57.63 & 7.45 & 61.91 & 64.86 & 60.81 & 56.41 & 57.58 \\
\hline Or & 1.52 & 1.31 & 1.93 & 1.20 & 2.06 & 2.08 & 1.38 & 1.32 & 1.61 & 92.55 & 0.81 & 1.10 & 1.49 & 1.70 & 1.87 \\
\hline TOTAL & 100.00 & 100.00 & 100.00 & 100.00 & 100.00 & 100.00 & 100.00 & 100.00 & 100.00 & 100.00 & 100.00 & 100.00 & 100.00 & 100.00 & 100.00 \\
\hline
\end{tabular}




\section{Rochas charnockíticas (Amostra NLD-45D)}

FELDSPATO

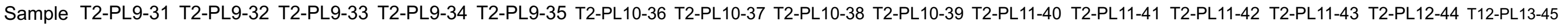

\begin{tabular}{|c|c|c|c|c|c|c|c|c|c|c|c|c|c|c|c|}
\hline Mineral & fsp & fsp & fsp & fsp & fsp & fsp & fsp & fsp & fsp & fsp & fsp & $f s p$ & fsp & fsp & fsp \\
\hline $\mathrm{SiO} 2$ & 57.33 & 57.52 & 57.75 & 58.45 & 57.72 & 58.64 & 58.11 & 58.48 & 59.03 & 58.46 & 58.6 & 58.44 & 58 & 58.05 & 56.4 \\
\hline TiO2 & 0.06 & 0 & 0 & 0 & 0.04 & 0.04 & 0 & 0.01 & 0 & 0 & 0 & 0.05 & 0.01 & 0 & 0.01 \\
\hline $\mathrm{Al} 2 \mathrm{O} 3$ & 26.86 & 26.89 & 26.5 & 26.41 & 27.02 & 26.33 & 26.79 & 25.18 & 26.55 & 26.18 & 25.58 & 26.01 & 26.01 & 26.33 & 26.37 \\
\hline Cr2O3 & 0 & 0 & 0 & 0 & 0 & 0 & 0 & 0 & 0 & 0 & 0 & 0 & 0 & 0 & 0 \\
\hline $\mathrm{Fe} 2 \mathrm{O} 3$ & 0 & 0 & 0 & 0 & 0 & 0 & 0 & 0 & 0 & 0 & 0 & 0 & 0 & 0 & 0 \\
\hline $\mathrm{FeO}$ & 0 & 0 & 0 & 0 & 0 & 0 & 0 & 0 & 0 & 0 & 0 & 0 & 0 & 0 & 0 \\
\hline $\mathrm{MnO}$ & 0.02 & 0.06 & 0.03 & 0.06 & 0 & 0.03 & 0.03 & 0.06 & 0.01 & 0.04 & 0.04 & 0.03 & 0.03 & 0.01 & 0.04 \\
\hline $\mathrm{MgO}$ & 0.02 & 0 & 0 & 0 & 0 & 0.01 & 0 & 0.49 & 0.15 & 0 & 0.25 & 0.01 & 0 & 0.07 & 0 \\
\hline $\mathrm{CaO}$ & 8.29 & 8.1 & 7.89 & 7.98 & 8.23 & 7.78 & 7.99 & 6.96 & 7.7 & 7.78 & 7.49 & 7.88 & 7.69 & 7.86 & 7.78 \\
\hline $\mathrm{Na} 2 \mathrm{O}$ & 6.63 & 6.69 & 6.86 & 6.95 & 6.57 & 7.24 & 7.25 & 7.06 & 6.88 & 7.29 & 7.03 & 7.13 & 6.96 & 6.75 & 7.04 \\
\hline $\mathrm{K} 2 \mathrm{O}$ & 0.33 & 0.36 & 0.35 & 0.36 & 0.27 & 0.16 & 0.23 & 0.25 & 0.19 & 0.34 & 0.41 & 0.25 & 0.33 & 0.22 & 0.35 \\
\hline Total & 99.53 & 99.62 & 99.38 & 100.2 & 99.85 & 100.23 & 100.39 & 98.5 & 100.51 & 100.09 & 99.41 & 99.8 & 99.03 & 99.3 & 98 \\
\hline Oxygens & 8 & 8 & 8 & 8 & 8 & 8 & 8 & 8 & 8 & 8 & 8 & 8 & 8 & 8 & 8 \\
\hline $\mathrm{Si}$ & 2.577 & 2.581 & 2.598 & 2.607 & 2.582 & 2.611 & 2.587 & 2.62 & 2.61 & 2.611 & 2.622 & 2.613 & 2.615 & 2.604 & 2.577 \\
\hline $\mathrm{Ti}$ & 0.002 & 0 & 0 & 0 & 0.001 & 0.001 & 0 & 0 & 0 & 0 & 0 & 0.002 & 0 & 0 & 0 \\
\hline $\mathrm{Al}$ & 1.423 & 1.423 & 1.405 & 1.389 & 1.425 & 1.382 & 1.406 & 1.33 & 1.384 & 1.378 & 1.349 & 1.371 & 1.383 & 1.392 & 1.42 \\
\hline $\mathrm{Cr}$ & 0 & 0 & 0 & 0 & 0 & 0 & 0 & 0 & 0 & 0 & 0 & 0 & 0 & 0 & 0 \\
\hline $\mathrm{Fe} 3$ & 0.005 & 0.007 & 0.003 & 0.006 & 0.005 & 0.008 & 0.009 & 0.054 & 0.019 & 0.008 & 0.026 & 0.012 & 0.006 & 0.014 & 0.007 \\
\hline $\mathrm{Fe} 2$ & 0 & 0 & 0 & 0 & 0 & 0 & 0 & 0 & 0 & 0 & 0 & 0 & 0 & 0 & 0 \\
\hline $\mathrm{Mn}$ & 0.001 & 0.002 & 0.001 & 0.002 & 0 & 0.001 & 0.001 & 0.002 & 0 & 0.002 & 0.002 & 0.001 & 0.001 & 0 & 0.002 \\
\hline $\mathrm{Mg}$ & 0.001 & 0 & 0 & 0 & 0 & 0.001 & 0 & 0.033 & 0.01 & 0 & 0.017 & 0.001 & 0 & 0.005 & 0 \\
\hline $\mathrm{Ca}$ & 0.399 & 0.389 & 0.38 & 0.382 & 0.395 & 0.371 & 0.381 & 0.334 & 0.365 & 0.372 & 0.359 & 0.377 & 0.371 & 0.378 & 0.381 \\
\hline $\mathrm{Na}$ & 0.578 & 0.582 & 0.599 & 0.601 & 0.57 & 0.625 & 0.626 & 0.613 & 0.59 & 0.631 & 0.61 & 0.618 & 0.608 & 0.587 & 0.624 \\
\hline $\mathrm{K}$ & 0.019 & 0.02 & 0.02 & 0.02 & 0.015 & 0.009 & 0.013 & 0.014 & 0.011 & 0.019 & 0.024 & 0.014 & 0.019 & 0.013 & 0.02 \\
\hline Sum & 5.005 & 5.005 & 5.007 & 5.006 & 4.994 & 5.009 & 5.024 & 4.998 & 4.987 & 5.021 & 5.006 & 5.009 & 5.003 & 4.992 & 5.031 \\
\hline An & 40.06 & 39.25 & 38.04 & 38.09 & 40.31 & 36.92 & 37.35 & 34.76 & 37.78 & 36.40 & 36.15 & 37.36 & 37.17 & 38.65 & 37.17 \\
\hline$A b$ & 58.03 & 58.73 & 59.96 & 59.92 & 58.16 & 62.19 & 61.37 & 63.79 & 61.08 & 61.74 & 61.43 & 61.25 & 60.92 & 60.02 & 60.88 \\
\hline Or & 1.91 & 2.02 & 2.00 & 1.99 & 1.53 & 0.90 & 1.27 & 1.46 & 1.14 & 1.86 & 2.42 & 1.39 & 1.90 & 1.33 & 1.95 \\
\hline TOTAL & 100.00 & 100.00 & 100.00 & 100.00 & 100.00 & 100.00 & 100.00 & 100.00 & 100.00 & 100.00 & 100.00 & 100.00 & 100.00 & 100.00 & 100.00 \\
\hline
\end{tabular}




\section{Rochas charnockíticas (Amostra NLD-45B)}

\section{PIROXÊNIO}

\begin{tabular}{|c|c|c|c|c|c|c|c|c|c|c|c|c|c|c|c|}
\hline Sample & T1-PX1-1 & T1-PX1-2 & T1-PX1-3 & T1-PX1-4 & T1-PX1-5 & T1-PX2-6 & T1-PX2-7 & T1-PX3-8 & T1-PX3-9 & T1-PX3-10 & T1-PX3-11 & T1-PX3-12 & T1-PX3-13 & T1-PX3-14 & T1-PX3-15 \\
\hline Mineral & $\mathrm{cpx}$ & $\mathrm{cpx}$ & $\mathrm{cpx}$ & $\mathrm{cpx}$ & $\mathrm{cpx}$ & $\mathrm{cpx}$ & $\mathrm{cpx}$ & opx & opx & opx & opx & opx & opx & opx & opx \\
\hline $\mathrm{SiO} 2$ & 52.52 & 52.26 & 52.52 & 52.37 & 52.25 & 52.02 & 51.9 & 50.81 & 50.13 & 50.52 & 50.28 & 50.92 & 50.82 & 51.3 & 50.21 \\
\hline $\mathrm{TiO} 2$ & 0.09 & 0.23 & 0.14 & 0.12 & 0.09 & 0.05 & 0.07 & 0.02 & 0.04 & 0.07 & 0.09 & 0 & 0.11 & 0.11 & 0 \\
\hline $\mathrm{Al} 2 \mathrm{O} 3$ & 0.96 & 0.98 & 1.03 & 0.87 & 0.96 & 1.11 & 1.01 & 0.67 & 0.68 & 0.67 & 0.67 & 0.62 & 0.64 & 0.65 & 0.62 \\
\hline $\mathrm{Cr} 2 \mathrm{O} 3$ & 0.08 & 0.1 & 0.06 & 0.03 & 0.02 & 0.08 & 0.05 & 0.04 & 0.04 & 0.05 & 0.07 & 0.05 & 0.02 & 0.03 & 0.06 \\
\hline $\mathrm{Fe} 2 \mathrm{O} 3$ & 0.85 & 0.55 & 0.76 & 1.18 & 1.07 & 1.01 & 0.91 & 0 & 2.03 & 2.42 & 2.19 & 1 & 0.12 & 0.94 & 0.32 \\
\hline $\mathrm{FeO}$ & 9.77 & 10.57 & 10.21 & 9.74 & 9.49 & 10.25 & 10.2 & 30.49 & 29.24 & 29.2 & 28.08 & 28.93 & 29.16 & 29.23 & 28.81 \\
\hline $\mathrm{MnO}$ & 0.17 & 0.23 & 0.23 & 0.19 & 0.19 & 0.19 & 0.19 & 0.61 & 0.56 & 0.53 & 0.57 & 0.56 & 0.47 & 0.45 & 0.48 \\
\hline $\mathrm{MgO}$ & 12.55 & 12.54 & 12.59 & 12.82 & 12.73 & 12.47 & 12.52 & 16.12 & 16.4 & 16.72 & 16.74 & 16.9 & 16.37 & 17.41 & 16.77 \\
\hline $\mathrm{CaO}$ & 22.52 & 21.95 & 22 & 22.22 & 22.3 & 21.89 & 21.72 & 0.52 & 0.62 & 0.6 & 1.19 & 0.88 & 1.5 & 0.5 & 0.61 \\
\hline $\mathrm{Na} 2 \mathrm{O}$ & 0.37 & 0.31 & 0.39 & 0.32 & 0.33 & 0.33 & 0.34 & 0.01 & 0.03 & 0.01 & 0.04 & 0.03 & 0.02 & 0.01 & 0.01 \\
\hline $\mathrm{K} 2 \mathrm{O}$ & 0 & 0 & 0.02 & 0 & 0.03 & 0.01 & 0.01 & 0 & 0 & 0.03 & 0.01 & 0.01 & 0.01 & 0.01 & 0.01 \\
\hline Total & 99.88 & 99.72 & 99.95 & 99.84 & 99.46 & 99.4 & 98.92 & 99.3 & 99.78 & 100.83 & 99.91 & 99.9 & 99.25 & 100.64 & 97.91 \\
\hline Oxygens & 6 & 6 & 6 & 6 & 6 & 6 & 6 & 6 & 6 & 6 & 6 & 6 & 6 & 6 & 6 \\
\hline $\mathrm{Si}$ & 1.977 & 1.974 & 1.976 & 1.972 & 1.973 & 1.97 & 1.974 & 1.986 & 1.954 & 1.948 & 1.951 & 1.972 & 1.981 & 1.969 & 1.98 \\
\hline $\mathrm{Ti}$ & 0.003 & 0.007 & 0.004 & 0.003 & 0.003 & 0.001 & 0.002 & 0.001 & 0.001 & 0.002 & 0.003 & 0 & 0.003 & 0.003 & 0 \\
\hline $\mathrm{Al}$ & 0.042 & 0.044 & 0.046 & 0.039 & 0.043 & 0.05 & 0.045 & 0.031 & 0.031 & 0.031 & 0.03 & 0.028 & 0.029 & 0.029 & 0.029 \\
\hline $\mathrm{Cr}$ & 0.002 & 0.003 & 0.002 & 0.001 & 0.001 & 0.002 & 0.002 & 0.001 & 0.001 & 0.002 & 0.002 & 0.002 & 0.001 & 0.001 & 0.002 \\
\hline $\mathrm{Fe} 3$ & 0.024 & 0.016 & 0.022 & 0.033 & 0.03 & 0.029 & 0.026 & 0 & 0.06 & 0.07 & 0.064 & 0.029 & 0.004 & 0.027 & 0.01 \\
\hline $\mathrm{Fe} 2$ & 0.307 & 0.334 & 0.321 & 0.307 & 0.3 & 0.325 & 0.325 & 0.997 & 0.953 & 0.942 & 0.911 & 0.937 & 0.951 & 0.938 & 0.95 \\
\hline $\mathrm{Mn}$ & 0.005 & 0.007 & 0.007 & 0.006 & 0.006 & 0.006 & 0.006 & 0.02 & 0.019 & 0.017 & 0.019 & 0.018 & 0.016 & 0.015 & 0.016 \\
\hline $\mathrm{Mg}$ & 0.704 & 0.706 & 0.706 & 0.72 & 0.717 & 0.704 & 0.71 & 0.939 & 0.953 & 0.961 & 0.968 & 0.975 & 0.951 & 0.996 & 0.986 \\
\hline $\mathrm{Ca}$ & 0.908 & 0.888 & 0.887 & 0.896 & 0.902 & 0.888 & 0.885 & 0.022 & 0.026 & 0.025 & 0.049 & 0.037 & 0.062 & 0.02 & 0.026 \\
\hline $\mathrm{Na}$ & 0.027 & 0.023 & 0.028 & 0.023 & 0.024 & 0.024 & 0.025 & 0.001 & 0.002 & 0.001 & 0.003 & 0.002 & 0.002 & 0.001 & 0.001 \\
\hline $\mathrm{K}$ & 0 & 0 & 0.001 & 0 & 0.001 & 0 & 0 & 0 & 0 & 0.002 & 0 & 0.001 & 0.001 & 0.001 & 0 \\
\hline Sum & 4 & 4 & 4 & 4 & 4 & 4 & 4 & 3.997 & 4 & 4 & 4 & 4 & 4 & 4 & 4 \\
\hline $\mathrm{X}(\mathrm{Fe})$ & 0.304 & 0.321 & 0.313 & 0.299 & 0.295 & 0.316 & 0.314 & 0.515 & 0.500 & 0.495 & 0.485 & 0.490 & 0.500 & 0.485 & 0.491 \\
\hline Mg\# & 69.63 & 67.88 & 68.74 & 70.11 & 70.50 & 68.42 & 68.60 & 48.50 & 50.00 & 50.50 & 51.52 & 50.99 & 50.00 & 51.50 & 50.93 \\
\hline
\end{tabular}




\section{Rochas charnockíticas (Amostra NLD-45B)}

PIROXÊNIO

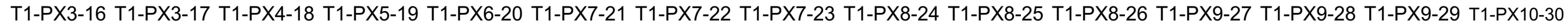

\begin{tabular}{|c|c|c|c|c|c|c|c|c|c|c|c|c|c|c|}
\hline opx & opx & $\mathrm{cpx}$ & $\mathrm{cpx}$ & $\mathrm{cpx}$ & opx & opx & opx & $\mathrm{cpx}$ & $\mathrm{cpx}$ & $\mathrm{cpx}$ & $\mathrm{cpx}$ & $\mathrm{cpx}$ & $\mathrm{cpx}$ & $\mathrm{cpx}$ \\
\hline 1.22 & 50.55 & 52.03 & 52.12 & 52.16 & 51.26 & 50.74 & 50.75 & 52.05 & 51.61 & 60.71 & 49.92 & 52.2 & 49.43 & 51.51 \\
\hline 0.04 & 0.04 & 0.05 & 0.02 & 0.09 & 0 & 0.15 & 0 & 0 & 0.12 & 0.02 & 0.14 & 0.09 & 0.04 & 0.02 \\
\hline 0.64 & 0.57 & 0.98 & 1.09 & 0.88 & 0.67 & 0.76 & 0.7 & 0.91 & 0.99 & 0.66 & 2.56 & 0.76 & 4.9 & 0.98 \\
\hline 0.03 & 0.02 & 0 & 0.12 & 0 & 0.04 & 0.08 & 0.08 & 0.04 & 0.09 & 0.06 & 0.07 & 0.05 & 0.04 & 0.05 \\
\hline 1.27 & 1.53 & 1.48 & 0.58 & 2.12 & 0.61 & 1.44 & 1.57 & 1.16 & 2.64 & 0 & 4.28 & 1.92 & 2.51 & 2.26 \\
\hline 9.81 & 29.34 & 9.77 & 10.44 & 8.42 & 29.19 & 29.18 & 28.75 & 9.07 & 7.95 & 8.04 & 7.76 & 8.07 & 11.6 & 8.59 \\
\hline 0.49 & 0.45 & 0.22 & 0.21 & 0.14 & 0.53 & 0.58 & 0.54 & 0.16 & 0.18 & 0.2 & 0.39 & 0.2 & 0.48 & 0.21 \\
\hline 7.07 & 16.89 & 12.69 & 12.43 & 13.29 & 16.84 & 16.81 & 16.54 & 12.72 & 12.93 & 10.41 & 12.61 & 13.15 & 11.48 & 12.82 \\
\hline 0.44 & 0.41 & 21.84 & 21.82 & 22.43 & 1.15 & 0.8 & 1.31 & 22.45 & 22.84 & 19.1 & 21.7 & 23.05 & 19.76 & 22.47 \\
\hline 0 & 0.01 & 0.36 & 0.34 & 0.31 & 0.02 & 0.01 & 0.05 & 0.34 & 0.3 & 0.17 & 0.3 & 0.27 & 0.27 & 0.25 \\
\hline 0 & 0.01 & 0 & 0.01 & 0.01 & 0 & 0 & 0 & 0.01 & 0 & 0.01 & 0 & 0 & 0.01 & 0 \\
\hline 01.02 & 99.82 & 99.41 & 99.17 & 99.87 & 100.31 & 100.56 & 100.29 & 98.89 & 99.64 & 99.39 & 99.72 & 99.77 & 100.52 & 99.16 \\
\hline 6 & 6 & 6 & 6 & 6 & 6 & 6 & 6 & 6 & 6 & 6 & 6 & 6 & 6 & 6 \\
\hline .965 & 1.964 & 1.969 & 1.978 & 1.959 & 1.976 & 1.957 & 1.962 & 1.975 & 1.947 & 2.198 & 1.888 & 1.962 & 1.864 & 1.954 \\
\hline .001 & 0.001 & 0.001 & 0.001 & 0.003 & 0 & 0.004 & 0 & 0 & 0.003 & 0.001 & 0.004 & 0.003 & 0.001 & 0.001 \\
\hline .029 & 0.026 & 0.044 & 0.049 & 0.039 & 0.03 & 0.035 & 0.032 & 0.041 & 0.044 & 0.028 & 0.114 & 0.034 & 0.218 & 0.044 \\
\hline .001 & 0.001 & 0 & 0.004 & 0 & 0.001 & 0.002 & 0.002 & 0.001 & 0.003 & 0.002 & 0.002 & 0.002 & 0.001 & 0.001 \\
\hline .037 & 0.045 & 0.042 & 0.016 & 0.06 & 0.018 & 0.042 & 0.046 & 0.033 & 0.075 & 0 & 0.122 & 0.054 & 0.071 & 0.065 \\
\hline .957 & 0.953 & 0.309 & 0.331 & 0.265 & 0.941 & 0.941 & 0.93 & 0.288 & 0.251 & 0.244 & 0.245 & 0.254 & 0.366 & 0.273 \\
\hline .016 & 0.015 & 0.007 & 0.007 & 0.005 & 0.017 & 0.019 & 0.018 & 0.005 & 0.006 & 0.006 & 0.013 & 0.006 & 0.015 & 0.007 \\
\hline .976 & 0.978 & 0.715 & 0.703 & 0.744 & 0.968 & 0.966 & 0.953 & 0.719 & 0.727 & 0.562 & 0.711 & 0.737 & 0.645 & 0.724 \\
\hline .018 & 0.017 & 0.886 & 0.887 & 0.903 & 0.047 & 0.033 & 0.054 & 0.913 & 0.923 & 0.741 & 0.879 & 0.929 & 0.798 & 0.913 \\
\hline 0 & 0.001 & 0.027 & 0.025 & 0.022 & 0.001 & 0.001 & 0.004 & 0.025 & 0.022 & 0.012 & 0.022 & 0.02 & 0.02 & 0.019 \\
\hline 0 & 0.001 & 0 & 0 & 0 & 0 & 0 & 0 & 0 & 0 & 0.001 & 0 & 0 & 0 & 0 \\
\hline 4 & 4 & 4 & 4 & 4 & 4 & 4 & 4 & 4 & 4 & 3.793 & 4 & 4 & 4 & 4 \\
\hline .495 & 0.494 & 0.302 & 0.320 & 0.263 & 0.493 & 0.493 & 0.494 & 0.286 & 0.257 & 0.303 & 0.256 & 0.256 & 0.362 & 0.274 \\
\hline 0.49 & 50.65 & 69.82 & 67.99 & 73.74 & 50.71 & 50.66 & 50.61 & 71.40 & 74.34 & 69.73 & 74.37 & 74.37 & 63.80 & 72.62 \\
\hline
\end{tabular}


Rochas charnockíticas (Amostra NLD-45B)

\section{PIROXÊNIO}

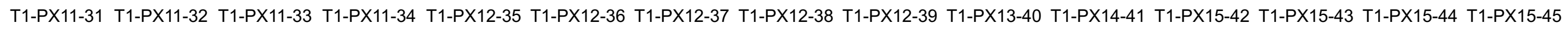

$51.7 \quad 50.65$

0.04

0.94

0.07

2.03

8.88

0.2

12.57

22.32

0.39

0

99.11$$
6
$$

$1.962 \quad 1.911$

0.001

0.042

0.002

0.058

0.282

0.006

0.711

0.908

0.028

$$
0
$$

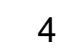

0.284

71.60

99.36$$
6
$$

$$
0.006
$$

0.145

0.001

0.046

0.268

0.007

0.692

0.9

0.025

4

0.279

72.08 cpx

51.79

0.12

0.12
0.95

$$
0.07
$$$$
1.62
$$$$
8.92
$$$$
0.21
$$

12.63

22.62

0.3
0.01

$$
6
$$

1.963

0.003

0.042

0.002

0.046

0.283

0.007

0.713

0.919

0.022

\section{4}

0.284

71.59 cpx

$\begin{array}{lll}51.39 & 51.7 & 51.85\end{array}$

$\begin{array}{ll}0.01 & 0.09\end{array}$

$0.99 \quad 0.78$
0.11

2.59

8.06

0.24

12.55

22.8

0.34
0

99.1

$$
6
$$

\subsection{7}

2.22

8.98

0.17

12.74

22.44

0.28
0

99.46

6

$1.951 \quad 1.958$

$0 \quad 0.003$

$0.044 \quad 0.035$

$0.003 \quad 0.002$

$0.074 \quad 0.063$

$0.256 \quad 0.284$

0.008

0.71

0.928

0.025

0.005

0.719

0.91

0.021

4

0.265

4

0.283

71.68
0.09

0.85
0.05

1.9

9.07

0.21

12.7

22.36

0.31
0.02

0.02

6

1.962

0.003

0.038

0.002

0.054

0.287

0.007

0.716

0.907

0.023

0.001

4

0.286

71.39 cpx

52.07

0.13

0.71

0.02

2.21
8.36

8.36

0.22

12.82

23.08

0.29
0

99.92

$$
6
$$

1.96

0.004

0.032

0.001

0.062

0.263

0.007

0.719

0.931

0.022

4

4
0.268

73.22 cpx

$\mathrm{cpx}$

$\mathrm{cpx}$

$\mathrm{cpx}$

$\mathrm{cpx}$

cpx

cpx

$\mathrm{cpx}$

$\begin{array}{ll}51.31 & 51.82 \\ 0.05 & 0.08\end{array}$

52.38

51.19

51.32

$1.11 \quad 0.88$

$0.04 \quad 0.04$

$0.21 \quad 0.15$

$12.64 \quad 13.43$

22.27

0.29

$$
0
$$

$99.98 \quad 99.93$$$
6
$$

1.937

0.001

0.05

0.001

0.094

0.277

0.007

0.711

0.901

0.021

4

4
0.280

71.96
0.82

0.05

1.44

9.13

0.19

23.16

0

12.96

22.44

0.32
0.02

$$
6
$$

0.07
1.09

0.11

3.87

7.72

0.19

12.79

22.53

0.37

0.37
0

99.8

$$
6
$$

1.944

$$
0.002
$$

0.039

0.001

0.086

0.222

0.005

0.751

$$
0.931
$$

0.019

$$
0
$$

\section{4}

0.228

77.18

6

\subsection{1}

0.002

0.036

0.001

0.041

0.287

0.006

0.727

0.905

0.023

0.001
0.06

0.98
0.06

3.19

7.78

0.19

12.83

22.57

0.35

0.01

$99.92 \quad 99.33$

$$
6
$$




\section{Rochas charnockíticas (Amostra NLD-45B)}

\section{PIROXÊNIO}

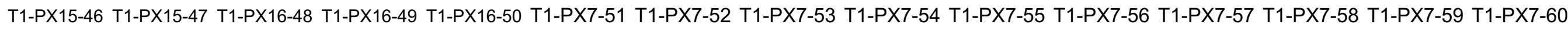

\begin{tabular}{|c|c|c|c|c|c|c|c|c|c|c|c|c|c|c|}
\hline$c p x$ & $\mathrm{cpx}$ & $\mathrm{cpx}$ & $\mathrm{cpx}$ & $\mathrm{cpx}$ & opx & opx & opx & opx & opx & opx & opx & opx & opx & opx \\
\hline 51.9 & 51.26 & 52 & 51.39 & 51.21 & 50.14 & 50 & 50.12 & 49.93 & 50.12 & 50.26 & 50.05 & 49.63 & 49.94 & 50.13 \\
\hline 0.01 & 0.05 & 0.04 & 0.06 & 0.05 & 0 & 0 & 0.01 & 0.01 & 0.06 & 0 & 0.04 & 0.12 & 0.11 & 0.15 \\
\hline 0.83 & 0.92 & 1.04 & 1.1 & 1.13 & 0.69 & 0.62 & 0.54 & 0.72 & 0.72 & 0.71 & 0.72 & 0.8 & 0.78 & 0.77 \\
\hline 0.03 & 0.03 & 0.09 & 0.13 & 0.18 & 0.1 & 0.01 & 0.05 & 0.05 & 0.06 & 0.05 & 0.06 & 0 & 0.05 & 0.05 \\
\hline 2.45 & 3.92 & 0.91 & 2.29 & 2.05 & 2.17 & 2.1 & 2.01 & 1.79 & 1.96 & 1.43 & 1.91 & 2.47 & 1.3 & 1.99 \\
\hline 9.31 & 7.96 & 9.83 & 9.08 & 8.8 & 28.09 & 28.47 & 28.4 & 28.7 & 28.25 & 28.64 & 28.99 & 28.5 & 28.84 & 28.94 \\
\hline 0.22 & 0.26 & 0.21 & 0.25 & 0.25 & 0.53 & 0.57 & 0.49 & 0.66 & 0.56 & 0.55 & 0.56 & 0.54 & 0.53 & 0.55 \\
\hline 12.66 & 12.73 & 12.41 & 12.4 & 12.45 & 16.89 & 16.97 & 16.97 & 16.59 & 16.58 & 16.44 & 16.58 & 16.31 & 16.64 & 16.43 \\
\hline 22.21 & 22.58 & 22.11 & 22.13 & 22.05 & 0.94 & 0.34 & 0.38 & 0.61 & 1.08 & 1.19 & 0.62 & 0.94 & 0.6 & 0.87 \\
\hline 0.33 & 0.33 & 0.37 & 0.37 & 0.38 & 0 & 0.01 & 0.06 & 0 & 0.04 & 0.02 & 0 & 0.03 & 0 & 0.03 \\
\hline 0 & 0 & 0 & 0 & 0 & 0 & 0.01 & 0.01 & 0 & 0.02 & 0 & 0 & 0 & 0 & 0.01 \\
\hline 99.95 & 100.02 & 99.02 & 99.2 & 98.56 & 99.55 & 99.1 & 99.05 & 99.06 & 99.45 & 99.28 & 99.53 & 99.34 & 98.78 & 99.93 \\
\hline 6 & 6 & 6 & 6 & 6 & 6 & 6 & 6 & 6 & 6 & 6 & 6 & 6 & 6 & 6 \\
\hline 1.958 & 1.934 & 1.975 & 1.953 & 1.955 & 1.951 & 1.955 & 1.959 & 1.956 & 1.954 & 1.962 & 1.953 & 1.943 & 1.959 & 1.95 \\
\hline 0 & 0.001 & 0.001 & 0.002 & 0.001 & 0 & 0 & 0 & 0 & 0.002 & 0 & 0.001 & 0.004 & 0.003 & 0.005 \\
\hline 0.037 & 0.041 & 0.046 & 0.049 & 0.051 & 0.032 & 0.029 & 0.025 & 0.033 & 0.033 & 0.033 & 0.033 & 0.037 & 0.036 & 0.035 \\
\hline 0.001 & 0.001 & 0.003 & 0.004 & 0.005 & 0.003 & 0 & 0.001 & 0.002 & 0.002 & 0.002 & 0.002 & 0 & 0.001 & 0.002 \\
\hline 0.07 & 0.111 & 0.026 & 0.065 & 0.059 & 0.063 & 0.062 & 0.059 & 0.053 & 0.058 & 0.042 & 0.056 & 0.073 & 0.038 & 0.058 \\
\hline 0.294 & 0.251 & 0.312 & 0.288 & 0.281 & 0.914 & 0.931 & 0.928 & 0.94 & 0.921 & 0.935 & 0.946 & 0.933 & 0.946 & 0.941 \\
\hline 0.007 & 0.008 & 0.007 & 0.008 & 0.008 & 0.017 & 0.019 & 0.016 & 0.022 & 0.018 & 0.018 & 0.019 & 0.018 & 0.018 & 0.018 \\
\hline 0.712 & 0.716 & 0.703 & 0.702 & 0.708 & 0.979 & 0.989 & 0.989 & 0.968 & 0.963 & 0.957 & 0.964 & 0.952 & 0.973 & 0.952 \\
\hline 0.898 & 0.913 & 0.9 & 0.901 & 0.902 & 0.039 & 0.014 & 0.016 & 0.026 & 0.045 & 0.05 & 0.026 & 0.04 & 0.025 & 0.036 \\
\hline 0.024 & 0.024 & 0.027 & 0.027 & 0.028 & 0 & 0.001 & 0.004 & 0 & 0.003 & 0.001 & 0 & 0.002 & 0 & 0.003 \\
\hline 0 & 0 & 0 & 0 & 0 & 0 & 0 & 0.001 & 0 & 0.001 & 0 & 0 & 0 & 0 & 0.001 \\
\hline 4 & 4 & 4 & 4 & 4 & 4 & 4 & 4 & 4 & 4 & 4 & 4 & 4 & 4 & 4 \\
\hline 0.292 & 0.260 & 0.307 & 0.291 & 0.284 & 0.483 & 0.485 & 0.484 & 0.493 & 0.489 & 0.494 & 0.495 & 0.495 & 0.493 & 0.497 \\
\hline 70.78 & 74.04 & 69.26 & 70.91 & 71.59 & 51.72 & 51.51 & 51.59 & 50.73 & 51.11 & 50.58 & 50.47 & 50.50 & 50.70 & 50.29 \\
\hline
\end{tabular}




\section{Rochas charnockíticas (Amostra NLD-45B)}

PIROXÊNIO

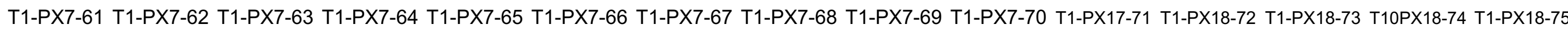

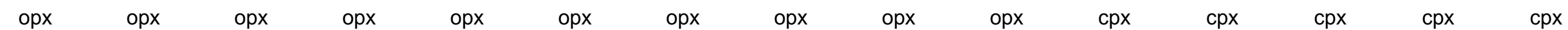

\begin{tabular}{|c|c|c|c|c|c|c|c|c|c|c|c|c|c|c|}
\hline 49.9 & 50.06 & 50.36 & 49.88 & 49.61 & 50.46 & 50.8 & 50.74 & 50.54 & 50.01 & 51.15 & 51.45 & 51.15 & 51.3 & 51.86 \\
\hline 0.04 & 0.04 & 0 & 0 & 0.04 & 0.03 & 0.14 & 0 & 0.01 & 0.07 & 0.1 & 0.14 & 0.12 & 0.16 & 0.12 \\
\hline 0.66 & 0.7 & 0.71 & 0.74 & 0.66 & 0.71 & 0.66 & 0.59 & 0.65 & 0.61 & 0.92 & 1.09 & 0.95 & 1.11 & 1.11 \\
\hline 0.05 & 0.01 & 0.1 & 0.01 & 0.09 & 0.05 & 0.04 & 0.02 & 0.07 & 0.02 & 0.04 & 0.05 & 0.06 & 0.02 & 0.06 \\
\hline 2.02 & 0.74 & 1.64 & 3.06 & 3.42 & 2.45 & 1.6 & 1.61 & 1.66 & 3.02 & 2.74 & 2.76 & 2.9 & 2.11 & 1.77 \\
\hline 28.68 & 29.16 & 28.3 & 28.56 & 28.28 & 27.42 & 28.33 & 28.63 & 27.39 & 27.74 & 8.9 & 9.01 & 8.71 & 8.74 & 8.93 \\
\hline 0.56 & 0.58 & 0.56 & 0.57 & 0.6 & 0.53 & 0.46 & 0.47 & 0.49 & 0.48 & 0.21 & 0.24 & 0.27 & 0.18 & 0.16 \\
\hline 16.68 & 16.56 & 16.47 & 16.62 & 16.68 & 16.91 & 17.02 & 17.31 & 17.44 & 17.31 & 12.37 & 12.5 & 12.62 & 12.37 & 12.49 \\
\hline 0.55 & 0.5 & 1.37 & 0.59 & 0.55 & 1.62 & 1.31 & 0.44 & 1.14 & 0.46 & 22.26 & 22.14 & 22.27 & 22.35 & 22.64 \\
\hline 0 & 0 & 0.05 & 0.03 & 0 & 0.04 & 0.01 & 0.01 & 0.01 & 0.03 & 0.34 & 0.38 & 0.27 & 0.39 & 0.37 \\
\hline 0.01 & 0 & 0 & 0 & 0.01 & 0 & 0 & 0.03 & 0 & 0.02 & 0 & 0 & 0 & 0.03 & 0.01 \\
\hline 99.16 & 98.36 & 99.55 & 100.07 & 99.96 & 100.22 & 100.37 & 99.86 & 99.38 & 99.78 & 99.03 & 99.76 & 99.31 & 98.75 & 99.5 \\
\hline
\end{tabular}

\begin{tabular}{|c|c|c|c|c|c|c|c|c|c|c|c|c|c|c|}
\hline 6 & 6 & 6 & 6 & 6 & 6 & 6 & 6 & 6 & 6 & 6 & 6 & 6 & 6 & 6 \\
\hline 1.953 & 1.971 & 1.96 & 1.939 & 1.932 & 1.948 & 1.958 & 1.964 & 1.96 & 1.941 & 1.949 & 1.945 & 1.943 & 1.955 & 1.96 \\
\hline 0.001 & 0.001 & 0 & 0 & 0.001 & 0.001 & 0.004 & 0 & 0 & 0.002 & 0.003 & 0.004 & 0.003 & 0.005 & 0.003 \\
\hline 0.03 & 0.032 & 0.032 & 0.034 & 0.03 & 0.032 & 0.03 & 0.027 & 0.03 & 0.028 & 0.041 & 0.049 & 0.043 & 0.05 & 0.049 \\
\hline 0.002 & 0 & 0.003 & 0 & 0.003 & 0.001 & 0.001 & 0.001 & 0.002 & 0.001 & 0.001 & 0.001 & 0.002 & 0.001 & 0.002 \\
\hline 0.059 & 0.022 & 0.048 & 0.09 & 0.1 & 0.071 & 0.046 & 0.047 & 0.048 & 0.088 & 0.078 & 0.079 & 0.083 & 0.061 & 0.05 \\
\hline 0.939 & 0.96 & 0.921 & 0.929 & 0.921 & 0.886 & 0.913 & 0.927 & 0.888 & 0.9 & 0.284 & 0.285 & 0.277 & 0.278 & 0.282 \\
\hline 0.019 & 0.019 & 0.018 & 0.019 & 0.02 & 0.017 & 0.015 & 0.015 & 0.016 & 0.016 & 0.007 & 0.008 & 0.009 & 0.006 & 0.005 \\
\hline 0.973 & 0.972 & 0.955 & 0.963 & 0.968 & 0.973 & 0.977 & 0.999 & 1.008 & 1.001 & 0.703 & 0.705 & 0.714 & 0.702 & 0.704 \\
\hline 0.023 & 0.021 & 0.057 & 0.025 & 0.023 & 0.067 & 0.054 & 0.018 & 0.047 & 0.019 & 0.909 & 0.897 & 0.906 & 0.913 & 0.917 \\
\hline 0 & 0 & 0.004 & 0.002 & 0 & 0.003 & 0.001 & 0.001 & 0 & 0.002 & 0.025 & 0.028 & 0.02 & 0.029 & 0.027 \\
\hline 0.001 & 0 & 0 & 0 & 0.001 & 0 & 0 & 0.001 & 0 & 0.001 & 0 & 0 & 0 & 0.002 & 0.001 \\
\hline 4 & 4 & 4 & 4 & 4 & 4 & 4 & 4 & 4 & 4 & 4 & 4 & 4 & 4 & 4 \\
\hline 0.491 & 0.497 & 0.491 & 0.491 & 0.488 & 0.477 & 0.483 & 0.481 & 0.468 & 0.473 & 0.288 & 0.288 & 0.280 & 0.284 & 0.286 \\
\hline 50.89 & 50.31 & 50.91 & 50.90 & 51.24 & 52.34 & 51.69 & 51.87 & 53.16 & 52.66 & 71.23 & 71.21 & 72.05 & 71.63 & 71.40 \\
\hline
\end{tabular}


Sample T1-PX1-1 T1-PX1-2 T1-PX1-3 T1-PX1-4 T1-PX1-5 T1-PX1-6 T1-PX1-7 T1-PX1-8 T1-PX1-9 T1-PX1-10 Mineral

$$
\text { opx }
$$$$
\text { opx }
$$$$
\text { opx }
$$$$
\text { opx }
$$$$
\text { opx }
$$$$
\text { opx }
$$$$
\text { opx }
$$$$
\text { opx }
$$

$$
\text { opx }
$$

opx

52.12
0.04$$
0.61
$$$$
0.06
$$$$
0
$$$$
0.03
$$$$
0.04
$$$$
0.03
$$$$
\begin{gathered}
0 \\
28.85
\end{gathered}
$$$$
0.41
$$$$
17.44
$$$$
\begin{gathered}
17.44 \\
0.7 \\
0.03 \\
0
\end{gathered}
$$$$
0
$$

99.76

100.75

6

Oxygens

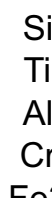

$\mathrm{Cr}$

$\mathrm{Fe} 2$

$\mathrm{M}$

$\mathrm{Mg}$

C

$\mathrm{Na}$

Sum

X(Fe)

$\mathrm{Mg \#}$

6

1.984
0.004

0.027

0.001

0

0.011

1.019

0.021

0.002

0

3.999

0.477

52.28

1.992
0

6

$$
0.027
$$

0.001

0

0.914

0.013

1.004

0.043

0.001

0
3.995

0.477

52.35

0

28.79

0.44
17.59

0.79

0.04
0

51.07
0.07

52.16

0.07
0.7

0.69

0.07

1.04

28.74
0.37

17.52

0.94

28.44

0.47

17.31

0.02

0.03

0.05

0
28.77

0.39

17.79

1.01

0.04

0.01

$\begin{array}{cc}52.3 & 52.34 \\ 0 & 0.09\end{array}$

$$
0.62
$$

0.01

0.68

0.04

0
29.14

0.46

28.4

0.43

17.68

0.4
0

0.03

17.73
0.54

0

100.93

100.41

100.14

100.98

100.63

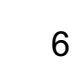

6

1.99

1.997

6

6

6

1.993

1.968

1.984

$\begin{array}{ccc}1.995 & 1.998 & 1.999 \\ 0 & 0.003 & 0 \\ 0.028 & 0.03 & 0.023 \\ 0 & 0.001 & 0.001 \\ 0 & 0 & 0 \\ 0.93 & 0.907 & 0.909 \\ 0.015 & 0.014 & 0.012 \\ 1.005 & 1.009 & 1.025 \\ 0.017 & 0.022 & 0.019 \\ 0 & 0 & 0.001 \\ 0.001 & 0 & 0.001 \\ & & \\ 3.991 & 3.984 & 3.99 \\ 0.481 & 0.473 & 0.470 \\ 51.94 & 52.66 & 53.00\end{array}$

6

0.001

0.001

0.001

0.002

0.002

0.031

0.002

0.001

0.001

0.002

0.002

0.03

0
0.915
0.012

0.929

0.013

0.915

0.014

0.919

0.012

0.916

0.015

1.008

0.041

0.002

0.032

0.038

0.039

0.001

0.001

0

0

4

0.480

4
0.476

0.476

52.42

52.01
0
0.51
0.03
0
28.28
0.36
17.89
0.47
0.01
0.02

99.58

6

6

$\begin{array}{cccc}6 & 6 & 6 & 6 \\ 1.941 & 1.945 & 1.938 & 1.961 \\ 0.001 & 0.001 & 0.001 & 0.001 \\ 0.046 & 0.054 & 0.047 & 0.049 \\ 0.002 & 0.002 & 0.003 & 0.002 \\ 0.094 & 0.079 & 0.097 & 0.049 \\ 0.261 & 0.276 & 0.261 & 0.288 \\ 0.006 & 0.007 & 0.007 & 0.005 \\ 0.708 & 0.707 & 0.716 & 0.716 \\ 0.915 & 0.901 & 0.906 & 0.906 \\ 0.026 & 0.027 & 0.023 & 0.023 \\ 0 & 0 & 0.001 & 0 \\ & & & \\ 4 & 4 & 4 & 4 \\ 0.269 & 0.281 & 0.267 & 0.287 \\ 73.07 & 71.92 & 73.29 & 71.31\end{array}$


Rochas charnockíticas (Amostra NLD-45D)

\section{PIROXÊNIO}

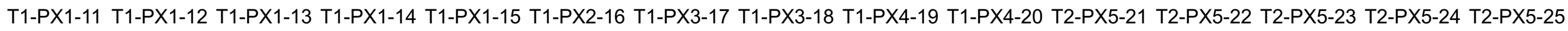

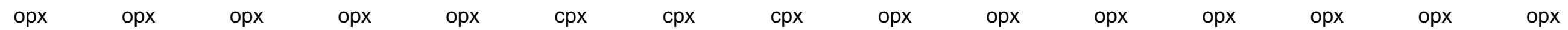

\begin{tabular}{|c|c|c|c|c|c|c|c|c|c|c|c|c|c|c|}
\hline 51.55 & 52.47 & 52.01 & 52 & 52.3 & 52.63 & 53.02 & 53.56 & 51.83 & 52.06 & 52.07 & 52.12 & 50.97 & 51.48 & 51.69 \\
\hline 0.11 & 0 & 0 & 0 & 0 & 0.18 & 0 & 0.12 & 0.13 & 0.17 & 0 & 0.09 & 0.42 & 0.09 & 0.09 \\
\hline 0.57 & 0.61 & 0.66 & 0.65 & 0.62 & 0.83 & 0.82 & 0.98 & 0.57 & 0.55 & 0.61 & 0.61 & 0.67 & 0.64 & 0.69 \\
\hline 0.02 & 0 & 0.02 & 0.06 & 0.02 & 0.09 & 0.03 & 0.02 & 0.03 & 0.04 & 0.02 & 0.03 & 0.02 & 0.08 & 0.06 \\
\hline 1.5 & 0 & 0 & 0 & 0.31 & 1.67 & 0 & 0 & 0.4 & 0 & 0.02 & 0.08 & 1.15 & 0.02 & 0.15 \\
\hline 29 & 29.34 & 28.68 & 29.3 & 29.28 & 17.08 & 9.64 & 9.33 & 29.86 & 29.94 & 29.76 & 30.27 & 28.64 & 29.03 & 30.05 \\
\hline 0.43 & 0.45 & 0.38 & 0.39 & 0.33 & 0.26 & 0.12 & 0.14 & 0.43 & 0.46 & 0.52 & 0.57 & 0.53 & 0.52 & 0.51 \\
\hline 17.7 & 17.7 & 17.76 & 17.65 & 17.72 & 15.57 & 12.99 & 13.22 & 17.4 & 17.35 & 17.53 & 17.38 & 16.9 & 17.07 & 16.92 \\
\hline 0.46 & 0.53 & 1.04 & 0.53 & 0.94 & 13.27 & 22.49 & 22.86 & 0.57 & 0.47 & 0.53 & 0.38 & 1.42 & 1.16 & 0.73 \\
\hline 0.02 & 0 & 0.01 & 0 & 0.03 & 0.21 & 0.32 & 0.32 & 0.01 & 0.01 & 0.01 & 0.02 & 0.01 & 0.03 & 0.04 \\
\hline 0.02 & 0.01 & 0.02 & 0.02 & 0.01 & 0 & 0 & 0.01 & 0 & 0.01 & 0 & 0 & 0.06 & 0 & 0.03 \\
\hline 101.4 & 101.1 & 100.59 & 100.59 & 101.54 & 101.81 & 99.44 & 100.57 & 101.23 & 101.06 & 101.07 & 101.54 & 100.76 & 100.13 & 100.94 \\
\hline 6 & 6 & 6 & 6 & 6 & 6 & 6 & 6 & 6 & 6 & 6 & 6 & 6 & 6 & 6 \\
\hline 1.963 & 1.994 & 1.986 & 1.988 & 1.983 & 1.96 & 1.995 & 1.99 & 1.978 & 1.987 & 1.986 & 1.983 & 1.958 & 1.983 & 1.981 \\
\hline 0.003 & 0 & 0 & 0 & 0 & 0.005 & 0 & 0.003 & 0.004 & 0.005 & 0 & 0.002 & 0.012 & 0.003 & 0.003 \\
\hline 0.026 & 0.027 & 0.03 & 0.029 & 0.028 & 0.036 & 0.037 & 0.043 & 0.026 & 0.025 & 0.028 & 0.027 & 0.03 & 0.029 & 0.031 \\
\hline 0.001 & 0 & 0.001 & 0.002 & 0 & 0.003 & 0.001 & 0.001 & 0.001 & 0.001 & 0 & 0.001 & 0.001 & 0.002 & 0.002 \\
\hline 0.043 & 0 & 0 & 0 & 0.009 & 0.047 & 0 & 0 & 0.011 & 0 & 0.001 & 0.002 & 0.033 & 0.001 & 0.004 \\
\hline 0.924 & 0.932 & 0.916 & 0.937 & 0.928 & 0.532 & 0.303 & 0.29 & 0.953 & 0.956 & 0.949 & 0.963 & 0.92 & 0.935 & 0.963 \\
\hline 0.014 & 0.014 & 0.012 & 0.013 & 0.011 & 0.008 & 0.004 & 0.004 & 0.014 & 0.015 & 0.017 & 0.018 & 0.017 & 0.017 & 0.017 \\
\hline 1.005 & 1.002 & 1.011 & 1.006 & 1.001 & 0.864 & 0.728 & 0.732 & 0.989 & 0.987 & 0.997 & 0.986 & 0.968 & 0.98 & 0.966 \\
\hline 0.019 & 0.022 & 0.043 & 0.022 & 0.038 & 0.53 & 0.907 & 0.91 & 0.023 & 0.019 & 0.022 & 0.016 & 0.058 & 0.048 & 0.03 \\
\hline 0.002 & 0 & 0.001 & 0 & 0.002 & 0.015 & 0.023 & 0.023 & 0.001 & 0 & 0.001 & 0.001 & 0.001 & 0.002 & 0.003 \\
\hline 0.001 & 0.001 & 0.001 & 0.001 & 0 & 0 & 0 & 0 & 0 & 0 & 0 & 0 & 0.003 & 0 & 0.001 \\
\hline 4 & 3.993 & 4 & 3.997 & 4 & 4 & 3.998 & 3.997 & 4 & 3.995 & 4 & 4 & 4 & 4 & 4 \\
\hline 0.479 & 0.482 & 0.475 & 0.482 & 0.481 & 0.381 & 0.294 & 0.284 & 0.491 & 0.492 & 0.488 & 0.494 & 0.487 & 0.488 & 0.499 \\
\hline 52.10 & 51.81 & 52.46 & 51.78 & 51.89 & 61.89 & 70.61 & 71.62 & 50.93 & 50.80 & 51.23 & 50.59 & 51.27 & 51.17 & 50.08 \\
\hline
\end{tabular}


Rochas charnockíticas (Amostra NLD-45D)

PIROXÊNIO

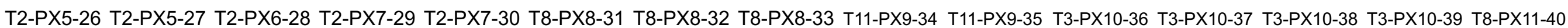

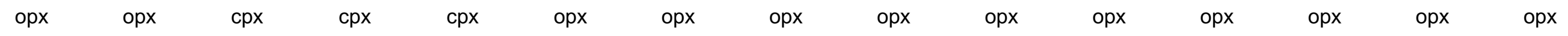

\begin{tabular}{|c|c|c|c|c|c|c|c|c|c|c|c|c|c|c|}
\hline 52.04 & 52.18 & 47.94 & 53.76 & 53.6 & 51.83 & 52.24 & 51.85 & 52.38 & 52.34 & 52.42 & 52.39 & 52.55 & 51.75 & 51.92 \\
\hline 0 & 0.11 & 1.03 & 0.05 & 0.02 & 0.04 & 0.09 & 0 & 0.04 & 0.09 & 0.04 & 0.09 & 0 & 0.15 & 0 \\
\hline 0.63 & 0.67 & 10.33 & 0.88 & 1.04 & 0.64 & 0.63 & 0.63 & 0.64 & 0.64 & 0.57 & 0.63 & 0.7 & 0.63 & 0.59 \\
\hline 0.08 & 0 & 0.12 & 0.06 & 0.08 & 0.04 & 0 & 0.05 & 0 & 0.02 & 0.06 & 0.03 & 0.05 & 0.06 & 0.02 \\
\hline 0.12 & 0.5 & 0 & 0 & 0 & 0.45 & 0.28 & 0.02 & 0 & 0.31 & 0 & 0 & 0 & 0 & 0.36 \\
\hline 29.68 & 29.67 & 14.55 & 9.78 & 10.5 & 28.69 & 29.11 & 28.59 & 29.23 & 28.43 & 29.44 & 29.58 & 30.29 & 28.02 & 30.08 \\
\hline 0.5 & 0.52 & 0.1 & 0.09 & 0.23 & 0.38 & 0.42 & 0.37 & 0.32 & 0.28 & 0.5 & 0.52 & 0.54 & 0.43 & 0.46 \\
\hline 16.99 & 17.59 & 11.07 & 13.47 & 12.66 & 18.07 & 18.12 & 18.12 & 18.2 & 18.65 & 17.21 & 17.03 & 17.32 & 16.95 & 17.29 \\
\hline 1.22 & 0.6 & 11.09 & 22.46 & 22.53 & 0.55 & 0.52 & 0.55 & 0.41 & 0.48 & 0.52 & 0.82 & 0.52 & 0.83 & 0.47 \\
\hline 0.05 & 0.01 & 0.98 & 0.24 & 0.34 & 0.01 & 0 & 0 & 0 & 0.01 & 0.01 & 0 & 0.02 & 0 & 0.02 \\
\hline 0 & 0.04 & 1.25 & 0 & 0 & 0 & 0.01 & 0 & 0 & 0.03 & 0 & 0 & 0.01 & 0.01 & 0 \\
\hline 101.3 & 101.89 & 98.45 & 100.8 & 101 & 100.71 & 101.42 & 100.2 & 101.22 & 101.26 & 100.77 & 101.09 & 101.99 & 98.85 & 101.23 \\
\hline 6 & 6 & 6 & 6 & 6 & 6 & 6 & 6 & 6 & 6 & 6 & 6 & 6 & 6 & 6 \\
\hline 1.984 & 1.976 & 1.818 & 1.993 & 1.992 & 1.978 & 1.98 & 1.985 & 1.986 & 1.98 & 2 & 1.996 & 1.988 & 2.005 & 1.982 \\
\hline 0 & 0.003 & 0.029 & 0.001 & 0.001 & 0.001 & 0.003 & 0 & 0.001 & 0.003 & 0.001 & 0.003 & 0 & 0.005 & 0 \\
\hline 0.029 & 0.03 & 0.462 & 0.039 & 0.046 & 0.029 & 0.028 & 0.029 & 0.028 & 0.028 & 0.026 & 0.028 & 0.031 & 0.029 & 0.027 \\
\hline 0.002 & 0 & 0.003 & 0.002 & 0.002 & 0.001 & 0 & 0.002 & 0 & 0.001 & 0.002 & 0.001 & 0.002 & 0.002 & 0.001 \\
\hline 0.004 & 0.014 & 0 & 0 & 0 & 0.013 & 0.008 & 0 & 0 & 0.009 & 0 & 0 & 0 & 0 & 0.01 \\
\hline 0.946 & 0.94 & 0.462 & 0.303 & 0.326 & 0.916 & 0.923 & 0.916 & 0.927 & 0.899 & 0.94 & 0.942 & 0.958 & 0.908 & 0.96 \\
\hline 0.016 & 0.017 & 0.003 & 0.003 & 0.007 & 0.012 & 0.014 & 0.012 & 0.01 & 0.009 & 0.016 & 0.017 & 0.017 & 0.014 & 0.015 \\
\hline 0.965 & 0.993 & 0.626 & 0.744 & 0.701 & 1.028 & 1.024 & 1.034 & 1.028 & 1.051 & 0.979 & 0.967 & 0.977 & 0.979 & 0.984 \\
\hline 0.05 & 0.024 & 0.451 & 0.892 & 0.897 & 0.023 & 0.021 & 0.022 & 0.017 & 0.019 & 0.021 & 0.034 & 0.021 & 0.035 & 0.019 \\
\hline 0.003 & 0.001 & 0.072 & 0.017 & 0.024 & 0 & 0 & 0 & 0 & 0 & 0.001 & 0 & 0.001 & 0 & 0.002 \\
\hline 0 & 0.002 & 0.061 & 0 & 0 & 0 & 0 & 0 & 0 & 0.001 & 0 & 0 & 0 & 0.001 & 0 \\
\hline 4 & 4 & 3.986 & 3.994 & 3.996 & 4 & 4 & 4 & 3.998 & 4 & 3.985 & 3.987 & 3.996 & 3.976 & 4 \\
\hline 0.495 & 0.486 & 0.425 & 0.289 & 0.317 & 0.471 & 0.474 & 0.470 & 0.474 & 0.461 & 0.490 & 0.493 & 0.495 & 0.481 & 0.494 \\
\hline 50.50 & 51.37 & 57.54 & 71.06 & 68.26 & 52.88 & 52.59 & 53.03 & 52.58 & 53.90 & 51.02 & 50.65 & 50.49 & 51.88 & 50.62 \\
\hline
\end{tabular}




\section{Rochas charnockíticas (Amostra NLD-45D)}

\section{PIROXÊNIO}

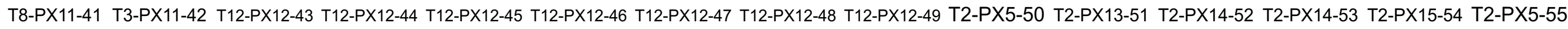

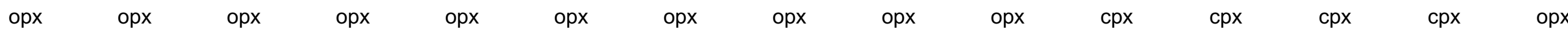

\begin{tabular}{|c|c|c|c|c|c|c|c|c|c|c|c|c|c|c|}
\hline 52.16 & 51.61 & 51.46 & 52.21 & 51.83 & 50.3 & 52.11 & 51.92 & 51.68 & 50.58 & 51.86 & 51.59 & 51.63 & 52.17 & 50.64 \\
\hline 0.13 & 0.04 & 0.17 & 0 & 0 & 1.76 & 0.02 & 0 & 0.09 & 0 & 0.14 & 0.06 & 0.1 & 0.01 & 0 \\
\hline 0.65 & 0.6 & 0.51 & 0.64 & 0.68 & 0.64 & 0.62 & 0.6 & 0.64 & 0.6 & 0.98 & 1.01 & 0.8 & 0.95 & 0.65 \\
\hline 0.05 & 0.01 & 0.02 & 0.04 & 0.01 & 0.04 & 0.04 & 0.04 & 0.01 & 0.02 & 0.04 & 0.06 & 0.02 & 0.01 & 0.02 \\
\hline 0 & 1.38 & 0 & 0 & 0 & 0.41 & 0 & 0 & 0 & 1.79 & 2.4 & 2.47 & 2.94 & 2.73 & 2.49 \\
\hline 29.33 & 29.35 & 29.67 & 30.1 & 30.36 & 30.57 & 30.46 & 29.88 & 29.77 & 28.69 & 9.1 & 10.39 & 7.72 & 7.17 & 28.15 \\
\hline 0.51 & 0.51 & 0.55 & 0.65 & 0.67 & 0.59 & 0.56 & 0.57 & 0.58 & 0.54 & 0.24 & 0.24 & 0.2 & 0.23 & 0.51 \\
\hline 17.18 & 17.31 & 16.56 & 16.68 & 16.63 & 16.11 & 16.66 & 16.97 & 16.75 & 17.18 & 12.83 & 13.89 & 13.22 & 13.41 & 17.49 \\
\hline 0.84 & 0.65 & 0.43 & 0.52 & 0.69 & 1.23 & 0.64 & 0.86 & 0.61 & 0.47 & 22.17 & 19.54 & 22.49 & 23 & 0.48 \\
\hline 0 & 0.03 & 0 & 0 & 0 & 0.04 & 0 & 0.03 & 0.01 & 0.01 & 0.33 & 0.28 & 0.32 & 0.35 & 0.02 \\
\hline 0.02 & 0.02 & 0 & 0 & 0 & 0.02 & 0 & 0 & 0 & 0 & 0 & 0.02 & 0.01 & 0 & 0 \\
\hline 100.87 & 101.51 & 99.35 & 100.86 & 100.86 & 101.72 & 101.11 & 100.87 & 100.13 & 99.87 & 100.09 & 99.55 & 99.47 & 100.04 & 100.46 \\
\hline 6 & 6 & 6 & 6 & 6 & 6 & 6 & 6 & 6 & 6 & 6 & 6 & 6 & 6 & 6 \\
\hline 1.991 & 1.967 & 1.998 & 1.998 & 1.989 & 1.93 & 1.993 & 1.988 & 1.992 & 1.96 & 1.952 & 1.95 & 1.949 & 1.953 & 1.95 \\
\hline 0.004 & 0.001 & 0.005 & 0 & 0 & 0.051 & 0.001 & 0 & 0.003 & 0 & 0.004 & 0.002 & 0.003 & 0 & 0 \\
\hline 0.029 & 0.027 & 0.023 & 0.029 & 0.031 & 0.029 & 0.028 & 0.027 & 0.029 & 0.027 & 0.043 & 0.045 & 0.036 & 0.042 & 0.029 \\
\hline 0.002 & 0 & 0 & 0.001 & 0 & 0.001 & 0.001 & 0.001 & 0 & 0.001 & 0.001 & 0.002 & 0.001 & 0 & 0.001 \\
\hline 0 & 0.04 & 0 & 0 & 0 & 0.012 & 0 & 0 & 0 & 0.052 & 0.068 & 0.07 & 0.084 & 0.077 & 0.072 \\
\hline 0.936 & 0.936 & 0.964 & 0.964 & 0.974 & 0.981 & 0.975 & 0.957 & 0.96 & 0.93 & 0.287 & 0.328 & 0.244 & 0.224 & 0.906 \\
\hline 0.016 & 0.017 & 0.018 & 0.021 & 0.022 & 0.019 & 0.018 & 0.018 & 0.019 & 0.018 & 0.008 & 0.008 & 0.006 & 0.007 & 0.017 \\
\hline 0.977 & 0.983 & 0.958 & 0.952 & 0.951 & 0.922 & 0.95 & 0.969 & 0.962 & 0.992 & 0.719 & 0.783 & 0.744 & 0.748 & 1.004 \\
\hline 0.034 & 0.027 & 0.018 & 0.021 & 0.028 & 0.051 & 0.026 & 0.035 & 0.025 & 0.019 & 0.894 & 0.791 & 0.91 & 0.923 & 0.02 \\
\hline 0 & 0.002 & 0 & 0 & 0 & 0.003 & 0 & 0.002 & 0.001 & 0 & 0.024 & 0.02 & 0.023 & 0.025 & 0.002 \\
\hline 0.001 & 0.001 & 0 & 0 & 0 & 0.001 & 0 & 0 & 0 & 0 & 0 & 0.001 & 0.001 & 0 & 0 \\
\hline 3.991 & 4 & 3.985 & 3.986 & 3.995 & 4 & 3.992 & 3.998 & 3.991 & 4 & 4 & 4 & 4 & 4 & 4 \\
\hline 0.489 & 0.488 & 0.502 & 0.503 & 0.506 & 0.516 & 0.506 & 0.497 & 0.499 & 0.484 & 0.285 & 0.295 & 0.247 & 0.230 & 0.474 \\
\hline 51.07 & 51.22 & 49.84 & 49.69 & 49.40 & 48.45 & 49.35 & 50.31 & 50.05 & 51.61 & 71.47 & 70.48 & 75.30 & 76.95 & 52.57 \\
\hline
\end{tabular}


Rochas charnockíticas (Amostra NLD-45D)

PIROXÊNIO

T2-PX5-56 T2-PX5-57 T2-PX5-58 T2-PX5-59 T2-PX5-60 T2-PX5-61 T2-PX5-62 T2-PX5-63 T2-PX5-64

\begin{tabular}{|c|c|c|c|c|c|c|c|c|}
\hline opx & opx & opx & opx & opx & opx & opx & opx & opx \\
\hline 50.47 & 49.84 & 50.36 & 50.17 & 50.95 & 50.26 & 50.64 & 50.95 & 50.93 \\
\hline 0 & 0 & 0.07 & 0.11 & 0.07 & 0.45 & 0.07 & 0.08 & 0.1 \\
\hline 0.64 & 0.65 & 0.64 & 0.67 & 0.7 & 0.78 & 0.67 & 0.68 & 0.66 \\
\hline 0.03 & 0.04 & 0.04 & 0.05 & 0.09 & 0.08 & 0.03 & 0.04 & 0.04 \\
\hline 3.49 & 4.51 & 2.97 & 2.85 & 0.77 & 1.64 & 2.69 & 1.71 & 1.35 \\
\hline 27.42 & 26.39 & 27.32 & 27.25 & 28.84 & 27.49 & 28.4 & 29.01 & 29.02 \\
\hline 0.56 & 0.56 & 0.55 & 0.63 & 0.55 & 0.57 & 0.61 & 0.55 & 0.55 \\
\hline 17.3 & 17.07 & 16.99 & 17.35 & 17.1 & 17.36 & 17.28 & 17.3 & 17.21 \\
\hline 1.16 & 1.54 & 1.47 & 0.91 & 0.86 & 1.1 & 0.37 & 0.43 & 0.49 \\
\hline 0 & 0.05 & 0.05 & 0.03 & 0 & 0.02 & 0.06 & 0.01 & 0.02 \\
\hline 0.01 & 0 & 0 & 0 & 0 & 0.01 & 0.01 & 0 & 0 \\
\hline 101.08 & 100.64 & 100.45 & 100.01 & 99.93 & 99.74 & 100.84 & 100.76 & 100.38 \\
\hline 6 & 6 & 6 & 6 & 6 & 6 & 6 & 6 & 6 \\
\hline 1.935 & 1.921 & 1.942 & 1.94 & 1.97 & 1.945 & 1.946 & 1.957 & 1.963 \\
\hline 0 & 0 & 0.002 & 0.003 & 0.002 & 0.013 & 0.002 & 0.002 & 0.003 \\
\hline 0.029 & 0.029 & 0.029 & 0.031 & 0.032 & 0.035 & 0.03 & 0.031 & 0.03 \\
\hline 0.001 & 0.001 & 0.001 & 0.002 & 0.003 & 0.002 & 0.001 & 0.001 & 0.001 \\
\hline 0.101 & 0.131 & 0.086 & 0.083 & 0.022 & 0.048 & 0.078 & 0.049 & 0.039 \\
\hline 0.879 & 0.851 & 0.881 & 0.881 & 0.932 & 0.89 & 0.913 & 0.932 & 0.935 \\
\hline 0.018 & 0.018 & 0.018 & 0.021 & 0.018 & 0.019 & 0.02 & 0.018 & 0.018 \\
\hline 0.989 & 0.981 & 0.976 & 1 & 0.985 & 1.001 & 0.99 & 0.991 & 0.989 \\
\hline 0.047 & 0.064 & 0.061 & 0.038 & 0.036 & 0.046 & 0.015 & 0.018 & 0.02 \\
\hline 0 & 0.004 & 0.004 & 0.002 & 0 & 0.001 & 0.004 & 0.001 & 0.002 \\
\hline 0.001 & 0 & 0 & 0 & 0 & 0 & 0.001 & 0 & 0 \\
\hline 4 & 4 & 4 & 4 & 4 & 4 & 4 & 4 & 4 \\
\hline 0.471 & 0.465 & 0.474 & 0.468 & 0.486 & 0.471 & 0.480 & 0.485 & 0.486 \\
\hline 52.94 & 53.55 & 52.56 & 53.16 & 51.38 & 52.93 & 52.02 & 51.53 & 51.40 \\
\hline
\end{tabular}




\section{Rochas charnockíticas (Amostra NLD-45B)}

\section{ANFIBÓLIO}

\begin{tabular}{|c|c|c|c|c|c|c|c|c|c|c|c|c|c|c|c|}
\hline Analysis & ANF1 & ANF2 & ANF3 & ANF4 & ANF5 & ANF6 & ANF7 & ANF8 & ANF9 & ANF10 & ANF11 & ANF12 & ANF13 & ANF14 & ANF15 \\
\hline $\mathrm{SiO} 2$ & 42.857 & 42.188 & 42.616 & 42.417 & 42.797 & 40.904 & 43.172 & 42.989 & 42.968 & 43.051 & 43.496 & 43.016 & 43.248 & 41.593 & 41.888 \\
\hline TiO2 & 1.128 & 1.125 & 1.068 & 0.94 & 1.068 & 1.193 & 1.213 & 1.134 & 1.319 & 1.457 & 1.434 & 1.065 & 1.309 & 1.626 & 1.51 \\
\hline $\mathrm{Al} 2 \mathrm{O} 3$ & 11.588 & 12.449 & 12.42 & 12.443 & 11.654 & 13.394 & 11.252 & 11.442 & 11.652 & 11.28 & 11.354 & 11.178 & 11.502 & 10.735 & 10.848 \\
\hline $\mathrm{FeO}$ & 16.024 & 16.662 & 16.593 & 16.107 & 16.422 & 17.137 & 17.038 & 16.225 & 16.398 & 16.586 & 16.75 & 16.201 & 15.9 & 16.483 & 16.55 \\
\hline $\mathrm{MnO}$ & 0.081 & 0.129 & 0.132 & 0.117 & 0.098 & 0.099 & 0.181 & 0.156 & 0.143 & 0.164 & 0.139 & 0.088 & 0.072 & 0.138 & 0.147 \\
\hline $\mathrm{MgO}$ & 10.734 & 10.213 & 10.075 & 10.231 & 10.636 & 9.359 & 10.818 & 10.66 & 10.564 & 10.73 & 10.654 & 10.685 & 10.52 & 9.32 & 9.408 \\
\hline $\mathrm{CaO}$ & 11.898 & 11.549 & 11.589 & 11.924 & 11.642 & 11.751 & 11.619 & 11.265 & 11.583 & 11.662 & 11.565 & 11.625 & 11.338 & 10.758 & 10.758 \\
\hline $\mathrm{Na} 2 \mathrm{O}$ & 1.12 & 1.175 & 0.965 & 1.213 & 1.211 & 0.934 & 1.26 & 1.281 & 1.077 & 1.247 & 1.296 & 1.274 & 1.276 & 1.472 & 1.517 \\
\hline $\mathrm{K} 2 \mathrm{O}$ & 1.511 & 1.607 & 1.584 & 1.578 & 1.499 & 1.909 & 1.43 & 1.453 & 1.482 & 1.42 & 1.457 & 1.468 & 1.456 & 1.166 & 1.239 \\
\hline$F$ & 0.208 & 0.174 & 0.138 & 0.036 & 0.376 & 0.108 & 0.241 & 0.066 & 0.247 & 0.006 & 0.172 & 0 & 0.245 & 0.134 & 0.137 \\
\hline $\mathrm{Cl}$ & 0.184 & 0.268 & 0.249 & 0.201 & 0.223 & 0.345 & 0.178 & 0.188 & 0.162 & 0.176 & 0.133 & 0.203 & 0.159 & 0.133 & 0.178 \\
\hline Total & 97.33 & 97.54 & 97.43 & 97.21 & 97.63 & 97.13 & 98.4 & 96.86 & 97.6 & 97.78 & 98.45 & 96.8 & 97.03 & 93.56 & 94.18 \\
\hline O_F_Cl & 0.13 & 0.13 & 0.11 & 0.06 & 0.21 & 0.12 & 0.14 & 0.07 & 0.14 & 0.04 & 0.1 & 0.05 & 0.14 & 0.09 & 0.1 \\
\hline O_F & 0.09 & 0.07 & 0.06 & 0.02 & 0.16 & 0.05 & 0.1 & 0.03 & 0.1 & 0 & 0.07 & 0 & 0.1 & 0.06 & 0.06 \\
\hline $\mathrm{O} \_\mathrm{Cl}$ & 0.04 & 0.06 & 0.06 & 0.05 & 0.05 & 0.08 & 0.04 & 0.04 & 0.04 & 0.04 & 0.03 & 0.05 & 0.04 & 0.03 & 0.04 \\
\hline$\overline{\mathrm{TS}} \mathrm{i}$ & 6.417 & 6.307 & 6.364 & 6.368 & 6.395 & 6.187 & 6.387 & 6.43 & 6.401 & 6.401 & 6.429 & 6.462 & 6.476 & 6.495 & 6.499 \\
\hline TAl & 1.583 & 1.693 & 1.636 & 1.632 & 1.605 & 1.813 & 1.613 & 1.57 & 1.599 & 1.599 & 1.571 & 1.538 & 1.524 & 1.505 & 1.501 \\
\hline TFe3 & 0 & 0 & 0 & 0 & 0 & 0 & 0 & 0 & 0 & 0 & 0 & 0 & 0 & 0 & 0 \\
\hline TTi & 0 & 0 & 0 & 0 & 0 & 0 & 0 & 0 & 0 & 0 & 0 & 0 & 0 & 0 & 0 \\
\hline Sum_T & 8 & 8 & 8 & 8 & 8 & 8 & 8 & 8 & 8 & 8 & 8 & 8 & 8 & 8 & 8 \\
\hline CAI & 0.46 & 0.498 & 0.548 & 0.567 & 0.446 & 0.573 & 0.348 & 0.446 & 0.445 & 0.376 & 0.405 & 0.44 & 0.504 & 0.469 & 0.481 \\
\hline $\mathrm{CCr}$ & 0 & 0 & 0 & 0 & 0 & 0 & 0 & 0 & 0 & 0 & 0 & 0 & 0 & 0 & 0 \\
\hline CFe3 & 0.438 & 0.596 & 0.558 & 0.362 & 0.554 & 0.517 & 0.679 & 0.609 & 0.568 & 0.553 & 0.538 & 0.462 & 0.439 & 0.377 & 0.389 \\
\hline $\mathrm{CTi}$ & 0.127 & 0.126 & 0.12 & 0.106 & 0.12 & 0.136 & 0.135 & 0.128 & 0.148 & 0.163 & 0.159 & 0.12 & 0.147 & 0.191 & 0.176 \\
\hline $\mathrm{CMg}$ & 2.396 & 2.276 & 2.243 & 2.29 & 2.369 & 2.11 & 2.386 & 2.377 & 2.346 & 2.378 & 2.348 & 2.393 & 2.348 & 2.17 & 2.176 \\
\hline CFe2 & 1.569 & 1.487 & 1.514 & 1.66 & 1.498 & 1.651 & 1.429 & 1.421 & 1.475 & 1.509 & 1.532 & 1.573 & 1.552 & 1.776 & 1.758 \\
\hline CMn & 0.01 & 0.016 & 0.017 & 0.015 & 0.012 & 0.013 & 0.023 & 0.02 & 0.018 & 0.021 & 0.017 & 0.011 & 0.009 & 0.018 & 0.019 \\
\hline $\mathrm{CCa}$ & 0 & 0 & 0 & 0 & 0 & 0 & 0 & 0 & 0 & 0 & 0 & 0 & 0 & 0 & 0 \\
\hline BMg & 0 & 0 & 0 & 0 & 0 & 0 & 0 & 0 & 0 & 0 & 0 & 0 & 0 & 0 & 0 \\
\hline BFe2 & 0 & 0 & 0 & 0 & 0 & 0 & 0 & 0 & 0 & 0 & 0 & 0 & 0 & 0 & 0 \\
\hline BMn & 0 & 0 & 0 & 0 & 0 & 0 & 0 & 0 & 0 & 0 & 0 & 0 & 0 & 0 & 0 \\
\hline $\mathrm{BCa}$ & 1.909 & 1.85 & 1.854 & 1.918 & 1.864 & 1.904 & 1.842 & 1.805 & 1.849 & 1.858 & 1.831 & 1.871 & 1.819 & 1.8 & 1.788 \\
\hline $\mathrm{BNa}$ & 0.091 & 0.15 & 0.146 & 0.082 & 0.136 & 0.096 & 0.158 & 0.195 & 0.151 & 0.142 & 0.169 & 0.129 & 0.181 & 0.2 & 0.212 \\
\hline $\mathrm{ACa}$ & 0 & 0 & 0 & 0 & 0 & 0 & 0 & 0 & 0 & 0 & 0 & 0 & 0 & 0 & 0 \\
\hline $\mathrm{ANa}$ & 0.234 & 0.19 & 0.134 & 0.271 & 0.215 & 0.178 & 0.203 & 0.177 & 0.16 & 0.217 & 0.203 & 0.242 & 0.189 & 0.246 & 0.245 \\
\hline AK & 0.289 & 0.306 & 0.302 & 0.302 & 0.286 & 0.368 & 0.27 & 0.277 & 0.282 & 0.269 & 0.275 & 0.281 & 0.278 & 0.232 & 0.245 \\
\hline Sum_A & 0.523 & 0.497 & 0.435 & 0.573 & 0.501 & 0.547 & 0.473 & 0.454 & 0.442 & 0.487 & 0.478 & 0.524 & 0.468 & 0.478 & 0.49 \\
\hline Sum_cat & 15.523 & 15.497 & 15.435 & 15.573 & 15.501 & 15.547 & 15.473 & 15.454 & 15.442 & 15.487 & 15.478 & 15.524 & 15.468 & 15.478 & 15.49 \\
\hline $\mathrm{CCl}$ & 0.047 & 0.068 & 0.063 & 0.051 & 0.057 & 0.088 & 0.045 & 0.048 & 0.041 & 0.044 & 0.033 & 0.052 & 0.04 & 0.035 & 0.047 \\
\hline CF & 0.098 & 0.082 & 0.065 & 0.017 & 0.178 & 0.052 & 0.113 & 0.031 & 0.116 & 0.003 & 0.08 & 0 & 0.116 & 0.066 & 0.067 \\
\hline Sum_oxy & 23 & 23 & 23 & 23 & 23 & 23 & 23 & 23 & 23 & 23 & 23 & 23 & 23 & 23 & 23 \\
\hline Mg\# & 60.43 & 60.48 & 59.70 & 57.97 & 61.26 & 56.10 & 62.54 & 62.59 & 61.40 & 61.18 & 60.52 & 60.34 & 60.21 & 54.99 & 55.31 \\
\hline
\end{tabular}


Rochas charnockíticas (Amostra NLD-45B)

\section{ANFIBÓLIO}

\begin{tabular}{|c|c|c|c|c|c|c|c|c|c|c|c|c|c|c|}
\hline ANF16 & ANF17 & ANF18 & ANF19 & ANF20 & ANF21 & ANF22 & ANF23 & ANF24 & ANF25 & ANF26 & ANF27 & ANF28 & ANF29 & ANF30 \\
\hline 41.628 & 41.585 & 42.853 & 43.357 & 42.897 & 44.063 & 43.428 & 43.091 & 43.439 & 42.271 & 42.885 & 42.646 & 43.058 & 42.78 & 42.602 \\
\hline 1.384 & 1.635 & 1.202 & 0.773 & 0.819 & 0.819 & 0.83 & 1.198 & 0.969 & 1.531 & 1.74 & 1.337 & 1.947 & 1.223 & 1.431 \\
\hline 10.761 & 10.814 & 11.397 & 11.526 & 11.529 & 10.861 & 11.358 & 11.402 & 11.144 & 11.079 & 11.175 & 10.67 & 10.994 & 11.027 & 11.237 \\
\hline 16.074 & 16.36 & 15.686 & 16.611 & 16.401 & 16.589 & 16.373 & 16.629 & 16.202 & 16.609 & 16.022 & 16.883 & 16.052 & 16.706 & 16.293 \\
\hline 0.139 & 0.186 & 0.134 & 0.136 & 0.211 & 0.149 & 0.114 & 0.073 & 0.17 & 0.14 & 0.137 & 0.151 & 0.145 & 0.118 & 0.123 \\
\hline 9.328 & 9.139 & 10.473 & 10.49 & 10.526 & 10.696 & 10.307 & 10.505 & 10.875 & 10.488 & 10.338 & 10.496 & 10.528 & 10.642 & 10.306 \\
\hline 10.667 & 10.608 & 11.685 & 11.797 & 11.705 & 11.667 & 11.91 & 11.759 & 11.815 & 11.624 & 11.418 & 11.71 & 11.494 & 11.874 & 11.559 \\
\hline 1.457 & 1.427 & 1.037 & 1.138 & 1.013 & 1.026 & 1.068 & 1.073 & 0.994 & 1.102 & 1.205 & 1.128 & 1.247 & 1.264 & 1.226 \\
\hline 1.224 & 1.231 & 1.48 & 1.409 & 1.371 & 1.363 & 1.41 & 1.491 & 1.391 & 1.481 & 1.447 & 1.459 & 1.499 & 1.493 & 1.49 \\
\hline 0 & 0.269 & 0.074 & 0.068 & 0.235 & 0.169 & 0.17 & 0.174 & 0.036 & 0.132 & 0.102 & 0.341 & 0.074 & 0.138 & 0 \\
\hline 0.205 & 0.265 & 0.217 & 0.243 & 0.209 & 0.282 & 0.238 & 0.219 & 0.255 & 0.226 & 0.197 & 0.247 & 0.226 & 0.257 & 0.25 \\
\hline 92.87 & 93.52 & 96.24 & 97.55 & 96.92 & 97.68 & 97.21 & 97.61 & 97.29 & 96.68 & 96.67 & 97.07 & 97.26 & 97.52 & 96.52 \\
\hline 0.05 & 0.17 & 0.08 & 0.08 & 0.15 & 0.13 & 0.13 & 0.12 & 0.07 & 0.11 & 0.09 & 0.2 & 0.08 & 0.12 & 0.06 \\
\hline 0 & 0.11 & 0.03 & 0.03 & 0.1 & 0.07 & 0.07 & 0.07 & 0.02 & 0.06 & 0.04 & 0.14 & 0.03 & 0.06 & 0 \\
\hline 0.05 & 0.06 & 0.05 & 0.05 & 0.05 & 0.06 & 0.05 & 0.05 & 0.06 & 0.05 & 0.04 & 0.06 & 0.05 & 0.06 & 0.06 \\
\hline 6.535 & 6.512 & 6.476 & 6.467 & 6.434 & 6.553 & 6.521 & 6.435 & 6.476 & 6.381 & 6.462 & 6.438 & 6.455 & 6.42 & 6.439 \\
\hline 1.465 & 1.488 & 1.524 & 1.533 & 1.566 & 1.447 & 1.479 & 1.565 & 1.524 & 1.619 & 1.538 & 1.562 & 1.545 & 1.58 & 1.561 \\
\hline 0 & 0 & 0 & 0 & 0 & 0 & 0 & 0 & 0 & 0 & 0 & 0 & 0 & 0 & 0 \\
\hline 0 & 0 & 0 & 0 & 0 & 0 & 0 & 0 & 0 & 0 & 0 & 0 & 0 & 0 & 0 \\
\hline 8 & 8 & 8 & 8 & 8 & 8 & 8 & 8 & 8 & 8 & 8 & 8 & 8 & 8 & 8 \\
\hline 0.525 & 0.507 & 0.504 & 0.492 & 0.47 & 0.455 & 0.529 & 0.441 & 0.433 & 0.351 & 0.444 & 0.335 & 0.396 & 0.369 & 0.44 \\
\hline 0 & 0 & 0 & 0 & 0 & 0 & 0 & 0 & 0 & 0 & 0 & 0 & 0 & 0 & 0 \\
\hline 0.336 & 0.357 & 0.373 & 0.5 & 0.593 & 0.536 & 0.35 & 0.497 & 0.547 & 0.552 & 0.383 & 0.524 & 0.367 & 0.462 & 0.405 \\
\hline 0.163 & 0.193 & 0.137 & 0.087 & 0.092 & 0.092 & 0.094 & 0.135 & 0.109 & 0.174 & 0.197 & 0.152 & 0.22 & 0.138 & 0.163 \\
\hline 2.183 & 2.134 & 2.359 & 2.333 & 2.353 & 2.371 & 2.307 & 2.339 & 2.417 & 2.36 & 2.322 & 2.362 & 2.353 & 2.381 & 2.322 \\
\hline 1.774 & 1.786 & 1.609 & 1.572 & 1.465 & 1.527 & 1.706 & 1.58 & 1.473 & 1.545 & 1.636 & 1.608 & 1.645 & 1.635 & 1.655 \\
\hline 0.018 & 0.025 & 0.017 & 0.017 & 0.027 & 0.019 & 0.014 & 0.009 & 0.021 & 0.018 & 0.017 & 0.019 & 0.018 & 0.015 & 0.016 \\
\hline 0 & 0 & 0 & 0 & 0 & 0 & 0 & 0 & 0 & 0 & 0 & 0 & 0 & 0 & 0 \\
\hline 0 & 0 & 0 & 0 & 0 & 0 & 0 & 0 & 0 & 0 & 0 & 0 & 0 & 0 & 0 \\
\hline 0 & 0 & 0 & 0 & 0 & 0 & 0 & 0 & 0 & 0 & 0 & 0 & 0 & 0 & 0 \\
\hline 0 & 0 & 0 & 0 & 0 & 0 & 0 & 0 & 0 & 0 & 0 & 0 & 0 & 0 & 0 \\
\hline 1.794 & 1.78 & 1.892 & 1.885 & 1.881 & 1.859 & 1.916 & 1.882 & 1.887 & 1.88 & 1.843 & 1.894 & 1.846 & 1.909 & 1.872 \\
\hline 0.206 & 0.22 & 0.108 & 0.115 & 0.119 & 0.141 & 0.084 & 0.118 & 0.113 & 0.12 & 0.157 & 0.106 & 0.154 & 0.091 & 0.128 \\
\hline 0 & 0 & 0 & 0 & 0 & 0 & 0 & 0 & 0 & 0 & 0 & 0 & 0 & 0 & 0 \\
\hline 0.238 & 0.213 & 0.196 & 0.214 & 0.176 & 0.155 & 0.227 & 0.192 & 0.175 & 0.203 & 0.195 & 0.224 & 0.209 & 0.277 & 0.231 \\
\hline 0.245 & 0.246 & 0.285 & 0.268 & 0.262 & 0.259 & 0.27 & 0.284 & 0.265 & 0.285 & 0.278 & 0.281 & 0.287 & 0.286 & 0.287 \\
\hline 0.483 & 0.459 & 0.481 & 0.483 & 0.438 & 0.413 & 0.497 & 0.476 & 0.439 & 0.488 & 0.473 & 0.505 & 0.495 & 0.563 & 0.519 \\
\hline 15.483 & 15.459 & 15.481 & 15.483 & 15.438 & 15.413 & 15.497 & 15.476 & 15.439 & 15.488 & 15.473 & 15.505 & 15.495 & 15.563 & 15.519 \\
\hline 0.055 & 0.07 & 0.056 & 0.061 & 0.053 & 0.071 & 0.061 & 0.055 & 0.064 & 0.058 & 0.05 & 0.063 & 0.057 & 0.065 & 0.064 \\
\hline 0 & 0.133 & 0.035 & 0.032 & 0.111 & 0.079 & 0.081 & 0.082 & 0.017 & 0.063 & 0.049 & 0.163 & 0.035 & 0.065 & 0 \\
\hline 23 & 23 & 23 & 23 & 23 & 23 & 23 & 23 & 23 & 23 & 23 & 23 & 23 & 23 & 23 \\
\hline 55.17 & 54.44 & 59.45 & 59.74 & 61.63 & 60.83 & 57.49 & 59.68 & 62.13 & 60.44 & 58.67 & 59.50 & 58.85 & 59.29 & 58.39 \\
\hline
\end{tabular}


Rochas charnockíticas (Amostra NLD-45B, NLD-45D, NLD-42C)

ANFIBÓLIO

NLD-45B NLD-45B NLD-45B NLD-45B NLD-45B NLD-45B NLD-45D NLD-45

\begin{tabular}{|c|c|c|c|c|c|c|c|c|c|c|c|c|c|c|}
\hline $5 B$ & LD-45B & LD-45B & LD-45B & JLD-45B & NLD-45B & NLD-45D & NLD-45D & NLD-45D & NLD-45D & NLD-45D & NLD-45D & NLD-42C & NLD-42C & NLD-42C \\
\hline ANF31 & ANF32 & ANF33 & ANF34 & ANF35 & ANF36 & ANF16 & ANF17 & ANF18 & ANF19 & ANF20 & ANF21 & 16 & 17 & 18 \\
\hline 43.49 & 42.458 & 42.411 & 42.222 & 43.162 & 43.504 & 43.863 & 44.323 & 46.107 & 44.287 & 44.369 & 43.376 & ANF & ANF & ANF \\
\hline 1.592 & 1.248 & 0.924 & 1.235 & 1.099 & 1.478 & 1.583 & 1.515 & 0.718 & 0.681 & 0.728 & 1.514 & 39.365 & 39.467 & 39.481 \\
\hline 10.926 & 11.583 & 11.332 & 11.556 & 11.18 & 10.419 & 10.782 & 10.847 & 9.547 & 10.693 & 10.613 & 10.969 & 1.928 & 2.5 & 1.611 \\
\hline 16.565 & 15.49 & 15.677 & 15.934 & 15.43 & 16.091 & 14.96 & 14.854 & 15.003 & 16.13 & 15.639 & 15.05 & 11.744 & 11.917 & 12.74 \\
\hline 0.128 & 0.148 & 0.134 & 0.088 & 0.101 & 0.083 & 0.066 & 0.079 & 0.091 & 0.121 & 0.118 & 0.123 & 20.847 & 20.193 & 20.32 \\
\hline 10.509 & 10.41 & 10.588 & 10.271 & 10.831 & 10.559 & 11.905 & 11.849 & 12.383 & 11.592 & 11.818 & 11.398 & 0.107 & 0.176 & 0.165 \\
\hline 11.664 & 11.411 & 11.487 & 11.418 & 11.436 & 11.993 & 11.849 & 11.964 & 11.732 & 11.959 & 11.798 & 11.637 & 7.415 & 7.645 & 7.889 \\
\hline 1.127 & 1.118 & 1.262 & 1.144 & 1.27 & 1.103 & 1.41 & 1.4 & 0.994 & 1.059 & 1.161 & 1.528 & 11.53 & 11.344 & 11.675 \\
\hline 1.419 & 1.393 & 1.46 & 1.486 & 1.464 & 1.427 & 1.069 & 1.05 & 1.055 & 1.244 & 1.145 & 1.164 & 1.412 & 1.482 & 1.285 \\
\hline 0.07 & 0 & 0.242 & 0.002 & . & 0 & 0.137 & 0.141 & 0.102 & 0.108 & 0.034 & 0.143 & 2.165 & 2.201 & 2.239 \\
\hline 0.236 & 0.185 & 0.178 & 0.18 & 0.19 & 0.149 & 0.246 & 0.253 & 0.203 & 0.234 & 0.243 & 0.171 & 0.068 & 0.092 & 0.17 \\
\hline 97.73 & 95.44 & 95.69 & 95.54 & 96.16 & 96.81 & 97.87 & 98.28 & 97.94 & 98.11 & 97.67 & 97.07 & 0.771 & 0.703 & 0.623 \\
\hline 0.08 & 0.04 & 0.14 & 0.04 & 0.04 & 0.03 & 0.11 & 0.12 & 0.09 & 0.1 & 0.07 & 0.1 & 97.35 & 97.72 & 98.2 \\
\hline 0.03 & 0 & 0.1 & 0 & 0 & 0 & 0.06 & 0.06 & 0.04 & 0.05 & 0.01 & 0.06 & 0.2 & 0.2 & 0.21 \\
\hline 0.05 & 0.04 & 0.04 & 0.04 & 0.04 & 0.03 & 0.06 & 0.06 & 0.05 & 0.05 & 0.05 & 0.04 & 0.03 & 0.04 & 0.07 \\
\hline 6.485 & 6.445 & 6.451 & 6.422 & 6.502 & 6.564 & 6.475 & 6.519 & 6.737 & 6.523 & 6.539 & 6.473 & 6.149 & 6.121 & 6.068 \\
\hline 1.515 & 1.555 & 1.549 & 1.578 & 1.498 & 1.436 & 1.525 & 1.481 & 1.263 & 1.477 & 1.461 & 1.527 & 1.851 & 1.879 & 1.932 \\
\hline 0 & 0 & 0 & 0 & 0 & 0 & 0 & 0 & 0 & 0 & 0 & 0 & 0 & 0 & 0 \\
\hline 0 & 0 & 0 & 0 & 0 & 0 & 0 & 0 & 0 & 0 & 0 & 0 & 0 & 0 & 0 \\
\hline 8 & 8 & 8 & 8 & 8 & 8 & 8 & 8 & 8 & 8 & 8 & 8 & 8 & 8 & 8 \\
\hline 0.404 & 0.516 & 0.482 & 0.492 & 0.486 & 0.416 & 0.349 & 0.398 & 0.379 & 0.377 & 0.381 & 0.401 & 0.309 & 0.298 & 0.373 \\
\hline 0 & 0 & 0 & 0 & 0 & 0 & 0 & 0 & 0 & 0 & 0 & 0 & 0 & 0 & 0 \\
\hline 0.432 & 0.443 & 0.456 & 0.457 & 0.418 & 0.209 & 0.471 & 0.382 & 0.575 & 0.638 & 0.646 & 0.402 & 0.37 & 0.345 & 0.52 \\
\hline 0.179 & 0.143 & 0.106 & 0.141 & 0.125 & 0.168 & 0.176 & 0.168 & 0.079 & 0.075 & 0.081 & 0.17 & 0.227 & 0.292 & 0.186 \\
\hline 2.336 & 2.356 & 2.401 & 2.329 & 2.433 & 2.375 & 2.62 & 2.598 & 2.697 & 2.545 & 2.596 & 2.536 & 1.727 & 1.768 & 1.807 \\
\hline 1.634 & 1.524 & 1.539 & 1.57 & 1.526 & 1.822 & 1.376 & 1.445 & 1.259 & 1.348 & 1.281 & 1.477 & 2.353 & 2.274 & 2.092 \\
\hline 0.016 & 0.019 & 0.017 & 0.011 & 0.013 & 0.011 & 0.008 & 0.01 & 0.011 & 0.015 & 0.015 & 0.016 & 0.014 & 0.023 & 0.021 \\
\hline 0 & 0 & 0 & 0 & 0 & 0 & 0 & 0 & 0 & 0 & 0 & 0 & 0 & 0 & 0 \\
\hline 0 & 0 & 0 & 0 & 0 & 0 & 5 & 5 & 5 & 5 & 5 & 5 & 0 & 0 & 0 \\
\hline 0 & 0 & 0 & 0 & 0 & 0 & 0 & 0 & 0 & 0 & 0 & 0 & 0 & 0 & 0 \\
\hline 0 & 0 & 0 & 0 & 0 & 0 & 0 & 0 & 0 & 0 & 0 & 0 & 0 & 0 & 0 \\
\hline 1.863 & 1.856 & 1.872 & 1.861 & 1.846 & 1.939 & 1.874 & 1.885 & 1.837 & 1.887 & 1.863 & 1.861 & 1.93 & 1.885 & 1.922 \\
\hline 0.137 & 0.144 & 0.128 & 0.139 & 0.154 & 0.061 & 0.126 & 0.115 & 0.163 & 0.113 & 0.137 & 0.139 & 0.07 & 0.115 & 0.078 \\
\hline 0 & 0 & 0 & 0 & 0 & 0 & 2 & 2 & 2 & 2 & 2 & 2 & 2 & 2 & 2 \\
\hline 0.189 & 0.185 & 0.244 & 0.198 & 0.217 & 0.262 & 0.278 & 0.285 & 0.118 & 0.19 & 0.195 & 0.303 & 0.357 & 0.331 & 0.305 \\
\hline 0.27 & 0.27 & 0.283 & 0.288 & 0.281 & 0.275 & 0.201 & 0.197 & 0.197 & 0.234 & 0.215 & 0.222 & 0.431 & 0.436 & 0.439 \\
\hline 0.459 & 0.455 & 0.528 & 0.486 & 0.498 & 0.536 & 0.479 & 0.482 & 0.315 & 0.423 & 0.41 & 0.524 & 0.789 & 0.766 & 0.744 \\
\hline 15.459 & 15.455 & 15.528 & 15.486 & 15.498 & 15.536 & 15.479 & 15.482 & 15.315 & 15.423 & 15.41 & 15.524 & 15.789 & 15.766 & 15.744 \\
\hline 0.06 & 0.048 & 0.046 & 0.046 & 0.049 & 0.038 & 0.062 & 0.063 & 0.05 & 0.058 & 0.061 & 0.043 & 0.204 & 0.185 & 0.162 \\
\hline 0.033 & 0 & 0.116 & 0.001 & 0 & 0 & 0.064 & 0.066 & 0.047 & 0.05 & 0.016 & 0.067 & 0.034 & 0.045 & 0.083 \\
\hline 23 & 23 & 23 & 23 & 23 & 23 & 23 & 23 & 23 & 23 & 23 & 23 & 23 & 23 & 23 \\
\hline
\end{tabular}

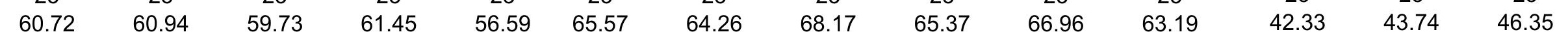


Rochas charnockíticas (Amostra NLD-45D)

\section{ANFIBÓLIO}

\begin{tabular}{|c|c|c|c|c|c|c|c|c|c|c|c|c|c|c|c|}
\hline Analysis & ANF1 & ANF2 & ANF3 & ANF4 & ANF5 & ANF6 & ANF7 & ANF8 & ANF9 & ANF10 & ANF11 & ANF12 & ANF13 & ANF14 & ANF15 \\
\hline $\mathrm{SiO} 2$ & 44.308 & 44.341 & 44.072 & 44.005 & 43.999 & 44.018 & 44.036 & 46.478 & 43.788 & 44.28 & 43.969 & 44.471 & 41.668 & 43.865 & 43.378 \\
\hline $\mathrm{TiO} 2$ & 1.409 & 1.374 & 1.19 & 0.704 & 0.692 & 0.786 & 1.028 & 0.813 & 1.212 & 1.259 & 1.547 & 1.399 & 1.198 & 1.05 & 1.406 \\
\hline $\mathrm{Al} 2 \mathrm{O} 3$ & 10.763 & 10.719 & 10.846 & 11.22 & 11.13 & 11.105 & 10.969 & 8.374 & 11.116 & 11.128 & 11.241 & 10.764 & 12.758 & 11.096 & 11.331 \\
\hline $\mathrm{FeO}$ & 15.991 & 16.29 & 15.751 & 16.443 & 16.435 & 15.831 & 15.873 & 18.573 & 15.716 & 15.691 & 15.318 & 14.982 & 16.215 & 15.949 & 15.904 \\
\hline $\mathrm{MnO}$ & 0.104 & 0.094 & 0.113 & 0.114 & 0.154 & 0.092 & 0.096 & 0.157 & 0.107 & 0.109 & 0.084 & 0.132 & 0.093 & 0.134 & 0.147 \\
\hline $\mathrm{MgO}$ & 11.588 & 11.631 & 11.634 & 11.587 & 11.453 & 11.29 & 11.501 & 12.337 & 11.389 & 11.449 & 11.455 & 11.627 & 9.995 & 11.344 & 11.245 \\
\hline $\mathrm{CaO}$ & 11.691 & 11.835 & 11.883 & 11.779 & 11.773 & 11.636 & 11.815 & 8.921 & 11.861 & 11.743 & 11.721 & 11.828 & 11.614 & 12.046 & 11.572 \\
\hline $\mathrm{Na} 2 \mathrm{O}$ & 1.162 & 1.261 & 1.229 & 1.288 & 1.256 & 1.249 & 1.311 & 0.766 & 1.264 & 1.273 & 1.207 & 1.02 & 1.406 & 1.192 & 1.316 \\
\hline $\mathrm{K} 2 \mathrm{O}$ & 1.195 & 1.173 & 1.122 & 1.142 & 1.246 & 1.157 & 1.156 & 0.768 & 1.272 & 1.22 & 1.153 & 1.081 & 1.371 & 1.351 & 1.355 \\
\hline $\mathrm{F}$ & 0.21 & 0 & 0.042 & 0.135 & 0.209 & 0.104 & 0.002 & 0 & 0.066 & 0.068 & 0.275 & 0 & 0.07 & 0.07 & 0 \\
\hline $\mathrm{Cl}$ & 0.27 & 0.272 & 0.27 & 0.243 & 0.294 & 0.297 & 0.277 & 0.191 & 0.318 & 0.277 & 0.245 & 0.253 & 0.437 & 0.236 & 0.269 \\
\hline Total & 98.69 & 98.99 & 98.15 & 98.66 & 98.64 & 97.57 & 98.06 & 97.38 & 98.11 & 98.5 & 98.22 & 97.56 & 96.83 & 98.33 & 97.92 \\
\hline O_F_Cl & 0.15 & 0.06 & 0.08 & 0.11 & 0.15 & 0.11 & 0.06 & 0.04 & 0.1 & 0.09 & 0.17 & 0.06 & 0.13 & 0.08 & 0.06 \\
\hline O_F & 0.09 & 0 & 0.02 & 0.06 & 0.09 & 0.04 & 0 & 0 & 0.03 & 0.03 & 0.12 & 0 & 0.03 & 0.03 & 0 \\
\hline$\underset{\mathrm{OS}}{\mathrm{O}} \mathrm{Cl}$ & $\begin{array}{c}0.06 \\
6.488\end{array}$ & $\begin{array}{c}0.06 \\
6.474\end{array}$ & $\begin{array}{l}0.06 \\
6.485\end{array}$ & $\begin{array}{l}0.05 \\
6.437\end{array}$ & $\begin{array}{l}0.07 \\
6.458\end{array}$ & $\begin{array}{c}0.07 \\
6.515\end{array}$ & $\begin{array}{c}0.06 \\
6.488\end{array}$ & $\begin{array}{c}0.04 \\
6.639\end{array}$ & $\begin{array}{l}0.07 \\
6.468\end{array}$ & $\begin{array}{c}0.06 \\
6.496\end{array}$ & $\begin{array}{c}0.06 \\
6.471\end{array}$ & $\begin{array}{c}0.06 \\
6.557\end{array}$ & $\begin{array}{c}0.1 \\
6.289\end{array}$ & $\begin{array}{l}0.05 \\
6.474\end{array}$ & $\begin{array}{l}0.06 \\
6.41\end{array}$ \\
\hline TAl & 1.512 & 1.526 & 1.515 & 1.563 & 1.542 & 1.485 & 1.512 & 1.361 & 1.532 & 1.504 & 1.529 & 1.443 & 1.711 & 1.526 & 1.59 \\
\hline TFe3 & 0 & 0 & 0 & 0 & 0 & 0 & 0 & 0 & 0 & 0 & 0 & 0 & 0 & 0 & 0 \\
\hline TTi & 0 & 0 & 0 & 0 & 0 & 0 & 0 & 0 & 0 & 0 & 0 & 0 & 0 & 0 & 0 \\
\hline Sum_T & 8 & 8 & 8 & 8 & 8 & 8 & 8 & 8 & 8 & 8 & 8 & 8 & 8 & 8 & 8 \\
\hline CĀ & 0.344 & 0.317 & 0.364 & 0.37 & 0.381 & 0.45 & 0.392 & 0.048 & 0.402 & 0.419 & 0.42 & 0.426 & 0.557 & 0.402 & 0.382 \\
\hline $\mathrm{CCr}$ & 0 & 0 & 0 & 0 & 0 & 0 & 0 & 0 & 0 & 0 & 0 & 0 & 0 & 0 & 0 \\
\hline CFe3 & 0.636 & 0.629 & 0.58 & 0.767 & 0.715 & 0.592 & 0.569 & 2.056 & 0.504 & 0.526 & 0.509 & 0.476 & 0.451 & 0.486 & 0.598 \\
\hline $\mathrm{CTi}$ & 0.155 & 0.151 & 0.132 & 0.077 & 0.076 & 0.088 & 0.114 & 0.087 & 0.135 & 0.139 & 0.171 & 0.155 & 0.136 & 0.117 & 0.156 \\
\hline $\mathrm{CMg}$ & 2.53 & 2.532 & 2.552 & 2.527 & 2.506 & 2.491 & 2.526 & 2.627 & 2.508 & 2.504 & 2.513 & 2.556 & 2.249 & 2.496 & 2.477 \\
\hline CFe2 & 1.322 & 1.36 & 1.358 & 1.244 & 1.302 & 1.367 & 1.386 & 0.163 & 1.438 & 1.399 & 1.376 & 1.372 & 1.596 & 1.483 & 1.368 \\
\hline $\mathrm{CMn}$ & 0.013 & 0.012 & 0.014 & 0.014 & 0.019 & 0.012 & 0.012 & 0.019 & 0.013 & 0.014 & 0.01 & 0.016 & 0.012 & 0.017 & 0.018 \\
\hline $\mathrm{CCa}$ & 0 & 0 & 0 & 0 & 0 & 0 & 0 & 0 & 0 & 0 & 0 & 0 & 0 & 0 & 0 \\
\hline Sum_C & 5 & 5 & 5 & 5 & 5 & 5 & 5 & 5 & 5 & 5 & 5 & 5 & 5 & 5 & 5 \\
\hline $\mathrm{BCa}$ & 1.834 & 1.851 & 1.873 & 1.846 & 1.851 & 1.845 & 1.865 & 1.365 & 1.877 & 1.846 & 1.848 & 1.868 & 1.878 & 1.905 & 1.832 \\
\hline $\mathrm{BNa}$ & 0.166 & 0.149 & 0.127 & 0.154 & 0.149 & 0.155 & 0.135 & 0.212 & 0.123 & 0.154 & 0.152 & 0.132 & 0.122 & 0.095 & 0.168 \\
\hline Sum_B & 2 & 2 & 2 & 2 & 2 & 2 & 2 & 1.577 & 2 & 2 & 2 & 2 & 2 & 2 & 2 \\
\hline $\mathrm{ACa}$ & 0 & 0 & 0 & 0 & 0 & 0 & 0 & 0 & 0 & 0 & 0 & 0 & 0 & 0 & 0 \\
\hline $\mathrm{ANa}$ & 0.164 & 0.208 & 0.224 & 0.211 & 0.209 & 0.204 & 0.24 & 0 & 0.239 & 0.208 & 0.193 & 0.16 & 0.29 & 0.246 & 0.209 \\
\hline AK & 0.223 & 0.218 & 0.211 & 0.213 & 0.233 & 0.218 & 0.217 & 0.14 & 0.24 & 0.228 & 0.216 & 0.203 & 0.264 & 0.254 & 0.255 \\
\hline Sum_A & 0.387 & 0.427 & 0.435 & 0.425 & 0.442 & 0.422 & 0.457 & 0.14 & 0.479 & 0.436 & 0.409 & 0.363 & 0.554 & 0.5 & 0.465 \\
\hline Sum_cat & 15.387 & 15.427 & 15.435 & 15.425 & 15.442 & 15.422 & 15.457 & 14.717 & 15.479 & 15.436 & 15.409 & 15.363 & 15.554 & 15.5 & 15.465 \\
\hline $\mathrm{CCl}$ & 0.067 & 0.067 & 0.067 & 0.06 & 0.073 & 0.075 & 0.069 & 0.046 & 0.08 & 0.069 & 0.061 & 0.063 & 0.112 & 0.059 & 0.067 \\
\hline CF & 0.097 & 0 & 0.02 & 0.062 & 0.097 & 0.049 & 0.001 & 0 & 0.031 & 0.032 & 0.128 & 0 & 0.033 & 0.033 & 0 \\
\hline Sum_oxy & 23 & 23 & 23 & 23 & 23 & 23 & 23 & 23 & 23 & 23 & 23 & 23 & 23 & 23 & 23 \\
\hline Mg\# & 65.68 & 65.06 & 65.27 & 67.01 & 65.81 & 64.57 & 64.57 & 94.16 & 63.56 & 64.16 & 64.62 & 65.07 & 58.49 & 62.73 & 64.42 \\
\hline
\end{tabular}




\section{Rochas charnockíticas (Amostra NLD-42C)}

\section{ANFIBOLIO}

\section{$\mathrm{SiO} 2 \quad 39.512$}

39.427

$39.939 \quad 39.504$

$\mathrm{Al} 2 \mathrm{O} 3 \quad 11.695$

2.058

42.256

39.172

39.089

39.088

40.076

38.521

2.061

2.06

2.142

$15.409 \quad 12.156$

12.119

$21.141 \quad 16.498$

21.318

21.539

12.677

2.002

1.674

39.815

11.844

13.084

1.886

40.235

20.469

21.482

12.402

12.426

0.094

0.196

7.417

7.391

5.846

$\begin{array}{lll}\mathrm{MgO} & 7.629 & 7.529\end{array}$

$\begin{array}{ccc}\mathrm{CaO} & 11.904 & 11.735 \\ \mathrm{Na} 2 \mathrm{O} & 1.427 & 1.449\end{array}$

$\mathrm{K} 2 \mathrm{O}$

2.337

11.45

1.484

11.317

1.414

7.232

7.304

6.921

7.61

0.15

11.302

F $\quad 0.177$

0.066

2.084

2.127

2.654

1.414

1.443

11.282
1.405

$2.194 \quad 2.189$

0.107

1.993

0.062

0.745

0.585

0.165

Total $\quad 98.32$

98.44

0.17

98.56

0.18

_F-Cl

0.07

0.03

0.14

0.03

97.89

0.21

O_Cl 0.16

$\begin{array}{lll}\text { TSi } & 6.139 & 6.106 \\ \text { TAI } & 1.861 & 1.894\end{array}$

6.147

1.853

0.17

97.2

0.13

0.747

0.362

2.189
0.136

0.702

11.652
1.421

2.215

0.035

0.714

98.28

0.33

97.56

0.22

0.17

0.13

0.07
0.17

0.15

6.118

6.555

6.08

TFe3

0

TTi

Sum_T

0

CĀ $\quad 0.279$

8

0.241

0

1.882

1.445

1.92

1.943

0.16

6.084

1.916

$\begin{array}{lll}8 & 8 & 8\end{array}$

0.283

0.301

1.37

0.301

$\begin{array}{lll}\mathrm{CFe} 3 & 0.134 & 0.33\end{array}$

CTi 0.303

0.266

0.41

0.266

0.501

0.24

$\begin{array}{cc}0 & 0 \\ 0 & 0.464 \\ 0.13 & 0.241\end{array}$

0.269

0.573

0.24

1.673

2.237

1.352

2.14

2.302

1.687

2.218

$0.018 \quad 0.015$

$0.007 \quad 0.018$

0.012

$\begin{array}{ccc}0 & 0 & 0 \\ 0 & 0 & 0\end{array}$

$\mathrm{BMg}$

BFe2

$\mathrm{BMn}$

$\mathrm{BCa} \quad 1.982$

0.018

ACa $\quad 0$

ANa $\quad 0.412$

AK $\quad 0.448$

Sum A

0.86

Sum_cat

$\mathrm{CCl}$

0.087

0
0
0
0

0

0

1.947

0.053

1.888

0.112

$$
0
$$

1.878

0.122

1.793

0.207

0

1.912

0.088

1.876

$\begin{array}{cc}0.124 & 0.119\end{array}$

0

0.462

0.331

0.409

0.74

0.302

0.42

0.591

0.394

0.986

0.337

0.337
0.425

0.762

15.723

0.196

15.986

0.154

15.762

$0.168 \quad 0.178$

0.032

0.03

0.052

0

0.197

43.27

23.482

23

2

$$
0
$$

0.31

0.434

0.744

15.744
0.203

0.177

38.72

42.09

98.15

0.18

0.01

0.16

6.196

1.804

6.722

1.266

2.457

0

0.784

97.74

0.18

0
0.18

6.012

1.988

0

0.407

0.386

0.251

1.606

2.324

0
0

(

Mg\# $\quad 41.43$

41.95

42.31

2
0
0.305
0.435

0.352

0.352
0
0.264

0.233

1.754

2.382

0.015

$\begin{array}{ll}0 & 0.02 \\ 0 & 0\end{array}$

0

0

1.93

0.07

$$
\begin{aligned}
& 2 \\
& 0
\end{aligned}
$$

0
0.356

0.74

0.437

0.793

15.74

15.793

0.185

0.187

23

23

42.41

0.416

0

0.427

0.197 